LATE ANTIQUE AND EARLY MEDIEVAL IBERIA
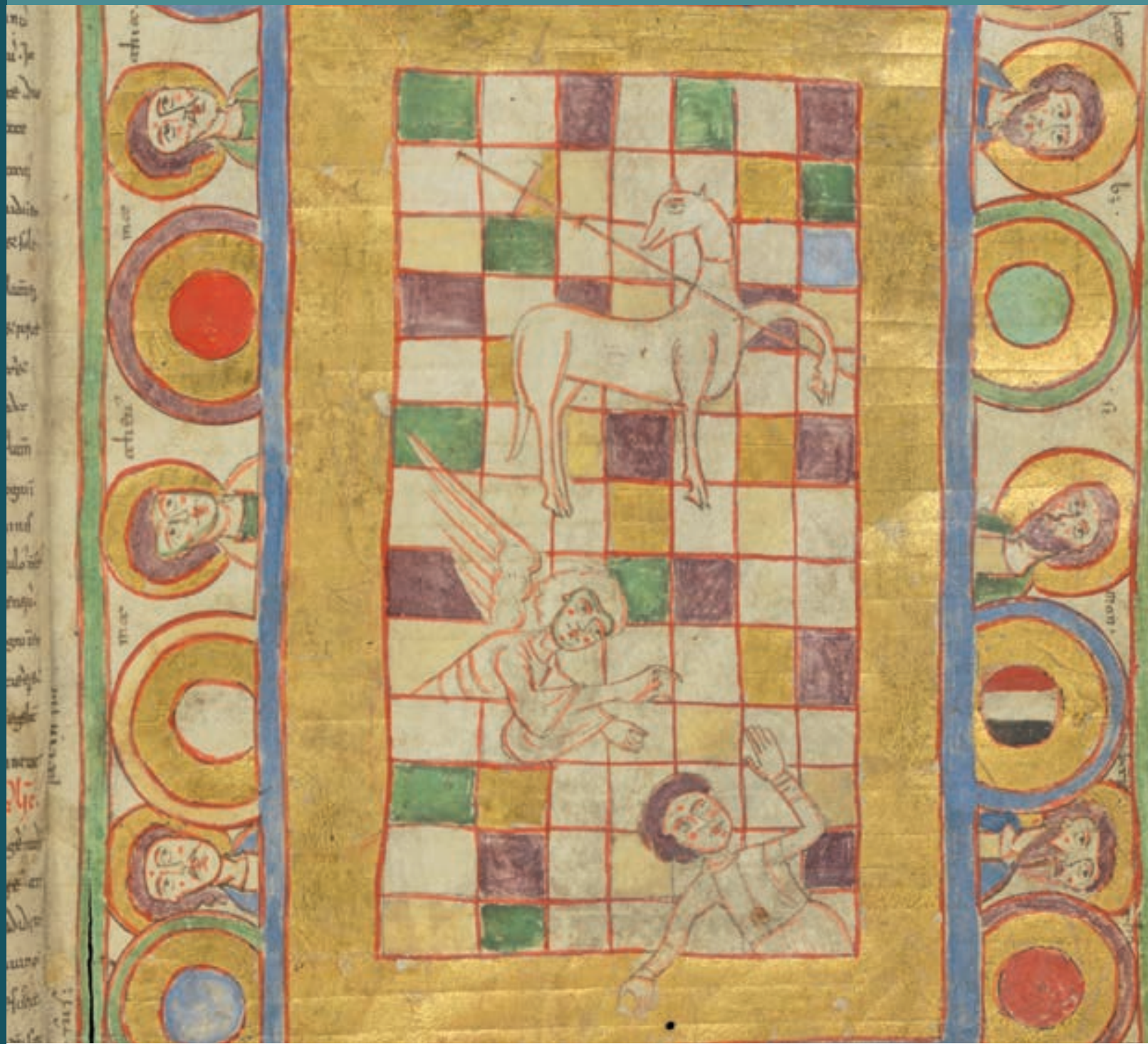

John Williams

\title{
Visions of the End in Medieval Spain
}

Catalogue of Illustrated Beatus Commentaries on the Apocalypse and Study of the Geneva Beatus

Edited by Therese Martin 
Visions of the End in Medieval Spain 


\section{Late Antique and Early Medieval Iberia}

Scholarship on the Iberian Peninsula in late antiquity and the early Middle Ages is burgeoning across a variety of disciplines and time periods, yet the publication profile of the field remains disjointed. 'Late Antique and Early Medieval Iberia' (LAEMI) provides a publication hub for highquality research on Iberian Studies from the fields of history, archaeology, theology and religious studies, numismatics, palaeography, music, and cognate disciplines.

Another key aim of the series is to break down barriers between the excellent scholarship that takes place in Iberia and Latin America and the Anglophone world.

\section{Series Editor}

Jamie Wood, University of Lincoln, UK

Editorial Board Members

Andrew Fear, University of Manchester, UK

Nicola Clarke, Newcastle University, UK

Iñaki Martín Viso, University of Salamanca, Spain

Glaire Anderson, University of North Carolina, USA

Eleonora Dell'Elicine, University of Buenos Aires, Argentina 


\section{Visions of the End in Medieval Spain}

Catalogue of Illustrated Beatus Commentaries on the Apocalypse and Study of the Geneva Beatus

John Williams

Edited by Therese Martin 
Front cover illustration: Geneva, Bibliothèque de Genève, Ms. lat. 357, fol. 241: The Institutions of Priscian and the Commentary on the Apocalypse by Beatus of Liébana Back cover illustration: Geneva, Bibliothèque de Genève, Ms. lat. 357, fol. 228: The Institutions of Priscian and the Commentary on the Apocalypse by Beatus of Liébana Cover design: Coördesign, Leiden Lay-out: Crius Group, Hulshout

Amsterdam University Press English-language titles are distributed in the US and Canada by the University of Chicago Press.
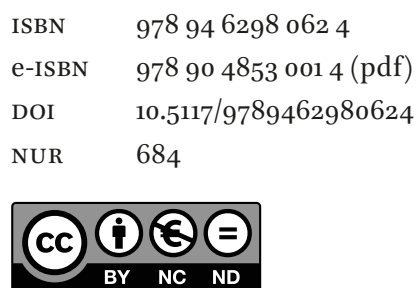

https://creativecommons.org/about/downloads/]

Creative Commons License CC BY NC ND (http://creativecommons.org/licenses/ by-nc/3.0)

@ John Williams \& Therese Martin / Amsterdam University Press B.V., Amsterdam 2017

All rights reserved. Without limiting the rights under copyright reserved above, no part of this book may be reproduced, stored in or introduced into a retrieval system, or transmitted, in any form or by any means (electronic, mechanical, photocopying, recording or otherwise) without the written permission of both the copyright owner and the author of the book.

Every effort has been made to obtain permission to use all copyrighted illustrations reproduced in this book. Nonetheless, whosoever believes to have rights to this material is advised to contact the publisher. 


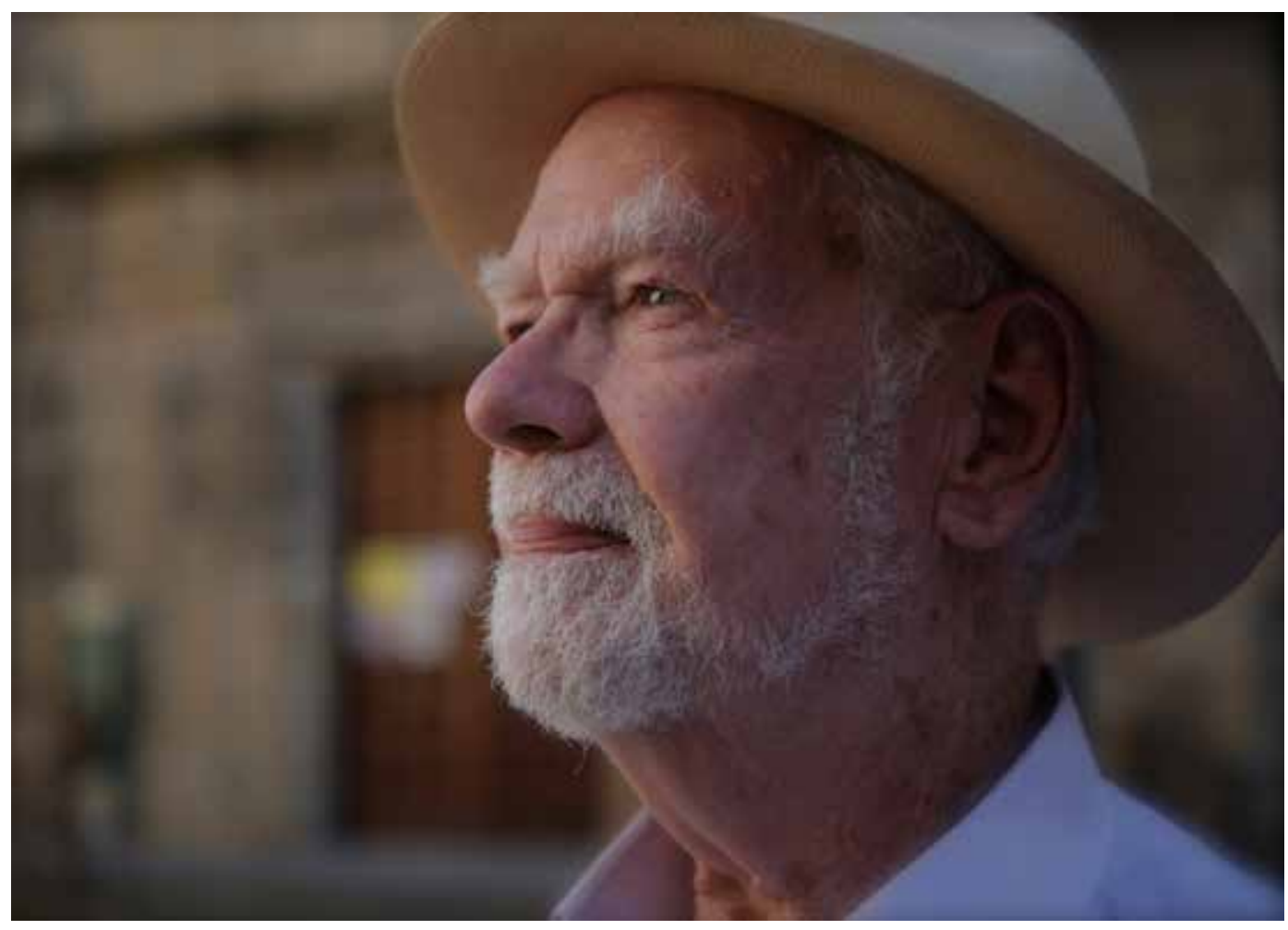

John Williams

Photo: Hamid Shams 


\section{Contents}

$\begin{array}{ll}\text { Editor's Foreword } & 17\end{array}$

$\begin{array}{ll}\text { Acknowledgements } & 19\end{array}$

$1 \quad$ Visions of the End in Medieval Spain $\quad 21$

Introductory Essay

2 The Census $\quad 67$

A Complete Register of Illustrated Beatus Commentaries and Fragments

3 Introduction to the Geneva Beatus $\quad 149$

4 Geneva Illustrations with Apocalyptic Storiae and Analysis of the Images $\quad 167$

$\begin{array}{ll}\text { Appendix } & 269\end{array}$

Geneva Beatus Codicological Construction

$\begin{array}{ll}\text { Bibliography } & 273\end{array}$

Index of People $\quad 285$

$\begin{array}{ll}\text { Index of Places } & 287\end{array}$

$\begin{array}{ll}\text { Index of Subjects } & 289\end{array}$ 



\section{List of Illustrations}

John Williams $\quad 6$

Figure 1 Great Mosque of Córdoba, late tenth century 21

Figure 2 Cathedral of Santiago de Compostela, early twelfth century 21

Figure 3 Map of the World. Morgan Beatus, fols. $33^{\mathrm{v}}{ }^{\mathrm{V}} 34$. New York, The Morgan Library \& Museum, MS M.644 23

Figure $4 \quad$ Family tree of copies of the Commentary (Williams over Gryson)

Figure 5 Relief of Christ with Angels, Quintanilla de las Viñas, late seventh century $\quad 27$

Figure 6 Map of Iberian sites connected to the history of the Beatus Commentary $\quad 27$

Figure $7 \quad$ Santa María (formerly San Salvador) de Tábara, consecrated $1137 \quad 28$

Figure 8 San Miguel de Moreruela, thirteenth century 30

Figure 9 San Miguel de Moreruela, window from time of foundation, c. $900 \quad 31$

Figure 10 Omega. Tábara Beatus, fol. 167. Madrid, Archivo Histórico Nacional, Cod. 1097B 32

Figure 11 Whore of Babylon and a King (Apoc. XVII, 1-3). Vitrina 14-1 Beatus, fol. 137v.

Madrid, Biblioteca Nacional de España, MS Vitrina 14-1 33

Figure 12 Daniel in the Lions' Den. Bible of 96o, León, Real Colegiata de San Isidoro Cod. 2 , fol. $233^{v}$

Figure 13 Daniel in the Lions' Den. Morgan Beatus, fol. 260. New York, The Morgan Library \& Museum, MS M.644

(1)

1
.

(1)

(1)

o
3

Figure 14 Christ in Majesty. Moralia in Iob, Madrid, Biblioteca Nacional de España, Cod.

80, fol. $2 \quad 36$

Figure 15 Silver base of agate casket with Cross and Evangelist symbols, first decade of tenth century. Cámara Santa, Oviedo Cathedral

Figure 16 Adoration of the Lamb (Apoc. IV, 6-V, 14). Morgan Beatus, fol. 87. New York, The Morgan Library \& Museum, MS M.644 38

Figure 17 Christ in Majesty. Silos Beatus, fol. 7 v $^{\mathrm{v}}$. London, British Library, MS Add. $11695 \quad 39$

Figure 18 Christ in Majesty. Bible of 960, León, Real Colegiata de San Isidoro, Cod. 2, fol. 240

Figure 19 Symbols of the Evangelists Luke and John. Biblia Hispalense, c. 900, Madrid, Biblioteca Nacional de España, MS Vitrina 13-1 43

Figure 20 Symbols of the Evangelists Matthew, Mark, and Luke. Bible of 920, León Cathedral, Cod. 6

Figure 21 Initial I. Morgan Beatus, fol. 10. New York, The Morgan Library \& Museum, MS M.644 45

Figure 22 Initial I. Zurich, Zentralbibliothek, MS Car. C 1, fol. $453^{\mathrm{v}}$

Figure 23 Genesis frontispiece. Moutier-Grandval Bible, London, British Library, MS Add. 10546 , fol. $5^{\mathrm{v}} \quad{ }_{46}$

Figure 24 Omega and colophon. Girona Beatus, fol. 284. Museu de la Catedral de Girona, Num. Inv. 7(11) 48 
Figure 25 Adoration; Flight into Egypt and Herod Wounded by his Horse; Herod Bedridden. Girona Beatus, fol. $15^{\mathrm{v}}$. Museu de la Catedral de Girona, Num. Inv. $7(11)$

Figure 26 Simurgh, Eagle, and Gazelle. Girona Beatus, fol. $165^{\mathrm{v}}$. Museu de la Catedral de Girona, Num. Inv. 7(11)

Figure 27 Great Mosque of Córdoba, St. Stephen's Door, 855 Mounted Warrior. Girona Beatus, fol. 134. Museu de la Catedral de Girona, Num. Inv. 7(11)

Figure 30 Bird Attacking a Serpent. Girona Beatus, fol. $18^{v}$. Museu de la Catedral de Girona, Num. Inv. 7(11)

Figure 31 Ivory pyxis of al-Mughira, Córdoba, 968. Paris, Musée du Louvre, OA 4068 Compostela, MS 609 (Res. 1), fol. $6^{\mathrm{v}}$

Figure 34 The Opening of the Fifth Seal: The Souls under the Altar (Apoc. VI, 9-11). Silos Fragment. Silos, Biblioteca del Monasterio de Santo Domingo, frag. 4

Figure 35 The Lamb on Mount Sion (Apoc. XIV, 1-5). Morgan Beatus, fol. 174. New York, The Morgan Library \& Museum, MS M.644

Figure 36 Heavenly Jerusalem (Apoc. XXI, 1-27). Morgan Beatus, fol. 222 ${ }^{\mathrm{v}}$. New York, The Morgan Library \& Museum, MS M.644

Figure 37 The Seven Plague Angels (Apoc. XV, 1-4). Vitrina 14-1 Beatus, fol. 130. Madrid, Biblioteca Nacional de España, MS Vitrina 14-1

Figure 38 The Winepress of God's Wrath (Apoc. XIV, 14-20). Vitrina 14-1 Beatus, fol. $127^{\mathrm{v}}$. Madrid, Biblioteca Nacional de España, MS Vitrina 14-1

Figure 39 The Adoration of the Statue and the Three Hebrews in the Furnace (Dan. III). Valcavado Beatus, fol. 199v. Valladolid, Biblioteca de la Universidad, MS 433

Figure 40 Last Judgment (Apoc. XX, 11-15). Valcavado Beatus, fols. 180 ${ }^{\mathrm{v}}-181$. Valladolid, Biblioteca de la Universidad, MS 433

Figure 41 Tower Scriptorium. Tábara Beatus, fol. 167v . Madrid, Archivo Histórico Nacional, Cod. ${ }_{1097} \mathrm{~B}$

Figure 42 Feast of Baltassar (Dan. V). Tábara Beatus, fol. 143. Madrid, Archivo Histórico Nacional, Cod. ${ }_{1097} \mathrm{~B}$

Figure 43 Descent into Hell. Girona Beatus, fol. $17^{\mathrm{v}}$. Museu de la Catedral de Girona, Num. Inv. 7(11)

Figure 44 Christ in Majesty. Girona Beatus, fol. 2. Museu de la Catedral de Girona, Num. Inv. 7(11)

Figure 45 Genealogical Table X. Vitrina 14-2 Fragment, fol. 1. Madrid, Biblioteca Nacional de España, MS Vitrina 14-2

Figure 46 The Two Witnesses Killed by the Antichrist (Apoc. XI, 7-10). Urgell Beatus, fol. $136^{v}$. Museu Diocesà de la Seu d'Urgell, Num. Inv. 501

Figure 47 Nebuchadnezzar's Dream of the Tree (Dan. IV). Urgell Beatus, fol. 204v. Museu Diocesà de la Seu d'Urgell, Num. Inv. 501 
Figure 48 Vision of the Lamb (Apoc. V, 6-14). San Millán Beatus (Moz.), fol. 92. Madrid, Real Academia de la Historia, Cod. 33

Figure 49 Daniel with the Angels on the Banks of the Tigris (Dan. X). San Millán Beatus (Rom.), fol. $268^{v}$. Madrid, Real Academia de la Historia, Cod. 33

Figure 50 Adam and Eve. Escorial Beatus, fol. 18. Escorial, Biblioteca del Monasterio, \&.II.5 94

Figure $5^{1}$ Satan's Last Attack; Gog and Magog (Apoc. XX, 7-8). Escorial Beatus, fol. 135 . Escorial, Biblioteca del Monasterio, \&.II.5

Figure $5^{2}$ Alpha with Figure of Christ. Facundus Beatus, fol. 6. Madrid, Biblioteca Nacional de España, MS Vitrina 14-2

Figure 53 The Burning of Babylon (Apoc. XVIII, 1-20). Facundus Beatus, fol. $233^{\mathrm{v}}$. Madrid, Biblioteca Nacional de España, MS Vitrina 14-2

Figure 54 Acrostic. Fanlo Beatus, fol. 11. New York, The Morgan Library \& Museum, MS M.1079, fols. 6-12 100

Figure 55 Cross frontispiece. Fanlo Beatus, fol. 10 ${ }^{v}$. New York, The Morgan Library \& Museum, MS M.1079, fols. 6-12

Figure ${ }_{5} 6$ Acrostic. Saint-Sever Beatus, fol. 1. Paris, Bibliothèque nationale de France, MS lat. 8878

Figure 57 The Opening of the First Four Seals: The Four Horsemen (Apoc. VI, 1-8). Saint-Sever Beatus, fols. $108^{\mathrm{v}}$-109. Paris, Bibliothèque nationale de France, MS lat. 8878

Figure $5^{8}$ Victory of the Lamb over the Kings (Apoc. XVII, 14-18). Osma Beatus, fol. $55^{\mathrm{v}}$. Burgo de Osma, Cabildo de la Catedral

Figure 59 Map of the World. Osma Beatus, fols. 34 ${ }^{\mathrm{v}}$-35. Burgo de Osma, Cabildo de la Catedral

Figure 6o Washing of the Feet; Peter's Denial and Last Supper; Kiss of Judas; "legiones angelorum." Turin Beatus, fol. 16. Turin, Biblioteca Nazionale Universitaria, Sgn. I.II.I

Figure 61 Warning Angels and Fall of Babylon (Apoc. XIV, 6-13). Turin Beatus, fol. 146 . Turin, Biblioteca Nazionale Universitaria, Sgn. I.II.I

Figure 62 Man with Viol and Man with Bird. Silos Beatus, fol. 86. London, British Library, MS Add. 11695

Figure 63 Hell. Silos Beatus, fol. 2. London, British Library, MS Add. 11695

Figure 64 The Two Witnesses Killed by the Antichrist (Apoc. XI, 7-10). Corsini Beatus, fol. 126. Rome, Biblioteca dell'Accademia Nazionale dei Lincei e Corsiniana, Segn. 4o.E.6

Figure 65 Appearance of Christ in the Clouds (Apoc. I, 7-8). Corsini Beatus, fol. 155. Rome, Biblioteca dell'Accademia Nazionale dei Lincei e Corsiniana, Segn. 40.E.6

Figure 66 Letter to the Church of Philadelphia (Apoc. III, 7-13). León Fragment, fol. 1. León, Archivo Histórico Provincial, Perg., Astorga 1

Figure 67 Vision of the Lamb (Apoc. V, 6-14). Berlin Beatus, fol. 38. Berlin, Staatsbibliothek Preussischer Kulturbesitz, MS Theol. lat. Fol. $5^{61}$ 
Figure 68 The Woman Clothed in the Sun (Apoc. XII, 1-18). Berlin Beatus, fol. 70. Berlin, Staatsbibliothek Preussischer Kulturbesitz, MS Theol. lat. Fol. $5^{61}$

Figure 69 Noah's Ark (Bk. II). Rylands Beatus, fol. 15. Manchester, John Rylands University Library, MS lat. 8

Figure 70 Babylon (Dan. I, 1; Apoc. XIV, 23). Rylands Beatus, fol. 204. Manchester, John Rylands University Library, MS lat. 8

Figure 71 Adoration of the Magi, Genealogical Table XIV. Cardeña Beatus, fol. 3. New York, Metropolitan Museum of Art

Figure 72 Revelation to St. John (Apoc. I, 1-6). Cardeña Beatus, fol. 4. New York, Metropolitan Museum of Art

Figure 73 Angels Restraining the Winds (Apoc. VII, 1-3). Lorvão Beatus, fol. 118. Lisbon, Arquivo Nacional da Torre do Tombo

Figure 74 The Opening of the Fifth Seal: The Souls under the Altar (Apoc. VI, 9-11). Lorvão Beatus, fol. 112. Lisbon, Arquivo Nacional da Torre do Tombo

Figure 75 Map of the World. Navarre Beatus, fols. $24^{\mathrm{v}}-25$. Paris, Bibliothèque nationale de France, Nouv. acq. lat. 1366

Figure 76 The Two Witnesses Killed by the Antichrist (Apoc. XI, 7-10). Navarre Beatus, fol. $98^{v}$. Paris, Bibliothèque nationale de France, Nouv. acq. lat. 1366

Figure 77 Tower Scriptorium. Las Huelgas Beatus, fol. 183. New York, The Morgan Library \& Museum, MS M.429

Figure 78 The Woman Clothed in the Sun (Apoc. XII, 1-18). Las Huelgas Beatus, fols. 101"-102. New York, The Morgan Library \& Museum, MS M.429

Figure 79 Victory of the Lamb over the Kings (Apoc. XVII, 14-18). Arroyo Beatus. Los Angeles, Getty Center (formerly B.H. Breslauer Coll.)

Figure 80 Last Judgment (Apoc. XX, 11-15). Arroyo Beatus, fol. 16o. Paris, Bibliothèque nationale de France, Nouv. acq. lat. 2290

Figure 81 Millennial Judges and the Souls of the Martyrs (Apoc. XX, 4-6). Rioseco Fragment. Ciudad de México, Archivo General de la Nación, Illustración 4852

Figure 82 San Pedro de León Fragment, fol. $1^{v}$. León, Archivo Parroquial de Santa Marina la Real de León, sig. ASM (SP), Libro de Difuntos, 4

Figure 83 Message to the Church of Laodicea. Milan Fragment, fol. $2^{v}$. Milan, Archivio di Stato, Rubriche notarili 3823

Figure 84 The Opening of the First Four Seals: The Four Horsemen (Apoc. VI, 1-8). Geneva Beatus, fol. 183v . Bibliothèque de Genève, MS lat. 357

Figure 85 The Opening of the Sixth Seal: The Earthquake (Apoc. VI, 12-17). Geneva Beatus, fol. 187. Bibliothèque de Genève, MS lat. 357

Figure 86 Numbering of the Names of the Antichrist: Table I. Vitrina 14-1 Beatus, fol. $121^{\mathrm{v}}$. Madrid, Biblioteca Nacional de España, MS Vitrina 14-1

Figure 87 Numbering of the Names of the Antichrist: Table I. Escorial Beatus, fol. 115. Escorial, Biblioteca del Monasterio, \&.II.5

Figure 88 Devil Chained in the Abyss (Apoc. XX, 1-3). Osma Beatus, fol. $153^{\mathrm{v}}$. Burgo de Osma, Cabildo de la Catedral 
Figure 89 Devil Chained in the Abyss (Apoc. XX, 1-3). Escorial Beatus, fol. 151. Escorial, Biblioteca del Monasterio, \&.II.5

Figure 90 Victory of the Lamb over the Kings (Apoc. XVII, 14-18). Escorial Beatus, fol. 145. Escorial, Biblioteca del Monasterio, \&.II.5

Figure 91 Letter to the Church of Thyatira (Apoc. II, 18-29). Escorial Beatus, fol. $40^{\mathrm{v}}$. Escorial, Biblioteca del Monasterio, \&.II.5

Figure 92 Letter to the Church of Sardis (Apoc. III, 1-6), San Millán Beatus, fol. $72^{\mathrm{v}}$. Madrid, Real Academia de la Historia, Cod. 33

Figure 93 Vision of God Enthroned with the Elders. Escorial Beatus, fol. $57^{\mathrm{v}}$. Escorial, Biblioteca del Monasterio, \&.II.5

Figure 94 Vision of God Enthroned with the Elders, Osma Beatus, fol. $70^{v}$. Burgo de Osma, Cabildo de la Catedral Last Judgment, Osma Beatus, fol. 157 ${ }^{\mathrm{v}}$. Burgo de Osma, Cabildo de la Catedral The Opening of the Sixth Seal: The Earthquake (Apoc. VI, 12-17). Osma Beatus, fol. 89. Burgo de Osma, Cabildo de la Catedral

Figure 97 The Opening of the Sixth Seal: The Earthquake (Apoc. VI, 12-17). Morgan Beatus, fol. 112. New York, The Morgan Library \& Museum, MS M.644

Figure 98 The Opening of the Sixth Seal: The Earthquake (Apoc. VI, 12-17). Berlin Beatus, fol. 5o. Berlin, Staatsbibliothek Preussischer Kulturbesitz, MS Theol. lat. Fol. 561

Figure 99 De rerum naturis by Hrabanus Maurus, Cod. Casin. 132, fol. 73, Archivio dell'Abbazia di Montecassino

Figure 100 Cod. Casin. $442^{\mathrm{I}-\mathrm{II}}$, fol. 12, Archivio dell'Abbazia di Montecassino Cod. Casin. 5, fol. 349, Archivio dell'Abbazia di Montecassino $\quad 165$

Figure 101

Figure 102 Christ in Majesty tympanum, St.-Pierre de Moissac Christ in Majesty. Osma Beatus, fol. 73v . Burgo de Osma, Cabildo de la Catedral 171

Figure 104 The Woman Clothed in the Sun (Apoc. XII, 1-18). Escorial Beatus, fols. 104 ${ }^{\mathrm{v}}$ 105. Escorial, Biblioteca del Monasterio, \&.II.5

Figure 105 The Great Whore and the Kings of the Earth (Apoc. XVII, 1-3). Escorial Beatus, fol. 133. Escorial, Biblioteca del Monasterio, \&.II.5

Figure 106 The Great Whore and the Kings of the Earth (Apoc. XVII, 1-3). Navarre Beatus, fol. 128. Paris, Bibliothèque nationale de France, Nouv. acq. lat. 1366

Figure 107 The Heavenly Jerusalem. Lorvão Beatus, fol. 209v Lisbon, Arquivo Nacional da Torre do Tombo

Figure 108 The Woman on the Beast (Apoc. Prol. Book II.8), Geneva Beatus, fol. 149. Bibliothèque de Genève, MS lat. 357 .

Figure 109 Letter to the Church of Ephesus (Apoc. II, 1-7). Geneva Beatus, fol. 152. Bibliothèque de Genève, MS lat. 357.

Figure 110 Letter to the Church of Smyrna (Apoc. II, 8-11). Geneva Beatus, fol. 154v . Bibliothèque de Genève, MS lat. 357 .

Figure 111 Letter to the Church of Pergamum (Apoc. II, 12-17). Geneva Beatus, fol. $157^{\text {v }}$. Bibliothèque de Genève, MS lat. 357 . 
Figure 112 Letter to the Church of Thyatira (Apoc. II, 18-19). Geneva Beatus, fol. 16o.

Bibliothèque de Genève, MS lat. 357 .

Figure 113 Letter to the Church of Sardis (Apoc. III, 1-6). Geneva Beatus, fol. 162 $2^{v}$.

Bibliothèque de Genève, MS lat. 357 .

Figure 114 Letter to the Church of Philadelphia (Apoc. III, 7-13). Geneva Beatus, fol. 165v . Bibliothèque de Genève, MS lat. 357.

Figure 115 Letter to the Church of Laodicea (Apoc. III, 14-22). Geneva Beatus, fol. 169 . Bibliothèque de Genève, MS lat. 357 .

Figure 116 Initial P, Geneva Beatus, fol. 171 v. Bibliothèque de Genève, MS lat. 357. Vision of God Enthroned with the Elders (Apoc. IV, 1-6). Geneva Beatus, fol. 172. Bibliothèque de Genève, MS lat. 357.

Figure 118 Vision of God Enthroned with the Four Living Creatures (Apoc. IV, 6-V, 14). Geneva Beatus, fol. 174. Bibliothèque de Genève, MS lat. 357 .

Figure 119 The Opening of the First Four Seals: The Four Horsemen (Apoc. VI, 1-8). Geneva Beatus, fol. $183^{v}$. Bibliothèque de Genève, MS lat. 357.

Figure 120 The Opening of the Fifth Seal: The Souls of the Martyrs under the Altar (Apoc. VI, 9-11). Geneva Beatus, fol. 185 $5^{\mathrm{v}}$. Bibliothèque de Genève, MS lat. 357.220

Figure 121 The Opening of the Sixth Seal: The Earthquake (Apoc. VI, 12-17). Geneva Beatus, fol. 187. Bibliothèque de Genève, MS lat. 357 .

Figure 122

The Four Angels of the Winds (Apoc. VII, 1-3). Geneva Beatus, fol. 189. Bibliothèque de Genève, MS lat. 357.

Figure 123 The Sealing of the Elect (Apoc. VII, 4-12). Geneva Beatus, fol. 190. Bibliothèque de Genève, MS lat. 357.

Figure 125 The First Trumpet: Hail, Fire, and Blood (Apoc. VIII, 6-7). Geneva Beatus, fol. 199. Bibliothèque de Genève, MS lat. 357 .

Figure 126 The Second Trumpet: The Mountain Cast into the Sea (Apoc. VIII, 8-9); The Third Trumpet: The Burning Star (Apoc. VIII, 10-11). Geneva Beatus, fol. 200. Bibliothèque de Genève, MS lat. 357.

Figure 127 The Fourth Trumpet: The Darkening of the Sun, the Moon, and the Stars (Apoc. VIII, 12-13). Geneva Beatus, fol. 200v . Bibliothèque de Genève, MS lat. 357.

Figure 128

The Fifth Trumpet: The Star that Falls from Heaven and the Plague of the Locusts (Apoc. IX, 1-6). Geneva Beatus, fol. 201v. Bibliothèque de Genève, MS lat. 357 .

Figure 129 The Angel of the Abyss and the Locusts (Apoc. IX, 7-12). Geneva Beatus, fol. 202. Bibliothèque de Genève, MS lat. 357 .

Figure 130 The Sixth Trumpet: The Angels of the Euphrates (Apoc. IX, 13-16). Geneva Beatus, fol. $202^{\mathrm{v}}$. Bibliothèque de Genève, MS lat. 357.

Figure 131 The Horses of Death and Their Riders (Apoc. IX, 17-21). Geneva Beatus, fol. $203^{v}$. Bibliothèque de Genève, MS lat. 357. 
Figure 132

Figure 133

Figure 134

Figure 135

Figure 136

Figure 137

Figure 138

Figure 139

Figure 140

Figure 141

Figure 142

Figure 143

Figure 144

Figure 145

Figure 146

Figure 147

Figure 148

Figure 149

Figure $15^{\circ}$

Figure ${ }^{15} 1$

The Strong Angel: St. John Eats the Book (Apoc. X, 1 - XI, 2). Geneva Beatus, fol. 204. Bibliothèque de Genève, MS lat. 357.

The Two Witnesses (Apoc. XI, 3-6). Geneva Beatus, fol. 205v . Bibliothèque de Genève, MS lat. 357 .

The Two Witnesses Killed by the Antichrist (Apoc. XI, 7-10). Geneva Beatus, fol. 206 . Bibliothèque de Genève, MS lat. 357 .

The Two Witnesses Ascend into Heaven and an Earthquake Is Produced (Apoc. XI, 11-14). Geneva Beatus, fol. 207. Bibliothèque de Genève, MS lat. 357.

The Angel of the Seventh Trumpet (Apoc. XI, 15-18). Geneva Beatus, fol. $207^{\mathrm{v}}$. Bibliothèque de Genève, MS lat. 357 .

The Temple of the Ark and the Beast of the Abyss (Apoc. XI, $19+$ Bk. VI).

Geneva Beatus, fol. 208. Bibliothèque de Genève, MS lat. 357. Bibliothèque de Genève, MS lat. 357.

Bibliothèque de Genève, MS lat. 357.

Bibliothèque de Genève, MS lat. 357.

fol. 218. Bibliothèque de Genève, MS lat. 357 . fol. 219. Bibliothèque de Genève, MS lat. 357 . fol. 221 ${ }^{\mathrm{v}}$. Bibliothèque de Genève, MS lat. 357 . fol. 222. Bibliothèque de Genève, MS lat. 357 .

The Plague Angels Are Ordered to Empty Their Bowls (Apoc. XVI, 1). Geneva Beatus, fol. 223. Bibliothèque de Genève, MS lat. 357.

Beatus, fol. 223 $3^{\mathrm{v}}$. Bibliothèque de Genève, MS lat. 357. fol. 224. Bibliothèque de Genève, MS lat. 357 .

Beatus, fol. 225. Bibliothèque de Genève, MS lat. 357.

The Fifth Angel Empties His Bowl on the Throne of the Beast (Apoc. XVI 10-11); The Sixth Angel Empties His Bowl on the Euphrates (Apoc. XVI, 12); The Unclean Spirits Like Frogs (Apoc. XVI, 13-16). Geneva Beatus, fol. 225 . Bibliothèque de Genève, MS lat. 357. 
Figure 152 The Seventh Angel Empties His Bowl in the Air (Apoc. XVI, 17-21). Geneva Beatus, fol. 227. Bibliothèque de Genève, MS lat. 357.

Figure 153 The Great Whore Seated upon the Waters (Apoc. XVII, 1-3). Geneva Beatus, fol. $227^{\mathrm{v}}$. Bibliothèque de Genève, MS lat. 357 .

Figure 154 The Woman Seated on the Scarlet Beast (Apoc. XVII, 3-13). Geneva Beatus, fol. 228. Bibliothèque de Genève, MS lat. 357 .

Figure 155 The Victory of the Lamb (Apoc. XVII, 14-18). Geneva Beatus, fol. 231. Bibliothèque de Genève, MS lat. 357.

Figure 156 The Burning of Babylon (Apoc. XVIII, 1-20). Geneva Beatus, fol. 232. Bibliothèque de Genève, MS lat. 357.

Figure 157 The Angel Casts the Millstone into the Sea (Apoc. XVIII, 21-24). Geneva Beatus, fol. $233^{\mathrm{v}}$. Bibliothèque de Genève, MS lat. 357.

Figure 158 The Multitude in Heaven Praise God (Apoc. XIX, 1-10). Geneva Beatus, fols. $234-234^{\mathrm{v}}$. Bibliothèque de Genève, MS lat. 357. 258

Figure 159 The Rider Faithful and True (Apoc. XIX, 11-16). Geneva Beatus, fol. 235. Bibliothèque de Genève, MS lat. 357.

Figure 160 The Angel Standing in the Sun (Apoc. XIX, 17-18). Geneva Beatus, fol. $235^{\mathrm{v}}$. Bibliothèque de Genève, MS lat. 357. 260

Figure 161 The Defeat of the Beast (Apoc. XIX, 19-21). Geneva Beatus, fol. 236. Bibliothèque de Genève, MS lat. 357 .

Figure 162 The Devil Chained in the Abyss (Apoc. XX, 1-3). Geneva Beatus, fol. $236^{v}$. Bibliothèque de Genève, MS lat. 357.

Figure 163 Satan Released and His Last Attack (Apoc. XX, 7-9). Geneva Beatus, fol. 238. Bibliothèque de Genève, MS lat. 357.

Figure 164 The Devil, the Beast, and the False Prophet in the Lake of Fire (Apoc. XX, 9-10). Geneva Beatus, fol. 239v . Bibliothèque de Genève, MS lat. 357.

Figure 165 The Last Judgment (Apoc. XX, 11-15). Geneva Beatus, fol. 240. Bibliothèque de Genève, MS lat. 357.

Figure 166 The Heavenly Jerusalem (Apoc. XXI, 1-27). Geneva Beatus, fol. 241. Bibliothèque de Genève, MS lat. 357.

Figure 167 St. John at the Feet of the Angel of the Apocalypse (Apoc. XXII, 6-21). Geneva Beatus, fol. 244v . Bibliothèque de Genève, MS lat. 357. 


\section{Editor's Foreword}

The five volumes of John Williams's magnum opus, The Illustrated Beatus: A Corpus of the Illustrations of the Commentary on the Apocalypse, came to conclusion in 2003. Throughout the following years, Williams carried on with his research and publications on the Beatus manuscripts, while new works by other scholars appeared, most notably Roger Gryson's 2012 textual analysis of the Beatus Commentary. In the meantime, two heretofore unknown Commentaries came to light, one fragmentary and one nearly complete. A decade after completing The Illustrated Beatus, Williams decided to publish an updated summary of his ideas and conclusions that would take into account these discoveries, gathering together, for the first time ever, all twenty-nine known illustrated copies of the Beatus Commentary on the Apocalypse, and undertaking a comparative analysis within a single volume. Williams offers here his latest considerations on the material, revising and summing up a lifetime of study.
This volume also presents an in-depth look at the recently discovered Geneva Beatus. One of only four Commentaries written outside the Iberian Peninsula, this Italian manuscript closely follows a Spanish model but was written in a Beneventan script and painted in a style dramatically different from the Iberian examples. The Geneva Beatus includes multiple exceptional elements that distinguish it from the rest of the Commentaries. Williams discusses each illustration, highlighting especially Geneva's unique characteristics, with the hope that the present publication will facilitate future studies.

When this book was in the final stages of preparation, John Williams was unable to continue working on it, so he asked me to see it through to completion. It was an honor to collaborate with him on its publication and a pleasure to continue learning from him. He died on 6 June 2015, a few months before the book went to press. When in doubt, I turned to his illustrated Beatus Corpus for clarification. 



\section{Acknowledgements}

The author wishes to thank Juan José García, Murray Grigor, Peter Klein, Barbara McCloskey, Teresa Mezquita Mesa, Pablo Molinero, Fernando Regueras, Roger Reynolds ( $\dagger$ ), Barbara Roth, Barbara Shailor, Hamid Shams, Ana Suárez González, and William Voelkle and The Morgan Library \& Museum. Thanks are due as well to all the institutions who hold the manuscripts illustrated in this book, as noted in the catalogue entries and figure captions.

The editor would like to add her gratitude to Erin Dailey, Simon Forde, Judith K. Golden,
Julie Harris, Pamela Patton, and above all to Shannon Wearing.

Both author and editor gratefully acknowledge support from the University of Pittsburgh's Richard D. and Mary Jane Edwards Endowed Publication Fund, and from the European Research Council under the European Union's Seventh Framework Programme $\left(\mathrm{FP}_{7} /\right.$ 2007- $^{-}$ 2013), ERC grant agreement no. 263036.

All translations are by John Williams unless otherwise indicated. 



\title{
1 Visions of the End in Medieval Spain
}

\author{
Introductory Essay
}

Three remarkable monuments bestow on Spain a preeminent position in the history of medieval art: the Great Mosque of Córdoba, founded in 784 (Fig. 1), the shrine of the Apostle James at Santiago, founded in the ninth century (Fig. 2), and the illustrated copies of the Commentary on the Apocalypse by Beatus of Liébana, the subject of this book.

The origins of the last two enterprises can be linked to a single person, the monk named Beatus. Although we have few details of his life, these two undertakings alone would preserve his name for posterity. Beatus completed his first edition of the Commentary on the Apocalypse

Figure 1 Great Mosque of Córdoba, late tenth century

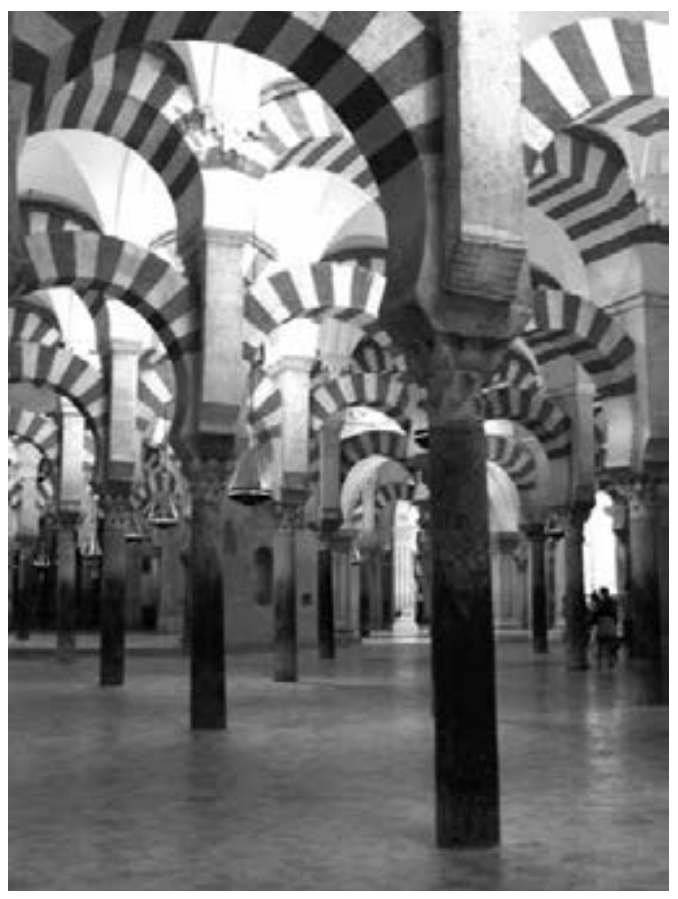

Photo: Therese Martin in the year 776 , and he was present in 785 in the Asturian capital when Adosinda, the widow of King Silo (r. 774-83), took her vows as a nun. He would thus have been known to Alfonso II, the king whose reign from 791 to 842 witnessed the discovery of the tomb of the Apostle James on the western frontier of his kingdom. The association between Saint James and Spain was not a local topic until Beatus in his Commentary credited him with the evangelization of the peninsula. Although Beatus did not speak of James's death and burial, he authored a hymn, "O Dei Verbum," for the predecessor of Alfonso II, King Mauregatus, where James was not only

Figure 2 Cathedral of Santiago de Compostela, early twelfth century

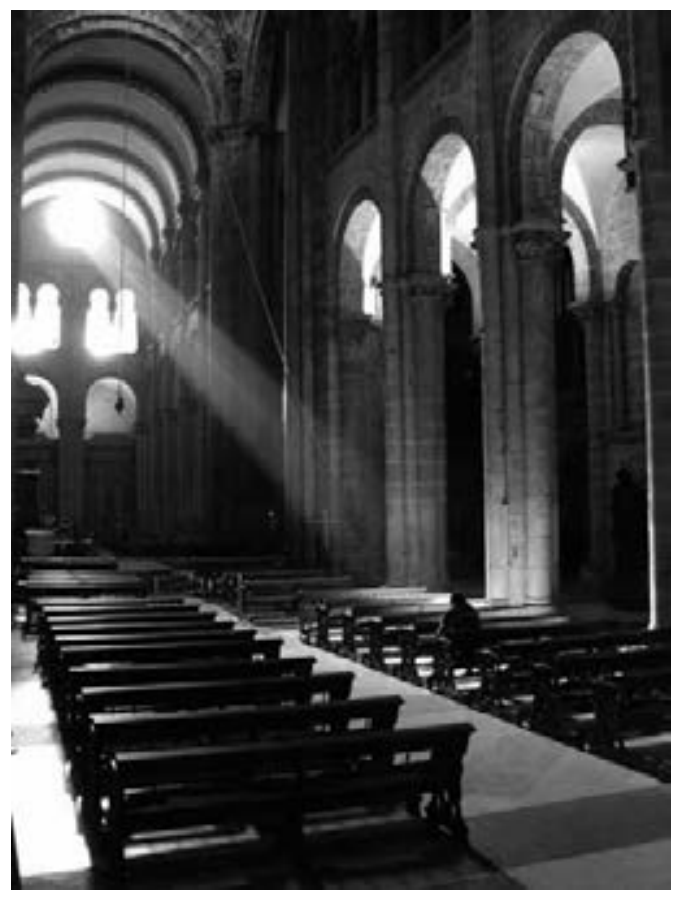

Photo: Jennifer S. Alexander 
identified as the preacher of the Gospel throughout the peninsula, but honored as the patron of Spain as well. ${ }^{1}$ The link between the royal family and Liébana, Beatus's monastery, would continue under Alfonso III, king from 866 to 910. A major expansion of the Compostelan locus sanctus took place when Sisnando, like Beatus a former abbot of Liébana, presided as bishop of Santiago. He oversaw the construction of the new basilica dedicated in 899, the largest church then in Spain. With this history, it is difficult to deny a connection between the writings of Beatus and the discovery of the apostolic tomb, which fostered a pilgrimage that even today brings thousands to Santiago every year.

\section{The Commentary on the Apocalypse}

If the eighth century was a difficult time for a Europe still coming to terms with the collapse of the Roman Empire, for Iberians it was calamitous. Their Christian kingdom disintegrated almost overnight after an army of Berbers led by Muslim Arabs crossed the narrow Strait of Gibraltar in 711 and took possession of rich lands that had supplied the Roman Empire with wheat, olives, wine, and metals, both precious and base. The lands were so integral to the empire that Caesar was a governor there, and the emperors Trajan and Hadrian were among its natives. For the most part, Iberians would remain where they were after the Islamic conquest and gradually assimilate. Although Muslims tolerated Christianity as a religion of the Book, Christians with a religious calling must have chafed under rules designed by their Islamic governors to veil the public face of Christianity. Numbers took the road north to the unoccupied margin behind the Cantabrian range. Among these refugees would have been a monk named

1 González Echegaray 1995, 667ff.

Beatus. We can only guess at his trajectory, but he must have left al-Andalus about the time Abd al-Rahman I (r. 756-88) arrived and made Córdoba his capital. Beatus then settled in Liébana, where he composed his Commentary.

Internal evidence assigns the Commentary a date around 776 . Thus it can be linked, if speculatively, to the prospect of an event even more momentous than the Muslim occupation of most of the peninsula: the end of the world that Christian tradition predicted would take place in the year 800 (Spanish era 838), based on calculations of the earth's age. ${ }^{2}$ Beatus was aware of the Church's official stand against trying to predict the end of time. After all, Jesus himself had warned against such attempts, and earlier predictions had proven wrong. However, Beatus's solemn warning that only a quarter of a century remained before the end must reflect his own belief: "Thus, for all that has been said above every catholic ought to ponder, wait, and fear, and to consider these twenty-five years as if they were no more than an hour, and day and night should weep in sackcloth and ashes for their destruction and the world's." ${ }^{3}$

Beatus composed his work by dividing the text of the Apocalypse or Revelation, the final book of the Bible, into sixty-eight sections, termed storiae. Typically a dozen or so verses, these present the text in its normal sequence. Each storia was followed by a series of exegetical passages - the explanatio - which interpret in allegorical and anagogical terms each of the verses or figures in the storia. Between the storia and its interpretation copied from a variety of sources, Beatus for the first time inserted an illustration that was essentially a pictorial reprise of the Apocalyptic narrative just above it. The Commentary itself was a collage of allegories and symbolic interpretations that would have been virtually impossible

Williams 1994a, 103ff. Gryson 2011; Gryson 2012, II: 523. 
Figure 3 Map of the World. Morgan Beatus, fols. 33ㄴ-34. New York, The Morgan Library \& Museum, MS M.644

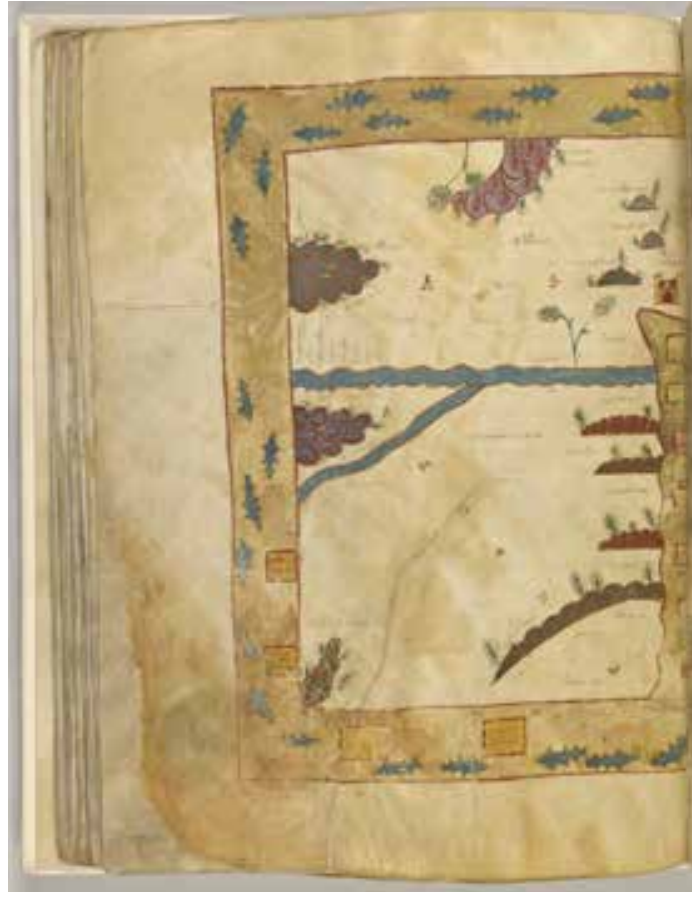

Photo: Joseph Zehavi

to present coherently in pictorial form, given the poetic, visionary language of John's Revelation.

A prominent exception to the Apocalyptic content of Beatus's Commentary was the map of the world present from the beginning (Fig. 3). ${ }^{4}$ It was prompted by Beatus's inclusion of De apostolis from Isidore of Seville's Etymologiae (Bk. VII, 9, 1-4), along with a short portion of the "Birth and Death of the Fathers" (De ortu et obitu patrum) sometimes attributed to Isidore, in which the Apostle James's mission was to convert Hispania. Probably based on a formula inherited from Late Antiquity, the map, spread across two pages, was one of the most all-encompassing to survive from the

4 For the map, see Saénz-López 2014a and Williams 2014. Crucial questions regarding the history of the map have not been resolved.

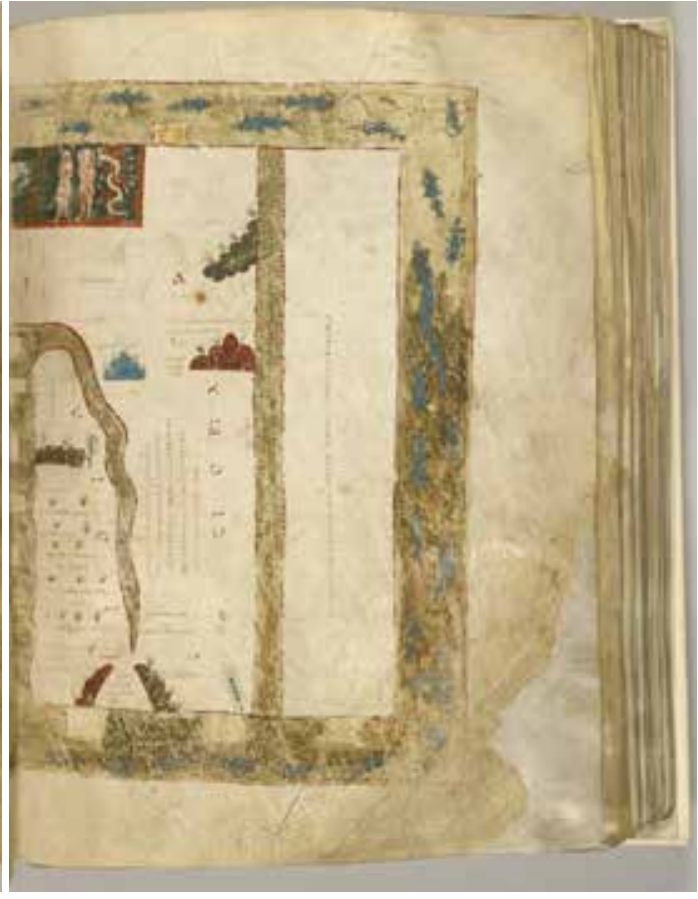

first millennium. ${ }^{5}$ Adam and Eve preside over Paradise, which appears in the premier locale at the top (direction east). This is the habitable world of Asia, Europe, and Africa above the equator, the world that in the Book of Genesis was divided among Noah's sons, Shem (Asia), Ham (Africa), and Japeth (Europe), with the ocean surrounding it.

\section{The Illustrated Commentary}

Most historians have assumed that the images in the first illustrated Commentary would not have been invented by Beatus or some scribal colleague, but appropriated from an inherited manuscript of the Apocalypse. 
However, surviving Apocalyptic imagery offers no counterpart for the illustrations, ${ }^{6}$ for the content of each Beatus picture was dictated by the storia just above it, and thus generated particular compositions unmatched in other traditions.

The texts of these storiae were borrowed from a commentary on the Apocalypse written in the second half of the fourth century by the North African writer Tyconius; ${ }^{7}$ one might therefore postulate a lost illustrated Tyconius as a model for Beatus's work. Despite the complete lack of surviving examples, claims for "lost models" played a significant role in the twentieth-century historiography of medieval illumination, and depressed the appreciation of invention in new works. In the case of the illustrated Beatus Commentary, a parallel tradition of original biblical illustration in northern Spain provides an additional reason for recognizing inventiveness in Spanish manuscript production: in the middle of the tenth century at the Castilian monastery of Valeránica, the scribe Florentius created a Bible with some ninety pictures placed next to the passages that provided their inspiration. ${ }^{8}$ This fact, together with my growing skepticism of the doctrine that medieval imagery was always based on some earlier model, eventually led me to reject my former assumption of a Tyconian model for the illustrations in favor of the originality of the images composed by Beatus for his Commentary. ${ }^{9}$ However, it may be that the Commentary subsequently served as an inspiration for Florentius's illustrated Bible, for, as we shall see, there is reason to think that Florentius himself was responsible for a copy of the Commentary. In any case, I am less certain

$6 \quad$ Klein 1992.

7 Gryson 2011; Gryson 2012, I, XVIII, CXXXVII.

8 Williams 1999b; Díaz y Díaz 1999; Williams 2012b. 9 Williams 2003a, 110-11. today that Beatus would have conceived an illustrated Commentary without a Tyconian model, for the storiae - the quotations from the Apocalypse that precede each illustration and essentially define their content - are virtual captions for the pictures. The challenging question of what inspired the inclusion of illustrations is too important to close; it is my hope that future generations of scholars will delve further into this matter.

The decision to incorporate a multitude of illustrations is perhaps the most surprising aspect of the enterprise. Beatus himself may never even have seen an illustrated book. Certainly none from the peninsula survives from so early a date, and claims for their existence lack real evidence. The oldest Iberian manuscript with an image, an orational now in Verona, dates from around the time of the Muslim invasion of 711 ; it has a drawing of a wind rose of the type associated with Isidore's De natura rerum, with personifications of the winds. ${ }^{10}$ Helmut Schlunk once argued for the existence of a Visigothic tradition of biblical illumination, in part on the basis of a comparison between the Offering of Isaac in the Bible of 960 and a similar iconography on a capital in the seventh-century church of San Pedro de la Nave. ${ }^{11}$ Whatever the origin of Beatus's decision to illustrate his Commentary, it resulted in the most densely illustrated Latin text of any Christian exegetical work up to that point. Ultimately, it was the pictorial cycle rather than Beatus's text that conferred upon him a fame that would endure to our own time, and in places not known to exist when he wrote.

Given the integral relationship of text and picture in the Beatus tradition and the uniformity of imagery and format through the centuries, scholars have assumed that the

10

11

Williams 1977, 10-11.

Schlunk 1945 . 
Figure 4 Family tree of copies of the Commentary (Williams over Gryson)

\section{Family Tree of the Illustrated Beatus}

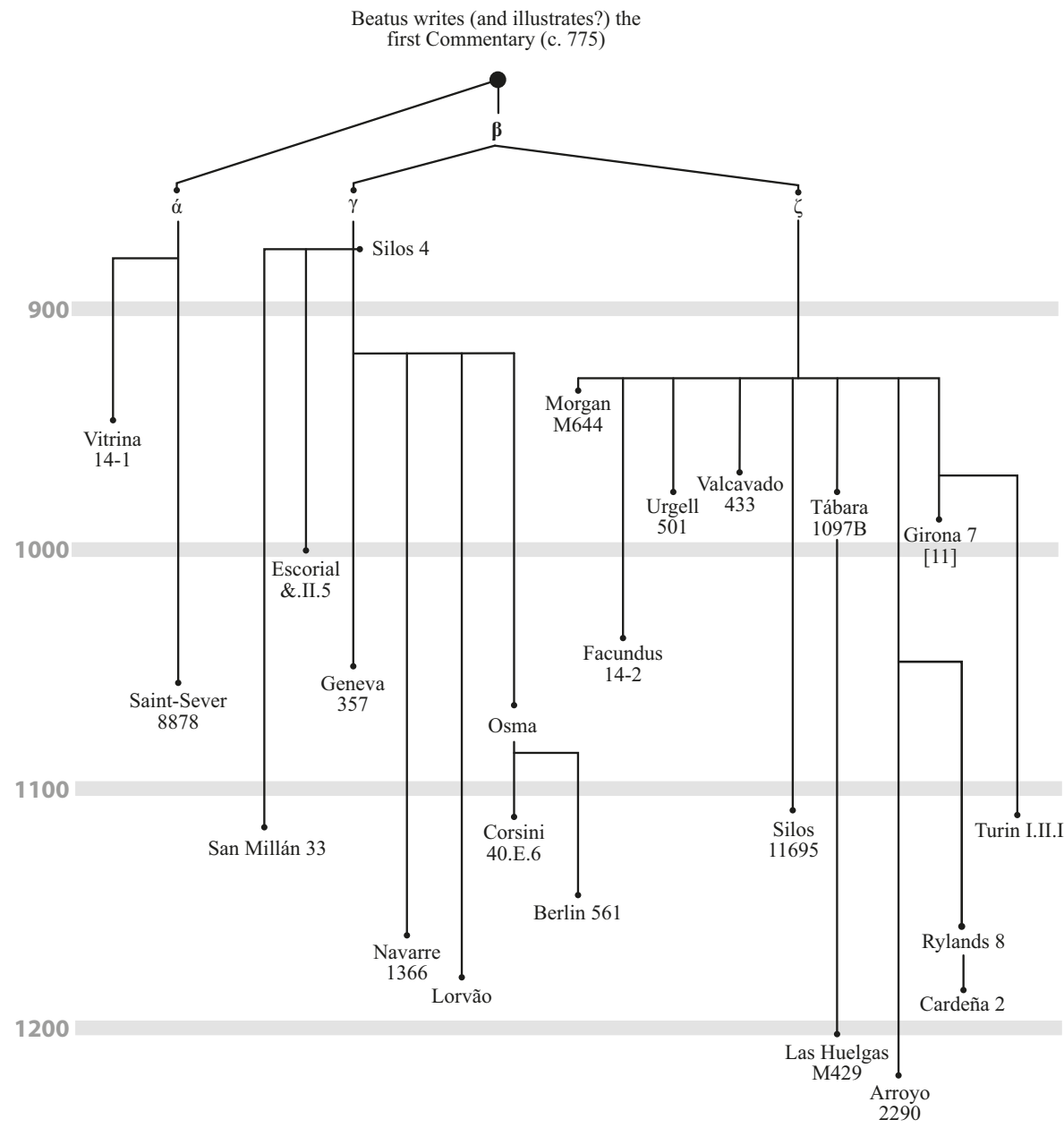

1300

Commentary was illustrated from the beginning. Roger Gryson, the editor of the latest and most authoritative edition of the Commentary, states definitively that "it is certain that the author never conceived of his work as other than illustrated." ${ }^{\prime 2}$ It can only be imagined that the illustrations were considered partners in the "reading" of the Apocalyptic narrative that appeared just above them. In the famous 12 Gryson 2012, I: XVIII. 
admonition Pope Gregory the Great (d. 604) made to a bishop who had scandalized believers by removing biblical paintings from a church to avoid idolatry, the pope said that pictures tell a story (historia), just as words do. ${ }^{13}$ Both the storiae of the Beatus Commentary and its pictures were designed to fix in the brothers' minds the message that God would mete out justice, punishing those who rebelled against him and rewarding the righteous, albeit after severe challenges.

As we shall see, post-medieval marginal glosses confirm that the Commentary was read aloud in a monastic setting during meals in the refectory, a practice that presumably dated from much earlier. ${ }^{14}$ Thus, as the monks consumed their daily meals, they would have meditated on the transcendent events that were just beyond the horizon.

\section{The Beatus Tradition: In the Beginning}

Although the first Beatus Commentary does not survive, the descent of the tradition through time has left us with forty-one witnesses, some mere fragments. ${ }^{15}$ Of the surviving manuscripts, the twenty-nine with illumination are described in the complete census gathered here for the first time; each is referred to parenthetically according to its

13 Carruthers 1990, 222-23; Miranda, C. 1998, 339-49. 14 The Commentary was not useful liturgically, for it divided the text of the Apocalypse in a way that did not correspond to the Easter readings of the mass in the Hispanic rite. However, a Silos lectionary (London, BL, MS Add. 30848) for the Roman rite appropriated Apocalyptic texts from the Commentary for readings on the four Sundays after the Easter octave. See Walker 1998,88 .

15 Gryson 2012, I: XIV-XVI. To this should be added a fragment in Milan, No. 28 in this volume's census. census number. Taking into account the presumed copies posited by the family tree of the texts (Fig. 4), at least 100 complete manuscripts may have been executed. ${ }^{16}$

Wilhelm Neuss, the original master of the illustrated Commentary's history, composed a family tree of illuminated copies according to which there was an earlier Branch I, closest to the original text, and a Branch II, subdivided, that arose in the tenth century. ${ }^{17}$ Neuss's genealogy has stood the test of time, albeit with modifications resulting from more precise analyses culminating in Gryson's 2012 critical edition.

The oldest witness to the tradition, the fragment now at the Castilian monastery of Santo Domingo de Silos (No. 1), is dated by the style of its script and illustration to the last quarter of the ninth century, about a century after Beatus composed the original. It came to Silos in the eighteenth century from Nájera. Although no earlier illustrated manuscripts survive from the Iberian peninsula, the color palette and ornamental details of the fragment recall manuscripts written during the reign of Alfonso III (d. 910) of Asturias, Beatus's home territory. If the Silos Commentary was Asturian in origin, or if it was slavishly copied from an Asturian model by someone with little experience, as it seems, then it is the Commentary with the closest ties to the region where the archetype originated.

Neuss imagined that the original Beatus resembled the Commentary copied in the middle of the eleventh century at the Gascon monastery of Saint-Sever-sur-l'Adour (No. 13). While it is true that the Saint-Sever Beatus employs the original edition of the text, its relatively naturalistic style, so attractive to Neuss,

16 "The history of the text [...] obliges us to suppose that there were as many lost examples as those that survive," Gryson 2012, XVIII.

17 Neuss 1931. 
Figure 5 Relief of Christ with Angels, Quintanilla de las Viñas, late seventh century

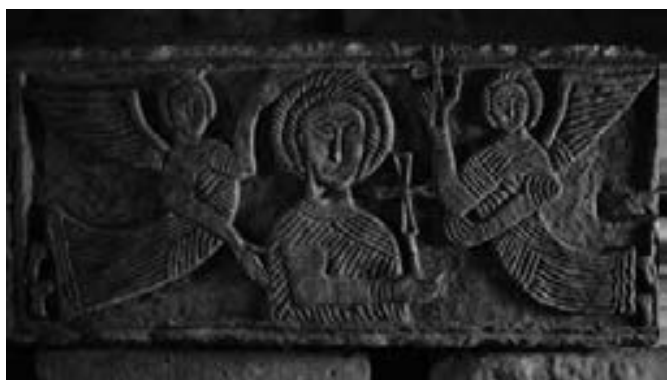

Photo: Hamid Shams

owes its character to an emerging Romanesque aesthetic. By the seventh century, however, peninsular style had already transformed from a Late Classical aesthetic into a more abstract medieval style, as confirmed by figural reliefs like those in the church of Quintanilla de las Viñas (Fig. 5). The schematic treatment of figures and space in the Silos fragment is almost certainly closer to the style of Beatus's original illustrator than the sophisticated illusionistic techniques employed by Garsia, the artist-scribe responsible for the Saint-Sever Beatus. Indeed, it is apparent that the latter's primitive text is accompanied by a set of images belonging to the tenth-century evolution of the illustrations.

\section{Monasteries and Scriptoria}

The premier sites in the dissemination of Beatus's Commentary after it was launched from Liébana were all in north-central Spain (Fig. 6), in the kingdoms of León, Castile, and Aragon.

Figure 6 Map of Iberian sites connected to the history of the Beatus Commentary

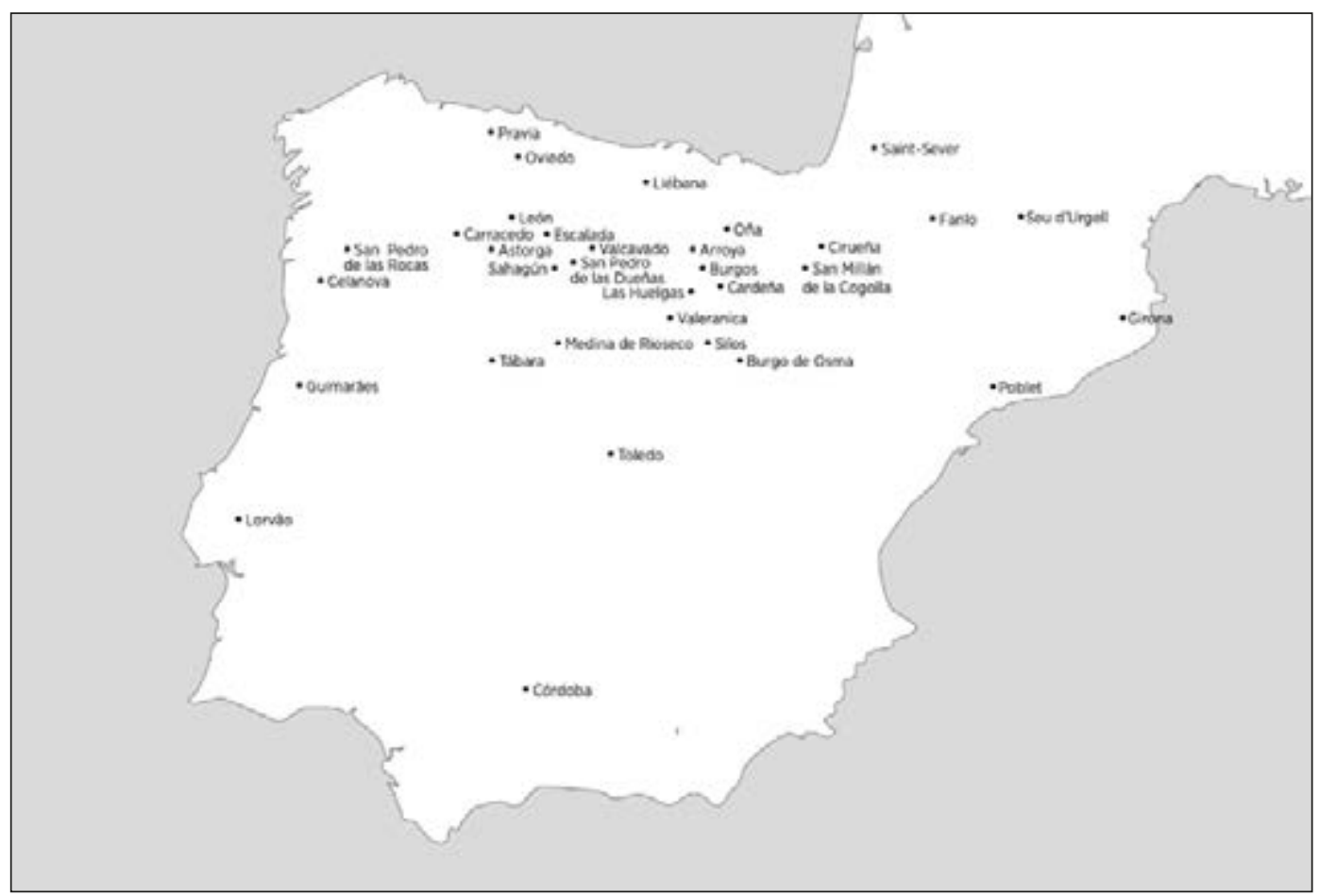

Map: Amelia Williams 
Strangely enough, none of the surviving copies originated in the region that sheltered Liébana, although, as we saw, the ornament and color of the Silos Commentary (No. 1), the earliest example, is linked to manuscripts from the Asturian region. Beatus's Commentary was born in a monastery, and nurtured by monastic and conventual culture throughout its history. As the original dedication of the Commentary states, it was designed for "the edification of the brothers." Some of these monasteries would have a special place in the history of the Commentary, themselves producing copies for other foundations into the thirteenth century.

Not all monasteries had a scriptorium, a space set aside for the copying of books. In the Beatus tradition, three are especially worthy of close attention because each produced multiple copies: Tábara, Sahagún, and San Millán de la Cogolla. San Salvador de Tábara had one of the most important, having produced at least six copies: three survive and three others are implied by the family tree of texts (see Fig. 4). Indeed, the illustrators of the Tábara Beatus of 970 (No. 5) honored their scriptorium in an extraordinary manner by including a portrait of it (see Fig. 41), the only such image from early medieval Europe. The scriptorium is attached to one side of a five-story bell tower whose masonry construction is indicated by the convention of a pattern of polychromed blocks. This early medieval tower may still survive, wrapped within the twelfth-century tower of the church of Santa María at Tábara, which replaced San Salvador (Fig. 7). In the painted image, it is topped off by a tile roof with two projecting belfries, a bell suspended in each. The tower is populated to a surprising extent: four men, of lay status to judge by their dress, occupy the wooden ladders that provide a means of communication between the floors, while another figure at ground level handles the ropes that allow

\section{Figure 7 Santa María (formerly San Salvador) de Tábara, consecrated 1137}

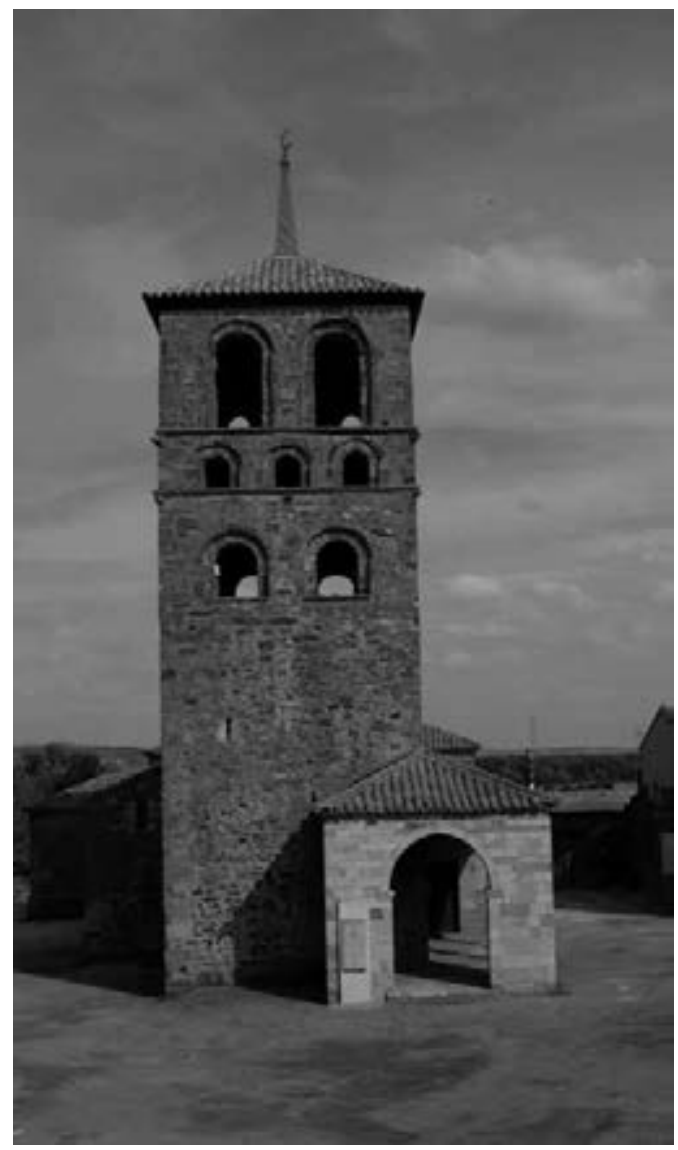

Photo: Hamid Shams

one of the bells to be rung. In the scriptorium are two scribes dressed as monks: the one on the right wearing the larger hat is identified as Emeterius, the other as Senior. Each holds with one hand what appears to be a book or a page attached to some support; with the other hand each applies a long pen or stylus to the surface. In an adjacent room another seated figure cuts the skin of a sheep or calf with a pair of shears, an earlier stage in the process of producing a manuscript. No windows are represented, but the space must have been well lit. 
The scriptorium depicted in the Tábara Beatus is a modest studio in comparison to the space allotted on the ninth-century plan of St. Gall in Switzerland, our earliest graphic witness to scriptorial space. ${ }^{18}$ The plan dedicates a generous upper area of 1600 square feet, reached by a monumental set of masonry steps, to the copying of books. Within are seven desks, illuminated by seven windows; each desk is large enough to serve a pair of scribes. St. Gall's idealized (though realistically conceived) plan includes sleeping accommodations for just over 100 monks plus some 130 to 150 servants. At Tábara, the writing room is also depicted as being on the second level, but is a far smaller and more cramped wooden structure communicating with ground level by means of a ladder. Yet if we accept the account in the Life of Froilanus, who founded Tábara around 9oo, this monastery housed "6oo souls devoted to God." ${ }^{19}$ Since this was a duplex foundation, this number would have included both monks and nuns; male and female lay figures, such as servants and laborers, could also have been included. Even so, it is an incredible number. As we shall see, Tábara's scriptorium played a seminal role in the history of the Beatus tradition.

Summer was an ideal time for writing and painting. The Beatus Commentary that was copied in 970 at Valcavado (No. 4) seems to have been largely the work of a single monk, Obecus, whose colophon states that the copy was completed between 8 June and 8 September. If a dozen Sundays are subtracted, he wrote the book's 230 folios in 79 days at a rate of at least two and a half folios per day, an impressive achievement. Although Obecus did not complain of the physical cost of this

18 Horn and Born 1979, I: 145-55; www.stgallplan.org/ en/index_plan.html.

19 Williams 2011a, 17. intensive labor, some of his colleagues did. Two decades earlier the eminent scribe Florentius of Valeránica, a key figure in the development of the Beatus tradition carried out by Maius of Tábara, penned a poetic lament in the colophon of the Book of Homilies by Smaragdus:

A man who knows how to write may think this no great feat. But only try to do it yourself and you shall learn how arduous is the writer's task. It dims your eyes, makes your back ache, and knits your chest and belly together - it is a terrible ordeal for the whole body. So, gentle reader, turn these pages carefully and keep your fingers far from the text. For just as hail plays havoc with the fruits of spring, so a careless reader is a bane to books and writing. ${ }^{20}$

\section{San Salvador de Tábara}

In the following sections, our focus turns to the scriptoria and individual artists whose activities are most important to the development and long chronology of the Beatus manuscripts, beginning with the critical significance of Tábara. It was at Tábara that the Beatus Commentary underwent a pictorial reformation that granted it a second life, and in turn offered posterity a splendid new chapter in the history of book illustration. Although we celebrate the eminence of Tábara on the basis of the three copies that survive, the textual stemma, as noted, testifies to another three now lost. The author of the seminal revision of the format was in all probability a monk named Maius (or Magius). He was responsible for the oldest surviving complete

20 Nordenfalk in Grabar and Nordenfalk 1957, 168. This would be repeated verbatim in 1091 by Munnius in a Beatus Commentary written at Santo Domingo de Silos (No. 16). Such laments were a part of European scribal traditions. 
copy, today in the Morgan Library \& Museum in New York (No. 2). Its colophon reveals that it was made for a monastery dedicated to St. Michael. The prevailing assumption is that this was San Miguel de Escalada, founded in 913 by monks from Córdoba, and that Maius must have headed its scriptorium; this identification is based on the fact that at one time the Morgan Commentary was in Escalada, for on folio $293^{\mathrm{v}}$ is a note in fourteenth-century script reading Obiit Petrus levita CSR. ${ }^{21}$ This reference to the death of a canon of San Rufe has been explained by the fact that in 1156 the monks of Escalada were replaced by canons of Saint-Rufe d'Avignon. It should be noted, however, that around 9oo, when Froilanus of León founded San Salvador de Tábara, he also founded San Miguel de Moreruela just six kilometers to the southeast (Figs. 8, 9). ${ }^{22}$ There is a strong circumstantial case to be made that Maius copied his text at Tábara for this sister monastery of Moreruela and not for Escalada, as we have no evidence otherwise of contact between Tábara and Escalada. Moreruela would have been destroyed when the Muslim general al-Mansur (also known as Almanzor, d. 1002) raided this area of Zamora at the end of the tenth century. If the Beatus Commentary were at Moreruela, it would have been relocated at that time to another monastery in the kingdom of León. Its eventual home at Escalada could well have been made possible by the fact that the royal daughters of the Leonese throne, by way of the inheritance termed the infantazgo, came into possession of the monasteries of the kingdom with all their goods. Documentary evidence testifies to gifts awarded by the infantas of León to the monastery of Escalada on more than one occasion.

21 García Lobo 2005, 58-65.

22 Ferrero Gutiérrez 2011; Williams 2011a, 3off.
Figure 8 San Miguel de Moreruela, thirteenth century

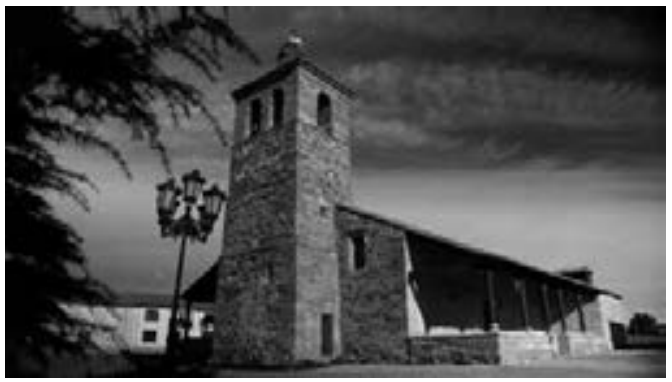

Photo: Hamid Shams

What we know of Maius comes from the extraordinarily informative colophon beneath the grand Omega (Fig. 10) at the end of a Commentary completed at Tábara by his disciple, Emeterius, in 970 (No. 5):

$\mathrm{O}$ truly blessed man, whose body lies in a coffin in the cloister and who wished to see the book brought to completion and bound. This was Magius, priest and monk, the worthy master-painter. He gave up the work he began when he went eternally to Christ on the feast of St. Faustus, the third day before he departed out of time, era 1006 [AD 968]. Then I, the priest Emeterius, formed by my master Magius, was called to the monastery which was raised under the protection of the Savior when they wished to complete the book for the most exalted Lord, and I took it up once more. From the kalends of May to the 6th kalends of August, I completed the book in all its authority. May he deserve to be crowned with Christ. Amen. O tower of Tábara, tall and of stone, the first place where Emeterius sat for three months bent over and with all his limbs maneuvered the pen. The book was finished the 6th kalends of August era 1008 [AD 970] [in the ninth hour]. ${ }^{23}$

23 Pérez 2010, 224-26. 
Figure 9 San Miguel de Moreruela, window from time of foundation, c. 900

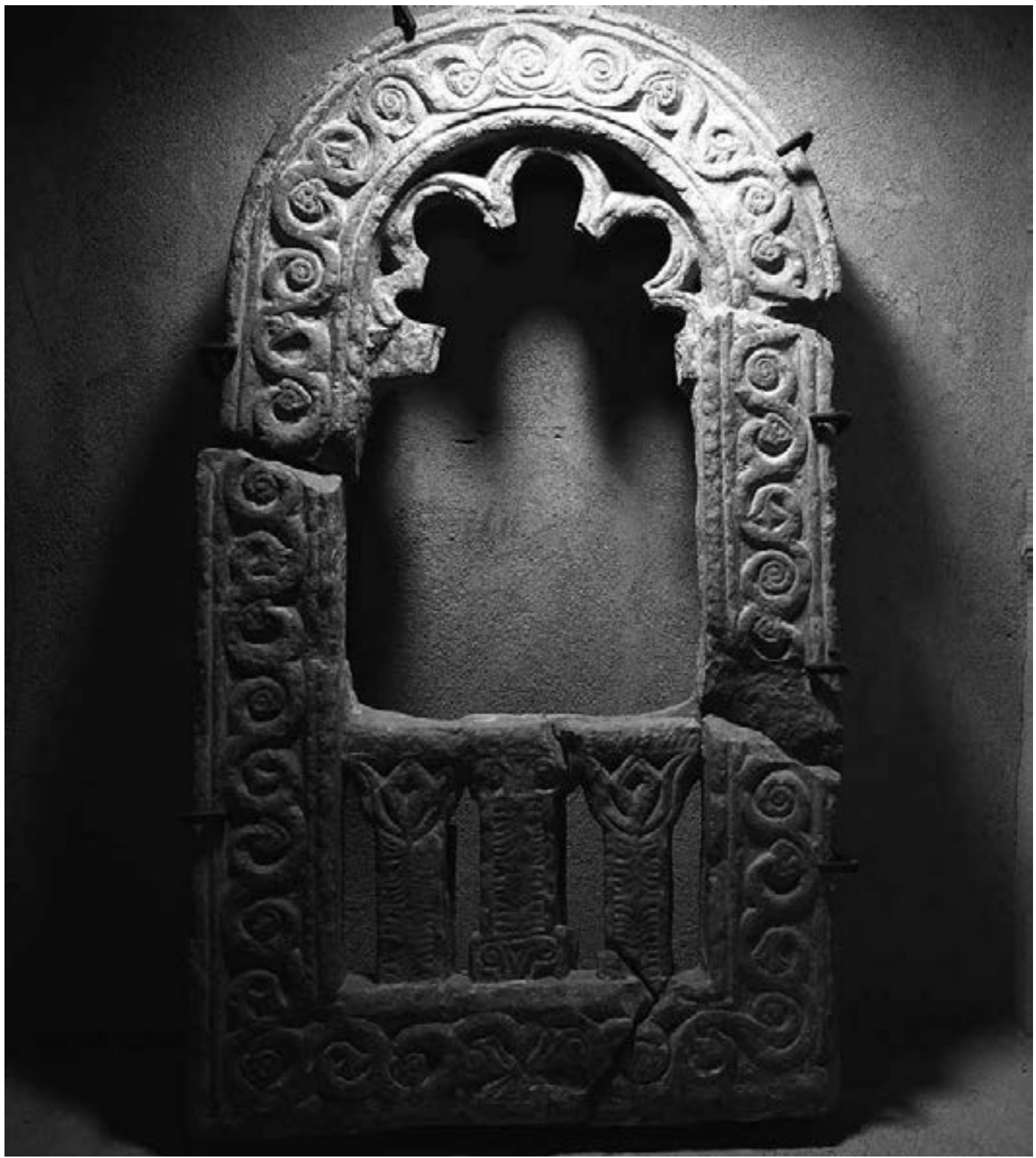

Photo: Hamid Shams

The Tábara Beatus is a poor relic of its original state, but invaluable in providing us a glimpse of its scriptorium together with details about Maius and the manuscript's production. Thanks to Peter Klein's analysis of the pictorial tradition of the Commentaries, we know that full-page and double-page pictures, as well as the systematic use of frames and painted backgrounds, were not part of the earliest stage of the tradition. ${ }^{24}$ By correlating textual edition

24 Klein 1976. 
Figure 10 Omega. Tábara Beatus, fol. 167. Madrid, Archivo Histórico Nacional, Cod. 1097B

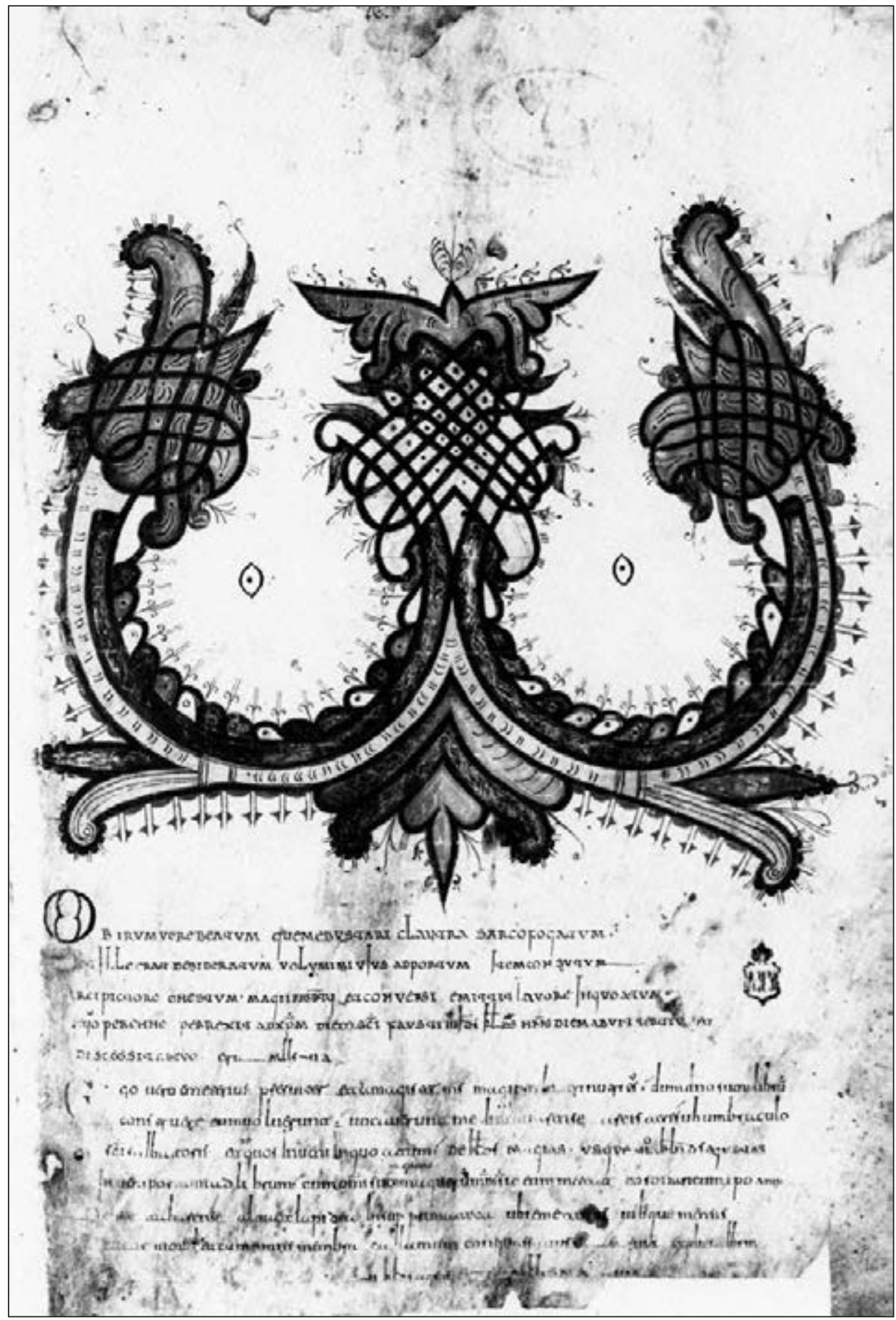

Photo: John Williams 
Figure 11 Whore of Babylon and a King (Apoc. XVII, 1-3). Vitrina 14-1 Beatus, fol. 137. Madrid, Biblioteca Nacional de España, MS Vitrina 14-1

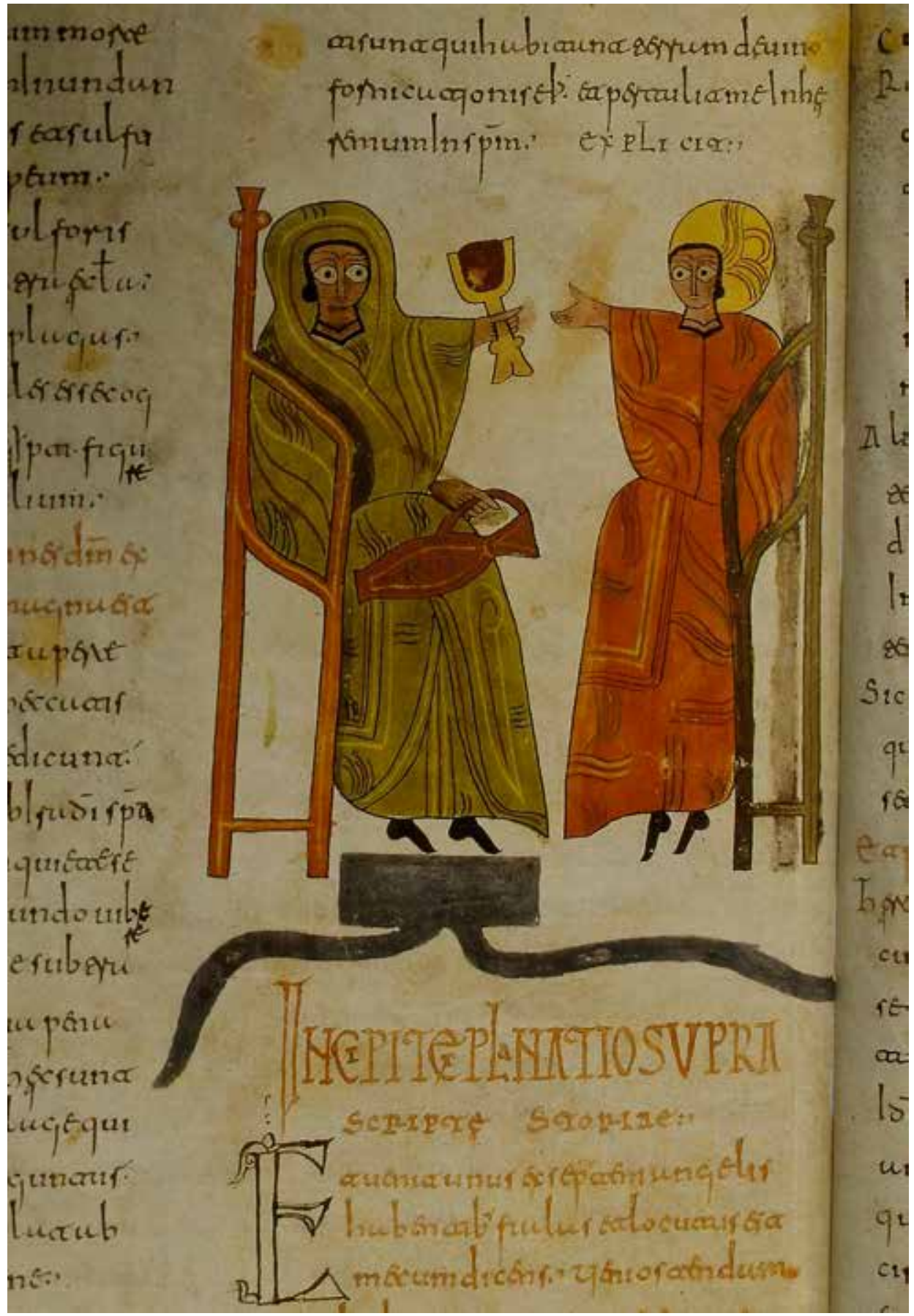

Photo: Hamid Shams 
and pictorial content, Klein encountered a consistency that allowed him to attach formats and iconographies to the progressive editions of the text. The initial stage of the tradition would have introduced the basic core of seventy-four Apocalyptic subjects composed essentially as they are found in all of the Commentaries regardless of date, but as pictures scarcely wider than the text columns in which they were inserted, and without frames or painted grounds (Fig. 11). The Morgan Beatus (No. 2) is the earliest surviving Commentary to display the opulent format associated with this phase of the illuminated Beatus tradition. Large framed illustrations, often filling an entire page or, for the very first time in the history of illustrated books, stretching across adjacent pages, are posed against the polychromatic striped backgrounds that characterize the socalled Mozarabic style of illumination.

At the same time, Maius decided to augment significantly the pictorial content by adding new subjects. This iconographic expansion was made possible by the tradition of biblical illustration invented contemporaneously by Florentius. Based at Valeránica in Castile (some 150 miles to the east of Tábara), Florentius is the only character in the history of early medieval Spanish manuscripts to rival Maius as a revolutionary scribe/painter. ${ }^{25}$ Florentius's Bible gave Maius the images of the Evangelists with witnesses paired with angels presenting the Gospels, which appear at the beginning of the manuscript. Known as the León Bible of 960 (León, Real Colegiata de San Isidoro, Cod. 2), this was also the source of Maius's preface with genealogical tables distributed over the following fourteen pages (see Fig. 45), where the family tree of Jesus is enumerated in a chain of linked circles comprising some 600 names. In

25 Williams 1970; Díaz y Díaz 1999, 56-58; Williams 1999a; Williams 2012a, 351-54. combination with portraits of such important ancestors as Adam, Noah, Abraham, and David, the genealogy of pre-Christian history was here divided roughly into four ages, culminating in a depiction of the Adoration of the Magi (see Fig. 71). The 96o Bible also supplied eleven scenes illustrating St. Jerome's Commentary on the Book of Daniel, which was appended to the back of Maius's book - perhaps Daniel's first appearance in a Beatus manuscript (Fig. 12). Since the set of Daniel illustrations in Florentius's Bible was more complete, these images were clearly appropriated for the Commentary (Fig. 13). This borrowing of Evangelist portraits, genealogical tables, and Daniel pictures for Maius's newly revised Commentary on the Apocalypse is not the only evidence for contact between Maius and Florentius. The Moralia in Iob completed in 945 by Florentius, now in the Biblioteca Nacional in Madrid (Cod. 80), includes an illustration of Christ in Majesty based on a combination of prophetic visions from Isaiah, Ezekiel, and the Apocalypse, with cherubim holding the heavenly glory that surrounds Christ while the animals symbolizing the Evangelists seem to converse below (Fig. 14). Although this was a prominent theme elsewhere in Europe, it is the first known Majesty picture from the Iberian Peninsula. Combining animal heads with human bodies, moreover, is a particularly Spanish treatment of the four Evangelists. That formula, as well as the disks with whorl patterns that support these figures, had appeared a half century earlier on two gilt silver reliquary caskets, gifts from the Asturian royal family to the cathedrals of Oviedo and Astorga (Fig. 15). ${ }^{26}$ More to the point, the whole composition assembles elements that resemble remarkably the Adoration of the Lamb in Maius's Beatus, held by the Morgan Library \& Museum (Fig. 16; no. 2).

26 Art of Medieval Spain 1993, 143-45. 
Figure 12 Daniel in the Lions' Den. Bible of 960, León, Real Colegiata de San Isidoro Cod. 2, fol. 233v

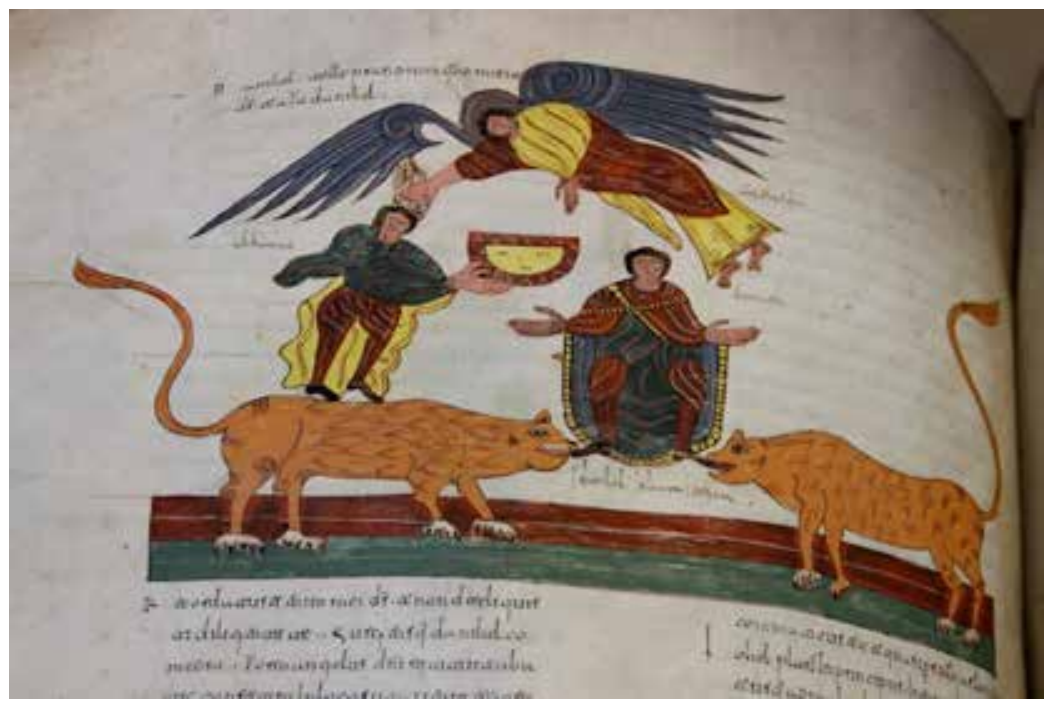

Photo: Fernando Ruiz Tomé, @ Museo San Isidoro de León

Figure 13 Daniel in the Lions' Den. Morgan Beatus, fol. 260. New York, The Morgan Library \& Museum, MS M.644

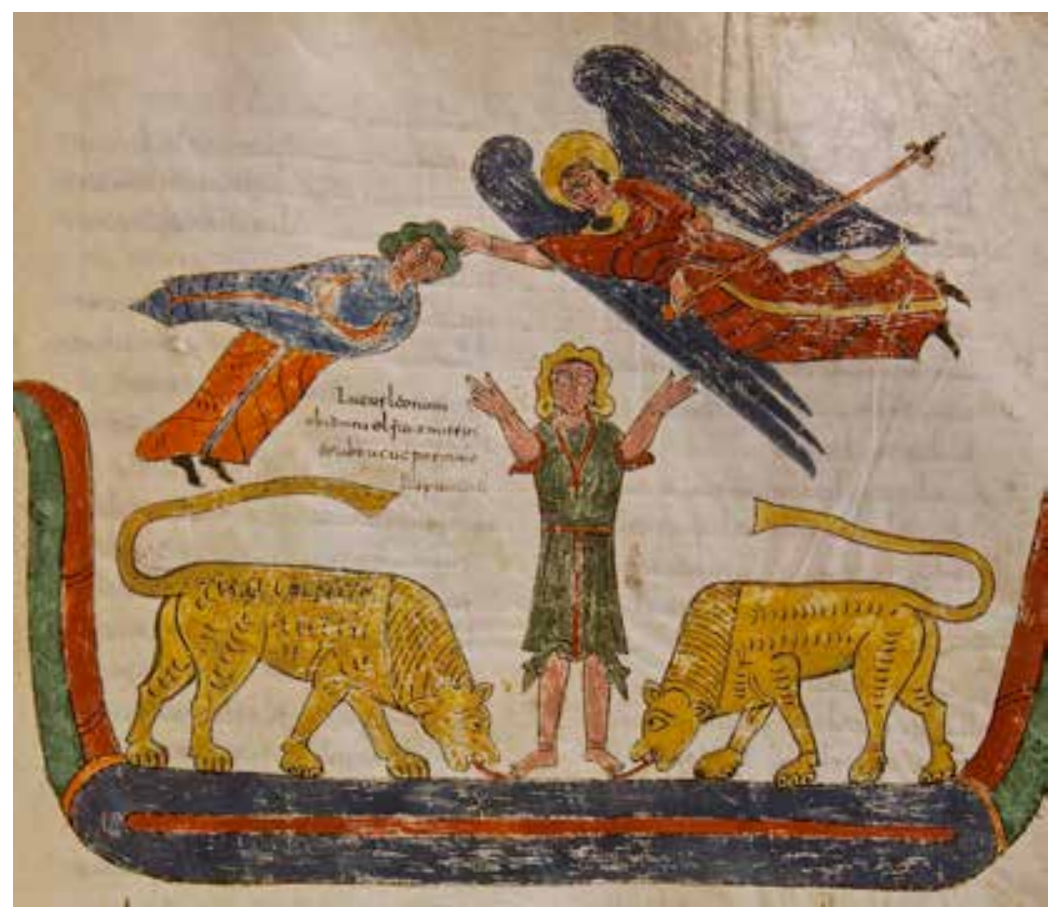

Photo: Hamid Shams 
Figure 14 Christ in Majesty. Moralia in lob, Madrid, Biblioteca Nacional de España, Cod. 80, fol. 2

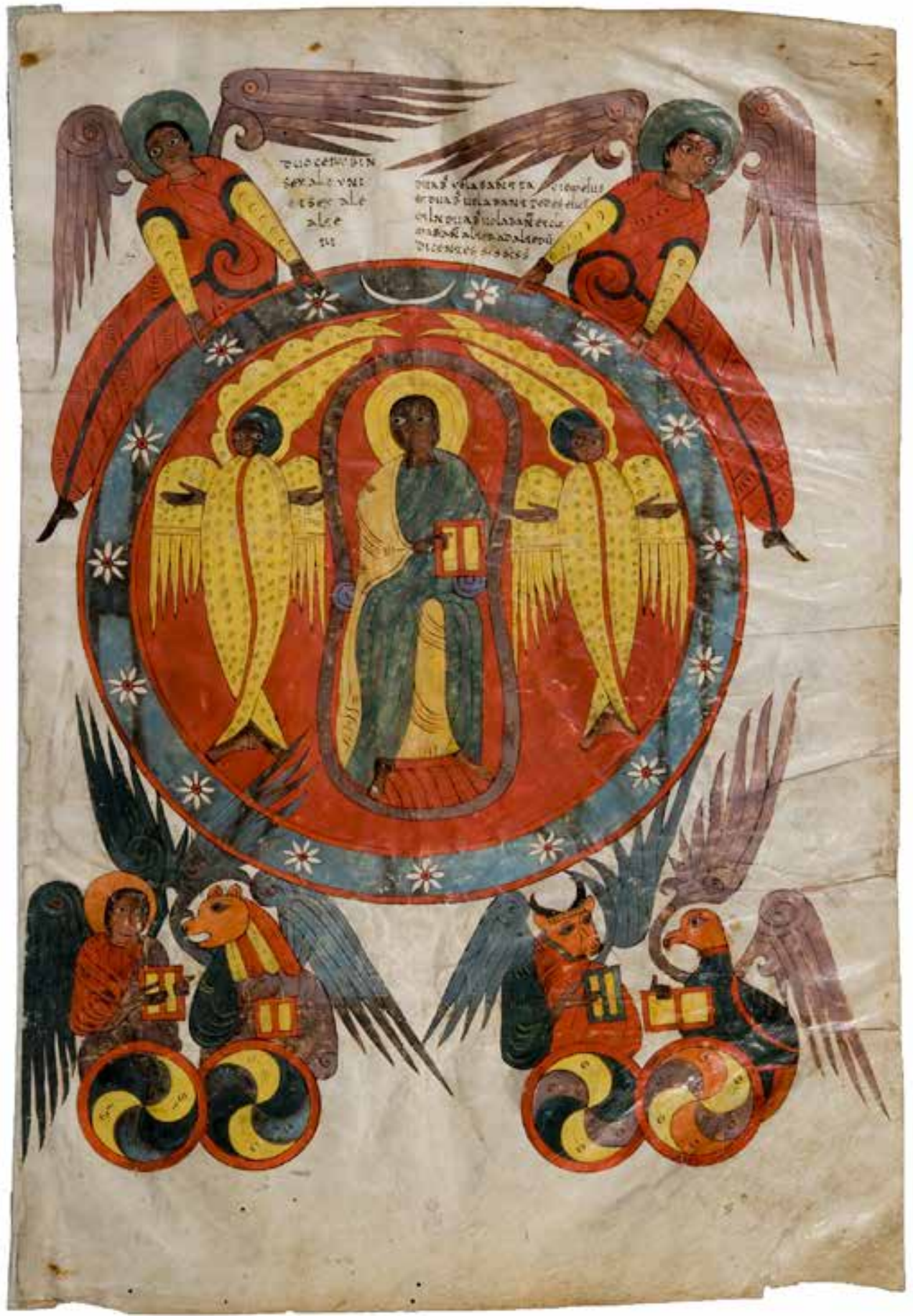


Figure 15 Silver base of agate casket with Cross and Evangelist symbols, first decade of tenth century. Cámara Santa, Oviedo Cathedral

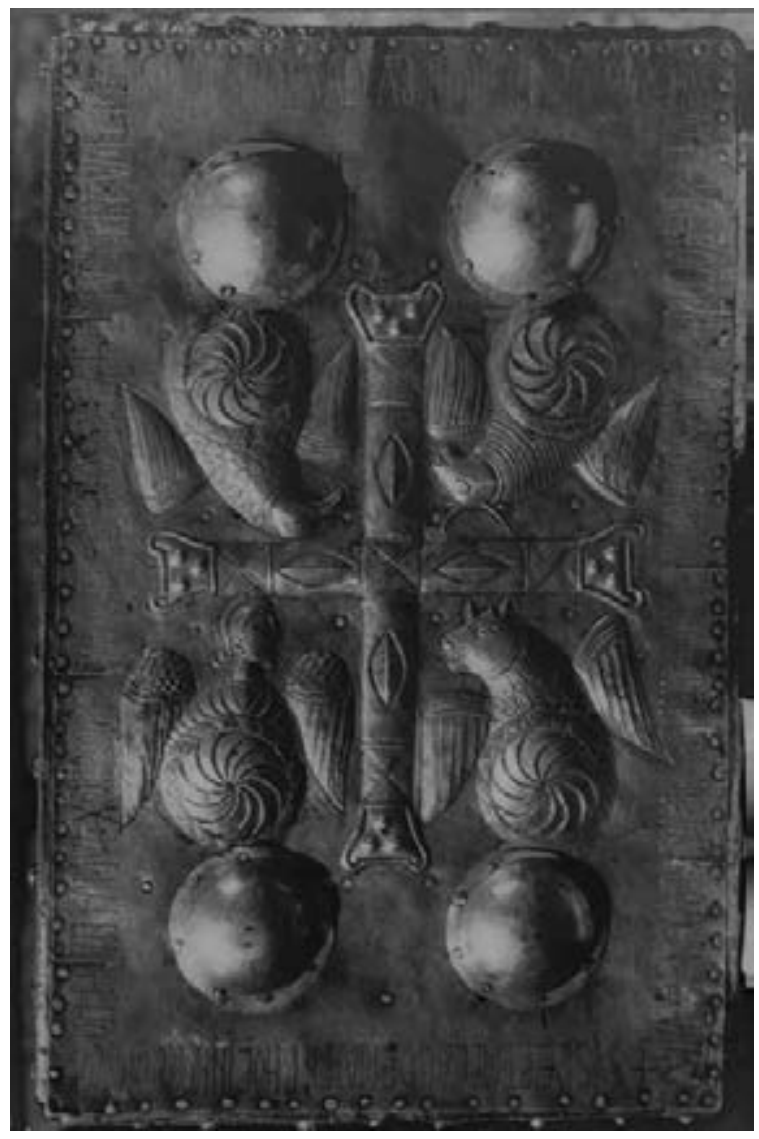

Photo: Fondo Manuel Gómez-Moreno - Ricardo Orueta, CCHS

The degree of replication exhibited by the cherubim holding a starry circle is so exceptionally close that it is certain that one could not have been made without knowledge of the other, or an image precisely like it.

So, which scribe followed the other? This composition's dependence on the fourth chapter of the Apocalypse suggests that Maius himself was its originator, as Florentius left us no Beatus Commentary. Nevertheless, the possibility, even probability, that Florentius had been responsible for one emerges from an examination of a later Beatus, copied at Santo Domingo de Silos in 1091 and illustrated in 1109 (No. 16). ${ }^{27}$ Not only does it incorporate colophonic texts such as the lament quoted above, which are identical to ones penned by Florentius, but it also includes a unique frontispiece, a Majesty page (Fig. 17) resembling that which introduced the Bible of 960 (Fig. 18), and probably the lost Bible of 943. While this conclusion leaves open the possibility that Florentius established the new Beatus format, the case for his candidacy is weaker than Maius's. The innovative design of frames and painted grounds in the Morgan

27 Boylan 2005, 175-77. 
Figure 16 Adoration of the Lamb (Apoc. IV, 6-V, 14). Morgan Beatus, fol. 87. New York, The Morgan Library \& Museum, MS M.644



Photo: Joseph Zehavi 
Figure 17 Christ in Majesty. Silos Beatus, fol. $7^{\mathrm{v}}$. London, British Library, MS Add. 11695

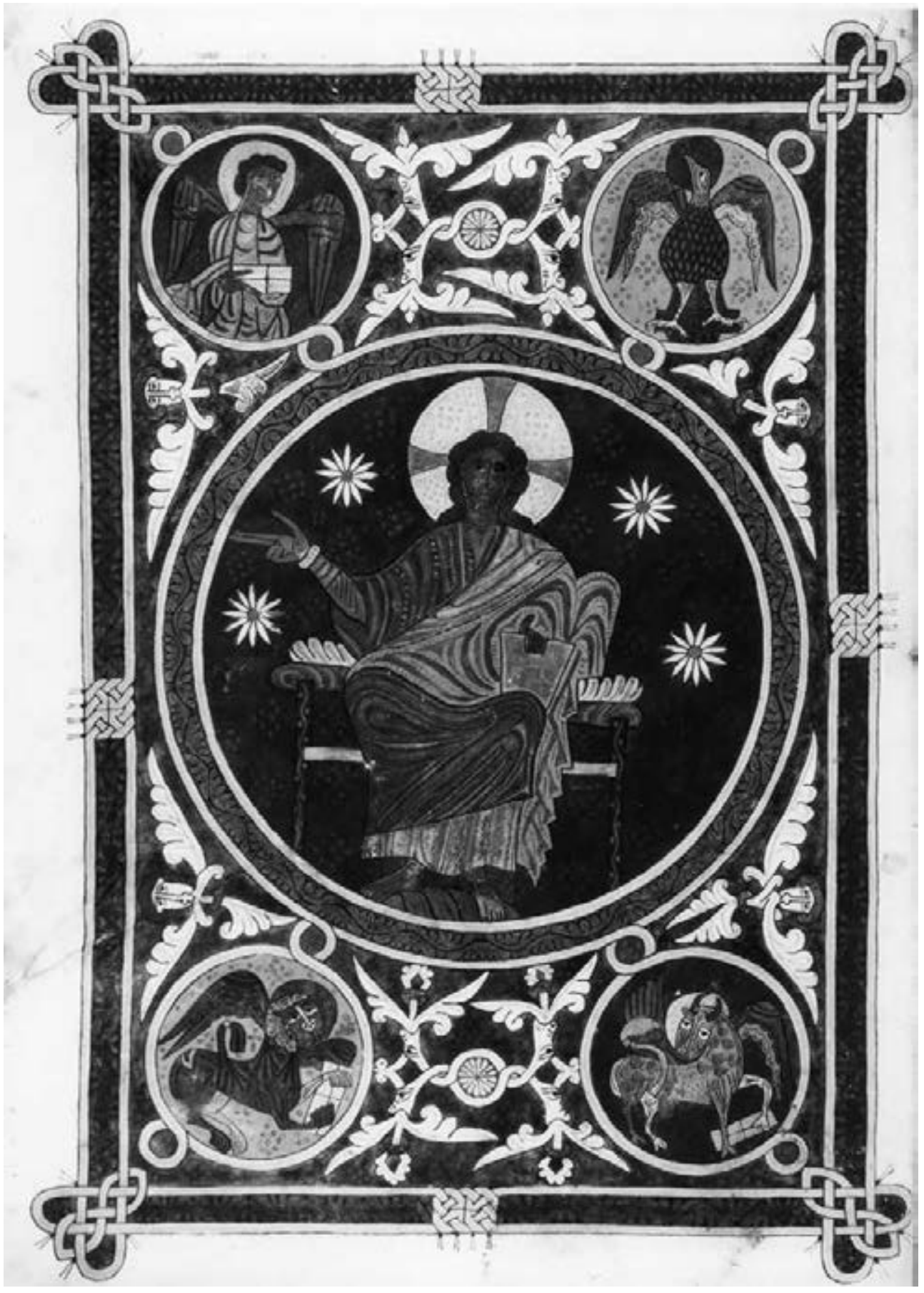

Photo: John Williams 
Figure 18 Christ in Majesty. Bible of 960, León, Real Colegiata de San Isidoro, Cod. 2, fol. 2

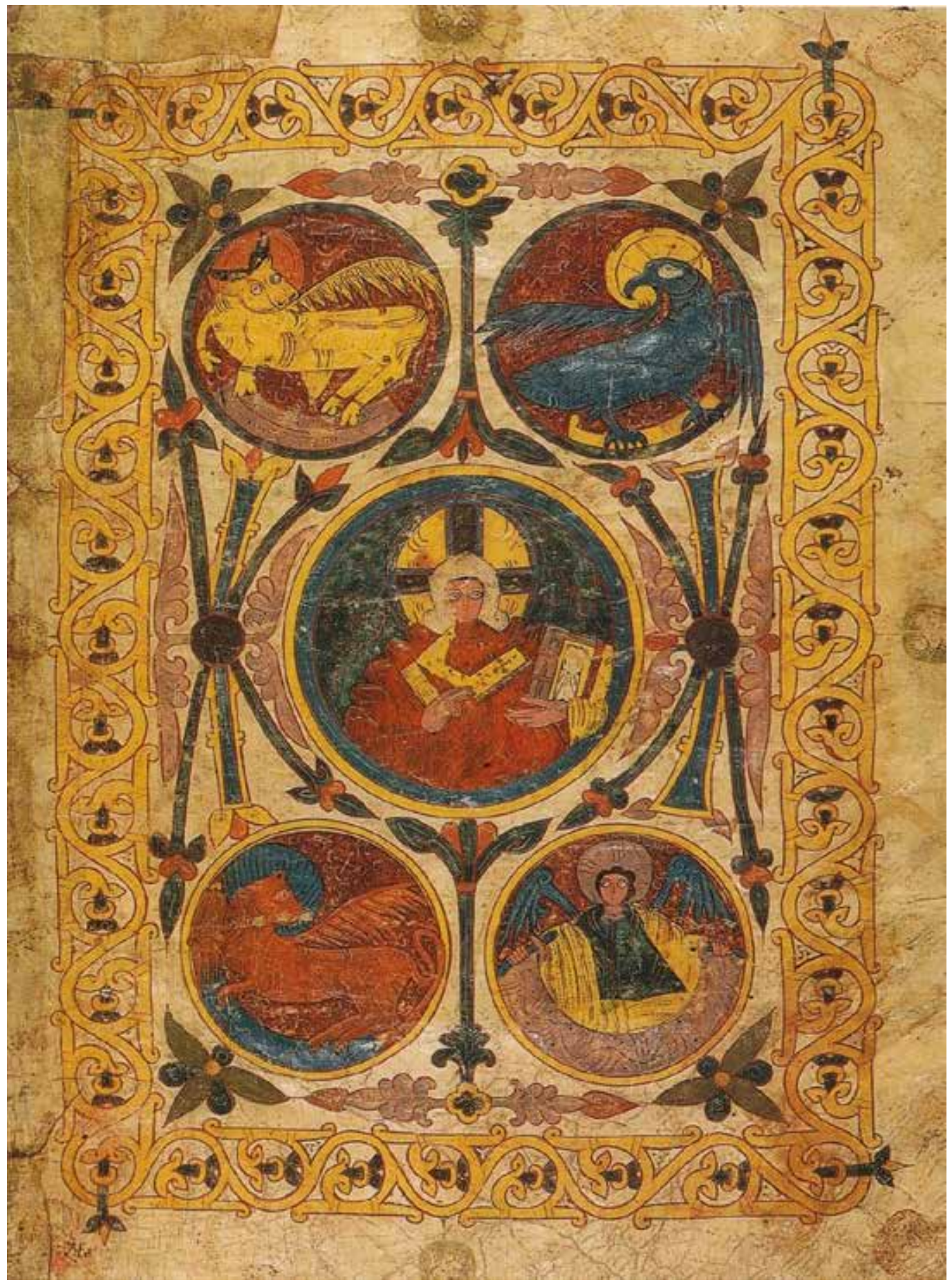

Photo: Fernando Ruiz Tomé, @ Museo San Isidoro de León 
Beatus was not employed in Florentius's Bible of 960 , and the figure style, tending toward the flat and abstract, does not display the pictorial sophistication Maius seems to have gained from emulating Touronian exemplars. More crucially, the connection between Tours and Tábara made clear by Maius's initials and the frontispieces of the Girona Beatus (No. 6) cannot be matched at Valeránica. Indeed, the Valeránican Bible tradition of pictures inserted without frames into the columns of text contrasts completely with the full-page images found in the Bible of Tours, while the initials employed by Florentius follow a Carolingian type not related to Tours. A date close to 945 seems apt for the Morgan Beatus (No. 2). Although Maius died in 968, Florentius was still active a decade later. In the ornamental vocabulary and liberal use of gold, the Girona Beatus of 975 (No. 6), a product of Tábara, reveals a new adhesion to Florentius's style of writing. ${ }^{28}$ In terms of figurative art, however, Valeránica had nothing to teach Tábara.

The mere fact that Maius's copy is the oldest Commentary to display the new format and expanded iconography does not guarantee that it was the first of its kind, or even that Maius was responsible for the pictorial revolution. Almost certainly this was not the first manuscript to display the new format: its technical brilliance presupposes earlier efforts by Maius; and in the family tree of manuscripts (see Fig. 4) the Morgan Beatus is not the first even in its own family. The larger question is whether Maius invented or inherited the revisions. One might reasonably imagine that Maius used as his model a Commentary by some other scribe, a manuscript that then would have disappeared without a trace in the following centuries. While the case for assuming the precedence of another scribe depends mainly on accepting

28 Shailor 2000, 638 . this hypothesis as probable rather than merely possible, the case for attributing this new Beatus to Maius himself has several more convincing components. One is the unprecedented and unparalleled praise for Maius as "worthy masterpainter" (arcipictore onestum) in the colophon of the Tábara Beatus quoted above, and the extraordinary skill applied to the manuscript in terms of design, layout, and execution. It is the only instance of such a designation for an artist in any Spanish medieval manuscript. The eloquent colophon of the Morgan Beatus itself emphasizes the imagery as bearer of content:

[...] As part of its adornment I have painted a series of pictures for the wonderful words of its stories so that the wise may fear the coming of the future judgment of the world's end. ${ }^{29}$

Given the repeating obsession with millennial years, it seems possible that this statement, written by a member of a generation that might see the year 1000, signals a concern with the imminent end of earthly time.$^{30}$ If there was anxiety at the approach of the year 1000, however, other kinds of contemporary documents do not reflect it, even though al-Mansur, Cordoban commander and scourge of the Christian kingdoms, who undertook numerous raids through the north as the millennium expired, could have been portrayed as an ally of the Antichrist; he was not. While this silence does not prove that Spain was free of millennial anxiety, it must be remembered that preparing for the end in the expectation of judgment was the central fact of life for every monk and nun, whether they thought that judgment was imminent or not. Anticipation of the end of time was not necessarily the primary reason for the Commentary's popularity, for more copies were made after the

29 Pérez 2010, 221-24.

30 Klein 2011b; Coffey 2010. 
year 1000 than before, at moments impossible to align with any millennial fears.

The Beatus Commentary was a reflection of revitalized monastic culture in the tenth century along the frontier between al-Andalus and the Christian kingdoms. Its remarkable pictorial narrative epitomized "Mozarabic" painting, that is, the brilliant polychromatic style associated with pre-Romanesque art in the peninsula. ${ }^{31}$ If taken literally, the label "Mozarabic" is misleading. Mozarabs were Christians living under Muslim rule in al-Andalus, but few examples of painting survive from that region. None of our Beatus Commentaries was made in al-Andalus, and there is no certain evidence that any of their creators underwent their cultural formation in Muslim-dominated territory. Acceptance of that label for our Commentaries and other illuminated manuscripts of the tenth and eleventh centuries seems born of a mistaken notion. The few early examples of painting from Islamic lands do not support such a view.

By contrast, the Biblia Hispalense, now in Madrid (Biblioteca Nacional, MS Vitrina 13-1), is the $c .900$ product of a Christian scribe in Seville, a true Mozarab. The Evangelist symbols of the Biblia Hispalense (Fig. 19), with their subdued color scheme and successful illusion of threedimensionality, stand in vivid contrast to those in a contemporary Leonese Bible of 920 (Fig. 20) in the Cathedral of León (Cod. 6), but it is the style of the Leonese example rather than the Sevillian one that has been labeled "Mozarabic." ${ }^{2}$

Although Maius benefited considerably from contacts with the pictorial art of Carolingian France, the flatness and brilliant color of his pages belong to a peninsular aesthetic formed in isolation. In the single Asturian illuminated manuscript surviving from the ninth century, the Bible of La Cava dei Tirreni (Biblioteca de la

\footnotetext{
Williams 1997a.

Williams 1977, Plates 3, 4 .
}

Badia, MS memb. I), intense hues are combined with archaic ornamental formulas..$^{33}$ Although, as will be noted in the discussion of the Girona Beatus (No. 6), Islamic iconographies might find their way into a Beatus Commentary, it is difficult to identify any Islamic contribution to the style. Simply put, there was no comparable Islamic manuscript painting in the tenth century. Where Christian and Islamic arts did share compositional formulas was in the figural representation of celebration and Majesty, as we shall see below. ${ }^{34}$

The illuminated initials of the Morgan Beatus offer a direct clue as to the inspiration for the new format and stylistic complexity. The rapid growth of scribal activity in the middle of the tenth century coincided with a revolution in the design of peninsular initials, for which Carolingian exemplars were taken as models. Initials whose best analogs are found within the repertory of Gallic manuscripts of the eighth century were displaced overnight by initials based on Carolingian types of the ninth century. In Valeránica, Florentius adopted the Carolingian Franco-Saxon style for the creation of his initials. ${ }^{35}$ Maius also used Carolingian initials as his inspiration for change, but they belonged to the particular format associated with the scriptorium of Saint-Martin de Tours in central France. ${ }^{36}$ Thus the initial I of Maius's Commentary has panels that are square and filled with rosettes and palmettes, a formula employed at Tours (Figs. 21, 22). No Touronian manuscript can be found in a peninsular library today, and the manner in which that center's characteristic vocabulary of illustration and ornament became known at Tábara remains a mystery. Its impact, however, is beyond 36 Williams 1987.

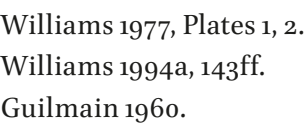


Figure 19 Symbols of the Evangelists Luke and John. Biblia Hispalense, c. 900, Madrid, Biblioteca Nacional de España, MS Vitrina 13-1

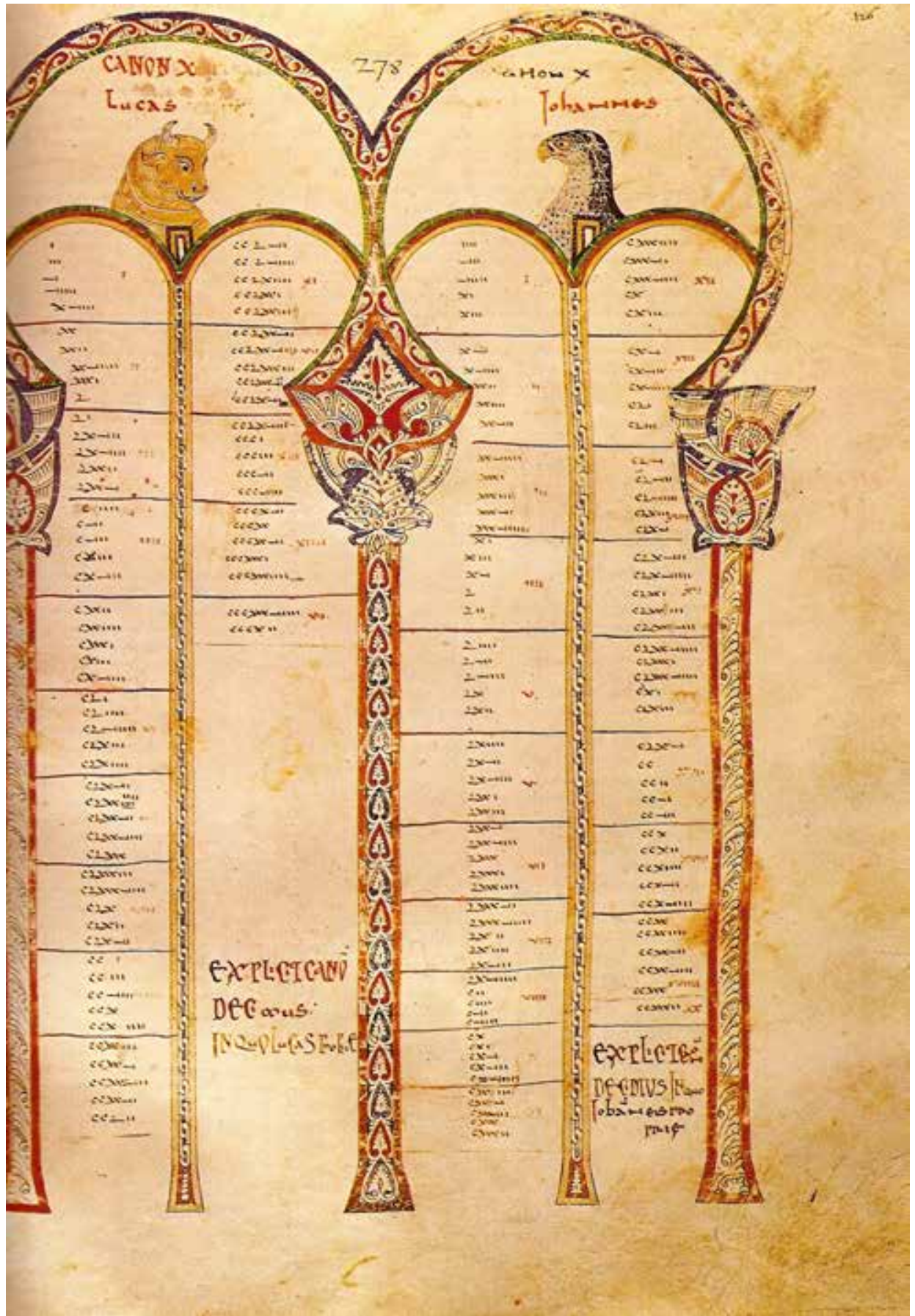

Photo: John Williams 
Figure 20 Symbols of the Evangelists Matthew, Mark, and Luke. Bible of 920, León Cathedral, Cod. 6

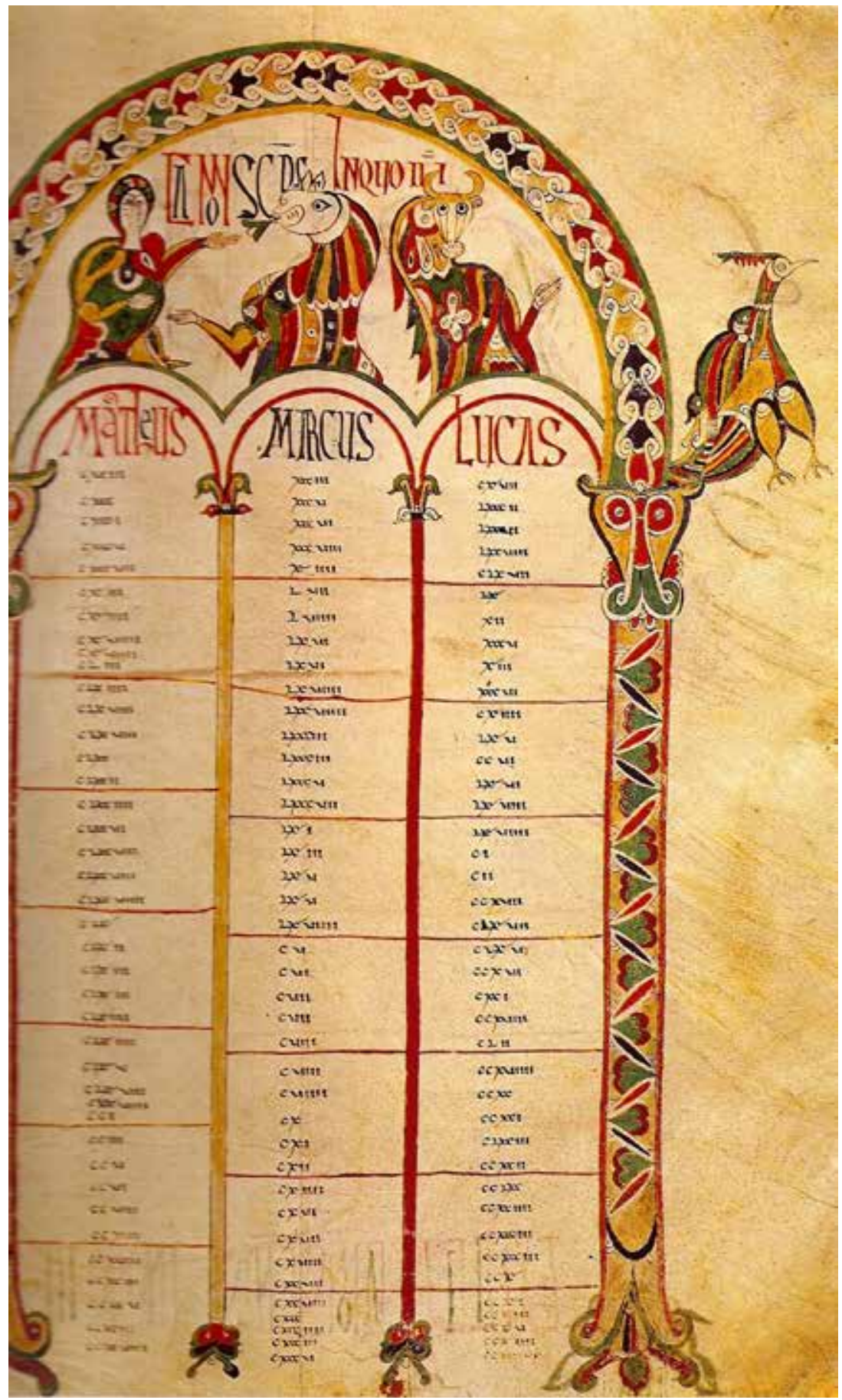

Photo: John Williams 
Figure 21 Initial I. Morgan Beatus, fol. 10. New York, The Morgan Library \& Museum, MS M.644

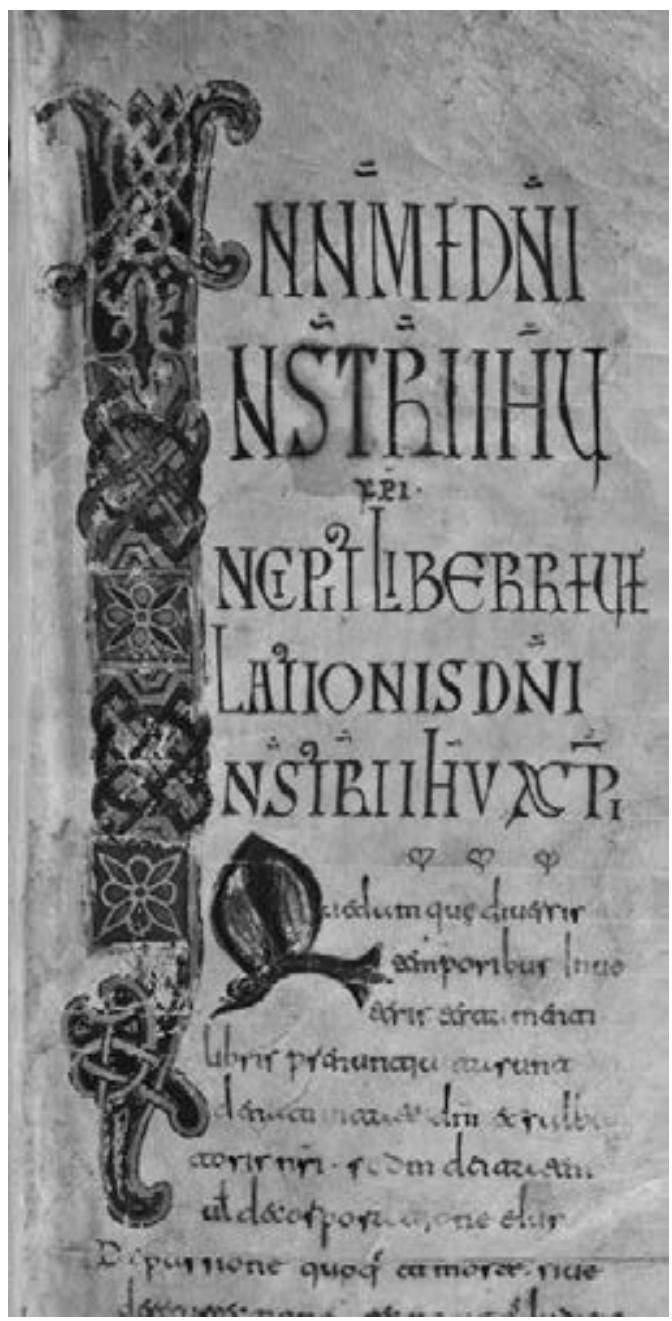

Photo: Hamid Shams

dispute. Moreover, fully illustrated Touronian manuscripts must have been known, for in a slightly later Commentary from Tábara, now in the cathedral of Girona (No. 6), the innovative Cross and Christ in Majesty frontispieces were based on formulas with exact counterparts in Touronian biblical manuscripts. Given these clear links, it seems likely that Touronian biblical illustration inspired Maius to abandon
Figure 22 Initial I. Zurich, Zentralbibliothek, MS Car. C 1, fol. $453^{v}$

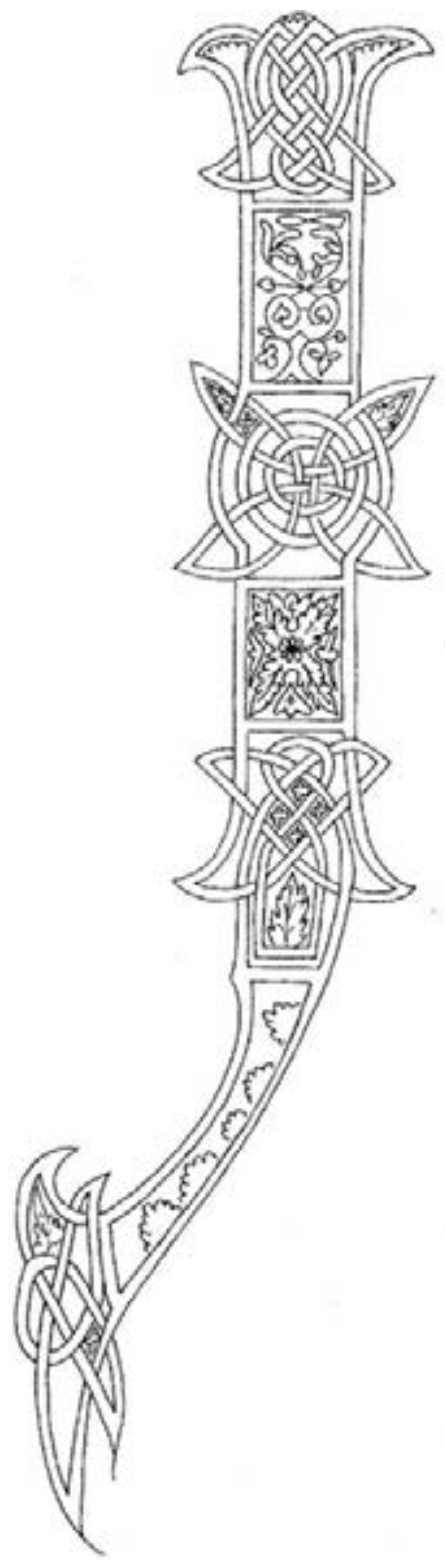

Drawing: John Williams

the small illustrations with plain parchment backgrounds (which had been standard in the earlier phase of the illustrated Commentary) in favor of the new format of framed illustrations 
Figure 23 Genesis frontispiece. Moutier-Grandval Bible, London, British Library, MS Add. 10546, fol. $5^{v}$

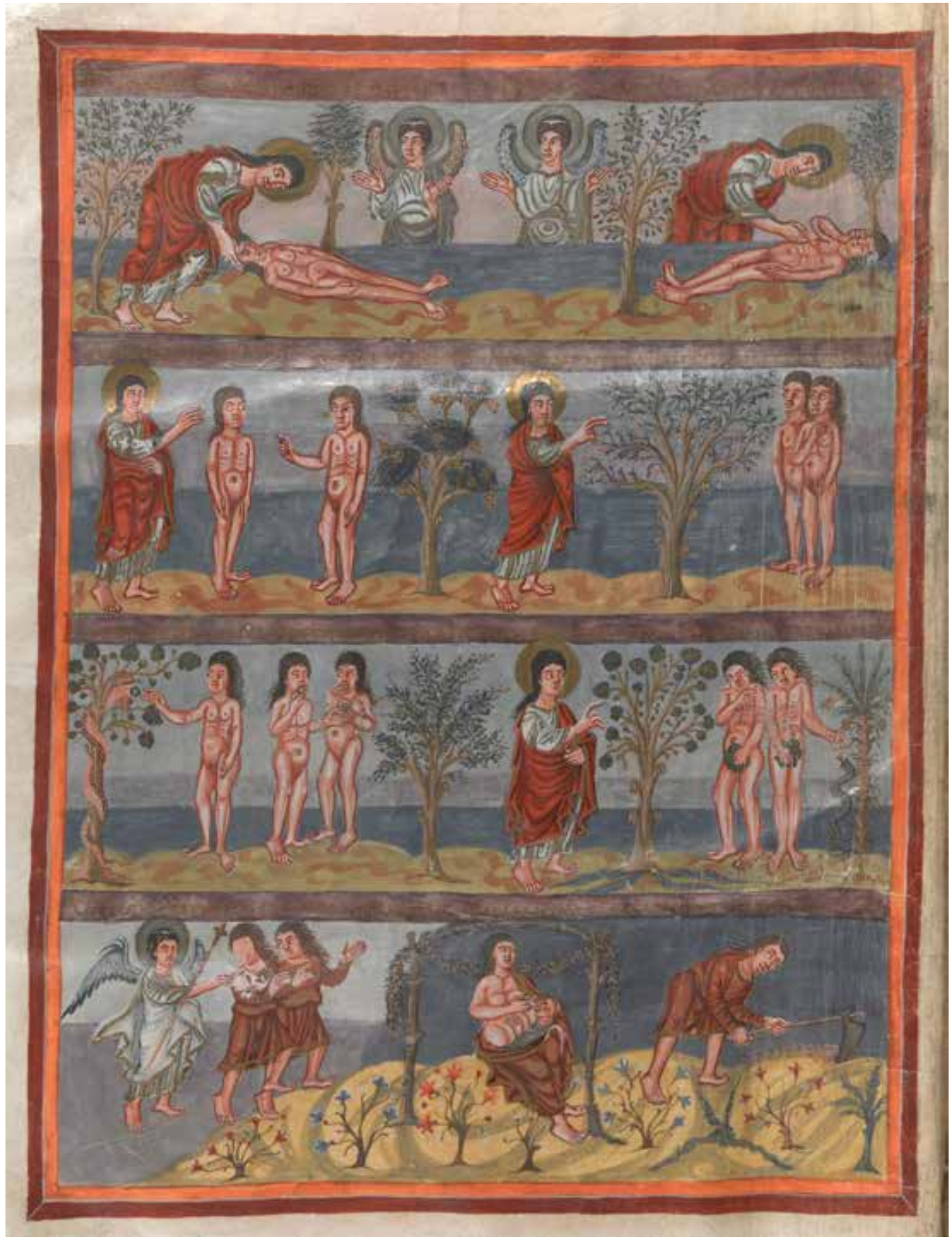


with painted backgrounds, for both are typical of the great illustrated Bibles of Tours (Fig. 23). While we cannot absolutely confirm Maius's responsibility for the reformation that made the Beatus Commentary one of the most resplendent manuscript traditions in the Middle Ages, the clear evidence of Touronian formats at Tábara points to the latter as the scriptorium responsible for the revolution. And Maius has no known rival for the honor of carrying out this revolution.

Emeterius, the disciple of Maius who completed at Tábara the Commentary of 970 (No. 5), collaborated five years later with two others, one of them a scribe named Senior, on the magnificent Beatus now in the Cathedral of Girona (No. 6). Emeterius's name appears at the end of the manuscript, below an immense interlace Omega (Fig. 24). Presented in an elaborate display script against a painted ground, his name is preceded by two others, the first of which, most extraordinarily, is that of a woman: "En, painter and helper of God, [and] brother Emeterius, priest" (En depintrix et $D[$ e $]$ i aiutrix frater Emeterius et presbiter).$^{37}$ The circumstances behind this celebration of a woman's participation in such an ambitious book are difficult to pin down. It is usually assumed, for this period, that the only women who could have been involved in manuscript production were nuns. We know that nuns worked as scribes: Leodegundia, for example, copied a Liberregularum in the region of Tábara around $930 .^{38}$ There were duplex monasteries in which monks and nuns lived, usually in separate establishments under a common abbot - or, at times, an abbess - and Tábara was one of these. The label Dei aiutrix, helper of God, has been seen as a confirmation of En's religious station, but this honorific title was also bestowed on

37 Pérez 2010, 226-27.

38 Escorial, Biblioteca del Monasterio, Cod. A.I.13. See Díaz y Díaz 1979, 38. non-religious, albeit persons of high rank, so a civil status for En is not out of the question. ${ }^{39}$ The search for a "feminine" hand among the miniatures has been rewarded to the satisfaction of some, but even En's role as a painter is not confirmed by the label depintrix, for it was a term sometimes used for purely scribal activity. One example comes from the monastery of Sahagún, where the scribe of a document that is not illuminated signed it Dominico depinxit, although scripsit was the usual verb employed by scribes in the Sahagún documents. ${ }^{40}$ Since writing and painting were done while the sheets of parchment were unbound, En's contribution did not necessarily require her presence in the scriptorium itself. The fact that her name is presented first and in an ornamental format may favor her identification as head painter or even as patron. In any case, she is accorded a special status within the Beatus tradition, although we cannot now determine just what her role was.

While it is true that the decimated state of the Tábara Beatus (No. 5) seriously reduces its visual impact, the extraordinary pictorial richness of its successor, the Girona Beatus (No. 6), strongly suggests that it was conceived as a much grander project, one that marked a renewed creativity in the venerable scriptorium and the introduction of another generation of scribes and painters. New pictures linked to Touronian biblical illustration appear here, and three frontispieces present the Cross (this time in the guise of the Crucifixion), Christ in Majesty (see Fig. 44), and a cosmic scheme of enclosed circles. These are followed by scenes of Christ's Infancy and Passion, whose prototypes remain elusive. New Testament scenes before the eleventh century

39 Ferrer Dalgá 1993, 267-72.

40 Herrero de la Fuente 1988, no. 549. On the verb depingere as signifying writing, see also Carruthers 1988 , 153. For a rejection of depingere as a word connoting anything but illumination, see Díaz y Díaz 1999, 66 . 
Figure 24 Omega and colophon. Girona Beatus, fol. 284. Museu de la Catedral de Girona, Num. Inv. 7(11)

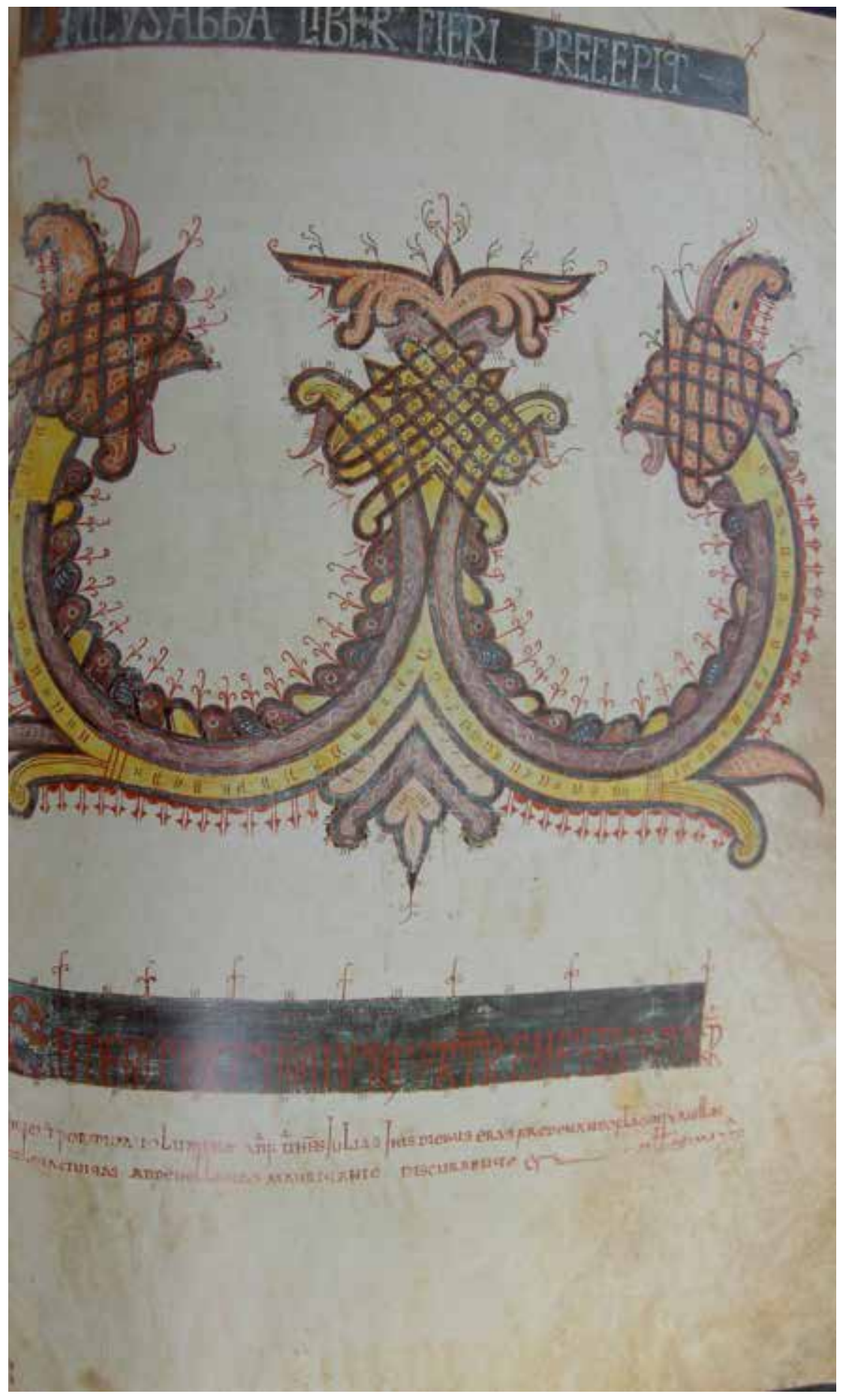

Photo: John Williams 
Figure 25 Adoration; Flight into Egypt and Herod Wounded by his Horse; Herod Bedridden. Girona Beatus, fol. 15². Museu de la Catedral de Girona, Num. Inv. 7(11)

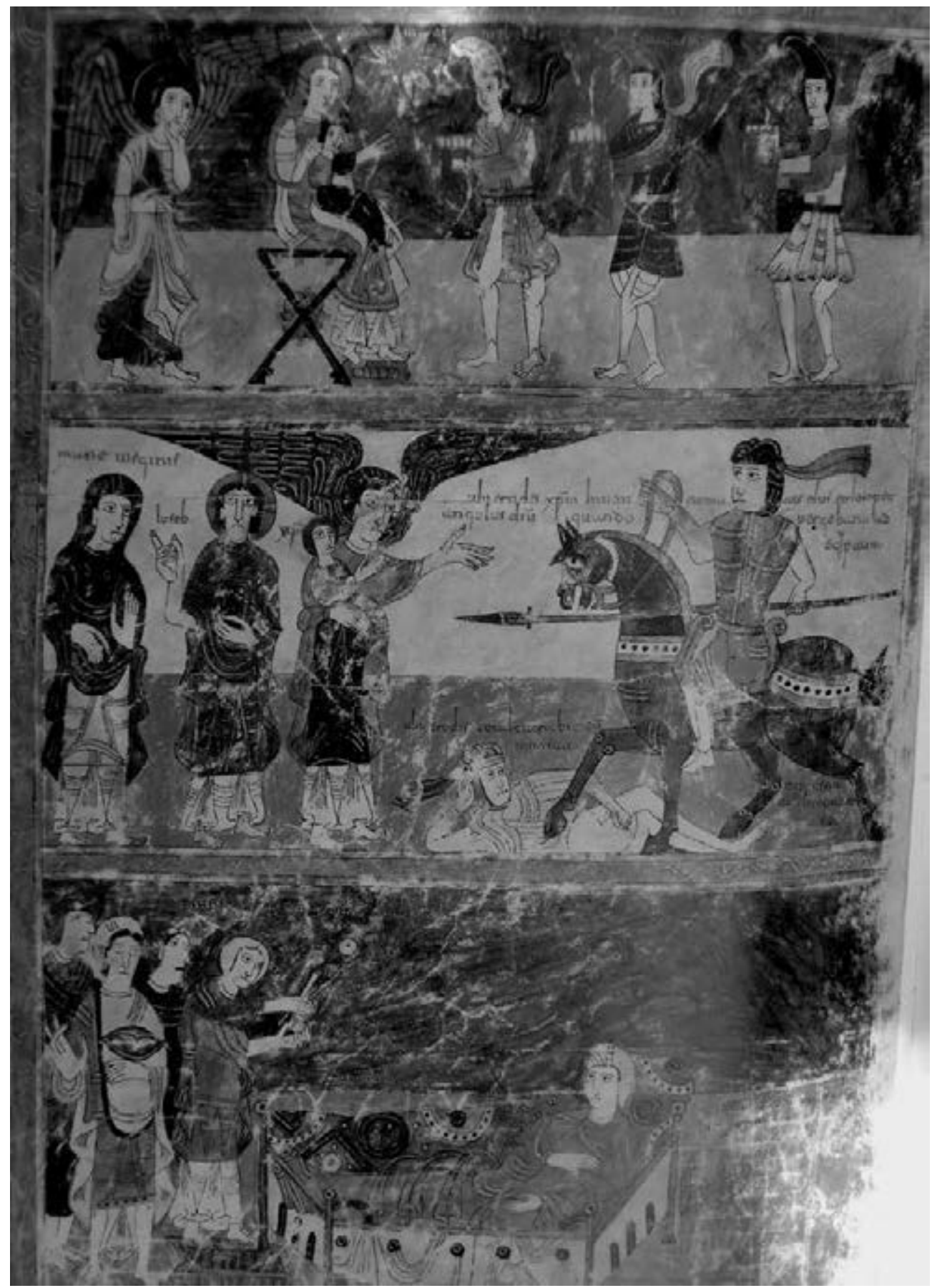

Photo: John Williams 
Figure 26 Simurgh, Eagle, and Gazelle. Girona Beatus, fol. 165․ Museu de la Catedral de Girona, Num. Inv. 7(11)

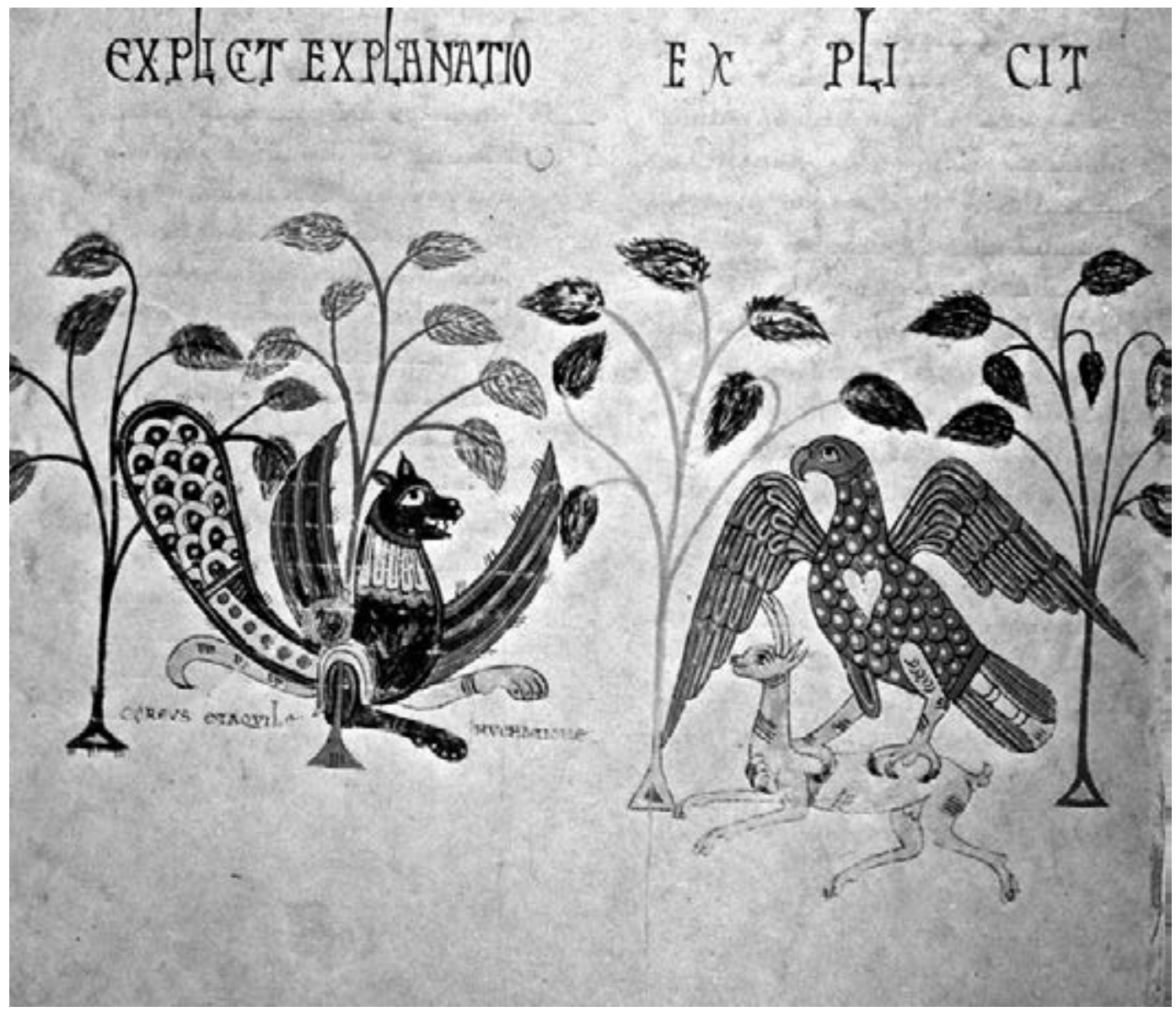

Photo: Hamid Shams

are rare in Spanish art, and those in the Girona Beatus are unexpectedly singular. They include non-biblical details and subjects that are without known counterparts inside or outside Spain. Exceptional episodes involving the life of Herod, for instance, are gathered on folio $15^{\mathrm{v}}$ (Fig. 25). The page begins at the top with the Adoration of the Magi. The middle register shows the Holy Family on their way to Egypt, where they encounter Herod, according to the inscription. Herod lies on the ground after his "horse kicked him and struck him in the thigh." While the source of this particular narrative is unknown, the scene in the bottom register, where Herod "is ill from the blow of his horse" and reclines on a bed, can be connected to the description of Herod's attempted suicide recounted in Josephus's Antiquities of the Jews (XVII, vi) and Wars of the Jews (I, xxxiii). The fact that Josephus does not include any mention of Herod being attacked by his horse suggests that the illuminator of the Girona Beatus was using a model that already combined various sources, biblical and apocryphal. Otherwise one must imagine that Tábara had a library 
Figure 27 Great Mosque of Córdoba, St. Stephen's Door, 855

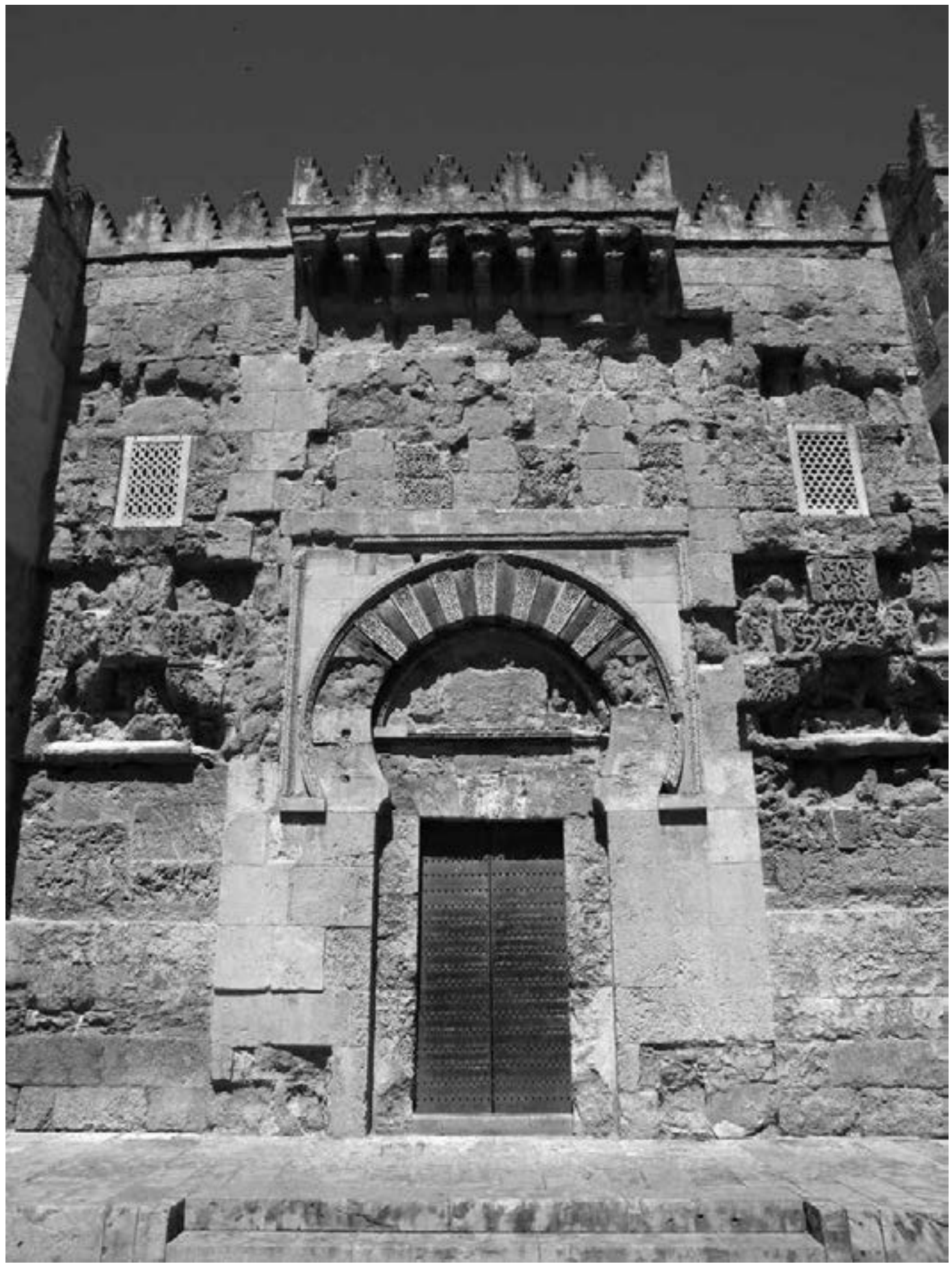

Photo: Therese Martin 
extraordinarily rich in resources from which the illuminator drew to create a new image.

In terms of style, the figures in the Girona Commentary differ significantly from Maius's copy in the design of drapery, employing formulas closer to those of the rest of Europe. The cultural horizons implied for Tábara by the Girona copy are difficult to reconcile with the monastery's isolated and modest nature. Was the presence of En, whose name is elevated even above that of Emeterius in the colophon, somehow key to the enrichment of subjects and styles, whether as artist or patron or both?

At the same time, the Girona Beatus displays the greatest number of iconographic and ornamental motifs borrowed from Islamic culture (though not style, as noted above), which are distributed throughout its generous margins (Fig. 26). Perhaps this is to be expected in a pictorial culture routinely labeled "Mozarabic." In fact, to a surprising degree, Christian architects of the tenth century in northern Spain adopted for their churches certain spatial formulas and motifs employed at the Great Mosque of Córdoba (Fig. 27). These Islamic architectural details - such as the horseshoe arch (of a proportion differing from those of the Visigothic culture of seventh-century Spain) and the alfiz (the rectangular framing of an arch) - are likewise found within the Beatus tradition. They appear not just as a means of designating an Islamic "other," but also within purely Christian contexts, as in the Morgan Beatus's depiction of Heavenly Jerusalem (see Fig. 36).

The ambiguous relationship between Andalusi images and Christian settings has inspired contradictory interpretations. ${ }^{41}$ On the one hand, quotations of motifs of Islamic origin can be placed within a condemnatory context. A prominent example is seen in the illustration of the Feast of Baltassar, one of the episodes from

Werckmeister 1993; Williams 2004.
Jerome's Commentary on the Book of Daniel, which came to beincluded in Beatus manuscripts (see Fig. 42). The setting of this scene beneath a large horseshoe arch made up of alternating red and white voussoirs would seem to identify the profane feast with the Muslims of al-Andalus, and especially with the Great Mosque of Córdoba (see Figs. 1, 27), giving the framework an apparently negative reading. On the other hand, for some scholars the presence of quotations from Islamic settings betrays a seductive beauty or exoticism too attractive to resist. There is yet another possibility to be taken seriously, however: this "Orientalization" might have been a neutral way of acknowledging the Middle Eastern setting of the events of the Apocalypse and of the biblical iconography based on the Book of Daniel. It should be noted, however, that the same features - horseshoe arch and alternating red and white voussoirs - were installed in the tenth-century Leonese church of San Cebrián de Mazote on the doorway used by the monks as they passed from cloister to choir, a context that calls for yet another reading of these features (Fig. 28). The ambiguity is nowhere more obvious and challenging than in the arresting image of a mounted warrior spearing a serpent or dragon in the Girona Beatus (Fig. 29; No. 6). While ancient tradition assigned the serpent a satanic identity that converts this image into an allegory of Christian triumph, the Orientalizing formulas - flying headband, shawl, and stirrups - employed for the rider have their closest counterparts in Sassanian and Coptic art. By implication, these details identify the warrior as an Andalusi, or at the very least as someone from the East. The storia of the facing illustration of the Angels restraining the Winds (Apoc. VII, 1-3) does not explain the warrior's appearance, nor does the commentary that accompanies it. However, the symbolic representation of Christian triumph over evil by means of figures battling serpents already had a long history and is found elsewhere in the Girona Beatus itself. Karl 
Figure 28 San Cebrián de Mazote, Kingdom of León, tenth century

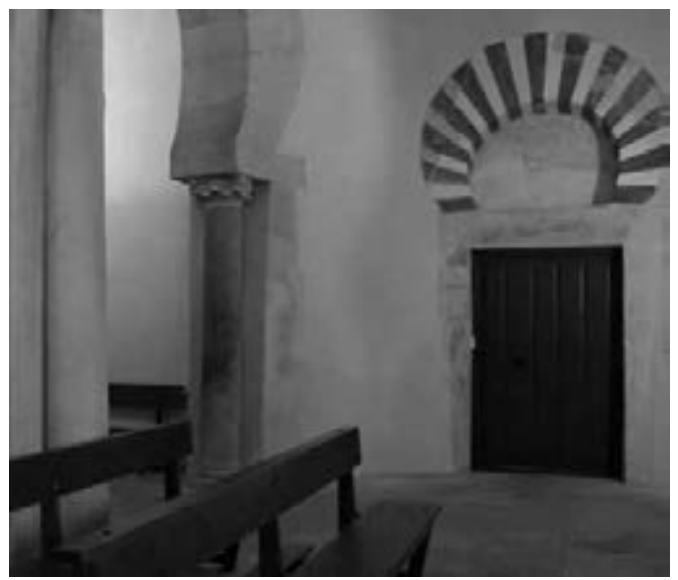

Photo: Hamid Shams

Werckmeister identified this serpent with the Christians in his interpretation of the image as a "biblical allegory of Muslim oppression," citing the exegetical tradition based on Matthew X, 16: "Behold I am sending you forth like sheep in the midst of wolves. Be therefore wise as serpents, and guileless as doves."${ }^{\prime 2}$

If one imagines an unrelenting identification of Muslims as the "enemy," the warrior's Islamic appearance indeed seems hard to interpret in other than negative terms; however, the positive use of Islamic motifs elsewhere in the commentary points to a need for nuance. Although mounted warriors spearing serpents do not appear in the repertory of surviving Islamic art in the peninsula, warriors spearing lions do. Such themes have been recognized as part of the iconography of the "celestial hunt," symbolizing Paradise. ${ }^{43}$ Elsewhere in the Girona Beatus, however, serpents have the common satanic identity, most compellingly in the full-page depiction of

42 Werckmeister 1997. For a counterview, see Williams 2004.

43 Shepherd 1978. a bird, which represents Christ according to the accompanying text, attacking a serpent (Fig. 30). Outside the Iberian Peninsula, on the twelfthcentury ceiling of the Cappella Palatina in Palermo, where artists painted Islamic themes within a Christian setting, a mounted warrior spearing a serpent appears more than once. ${ }^{44} \mathrm{In}$ the Girona Beatus, a direct reference to warfare between Christians and Muslims can be read in the note attached to its colophon, which states that as the book was being completed, a Christian nobleman, Fredenando Flaginiz, was near Toledo, fighting the Muslims. Yet the ready adoption of Islamic formulas for a Christian book is not ultimately paradoxical. While warring between Christians and Muslims did take place, Christians more often battled other Christians, sometimes as allies of Muslims. Culturally, the Islamic world had no Western rival. Its arts offered Mediterranean constituencies a rich repertory of iconography and ornamental motifs that transcended ideological boundaries.

Although the earliest scholarly appreciations of "Mozarabic" painting tended to see it as a surrogate for an imagined lost Islamic painting, it was not in the realm of style that Islamic culture influenced the Commentaries, but in its iconography, especially themes of a celebratory and triumphal nature. This was true even for subjects based on Christian themes inspired by the Apocalypse. Thus the Adoration of the Lamb on Mount Sion (see Fig. 35) includes musicians whose closest parallels are found on contemporary ivory containers produced at the caliphal workshop in Córdoba (Fig. 31). The triumphant warrior of the Girona Beatus should thus be seen as a reflection of a shared, Mediterranean iconographic tradition.

If we accept that Maius created the new Beatus at Tábara around 940 and imagine that the Girona Beatus of 975 was the last copy made

44 Monneret de Villard 1950, 45, Figs. 34, 58, 83, 236. 
Figure 29 Mounted Warrior. Girona Beatus, fol. 134. Museu de la Catedral de Girona, Num. Inv. 7(11)

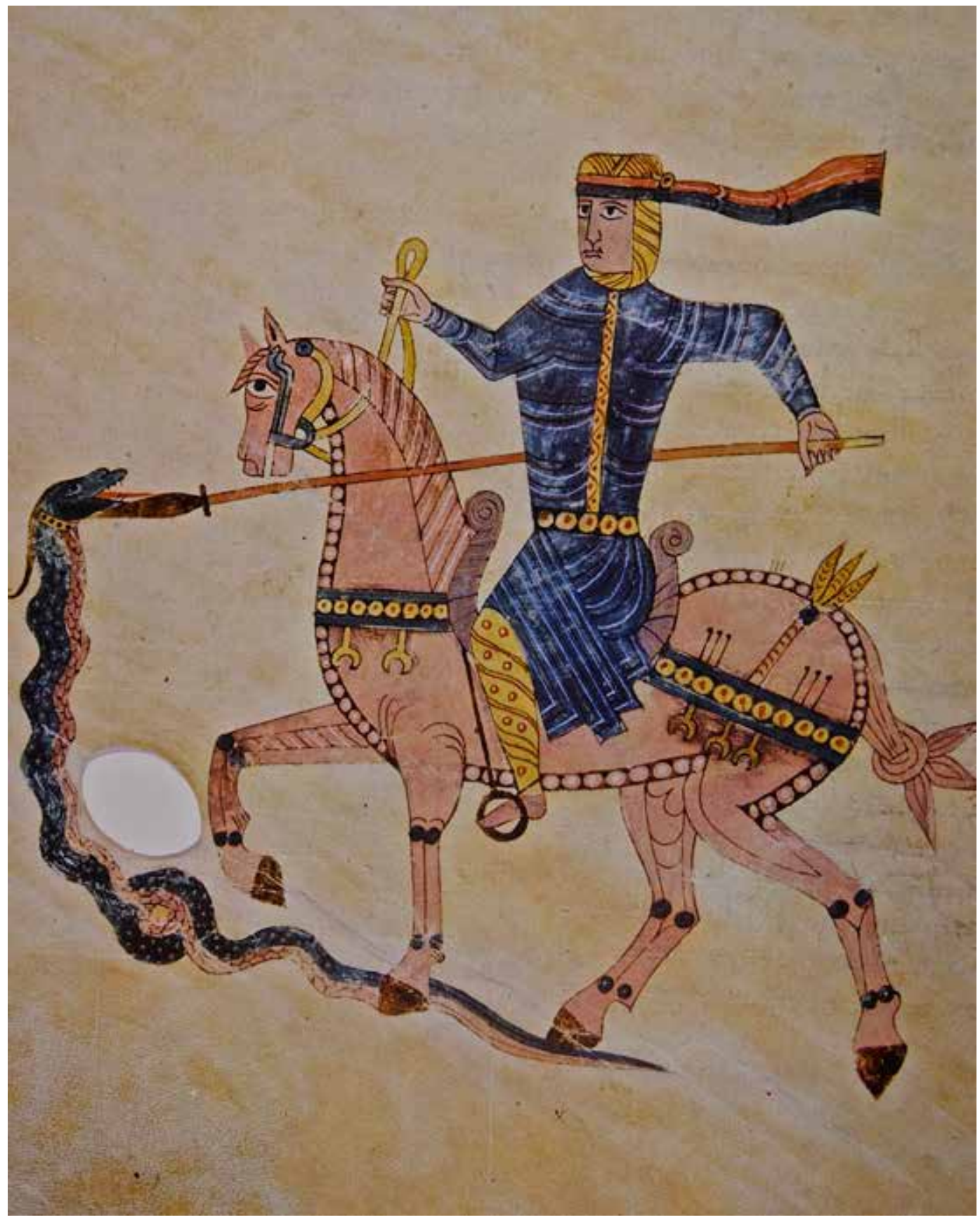

Photo: Hamid Shams 
Figure 30 Bird Attacking a Serpent. Girona Beatus, fol. 18v. Museu de la Catedral de Girona, Num. Inv. $7(11)$

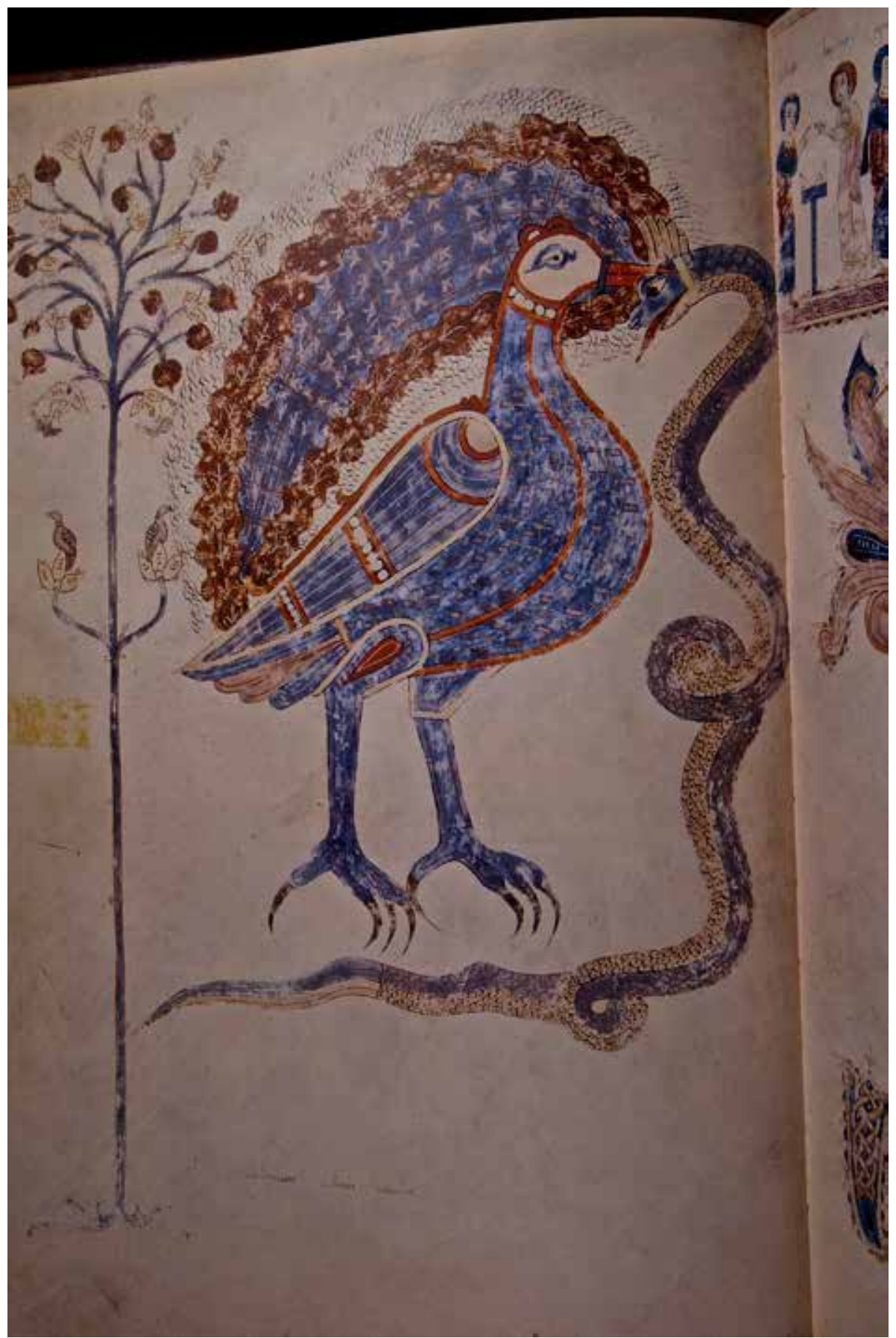

Photo: Hamid Shams 
Figure 31 Ivory pyxis of al-Mughira, Córdoba, 968. Paris, Musée du Louvre, OA 4068

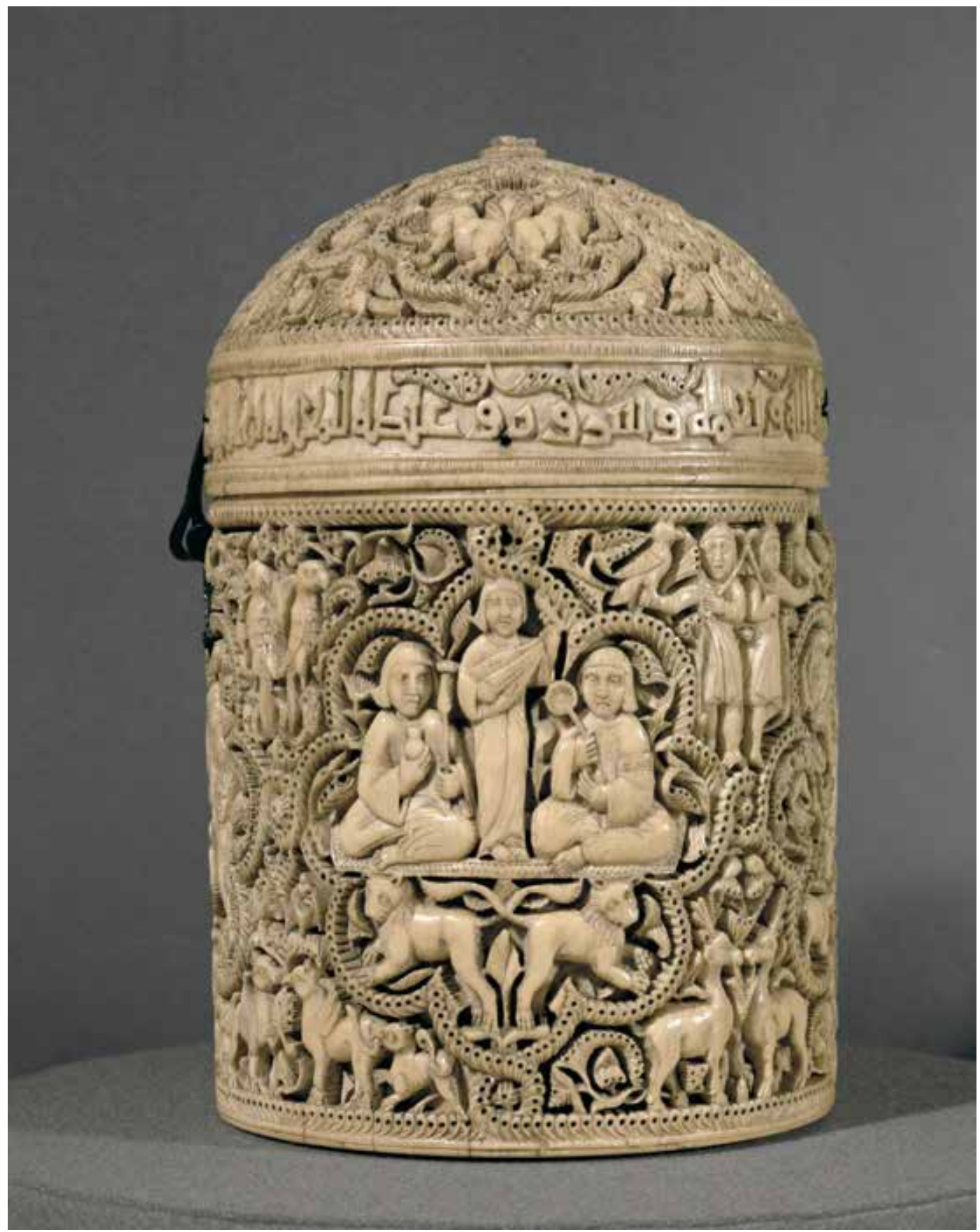

Photo: Erich Lessing / Art Resource, NY 
there, we have for the scriptorium a recorded life of thirty-five years involving at least two generations. The need to call Emeterius to Tábara implies that he was in residence elsewhere, even though he identified himself as Maius's disciple. Tábara may have trained scribes for other sites at a time when monasteries were proliferating and the demands for liturgical books and spiritual reading multiplied. Eximinus, a scribe of these same years associated with manuscripts from San Millán de la Cogolla, may also have begun his career at Valeránica. ${ }^{45}$ The picture of the specialized nature of copying and illuminating manuscripts that emerges thus highlights the role of scriptoria in the frontier culture of Spain around the millennium, and, within the scriptoria, the role of individuals with special talents. Scriptoria depended not only on the vitality of institutions, but also on the presence of talented individuals. Not every monastery could be expected to undertake the copying of books and the training of scribes. Still rarer would be a scriptorium with the skills worthy of illuminated manuscripts. Priest and monk as he was, Maius strikes us today primarily as a great artist. Florentius, too, had a clerical vocation, and he is associated with a script of exquisite refinement and with manuscripts resplendently endowed with illumination. Maius and Florentius belonged to a class of scribe that appreciated, sought out, and adapted artistic traditions. They communicated with professional colleagues from centers both nearby, as in the case of Tábara and Valeránica, and relatively distant, as in the case of Tours in north-central France.

\section{Sahagún}

Although the monastery of Sahagún produced several Beatus Commentaries, none of its

45 Pérez de Urbel 1977. scribes left the sort of colophon that would give us a sense of them as individuals, the way Maius and Florentius had done. Sahagún was one of the numerous monasteries founded or refounded early in the tenth century along the frontier with Muslim Spain..$^{46}$ It was settled by a dozen emigrant monks from Córdoba after the Asturian king, Alfonso III (r. 866-910), bought property on the River Cea. The name Sahagún represents an elision over time of the name of St. Facundus, who shared the dedication of the monastery with St. Primitivus. They were Leonese saints with a cult already flourishing in the seventh century. The benefit of royal interest would continue until the end of the twelfth century, and Sahagún even acted as the virtual capital of Alfonso VI (r. 1065-1109), with a palace, a thriving town, and eventually his mausoleum. ${ }^{47}$ At its height, Sahagún was the largest monastery in Spain. Almost none of it survives today. Bernard de La Sauvetat, a former scribe in the grand Burgundian monastery of Cluny, was its abbot until he assumed the archbishopric of Toledo after its capture by Alfonso VI in $1085 .{ }^{48}$

Although Sahagún received donations of books, it likely had a scriptorium from nearly the start of its history. It may have been responsible for the early tenth-century fragment of a Beatus now at a dependency of Sahagún's, the female monastery of San Pedro de las Dueñas, only a few miles south of the men's community. Its text belongs to the same branch of the family tree of copies as the ones assignable to Sahagún. ${ }^{49}$ The Dueñas Commentary may have been illustrated, but the remaining fragment is too partial for us to be sure.

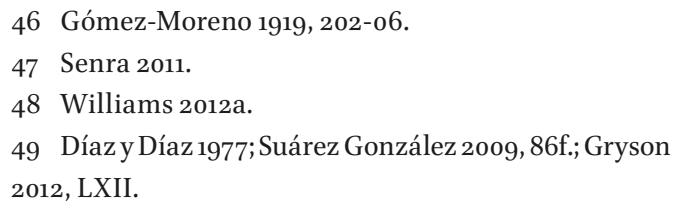


In 1086 the monk Petrus copied at Sahagún a Commentary now in the cathedral of Burgo de Osma in Castile (No. 14). Although the Alpha frontispiece of the Facundus Beatus of 1047 (No. 11) reveals in Christ's drapery patterns a rejection of "Mozarabic" formulas and hints at an awareness of the emerging Romanesque approach (see Fig. 52), the Osma Beatus is the first Spanish copy to display a completely Romanesque style, with figures designed to suggest volume and movement in a convincing if highly conventionalized way (see Fig. 58 ). The fact that Martinus, the artist of the Osma Beatus, was following a Commentary belonging to the earlier branch of the family tree, the branch that had not been "Mozarabicized" at Tábara in the tenth century, must have facilitated the shift toward stylistic modernization. However, the first Commentary to display this new Romanesque style had already been painted a generation earlier in the middle of the eleventh century in France, the home of the style, at the Gascon monastery of Saint-Sever-sur-l'Adour, just north of the Pyrenees (No. 13, see Figs. 56, 57). Somewhat later, at the turn of the century, a copy that survives only in fragments (Valladolid, Archivo de la Real Chancillería) was written at Sahagún, but for some reason the spaces left for illustrations remained empty. The format of these pages is identical to that of the Osma Beatus. ${ }^{5}$ In the second quarter of the twelfth century another, less ambitious, copy was made at Sahagún (No. 17), either from the Osma Beatus or a sister manuscript. It came to rest in Rome, apparently arriving in Italy by the twelfth century, as it served as a model for the Italian copy of the text now in Berlin (No. 19)..$^{51}$

In 1189 the only illustrated Commentary identified with Portugal was completed by the

50 Williams 1992, 21-22; Shailor 1992, 45-49; Suárez

González 2009, 55 f.

$5^{1}$ Gryson 2012, XLVIIff. scribe Egeas in the Cistercian monastery of Lorvão; the copy is now in Lisbon (No. 23). Egeas, if indeed he was responsible for the illustration as well as the writing, took a rudimentary approach to the illustrations (see Figs. 73, 74). This may have led him to be particularly faithful to the model that served him, a Commentary in the family of the Osma Beatus from Sahagún. Just how this model reached Lorvão and its subsequent trajectory are unknown.

\section{San Millán de la Cogolla}

Although of the three major scriptoria San Millán de la Cogolla is here addressed last, it was by no means a minor player in the illustrated Beatus tradition. Indeed, it is linked, albeit tentatively, to both the earliest and the latest copies. San Millán was an important monastery on several counts. The anchorite Emilianus (hence San Millán) died in 574 in the hills bordering a fertile valley in the Rioja. Whether the fellow hermits attracted there by his sanctity established an early center that survived through the centuries is a debated issue, but in the tenth century the site blossomed, thanks to its strategic location between territory claimed by the kings of Navarre and of León-Castile, as well as to the popularity of the cult of St. Emilian. The tenth-century church erected against the hill that enclosed Emilian's cave partially survives (Fig. 32), but the terrain suggests that the residence of the monastery and its scriptorium would have been located elsewhere, perhaps on the lower site now occupied by the present monastic complex, which dates to the sixteenth century. ${ }^{52}$ The Camino de Santiago passes only a few miles away.

In spite of its relative distance from Liébana, the birthplace of the Commentary, the Riojan

52 Monreal Jimeno 1988; Arbeiter and Noack-Haley 1999, 347-49. 
Figure 32 San Millán de la Cogolla, upper church, tenth-eleventh century

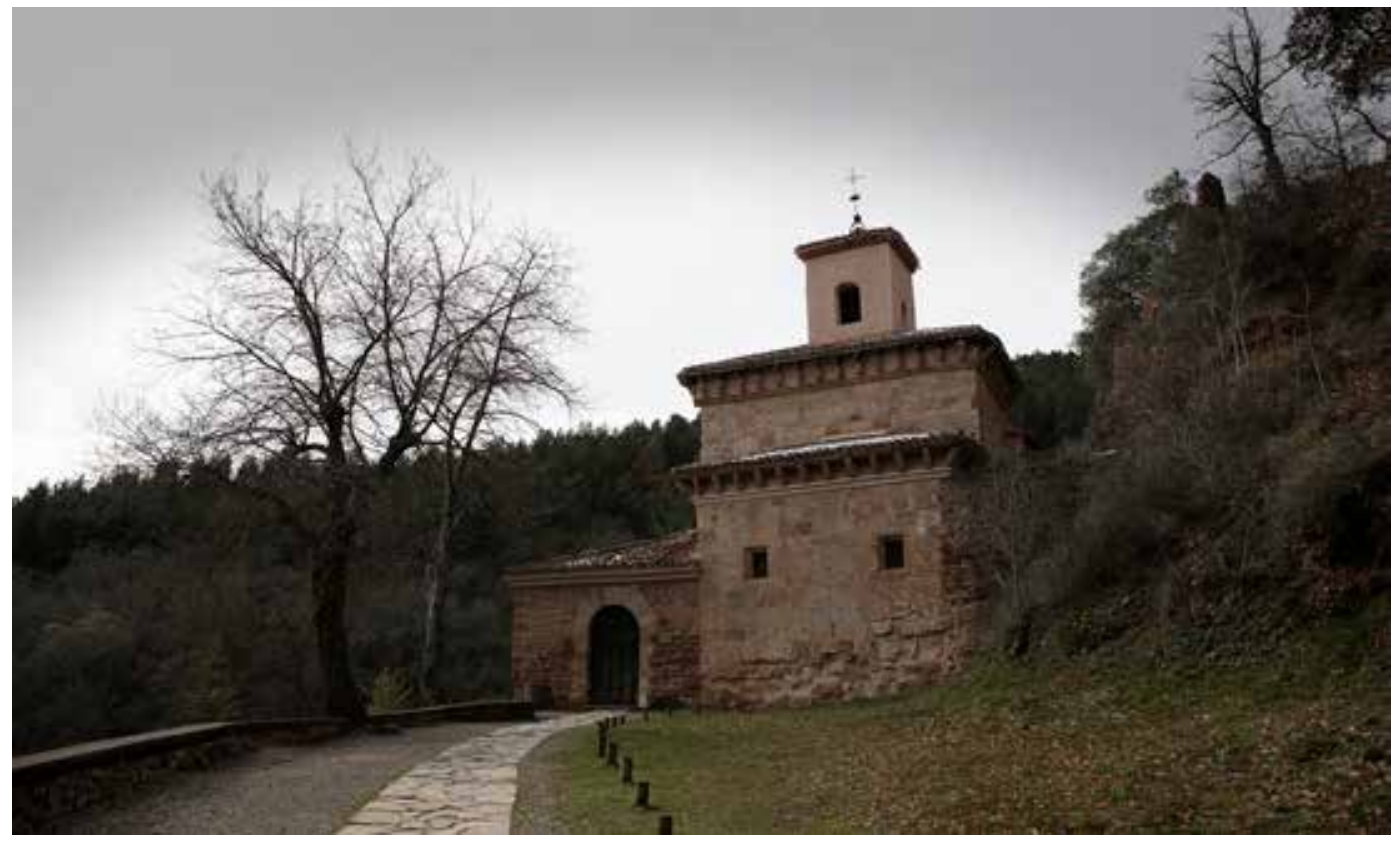

Photo: Hamid Shams

monastery of San Millán de la Cogolla played a key role in the history of the earlier branch of the text's family tree. It was a center of resistance to the invasion of the Roman rite, ${ }^{53}$ and one has to wonder if its defense of the traditions of the Hispanic Church included a special attachment to the Beatus Commentary. Although it has never before been proposed, a connection with our earliest surviving witness to the Beatus tradition is worth considering: the fragment now at Silos (No. 1) may have originated at San Millán. It came to Silos from Nájera in the eighteenth century, protecting documents from San Andrés de Cirueña, a monastery founded in the first quarter of the tenth century. This is later than the date usually accepted for the Silos fragment, and there is no guarantee that the fragment itself was ever in Cirueña, but the fact that it is located only a day's walk from San Millán at least opens the

53 Harris 2014. possibility that the fragment originated at San Millán. Beyond the coincidence of physical location, the Silos text is closest to two San Millán copies, the Escorial and San Millán Commentaries (Nos. 9, 10). ${ }^{54}$ Although this scriptorium is often assigned an original functioning date of the first quarter of the tenth century, there are good reasons to think it was established in the ninth..$^{55}$

If the Silos fragment cannot be definitively connected to San Millán, at least four other copies have some claim to an origin there:Vitrina 14-1 in the Biblioteca Nacional in Madrid (No. 3), the San Millán Beatus (No.9), the Escorial Beatus (No.10), and another commissioned for the Aragonese monastery of Fanlo, which does not survive, but for seven of its pages we have seventeenth-century replicas (No.12). The first three are tenth-century

54 Gryson 2012, LXI-LXII.

55 Olarte 1999, 136-38; see Díaz y Díaz 1979, 166-67 for a counterview. 
copies; the Fanlo Beatus was commissioned in the middle of the eleventh century. If Vitrina 14-1 did originate at San Millán, it would confirm the monastery's special early link to the Commentary tradition, for it employs the primitive edition of Beatus's text. San Millán's early and exceptional role as disseminator of the Commentary is further confirmed by the Geneva Beatus (No. 29), for that Italian copy, from the middle of the eleventh century, was also based on the Commentary behind the Escorial Beatus (see Fig. 4).

In contrast to the situations at Tábara and Sahagún, no particular name dominates the history of the scriptorium at San Millán. On both textual and iconographic grounds the Escorial and San Millán Commentaries have been seen as copies of the same model, and both date to the late tenth century. Yet they are clearly by different scribes and employ different versions of the "Mozarabic" style, as was the case of the successive copies at Tábara despite a fairly short separation in time. The distinctive style of the Escorial Beatus (see Fig. 51) is evidence of its creation at San Millán, for certain formulas have counterparts in the great Book of Councils (now Escorial Cod. d.I.1), which was copied at San Millán in 993/4. ${ }^{56}$

The heightened degree of abstraction in the San Millán examples, in comparison to Maius's manner of designing figures at Tábara, has its best counterpart in the manuscripts of Florentius at the Castilian monastery of Valeránica, a site reduced today to a few fragmentary foundations. Brown and yellow, favored colors in the San Millán Beatus, are not uncommon in the León Bible of 96o, which, as we saw above, was illuminated at Valeránica $\left(\right.$ fol. $\left.15^{\mathrm{v}}\right)$. Further, the clusters of short strokes distributed as a regular overlay of highlights are also found in the Bible of 960 , although not so rigidly in units of three. In addition, the representation of Adam and Eve (see Fig. 50) that serves in the Escorial Beatus as a surrogate for the usual Map of the World is a virtual replica of the scene of the First Parents in the Bible of 960 . These similarities strengthen the argument that the scriptorium of San Millán was influenced by that of Valeránica. Indeed, an apparent connection with Valeránica is a unifying theme in all four of the Commentaries associated with San Millán. Two frontispieces in the San Millán Beatus reflect types found in the Bible of 960 , one of which is a framed title page for the beginning of John's text (fol. 1). Although the Bible illuminated in 96o in Valeránica does not employ such an introduction for its Apocalypse, the title page for the entire book (fol. $3^{v}$ ) is comparable. Furthermore, the vine scroll that makes up its frame, like that of the Majesty page preceding it, is remarkably similar to that of the San Millán Beatus. The second frontispiece of the San Millán Beatus features a Cross (fol. $1^{v}$ ). It appears beneath an arcade, unlike the only other tenth-century Beatus Cross page, that on folio $1^{\mathrm{v}}$ of the 970 Valladolid Beatus (No. 4). The four arms of the San Millán Cross carry the symbols of the Evangelists. Once again it is the Bible of 960 that offers the closest parallel for the frame, for the arcade closely resembles those used in that manuscript's canon tables; the Evangelist symbols, rare in being full beasts rather than anthropomorphic types, are found on the Majesty page of the same Bible (see Fig. 18). Perhaps the most singular element shared by the 960 Bible and the San Millán Beatus is the representation of Jacob Wrestling with the Angel (Genesis 32, 24-29), which appears in the Beatus at the foot of folio $36^{v}$. This scene is not found in any other copy of the Commentary. The miniature is inspired by the text of the prologue of Book II: "Israel is 'the man that sees God.' Jacob received the name of Israel [...]." Precisely the same pair of figures in the same pose, with Jacob's right thigh and shoulder held by the Angel, appears 
on the Jacob page of the genealogical tables of the Bible of 960 (fol. 8). ${ }^{57}$

The oldest of the Commentaries with a connection to San Millán is the Vitrina 14-1 Beatus in the Biblioteca Nacional de España in Madrid (No.3). It was listed in an inventory of 1821 at San Millán, but textual corrections of a kind found in other works from the monastery suggest that the Commentary was already there around $1200 . .^{5}$ The figural style and palette employed (see Fig. 37) resemble those of tenth-century manuscripts such as the San Millán Beatus and the Bible of 960 from Valeránica, and it has been suggested that the scribe Eximinus of San Millán may have begun his career at Valeránica. ${ }^{59}$ Like the other three commentaries linked to San Millán, Vitrina 14-1 belongs to the Branch I family. Moreover, its text represents, along with the Saint-Sever Beatus, the first edition of the text. With no compelling evidence to assign Vitrina 14-1 elsewhere, the case for the monastery of San Millán, if not ironclad, is the best we have.

As the eleventh century gave way to the twelfth, the peninsula adopted the Romanesque style that marked the Gallicization of Hispanic culture. The relative proximity of San Millán to the Pyrenees, and its location just eight miles from the pilgrimage road to Santiago accelerated access to the new Romanesque currents. The early importance of San Millán in the growth of Romanesque painting in Iberia would be roundly confirmed if we knew for certain that this scriptorium was responsible for the prayer book Queen Sancha of León (d. 1067) commissioned in 1055 for her husband, Fernando I (r. 1037-65; Biblioteca Universitaria de Santiago de Compostela, MS6og Res. 1). At the time, Fernando occupied the Rioja, a zone that included San Millán. The scribe responsible, Fructuosus, was certainly a Spaniard, and the prayer book displays

57 Silva y Verástegui 1984, 174-75.

58 Klein 1976, 24; Díaz y Díaz 1979, 228.

59 Pérez de Urbel 1977. a sophisticated Romanesque style that rivals any contemporary works from the other side of the Pyrenees (Fig. 33). The few parallels between the prayer book and the manuscripts known to have come from San Millán are significant enough to suggest that it also was made there. ${ }^{60}$

Later, confirmed products of San Millán attest to its role as a foyer for the Romanesque style. In the twelfth century, a monk atSan Millán recalled a devastating raid by al-Mansur in the summer of 1002. This may have interrupted the completion of the San Millán Beatus (No. 9). In any case, with the resumption of the project in the early twelfth century, a different model based on the pictorial reform of Maius was followed; the added illustrations present a modern, Romanesque style (see Fig. 49). Clarity of color was replaced by a monochromatic tendency favoring a muddy green. The miniatures were now framed, but they scarcely contained the bulky figures. In contrast to the weightless and frozen figures of the tenth century, here they are dynamically posed and complexly structured of articulated subordinate parts with heavily emphasized contours. This is a Romanesque style, but one that differs from the earlier, mid-eleventh-century stages of that essentially foreign manner found, for example, in the Osma Beatus (No.14). The pattern of white highlights on the garments, most strikingly manifest in the comb-like patterns on thighs, indirectly echoes Byzantine formulas, but directly reflects the influence of French Romanesque painting from the turn of the century. It was another sign of the trans-Pyrenean reorientation of peninsular culture. For some reason, the completion of the San Millán Beatus was followed by a break of some decades in commissioning copies of the Commentary, if the chance survival of examples can be relied on. However, San Millán would continue drawing on the foundations laid earlier in León and Castile to produce in the thirteenth

6o Williams 2011b, 415-20. 
Figure 33 Prayer book of Fernando and Sancha. Biblioteca Universitaria, Santiago de Compostela, MS 609 (Res. 1), fol. $6^{v}$

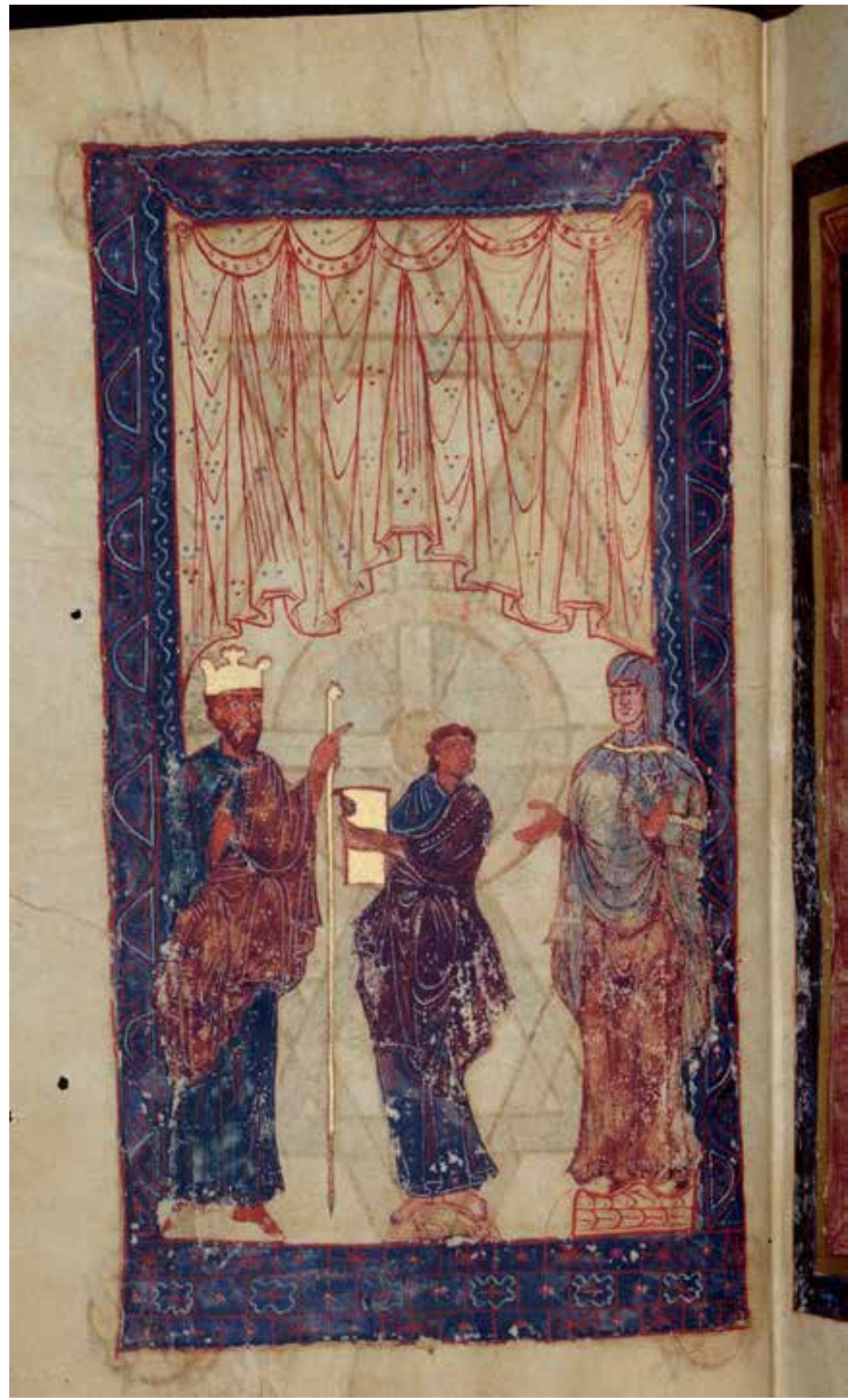


century a magnificent Bible with more than 125 illustrations. ${ }^{61}$ In the meantime, as we shall see, San Millán may have had a role in the late revival of the Beatus tradition.

In the tenth century, Tábara was not so strategically placed as San Millán nor did it have the kind of saint's cult that attracted pilgrims. Its scriptorium was called into being by the demand for books generated by a new foundation, but also by the fortuitous presence of Maius, a monk of extraordinary artistic talent. At Valeránica the importance of a single personality to the emergence of scriptorial eminence is even clearer: it was a small establishment with only nine monks under Abbot Belasco at the end of Florentius's life. Valeránica's scriptorium withered quickly thereafter, though not necessarily because of the passing of its great painter/calligrapher. Although Sahagún was founded at more or less the same time as the nearby frontier sites of Escalada, Tábara, and Valeránica, its part in the Beatus history is linked to the primitive branch of that tradition rather than the "Mozarabic" phase initiated by Maius. This may point to a still earlier local history for Sahagún, but it is only in the eleventh century, with the patronage of francophile Leonese monarchs and the creation of the Osma Beatus, that we have certain knowledge of its part in the development of the Beatus tradition. At San Millán, the personality of an individual artist-scribe played even less of a role. Its location facilitated communication across the Pyrenees, and the popularity of the cult of Saint Emilian together with royal support led to fame, prosperity, and the longevity of its scriptorium.

\section{Copies Made Outside the Peninsula}

While the Commentary of Beatus was preeminently an Iberian artifact, four surviving copies

61 Williams 1965. were produced outside the peninsula - three in southern Italy and one much closer to Spain, just across the Pyrenees in Gascony. The motive and means behind the arrival in Italy of the models serving the Geneva Beatus (No. 29) and the fragmentary Milan Beatus (No. 28) by the middle of the eleventh century remain unknown, although other Visigothic manuscripts also found their way to Italy as well. ${ }^{62}$ While the manner of composing illustrations in these two Italian Commentaries is eccentric in some instances (see Figs. 84, 85), both pictures and texts were certainly copied from a Spanish exemplar. This is not the case, however, for the illustrations of the Italian copy now in Berlin (see Figs. 67, 68; No. 19): although its text depended on the early twelfth-century Corsini Beatus from Sahagún (No. 17), the imagery relied on the artistic culture of Italy.

The three Italian copies are small, but the fourth foreign copy, produced at the monastery of Saint-Sever-sur-l'Adour (No.13), is among the most spectacular of all the Commentaries in terms of size and pictorial splendor. Textually it represents, as does Vitrina 14-1 (No. 3), the very earliest edition of the text. The illustrations, however, exemplify the most advanced version of the reformed Commentary invented by Maius. Access to distinct editions of the text in a monastery outside the peninsula defies easy explanation, but the early history of the site provides a possible answer. Saint-Sever was founded in 988 by the count/duke of Gascony, Guillaume-Sanche, and would effectively serve as his religious and military capital at the end of the tenth century. ${ }^{6}$ Its first inhabitants may well have been Navarrese monks. In any case, in 972-73 he had married Urraca, the daughter of García Sánchez of Pamplona (d. 970). She survived her husband and was a powerful patron

62 Reynolds 2012.

63 Mussot-Goulard 1982, 136f.; Klein 2014a, 20. 
of the abbey, which sat near their residence. ${ }^{64}$ Saint-Sever's possession of a copy with the earliest text of the Commentary may stem from this union. It is worth noting in this regard the Riojan location of San Millán de la Cogolla and its history of copies of the earlier editions of the text. If, as may well be the case, Vitrina 14-1 originated in San Millán, the fact that its text is the primitive one and the fact that it shares this distinction with the Saint-Sever Beatus may provide a clue for the origin of the model behind the Saint-Sever copy. Before going to Gascony, Urraca had been married to the Castilian count Fernán González (d. 970), who employed Florentius of Valeránica as his court scribe. ${ }^{65}$ Moreover, there is evidence that Florentius executed the copy of the Commentary that served as the model for the Silos Beatus (No.16), which employs the reformed format we know from the Morgan Beatus (No. 2). This Castilian background at least provided Urraca an opportunity to be aware of the new editions of the Commentary linked to Maius and Florentius. However, we must also reckon with the possibility that a first-edition copy arrived through the agency of Sanche-Guillaume (r. 1010-32). He spent his youth in Spain, being at San Millán de la Cogolla by 992, and residing later at the Navarrese court of García of Pamplona. ${ }^{66}$

\section{The Last Flowering}

The last flowering of the Beatus tradition was linked to the ascendancy of the kingdom of Castile and the spread of the Cistercian order. Castile began as a county within the older kingdom of León. Fernando I (d. 1065) had begun his rise

64 Lacarra 1972, 199-200; Cursente 2009, 15-16; Cabanot and Pon 2009, 4off.

65 Williams 1970.

66 Mussot-Goulard 1982, 169. as count and then briefly king of Castile before claiming the crown of the kingdom of León in 1037 through his marriage to the Leonese princess Sancha five years earlier. They became the first royal - rather than monastic - patrons of a Commentary when in 1047 the couple commissioned the Facundus Beatus (No.11), establishing a type of royal patronage that would characterize the final copies a century later. After the reign of their great-grandson, Alfonso VII (r. 1126-57) and the division of the kingdom into León and Castile (until it was reunited as Castile-León in 1230), the center of gravity shifted from the city of León to Burgos, the capital of Castile. It was within the then-separate kingdoms of Castile and León during the respective reigns of Alfonso VIII (r. 1158-1214) and Fernando II (r. 1157-88) that five of the last seven Commentaries known to us were carried out. Alfonso VIII had turned the tide in Christian Spain's crusade, capturing much of al-Andalus from the Muslims at the battle of Las Navas de Tolosa in 1212. Meanwhile, his marriage to Leonor (d.1214), the daughter of Henry II of England and Eleanor of Aquitaine, fostered international artistic ties. The shift of political and cultural weight from León to Castile coincided with the decline of the Benedictine Order and the ascendancy of the reform-minded Cistercians.

In contrast to the stylistic homogeneity that characterized the "Mozarabic" school, the late Romanesque copies display diverse styles, sometimes even within the same manuscript. In some instances this is surely a sign of itinerant artists. A clear case for this conclusion is provided by the copy of the Bible of 960 that was completed in 1162 at San Isidoro in León by visiting artists. One of the illustrators was also responsible for frescos in a distant Aragonese church in Navasa (now in the Museo Diocesano 
de Jaca) ${ }^{67}$ Colophons became rarer and tended to omit the names of scribes and sites, focusing rather on patronage. As in the case of the Cardeña Beatus (No. 21), some of these artists were from prestigious centers in northern Europe. These trends - the loss of colophons, the diminishing importance of monastic scriptoria, and migrant artists - make the assignment of these late copies to specific scriptoria speculative.

The earliest known exemplar to evoke the idea of a renaissance of the Beatus tradition is the splendid copy from around 1175, now in the John Rylands University Library in Manchester (No. 20). It has been identified conjecturally with the Commentary on the Apocalypse that appears in the 1821 inventory of codices sent to Burgos from San Millán de la Cogolla, which is described as being "in large format" and displaying "writing of the twelfth century." While there are no details in the manuscript to confirm a link to San Millán, neither is there counter-evidence favoring any other site. Whether produced at San Millán or not, it seems to have been linked to Burgos in the nineteenth century, for the bishop of Burgos informed Konrad Miller, the great cartographer, that a copy had been taken in 1869 from the city by the provincial governor. ${ }^{69}$ No other copy can be tied to this particular incident, and the date would make it available in time to be sold in 1870 .

The Rylands Beatus, as part of the revival of the Beatus tradition linked to the ascendancy of the kingdom of Castile, is related iconographically to another Commentary that was also once in Burgos and is now distributed between the Museo Arqueológico Nacional in Madrid and the Metropolitan Museum in New York (No. 21).

67 Yarza 1985, 385-86. Yarza hesitates to go beyond the participation of a single workshop, but to my eye the very same hand seems to be at work.

68 Andrés 1978, 543; Sánchez Mariana 2001, 34.

69 Miller 1895, 20.
This Commentary has been commonly labeled the "Cardeña Beatus" after a nineteenth-century claim that it had been in San Pedro de Cardeña, a monastery outside Burgos. The claim, however, has been roundly disputed..$^{70}$ More credible is the identification of this copy with the Beatus transferred in 1821 from San Millán to Burgos, the city that apparently received the Rylands Beatus later in the nineteenth century. ${ }^{71}$ There is no evidence confirming the execution of either of these copies at San Millán. Indeed, it is hard to imagine a reason for multiple copies to accumulate there. However, the Benedictine status of San Millán is not a mark against its possible authorship of copies destined for Cistercian convents; nor, at this date in the artistic culture, is the stylistic heterogeneity a telling mark against such an origin.

There are suggestions that the Rylands Commentary may have been based on the Tábara Beatus, for this tenth-century example also seems to have been connected to Burgos: it served as the model for the Las Huelgas Beatus of 1220 (No. 24), the later of the two copies today in the Morgan Library \& Museum..$^{2}$ That copy was commissioned for the royally sponsored Cistercian convent just outside Burgos, Santa María la Real de las Huelgas. While its origin in a scriptorium in Burgos cannot be dismissed, the existence of a scriptorium at Las Huelgas is unsupported by any evidence, and part of the team involved in its Beatus executed works in Toledo. ${ }^{73}$ The scriptorium responsible for the copy once in the convent of Cistercian nuns at San Andrés de Arroyo (No. 25), a dependency of Las Huelgas, also remains unknown. We can,

70 Suárez González 2010a, 99-101; Suárez González 2010b.

71 Sánchez Mariana 2001, 30-34.

72 Williams 2003a, 19-20. For a counter-argument, see Klein 2002, 32-33; 2014, 8-9.

73 Raizman 2004; Raizman 2005. 
however, affirm beyond doubt that the Las Huelgas Commentary was copied from the Tábara Beatus itself, for it includes a replica of the tower that distinguishes the Tábara Commentary (see Figs. 41, 77). The far-reaching and long-lasting significance of Tábara within the tradition is manifest, for only one of the representatives of this final blossoming of the tradition, the Arroyo Beatus (No. 25), belongs to the earlier branch of the family tree. The others descended from the revision of that branch that took place at Tábara under Maius, Emeterius, and En.

\section{The Beatus Tradition: The End}

The Cistercian copies from Castile represent the swan song of the Beatus tradition. After them, the Commentary ceased to play a crucial role in monastic culture as contemplative communities gave way to the preaching orders. The few copies made later were merely unadorned texts. Still, it had been a good, long run, and a pair of Commentaries confirms that these manuscripts continued to be used well after new production ceased. A marginal note of around 1500 on folio 12 at the beginning of Book I of the Lorvão Beatus (No. 22) states, "When Matins begin, start here." The same reminder appears on folio 17 , with the addition that it is to be read in the refectory. Seventeenth-century glosses in the Las Huelgas Beatus (No. 24) also mark readings for mealtime in the refectory. Thus, folio 40 has "fourth day" written in the margin under the first portion of the explanatio of the Message to the Church of Ephesus. After the first thirty-six words, the word "quit" and a slash tell the reader to stop. In a similar fashion, forty words of the explanatio of the Church of Smyrna are set aside with a "take up" and a "quit" on folio $43^{v}$. The same instructions occur in the explanatio of the Church of Thyatira on folio 42. "The fifth day" appears beside the explanatio of the Church of Sardis, and passages from the explanatio of Philadelphia and Laodicea are marked. It seems likely that the Commentary had been similarly exploited early in the history of the tradition.

As I reflect now, I am struck by the degree to which my earlier work was unsurprised by Maius's invention of a radically new relationship between the illustrations of the tradition and the text. This would have occurred as he perceived the extent to which works from the scriptorium at Tours had made visible a world where words summoned up familiar images, while also revealing a new kind of pictorial concept. I have on occasion referred to Maius as the Picasso of his time; I don't find that an exaggeration. Like Picasso, Maius was capable of making creative leaps beyond what anyone in his own cultural background might have imagined possible. Could just any scribe accomplish this? I say no. We are not even sure to what degree Maius would have been exposed to the Touronian illustrations, for not one manuscript from that location has ever been traced to the peninsula. However, as iconographic formulas testify without question, he must have seen the magnificent full-page illustrations that accompany the sacred texts produced there. Perhaps it was the result of a journey or several journeys across the Pyrenees and on to Tours, and many days devoted to devouring what was laid out before him at the scriptorium, taking their visual concepts and making them his own. Like Picasso, Maius had an incomparably fertile pictorial imagination, as was recognized by the title "master-painter." Still, I think I took it too much for granted. Although the text so patiently assembled by Beatus has sunk into obscurity, it is in large part due to Maius that the vibrant, stunning, and mysterious imagery of the Beatus tradition continues to awe, inspire, and resonate to this day. 


\section{$2 \quad$ The Census}

\section{A Complete Register of Illustrated Beatus Commentaries and Fragments}

The following entries summarize and update the scholarship on the twenty-nine known illustrated copies of the Beatus Commentary on the Apocalypse. Twenty-seven were studied in John Williams's five-volume corpus, The Illustrated Beatus (London, 1994-2003); here, the copies discovered since then - the Milan fragment and the Geneva Beatus - are added to complete the catalogue.

Brief citations appear at the end of each census entry: they begin with the bibliography in The Illustrated Beatus; this is followed by the relevant pages in Joaquín Yarza, Beato de Liébana: manuscritosiluminados (Barcelona, 1998), a useful, well-illustrated introduction to the Beatus Commentaries, and then by other publications specific to each entry in chronological order. For these and the parenthetical references within the text, complete citations can be found in the bibliography at the end of the volume.

\section{The Silos Fragment}

Silos, Biblioteca del Monasterio de Santo Domingo, frag. 4

1 fol., 12 x 9.8 in. ( 305 × $250 \mathrm{~mm})$

Last quarter of the ninth century

Origin: Northern Spain (Asturias? San Millán?)

The writing and decoration on this page indicate an origin at the end of the ninth century, making it the oldest surviving copy of the Commentary of Beatus. The technical simplicity of the picture of the Opening of the Fifth Seal (Apoc. VI, 9-11) suggests a scribe/miniaturist with very limited experience in the art of painting. However, this does not necessarily invalidate it as a reliable witness for the appearance of the original Commentary. As in the beginning of the tradition, the miniatures were inserted in breaks in the text, rather than composed as full-page pictures that sometimes even spanned adjoining pages, as they would after the tenth century. The framing of the illustration, on the other hand, seems to belong to the manuscript culture of Asturias, in the north of the peninsula, during the reign of Alfonso III (d. 910). Contemporary Asturian illustrated manuscripts do not survive, but the green and terracotta colors and the frames with comparable decoration appear in manuscripts without figural decoration. The fact that the composition of the scene has a marked resemblance to the same subject in the Commentary from Lorvão (see Fig. 74; No. 22), copied in 1189, indicates that the Silos fragment is an authentic witness to the Beatus tradition despite the limited talents of its illuminator.

The folio with the illustration came from Nájera, encasing a document that dealt with San Andrés de Cirueña, a Navarrese monastery founded in the tenth century - too late, apparently, to have been its producer, and there is no proof that it originated there. Although it resembles in its color and simplicity manuscripts associated with Alfonso III of Asturias, we have such a limited knowledge of manuscripts from this date in Navarre that it is impossible to rule out an origin there. In fact, as is discussed in the introductory essay, the nearness of Cirueña to San Millán de la Cogolla, where several copies were made later, raises the question of a possible connection there, for its text, moreover, is linked to that of the San Millán (No. 9) and Escorial (No.10) Commentaries, both produced at the scriptorium of San Millán (Gryson).

With the opening of the fifth seal, St. John has a vision of "those who had been slain for 
Figure 34 The Opening of the Fifth Seal: The Souls under the Altar (Apoc. VI, 9-11). Silos Fragment. Silos, Biblioteca del Monasterio de Santo Domingo, frag. 4

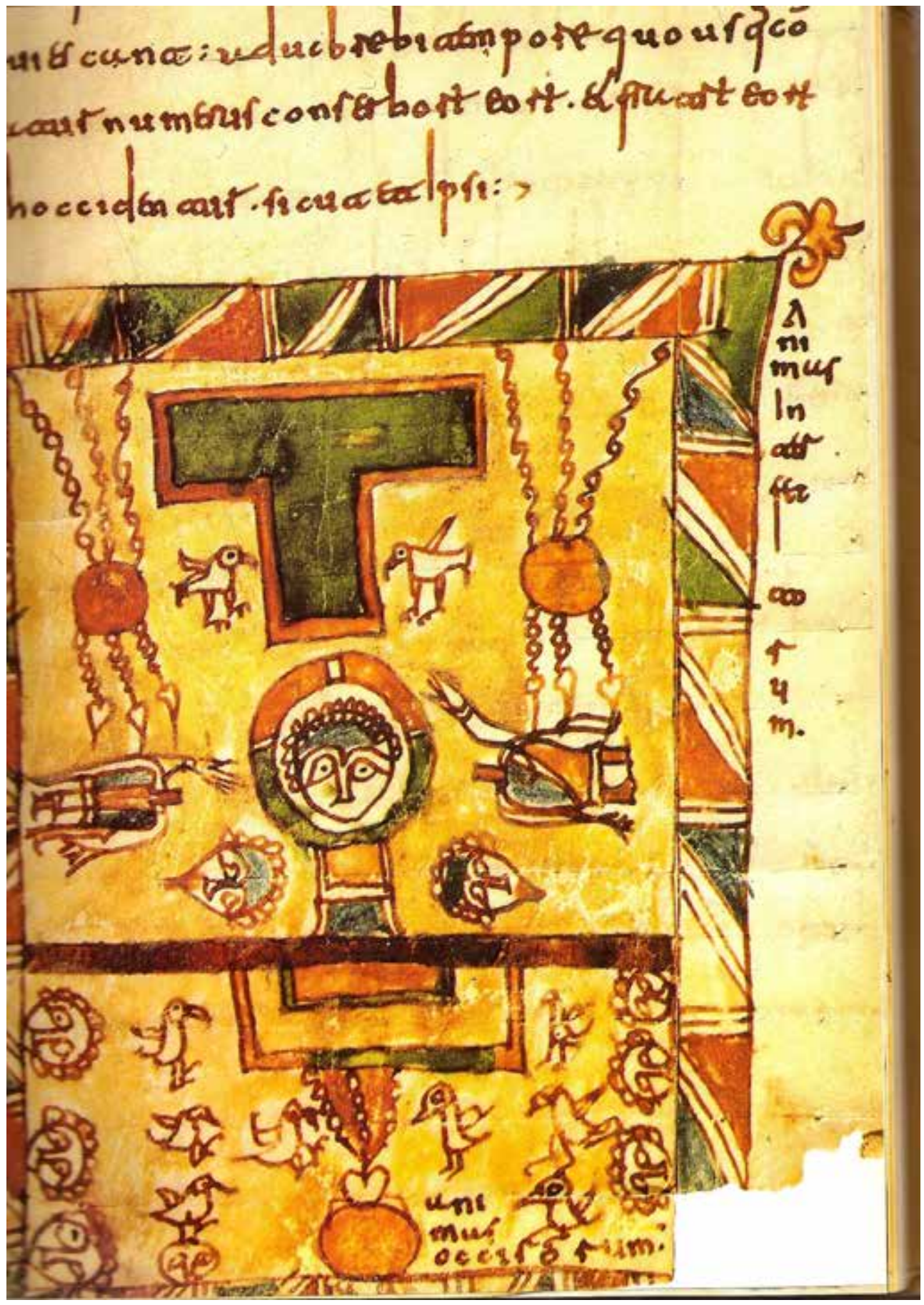

Photo: John Williams 
the word of God." They are "under the altar," given robes of white, and told to wait until their number is complete. In the Silos fragment, the T-shaped object at the top reflects the early medieval form of peninsular altars, which rested on single supports. Votive crowns donated by rulers were suspended in sanctuaries as early as the fourth century, and several such crowns survive in Spain from the seventh century. This is most likely the identity of the disks hanging beside the altar. Although decapitated, the martyrs (labeled "souls of the martyred" by the inscription running beside the frame on the right side) still manage to gesture toward the altar. Closer to the altar a pair of souls, symbolized in a traditional Christian way as doves, confirm the martyrs' salvation.

The martyrs appear again as heads and as doves in the space below formed by a horizontal bar that segregates the lower third of the composition. This repetition probably reflects the fact that the Commentary, unlike the biblical text, speaks of two altars, "one of gold and one of bronze, one in the interior and one in the exterior." Although anomalous in shape, the altar seems securely identified by the suspended crown. If so, this composition would be one of the few in the Beatus tradition that is not tied exclusively to the biblical text, but draws also on the text of the Commentary.

Williams 1994b, 17-20; Yarza 1998a, 12ff.; Suárez González 2009, 40-46; Williams 2009, 103-05; Gryson 2012, LXI-LXII; Klein 2014a, 10-11.

\section{The Morgan Beatus}

New York, The Morgan Library \& Museum, MS M.644. 300 fols., $15.2 \times 11.2$ in. ( $387 \times 285 \mathrm{~mm})$

c. 940-45

Origin: San Salvador de Tábara

Illuminator: Maius
Let the voice of the faithful resound, and re-echo! Let Maius, small indeed, but eager, rejoice, sing, re-echo, and cry out! Remember me, servants of Christ, you who dwell in the monastery of the supreme messenger, the Archangel Michael. I write this in awe of the exalted patron, at the command of the abbot of the victor [St. Michael], out of love for the book of the vision of John the beloved disciple. As part of its adornment I have painted a series of pictures for the wonderful words of its stories so that the wise may fear the coming of the future judgment of the world's end.

To complete this book, two complementary works of similar tenor have been added.

Thus this book from beginning to end is completed in the era of twice two (and) three times three hundred and three times twice ten.

Be glory to the Father and to his only Son, to the Holy Spirit, and the Trinity from age to age to the end of time. (Pérez/Williams)

From this copy's unusually informative scribal colophon, we learn that it was carried out by a monk named Maius for a monastery dedicated to St. Michael. The assumption that this was San Miguel de Escalada, a monastery founded in 913 south of the capital of León by monks from Córdoba, and that Maius headed the scriptorium there (García Lobo), is based on the fact that at one time the Morgan Commentary was in Escalada. In the introductory essay, I questioned this assumption: location and circumstance instead make it possible, even probable, that the Morgan copy was made at Tábara for San Miguel de Moreruela.

Maius's colophon includes a ciphered date of 926, but this part of the colophon seems to have been changed, perhaps by Maius himself; the initials and figure style, as well as a comparison with an illustration produced at Valeránica in 
Figure 35 The Lamb on Mount Sion (Apoc. XIV, 1-5). Morgan Beatus, fol. 174 ${ }^{\mathrm{v}}$. New York, The Morgan Library \& Museum, MS M.644

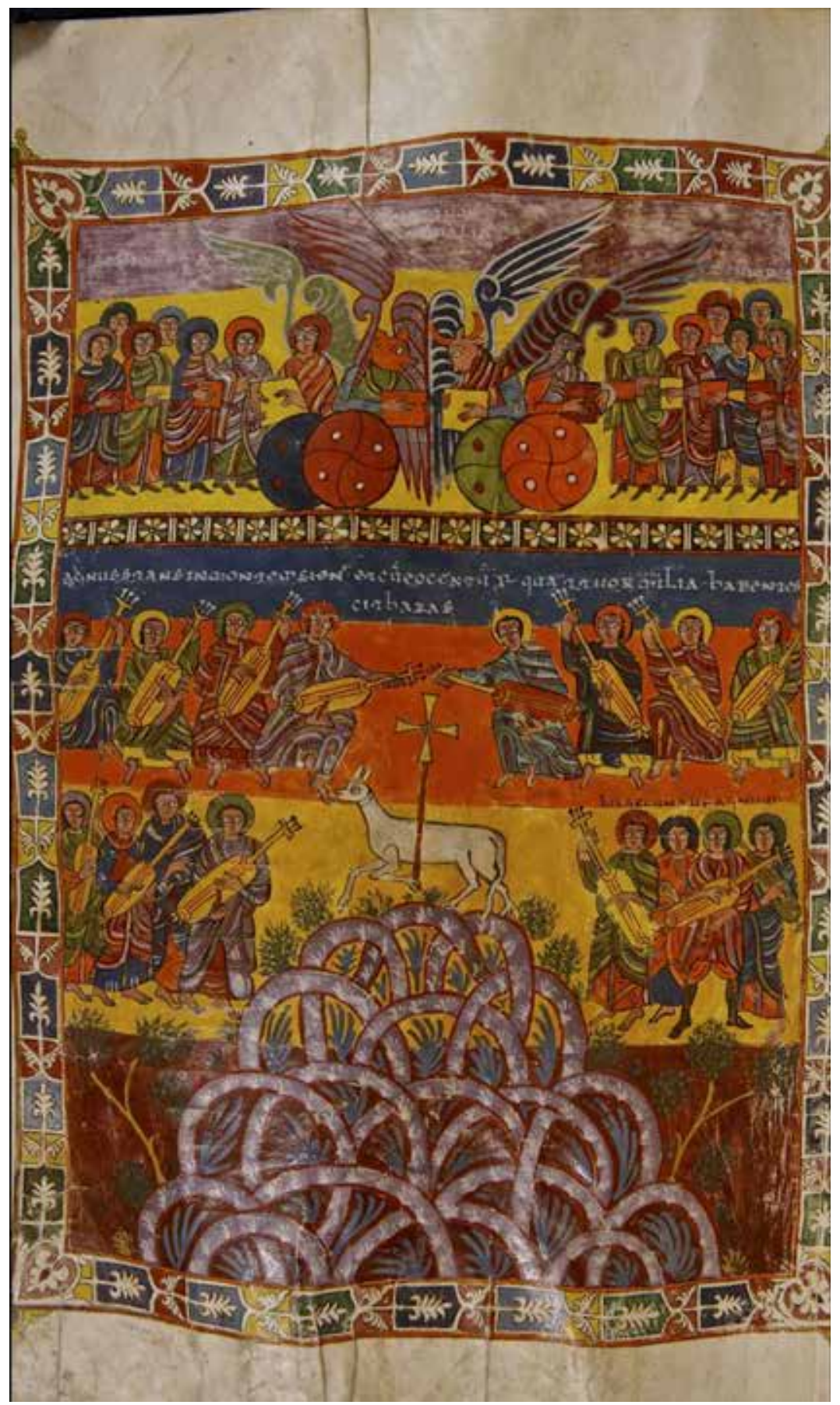

Photo: Hamid Shams 
Figure 36 Heavenly Jerusalem (Apoc. XXI, 1-27). Morgan Beatus, fol. 222v. New York, The Morgan Library \& Museum, MS M.644

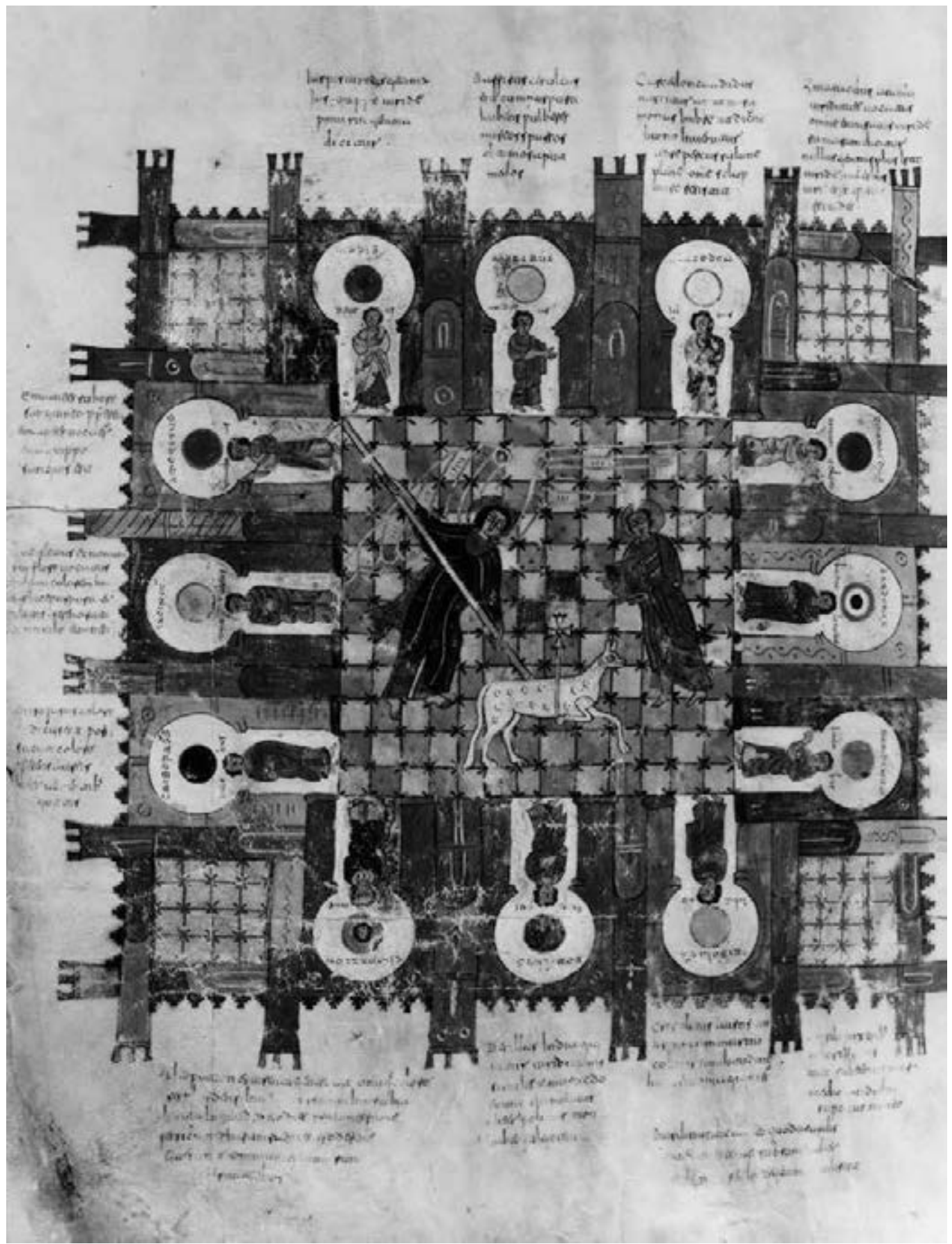

Photo: Joseph Zehavi 
945, indicate rather a date toward the middle of the tenth century. Although the artistic level attained in this copy implies a prior history of manuscript production on Maius's part, the Morgan copy must have been carried out relatively early in his career, which ended with his death at Tábara in 968, where he was interred with honor in the cloister, perhaps in the Late Antique sarcophagus that survives in Tábara only in fragments (Regueras and García-Aráez Ferrer).

The rewards granted us by the survival of this Commentary are twofold. In the first place, the Commentary offers a magnificent display of the visual splendor made possible in the pre-Romanesque manuscript culture of the peninsula. Illusions of depth and mass are systematically suppressed in order to create a brilliant polychromatic surface. Figures are swathed in robes composed of an intarsia-like pattern of sharply contrasted hues played off against broad bands of contrasting color. These help to subdivide the narrative while reinforcing the basic aesthetic of a dazzling surface. Manuel Gómez-Moreno, in his seminal Iglesias mozárabes, coined the label "Mozarabic" for this style, implying a major dependence on the Islamic arts of al-Andalus. While the churches contemporaneous with the Morgan Beatus owe a fundamental debt to Islamic architectural traditions, from the little we know of medieval Islamic painting in the peninsula, it exercised no influence on the formal qualities of Christian manuscript illumination. However, certain motifs in the Beatus Commentaries - such as lute-playing attendants and the substitution of cushions for thrones in scenes of majesty and adoration - are linked to Islamic objects produced in al-Andalus. Contrary to the "Mozarabic" label assigned to works of this era, it was actually to northern European artistic culture - specifically manuscripts produced at Saint-Martin in Tours - that Maius turned in his reform of the appearance of the Commentary.
In fact, the style employed by Maius has elements that exceed the usual boundaries of "Mozarabic" art. He employed an unmatched range of hues, including an intense blue infrequently used in other tenth-century codices. The primary colors are present in saturated states, but also in combination with each other, the blue and red producing a favored purple. White is much in evidence in combination with other hues, as well as by itself. Precious metals were also used in the early folios: the column bases and nimbi or haloes of the Evangelist and Angel/Gospel pages have oxidized, indicating the presence of silver, while small initials show evidence of gilding. Maius's figure style stands apart also. It did not retreat from the principle of making the surface paramount, which marked the peninsular style, but relied on color to reinforce this effect, with garments parti-colored to a fantastic degree. The drapery is exceptionally complex, employing a vocabulary seemingly designed to establish rapport with the figure, even if at times within a syntax that contradicted such rapport. In the almost bewildering number of directional changes in the linear description of his figures' mantles, Maius seems to reveal some sense of the plasticity that the rest of the school ignored. In a comparable indication of different artistic principles, many of Maius's figures stand with one foot in profile, the other frontal. This contrappostic formula would have allowed the figures painted by Maius to inhabit comfortably an illusionistic space, had the style recognized such a concept.

Williams 1994b, 21-33; Pérez de Urbel 1945, II: 309; Shailor 2000; Williams 2000a; Regueras Grande and García-Aráez Ferrer 2001, 53, Figs. 47-48; García Lobo 2005, 58-65; Pérez 2010; Ferrero Gutiérrez 2011, 6off.; Ramos Blassi 2011; Williams 2011a; Klein 2012a. 
3. The Vitrina 14-1 Beatus

Madrid, Biblioteca Nacional de España, MS

Vitrina 14-1

144 fols., 13.5 X 11 in. (345 X $257 \mathrm{~mm})$

Middle of the tenth century

Origin: Kingdom of León (San Millán de la Cogolla?)

The lack of a familiar name is a sign of the orphan status of this Beatus. It is a curiously mutilated copy, preserving only twenty-seven of its original Apocalyptic illustrations. The opening and final folios are gone and with them the kind of distinctive features or colophons that help to assign a home. The figures are painted in the flat, parti-colored manner of the mature phase of the "Mozarabic" style that was found in León and Castile by the middle of the tenth century. The Bible produced in 960 at the Castilian monastery of Valeránica provides a good analog for the figure style. A somewhat less complicated version of this style

Figure 37 The Seven Plague Angels (Apoc. XV, 1-4). Vitrina 14-1 Beatus, fol. 130. Madrid, Biblioteca Nacional de España, MS Vitrina 14-1

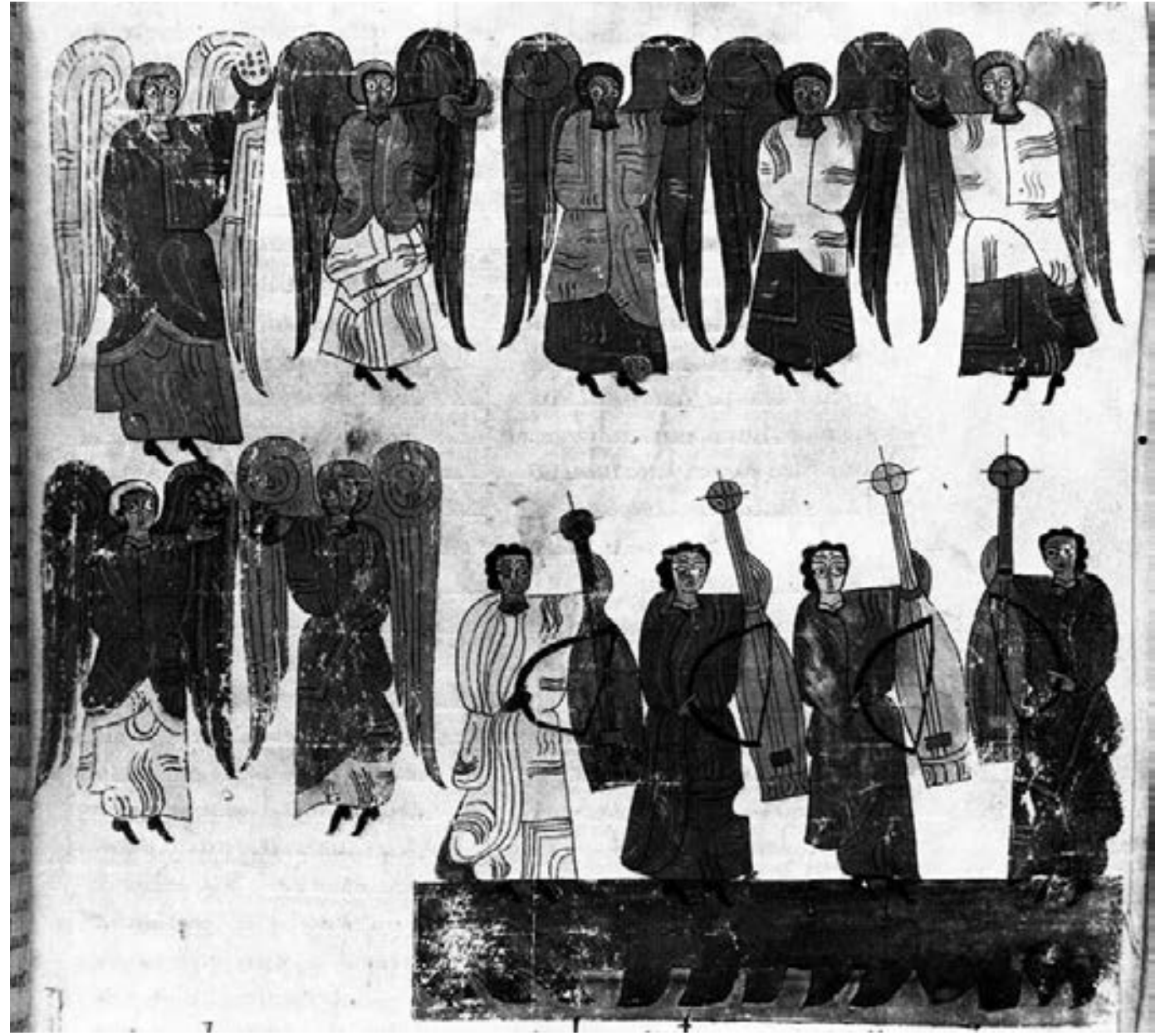

Photo: John Williams 
Figure 38 The Winepress of God's Wrath (Apoc. XIV, 14-20). Vitrina 14-1 Beatus, fol. 127". Madrid, Biblioteca Nacional de España, MS Vitrina 14-1

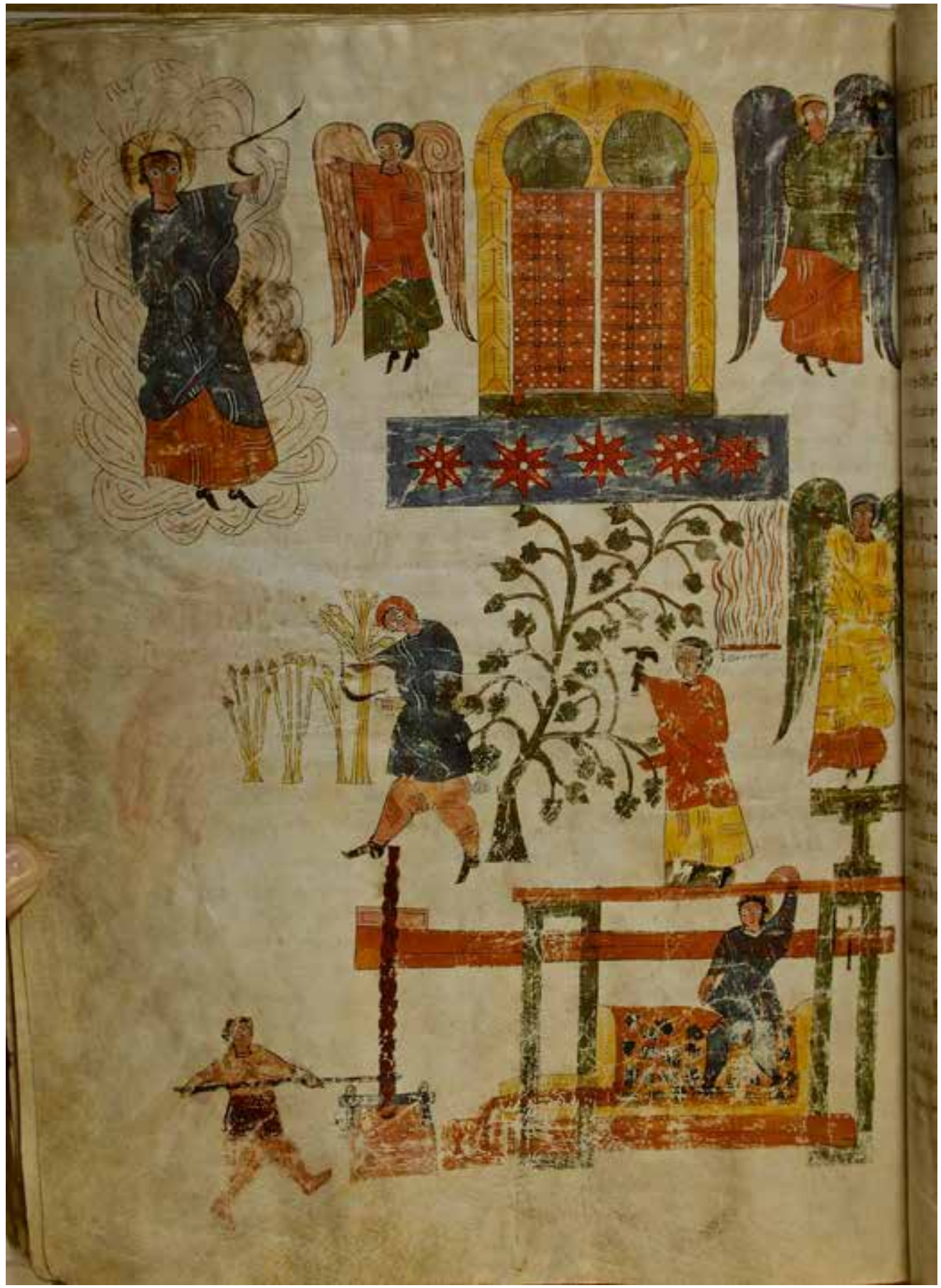

Photo: Hamid Shams 
is found in the "Mozarabic" part of the Beatus from San Millán de la Cogolla (No. 9), and a case has been made for a connection between Valeránica and the scriptorium of San Millán (Pérez de Urbel). In fact, Vitrina 14-1 was listed in an inventory of 1821 at San Millán, and its presence there much earlier, around 1200 , is indicated by textual corrections of a kind found in other San Millán products. The lack of interlace initials fits with their relatively late appearance at San Millán, in the second half of the tenth century, but this virtually exhausts the style-based argument that would place its origin there. In a comprehensive monograph and a later publication that accompanied the facsimile, Peter Klein assigned Vitrina 14-1 to some unspecified site in southeastern León. His case rested essentially on similarities between its initials and those of a Conciliar manuscript (Madrid, B.N. Cod. 1872) that was seen in the sixteenth century at the monastery of Sahagún, but Klein did not suggest Vitrina 14-1 originated there. The figures of the two are radically different, but that tells us only that they were painted by different hands. Both of these manuscripts are glossed in Arabic. In addition, Vitrina 14-1 has decorative motifs of Andalusi flavor. On folio 28 , for example, Kufic script has been converted into an ornamental frieze on the lowest register of the Church of Pergamum. These signs of familiarity with the culture of Islamic Spain are consistent with the fact that Sahagún was founded by emigrant monks from al-Andalus. San Millán, for its part, was a center associated with Branch I Commentaries.

In spite of its mutilated state, Vitrina 14-1 remains of exceptional interest, thanks to the fact that its text represents, with the SaintSever Beatus (No. 13), the earliest version of the Commentary. It is, however, a better witness to the beginnings of the tradition than Saint-Sever, which exhibits the pattern of illustrations found in the revision of the tradition that accompanied the Branch II textual family. True to the original format, the illustrations of Vitrina 14-1 are unframed and posed against unpainted backgrounds (see Fig. 11). When compared to the other representatives of the Branch I family, however, Vitrina 14-1 seems eccentric and adventurous in the design of its illustrations. One also gets the sense that the pictorial content is accommodated imperfectly by the text and has been amended to fit a picture space frequently inadequate for a more developed orthodox iconography.

Williams 1994b, 34-37; Yarza 1998a, 76-80; Pérez de Urbel 1977; Silva y Verástegui 2004; Klein 2011a, 2011b, 2014.

\section{The Valcavado Beatus}

Valladolid, Biblioteca de la Universidad, MS 433 230 fols., $13.7 \times 9.5$ in. (350 x $240 \mathrm{~mm})$

8 June-8 September 970

Origin: Kingdom of León (Monastery of Valcavado?)

Scribe and illuminator: Obecus

This Beatus, sometimes referred to as the Vallodolid Commentary, has been customarily attributed to the monastery of Valcavado, which occupied a site now in Valcavadillo near Saldaña, sixty-five kilometers east of León. It was seen there in 1572 by Philip II's bibliographer, Ambrosio de Morales. An acrostic on folio 2 states that the manuscript belonged to an Abbot Sempronius (SEMPRONIUS ABBA LIBRUM), a fact repeated in the colophon of folio $2^{\mathrm{v}}$. We are also informed that the Commentary was painted by Obecus, and on the next page the dates of his three-month campaign are given: 8 June to 8 September. There is some disagreement as to the number of hands responsible for the writing, as well as the meaning of depingere, which, as discussed in the Introduction in connection with En's 
Figure 39 The Adoration of the Statue and the Three Hebrews in the Furnace (Dan. III). Valcavado Beatus, fol. 199v'. Valladolid, Biblioteca de la Universidad, MS 433

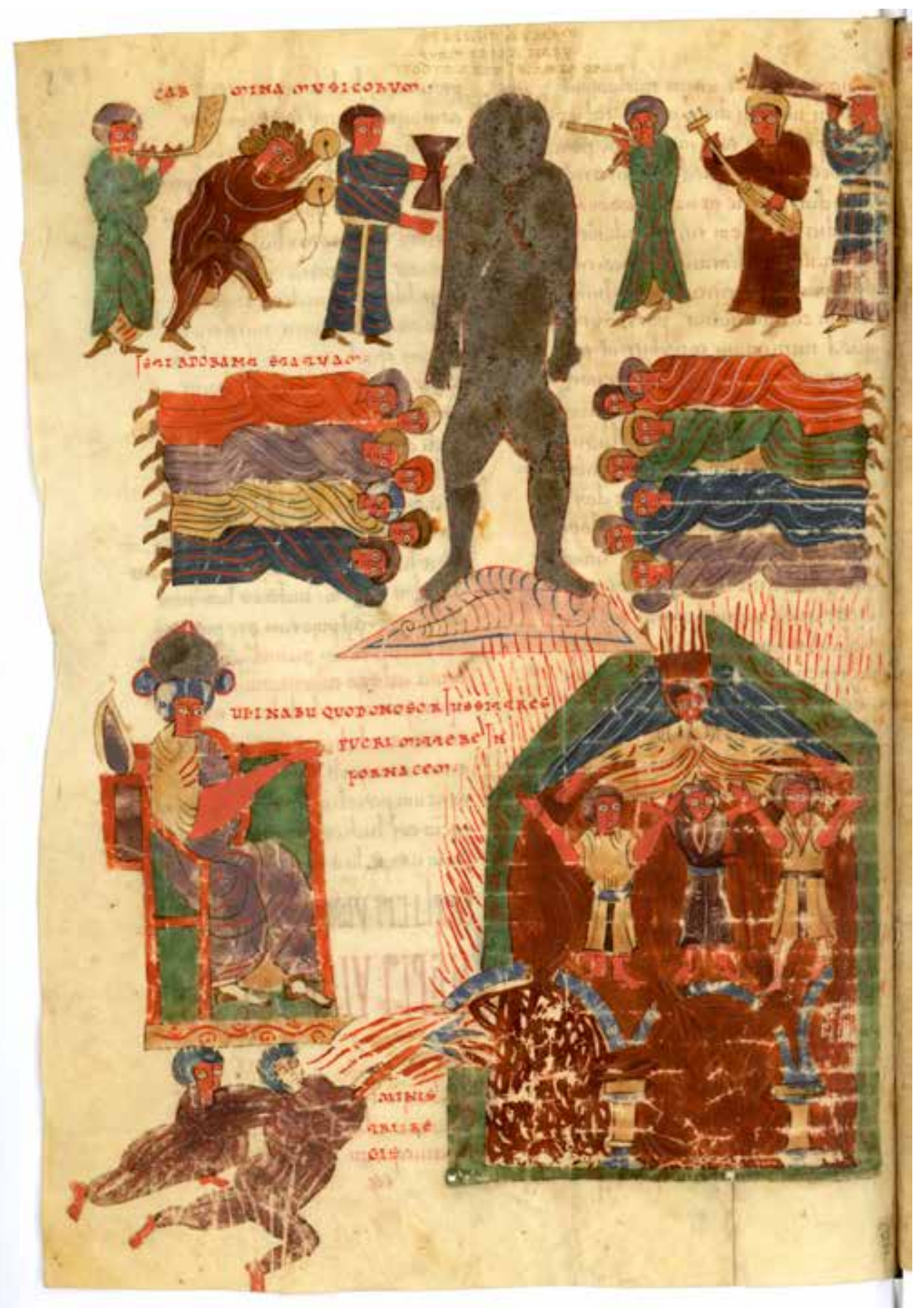


Figure 40 Last Judgment (Apoc. XX, 11-15). Valcavado Beatus, fols. 180-181. Valladolid, Biblioteca de la Universidad, MS 433

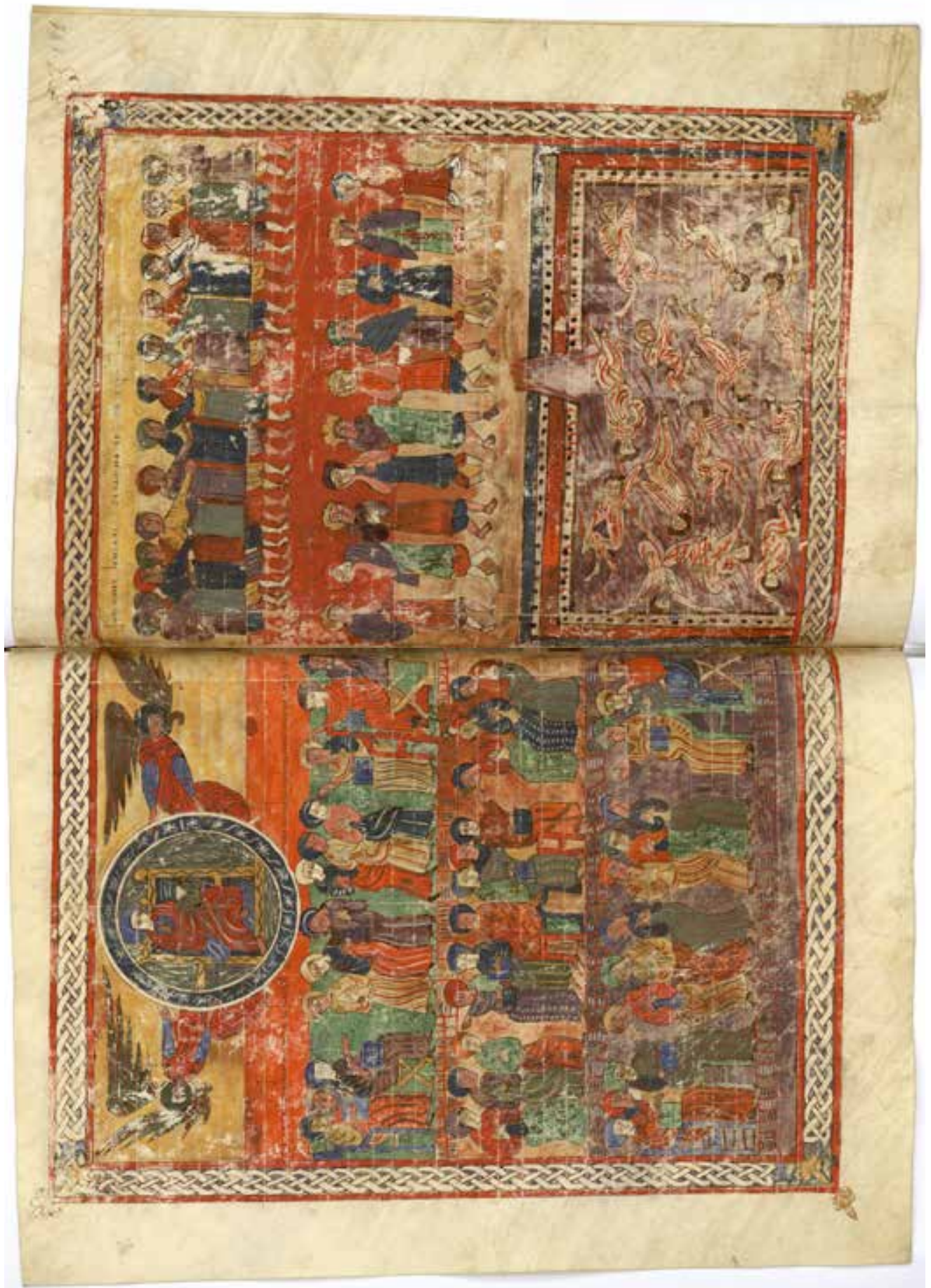


involvement in the Girona Beatus (No. 6), could be used for both writing and painting. In any case, only one hand was responsible for the illustrations.

Without the notice by Ambrosio de Morales, it is doubtful that this copy would ever have been associated with Valcavado, whose first documented mention is in 1036. There is really no confirmation that it was written and painted in Valcavado. However, this monastery came to enjoy a stricter association with the monk Beatus than it deserved. In a curious development, esteem for Obecus's accomplishment eventually led to the formation of a devotional cult surrounding his person, for in the sixteenth century Ambrosio de Morales reported that the body of a Saint Vieco (that is, Obecus) was interred with great dignity in the church of Valcavado. His right arm had been encased separately in a reliquary, an extraordinary testament to the pride of place the Commentary enjoyed there. Long after the time of the Beatus Commentary, Valcavado was attached to Liébana, and Morales mistakenly concluded that the beatified Obecus was in fact Beatus of Liébana himself, who would have ended his days in Valcavado. With the decline of Valcavado this reliquary was translated in 1635 to the Santuario de la Virgen del Valle in nearby Saldaña, where it may be seen today.

Obecus copied his Commentary for Abbot Sempronius from a manuscript representing the Leonese reformation of the tradition by Maius of Tábara. Indeed, there is a strong coincidence between the decorative patterns employed in the frames of the illustrations in the Valcavado Beatus and the Morgan Commentary (No.2). Obecus conceives figures much as Maius does: essentially flat and swathed in draperies composed of panels of bright color. In draftsmanship, however, Obecus displays less control. There is something of a folk-art quality that endows this manuscript with a special expressiveness. Obecus achieved it through the use of active postures and by the introduction of dramatic details. Both techniques are seen clearly in the depiction of the Adoration of the Statue and the Three Hebrews in the Furnace $\left(\right.$ fol. $\left.199^{v}\right)$, where two ministers of the king strenuously pump bellows to raise the heat of the furnace at Nebuchadnezzar's command (Fig. 39). The copy by Obecus is also unique in showing a servant holding a fan in the scene of the Feast of Baltassar (fol. 204). Also original is his choice of a semi-recumbent posture on a throne-divan for the figure of Baltassar in this scene and for that of Nebuchadnezzar in the scene of Daniel Interpreting the Dream of the Tree (fol. $201^{\mathrm{v}}$ ); in the other Commentaries the rulers sit erect on typical thrones. These details may have been inspired by a desire to invoke the Eastern setting of Daniel's history. Perhaps we may speculate that Obecus went further and even sought to identify the pagan rulers of Persia with those of al-Andalus in his own time.

Williams 1994b, 38-42; Yarza 1998a, 100-05; Ruiz Asencio 1993, 2002; Ara Gil 2002; Fernández Flórez 2002; Herrero Jiménez 2002.

\section{The Tábara Beatus}

Madrid, Archivo Histórico Nacional, Cod. ${ }_{1097}$ B 168 fols., 14 x 10 in. (36o x $255 \mathrm{~mm})$

Completed 27 July 970

Origin: San Salvador de Tábara

Scribes: Monnius, Senior

Illuminators: Magius/Maius, Emeterius

This manuscript - produced at the monastery of San Salvador de Tábara in the Kingdom of León - retains only three Apocalypse illustrations and two pages with scenes from St. Jerome's Commentary on the Book of Daniel. However, we have some knowledge of its original illustrative program, for the Las Huelgas Beatus (No. 24) certainly copied it, and the 
Figure 41 Tower Scriptorium. Tábara Beatus, fol. 167 . Madrid, Archivo Histórico Nacional, Cod. 1097B

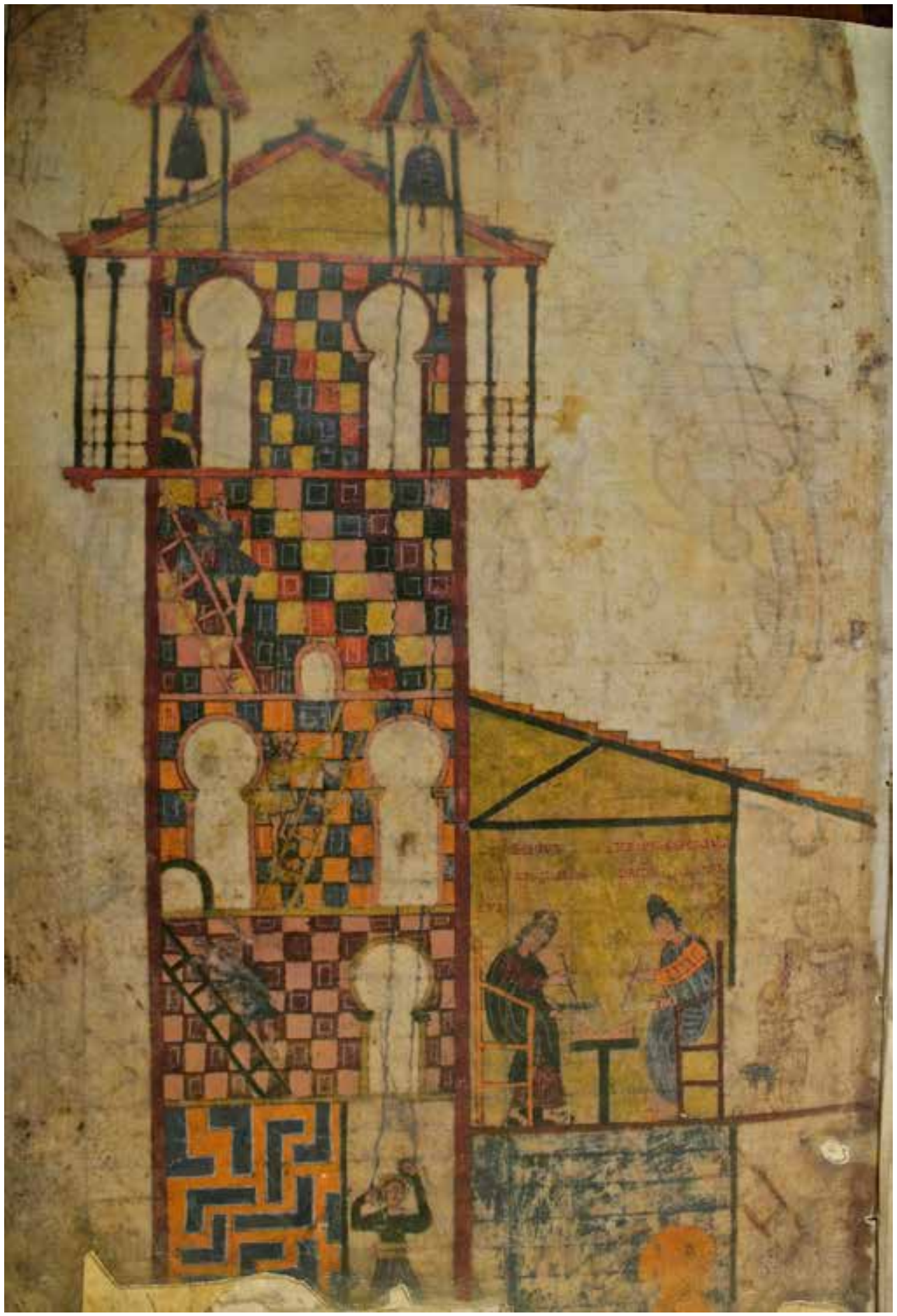

Photo: Hamid Shams 
Figure 42 Feast of Baltassar (Dan. V). Tábara Beatus, fol. 143. Madrid, Archivo Histórico Nacional, Cod. 1097B

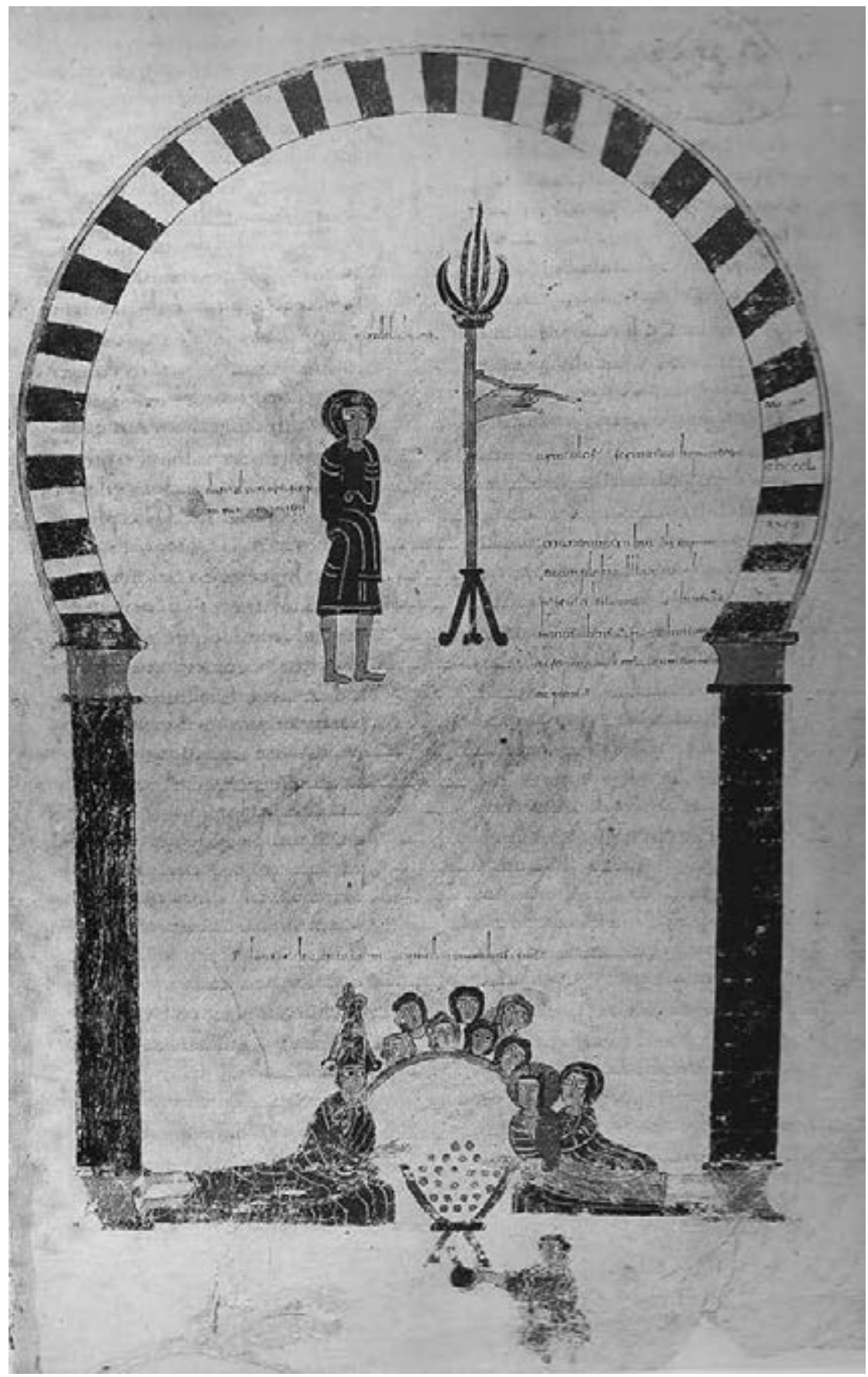

Photo: Fernando Regueras 
Rylands Beatus (No. 20) may have done so as well. Beyond providing a model for later copies, the Tábara Beatus helps document the history of the tradition: it ends with an extraordinary portrait of the scriptorium itself (Fig. 41). It was attached to the second story of a bell tower that may partially survive within the actual twelfth-century church tower of Santa María in Tábara (see Fig. 7), a Leonese town some fifteen miles north of Zamora. One of the scribes depicted, distinguished by a large hat, is identified by inscription as Emeterius, and the colophon appearing below the imposing Omega on the recto of this same folio recounts that Emeterius was called to Tábara to complete the Commentary begun by his master, Magius, in 968. Magius died on the thirtieth of October that same year. Emeterius worked on the commission from May until 27 July 970. Thus the special status of Tábara as a center for the production of illuminated manuscripts, implied by the extraordinary portrait of the scriptorium, is confirmed by the colophon, for the Magius of the Tábara colophon is certainly the Maius of the colophon of the Morgan Beatus (No. 2). While his hand is responsible for the first sixty-eight surviving folios of the Tábara Beatus (see Shailor), the difference in the stylistic character of its remaining illustrations suggests that Maius had not begun the task of painting. Indeed, a match for the energy and polychromatic brilliance of the Morgan Beatus cannot be found in the surviving miniatures of the Tábara Beatus. If anything, Tábara marks a tendency toward simplification. It may be seen in the preference for axial symmetry over the Morgan copy's more random narrative quality. None of the surviving miniatures would seem to have been executed by Maius.

The Tábara Beatus also differs from that in the Morgan Library in being the first known example to employ the modified Commentary text that Wilhelm Neuss designated Branch IIb, which appears in the Gryson stemma as Rho (see Fig. 4). It was a slight modification distinguished chiefly by the repetition of Augustine's De Antichristo at the end of the Prologue to Book II. This addition may represent a new anti-Islamic sentiment on the part of Christian emigrants moving northward from al-Andalus, for the Tábara Beatus is also distinguished from the Morgan copy by the presence of marginal glosses in Arabic. Thus on folio $29^{\mathrm{v}}$, beside the explanation of the Antichrist, the reader is enjoined in Kufic script to "understand the conditions and the rule of the Antichrist, the imposter." At the same time, however, the influence of Islamic decorative conventions can be detected. The blue and orange meander pattern of the bottom story of the tower is one example. Painted stucco reliefs with similar geometric patterns raised against a red background are found on the walls of the tenth-century caliphal palace of Madinat al-Zahra outside Córdoba, and the polychrome meander was employed on the facades of the Great Mosque of Córdoba. Tábara was on the route of alMansur's destructive raid of 988 . Perhaps San Salvador de Tábara was a target at that time, and the Tábara Beatus launched on a journey that would end with its arrival at its present home in Madrid at the end of the nineteenth century - assuming it was originally made for the library of Tábara. In any case, it would play a key role in the final efflorescence of the Beatus tradition in the Kingdom of Castile at the end of the twelfth century and the beginning of the thirteenth: the tower would once more make an appearance in the Beatus of Las Huelgas (see Fig. 77).

Williams 1994b, 43-49; Yarza 1998a, 96-98; Shailor 2000, 635; García Lobo 2005; Williams 2005 a. 


\section{The Girona Beatus}

Museu de la Catedral de Girona, Num. Inv. 7(11) 284 fols., $15.7 \times 10.2$ in. (400 x $260 \mathrm{~mm}$ )

6 July 975

Origin: San Salvador de Tábara

Scribe: Senior

Illuminators: En (?), Emeterius (?)

This copy was given to the Cathedral of Girona by its choirmaster, Johannes, in 1078. How he acquired it is not known, but it is the third and latest surviving Commentary linked to Tábara. An origin there is deduced from the participation in its production by the Emeterius who completed the Tábara Beatus in 970 (No.5), following the death of Maius. His name appears below the grand Omega that closes the manuscript, as was the case in the Tábara Beatus. We also learn from a colophon in the Girona copy that it was completed on Tuesday, 6 July 975, a date that confirms that writing and painting were summertime activities. Although the severe mutilation of the Tábara Beatus makes it difficult to appreciate, the extraordinary pictorial density of the Girona Commentary is a glorious testament to the final maturity of the scriptorium, with a lessening of its distinctively provincial, "Mozarabic" character. The figures are rendered with less complex drapery formulas than those of Maius, and come closer to those employed elsewhere in European illumination. At the same time the Girona Beatus is remarkable for the evidence it provides of the extraordinary resources available at a frontier monastery, for it expanded the Christological complexion of the iconography by following the Genealogical Tables with a seven-page Christological cycle (fols. 15-18), including unique episodes involving Herod (see Fig. 25). The sources for these scenes remain puzzling, except for the two frontispieces: certain details of the Cross (fol. $1^{\mathrm{v}}$ ) and Christ in Majesty (Fig. 44), such as the mundus (world) held by Christ and the figure-eight shape of the mandorla surrounding him, point unmistakably to the continued availability of imagery linked to the Carolingian scriptorium of Tours. This was the source, as we saw in the introductory essay, of the new pictorial format adopted by Maius as well as the type of interlace initial he introduced to peninsular illumination (see Fig. 21).

The Girona Beatus has a Janus-like complexity. On the one hand, in comparison to the other Commentaries of whatever family or date, it is most remarkable for the introduction of Christian subjects not otherwise found in Iberia, and for the links it reveals to Carolingian art of the previous century. On the other hand, it is the optimum Commentary for discussing the thorny question of Islamic influence, a tendency anticipated in its predecessor, the Tábara Beatus (No. 5). Other Commentaries might portray buildings displaying architectural formulas associated with Islam, such as the horseshoe arch, but the illuminator of the Girona Beatus went out of his or her way to include subjects of unmistakable Islamic or Eastern provenance. A mythical creature combining eagle and lion, the simurgh, fills the lower half of folio $165^{\mathrm{v}}$ (see Fig. 26). Of Near Eastern origin but familiar from Andalusi textiles, the simurgh here accompanies another royal theme common to Islamic art, the eagle with a captive gazelle, versions of which were depicted on ivories produced at the Andalusi capital of Córdoba.

Even more remarkable, the Girona Beatus is unique in having a named woman take part in its production. Maius's pupil, Emeterius, is named below an immense interlace Omega (see Fig. 24) in an elaborate display script against a painted ground. He is not, however, the first person listed there. Emeterius is preceded and upstaged by "En, painter and helper of God" (En depintrix et D[e]i aiutrix). The label "helper 
Figure 43 Descent into Hell. Girona Beatus, fol. 17². Museu de la Catedral de Girona, Num. Inv. 7(11)

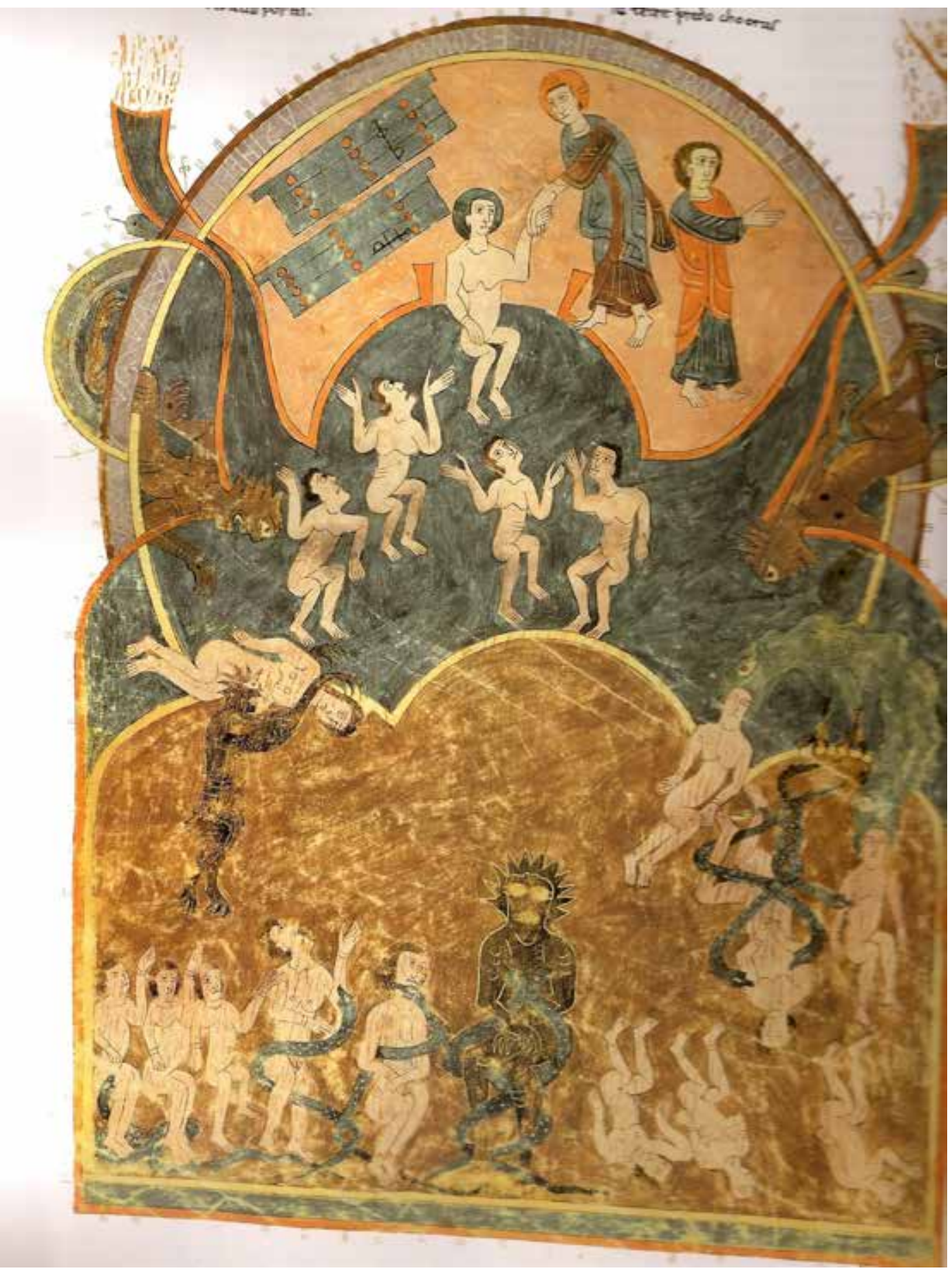

Photo: John Williams 
Figure 44 Christ in Majesty. Girona Beatus, fol. 2. Museu de la Catedral de Girona, Num. Inv. 7(11)

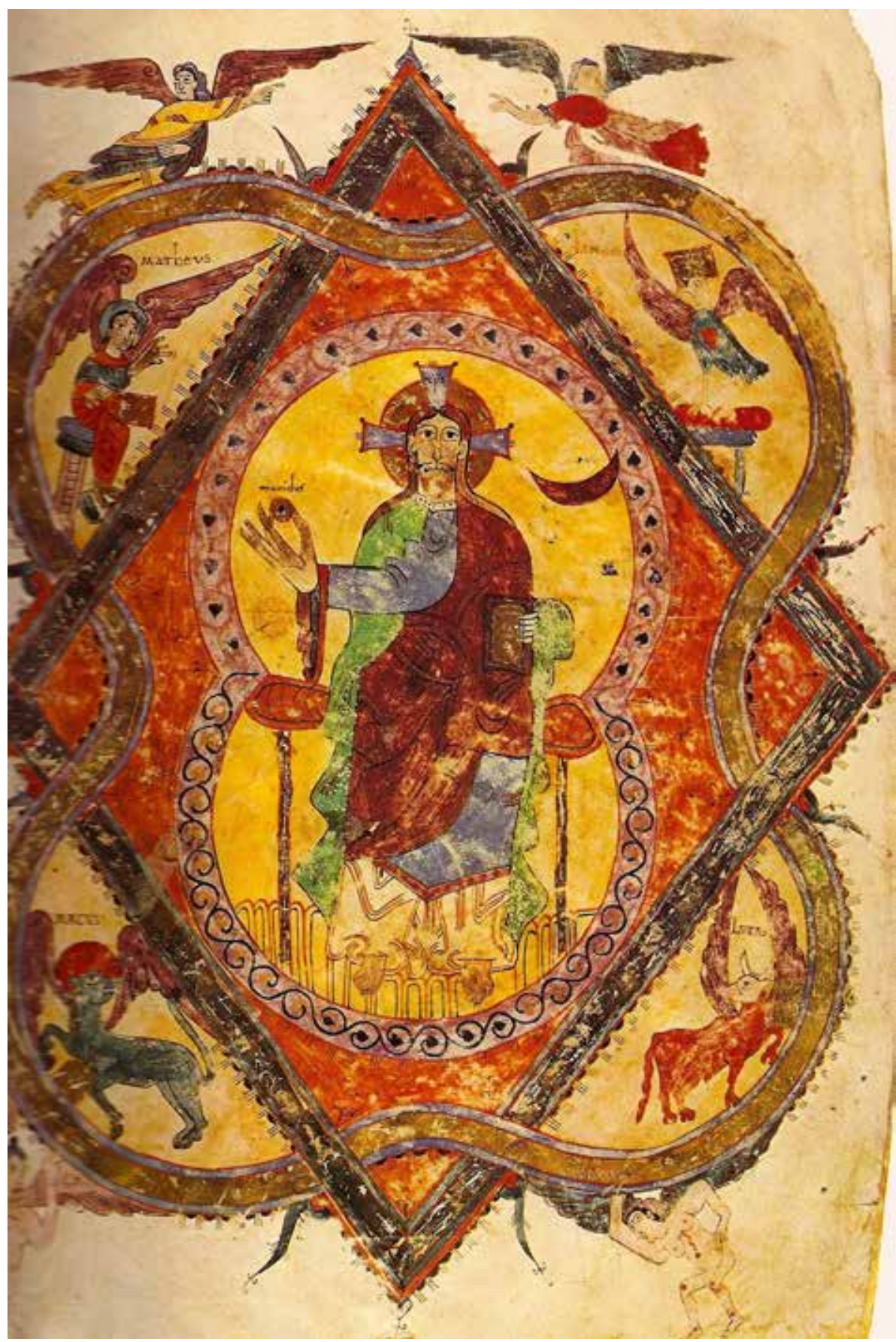

Photo: John Williams 
of God," with its feminine ending is generally taken to mean that En was a nun at the double monastery of San Salvador de Tábara. Yet as an honorific title, Dei aiutrix could be bestowed on elite women outside a religious setting as well, and so a civil status for En is not out of the question. Nuns could be scribes, and the designation "depintrix" did at times indicate that role, as Ferrer Dalgá emphasized. Read literally, the term would mean that En was a painter. The priority accorded her name in the colophon may indicate a layperson of high rank, possibly acting as patroness. That is mere conjecture, but her link to the manuscript's production is not. While it is impossible to confirm the nature of En's responsibility, it is an enticing fact that this Commentary displays the most extensive range of Eastern/Islamic subjects found among all surviving copies.

Williams 1994b, 51-64; Yarza 1998a, 106-41; Ferrer Dalgá 1993; Werckmeister 1997; Miranda, C. 2004; Roura i Güibas 2004; Coffey 2010.

\section{The Vitrina 14-2 Fragment}

Madrid, Biblioteca Nacional de España, MS

Vitrina 14-2, fols. 1-5

5 fols., $14.3 \times 10.4$ in. $(365 \times 265 \mathrm{~mm})$

Second half of the tenth century

Origin: Kingdom of León

A fragment of five folios has been bound, at least since the eighteenth century, as the first five leaves of the manuscript that is otherwise the Facundus Beatus (No. 11). These five folios, not assembled in their correct sequence, make up an incomplete set of Genealogical Tables of the type introduced with the pictorial revision at Tábara. The composition of the pages most closely resembles those employed in the earlier sub-branch of the final edition of the text, and if they are numbered accordingly, the set has this shape: Tables I-II (fol. 5), III (fol. $5^{\mathrm{v}}$ ), VI (fol. 2), VII (fol. $2^{\mathrm{v}}$ ), VIII (fol. 3 ), IX (fol. $3^{\mathrm{v}}$ ), X (fol. 1), Xbis (fol. 1 ${ }^{v}$ ), XI (fol. 4), XII (fol. $4^{v}$ ). They are idiosyncratic, however, in their conflation of Tables I and II and the manner in which Table $\mathrm{X}$ is divided.

It has been argued that this set is a fragment of the Valcavado Commentary (No. 4), which lacks the Genealogical Tables, and indeed it seems to have originated in the same general period and region. However, the ruling of the parchment does not match that of the Valcavado Beatus, nor does its palette of pale green and red hues. The lack of illustrations further speaks against such an origin. Although biblical manuscripts such as the León Bible of 960 also include such tables, chances are these were designed for a Beatus Commentary.

Williams 1994b, 65; Yarza 2006a. 
Figure 45 Genealogical Table X. Vitrina 14-2 Fragment, fol. 1. Madrid, Biblioteca Nacional de España, MS Vitrina 14-2

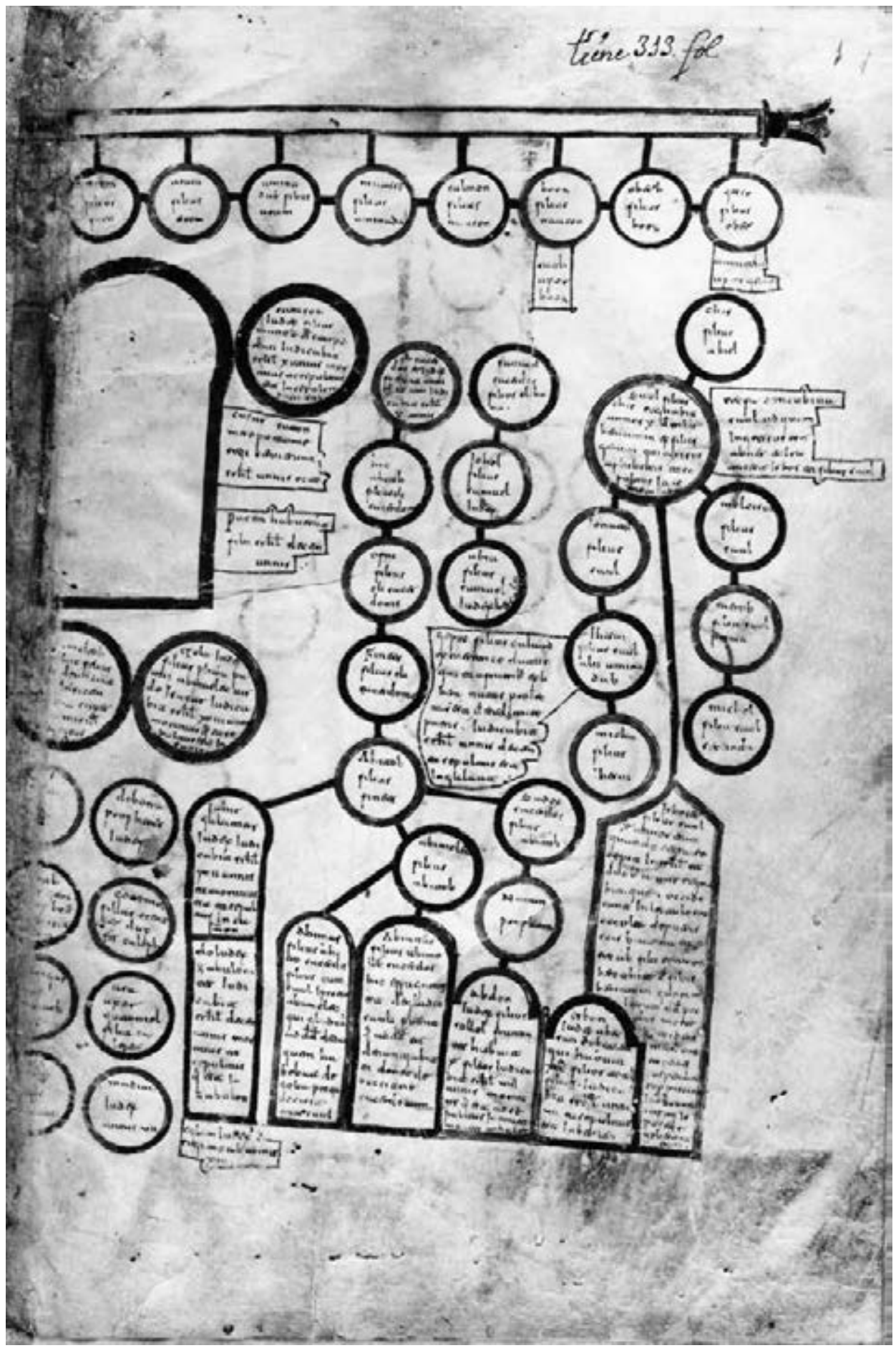




\section{The Urgell Beatus}

Museu Diocesà de la Seu d'Urgell, Num. Inv. 501 232 fols., $15.8 \times 10.5$ in. $(402 \times 265 \mathrm{~mm})$

Last quarter of the tenth century

Origin: Kingdom of León

The Beatus Commentary of the Cathedral of Seu d'Urgell was carried out, it seems, by a single illuminator who was a draftsman of limited competence. However, the wide range of colors employed, with orange, pale yellow, purple, and terracotta dominant, indicates a scriptorium with some experience in illumination. The pictorial contents of the first quire are anomalous. With the exception of the Genealogical Tables, the failure to include the frontispieces customarily attached to copies in this branch of the family tree is notable. Moreover, the Genealogical Tables are of a special type otherwise associated with Bibles rather than Beatus manuscripts, and may not have been copied from the Commentary that was the model for the rest of this Beatus. The irregularity of the opening of Urgell continues with the presence of the Bird and Serpent Combat, which in the Beatus tradition is connected with copies representing the final elaboration of the text, such as the Girona Beatus (see Fig. 30; No. 6), rather than the revision appearing first in the Morgan Beatus (No. 2). Like the Genealogical Tables, this is a subject associated with biblical codices and need not have been taken from a Beatus model. In Urgell, the Bird and Serpent illustration is untinted, and not accompanied by its allegorical text. Despite these anomalies in the first quire, the style employed is that of the rest of the manuscript. Finally, the Map of the World normally located in the Prologue to Book II is included in the first quire, but, uniquely, it is not tinted.

The Urgell Commentary contains no statement about origin, patron, or scribe. Its possession by the Cathedral dates back at least to 1147, the year it appeared in a catalogue of books in its library. A comparison of the parallels between Urgell and Valcavado (No. 4) in the decoration of the frames and in the details of selected miniatures reveals an especially close relationship between the two. Indeed, the family tree of texts (see Fig. 4) indicates the use of the same model for both. Neuss proposed an origin in the Aragonese-Navarrese region, chiefly because he felt that its style was distinct from that found in such Leonese Commentaries as the Morgan and Valcavado copies; Klein adopted this conclusion on the basis of its small initials. However, most paleographers have proposed an origin further to the west, and Urgell and Valcavado resemble each other stylistically as much as any pair of Commentaries. To my eye, the format, color, and iconography place Urgell squarely within the Beatus tradition of the Kingdom of León. The interlace initials of this Beatus are also consistent with such an origin. While the debility of the technique of Urgell may leave open the possibility that a Navarrese illuminator was unusually subservient to the style of his Leonese model, it seems preferable to assign our Beatus to the Kingdom of León.

The relationship between Urgell and Valcavado would not be as close as that of mother and daughter. Valcavado has unique renderings of such scenes as the Feast of Baltassar that are not found in Urgell. However, it seems unlikely that the Urgell Beatus dates as early as 970, the year of Valcavado's creation. Its "Mozarabic" style seems carefully, if somewhat clumsily, carried over from its model by an illuminator of limited experience, and the model itself could not have been made much earlier than 970. A date toward the end of the tenth century seems apt.

Williams 1998, 17-20; Yarza 1998a, 143ff.; Cagigós Soro 2001; Klein 2001. 
Figure 46 The Two Witnesses Killed by the Antichrist (Apoc. XI, 7-10). Urgell Beatus, fol. 136. Museu Diocesà de la Seu d'Urgell, Num. Inv. 501

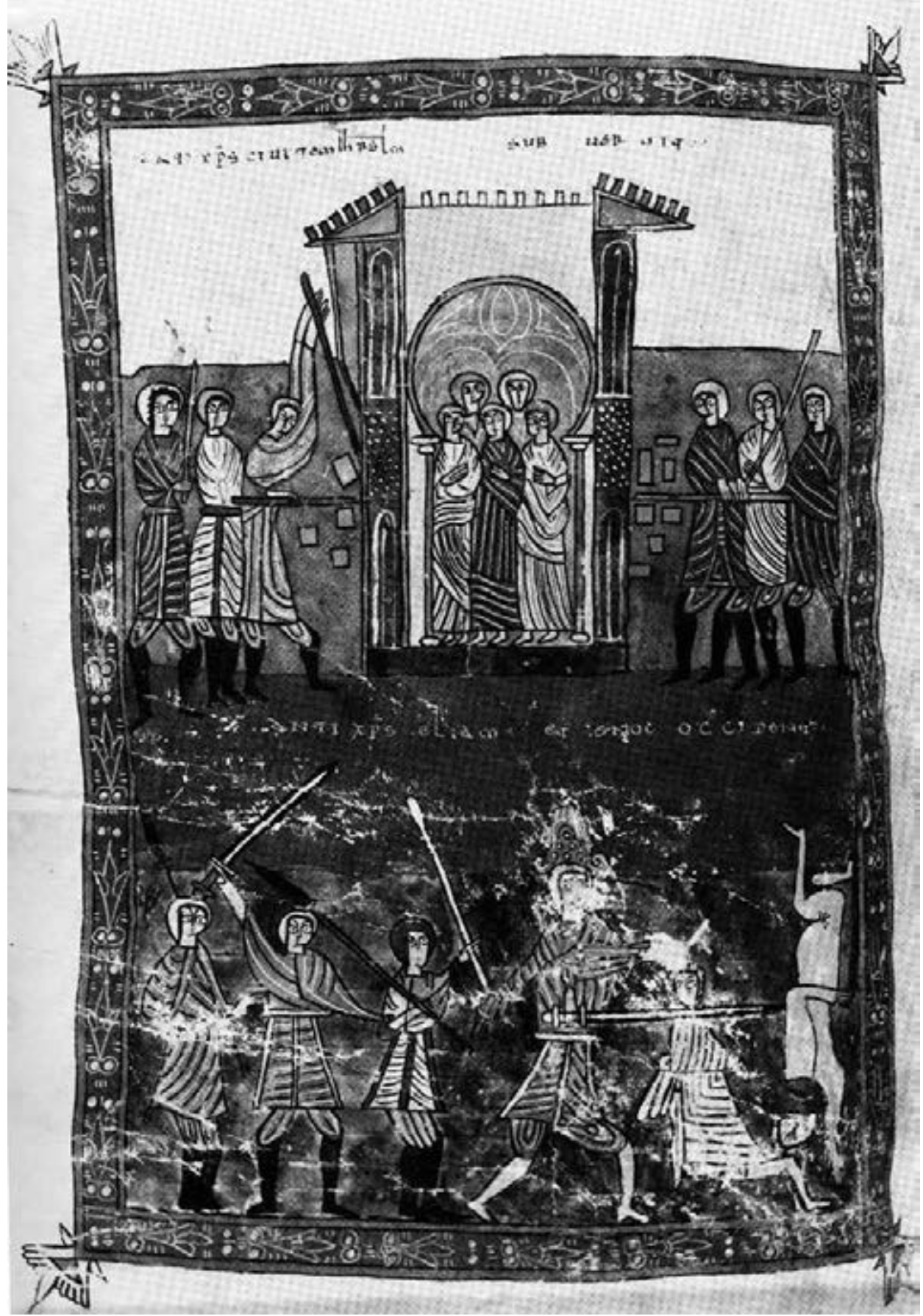

Photo: John Williams 
Figure 47 Nebuchadnezzar's Dream of the Tree (Dan. IV). Urgell Beatus, fol. 204v. Museu Diocesà de la Seu d'Urgell, Num. Inv. 501

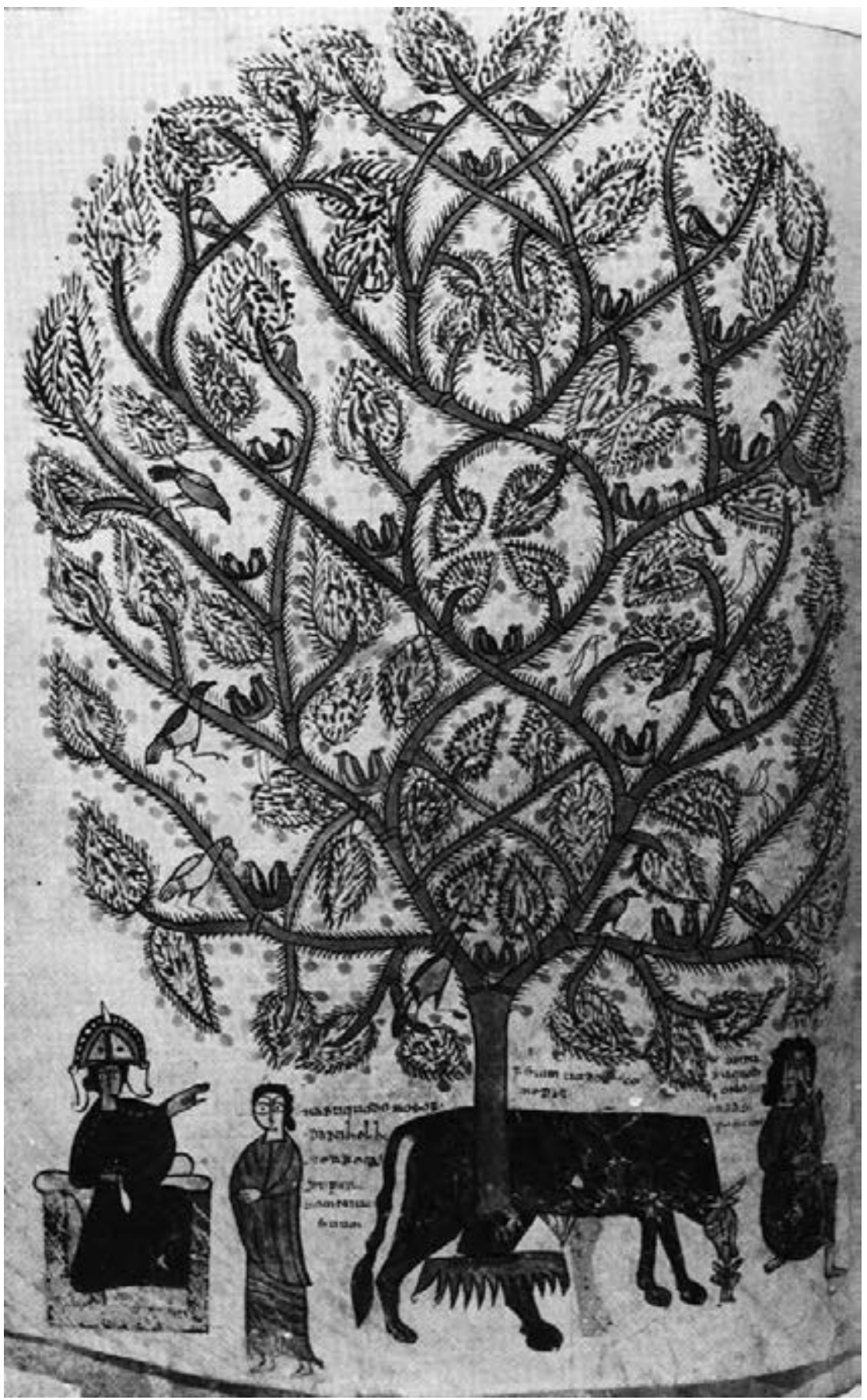

Photo: John Williams 


\section{The San Millán Beatus}

Madrid, Real Academia de la Historia, Cod. 33 282 fols., $14 \times 9.5$ in. $(355 \times 240 \mathrm{~mm})$

Last quarter of tenth century (RAH 33 Mozarabic)

First quarter of twelfth century (RAH 33 Romanesque)

Origin: Castile (RAH 33 Moz.)?, San Millán de la Cogolla (RAH 33 Rom.)?

The illustrations of this Commentary capture the stylistic transition of Spanish illumination from "Mozarabic" to Romanesque. It was begun, probably around 1000, as a copy of some model from the first stage of the tradition. Near the end, with the completion of the commentary on the Heavenly Jerusalem, production came to a halt until some time early in the twelfth century.

The illustrations executed in the first campaign exhibit a somewhat simplified version of the anti-plastic "Mozarabic" style that had flourished since the second quarter of the tenth century. As the model was a Branch I copy employing the format found in the primitive stage of the tradition, the scenes had neither painted grounds nor frames. When scribal activity resumed on folio $228^{\mathrm{v}}$, it was in a similar but less elegant version of the so-called Visigothic script native to the peninsula, and the model serving the illustrators was a copy from the revision of the pictorial content at Tábara. As a result, Jerome's Commentary on the Book of Daniel was appended and illustrated, if incompletely.

The illustrations of the second campaign replaced the peculiarly Spanish "Mozarabic" style with a frankly Romanesque one linked to France. It reversed the earlier tendency to suppress any sense of a third dimension, and used formulas in drawing and coloring that sought to achieve an illusion of mass. The new style had begun to appear in the ivories and manuscripts produced under the patronage of Fernando I and Sancha of León-Castile in the middle of the eleventh century. As we saw, the first Beatus Commentary in Iberia to display a Romanesque style, the copy now in the Cathedral of Burgos de Osma (No. 14), was produced in 1086 at the royally favored Leonese monastery of Sahagún. A generation later, the San Millán Beatus reflected a particular version of the Romanesque style that has been linked with Italo-Byzantine currents - one that drew inspiration from the design formulas native to Byzantine art, and which originally entered European painting through Italy, Byzantium's neighbor. The Byzantinizing Romanesque style in this Commentary is similar to that of Berzéla-Ville, a dependency of the great Burgundian monastery of Cluny, which was much esteemed by the Leonese monarchs Fernando I and his son Alfonso VI. The workshop responsible for painting Berzé-la-Ville may have undertaken the murals of around 1100 in the Aragonese church of San Juan de la Peña, a site not far from San Millán. A hallmark of this style is a comb-like pattern of white highlights, which are displayed prominently on the figures populating the Romanesque folios (Fig. 49).

This Beatus was number 8 in the list of codices found at San Millán de la Cogolla in 1821, having been seen there in the eighteenth century; it entered the Real Academia de la Historia in Madrid in the nineteenth century. Still, its origin at San Millán is debated (Klein). Stylistically it bears almost no resemblance to a slightly later confirmed San Millán product, the Escorial Beatus (No. 10), but the two are from the same sub-branch of the text (see Fig. 4). Nothing in the manuscript guarantees an origin elsewhere, however, and the completion of the Commentary early in the twelfth century seems an inescapable conclusion. Since it has the same kind of corrections in a hand of the twelfth/thirteenth century found in other manuscripts once at San Millán, its 
Figure 48 Vision of the Lamb (Apoc. V, 6-14). San Millán Beatus (Moz.), fol. 92. Madrid, Real Academia de la Historia, Cod. 33

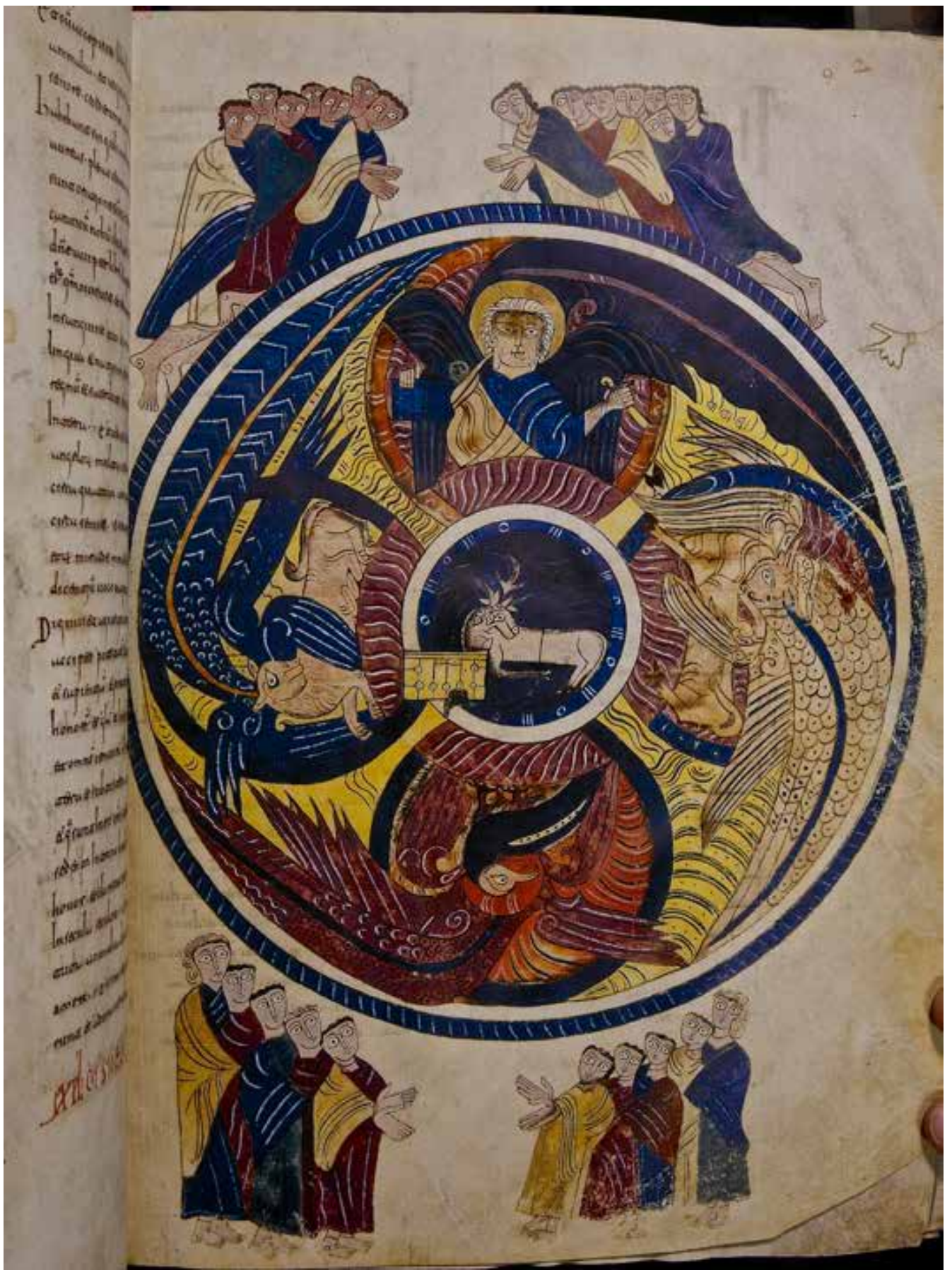

Photo: Hamid Shams 
Figure 49 Daniel with the Angels on the Banks of the Tigris (Dan. X). San Millán Beatus (Rom.), fol. 268v. Madrid, Real Academia de la Historia, Cod. 33

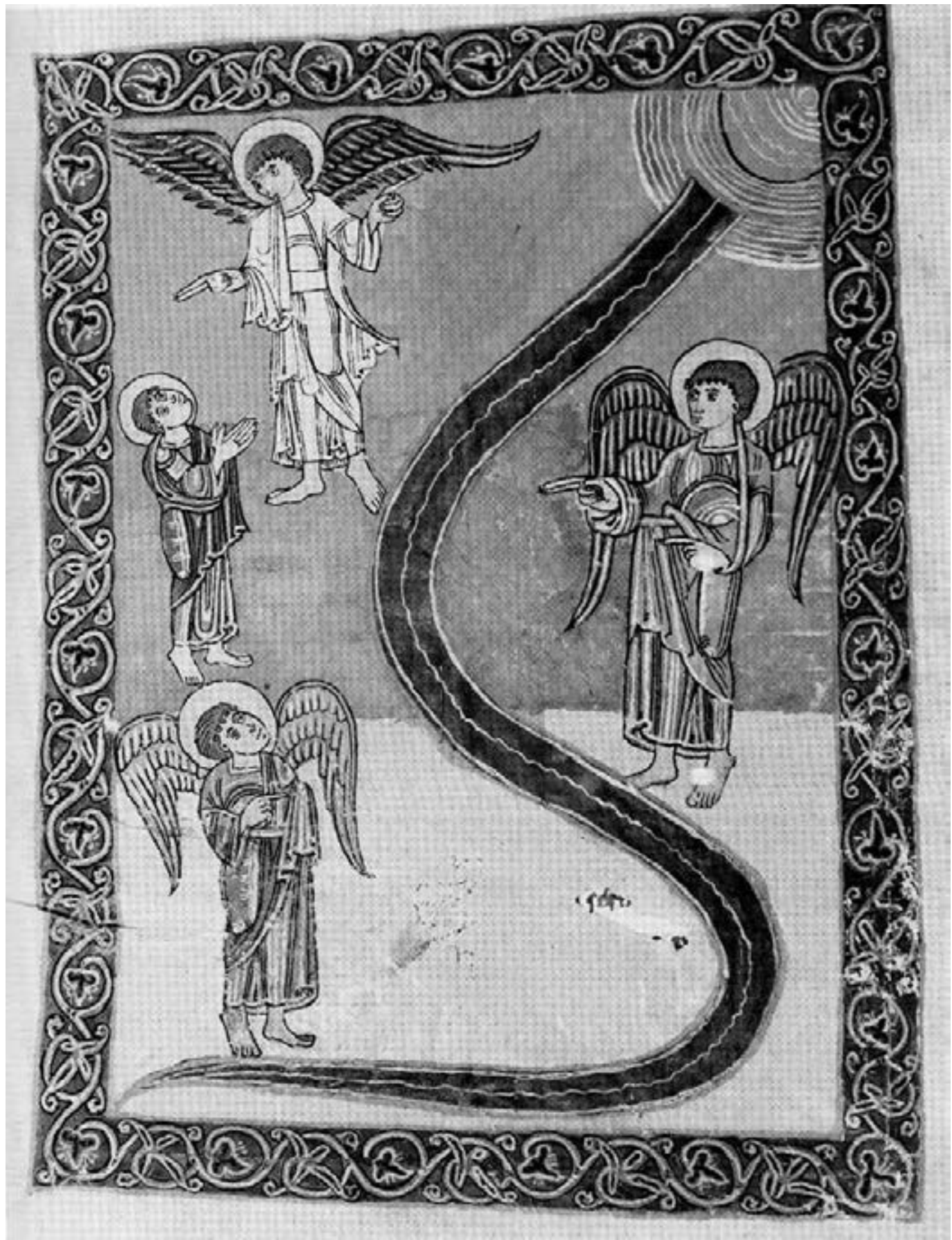

Photo: John Williams 
presence there is accounted for not long after its completion. Other twelfth-century manuscripts certainly from San Millán confirm the currency at that Riojan scriptorium of a similar Romanesque style and comparable types of initials.

Williams 1998, 21-28; Yarza 1998a, 151f.; Klein 1987; Díaz y Díaz 2005; Williams 2005b.

\section{The Escorial Beatus}

Escorial, Biblioteca del Monasterio, \&.II.5

151 fols., 13 x 9 in. (335 X $225 \mathrm{~mm})$

c. 1000

Origin: San Millán de la Cogolla

The style and technique of the Escorial Beatus diverge markedly from the more standard approach taken in the contemporaneous San Millán Beatus (No. 9), for which the same origin, San Millán de la Cogolla, is probable. The blues and reds more typical of tenth-century illumination give way to an idiosyncratic reliance on yellows, muddy browns, and dark greens. Maius at Tábara was liberal in his use of white as a highlight for drapery, usually as a long, continuous line tracing the contours of folds. In the Escorial Beatus white highlights appear instead as uniform short dashes in units of three, distributed in a regular pattern over the surface, whether on drapery, frames, or wings of angels. This contributes to a style expressive through a frozen abstractness rather than dramatic movement. The incipient illusionism of Maius's style is reduced.

Although it was surely not intended, there is something almost comical in the heightened sense of drama conveyed by the faces of this Commentary. This stems in part from the particular set of formulas employed by the painter, most importantly an unusually dark flesh tone whose contrast with the large, white eyes grants them a particular intensity. The effect is not merely accidental, as can be seen in the representation of Adam and Eve (Fig. 50) that stands in the place normally occupied by the Map of the World. The nude First Parents are depicted after the Fall, carefully covering their genitals, and clearly exhibiting the attributes of their respective genders, such as button-like nipples and more ample hips for Eve. But it is their exchange of guilty glances that amplifies the dramatic content of the scene.

The Escorial Beatus represents a special version of the "Mozarabic" style. In part this is because it is a member of the branch of the family that never underwent the pictorial reformation at Tábara that framed the miniatures, providing them with painted grounds made up of colored bands and incorporating Islamic motifs. Breaking with the original format of the Branch I Commentaries, the Escorial copy also employs frames and painted grounds. Here the frames, however, are not treated as devices for setting off the pictures like window frames; instead they are routinely ignored and overlapped by elements of the scene. Frames do not neatly mark off pictorial space so much as act as a foil for the figures within, establishing a dynamic that pushes the figures toward us rather than suggesting a space behind the page. As a result the pictures crowd the text, and the compositions tend to build up toward the viewer. This is another step back from illusionism.

Most of the other manuscripts from the monastery of San Millán de la Cogolla stayed there until the nineteenth century, when many were taken to the Real Academia de la Historia in Madrid. The attribution of this Commentary as well to San Millán remains the most plausible, despite the fact that it ended up in the royal collection of the Escorial in the sixteenth century. Stylistically it has a counterpart in the great tenth-century conciliar codex of San Millán that landed in the Escorial in 1573 (Escorial 
Figure 50 Adam and Eve. Escorial Beatus, fol. 18. Escorial, Biblioteca del Monasterio, \&.II.5

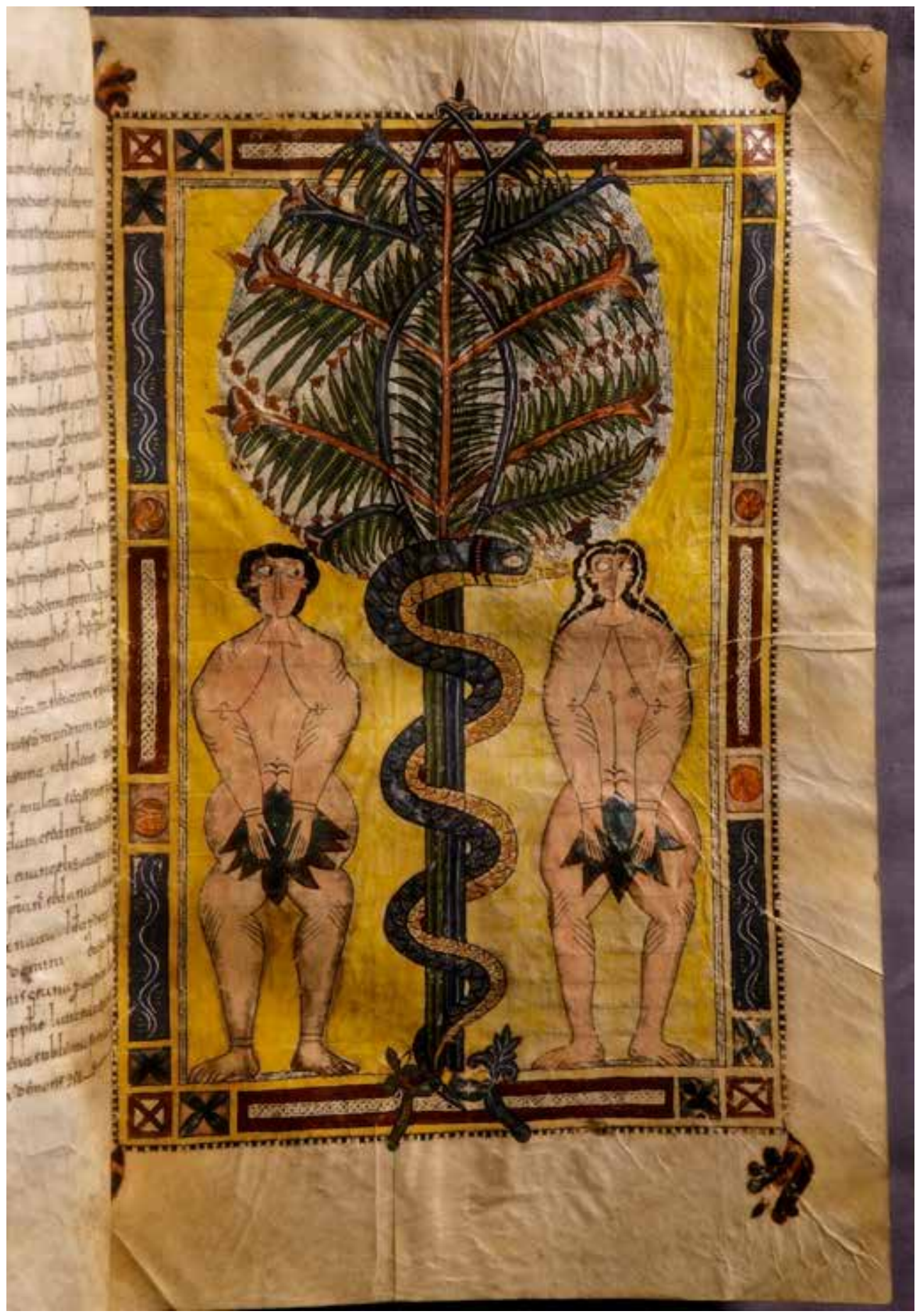

Photo: Hamid Shams 
Figure 51 Satan's Last Attack; Gog and Magog (Apoc. XX, 7-8). Escorial Beatus, fol. 135². Escorial, Biblioteca del Monasterio, \&.II.5

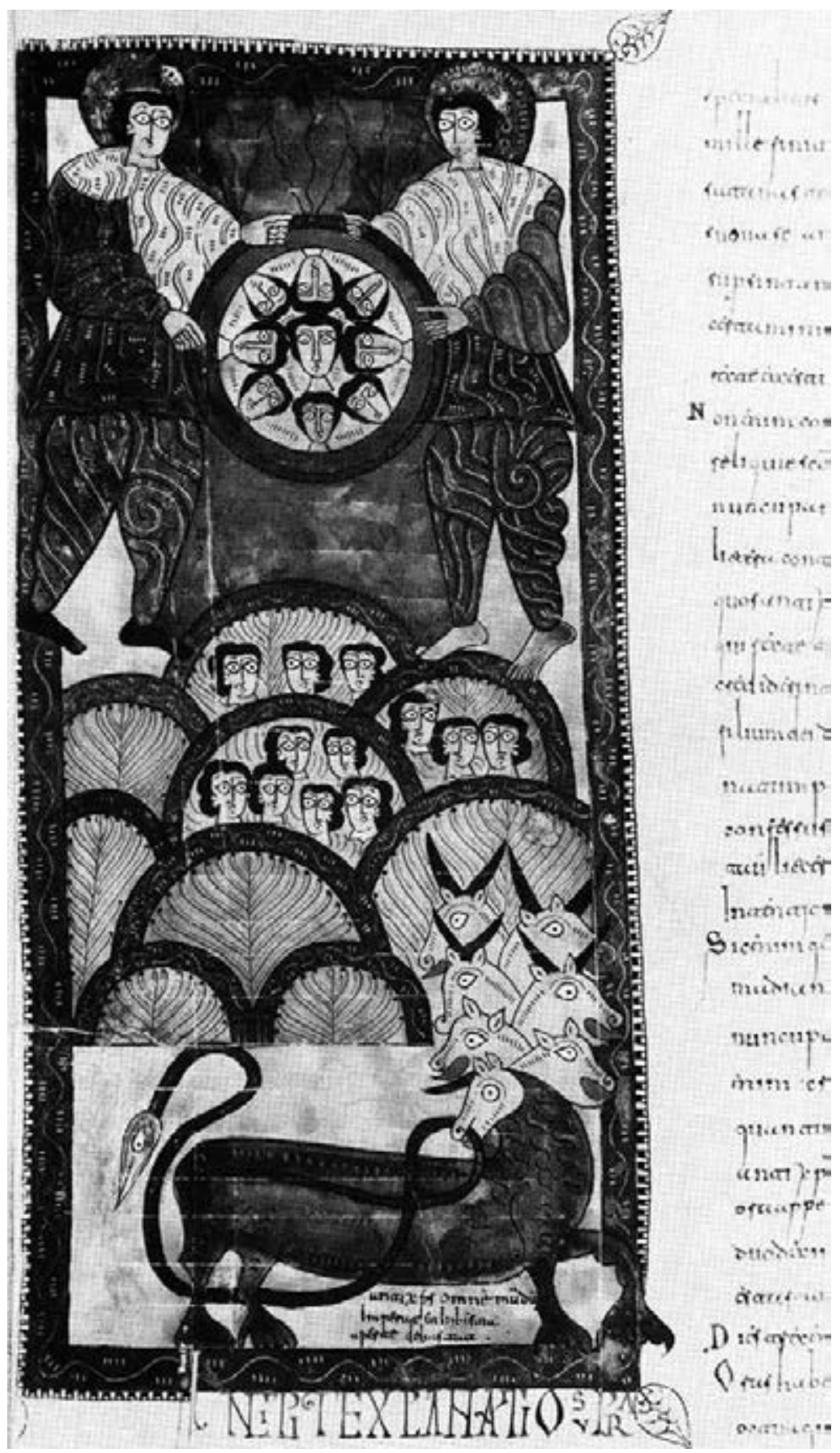

Photo: John Williams 
d.I.1). In fact, it is this manuscript that offers the best evidence for the origin of our Beatus, for they share idiosyncratic details, such as a peculiar way of rendering facial features. The nose and one eyebrow are delineated as straight lines which meet at a right angle, with a single nostril depicted as an undulating line.

In the middle of the eleventh century the Escorial Beatus, or its twin, provided the model for a copy destined for the Aragonese monastery of Fanlo (No. 12), then ruled by Abbot Pantio. The original Fanlo Beatus is lost, but seven of its pages were replicated in the seventeenth century. These copies, now in the Morgan Library \& Museum, provide a means of reconstructing the lost Cross frontispiece of the Escorial Beatus (see Fig. 55).

Williams 1998, 29-33; Yarza 1998a, 146f.; Fernández Flórez 1995.

\section{The Facundus Beatus}

Madrid, Biblioteca Nacional de España, Vitrina 14-2

312 fols., $14 \times 11$ in. (36o x $280 \mathrm{~mm})$

1047

Origin: León, royal scriptorium (?)

Scribe (and Illuminator?): Facundus

With the possible exception of the Las Huelgas Beatus (No. 24), this is the sole Beatus Commentary with a confirmed royal, rather than monastic, sponsorship. The patronage of King Fernando I and Queen Sancha of León-Castile is commemorated in an acrostic on folio 7: FREDENANDUS REX DEI GRA[TIA] M[EMO] R[I]A LIBER / SANCIA M[EMO]R[I]A L[I]BRI (These books in memory of Fernando, by the grace of God king, and of Sancha). The patronage of Fernando and Sancha is commemorated again in a colophon at the conclusion of the Commentary on Daniel (fol. 316), where the scribe, Facundus, is identified, and the date of completion, 1047, is recorded. This was fifteen years after Fernando, count of Castile, became king through his marriage to Sancha, infanta of León. During their reign, the royal couple established a capital in León that was seminal in opening the peninsula to trans-Pyrenean influences, including an artistic vocabulary on the threshold of the new Romanesque style that would supplant local Hispanic traditions.

This Commentary materially reflects its elevated patronage through the elegance of its materials; liberal use of purple, silver, and gold; and a polished technique of writing and illustrations. This refinement is especially noticeable in the illumination of the great Alpha frontispiece (Fig. 52) with a standing figure of Christ, and the frontispieces that follow, the Cross page, the Acrostic, the Evangelist/ Gospel pages, Genealogical Tables, and the elaborate initial and display titles of folio $3^{0 .}$ The exquisite detail and greater corporeal logic of the drapery of the Evangelist/Gospel pages (fols. $7^{\mathrm{v}}$-10), the use of a puffed-up style of hair, the small red dots on the cheeks, and the wide mouth with a full under-lip set these figures apart from those of the Apocalypse cycle that follows. Either the primary painter (Facundus?) lavished greater care on these frontispieces, or the scribe, Facundus, devoted most of his time to writing while a talented disciple undertook the painting.

This is the earliest of the known artistic commissions of Fernando and Sancha, and the most traditional. It belongs to the family of Commentaries whose oldest surviving member was carried out by Maius in the middle of the tenth century (No. 2). While it is not a copy of that Commentary, the text suggests that the same model was used (see Fig. 4). However, the ornamental vocabulary - especially the initials, including the great Alpha - departs from the formulas employed by Maius. It depends rather on those favored 
Figure 52 Alpha with Figure of Christ. Facundus Beatus, fol. 6. Madrid, Biblioteca Nacional de España, MS Vitrina 14-2

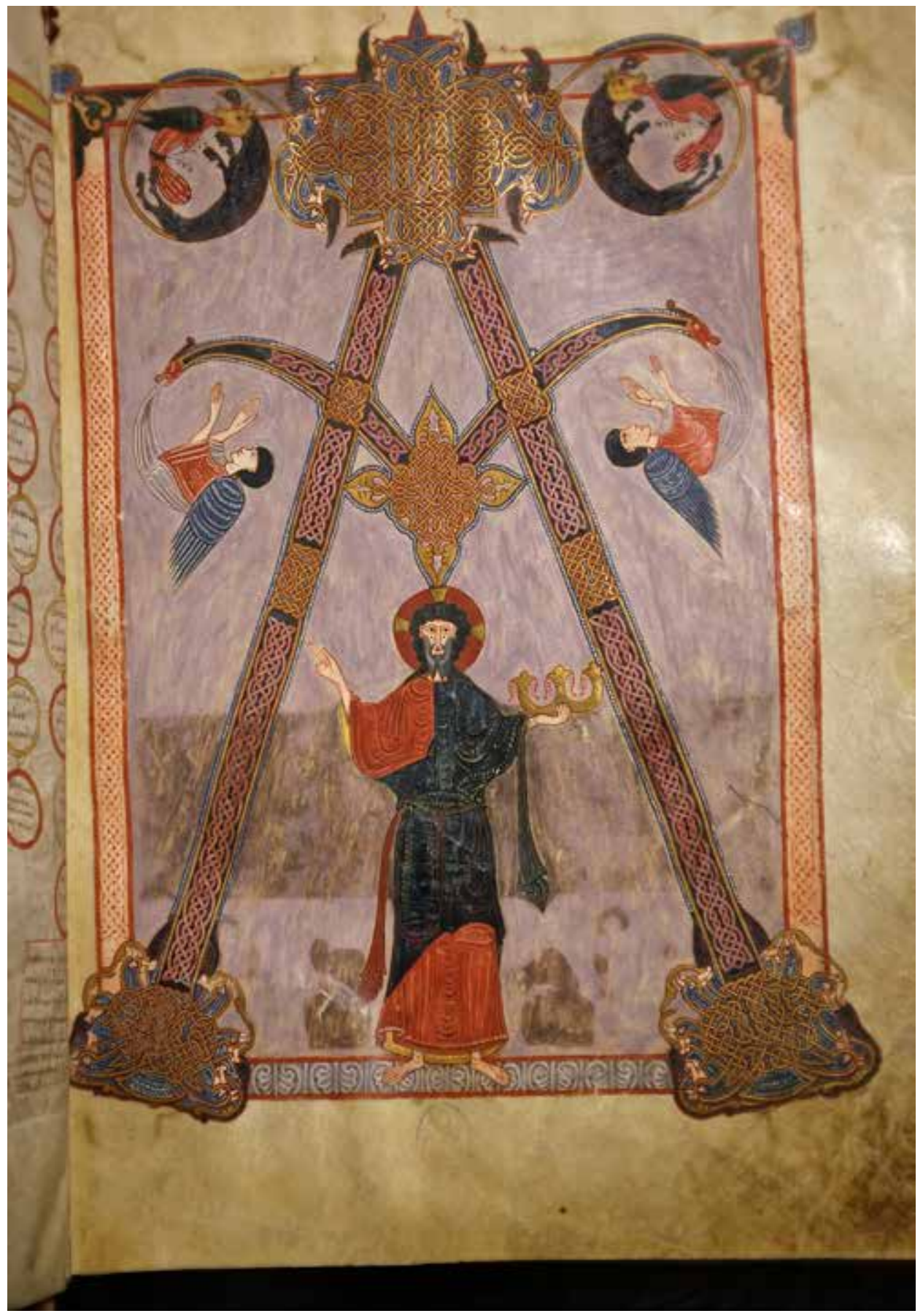

Photo: Hamid Shams 
Figure 53 The Burning of Babylon (Apoc. XVIII, 1-20). Facundus Beatus, fol. 233v. Madrid, Biblioteca Nacional de España, MS Vitrina 14-2

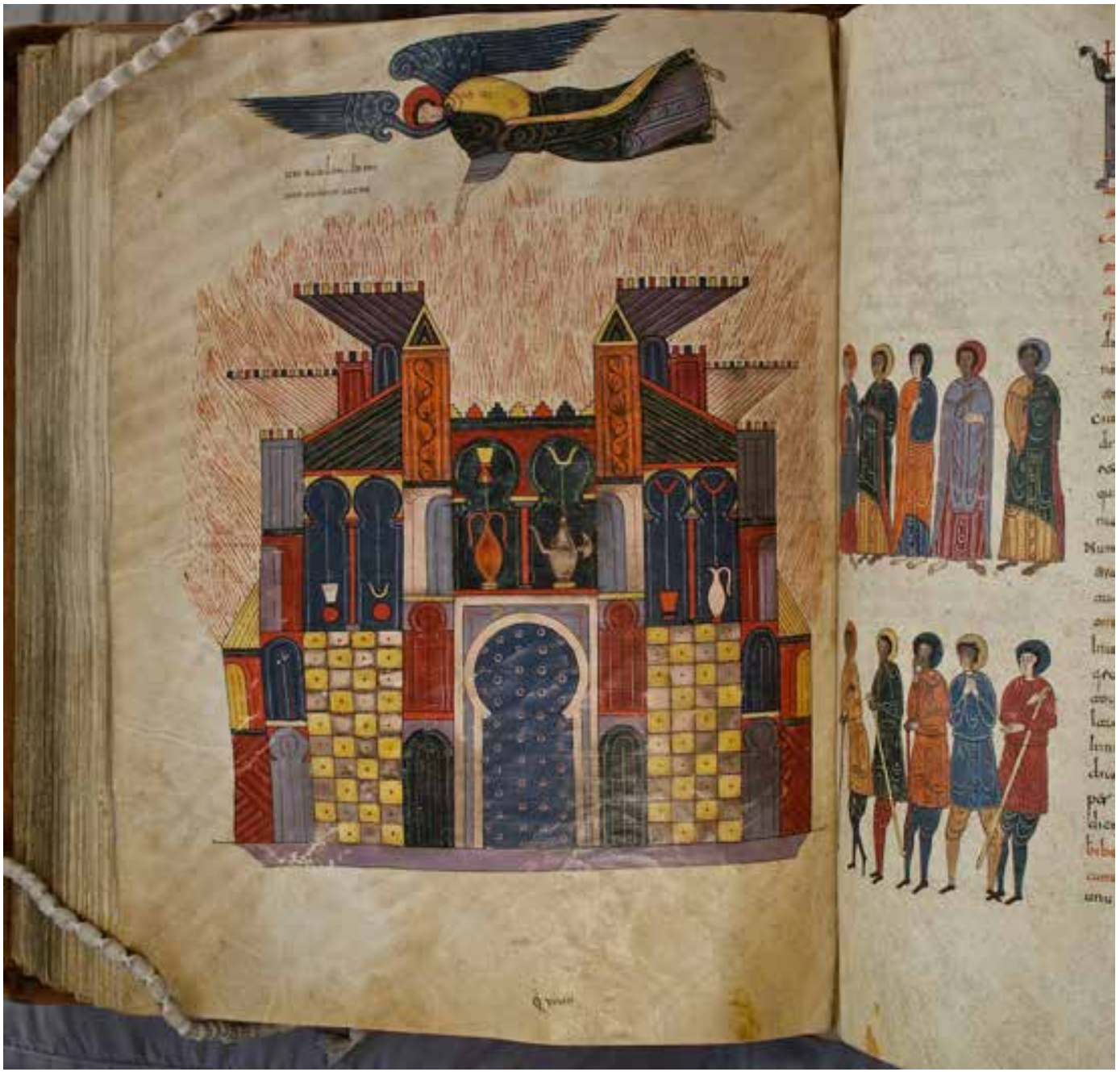

Photo: Hamid Shams

in Castile, notably at the monastery of Valeránica, where Florentius, the only rival Maius had as Christian Spain's foremost calligrapher, presided in the second half of the tenth century. Did a Castilian Beatus serve as Facundus's model, or did he merely adopt the Castilian repertory from other sources? King Fernando's own Castilian heritage may be relevant here.
The writing style has been termed "archaic," and artistically the Facundus Beatus is a special case: with the exception of the Silos Beatus (No. 16), completed in 1109, this is the last copy to present itself as "Mozarabic," that is, as a traditionally Leonese monument. At the same time the articulation of the human figure reveals the new direction art was beginning to take. In the painting of the 
tenth century - whose formulas for color and composition this Beatus follows - drapery folds were routinely portrayed in systems that ignored or even contradicted a relationship with the corporeality of the figures. This is the case even in the most sophisticated manifestations of the style, such as the figures in the Morgan Commentary (No. 2). In the Facundus Beatus, however, especially in the frontispieces highlighted above as qualitatively superior, elliptical panels are used to indicate the presence of a thigh in its proper place, while circular forms signal the location of knees. This articulation of the organic structure of figures led to a greater emphasis on the spatial coherence of the composition. In tenth-century Commentaries such as the Valcavado Beatus (No. 4), the copy closest to the Facundus in its iconographic details, figures tend to be suspended in space or tipped vertiginously on angled feet. In contrast, the figures of the Facundus Beatus stand firmly on ground planes, even if there is no attempt to open up the space through an allusion to a third dimension. These steps in the direction of the more rational art of the Romanesque period are especially noteworthy in that they surface even before Fernando's contacts, in the early 1050s, with the great Burgundian abbey of Cluny. The still more advanced Romanesque approach of the prayer book commissioned by Sancha for Fernando in 1055 (see Fig. 33) exhibits a growing knowledge of artistic developments north of the Pyrenees (Williams 2011b). Such "progress" is especially to be seen in the Alpha page of this prayer book, which is similar enough to that in the Facundus Beatus to suggest that the 1055 image was based on its Apocalyptic predecessor.

While the Facundus Commentary may predict the future stylistically, it must be admitted that this refined version of the "Mozarabic" style compromises the expressive power that made that style a particularly apt partner for the powerful imagery of the Apocalypse.

Williams 1998, 34-40; Yarza 1998a, 16off.; Yarza 1994; Sánchez Mariana 2006; Yarza 2006; Williams 2011b.

\section{The Fanlo Beatus}

New York, The Morgan Library \& Museum, MS M.1079, fols. 6-12

Seventeenth-century copies of seven pages from a mid-eleventh-century Commentary formerly in the Monastery of Montearagón

$12.5 \times 8.5$ in. $(315 \times 220 \mathrm{~mm})$

c. 1050

Origin: San Andrés de Fanlo? San Millán de la Cogolla?

Scribe: Sancius

Within a volume of Spanish papers bought by Thomas Phillips in the eighteenth century, and then in 1988 by the Morgan Library \& Museum, were seven pages of watercolors, all copies of a Beatus Commentary written in the middle of the eleventh century. The watercolors came from the collection of the notable Aragonese historian Juan Francisco Andrés de Uztarroz (1606-53); they had been commissioned by his lifelong friend Vicencio Juan de Lastanosa (1607-81), a prodigious collector, bibliophile, soldier, and respected amateur painter. These copies can easily be recognized as extraordinarily faithful replicas of the originals. Although trimmed, the pages measure $315 \times 220 \mathrm{~mm}$, a size consistent with an original manuscript from the eleventh century; also consistent are the colors of yellow, red, slate blue, and deep green. Although a note by Lastanosa alludes to "figures," the word probably should be taken in the general sense, for the copies do not include any pages with animal or human figures. However, the pages chosen hold the greatest significance for disclosing for whom, 
Figure 54 Acrostic. Fanlo Beatus, fol. 11. New York, The Morgan Library \& Museum, MS M.1079, fols. 6-12

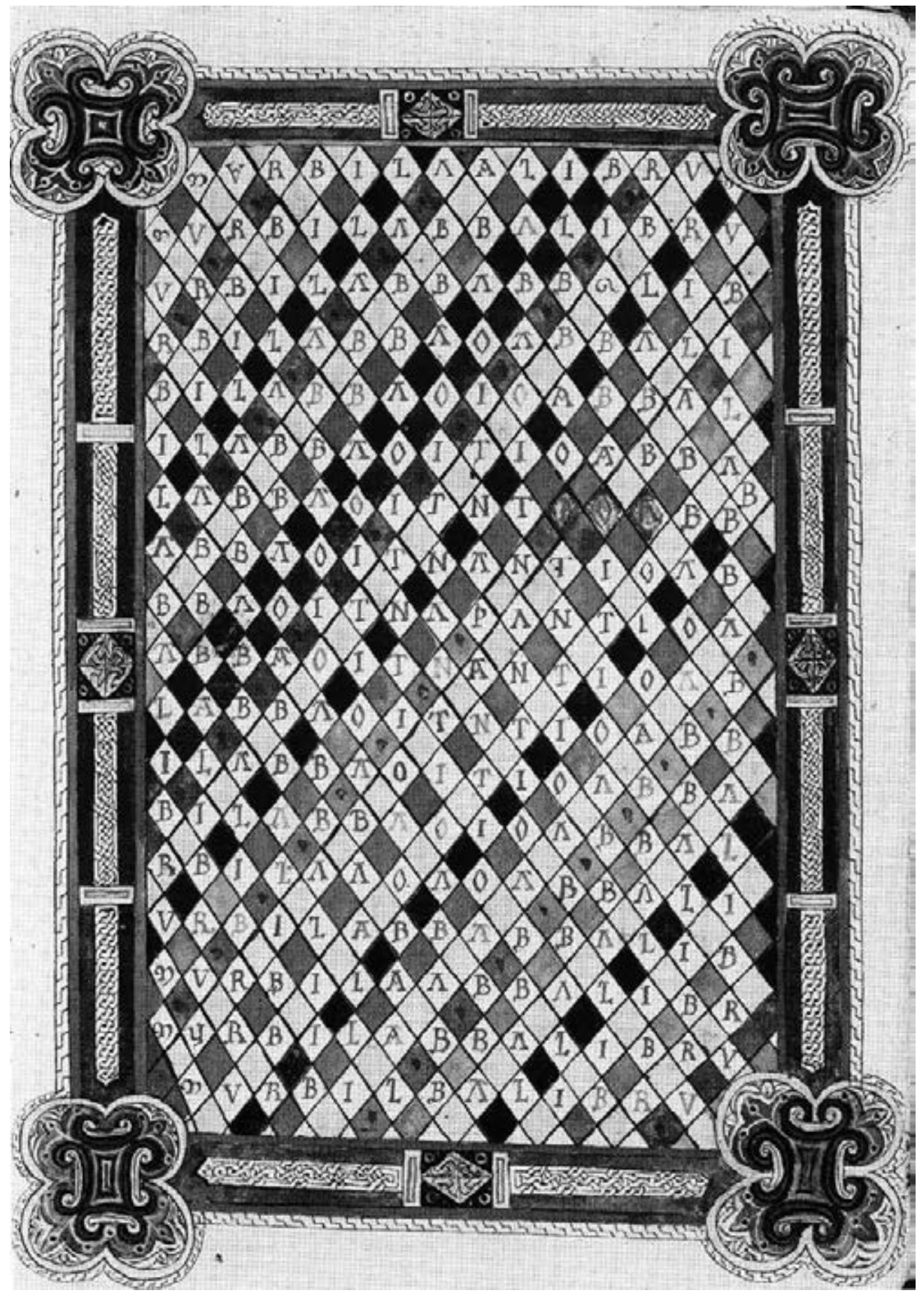

Photo: Joseph Zehavi 
Figure 55 Cross frontispiece. Fanlo Beatus, fol. 10. New York, The Morgan Library \& Museum, MS M.1079, fols. 6-12

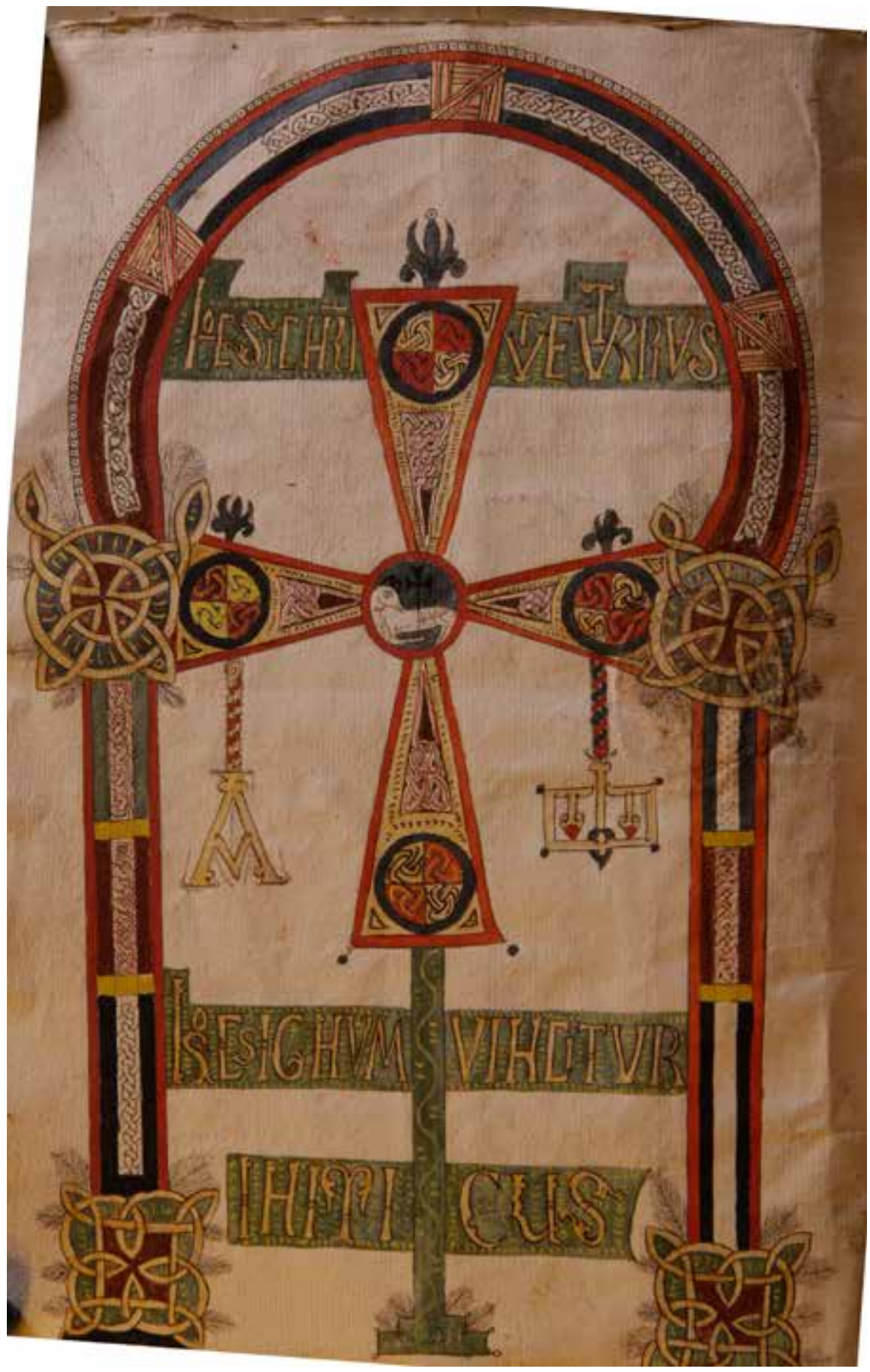

Photo: Hamid Shams 
by whom, and when the original Commentary was written. Lastanosa's reproductions of the acrostics and colophons reveal that the original manuscript was written by a scribe Sancius, who is commemorated in one acrostic on folio 12: SANCIUS NOTARIUS PRESBITER MEMENTOTE. In the colophon on folio $11^{\mathrm{v}}$, he is called Santius. The manuscript was made during the rule of Ramiro I of Aragón (1035-63) for Abbot Pantio, as another acrostic on folio 11 affirms (PANTIO ABBA LIBRUM; Fig. 54). Pantio (or Banzo, according to Galtier Martí) was abbot of San Andrés de Fanlo, an Aragonese monastery founded in the middle of the tenth century. Due to the painstaking fidelity of the seventeenthcentury drawings, along with the selection of textual pages rather than pictorial content, we are able to identify this Beatus as a copy of the Commentary now in the Escorial (or its exact twin), which was made around the year 1000 (No. 10). The Escorial Beatus was carried out at the monastery of San Millán de la Cogolla, not far from Fanlo.

Lastanosa's fortuitous inclusion of the Antichrist Tables provides a readily available measure of the Fanlo Beatus's relationship to the other Commentaries, thanks to Peter Klein's collation of these pages in all copies. In his commentary on the Beast from the Earth (Apoc. XIII, 18), Beatus inserted two tables that calculate the number of the Beast, introducing them with "Here is the wisdom. He who has understanding, let him calculate the number of the beast, for it is the number of a man; and its number is six hundred and sixty-six." The tables calculate this number by assigning numerical values to the letters of the alphabet. The peculiarities of the text of the Fanlo Beatus's tables are matched identically by the Escorial Beatus, as are the ornamental details of the frames. Also of interest is the Fanlo Beatus's Cross page (Fig. 55), which features the Lamb in a medallion in the center. The only other example of this motif in this context is found in the Beatus now in the Real Academia de la Historia (No. 9, fol. $\left.1^{v}\right)$, a manuscript probably executed at San Millán. The presence of such a Cross in the Fanlo copy means that one must have once introduced the Escorial Beatus as well.

Williams 1998, 41-43; Cabanes Pecourt 2005; Galtier Martí 2005a; Morte García 2005.

\section{The Saint-Sever Beatus}

Paris, Bibliothèque nationale de France, MS lat. 8878

292 fols., $14.4 \times 11$ inches $(365 \times 280 \mathrm{~mm})$

Third quarter of the eleventh century

Origin: Saint-Sever-sur-l'Adour (Gascony)

Illuminators: Stephanus Garsia, Placidus, et al.

Because of its splendid and precocious illumination, the Saint-Sever Beatus occupies a very special place in the roster of Beatus Commentaries. It shares with the Geneva Beatus (No. 29) the anomaly of being an illustrated copy following the old format, yet produced outside the Iberian peninsula. Its provenance is unmistakable. Not only does the scribe identify himself with the common Gascon name of Garsia on the outermost column of an arcade on folio 6 , but the part of the map corresponding with Gascony features a large church facade with the legend ECLESIA SCI SEVERI. Moreover, the ex libris of folio 1 proclaims Abbot Gregory as patron (Fig. 56). Gregory Muntaner ruled at Saint-Seversur-l'Adour from 1028 to 1072 . The manuscript includes decorative elements that belong to its own, Frankish ambience, such as the vignette on folio $183^{\mathrm{v}}$ and the full-page interlace pattern inhabited by animals on folio 138 . Yet style aside, the manuscript presents a peninsular face, with an emphasis on color, including banded backgrounds, the hallmark of the Leonese copies.

There are anomalies, however. This is the only Commentary where there is a radical 
Figure 56 Acrostic. Saint-Sever Beatus, fol. 1. Paris, Bibliothèque nationale de France, MS lat. 8878

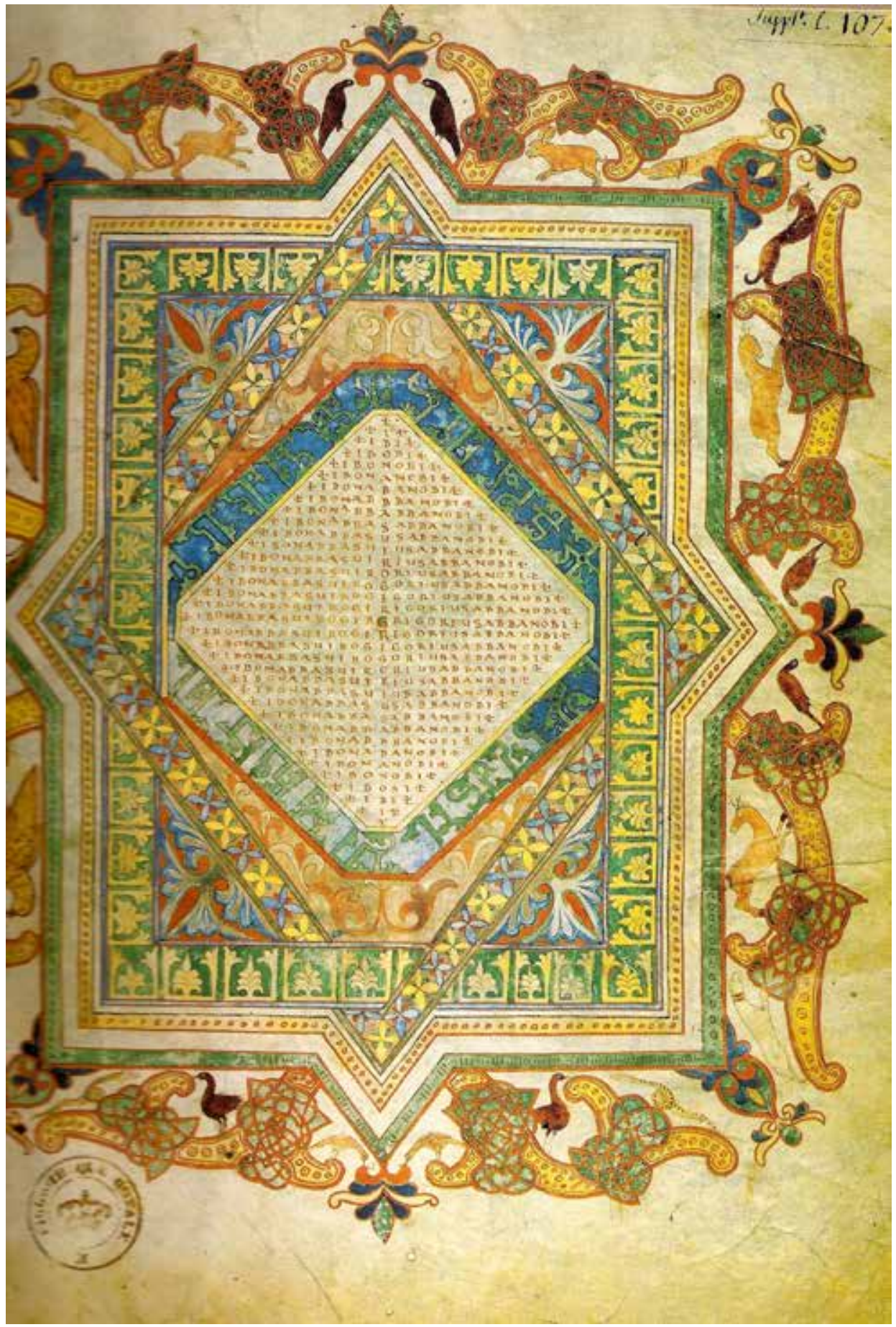

Photo: John Williams 
Figure 57 The Opening of the First Four Seals: The Four Horsemen (Apoc. VI, 1-8). Saint-Sever Beatus, fols. 108v-109. Paris, Bibliothèque nationale de France, MS lat. 8878

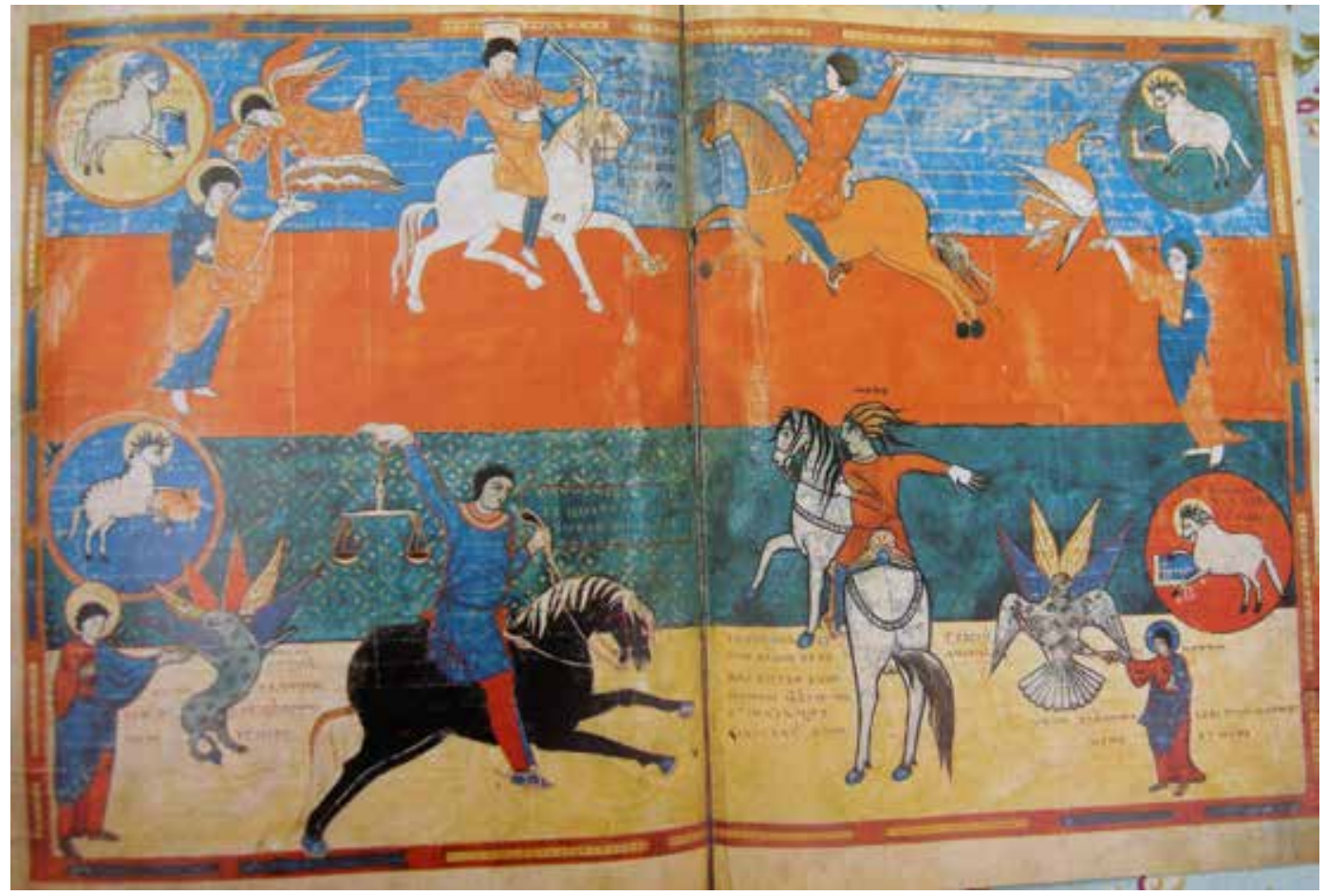

Photo: John Williams

disjunction between the textual recension and the pictorial content. Whereas the text belongs to the original edition of Beatus's Commentary, a distinction it shares only with Vitrina 14-1 in Madrid (No. 3), most of its illustrations represent the most advanced stage of the Commentary's evolution. Yet here, too, the anomalies continue, for the compositions side sometimes with the pictorial character of the earlier manuscripts of the revised Commentary and sometimes with the slightly later revision of that branch (Klein 2012b). Certain iconographic details, such as the centrality of Christ in the illustration of his Appearance in the Clouds and the presence of the writing hand next to the arch at the Feast of Baltassar, follow the revision made by Maius in the tenth century. Other details, like the inclusion of a flood in the illustration of Noah's Ark and the dual sources of the Nile in the Map of the World, align Saint-Sever with the slightly later revision of this branch. As was explained in the Introduction, the history of the abbey of Saint-Sever offered an exceptional opportunity for its library to have harbored more than one copy of the Beatus Commentary. Its foundation is linked to Spanish monks, and it enjoyed the patronage of Urraca, the Spanish consort of the count/duke of Gascony, Guillaume-Sanche, who founded the monastery in 988 .

Neuss's strong attachment to the kind of academic realism we associate with Classical art, and his recognition that the text belonged to the primitive stage, led him to identify the Saint-Sever Beatus as the best witness to the original Commentary, which in his opinion 
would have based its illustrations on some Late Classical illustrated Apocalypse. This reading of the manuscript's style was never endorsed by later historians, for it ignored the turn toward realism exhibited by Romanesque art around the time the Saint-Sever copy was produced. Ancient models would have been unnecessary for the implementation of naturalism, as the Carolingian revival of Classicism had prepared the way for the style called Romanesque. Still, the Gascon location and mid-eleventh-century date of this Commentary do not readily offer a convincing context for the very high level of accomplishment it represents. Although revisions to the text indicate an extraordinary concern with correct wording, the Saint-Sever Beatus is a picture book par excellence. A commanding concern for its pictorial character is reflected in the degree to which the accommodation of the miniatures affected the process of copying. Moreover, some compositions, such as the Majesty (fols. 121 ${ }^{\mathrm{v}}$-122) and the Four Horsemen (Fig. 57), reveal an extraordinary appreciation of the possibilities of pictorial space. This kind of artistic consciousness implies a catholic alertness to pictorial traditions. The dorsal views in the two miniatures suggest, for example, a knowledge of comparable Carolingian experiments. Counterparts for such an advanced Romanesque style in Gascony or central France are obvious only several decades later. In fact, the best mid-century stylistic parallels are found in Spain, especially in the prayer book Sancha of León commissioned in 1055 for her husband Fernando I (see Fig. 33). The resemblance of these two manuscripts extends to draftsmanship, drapery design, movement, and the acrobatic figures forming initials, while the habit of clustering triple dots over drapery is close enough to suggest a specific relationship between the two centers (Williams 2012a). Fernando is known to have imported Gascon cults in the 1050s (Bishko), about the time of the Saint-Sever Beatus, and lost French sources must lie behind the art he patronized as well as that produced by Garsia.

The artistic level reached in the SaintSever Beatus called for a team of considerable experience. If Garsia was responsible for a Commentary for Gregory's monastery, it does not necessarily follow that he belonged to it, or even that he was a monk. Since its library was decimated, we cannot assume that the lack of comparable examples of book production at Saint-Sever means there was no scriptorium there. To be sure, certain aspects of the manuscript indicate an unusual degree of clerical participation, such as the emendations of the text through a review of Vulgate readings and the various adjustments made in the iconography to fit the text more literally. At the same time, at least three skilled illuminators participated in the painting. It could be that it was not carried out by monks of Saint-Sever but by a team of lay professionals who moved from commission to commission. Given the sureness and incipient monumentality of the style, it can even be imagined that the team undertook commissions for wall paintings as well.

Williams 1998, 54-57; Yarza 1998a, 19of.; Bishko 1968, 49-50; Klein 1976, I: 205; Cabanot and Pon 2009, 40-49; Cabrero-Ravel 2009; Henriet 2011, 415-17; Williams 2011b, 414-17; Klein 2012b; Werckmeister 2012a.

\section{The Osma Beatus}

Burgo de Osma, Cabildo de la Catedral 166 fols., $14.2 \times 10$ in. (36o x $253 \mathrm{~mm})$

Begun 3 January or 3 June 1086

Origin: Sahagún, Monastery of Sts. Facundus and Primitivus

Scribe: Petrus

Illuminator: Martinus 
Figure 58 Victory of the Lamb over the Kings (Apoc. XVII, 14-18). Osma Beatus, fol. 55². Burgo de Osma, Cabildo de la Catedral

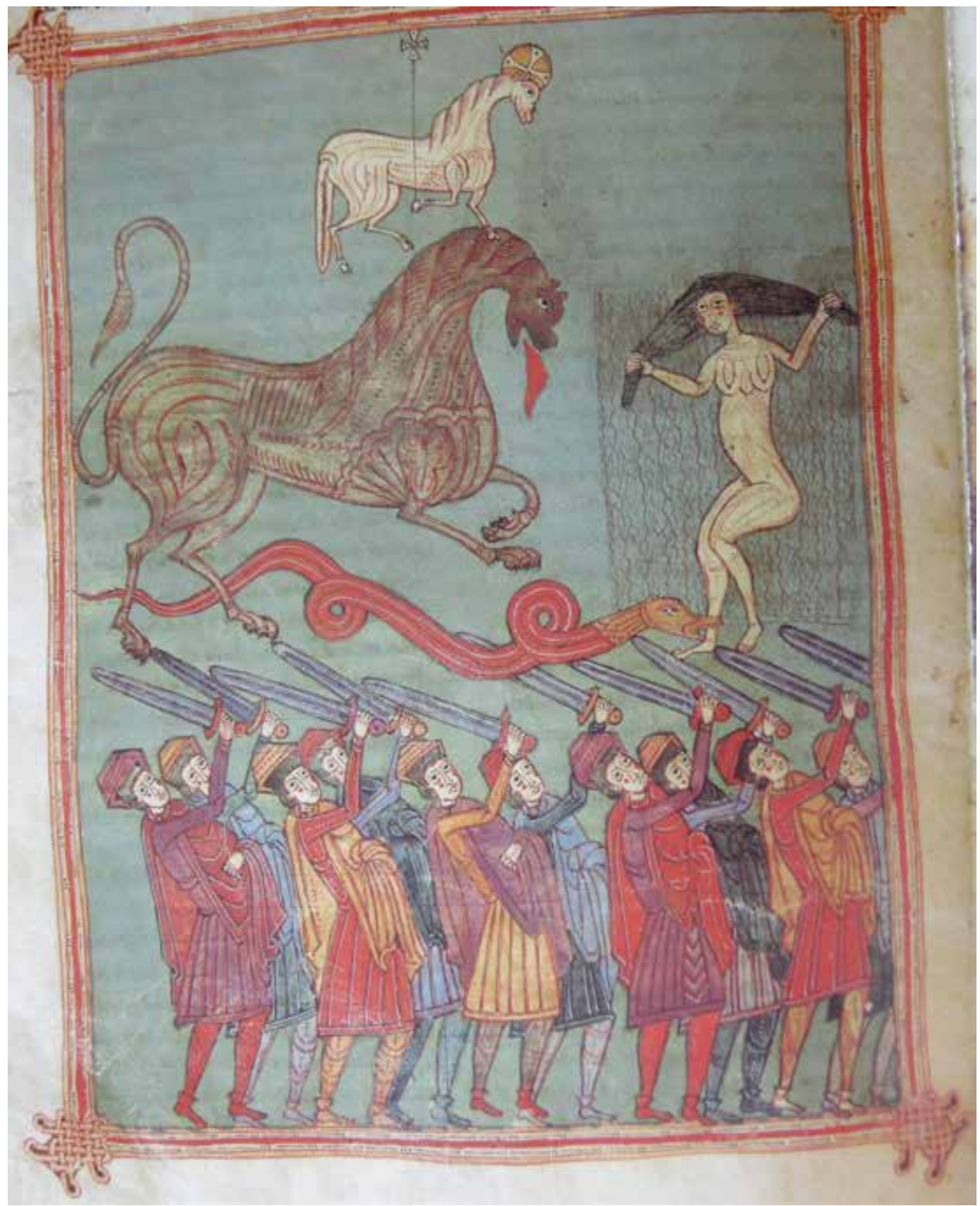

Photo: John Williams 


\section{Figure 59 Map of the World. Osma Beatus, fols. 34v-35. Burgo de Osma, Cabildo de la Catedral}

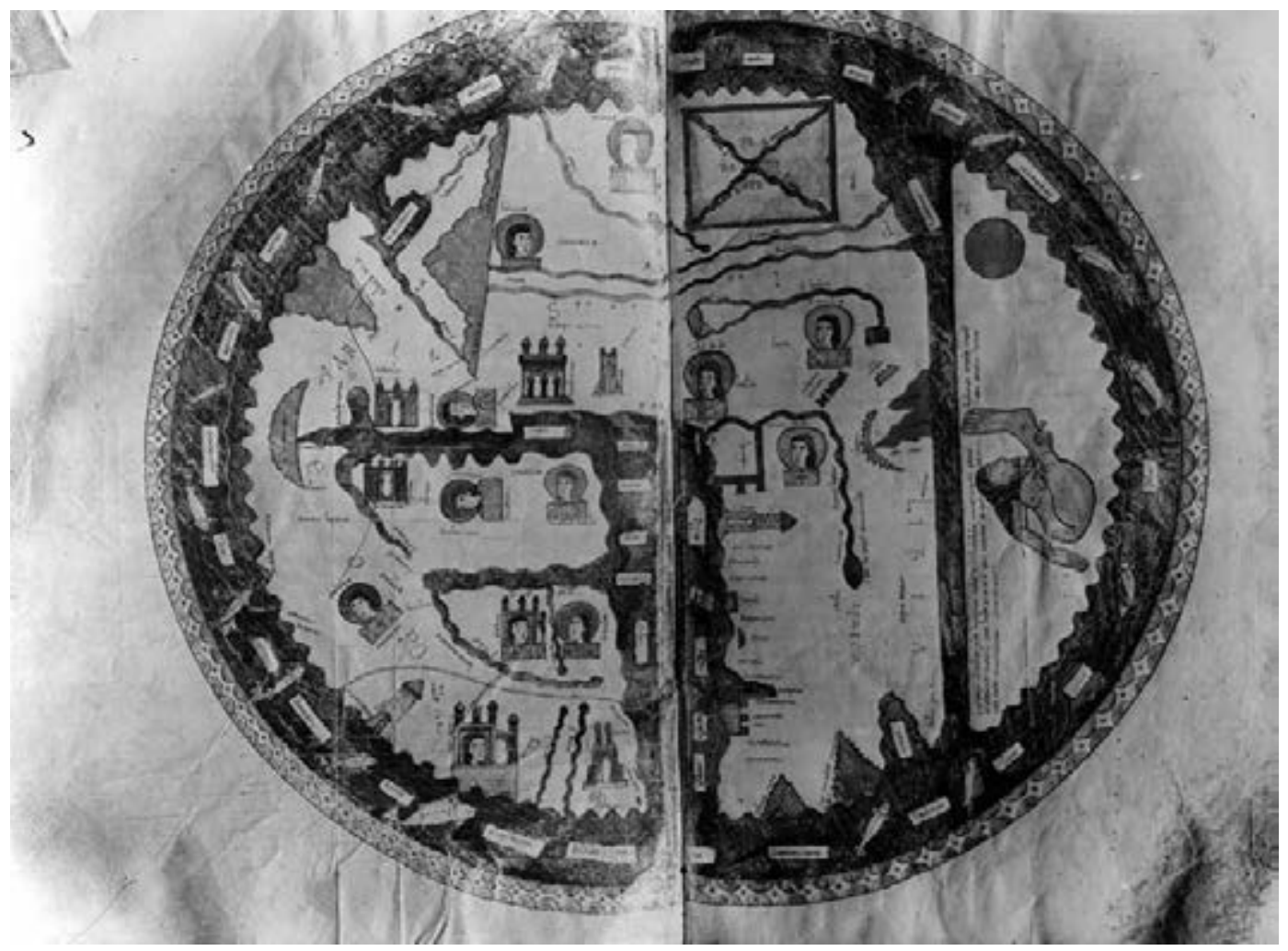

Photo: John Williams

The Osma Beatus has not attracted the interest it deserves. It is not a "typical" Beatus; that is, it does not look "Mozarabic," and it has suffered, too, from a tardy recognition of the scriptorium that produced it. Yet this manuscript is of extraordinary interest for its artistic content and its intersection with important personages and currents in Spanish history. Thanks to Barbara Shailor's paleographic analysis, we know that it was created at Sahagún, the great monastery south of the capital of León favored by Alfonso VI (d. 1109), who virtually made it his capital. To an exceptional degree Sahagún was a key site for the influx of currents that led to Christian Spain's Europeanization, a transformation epitomized by the replacement of its ancient liturgy with the Roman rite. Sahagún's history reveals the effects of the increasing presence of French clerics at Spanish sites. The most important of these was Bernard de La Sauvetat, a monk from Cluny, the great Burgundian monastery that represented for many the height of spiritual life. Bernard was installed as abbot at Sahagún in 1080 , and he remained there until November 1086, when he was installed as archbishop of Toledo, the ancient Hispanic capital conquered by Alfonso VI the preceding year. The Osma Beatus was undertaken by June of 1086, making it a product of Bernard's Sahagún.

Consistent with this cultural orientation and link to centers north of the Pyrenees, the Osma Beatus is the first peninsular copy to employ consistently a Romanesque figure style. Belonging to the branch that did not undergo the 
changes introduced at Tábara by Maius, it lacks the distinctive "Mozarabic" characteristic of brilliantly striped backgrounds. This may have made it easier to absorb the lessons offered by the emerging Romanesque character of French art. Tentative steps had been made in this direction in the Commentary carried out by Facundus for the Leonese rulers Fernando and Sancha in 1047 (No. 11), but all of the figures in the Osma Beatus attempt to provide an illusion of mass and energy with formulas that are more associated with French manuscripts like the Saint-Sever Beatus (No. 13) than Spanish examples.

At the same time, Martinus, the illuminator, showed an extraordinary disposition within what remained a very conservative tradition, breaking the customary rigid adherence to detailed repetitions of the iconographic standards. For example, in the illustration of the Church of Thyatira, the standard formula depicting the angel and St. John is expanded to include a woman in bed, an idol (hydolum), a man offering the head and hind leg of a goat to the woman, and two groups of witnesses. The origin of these additions is to be found in a part of the Apocalyptic text habitually ignored by Beatus illuminators: "But I have against you that you suffer the woman Jezabel, who calls herself a prophetess, to teach, to seduce my servants, to commit fornication, and to eat of things sacrificed to idols [...] Behold I will cast her upon a bed and those who commit adultery with her into great tribulation" (Apoc. II, 20-22). The woman is Jezabel the Whore, as the label states (Zezabel meretrix).

Radical iconographic change is also displayed in the illustration of the Victory of the Lamb over the Kings (Fig. 58). The Arroyo Beatus (see Fig. 79; No. 25) offers a traditional version. In the Osma Beatus, however, the Lamb is reduced to a minor focus, and his battle with the kings is no longer the apparent theme. With the earlier sections of this chapter of the Apocalypse in mind, a straightforward reading of the storia would suggest that the beast has turned on the Whore of Babylon and the forces of evil are at war with themselves. Stripped naked and pulling her hair in agony, a gesture employed by mourning merchants and sailors in the depiction of Babylon that follows (fol. 147), she is attacked by the dragon and stands in a shower of fire from the beast's mouth. If this depiction of her plight evokes sympathy, it should, for in the explanatio the Whore is now the Woman of the Lamb, who, through the Lamb/Christ, has dominion over the kings of the earth. In another inversion, the attitude of the kings scarcely suggests defeat. Rather, they raise their swords in unison toward the woman. The kings are, according to the explanatio, both within the city of God and within the city of Satan. The illustration is still a depiction of royal submission in the face of the church, but the kings have been given a new dignity.

The inventiveness of Martinus's approach is even more evident in his interpretation of the Map of the World (Fig. 59). The seemingly anomalous presence of a map in the Commentary is due to Beatus's inclusion (in Book II) of Isidore of Seville's discussion of the Evangelists' travels. This Osma illustration is singularly rich in including map lore, and it has been posited, along with the Lorvão Beatus's fragmented map (No. 22), as the best witness to the original, which would have been based on some hypothetical Roman or Isidoran exemplar (Sáenz-López). In fact, the best reflection of the original map is actually that found in the Morgan Beatus (see Fig. 3; No. 2) and the copies dependent on it (Williams). For the first time, or so it seems, the heads of the apostles were distributed over the geography of the earth. That of St. James (Santiago) is shown in a structure that represents the great shrine at Santiago de Compostela where he lay buried, 
as legend testified. The monastery of Sahagún, whose scriptorium produced this map, was a prominent stop on the Camino de Santiago.

Williams 2002, 17-25; Yarza 1998a, 202f.; Shailor 1992; Deswarte 2010, 121, 127-30; Williams 2012a; Sáenz-López 2014a, 268-69.

\section{The Turin Beatus}

Turin, Biblioteca Nazionale Universitaria, Sgn. I.II.I

223 fols. (214 original), 14.6 x 11.6 in. (372 x 296 $\mathrm{mm}$ )

First quarter of twelfth century

Origin: Catalonia (Girona or Ripoll?)

Although some pages of the Turin Beatus were scorched in the fire of 1904, and the leaves are now attached by paper leads, it is more or less intact. Most illustrations seem to have been designed by one hand, though some folios $\left(4^{\mathrm{v}}\right.$, $\left.8,55^{\mathrm{V}}-56,59\right)$ suggest the presence of a different and weaker hand. The principal colors employed are the primaries - red, yellow, and blue - all of which appear on the first illustrated page, the Majesty (fol. 2). The style is a very competent Romanesque one.

The Beatus in Turin is the only known illustrated Beatus Commentary originating in Catalonia, a provenance confirmed by comparisons with the ornament in other manuscripts from the province. This origin, together with the striking similarity to the Beatus that arrived at the Cathedral of Girona in Catalonia in the eleventh century (No. 6), has led to the almost unanimous conclusion that the Turin illustrations were copied from the Girona Commentary. However, the collation of the text of the two Commentaries makes such a conclusion problematic. The text of Turin is closer to an unillustrated late twelfthcentury Catalonian Beatus Commentary from Poblet (now in Salamanca, Biblioteca de la
Universidad, 2632) and to a fragment of two leaves of a Beatus (illustrated?) of the midtwelfth century in the Archivo de la Corona de Aragón (209) than it is to Girona's. As is clear from the family tree of texts (see Fig. 4), the differences point to a common model rather than a direct copy of the Girona text by the Catalonian scribes of the Turin Commentary.

According to Neuss, the proposed archetype would have been illustrated and served as the model for the Turin Beatus. To be sure, some changes were introduced in copying the illustrations in an effort to employ new compositions: the marginal vignettes of Girona inspired by an Islamic repertory of ornamental motifs were not included, and the elliptical rather than rectangular shape of the Map of the World reflects a general trend in the twelfth century. Still, the extraordinary agreement between the pictorial content of the Turin and Girona Commentaries makes it difficult to reject a direct relationship between the two sets of illustrations. If it was in fact direct, the Turin copy would expand our knowledge of the original pictorial content of the Girona Beatus: it follows the page with the depiction of Herod's fall, a scene included in the Girona copy (see Fig. 25), with a page of New Testament scenes not included in Girona (Fig. 60).

The question of where the copy was made remains open. One deviation in the map suggests Girona, for elements of it seem to have been inspired by a monumental embroidery of $c .1100$ in Girona Cathedral representing the creation of the world. The conversion of the Beatus Map from a rectangle to an oval results in spandrels that are occupied by personifications of the winds at the four corners of the world. Unusually, these personifications take the form of nude figures astride inflated skins, precisely as in the Girona textile (Castiñeiras). Although this would seem to indicate the illustrator's knowledge 
Figure 60 Washing of the Feet; Peter's Denial and Last Supper; Kiss of Judas; “legiones angelorum.” Turin Beatus, fol. 16. Turin, Biblioteca Nazionale Universitaria, Sgn. I.II.I

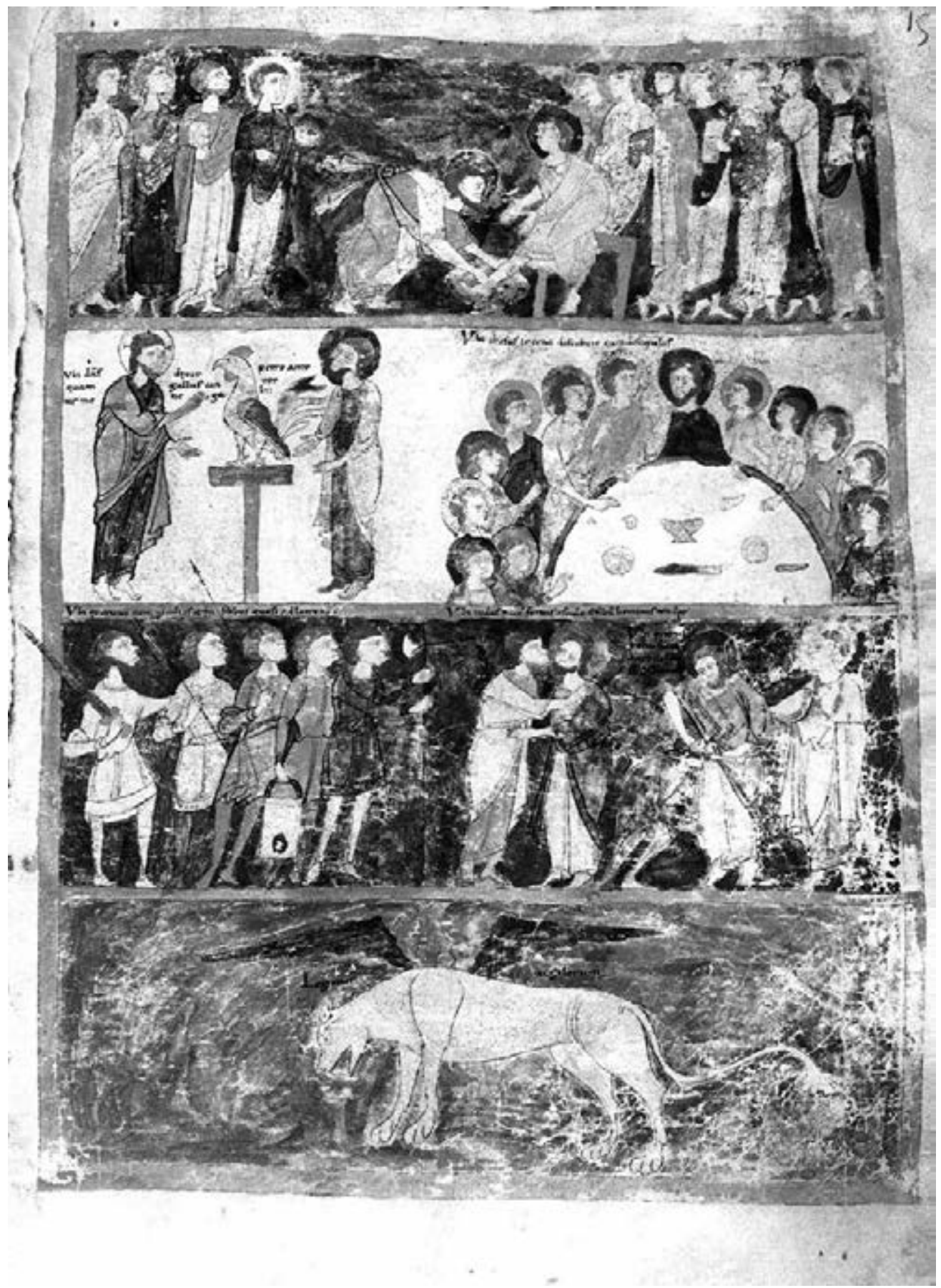

Photo: John Williams 
Figure 61 Warning Angels and Fall of Babylon (Apoc. XIV, 6-13). Turin Beatus, fol. 146v . Turin, Biblioteca Nazionale Universitaria, Sgn. I.II.I

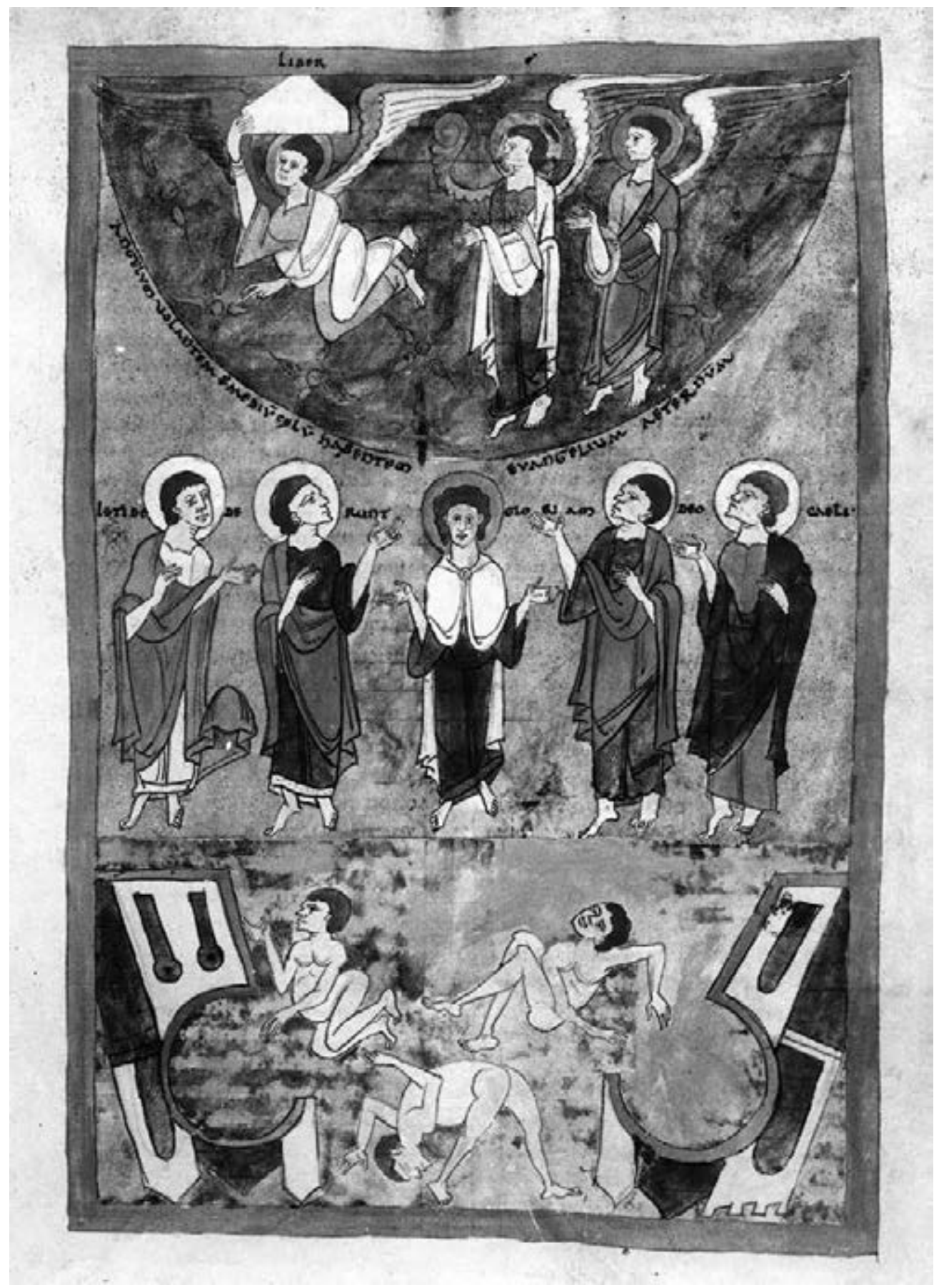

Photo: John Williams 
of the embroidery, we lack a corpus of illuminated Girona manuscripts to confirm the existence of a scriptorium there capable of carrying out such an ambitious task as this Beatus Commentary. Moreover, the use of a different text weakens the exclusive link to Girona. The illustrations of the Turin copy resemble the figural and decorative style of manuscripts associated with Santa María de Ripoll, a grand monastery only some forty miles away. This may be evidence that the Beatus was entrusted to that important center of manuscript production, or to a scribe from there. A date at the turn of the twelfth century or in its first decades seems reasonable.

Williams 2002, 26-30; Yarza 1998a, 229f.; Herrero Jiménez 2001; Suárez González 2009, 68-74; Suárez González 2010a, 112-29; Castiñeiras 2011.

\section{The Silos Beatus}

London, British Library, MS Add. 11695

28 o fols., $15 \times 9.2$ in. $(378 \times 235 \mathrm{~mm})$

18 April 1091 (writing)

1 July 1109 (illustration)

Origin: Santo Domingo de Silos

Scribes: Munnius, Dominicus, et al.

Illuminator: Petrus

With its adherence to key elements of the so-called Mozarabic style, such as the banded backgrounds and the rejection of the illusion of depth and corporeality, the Silos Beatus seems to ignore stylistic updates noted in earlier copies such as the Facundus Beatus (No. 11), which is of the same branch of the family tree, and the Osma Commentary (No. 14). In a memorable essay, Meyer Schapiro ascribed the style's apparent anachronistic character to a deliberate revival motivated by nostalgia for a local culture challenged by Europeanization. This is doubtful. This was the first - and only - illustrated manuscript produced at Silos, and it is not likely that its scriptorium could indulge in choosing styles. Its colophons repeat verbatim ones found in manuscripts by Florentius of Valeránica. It is likely that a Beatus from Valeránica, whose existence was speculatively introduced in the Introduction, served as the model for the Silos copy. This model would have strongly influenced its appearance. More to the point, while the format is "Mozarabic," the figures themselves hint at a Romanesque vocabulary aimed at breaking down the strict two-dimensionality of the tenth-century prototypes.

Thanks to its six colophons, we are exceptionally well informed about the circumstances of the production of this Beatus. It was begun under Abbot Fortunius in 1091, three years after the altars of the new church at Silos had been dedicated in 1088. The primary altar was dedicated to St. Sebastian, but Domingo, the abbot who had died in 1073, also had one, and within two decades he would replace Sebastian as titular saint of the monastery. The Beatus symbolized, in a sense, the Castilian monastery's ascendancy. However, the completion of the copy stalled in 1091. Munnius had been in charge, and the tentativeness of the pair of illuminated pages completed by him suggests that the illustrations were beyond his competence. In any case, it was only in 1109 that Petrus, a relative of Abbot Nunnus, added pictures to the spaces left by Munnius. They are extravagant and affective but not without a certain naïveté.

This Commentary is one of the monumental copies of the Beatus, a kin to that produced at Tábara by Maius (No. 2). The standard sets of Apocalyptic and Daniel illustrations are joined by others, allowed by the generous margins of the folios. Whereas the marginal insertions in the Girona Beatus consisted primarily of motifs borrowed from a repertory 
Figure 62 Man with Viol and Man with Bird. Silos Beatus, fol. 86. London, British Library, MS Add. 11695

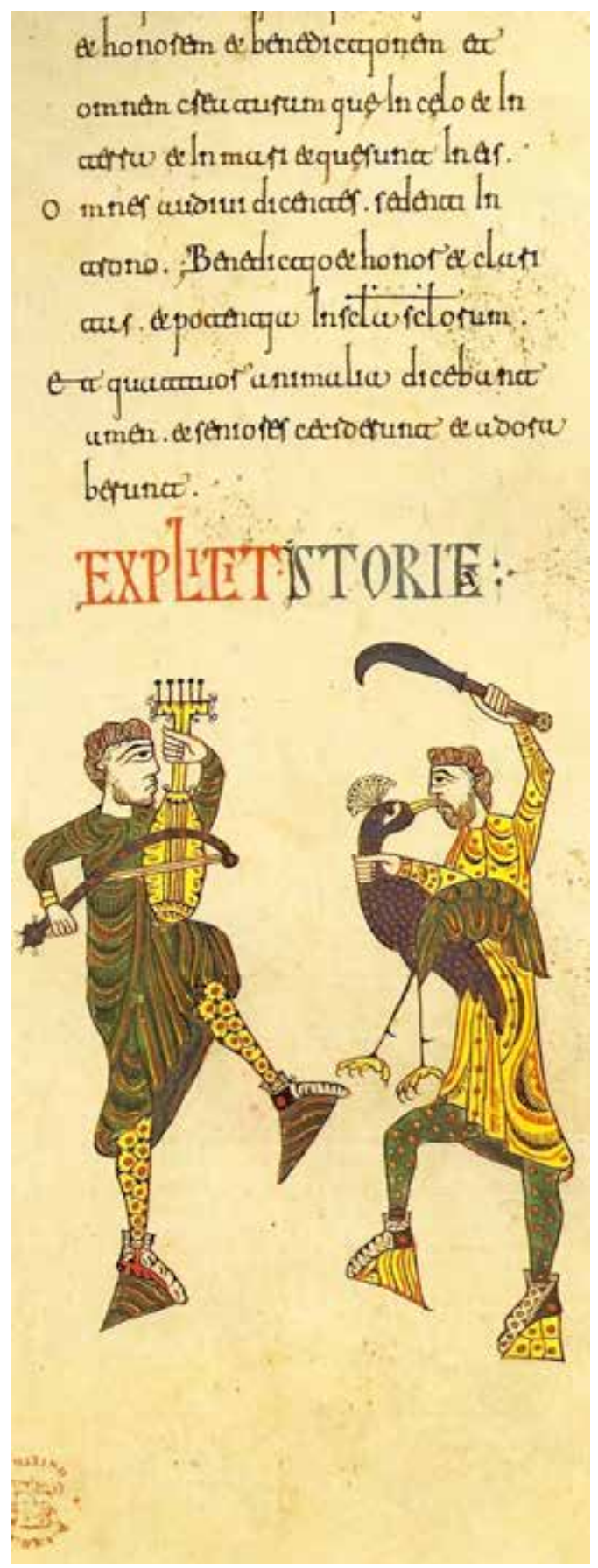

Photo: John Williams
Near Eastern in origin and shared with alAndalus (see Fig. 26; No. 6), those in the Silos Beatus reflect the new European orientation of northern Spanish culture. Thus a marginal figure plays a stringed instrument with a bow, while a facing figure wielding a large knife grasps a peacock whose beak touches his mouth (Fig. 62). The musician resembles the jongleurs depicted in French musical manuscripts. The location of this pair just before the illustration on the verso of the adoration of God by the twenty-four musical Elders is probably not accidental; rather, they share in this iconography of celebration.

Despite the seemingly conservative character imposed by the retention of the "Mozarabic" style, the Silos Beatus reflected the contemporary world. The most spectacular as well as the most up-to-date of the illustrations is the representation of Hell that serves as a frontispiece (Fig. 63). St. Michael holds a scale, confirming his role at the Last Judgment. He presides over sinners who are tormented by demonic torturers. At the center is a man attacked by reptiles. His sin, as labels and bags of money inform us, was greed. To one side an amorous couple clings to each other in a bed as they face torments served up by monsters. There is also a depiction of Hell in the Girona Beatus (see Fig. 43), but without any specific parallels with this frontispiece. The Silos version, centered on greed and lust, reflects the iconographic priorities of Languedoc, just over the Pyrenees, where sculptural ensembles at churches such as Saint-Sernin de Toulouse and Saint-Pierre de Moissac emphasized these sins. This is an iconography of personal behavior addressing sins that became more prominent in an evolving society where money and erotic secular literature had an unprecedented importance. The Hell of the Silos Beatus has no link to traditional Beatus iconography; it 
Figure 63 Hell. Silos Beatus, fol. 2. London, British Library, MS Add. 11695

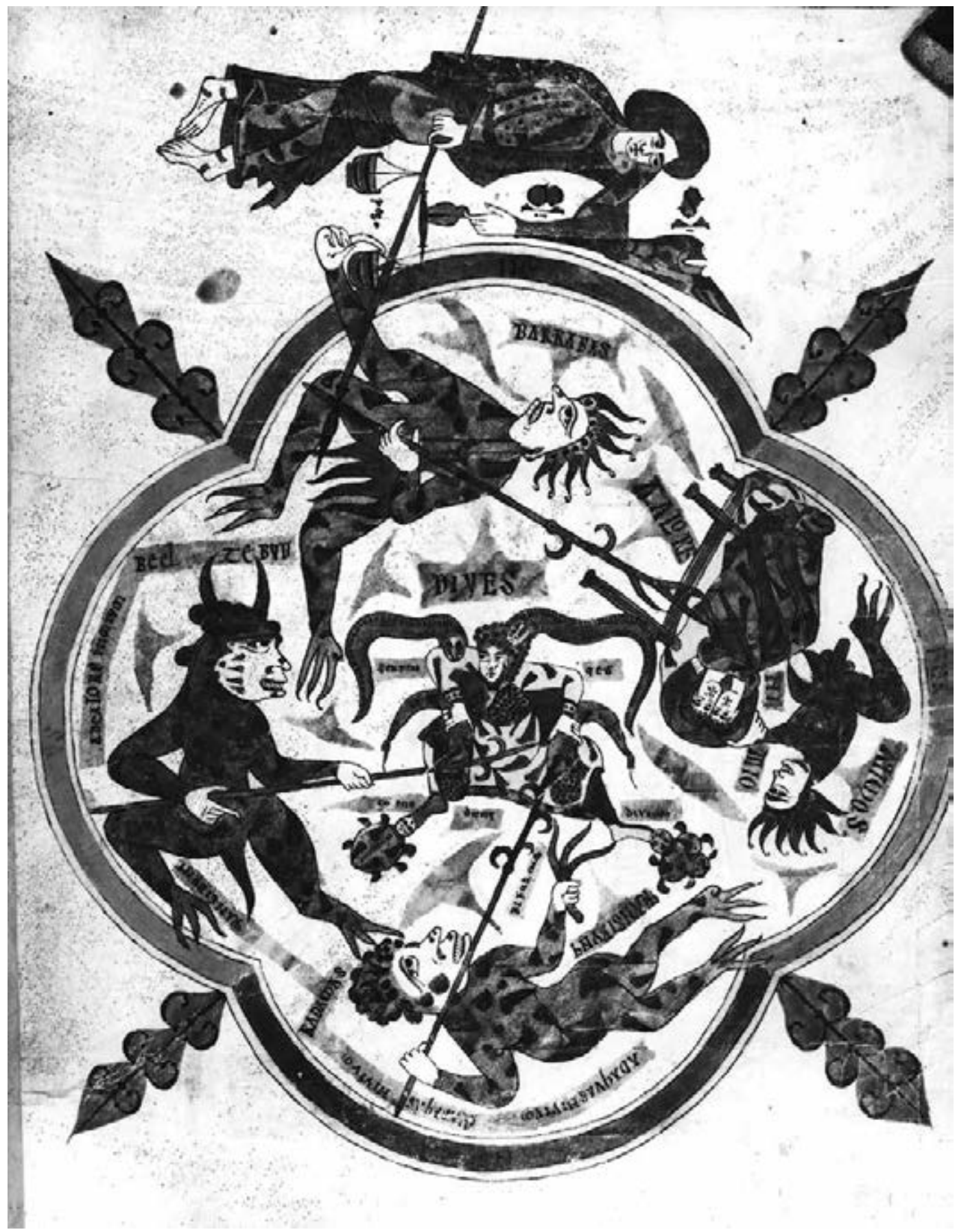

Photo: John Williams 
offered a modern opening into this relic of the past.

The posture of St. Michael on the Hell page has a parallel among the Silos cloister reliefs: the figure of Christ performs a similar pirouette in the magnificent carving of Jesus and his Disciples on the Road to Emmaus. This suggests that the designer of the frontispiece may have been among those responsible for the cloister sculpture. He was most likely from Languedoc. In any case, the design and execution of the Hell scene was not the work of Petrus.

Williams 2002, 31-40; Yarza 1998a, 218f.; Schapiro 1939; Díazy Díaz 1992; Vivancos 1996; Walker 1998; Franco Mata 2003; Silva y Verástegui 2003, 242-51; Vivancos 2003; Williams 2003b, 2003c; Boylan 2005; Franco Mata 2005; Werckmeister 2007 .

\section{The Corsini Beatus}

Rome, Biblioteca dell'Accademia Nazionale dei Lincei e Corsiniana, Segn. 40.E.6

151 fols., $6.7 \times 3.7$ in. $(170 \times 95 \mathrm{~mm})$

Second quarter (?) twelfth century

Origin: Sahagún, Monastery of Sts. Facundus and Primitivus

The small size of this copy imposed, uniquely, a format of a single column of text. In a sense, it is a pocket version of the 1086 Beatus of Burgo de Osma (No. 14). Like that manuscript, it was produced, as the style of writing reveals and figure style confirms, in the great Leonese monastery of Sahagún, albeit a generation later. The replication of Osma is apparent in the extremely rare rendition of the Killing of the Two Witnesses by the Antichrist (Fig. 64), shared only by these two Commentaries. The representation of Christ's Appearance in the Clouds (Fig. 65) depicts him as a Christ in Majesty, another commonality between the two copies. Even though it is badly flaked, this illustration features a more accomplished and mature Romanesque style, employing a different palette of the primary colors. Since only seven miniatures survive (one of them an incomplete drawing) out of what would have presumably been about ninety, it is possible that the Maiestas page was the responsibility of the chief hand of the manuscript. One can only begin to speculate on the reasons why the rest of the images might have been eliminated from the manuscript.

The extreme difference between the artistic hands extends to the writing: two quires, now making up folios 144-156 but originally among the initial gatherings, are in so-called Visigothic minuscule, the traditional Hispanic script, while the remainder of the folios are in the Caroline writing that displaced the peninsular script in the twelfth century. This switch does not indicate separate campaigns, for the inscriptions of all miniatures are in Visigothic script, even where the main text is in Caroline. Sahagún, with strong ties to the Burgundian abbey of Cluny, was a foyer for French influences, including Caroline script.

We know that the Corsini manuscript was brought back to Spain in 1802 after it was purchased in Spain a century earlier by the papal nuncio who attended the coronation of Philip V. However, the text of the Berlin Beatus (No. 19), written in Italy in the twelfth century, is virtually identical to the Corsini Beatus, allowing us to conclude that the latter was in Italy by the twelfth century (Gryson). The circumstances of its arrival there, as is the case with the model for the Geneva Beatus (No. 29) and the Milan fragment (No. 28), are unknown.

Williams 2002, 41-44; Yarza 1998a, 217f.; Gryson 2012, XLVII-LI; Shailor 2016; Williams 2016. 
Figure 64 The Two Witnesses Killed by the Antichrist (Apoc. XI, 7-10). Corsini Beatus, fol. 126. Rome, Biblioteca dell'Accademia Nazionale dei Lincei e Corsiniana, Segn. 40.E.6

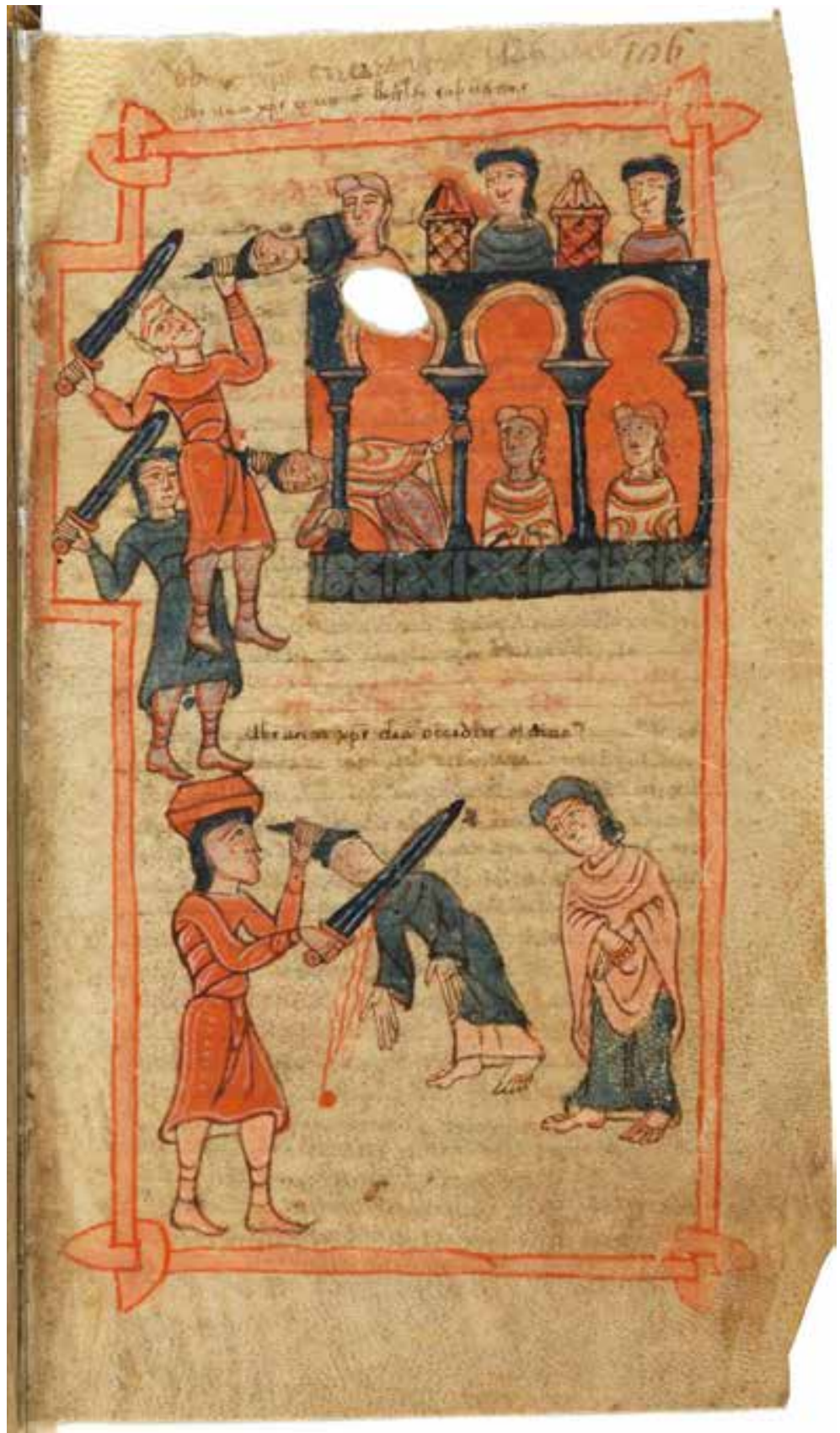

Photo: John Williams 
Figure 65 Appearance of Christ in the Clouds (Apoc. I, 7-8). Corsini Beatus, fol. 155. Rome, Biblioteca dell'Accademia Nazionale dei Lincei e Corsiniana, Segn. 40.E.6

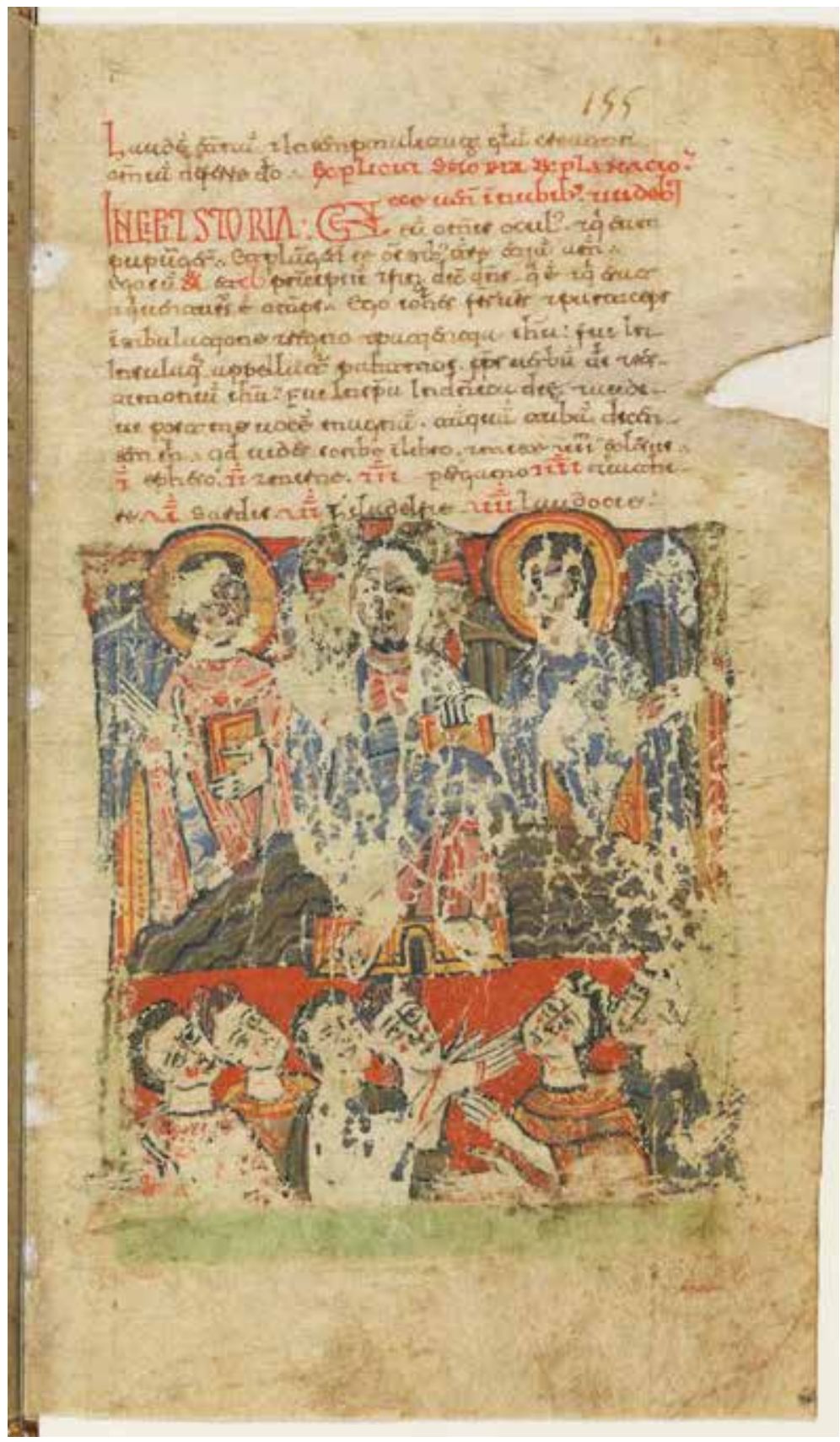

Photo: John Williams 


\section{The León Fragment}

León, Archivo Histórico Provincial, Perg., Astorga 1

2 fols., $15.4 \times 12.2$ in. (390 X $310 \mathrm{~mm})$

Mid-twelfth century

Origin: Kingdom of León (region of Astorga?)

The two mutilated folios to which this Commentary has been reduced were discovered in the fall of 1976 as the wrappers of documents from Astorga. On folio 1 both the text and the illustration, which shows St. John with a key greeting an angel within a simple structure (Fig. 66), clearly identify the scene as the Message to the Church of Philadelphia (Apoc. III, 7-13). The second fragment would have succeeded the first in the Commentary. It has the text of the Church of Laodicea; the only evidence of the original image is a part of the red gable that would have framed the figures of St. John and the angel. The writing, an early version of twelfth-century Caroline script, is a better indication of date than the crude style of the illustration.

If the Astorga provenance suggests an origin in the Bierzo of western León, there is no possibility of confirming it through stylistic comparisons with other illustrated manuscripts. Not only is there little style left to see, but also the simplicity of the figures indicates that a hand and scriptorium with little experience in illumination attempted to duplicate the images of another Commentary. Ochre and red are the only colors used, and the church seems never to have been completed. The sketchy wings that each figure displays may have been added later. They are, of course, inappropriate for the figure of St. John, who stands at the left.

With regards to format, the lack of a frame enclosing the church and figures, along with the unpainted ground, aligns the illustration with imagery associated with the earlier recension of the text. Surprisingly, the text is that of the later, tenth-century, recension (Gryson), a
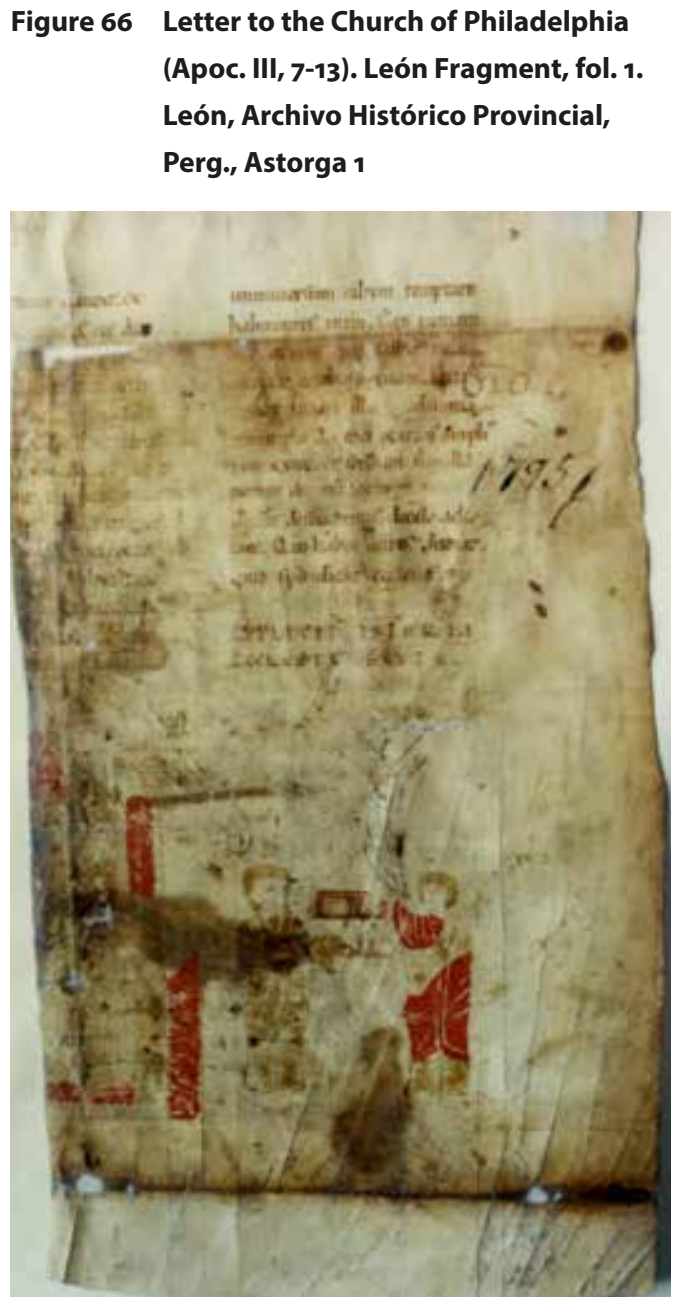

Photo: John Williams

singular combination that may be explained by a shortage of talent and/or a poorly endowed scriptorium. However, the fragment has parallels with the Lorvão Beatus (No. 22), a Commentary in the same sub-branch of the family tree as the Beatus of Burgo de Osma (No. 14), specifically the type of key held by St. John or the angel, as well as the use of red and yellow.

Williams 2002, 45; Galván Freile 1996; Galván Freile 2000; Suárez González 2009, 111-13; Gryson 2012, LXII-LXIII. 


\section{The Berlin Beatus}

Berlin, Staatsbibliothek Preussischer Kulturbesitz, MS theol. lat. fol. 561

98 fols., $12 \times 7.5$ in. (302 x $190 \mathrm{~mm})$

Twelfth century

Origin: Southern Italy

Like the mid-eleventh-century Geneva Beatus (No. 29), this Commentary originated in Italy. The text of the Berlin Beatus indicates that the Corsini copy from Sahagún (No. 17) served as its model (Gryson). The traditional format was maintained in the Berlin Beatus, with pictures appearing at the same points between storia and explanatio. But the iconographic conventions of the peninsular copies were abandoned in favor of an Italian tradition of Apocalypse illustration, as may be seen in the Vision of the Lamb (Fig. 67) and the Woman Clothed in the Sun (Fig. 68), which diverge from the longlived tradition of their Spanish counterparts (see Figs. 16, 78). Stylistically and technically, too, the illustrations differ greatly from the Iberian examples. Here they are executed as pen drawings, with yellow, brown, and occasionally red tinting. They would seem to have been produced by three individuals working in a single style heavily indebted to a Byzantine vocabulary of forms. This Italo-Byzantine style was so prevalent that it is difficult to attach the Berlin Beatus to a specific center, or even to a region. In addition to the Caroline script used for the text, there are re-used leaves (fols. 91-98) whose original script was Beneventan, as well as notations in Beneventan, which indicate a south Italian provenance. As for the date, the first half of the twelfth century seems appropriate (Klein), although it has also been dated to the late eleventh century (Tristano).

Williams 2002, 46-47; Tristano 1979, 94; Fingernagel 1999, 29-35; Klein 2010; Gryson 2012, XLVII-LI; Reynolds 2012, 33-34; Klein 2014a, 21. 
Figure 67 Vision of the Lamb (Apoc. V, 6-14). Berlin Beatus, fol. 38. Berlin, Staatsbibliothek Preussischer Kulturbesitz, MS Theol. lat. Fol. 561

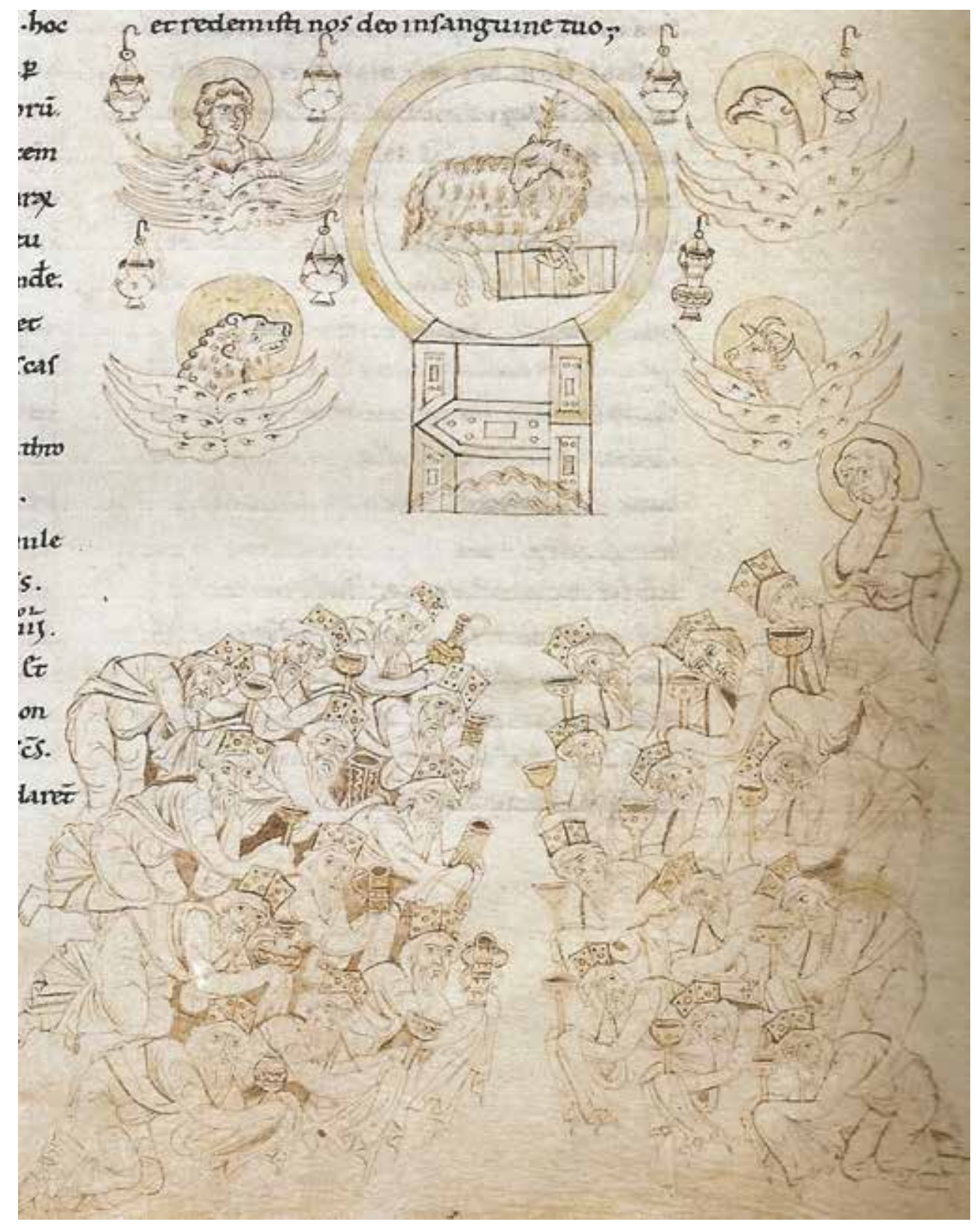

Photo: John Williams 
Figure 68 The Woman Clothed in the Sun (Apoc. XII, 1-18). Berlin Beatus, fol. 70. Berlin, Staatsbibliothek Preussischer Kulturbesitz, MS Theol. lat. Fol. 561

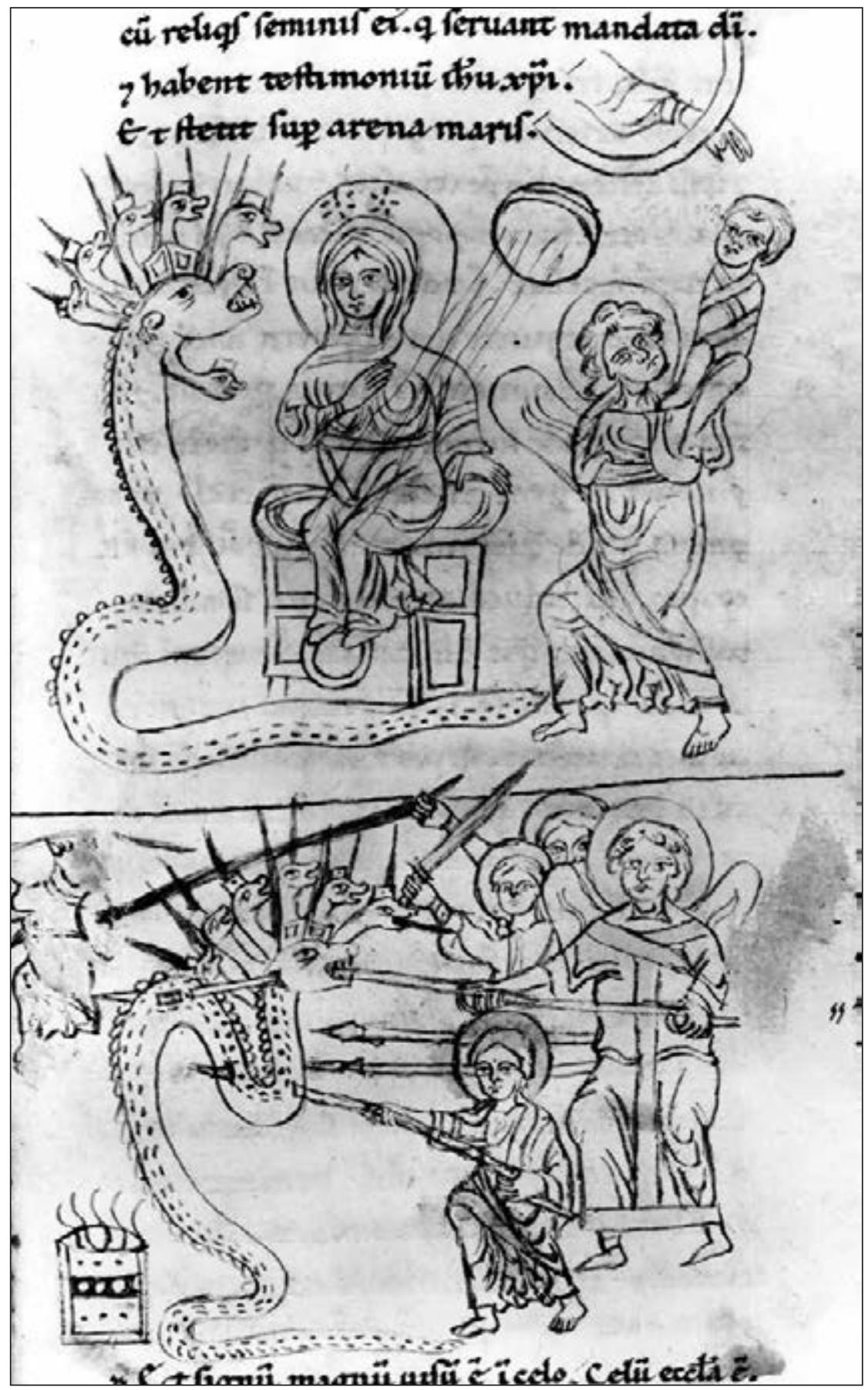

Photo: John Williams 
20. The Rylands Beatus

Manchester, John Rylands University Library, MS lat. 8

248 fols., $18 \times 12.8$ in. (454 x $326 \mathrm{~mm}$ )

c. 1175

Origin: Castile (region of Burgos? Toledo?)

The Rylands Beatus is one of five copies (along with Commentaries 21, 24, 25, 26) produced in the Kingdom of Castile during the late twelfth and early thirteenth centuries, in a "Renaissance" of the Beatus tradition linked to royally favored convents of Cistercian nuns. The place of origin of these Commentaries is debated, as are their mutual relationships, especially that between the Rylands copy and the manuscript customarily labeled the Cardeña Beatus (No. 21).

In terms of format and compositions, the inspiration for this copy can be traced back to the pictorial reform of Maius at Tábara in the middle of the tenth century, and more specifically to the second generation of Commentaries there. Its iconographic resemblance to the Girona Beatus (No. 6) - as in the Majesty page, with its ribbons and Atlas-Angels (fol. 2) - led Neuss and others to propose a Catalonian origin for the Rylands copy. However, this resemblance exhausts the case for Catalonia, whereas the case for Castile is substantial. It was reported by the bishop of Burgos that a Beatus similar to one then in the convent of Las Huelgas outside Burgos had been taken from the city in 1869 by the provincial governor. This date fits well with the 1870 sale of the Rylands manuscript in Madrid. Moreover, the sister manuscript of the Girona Beatus, the Tábara Commentary of 970 (No. 5), served as the model for the Las Huelgas Beatus (No. 24), which ended up in Burgos.

Although the Tábara Beatus is too mutilated to be a perfect witness, its parallels with the Rylands Commentary are stricter than those between Rylands and Girona. While there are reasons other than the historical role of Burgos for arguing that the Tábara Beatus also served as the model for Rylands (Williams), the alternate proposal of a common model other than the Tábara Beatus is supported by the family tree of texts (see Fig. 4). Thus, the identity of the scriptorium responsible for Rylands has not been resolved, but the one usually proposed, San Pedro de Cardeña, outside Burgos, does not seem a credible choice (a conclusion explained in the entry for the Cardeña Beatus, No. 21).

If the iconography of the Rylands Beatus was indigenous to Spain, the style of figures and initials was based on those found in French manuscripts of the middle of the twelfth century in such centers as Paris and Pontigny. It is a style ultimately based on Byzantine formulas for enhancing the illusion of well-articulated, substantial figures, and it was widely influential in Spain. A close match for the style of the Beatus illustrations is found in the portal sculpture of San Miguel de Estella, a site less than a hundred miles east of Burgos on the pilgrimage road to Santiago de Compostela. The curling acanthus leaves with rows of pearls along the stalks that appear in the depictions of capitals in Rylands (fols. 6, 14, etc.) have a sculptural counterpart in the western crypt of Santiago de Compostela. This sculpture is of Burgundian inspiration and dates to around 1170. The Rylands Beatus must date from the same era.

The story of Noah's Ark was highlighted in the Gospel of Matthew (XXIV, 36-39) as a prefiguration of the final judgment that would attend the end of ordinary time, a thematic association that may have encouraged Beatus to incorporate exegetical treatments of Noah's Ark in his Commentary (Fig. 69). Towards the end of Book II he returns to this topic, appropriating a treatise written in the fourth century by Gregory of Elvira. Gregory's treatise identified the Ark as a symbol of the Church, and made 
Figure 69 Noah's Ark (Bk. II). Rylands Beatus, fol. 15. Manchester, John Rylands University Library, MS lat. 8

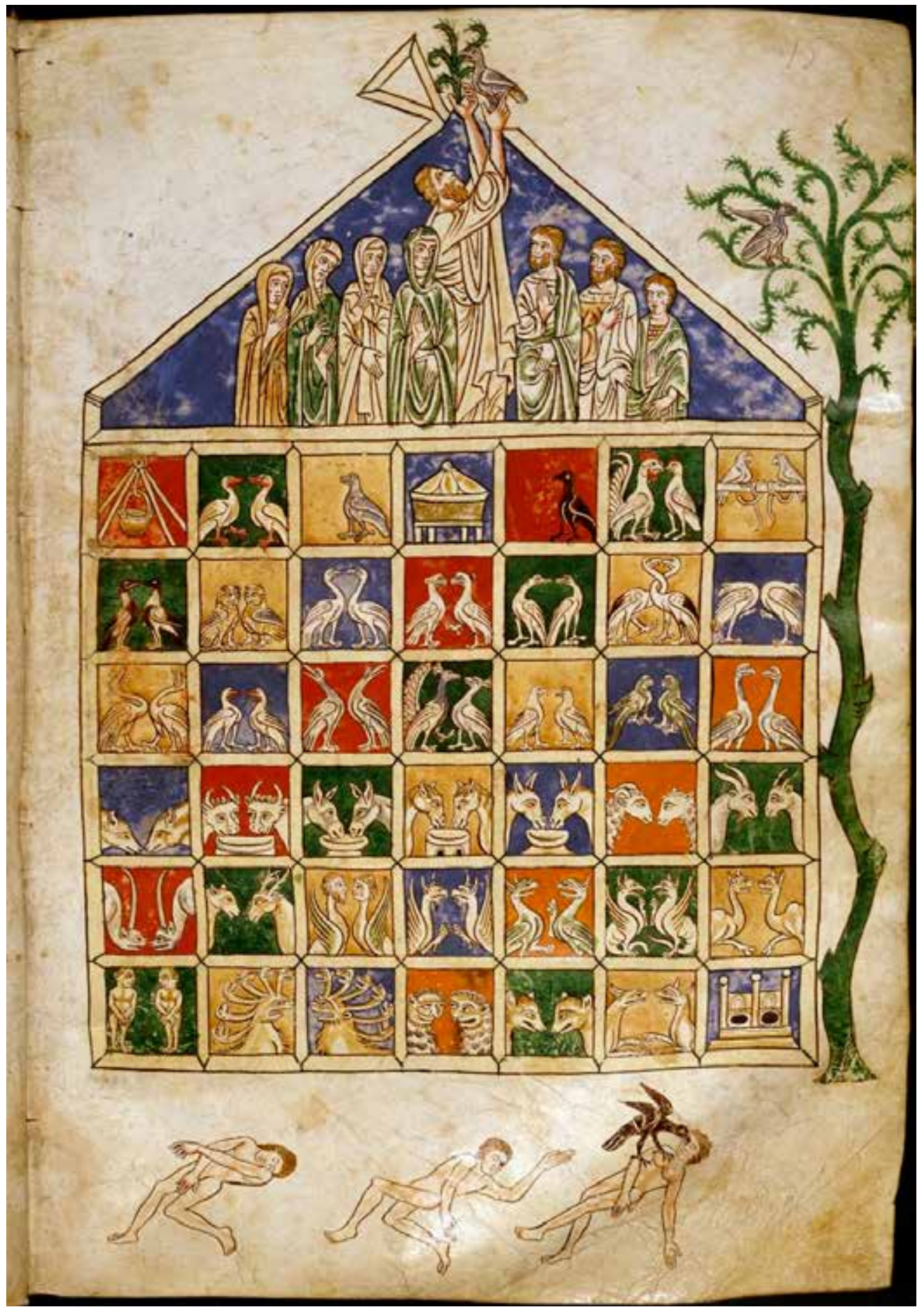

Photo: John Williams 
Figure 70 Babylon (Dan. I, 1; Apoc. XIV, 23). Rylands Beatus, fol. 204. Manchester, John Rylands University Library, MS lat. 8

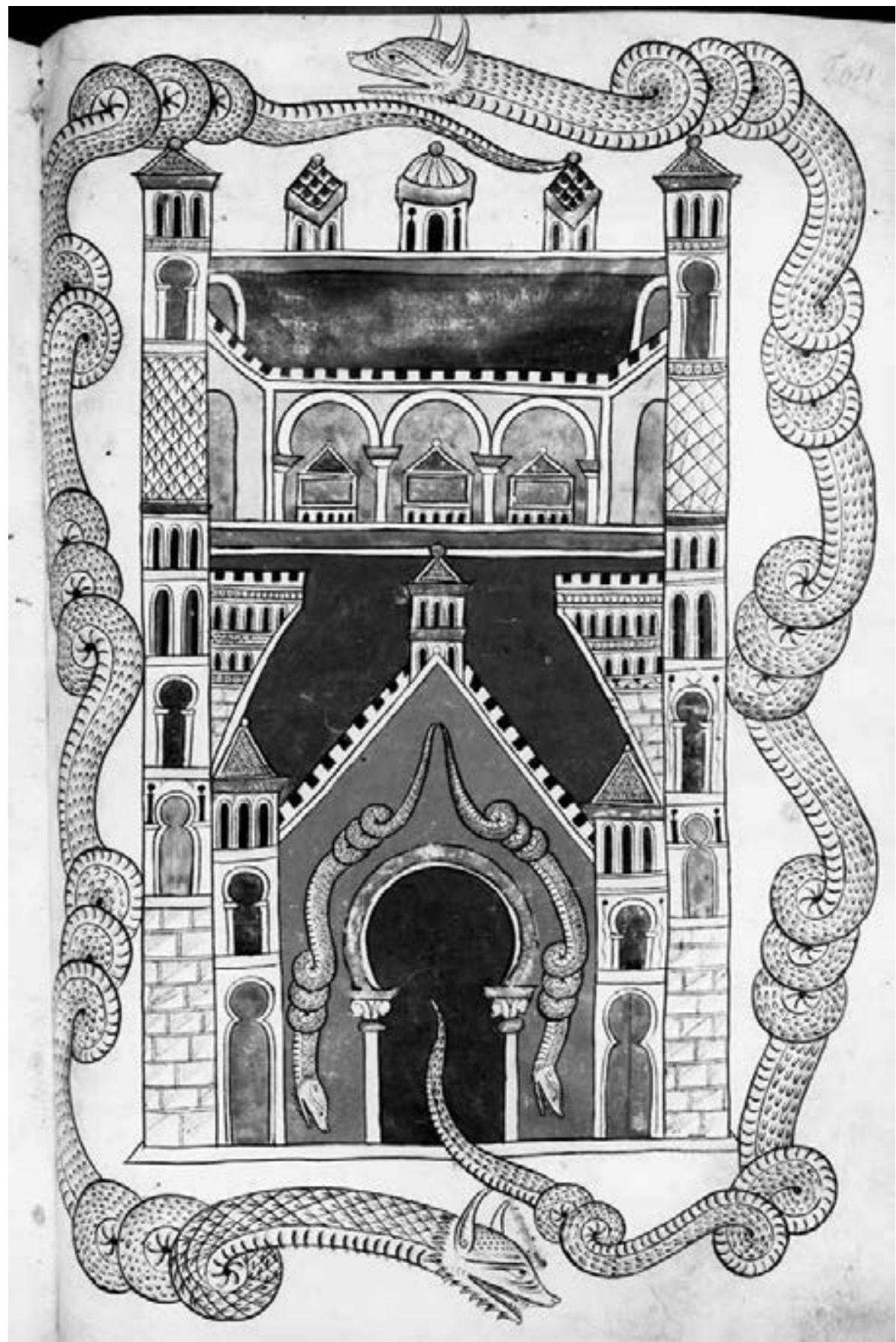

Photo: John Williams 
Noah a type for Christ. The seven members of Noah's family likewise symbolize those saved by Christ, as well as the Seven Churches mentioned in the Apocalypse. In the Rylands illustration the family is gathered in the top story as Noah reaches through the roof to receive from the dove a branch of the olive tree that grows to the right of the ark. In the explanatio the black raven is described as a symbol of impure spirits expelled from the Church, but there is no mention of him feeding on a corpse as the artist has shown. However, in references to the Flood in the early Church and in Jewish legend, ravens fed on the corpses revealed by the receding flood. In the exegetical text the Ark is divided into three floors representing, from top to bottom, Paradise, the terra nova where the New Jerusalem will descend, and the Kingdom of Heaven. The most evident departure from the text is the pictorial emphasis accorded the animals that were also saved; the explanatio does not mention them, but clearly they played a central role in the artist's imagination.

The city of Babylon serves as a frontispiece for the Daniel Commentary (Fig. 70). This image was prompted by the statement in the first verse of the Book of Daniel that "Nebuchadnezzar, King of Babylon," came to Jerusalem. Inscriptions in the Morgan Beatus (No. 2) explain the special features of this portrait of Babylon: "Babylon was founded by the giant, Nimrod. Its walls are said to be fifty cubits in breadth and 200 in height, and in circuit 469 stadia." These measurements ultimately go back to Herodotus. It then offers a synopsis of its history, concluding with its Christian significance: "Destroyed by the Medes and Chaldeans, it was rebuilt by Queen Semiramis. Resting in it are the bodies of the saints, Ananias, Azarias, and Misael." The bodies of these companions of Daniel (Dan. I, 6) - whose names were changed by the master of eunuchs under royal command to Sidrach, Abdenago, and Misach - are shown within caskets resting under an arcaded sanctuary in the center of the city.

The inscription continues with a reference to Nebuchadnezzar and an explanation of the serpents/dragons: "And the vessels of the Lord were carried from Jerusalem [to Babylon] by King Nebuchadnezzar. Because of the wrath of God, there are dragons, ostriches around [the city] and owls, and sirens sing seductively in the wicked city." The presence of dragon reliefs on the Ishtar gate of Babylon inspired fantastical accounts. According to one Byzantine legend, Nebuchadnezzar protected the city by having images of serpents placed on the gate, but during his wicked son's reign the images came alive to punish him, and devoured the populace. Thereafter Babylon was said to be a desolate site infested by serpents, including a dragon that had once been a great stone statue.

Williams 2003a, 19-23; Yarza 1998a, 248ff.; Bord and Skubiszewski 2000; Klein 2002.

\section{The Cardeña Beatus}

Madrid, Museo Arqueológico Nacional, MS 2, 165 fols. (127 original) $17.5 \times 11.8$ in. $(445 \times 300 \mathrm{~mm})$

New York, Metropolitan Museum of Art (formerly Paris, Coll. Marquet de Vasselot), 15 fols. Madrid, Coll. Francisco de Zabálburu y Basabe, 2 fols.

Girona, Museu d'Art de Girona, Num. Inv. 47, 1 fol.

c. 1180

Origin: Castile

The text of the Cardeña Beatus appears to be a copy of the same manuscript that served for the production of the Rylands Beatus (see Fig. 4), a relationship proposed by Klein on the basis of its pictorial content. Alternatively, I have proposed that Rylands itself was the pictorial 
model for Cardeña. That there is an especially close relationship between the two, and not just a shared dependence on an archetype, is found in such details as the duplication of a corrupted text of Antichrist Table I. However, most significant are their singular frontispieces with double arcades. The Rylands Commentary opens (fol. 1) with a page designed for one of the Genealogical Tables, but without any text in the medallions that appear at the top of the page and in the foot of an arcade. It would seem that this was an abandoned first project for its Genealogical Table III (fol. 7), then appropriated to serve as a guardian page. As is traditional for this table, Rylands features a double arcade as a frame for a text not inserted. The Cardeña Beatus opens with this same double arcade (fol. 1), but without the frame and medallions that would complete an authentic Genealogical Table. Logic indicates that the illuminator of Cardeña, determined to include even this odd frontispiece, eliminated the unnecessary medallions. A similar model/copy relationship is indicated by the fact that in the Rylands Genealogical Table IV, a network of twenty-two medallions was mistakenly designed when only twenty were needed to hold all the names designated for that table. The fact that Cardeña's designer left the superfluous medallions out of the corresponding table means that this illustration would be based on a correction to Rylands. It is possible, of course, that oddities such as this and the anomalous frontispiece with the unused arcade were in a common archetype that served both copies.

Certainly it is not the figure style that leads to proposals of an intimate relationship between the two. In tenth-century Commentaries such as the Morgan and Girona Beatus (Nos. 2 and 6), and in those of the eleventh century such as Osma, Saint-Sever, and Facundus (Nos. 14, 13, 11), a uniformity of style was maintained even when more than one painter was responsible. In contrast, two sharply different figure styles are accommodated in the Cardeña Commentary. The style of the prefatory folios - such as the concluding page of the Genealogical Tables (Fig. 71), the concluding half of the Apocalypse, and the Daniel illustrations beginning with the scene of the Palm Tree on folio 92 - is characterized by a high degree of plasticity in the articulation of drapery, as well as a fluidity of movement that is all the more marked through its contrast with the second style present in the manuscript. The illuminations representing this second style, such as the Revelation to St. John (Fig. 72), features figures that tend to be more frontally posed and more static in their alignment with each other. While the first painter's drapery folds build outward, the second artist displays them against the surface of the body in tubular configurations and teardrop or oval patterns - formulas ultimately traceable to Byzantine conventions. At the same time, both styles utilize crosshatching on the inner surfaces of garments and intense colors for the grounds. A surprising degree of unity is achieved through these colors. Whereas the home of the particular Byzantinizing style found in the Rylands Beatus (No. 20) was the area of Paris, the style of the Cardeña Beatus's second painter has a specific parallel in the peculiarly mannered interpretation of Byzantinizing drapery found in English manuscripts of the mid-twelfth century, such as the Winchester Psalter. The Kingdom of Castile obviously welcomed artistic influences from the north, just as its rulers tended to arrange marriages with the royal houses of England and France. These influences were not exclusive to Castile or to the medium of painting. A parallel to the Rylands style and its employment for carved figures on the façade of San Miguel de Estella can be seen for the Cardeña Beatus, which also has a surprisingly similar sculptural analogue. 
Figure 71 Adoration of the Magi, Genealogical Table XIV. Cardeña Beatus, fol. 3. New York, Metropolitan Museum of Art

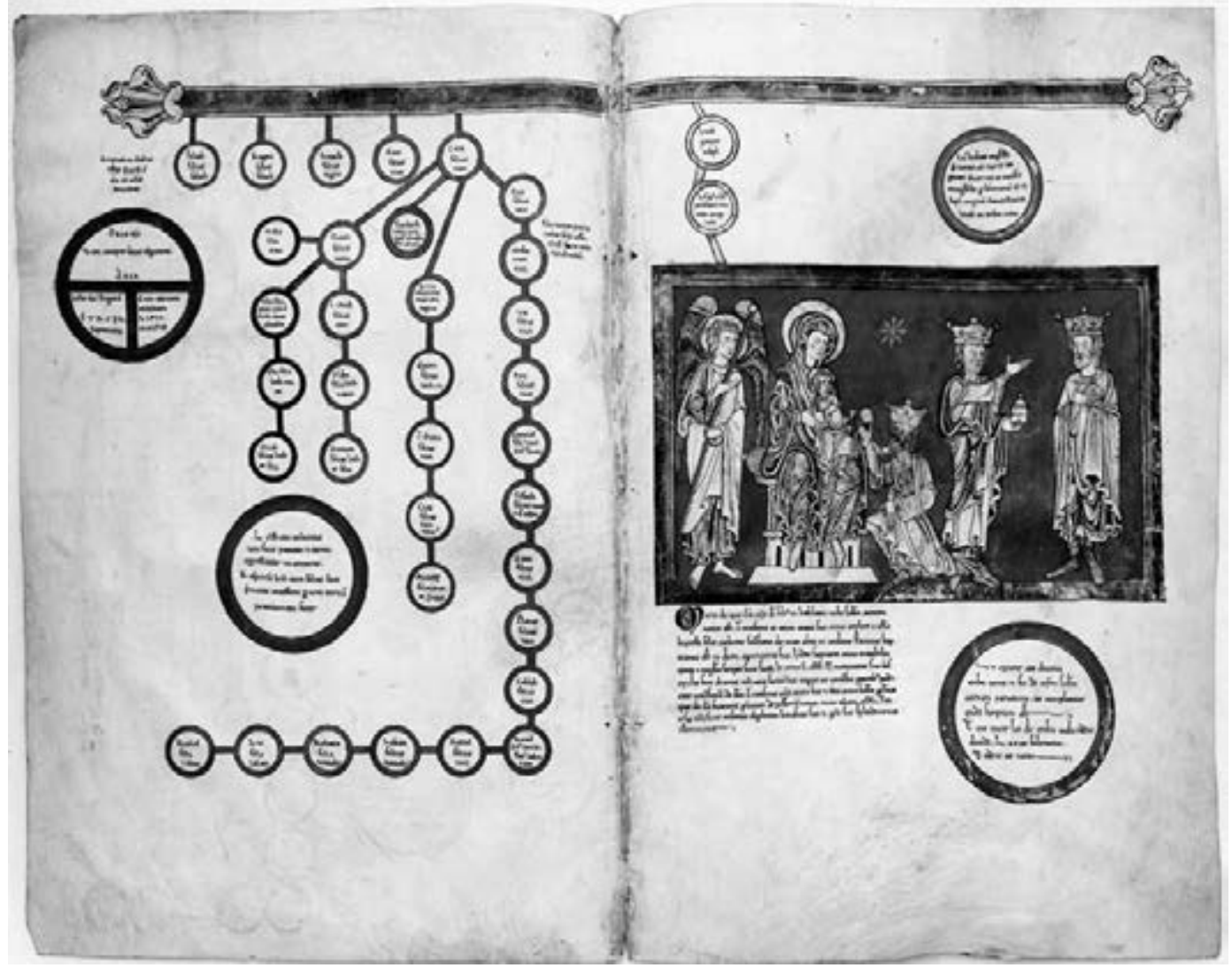

Photo: John Williams

Both styles used in the Cardeña Beatus appear as well in the sculpted apostles accompanying Christ in Majesty in the great frieze above the portal of the church of Santiago in Carrión de los Condes (Kingdom of León), which dates to the 116 os or 1170s. The Cardeña style is also found as far west as Oviedo, in the apostles adorning the columns of the Cámara Santa.

The routine assignment of this Commentary to Cardeña stems from a claim made in 1871 at the time of its arrival at the Museo Arqueológico Nacional that "this codex, according to a declaration made by Sr. Masa y Sanguinetti, came from San Pedro de Cardeña." Apparently bolstering this attribution, though in a circular way, is the labeling of the Burgos Bible (Biblioteca Pública del Estado in Burgos), which lacks a documented provenance, as the "Bible of Cardeña" (Yarza 2009). Part of the Burgos Bible's Genesis illustration seems to be by the Byzantinizing hand of the Cardeña Beatus. Some support for the attribution to Cardeña is provided by an image in an early thirteenthcentury manuscript produced at Cardeña featuring Isaiah with the "Winchester"-style drapery pattern (Faulhaber). Recent studies, however, noting the lack of evidence for a scriptorium at Cardeña in the latter part of the 
Figure 72 Revelation to St. John (Apoc. I, 1-6). Cardeña Beatus, fol. 4. New York, Metropolitan Museum of Art

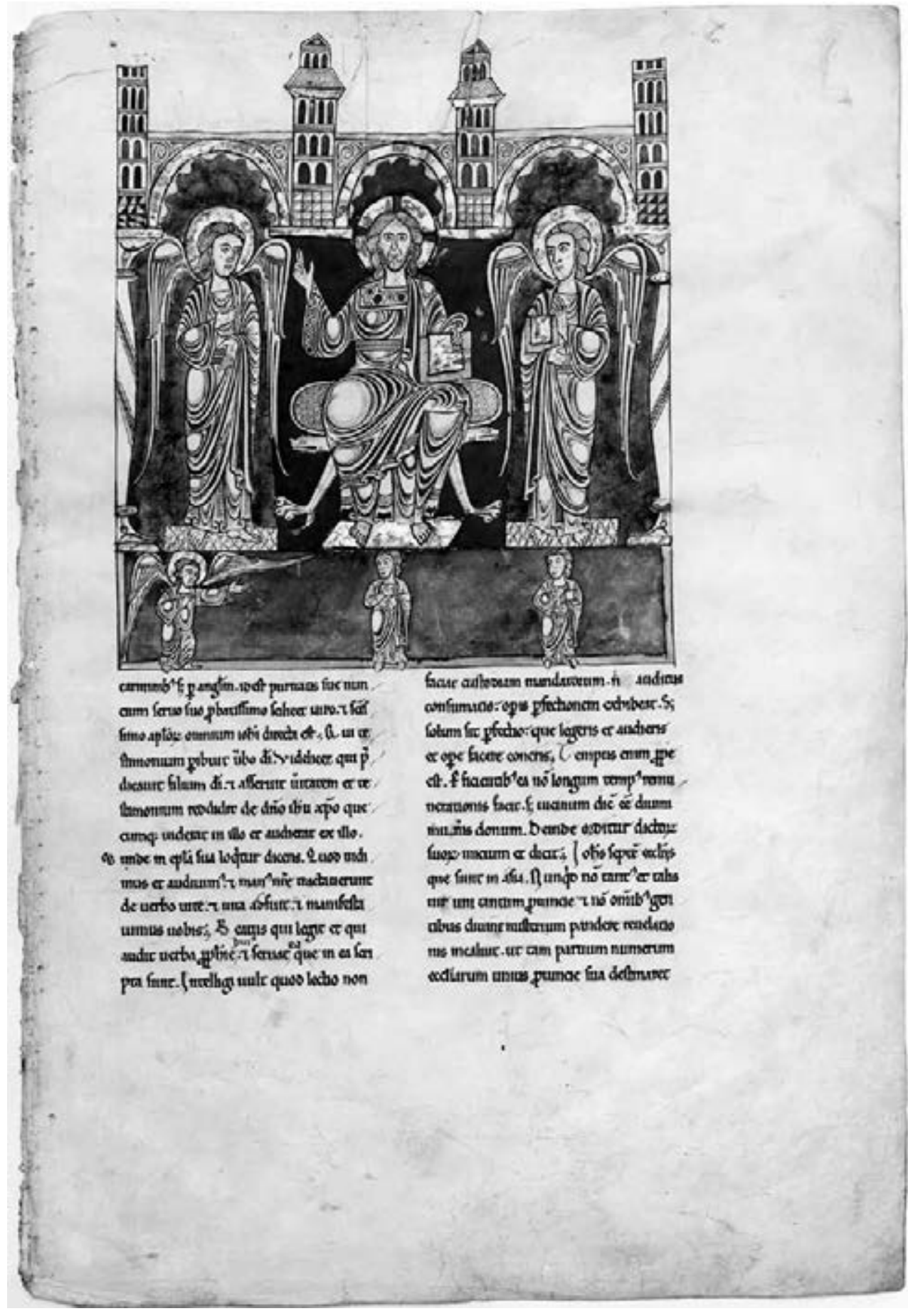

Photo: John Williams 
twelfth century, have rejected its role in the production of either this Beatus or the Burgos Bible, and suggested that both may have been French imports (Sánchez Mariana; Suárez González).

Williams 2003a, 24-30; Yarza 1998a, 234ff.; Faulhaber 1983, frontispiece, 21; Franco Mata 2001a, 2001b; Ruiz García 2001; Sánchez Mariana 2001; Klein 2002, 34f.; Yarza 2009; Suárez González 2010a, 99-101.

\section{The Lorvão Beatus}

Lisbon, Arquivo Nacional da Torre do Tombo 219 fols., 13.6 in. x 9.6 in. $(345 \times 245 \mathrm{~mm})$

1189

Origin: Monastery of São Mamede (San Mamés), Lorvão (Portugal)

Scribe: Egeas

Illuminator: Egeas (?)

Now the book is written. May he who wrote it be blessed. ERA MCCXXVII [A.D. 1189]. I, Egeas, who wrote this book, kept to the straight path laid out by others. May the charity which surpasses all excuse my failings. Amen.

With this colophon on folio $219^{\mathrm{v}}$, the final words of which are appropriated from Beatus's own preface, Egeas provides us with a scribal identity and a date for the only surviving illustrated Beatus Commentary associated with Portugal. This "foreign" provenance does not mean it is informed with an exotic style, for Portugal only gradually separated itself from Spain during the course of the twelfth century. No place name is included in the colophon, but the monastery of São Mamede (San Mamés) at Lorvão, outside Coimbra, very probably commissioned it. Not only did it enter the National Archive of Lisbon from there in 1853 , but also it shares pictorial formulas with a "Book of Birds" executed there six years before the Beatus.
Although Lorvão would later become a Cistercian convent, this copy cannot be linked to the Cistercian revival of the Commentary that took place in Castile, for Lorvão's conversion only took place in 1206 .

The superiority of the motifs that are closest to the craftsmanship of the skillfully decorated initials suggest that the principal scribe, Egeas, may have participated in the illumination. A reduced palette of orange, yellow, and red was very thinly applied. The lack of blue is especially apparent in those scenes calling for the depiction of water, where ink black is substituted. Egeas was copying some Commentary from the first family of texts, more specifically the sub-family that includes the Beatus of Burgo de Osma (No. 14). Not only is this relationship confirmed by the family tree based on the text (see Fig. 4), but the Map of the World in the Lorvão copy, only half of which survives, includes details that otherwise appear solely in the Osma map. Lorvão also uniquely shares with Osma an expansion of the Message to the Church of Thyatira (fol. 64), whereby the figure of Jezabel is introduced.

There are too many differences in text and imagery to make the Lorvão Beatus a direct copy of Osma, but a common archetype would explain these similarities. Although a tenth-century date for this archetype has been proposed (Klein), the Lorvão Beatus's format, together with its formal and iconographic elements, suggests a later common ancestor. The depictions of Hell in both Osma (fol. 23) and Lorvão (fol. 17) employ a framed image of the "Son of Man" (Christ) comforting St. John. The dynamic way the frame of the core scene incorporates lobes seems to be a significant indicator that the common model for Lorvão and Osma must not be much earlier than the latter part of the eleventh century, Osma's own date. Although the Osma Beatus itself cannot have been the model, their sharing of unique 
Figure 73 Angels Restraining the Winds (Apoc. VII, 1-3). Lorvão Beatus, fol. 118. Lisbon, Arquivo Nacional da Torre do Tombo

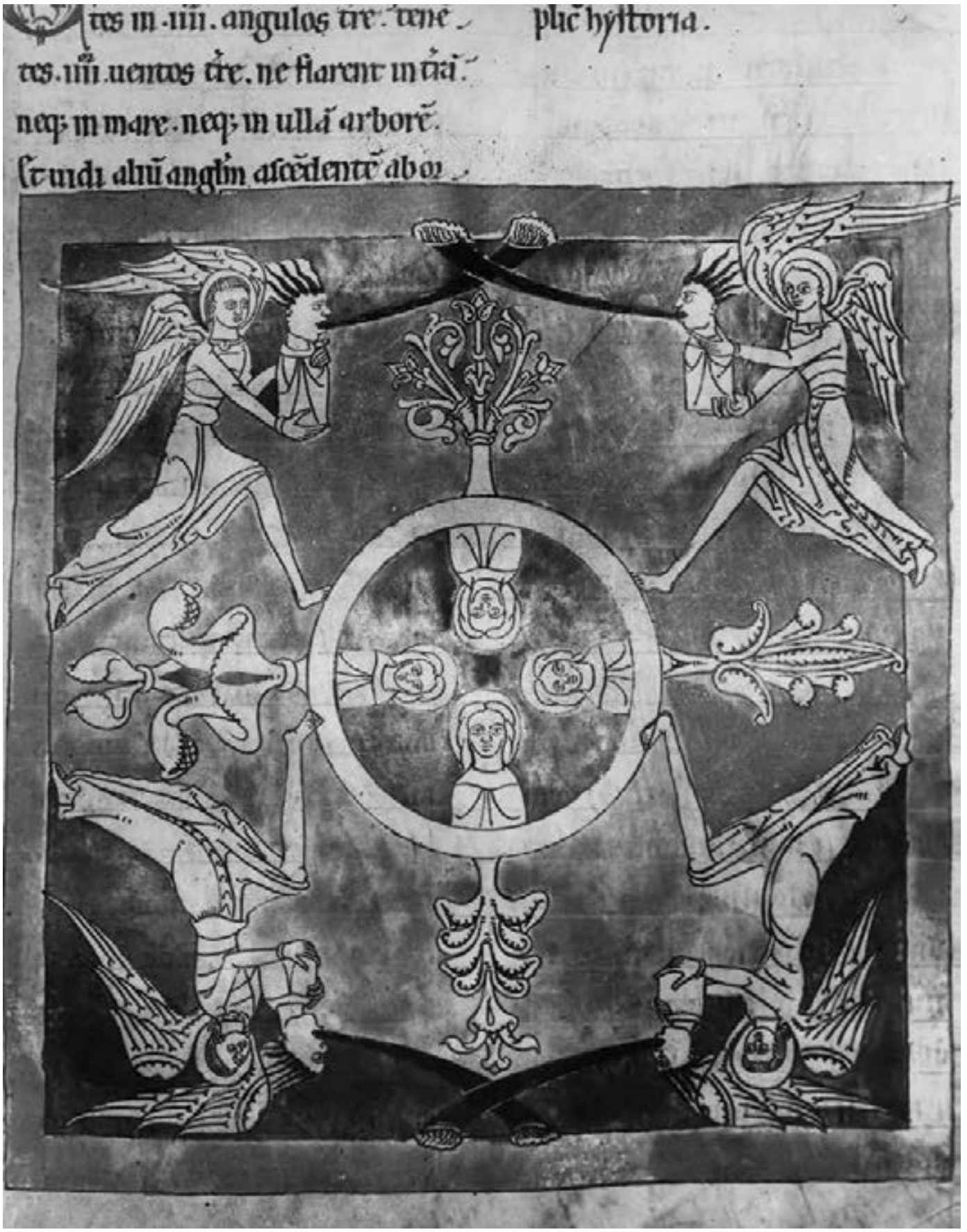

Photo: John Williams 
Figure 74 The Opening of the Fifth Seal: The Souls under the Altar (Apoc. VI, 9-11). Lorvão Beatus, fol. 112. Lisbon, Arquivo Nacional da Torre do Tombo

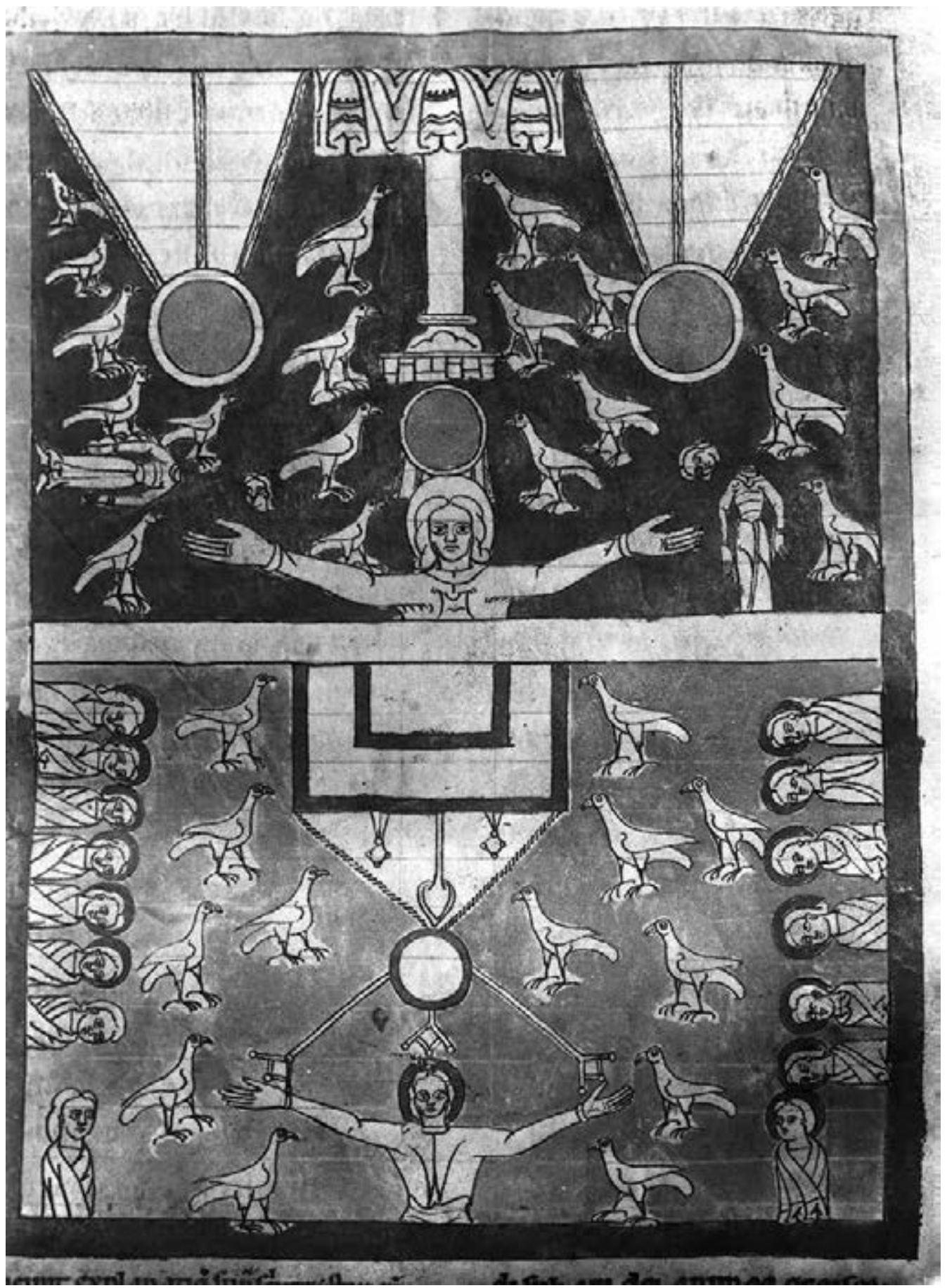

Photo: John Williams 
iconographies guarantees a link with some member of the immediate family.

The Commentaries of Lorvão and Las Huelgas (No. 24) offer the only direct evidence, in the form of marginal glosses, of how the Beatus functioned overall in monastic settings. On folio 12, at the beginning of Book I, we find in the Lorvão Beatus: "When Matins begin, start here." The second marginal note (fol. 17), with the same instruction, is placed at the end of the storia that contains the commission to write (Apoc. I, 10-20): "When this apocalypse enters Matins one is to begin here in the refectory." Although these rubrics are from the late fifteenth or early sixteenth century, it is reasonable to imagine that the Commentary served the same homiletic purpose for the community of Lorvão from the beginning, in addition to providing the kind of individual spiritual reading each monk or nun was required to exercise.

In the thirteenth century an unillustrated copy of the text was made at the Portuguese Cistercian monastery of Alcobaça; it is now in Lisbon (Biblioteca Nacional, MS Alc. 247).

Williams 2003a, 31-34; Yarza 1998a, 268f.; Moralejo 1992, 178; Williams 1992, 20-24; Peixeiro 1995, 17of., 184f.; Iluminura 1999; Miranda, M.A. 1999, 138ff.; Miranda, M.A. 2001, 193ff.; Klein 2004a.

\section{The Navarre Beatus}

Paris, Bibliothèque nationale de France, Nouv. acq. lat. 1366

157 fols., $13.8 \times 9$ in. ( $350 \times 230 \mathrm{~mm})$

Late twelfth century

Origin: Navarre? Astorga?

This copy, with its unusual violet palette, is difficult to link to a specific center. The label "Navarrese" that is traditionally assigned to it depends on a copy of an act of King Charles
III of Navarre, dated 4 May 1389, appended to the end of the manuscript. However, the Map of the World on folio 25 offers another possible clue to an origin farther west in the Kingdom of León (Fig. 75). Astorga is not normally present among sites identified on Beatus maps, and rather than being represented in the formulaic manner used for the numerous other cities, this map shows Astorga in plan as a circular, walled city. It was laid out in just this way in the fifth century, and parts of Astorga's circular walls are still preserved today. However, there are no Leonese counterparts for the manuscript's style. Nor is there any Navarrese counterpart among the illuminated manuscripts in the Archivo General de Navarra or the Cathedral of Pamplona, although a Beatus, possibly this one, was seen in 1665 in that cathedral. The figure style of this Beatus - its emphatic linearity, occasional flying folds (fol. 146), and suppression of illusionistic space - amounts to a Romanesque stylistic character resembling that of the late twelfth-century frescoes of the crypt of the Cathedral of Roda de Isábena, in nearby Aragon.

Although the Navarre Beatus falls chronologically within the era that saw a last resurgence of the Beatus tradition, it stands apart from most of the other copies of this time. Not only is it free of the influence of the Byzantine formulas employed in France and imported to the peninsula, it differs also from the Castilian copies in belonging to the earlier version of the Commentary's text and iconography. As a late Romanesque copy it did not adhere to the original format of small, frameless miniatures, and many of its illuminations reflect the iconographic conventions of such Branch I manuscripts as the Escorial Beatus (No. 10), although it belongs to a different sub-branch. A few are idiosyncratic, like the Map, where the usual orientation has been rotated ninety 
Figure 75 Map of the World. Navarre Beatus, fols. 24v-25. Paris, Bibliothèque nationale de France, Nouv. acq. lat. 1366

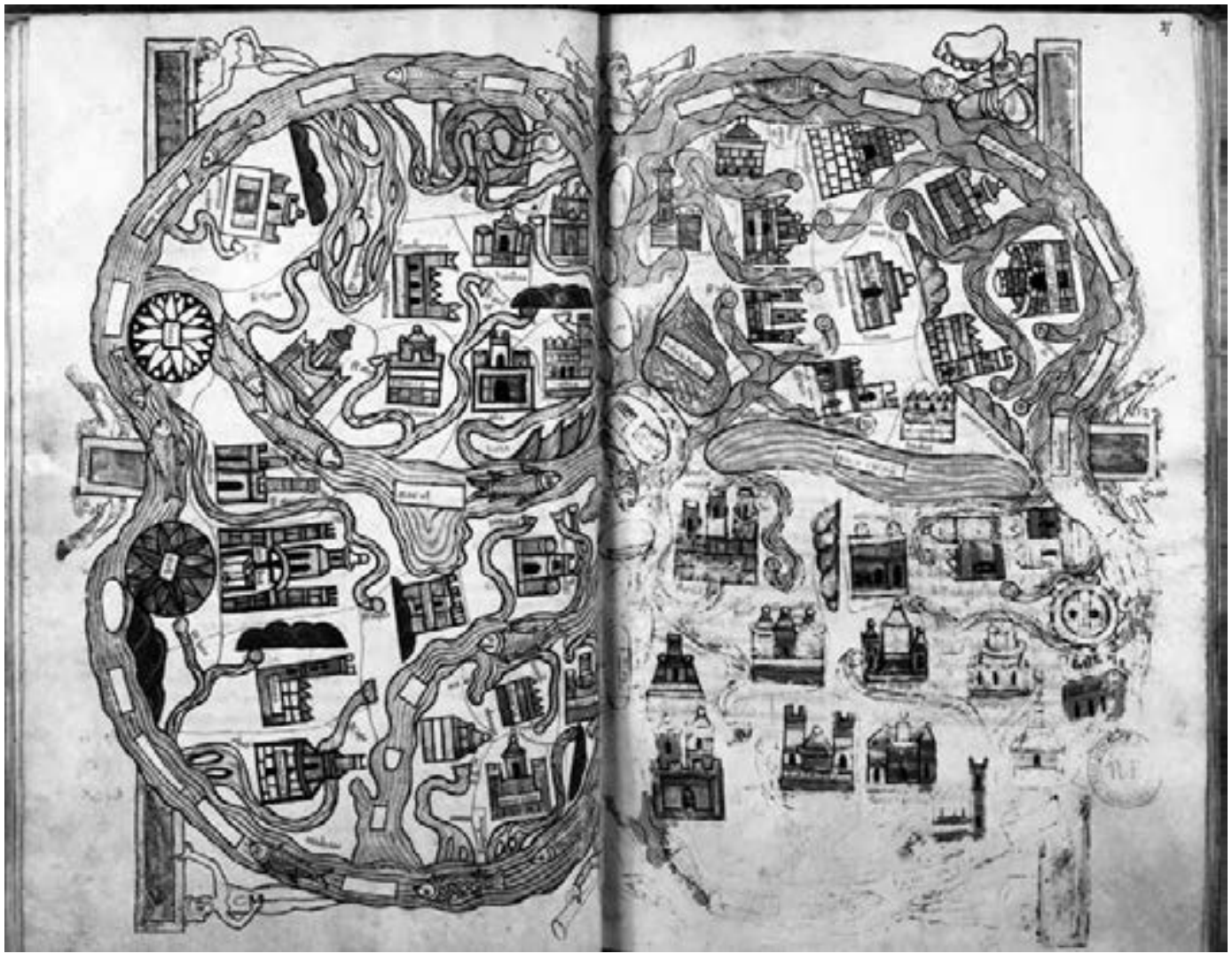

Photo: John Williams

degrees counterclockwise. In the Appearance of Christ in the Clouds, however, an exceptional effort was made to interpret the Apocalyptic text. That storia specifies that "every eye shall see him," and the occupants on the left side in the lower register, with one exception, indeed take notice. Those on the right do not look up, however; given their gestures, they likely represent "all the tribes of the earth" who "wail over him." As the Commentary affirms, he will be coming in his glory to judge, and it may be no accident that the ones who see are on his "good," right side, as they are in Last Judgment scenes. Are those at Christ's left hand his persecutors, mentioned in the explanatio?
An even more pronounced change is evident in the illustration of the Death of the Two Witnesses (Fig. 76). This full-page miniature shows Enoch and Elias being killed with spears rather than swords, and their assassination is carried out by subordinates rather than the Antichrist himself. In the early copies the Antichrist appeared as an exotic figure wearing headgear that suggested demonic authority (see Fig. 64). Here, shown in profile, he is made to fit the stereotype of the Jew, reflecting the pictorial anti-Semitism that marked the later Middle Ages. The narrative of the storia, in which the bodies of the Witnesses are said to "lie in the streets of the 
Figure 76 The Two Witnesses Killed by the Antichrist (Apoc. XI, 7-10). Navarre Beatus, fol. 98v. Paris, Bibliothèque nationale de France, Nouv. acq. lat. 1366

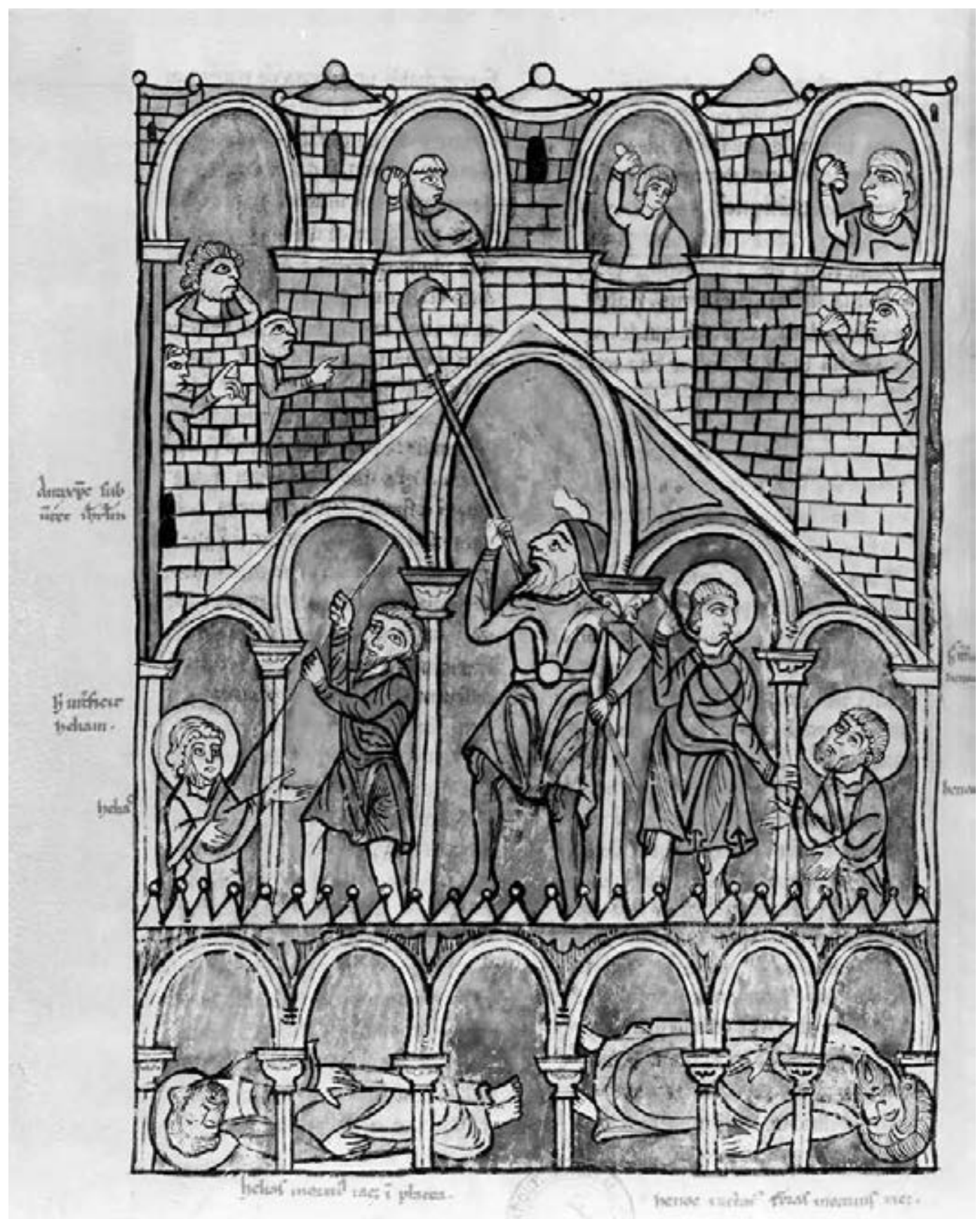

Photo: John Williams 
city," has informed the rendering of the lower part of the illustration.

Williams 2003a, 35-37; Yarza 1998a, 26off.; Ruiz García 2007; Silva y Verástegui 2007; SáenzLópez 2008.

\section{The Las Huelgas Beatus}

New York, The Morgan Library \& Museum, MS M.429

184 fols., 21 x 13.3 in. (530 x $340 \mathrm{~mm})$

September 1220

Origin: Toledo? Santa María la Real de las Huelgas?

The Las Huelgas Beatus has the distinction of being both the last of the dated Commentaries and the largest of them all. A collation of the texts confirms that this copy was based on the Tábara Beatus (No. 5), a relationship made obvious by the replica of the extraordinary depiction of the tower and scriptorium that closes Tábara (see Figs. 41, 77). The question of just where the Las Huelgas copy itself was carried out, however, has not been settled. In the eighteenth century it was seen by Enrique Flórez in the library of the Cistercian convent of Santa María la Real de Las Huelgas, the royally founded monastery in the suburbs of the Castilian capital of Burgos, which had jurisdiction over other Cistercian houses in Castile, León, and Navarre. However, despite an impressive library and its status as a "special daughter" of Cîteaux - the motherhouse of the Cistercian order - Las Huelgas has no confirmed history as a producer of manuscripts. Among the Cistercian houses dependent on Las Huelgas was the monastery of San Clemente de Toledo, founded in 1100 by King Alfonso VI. According to the dealer who sold the Las Huelgas Beatus to the Morgan Library, the manuscript had been purchased from San Clemente.
The apparent migration of the manuscript to Toledo remains a mystery. Although we cannot link the actual production of the Las Huelgas Beatus to San Clemente, there is good reason to link it to Toledo, for two of the painters responsible for its illustration painted other commissions in that city (Raizman 2004). The painter of one of the most impressive illustrations of the Las Huelgas Beatus, the Woman Clothed in the Sun (Fig. 78), was also responsible for murals in the Toledan converted mosque, Cristo de la Luz (originally Bab al-Mardum), as well as a copy of a Toledan Ildefonsus manuscript (Madrid, Biblioteca Nacional, MS 10087). Even if patronage in the Castilian capital of Burgos generated the manuscript, it would seem that Toledo served as the artistic capital of the kingdom. As a confirmed copy of Tábara, it is not surprising to find that the Las Huelgas manuscript adheres rather closely to its model in the composition of the majority of its miniatures. It is, however, less like Tábara compositionally than is the Rylands Beatus (No. 20) illustrated a half-century earlier.

The exalted status of the Las Huelgas Commentary's donor is strongly suggested by the language of the colophon of 1220, which refers to "the lady who gave a generous hand to the blessed Virgin and to the blessed John the Evangelist [...] and who, with smiling face and joyous spirit gave to God and to St. John and to her scribes." This lady who enriched the royal convent outside Burgos with the Beatus is likely to have been Queen Berenguela (d. 1246), eldest daughter of the founders of Las Huelgas. While queen of León, Berenguela is known to have commissioned books. In November of 1219 her son, King Fernando III, was armed at the altar of Las Huelgas, and three days later he married Beatrice of Swabia. These events were celebrated with gifts to the convent. Keeping in mind the precedent of his namesake Fernando I, who 
Figure 77 Tower Scriptorium. Las Huelgas Beatus, fol. 183. New York, The Morgan Library \& Museum, MS M.429

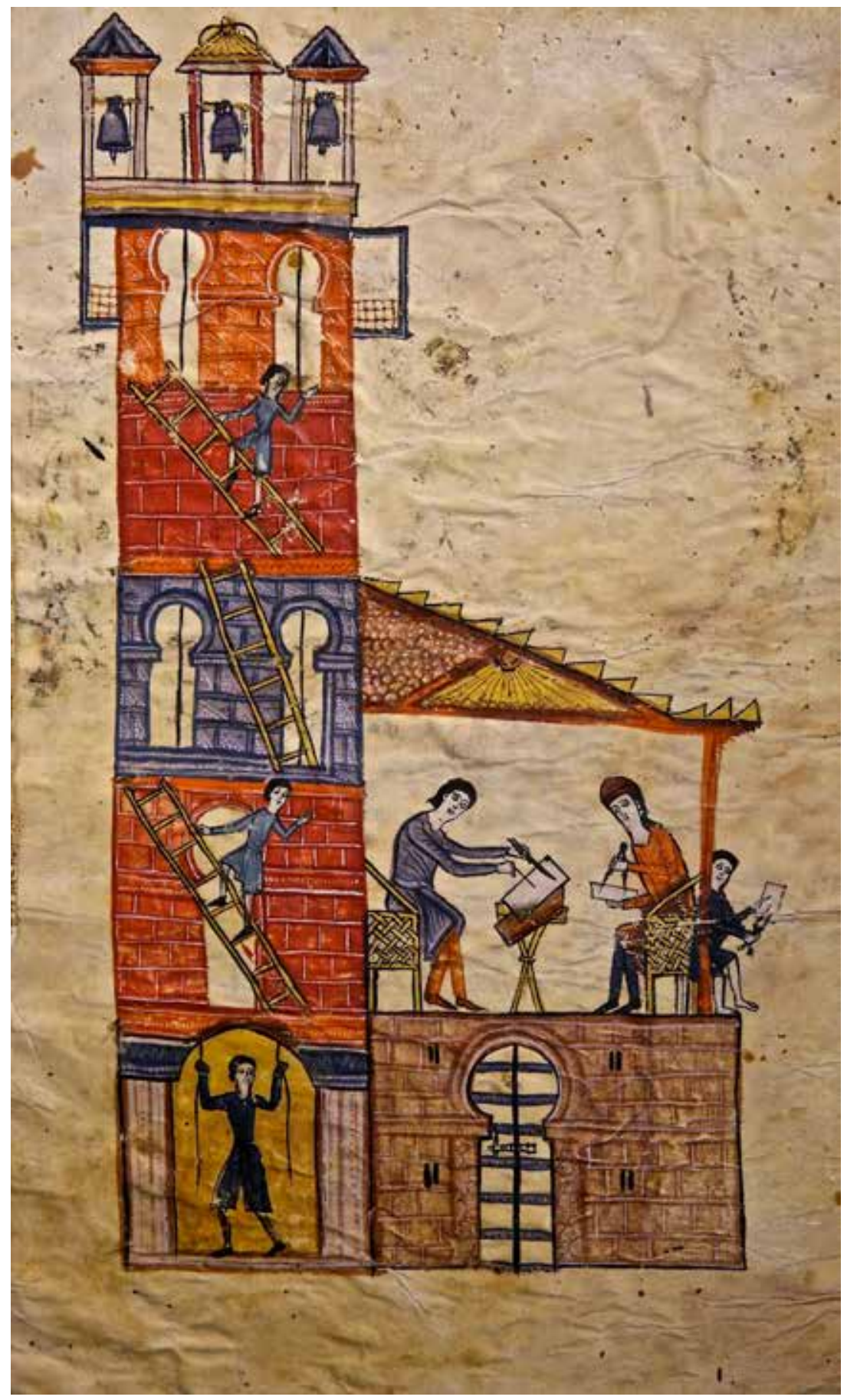

Photo: Hamid Shams 
Figure 78 The Woman Clothed in the Sun (Apoc. XII, 1-18). Las Huelgas Beatus, fols. 101 ${ }^{\mathrm{v}-102 .}$ New York, The Morgan Library \& Museum, MS M.429

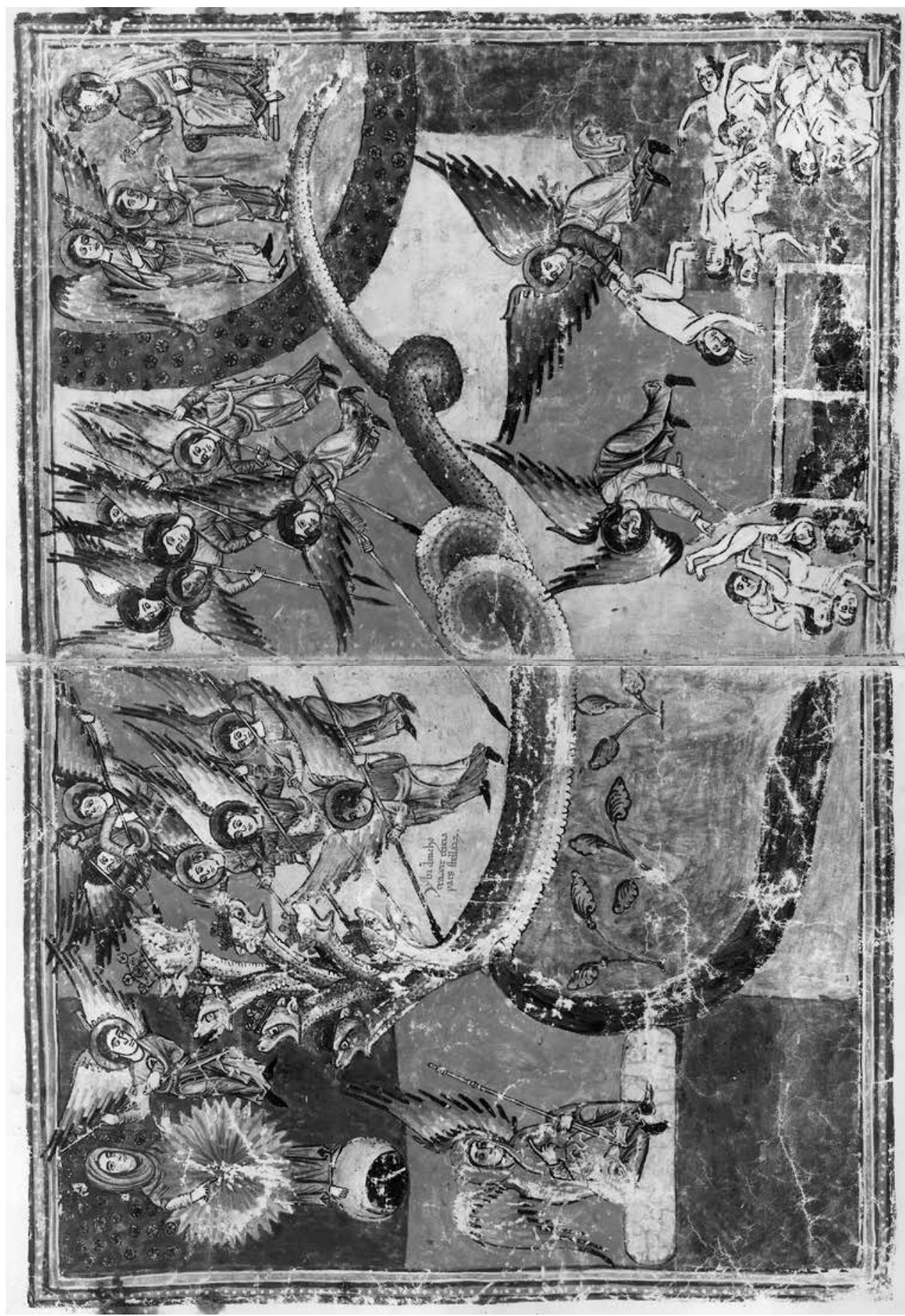

Photo: Joseph Zehavi 
along with Queen Sancha, commissioned the Facundus Beatus in 1047, one possibility might be a commission in 1219 designed to honor the new queen. Alternatively, Doña Sancha García, abbess of Las Huelgas from 1207 to 1230, has been suggested as a patron (Klein). However, Berenguela seems more certainly the patron praised in the colophon (Raizman 2005).

The style of the Las Huelgas Beatus is a distinct version of the Byzantine manner found in the Rylands, Cardeña, and Arroyo Commentaries (Nos. 20, 21, 25), yet more difficult than these other copies to link to centers north of the Pyrenees. It is not a uniform style, for three painters participated.

Williams 2003a, 38-42; Yarza 1998a, 296ff.; Yarza 1998b; Klein 2004b; Raizman 2004, 2005; Shadis 2009.

\section{The Arroyo Beatus}

Paris, Bibliothèque nationale de France, Nouv. acq. lat. 2290

167 fols., $17.3 \times 12$ in. ( $440 \times 305 \mathrm{~mm})$

Los Angeles, Getty Center (formerly B. H. Breslauer Coll.), 1 fol.

c. 1220-35

Origin: Region of Burgos?

San Andrés de Arroyo, along with Aguilar de Campoo and Las Huelgas, was one of a trio of late twelfth-century Cistercian foundations that enjoyed a high level of patronage from the Castilian crown. It was probably founded in 1181 by Doña Mencía, executrix of Alfonso VIII of Castile. This copy of the Commentary was at Arroyo at least by the fourteenth or fifteenth century, for an ex libris of that time jotted on the last folio (fol. 167) reads Conventus Sci Andree, followed by a monogram usually understood to mean as "Arroyo." It very likely was intended for this convent from its inception, but this does not mean it was carried out at Arroyo. As far as we know, Arroyo, like most other Spanish Cistercian convents, lacked a scriptorium. The issue of its origin is bound up with the thorny question of the Castilian resurgence of the Beatus tradition in the late twelfth and early thirteenth centuries, which also produced the Rylands and Cardeña Commentaries (Nos. 20, 21). The modern collation of the text determined that they, together with Arroyo, are dependent on the same archetype that served the Tábara and Girona copies (Nos. 5, 6) in the tenth century (see Fig. 4). Pictorial elements also link the Arroyo Beatus to these Commentaries, especially to Cardeña.

The prevailing style employs a formal language similar to that of the first illustrator of the Cardeña Beatus, with something of the Byzantine-based manner of its second artist. Even though there is a trace of this dichotomy of styles, Arroyo is marked by a stronger sense of stylistic unity. In some miniatures a vigorous Romanesque style is just beginning to give way to a softer Gothic manner, as on the folio now in the J. Paul Getty Museum (Fig. 79). This is most obvious in folios $93^{\mathrm{v}}-102^{\mathrm{v}}$, where the style of a second hand is accompanied by the introduction of blond angels, and color becomes more emphatic.

The question of the date of Arroyo's copy, often located around 1200, was reopened when Elena Ruiz Larrea focused on the rope garrote around the neck of the outer figure on the right side of the bottom row of figures in the illustration of the Sealing of the Elect $\left(\right.$ fol. $\left.79^{v}\right)$. She argued that it must be the early Christian martyr St. Beatrice, who was strangled, and she linked the presence of the martyr to the marriage of Fernando III of Castile and Beatrice of Swabia, daughter of the German emperor, in 1219. It is an attractive thesis, but the probability that the figure identified as St. Beatrice by Ruiz Larrea is in fact masculine does not allow it, even if the dates and larger hypothesis are reasonable. 
Figure 79 Victory of the Lamb over the Kings (Apoc. XVII, 14-18). Arroyo Beatus. Los Angeles, Getty Center (formerly B.H. Breslauer Coll.)

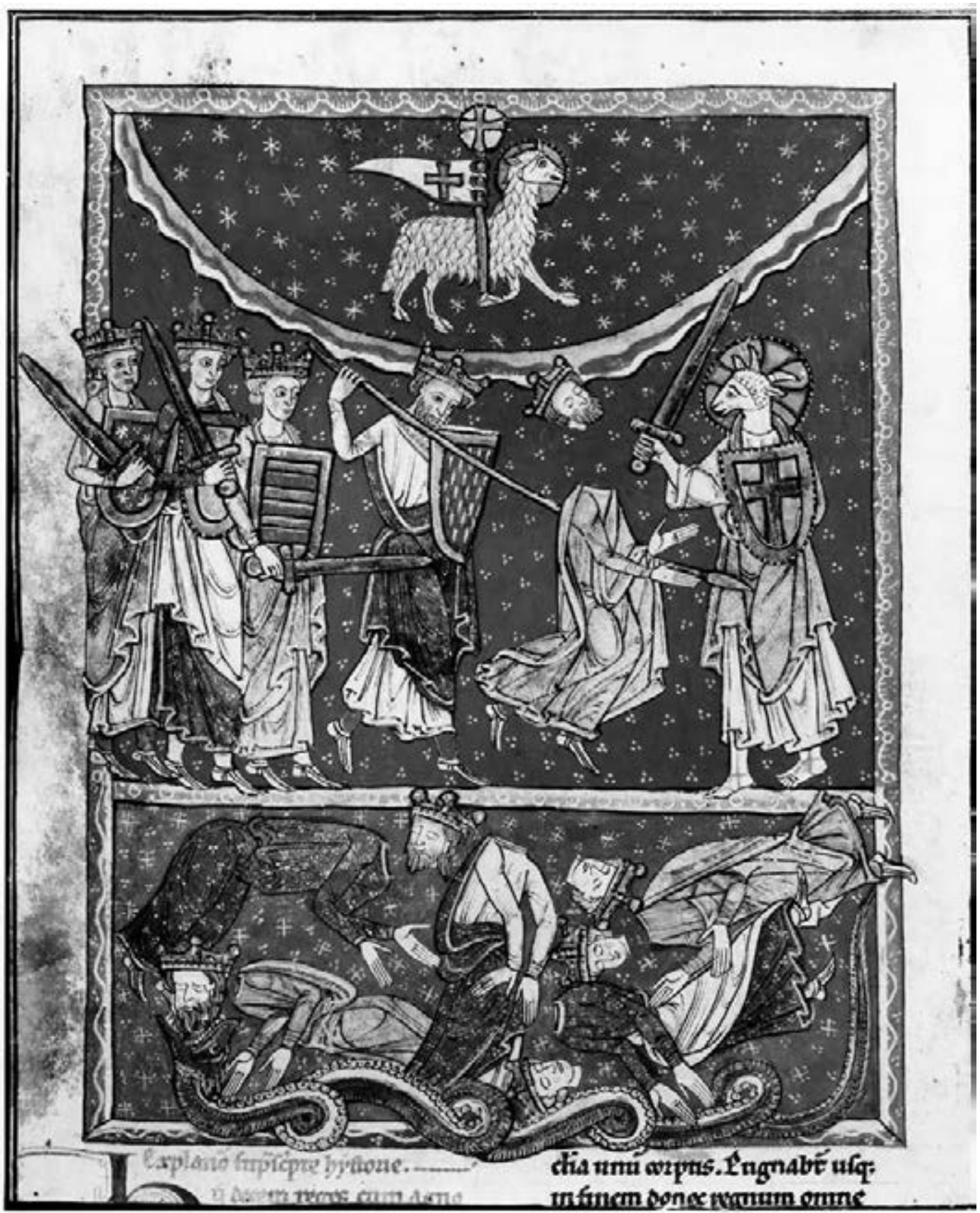

Photo: John Williams 
Figure 80 Last Judgment (Apoc. XX, 11-15). Arroyo Beatus, fol. 160. Paris, Bibliothèque nationale de France, Nouv. acq. lat. 2290

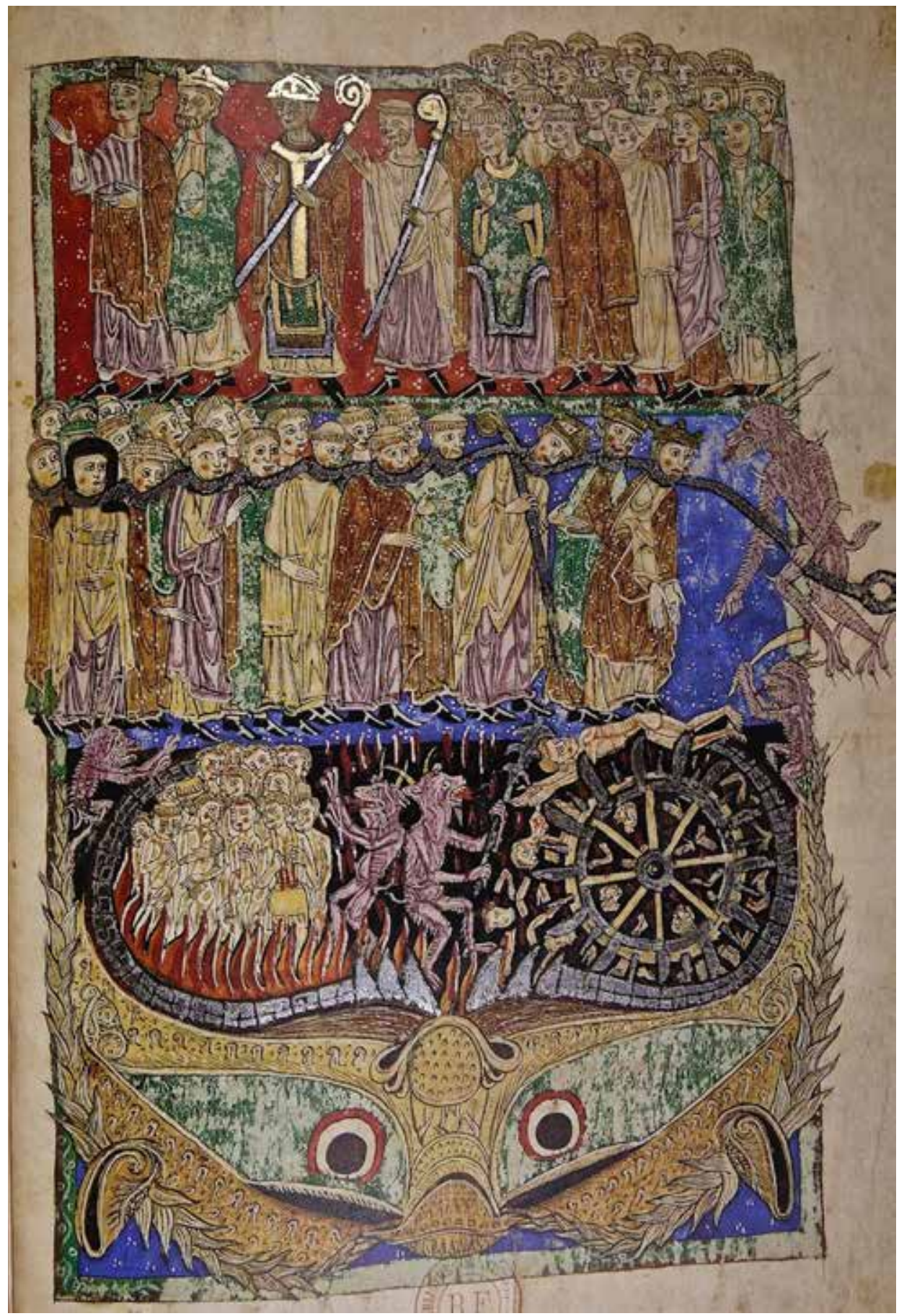

Photo: John Williams 
Fernando and Beatrice were married on the feast of St. Andrew the Apostle, titular saint of the convent of Arroyo, and this coincidence might tie the Arroyo Beatus to that event. Royal sponsorship could also explain the tendency to introduce courtly figures in the illustrations. Thus, the musicians of the Lamb on Mount Sion (fol. 126) wear crowns. More significantly, a king is isolated before all others as a worshipper in the illustration of Christ's Appearance in the Clouds (fol. 3). However, the almost total lack of stylistic similarity between the Las Huelgas copy of 1220 (No. 24), surely a product of the royal house's patronage, and that of Arroyo, together with the "advanced" iconographies such as the Last Judgment, make a somewhat later date for Arroyo more reasonable.

Royal French models would explain the upto-date reinterpretation of the Last Judgment (Fig. 80). Thus the damned include persons of high ecclesiastical and secular rank led by a rope held by a demon, and Hell is a great open beast's mouth. The bestial mouth of Hell waiting to receive sinners has its best counterpart in a French Psalter (Paris, Bibl. Arsenal MS 1086) made for Blanca, daughter of Alfonso VIII of Castile and Leonor Plantagenet, the founders of Las Huelgas. Blanca is better known as Blanche, whose wedding to Louis VIII of France took place in 1200 . Communication between French and Castilian manuscript centers is not surprising. The Hell-mouth iconography was hot off the presses, so to speak, for the Psalter is usually dated no earlier than the second quarter of the thirteenth century, the date of our Commentary. Indeed, the great wheel that adds to the tortures suffered by the damned in the Arroyo Last Judgment cannot be found among surviving French manuscripts from such an early date.

Williams 2003a, 43-47; Yarza 1998a, 274ff.; Bernis 1998; Miranda, C. 1998a, 1998b; Ocón
1998; Ruiz Larrea 1998; Vivancos 1998; Yarza 1998b, 404-05.

\section{The Rioseco Fragment}

Ciudad de México, Archivo General de la Nación, Illustración $485^{2}$

1 fol. + fragment, $19.3 \times 12.2$ in. ( $490 \times 310 \mathrm{~mm})$

First half of the thirteenth century

Origin: Castile?

This single folio plus a part of another was removed from a Beatus Commentary and sent from Medina de Rioseco in the province of Valladolid to Mexico as a cover for an expediente de limpieza de sangre requested in 1559 by the Inquisition. By chance both pieces were illustrated. The complete folio contains a miniature of the Millennial Judges (Fig. 81), while the fragment sewn to it preserves the left side of an illustration of the Angel Standing in the Sun (Apoc. XIX, 17-18).

The figures are simply drawn in black ink with a sureness that indicates an experienced hand, but it was a less ambitiously conceived copy, for color is restricted to the red of two small initials and the miniature frames, and a pale yellow in the halo and book. This illustration of the Millennial Judges is unique in having only a single row of doves to symbolize the souls, but its most unusual feature is the recurring pattern of radiating beams apparently attached to the thrones of four of the judges. This detail connects it to the same scene in the Arroyo Beatus (No. 25, fol. 156). There, however, the beams are curved in a way that suggests they make up a kind of faldstool. Still another detail recalls the Arroyo Beatus: the lower part of the figure of Christ is posed frontally, while the torso is seen in a three-quarter view.

The text of the Rioseco fragment also links it to the Arroyo Beatus (Gryson). Like San Andrés de Arroyo, Medina de Rioseco, founded around 1132, 
Figure 81 Millennial Judges and the Souls of the Martyrs (Apoc. XX, 4-6). Rioseco Fragment. Ciudad de México, Archivo General de la Nación, Illustración 4852

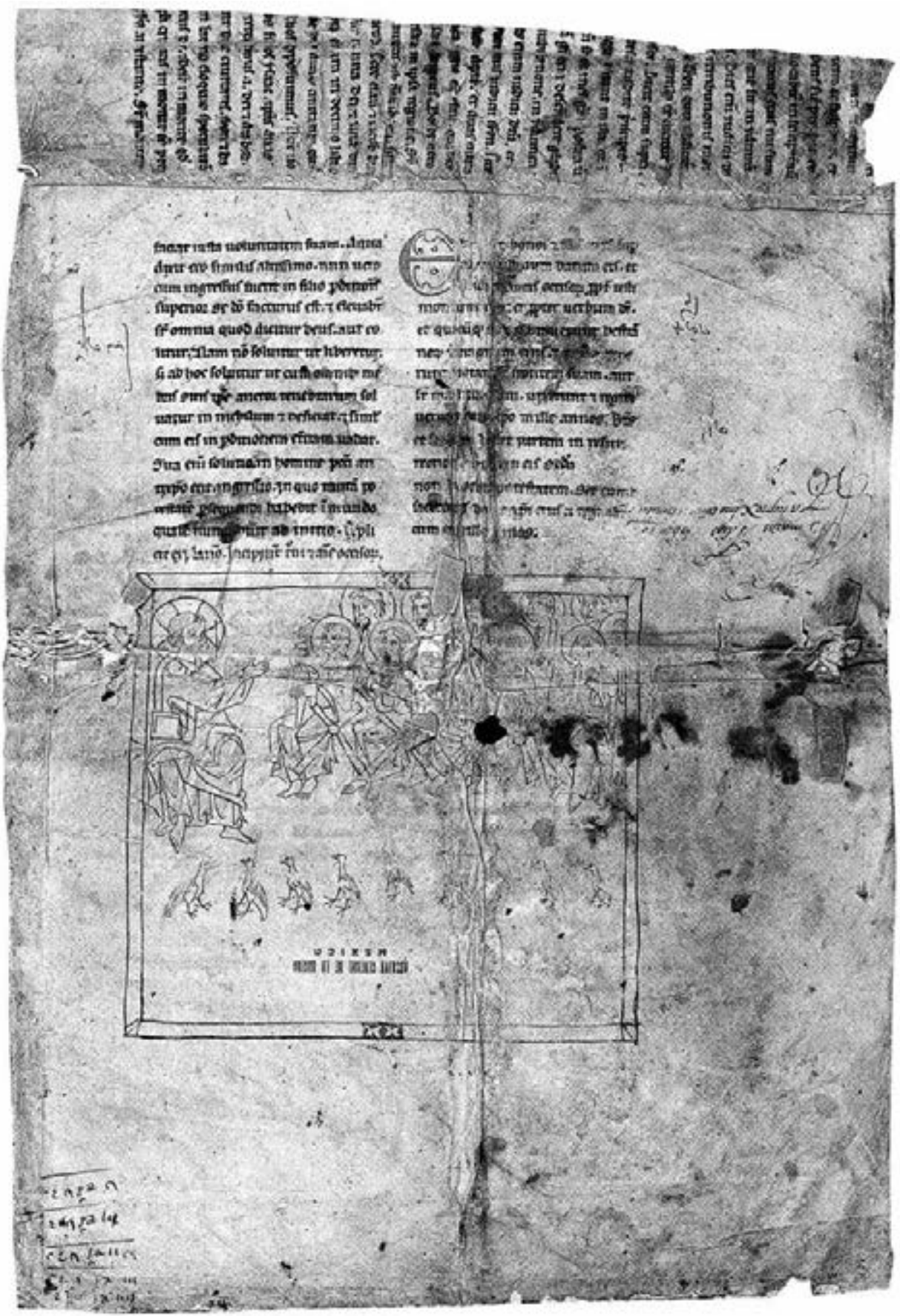

Photo: John Williams 
was Cistercian. A comparable date in the first half of the thirteenth century seems reasonable.

Williams 2003a, 48-49; Yarza 1998a, 304f.; Suárez González 2009, 79-83; Gryson 2012, LXIII.

\section{The San Pedro de León Fragment}

León, Archivo Parroquial de Santa Marina la Real de León, sig. ASM (SP),

Libro de Difuntos, 4

2 fragments, $4 \times 1.8$ in. (100 x $45 \mathrm{~mm})$ and $5 \times 2$

in. $(130 \times 50 \mathrm{~mm})$

c. 1000

Origin: Kingdom of León (?)

These fragments, found in 1998, were sewn as reinforcements onto a leaf from a choir book of the sixteenth century that served to protect a register of the deceased in the years 1638-1732 from the parish of San Pedro de León. San Pedro was a dependency first of the Real Colegiata de San Isidoro de León, and, after 1782, of Santa Marina la Real in the same city. The script has been assigned to the late tenth or early eleventh century. All that survives of the illustration, on folio $1^{\mathrm{v}}$, is the peaked upper part of a gable (Fig. 82). Against the yellow ground applied to it stands a bluish-green bird with folded wings, which holds a green sprig in its beak. The uppermost part of a rounded arch appears just below its feet. The delicate rendering ascribes a surprising priority to draftsmanship over color for a Leonese monument of the end of the tenth century.

As for its subject, the text on the verso locates it toward the conclusion of Book II, in the explanatio of the message to the church of Laodicea. This gable would correspond to the arcades that framed depictions of John and the Angel in Branch I Commentaries. The sprig carried by the dove may be explained by the fact that the Message to Laodicea is followed by Gregory of Elvira's treatise on the Ark, where Noah and the Ark symbolize Christ and the Church, and the seven souls that were saved with Noah represent the Seven Churches that were the subject of Book II. It inspired a rendering of the Ark of Noah in the Commentaries of

\section{Figure 82 San Pedro de León Fragment, fol. 1v. León, Archivo Parroquial de Santa Marina la Real de León,} sig. ASM (SP), Libro de Difuntos, 4

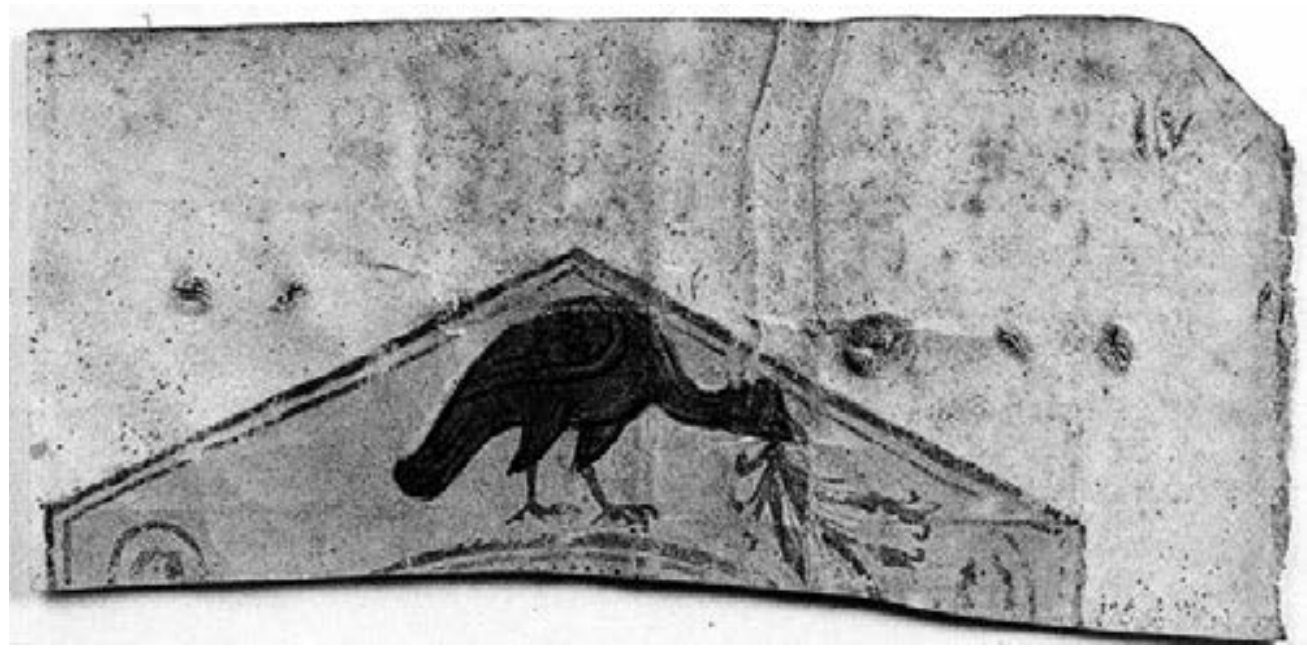

Photo: John Williams 
Branch II. Moreover, the fact that the gable belonged to an arcade rather than a church aligns it with the formulas employed for the Churches of Asia in the Branch I Commentaries. The text nevertheless belongs to Branch II, the recension of $c .940$ (Gryson). Thus it should have been followed by a rendering of Noah's Ark, but it was not. In its place, the dove with the sprig invokes the Flood and Gregory's treatise.

The San Pedro de León fragment joins the Vitrina 14-1 Commentary (No.3), which it would have resembled in size, the León fragment (No. 18), and the unillustrated fragment from San Pedro de las Dueñas (Williams 2002) in revealing that the Kingdom of León, so identified with the pictorially reformed Branch II Commentaries, also had an important stratum of Commentaries containing the earlier recension of the text. We are ignorant of the precise origin of the San Pedro fragment.

Williams 2003a, 50-51; Williams 2002; Suárez González 2009, 66-69; Williams 2009, 107-09; Gryson 2012, LXII.

\section{The Milan Fragment}

Milan, Archivio di Stato, Rubriche notarili 3823

2 fragments

Mid-eleventh century

Southern Italy

These recently discovered fragments, which serve as reinforcements for the binding of a volume of notarial records of the sixteenth century, include on folio $2^{\mathrm{v}}$ an illustration of the Message to the Church of Laodicea (Fig. 83). At the left, an angel in blue hands a book to John. Both the wings of the angel and the book have traces of gold. It is unframed and inserted in the column of text, the original format of the Beatus tradition. This format and the extravagant use of gold is the hallmark of another Italian copy of the mid-eleventh century, the Geneva Beatus (No. 29). Moreover, this text is Beneventan, as is part of the text in the Geneva Beatus. Although the script and illustration of the fragment are by different hands, these two copies display a notable similarity. Whether or not the text of the fragment is related has yet to be determined. One difference is evident: for

Figure 83 Message to the Church of Laodicea. Milan Fragment, fol. $2^{v}$. Milan, Archivio di Stato, Rubriche notarili 3823

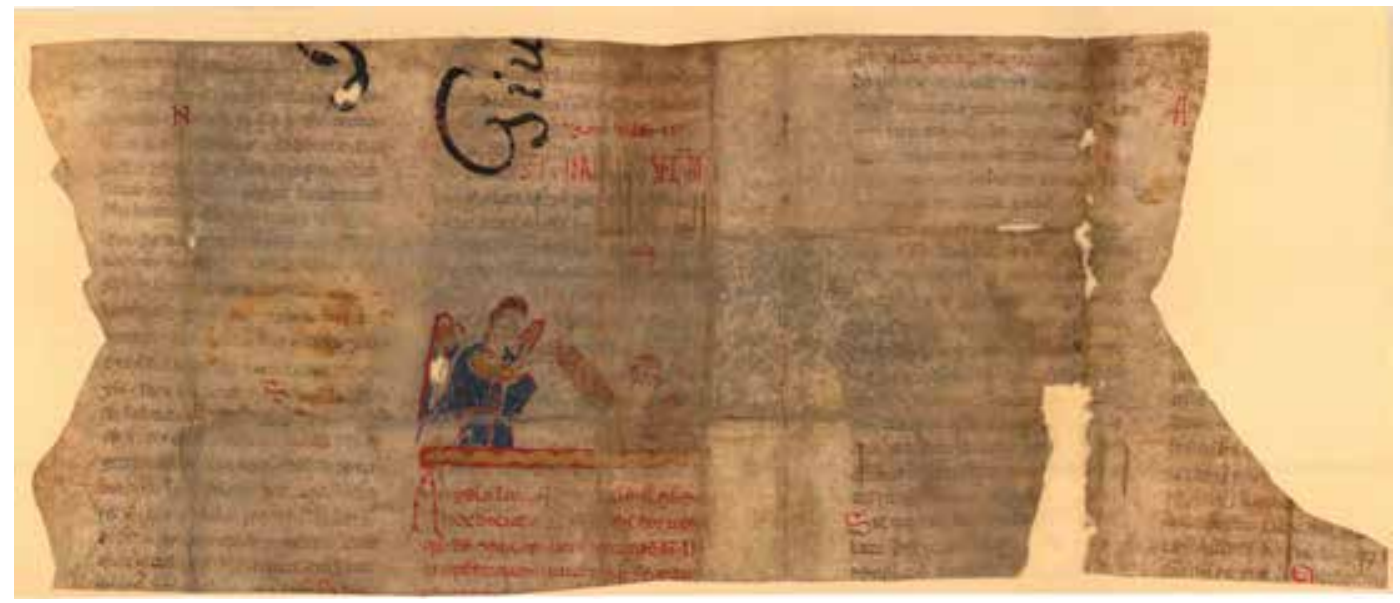

Photo: John Williams 
some reason the storia in the fragment was not included beyond the incipit.

Brown 2012, XIII, 181, 342; Reynolds 2012, 37-38.

\section{The Geneva Beatus}

Geneva, Bibliothèque de Genève, MS lat. 357

97 fols. [of 245], $9.8 \times 6$ in. ( $250 \times 160 \mathrm{~mm})$

Mid-eleventh century

Southern Italy
Judging by both writing and illustrations, the Geneva Beatus was produced around the middle of the eleventh century. The combination of Caroline and Beneventan scripts points to an origin in the south of Italy. The text is identifiable with the earlier branch of the family tree (see Fig. 4), and is most proximate to the copies apparently made at the Riojan monastery of San Millán de la Cogolla, even sharing, according to Gryson, a common model with the Escorial Beatus (No. 10).

Figure 84 The Opening of the First Four Seals: The Four Horsemen (Apoc. VI, 1-8). Geneva Beatus, fol. 183 ${ }^{v}$. Bibliothèque de Genève, MS lat. 357

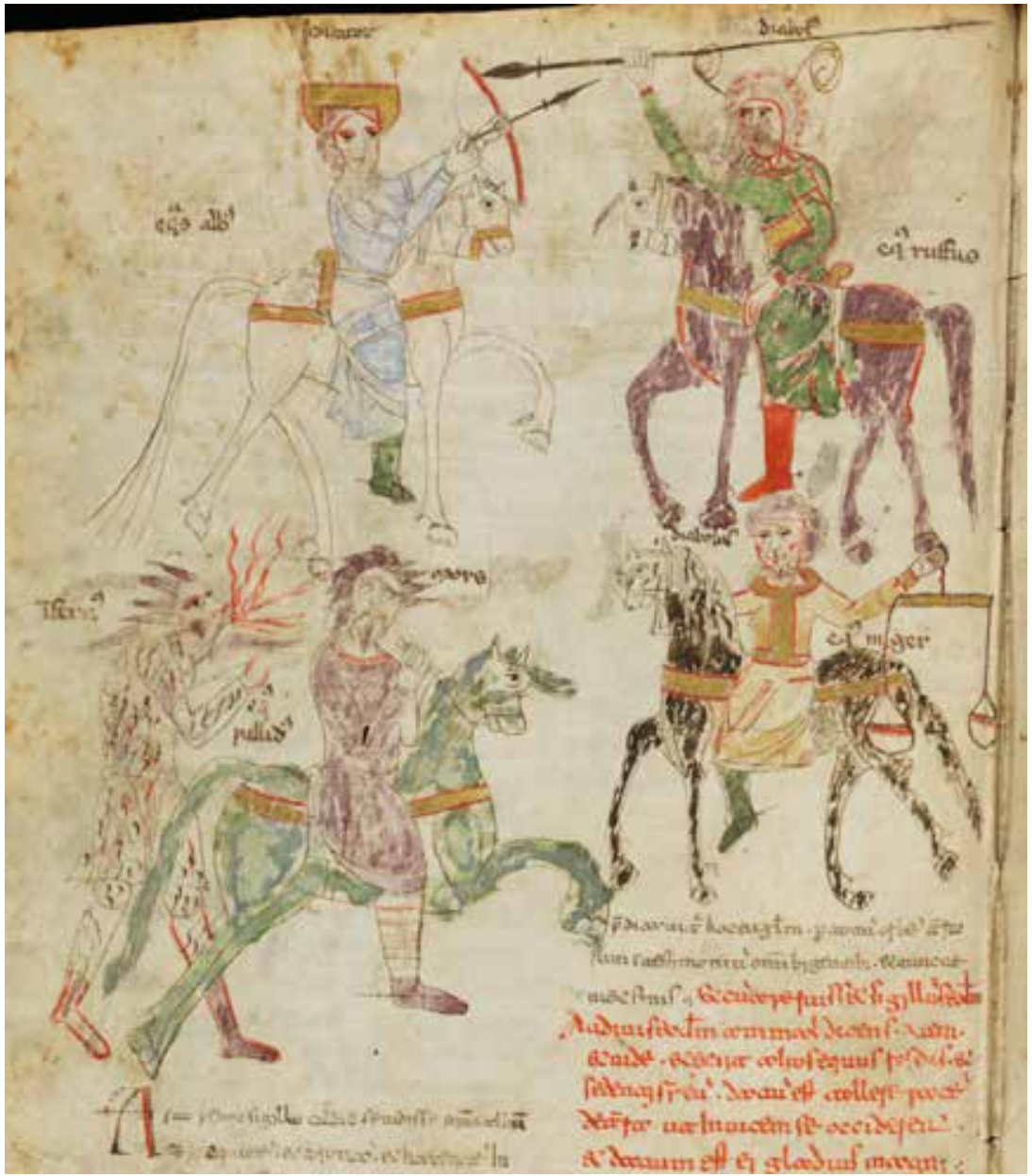


As a copy of a manuscript representing the pre-reformation stage of the pictorial format, the illustrations are inserted in the columns of text, a restrictive format that the miniaturist violated often, not by creating full-page pictures, but by expanding them into the next column. To a remarkable degree the relationship between text and picture shows that the illustration preceded the writing of the text. In the depiction of the Four Horsemen (Fig. 84, detail; see Fig. 119), the illuminator began with the rider on the white horse, for the generous space appropriated meant there was relatively less room for the figures on the right side. The four horses are not only rendered in the colors assigned them by the Apocalyptic text, but also labeled as to color as well, with the paint applied somewhat hastily. Although the rider of the red horse was described in the storia as bearing a large sword, in this illustration he instead challenges the rider of the white horse with a spear. He is also provided with a name, Devil (diabolus), not mentioned in the storia, but applied to him in the explanatio. The figure in the lower left, Death (mors), rides a pale green horse and is followed by a personification of Hell (infernus). Appropriately, he is covered with flames, and fire issues from his mouth.

In the post-medieval readings of the Apocalypse, all four horsemen were agents of devastation, as may be seen in Albrecht Dürer's powerful woodcut of charging riders. However, in Beatus's explanatio, following in this instance St. Jerome's edition of the Commentary on the Apocalypse by Victorinus of Pettau (d. c. 303), the first rider is an allegorical figure representing the preachers of the faith. His white horse and arrow symbolize the words of his message, and his crown is a gift of the Holy Spirit. The integral nature of text and picture might suggest that illustrator and writer were one, although the presence of more than one painter and more than one scribe does not allow this to be entirely the case.

Although it is clear that the illustrations were generally based on the Spanish model unlike another Italian copy, the Berlin Beatus (No. 19) - the compositions are frequently idiosyncratic. Nowhere is this more evident than in the illustration of the Opening of the Sixth Seal: The Earthquake (Fig. 85, detail; see Fig. 121). According to the Commentary, the sun and the moon represent the Church, within which are both the wise and the ignorant that is, heretics, schismatics, and hypocrites. The stars that fall are the faithful, some true, some false; they will find themselves distressed by the coming of the Antichrist, who will be accompanied by an earthquake. As for the mountains, they signify refuge, for they are the apostles, and it is to them that the kings and the powerful - that is, the saints who refuse to submit their necks to the swords of the impious - flee for protection. Beyond the fact that the sun is darkened and the moon is red, the picture scarcely reflects the contents of the storia. Moreover, this illustration differs markedly from the two surviving Branch I versions in the Beatus of Burgo de Osma (fol. 89) and the Lorvão Beatus (fol. 115). The failure to find significant parallels in the interpretation of the Opening of the Sixth Seal must mean that either there was no illustration of this scene in the model used for the Geneva Beatus, or, more likely, the illustrator of the Geneva Beatus chose for some reason to reinvent the scene. In the storia the kings and the other "saints" hide themselves in the caves and in the rocks of the mountains. In the illustration, the arcades that the kings approach clearly denote architecture, but the inscription between the columns reads, "where kings and magistrates and tribunes hide themselves in caves" (ubireges et magistratus et tribune absconderunt se in speluncis). 
Figure 85 The Opening of the Sixth Seal: The Earthquake (Apoc. VI, 12-17). Geneva Beatus, fol. 187. Bibliothèque de Genève, MS lat. 357

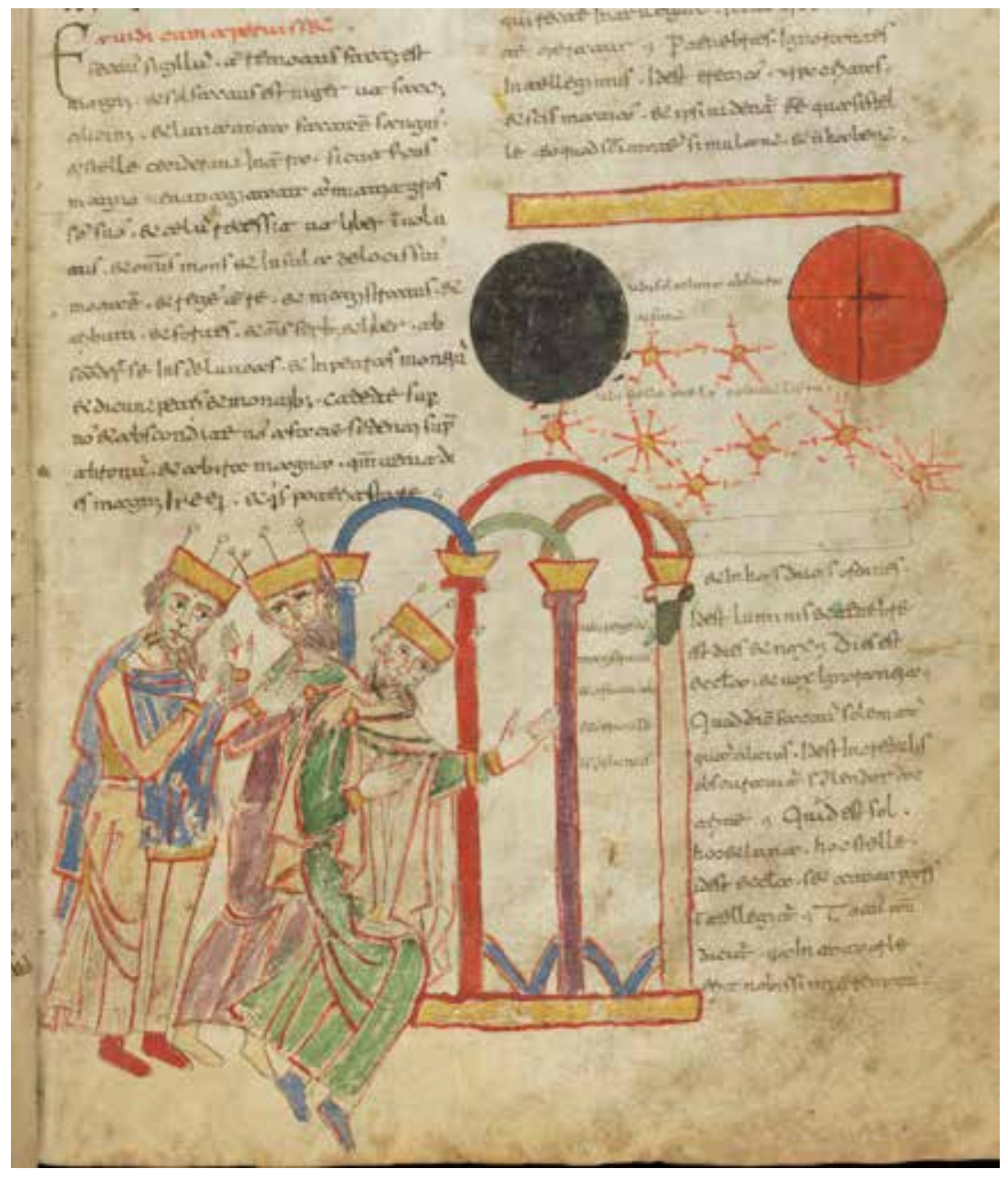

One must assume that this was not the first time this skilled draftsman undertook an artistic project. Color, however, was utilized in a surprisingly undisciplined, not to say haphazard, way. Not only does the pigment fail to follow closely the lines of the drawing, but it is often applied capriciously, as in the mauve and green that decorates the sensitively drawn head of the angel on folio $207^{\mathrm{v}}$ (see Fig. 136). Despite an extravagant use of gold, unparalleled in the history of Beatus manuscripts, which might imply a well-endowed scriptorium or patron of high rank, the impression of a provincial product persists. Was the copy originally conceived as one with uncolored drawings? The best-known Italian scriptorium of the time for its production of illustrated manuscripts, Monte Cassino, sometimes produced comparably imperfect combinations of line and color (see Figs. 99-101). However, there is no clear evidence that the Geneva Beatus originated there. 
Further, the Geneva copy complicates the accepted view of the pictorial evolution of the Commentary. Its text is closest to that of manuscripts originating at San Millán de la Cogolla, namely the Escorial and San Millán Commentaries (Nos. 10, 9). Both of these are lacking certain illustrations, reducing the possibility of comparison. Even so, the numerous coincidences detailed by Klein between compositions in the Geneva Beatus and the Lorvão copy (No. 22), from another sub-branch of the family tree, confirm an unexpected relationship between the scriptorium at San Millán and one further west, perhaps Sahagún.

Dubuis and Jeger 2009; Gryson 2012, LVIII-LXI; Reynolds 2012; Klein 2013, 2014; Gryson 2015; Shailor 2015; Williams 2015. 


\section{Introduction to the Geneva Beatus}

The Geneva Beatus Commentary on the Apocalypse came to light late in 2007, when the manuscript holdings of the Congrégation des Missionnaires de Saint François de Sales (Institut Floriment, Geneva) were given in deposit to the Bibliothèque de Genève. ${ }^{74} \mathrm{At}$ some point, probably in the fourteenth or fifteenth century, ${ }^{75}$ the Commentary had been bound together in a single codex with Priscian's Institutiones grammaticae (fols. 1-148v; the Beatus Commentary comprises folios $\left.149-245^{v}\right)$.

\section{Location in the Family Tree of Copies}

What position within the family tree (see Fig. 4) did the model for the Geneva Beatus occupy? As discussed in the opening essay to this volume, there are two basic branches. Branch I, the closest to the original textually, is represented by manuscripts dated between the tenth and the late twelfth centuries. Those copies that preserve an earlier state of the text employ a simpler format in which the illustrations were inserted in the columns of text, unframed, and with backgrounds that have been left unpainted (see Figs. 91-92). Some of the Branch I manuscripts offer clues to the iconography and format of the original Beatus Commentary, while others have undergone changes over time. The text of the Geneva copy points in one direction, as demonstrated by Roger Gryson's study: it is closest to the Branch I Commentaries dependent on the revision of

74 Dubuis and Jeger 2009. The complete manuscript is now available online: http://www.e-codices.unifr.ch/ en/bge/lato357/149r/o/Sequence-137

75 Shailor 2015. the first edition, represented by the Beatus in the Escorial (No. 10) and the San Millán Commentary now in Madrid at the Real Academia de la Historia (No. 9)..$^{7}$ Both of these are from the second half of the tenth century and both are likely to have been made at the monastery of San Millán de la Cogolla. One assumes that Geneva's model, a manuscript of the tenth or early part of the eleventh century, was also from there. It was an important center for the reproduction of the Commentary for two centuries, and the Geneva copy has the virtue of contributing, and calling further attention, to the importance of this Riojan scriptorium. ${ }^{77}$

The virtually complete set of illustrations in the Geneva Beatus potentially promised to enhance our knowledge of the character of that part of Branch I. Unfortunately, as we shall see, that expectation is difficult to realize when a comparison is made with the other Branch I copies, as even in the most densely illustrated - the Escorial Beatus - there are many gaps in the series of illustrations. In fact, intact copies belonging to this branch of the stemma are rare, reducing the chances for comparisons between illustrations. While not part of the sub-branch to which the Escorial Beatus belongs, other Branch I examples help fill out our knowledge of the composition of the illustrations, as presented below.

Although it is not an illustration per se, one page integral to the Beatus tradition offers in its design and general structure a non-textual, diagrammatic measure of relationships between Geneva and the Branch I copies. It represents the Antichrist Tables, where numerical values were assigned to

76 Gryson 2012, LVIII-LXI.

77 Díaz y Díaz 1979, $111 f$. 
Figure 86 Numbering of the Names of the Antichrist: Table I. Vitrina 14-1 Beatus, fol. 121\%. Madrid, Biblioteca Nacional de España, MS Vitrina 14-1

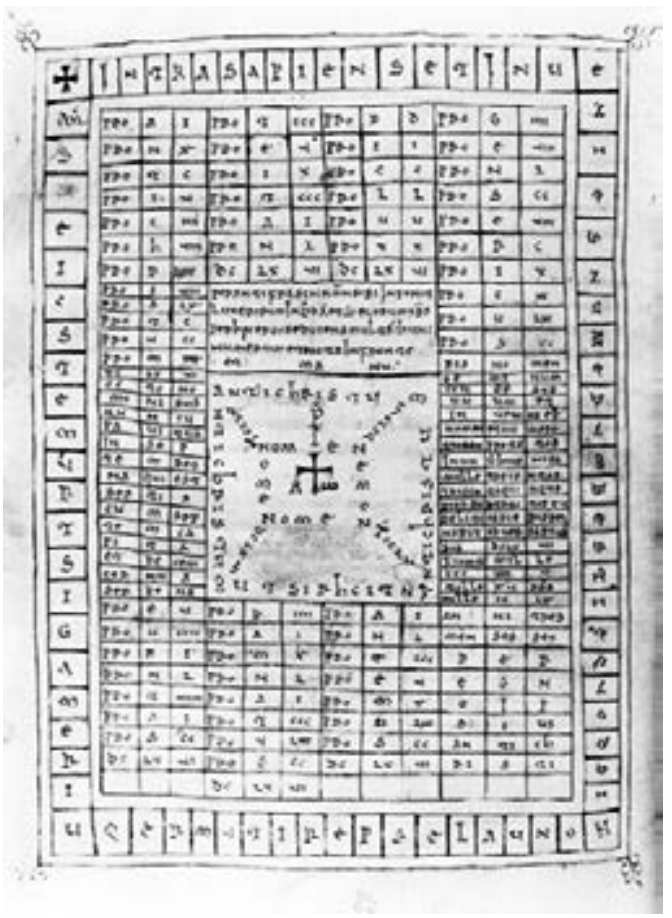

Photo: John Williams

the letters of the alphabet, Greek and Latin, in order to calculate the names of the Antichrist. Only the first of the two diagrams was included in the Geneva Beatus (see Fig. 141). A comparison of the six Branch I Commentaries that include Table I shows that the closest in design are the tables in Vitrina 14-1 (Fig. 86; No. 3) from the first half of the tenth century, and even more so those in the $c .1000$ Escorial copy for omitting the small cross as well as the monogram of Christ poised above the cross (Fig. 87; No. 10). These features of the scheme in Vitrina 14-1 are details shared with the later

\section{Figure 87 Numbering of the Names of the Antichrist: Table I. Escorial Beatus, fol. 115. Escorial, Biblioteca del Monasterio, \&.II.5}

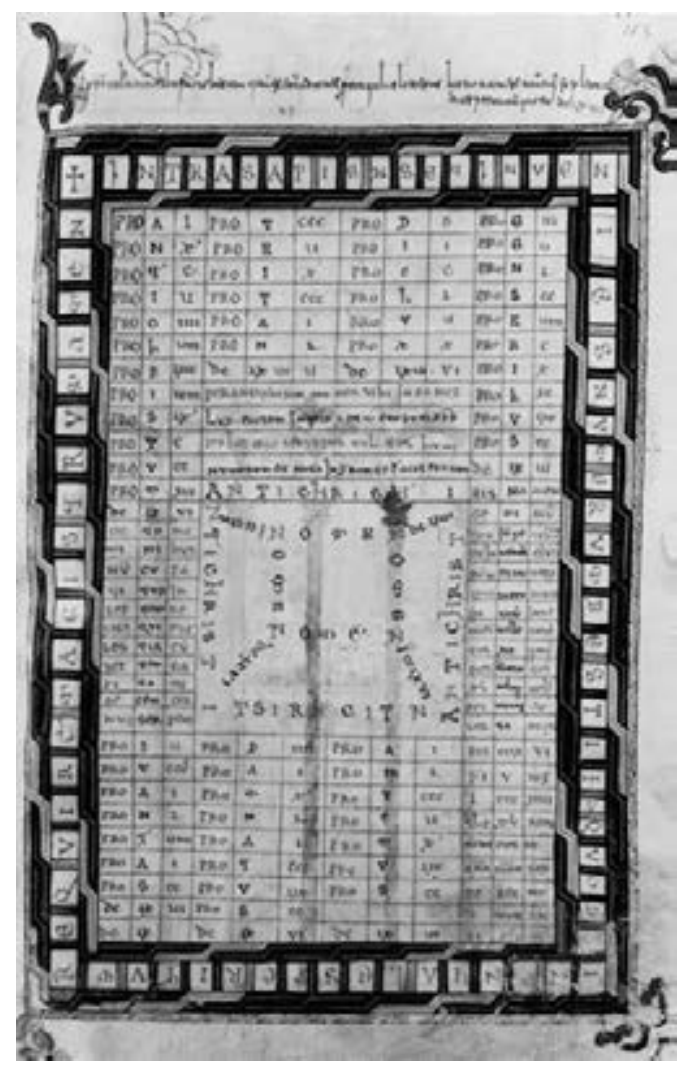

Photo: John Williams

copy of Branch I now in Paris (No. 23, fol. 114 v).$^{7^{8}}$ However, because Vitrina 14-1 has lost most of its illustrations, it is of little help in establishing a pictorial relationship to the Geneva Beatus. Its text, moreover, differs from that shared by the copies closest to Geneva. Since the San Millán Commentary (No. 9) was illustrated in the Branch I tradition only up to Apocalypse IV, $6-\mathrm{V}, 14$, it, too, is of limited help. Its illustrations chiefly consist of the Messages to the Churches,

78 For the correlation of the Antichrist Tables, see Klein 1976, I: 323-25. 
in which the relative positions of John and the Angel coincide with Geneva more often than not. However, San Millán's depiction of the Vision of God and the Four Living Creatures (see Fig. 48) bears very little resemblance to that in Geneva (see Fig. 118).

In sum, in the case of the non-pictorial components, namely the text and the Antichrist Table, there is a concrete signal that the model belonged to the part of the family tree that produced copies associated with the monastery of San Millán de la Cogolla. However, the loss of illustrations in the manuscripts connected to this scriptorium, and more importantly, the independent approach to the model on the part of the illustrator of the Geneva Beatus, make it impossible to affirm absolutely that San Millán produced the model eventually copied in southern Italy.

To determine the relationship of the pictures in the Geneva copy to its branch of the family tree, we must take into account the instances among the illustrations of the Geneva Beatus that differ significantly from the Escorial Commentary (No. 10), the best preserved but still incomplete copy with the textual recension closest to Geneva. This is certainly the case with the illustrations of the Seventh Angel Emptying His Bowl (see Fig. 152; Apoc. XVI, 17-21), Satan Released (see Fig. 163; Apoc. XX, 7-8), and others. At the same time, there are as many parallels - actually more, since it is almost intact - between Geneva and the copy executed at Sahagún, now in Burgo de Osma (No. 14), as there are with the Escorial Commentary (No. 10). The idiosyncratic character of the Geneva Beatus may be seen in the illustration of the Devil Chained in the Abyss (see Fig. 162; Apoc. XX, 1-3) when compared to the same scene in the Osma Beatus (Fig. 88) and the Escorial copy (Fig. 89). The last two agree in depicting the nude devil prostrate in debased human form, locked by two bars within a rectangular space at the bottom of the picture. One must conclude that the archetypal conception resembled this one and was passed down through the two distinct families of Branch I. In the Geneva illustration the devil is in the usual symbolic form resembling a bird as he emerges from a vertical abyss crisscrossed with wavy lines. The fact that the writing has been adjusted to the abyss and not vice versa shows the originality of the decision concerning the representation of the natures of the Devil and of the abyss, since a composition similar to that in the Osma and Escorial Commentaries would have been possible. Geneva's illustration of the Victory of the Lamb (see Fig. 155; Apoc. XVII, 14-18) also encourages the conclusion that the model being copied belonged to the same branch of the family tree as the Escorial Beatus (No. 10). ${ }^{79}$ Not only is it comparable in content and arrangement to the illustration in the Escorial copy on folio 145 (Fig. 9o), but the inscription (Agnus uincet pseudo prophetas / et draconem et diabolum et bestia) is similar as well (agnus vincet draconem et diabolum et bestia et pseudoprophetam).

As we saw in the introduction to this volume, at least three Commentaries besides the Escorial copy have some claim to an origin at the monastery of San Millán de la Cogolla: the San Millán Beatus of the Real Academia de la Historia, Madrid (No. 9), ${ }^{80}$ Vitrina 14-1 in the Biblioteca Nacional, Madrid (No. 3) ${ }^{81}$ and a copy that survives only as seven pages from a seventeenth-century replica of folios from a Beatus made for the Aragonese monastery of Fanlo (No. 12). ${ }^{82}$ The first three were made in the tenth century; the Fanlo Beatus was commissioned in the middle of the eleventh. The

79 Williams 1998, 29-31.

8o Williams 1998, 21-28; 2005b, 85-134.

81 Williams 1994b, 34-37; Klein 2011b, 33-102.

82 Williams 1994a, no. 12, 41f.; Galtier Martí 2005 a. 
Figure 88 Devil Chained in the Abyss (Apoc. XX, 1-3). Osma Beatus, fol. 153². Burgo de Osma, Cabildo de la Catedral



Photo: John Williams 
Figure 89 Devil Chained in the Abyss (Apoc. XX, 1-3). Escorial Beatus, fol. 151. Escorial, Biblioteca del Monasterio, \&.II.5

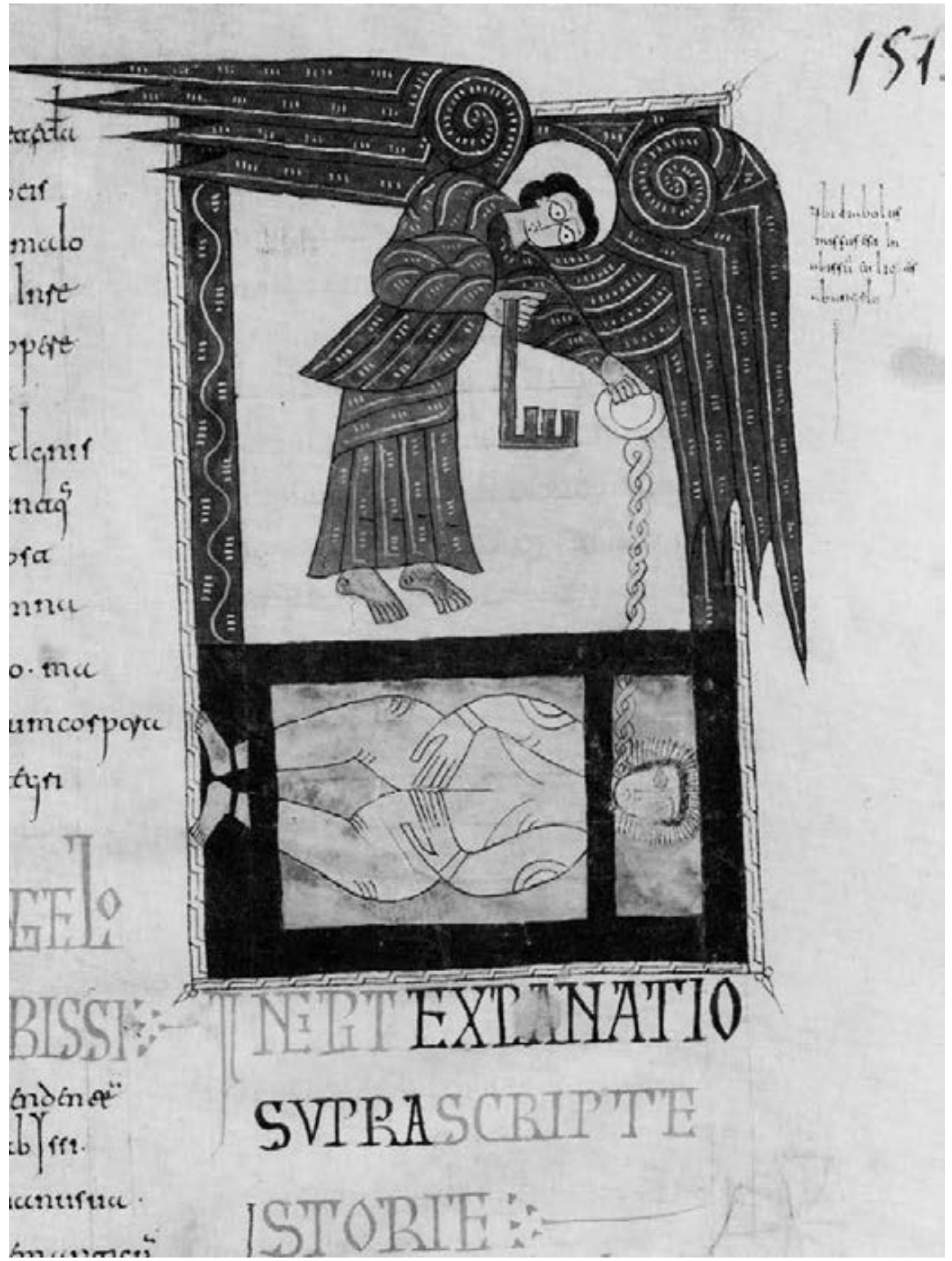

Photo: John Williams 
Figure 90 Victory of the Lamb over the Kings (Apoc. XVII, 14-18). Escorial Beatus, fol. 145. Escorial, Biblioteca del Monasterio, \&.II.5

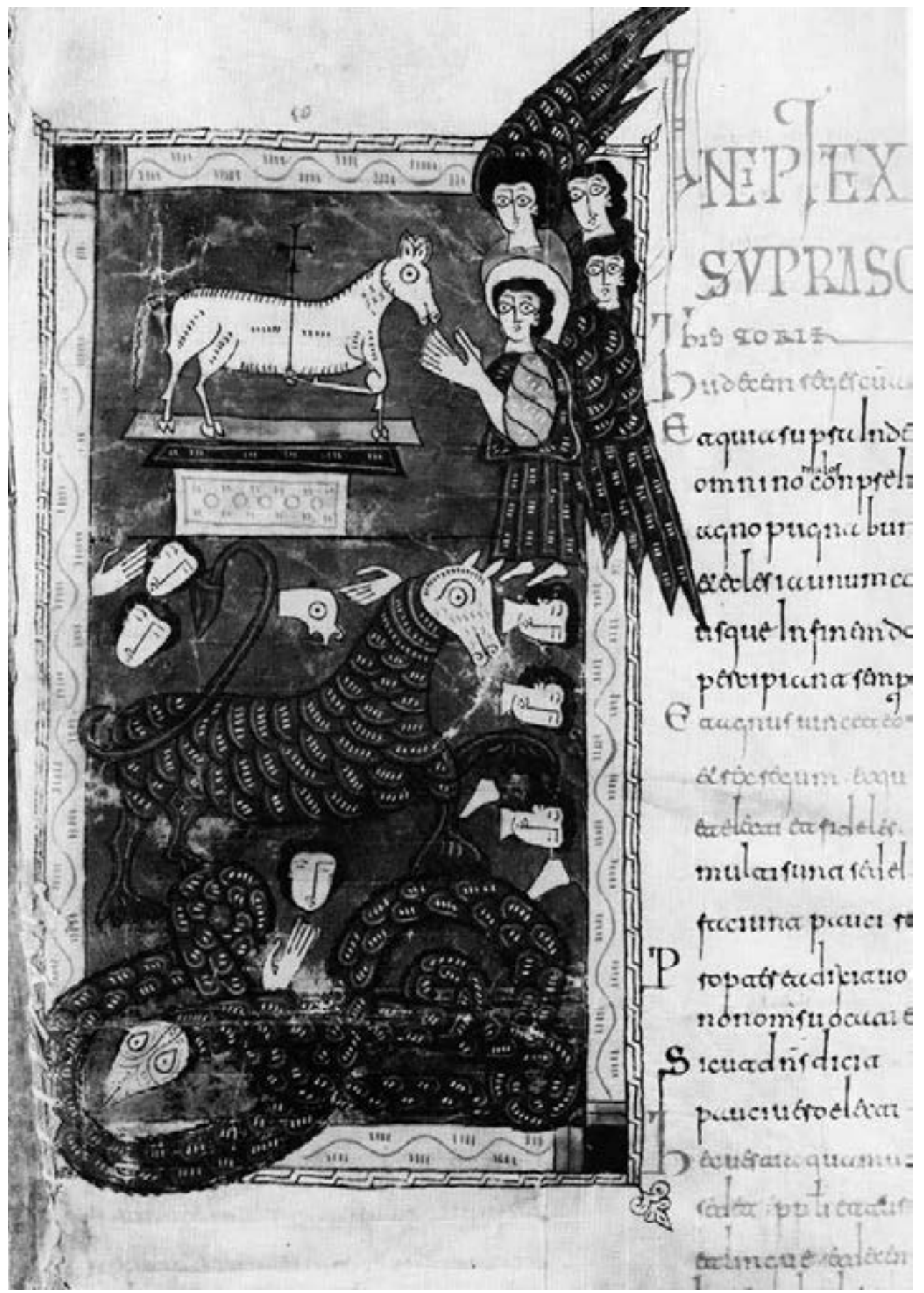

Photo: John Williams 
Figure 91 Letter to the Church of Thyatira (Apoc. II, 18-29). Escorial Beatus, fol. 40v. Escorial, Biblioteca del Monasterio, \&.II.5

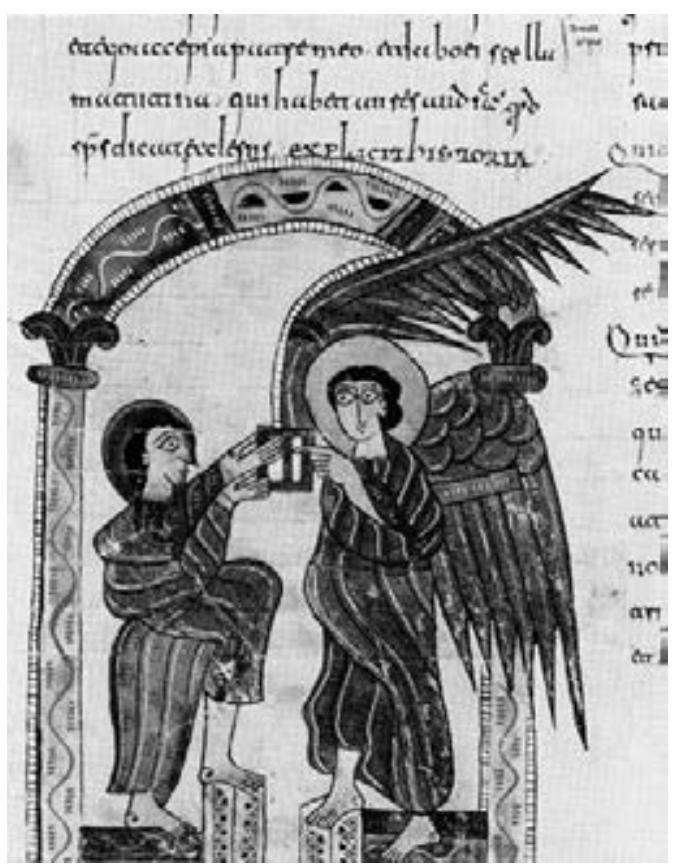

Photo: John Williams

pictorial content of these manuscripts differs to an extreme degree, but they share a disciplined regularity that conforms to the peninsular Beatus tradition. Can the model for the Geneva Beatus be associated with San Millán as well? This possibility is explored below.

When measured against the rest of the tradition, the approach taken to the illustrations in the Geneva Beatus differs in style and technique, as should be expected from a product of a different culture - Italian rather than Iberian. This we see in looking at the Messages to the Seven Churches of Asia. There is a more ambitious pictorial approach in the Spanish versions, a tendency to embellish the simple iconography of John receiving the book from an angel, as seen in the Geneva versions of Thyatira (see Fig. 112) when paired with Escorial (Fig. 91;
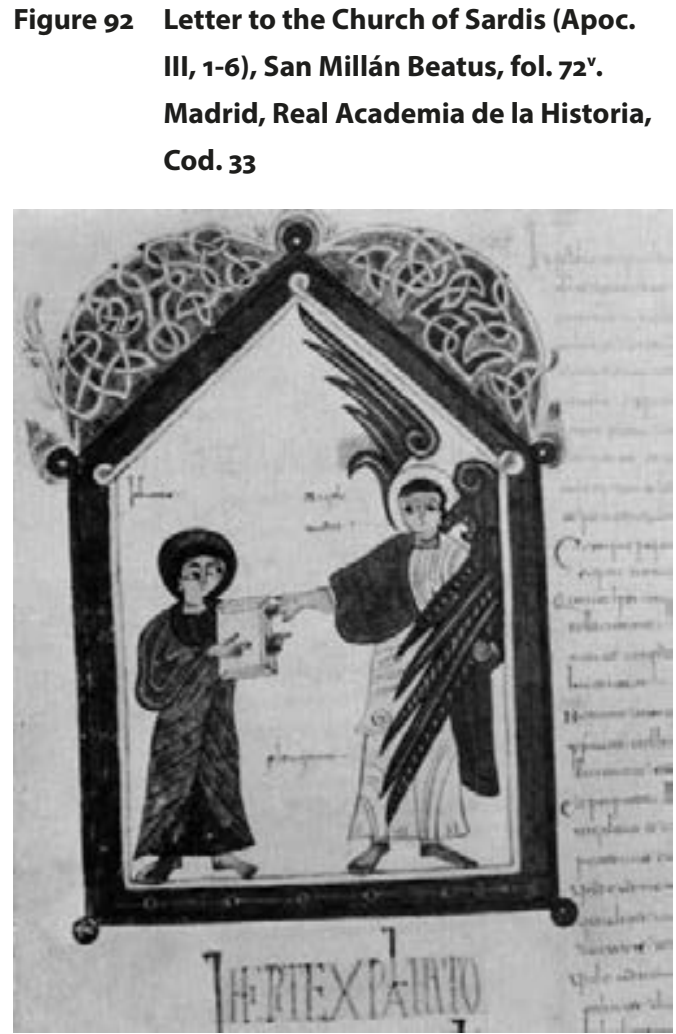

Photo: John Williams

No. 10), and of Sardis (see Fig. 113) compared with the San Millán copy (Fig. 92, No. 9). One might be tempted to attribute this difference to the provincial nature of artistic culture in the tenth and eleventh centuries in the Italian peninsula, or to the highly sophisticated level of ornament in the artistic culture coming from al-Andalus. However, the interlace we see in the San Millán Beatus (as in Fig. 92) is not Islamic but European in origin - Hiberno-Saxon and Carolingian - and influences of that kind were the wellspring that revolutionized the appearance of the Beatus Commentary, as we saw previously.

The Geneva copy differs from the Iberian approach also in its disregard for a regular integration of text and picture. In most cases, the illustration preceded and determined the 
layout of the text. This is apparent even in the least challenging examples, such as the Letters to the Churches (see Figs. 109-115), but it is even more striking in the ambitious illustrations, such as the Four Wind Angels on folio 189 (see Fig. 122) or God with the Four Living Creatures on folio 174 (see Fig. 118). These pages - and most of the rest - would have been bare when taken up by the illustrator, after which the writer was left to fill the remaining space. This sequence - picture or ornate initial followed by text - is unusual within the history of illustrated medieval manuscripts, but not highly so. Here the writing and illustrating are so integrally united that one imagines two possibilities: either scribe and illustrator were the same person, or, seeing as the two types of lettering indicate there was more than a single scribe, that the illustrator was senior and unbound by the rules or expectations of his or her colleagues. Or could the priority given to the illustrations have been due to a lack of experience? After all, we cannot assume that every scriptorium was prepared to produce books with multiple, detailed illustrations. The Geneva procedure was clearly not the one evident in an unfinished Beatus copy made at about the same time in the scriptorium at Sahagún in Spain, where the text was laid out first, leaving spaces for illustrations that were never filled in. ${ }^{83}$ Had the images been inserted, this manuscript would have been a twin of the model being copied, the Beatus of Burgo de Osma (No. 14).

Evidence provided by other Commentaries from the same early branch of the family tree as the Geneva Beatus indicate that, in the model before the eyes of the Italian copyist, the illustrations would have been located in the columns of text without frames or painted backgrounds. ${ }^{84}$ None of the other known copies, however, so

83 Shailor 1992, 45-49; Williams 1992, 21-22; Suárez González 2009, 55f.

84 Williams 1994b, 53-54. routinely transgresses the format of fitting an illustration within the column of text as Geneva. Such irregularity might be forced if a scribe left insufficient space for the illustrator, but here the images clearly had precedence, making such eccentric compositions difficult to explain.

Did Geneva have more than one illustrator? At times, for example in the Letters to the Churches of Philadelphia and Laodicea on folios $165^{\mathrm{V}}$ and 169 (see Figs. 114-115), the final state of figures with color applied seems to vary enough to make more than one artistic hand plausible, but I think that the drawing of these two examples can be attributed to the same individual. The application of color to the drawings, however, need not have been the responsibility of the same illustrator or of only one hand. I hope that future studies of this manuscript will test my conclusion that a single illustrator, but more than one painter, contributed to the Geneva illustrations.

\section{The Model}

Although we do not have the model on which the Commentary now in Geneva is based, its text, as noted, finds its closest match in the Escorial Beatus (No. 10). ${ }^{85}$ Further, the figural style of Escorial has been shown to resemble that in manuscripts executed at San Millán de la Cogolla, the scriptorium that played such a key role in the history of the primitive branch of Beatus Commentaries. It is thus a good possibility that the model for the Geneva Beatus also originated at San Millán. As for the motive behind its arrival at a monastery in southern Italy, we are completely ignorant. It was not the only Spanish Commentary to make the journey: the Beatus now in Berlin (No. 19) was copied in the twelfth century in the south of Italy from a different Spanish model. ${ }^{86}$ Still

85 Williams 1994b, $29 f$.

86 Klein 2010; Gryson 2015. 


\section{Figure 93 Vision of God Enthroned with the Elders. Escorial Beatus, fol. 57v. Escorial, Biblioteca del Monasterio, \&.II.5}

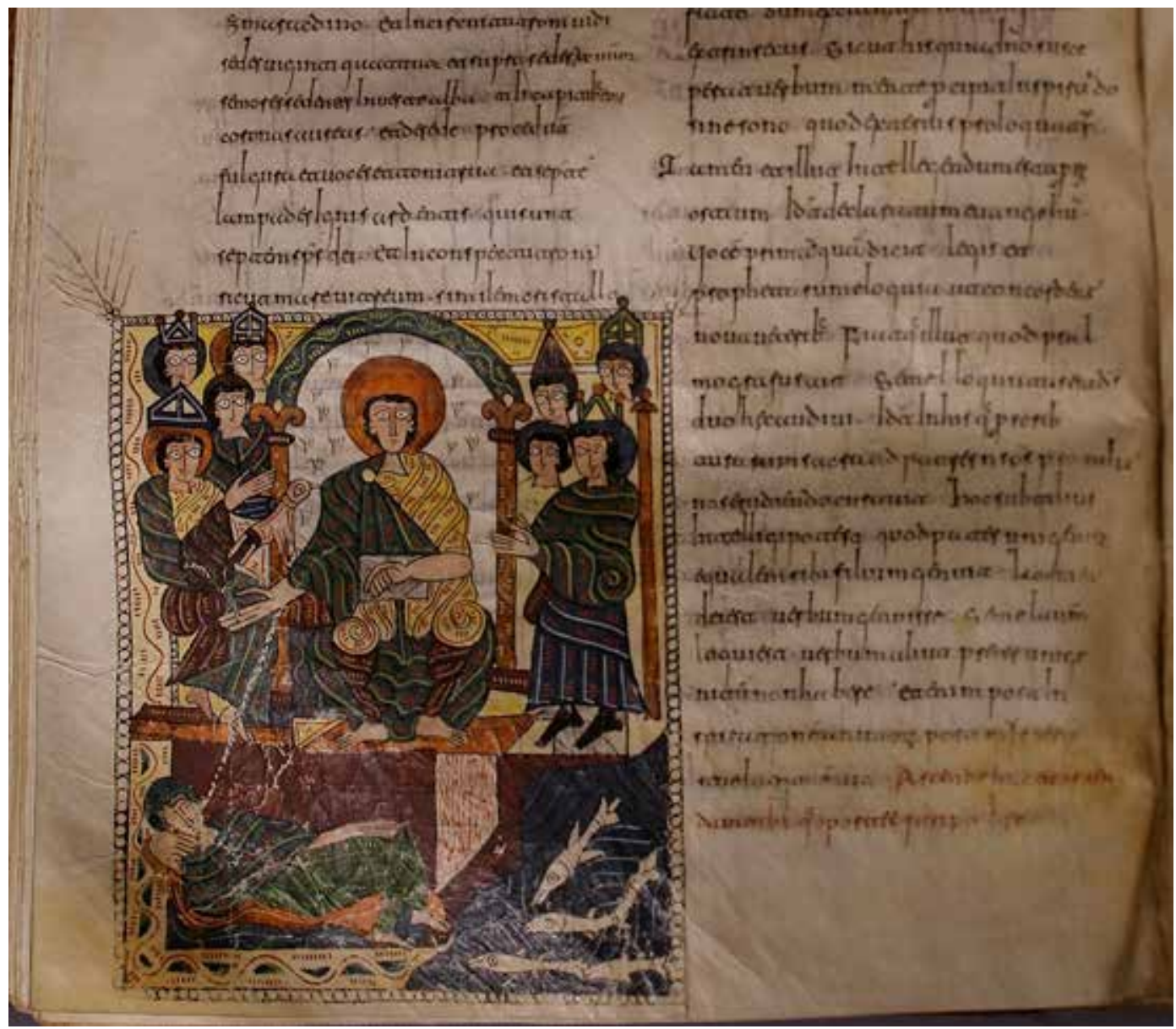

Photo: Hamid Shams

another brilliantly illuminated Spanish manuscript, the ninth-century Bible in the library of the monastery of La Cava dei Tirreni, near Salerno, ${ }^{87}$ has glosses in Beneventan script of the twelfth century. ${ }^{88}$ It may have arrived there earlier; how it arrived is unknown. ${ }^{89}$ The possible

87 Cherubini et al. 2010.

88 Lowe 1972.

89 According to Lowe 1972, 339, Abbot Amelli of La Cava suggested that it was a gift from Mauritius Bordinho, later known as the antipope Gregory VIII, conduits for such transfers have scarcely been assessed; they merit future research..$^{90}$

What does the Geneva Commentary add to our knowledge about the illustrated model from which it was copied? We know rather less about the original iconography than the text

who was bishop of Coimbra and archbishop of Braga as well as a welcome visitor at the abbey of La Cava in the twelfth century.

9o For connections in southern Italy through other texts, see Reynolds 2009 . 
Figure 94 Vision of God Enthroned with the Elders, Osma Beatus, fol. 70v. Burgo de Osma, Cabildo de la Catedral

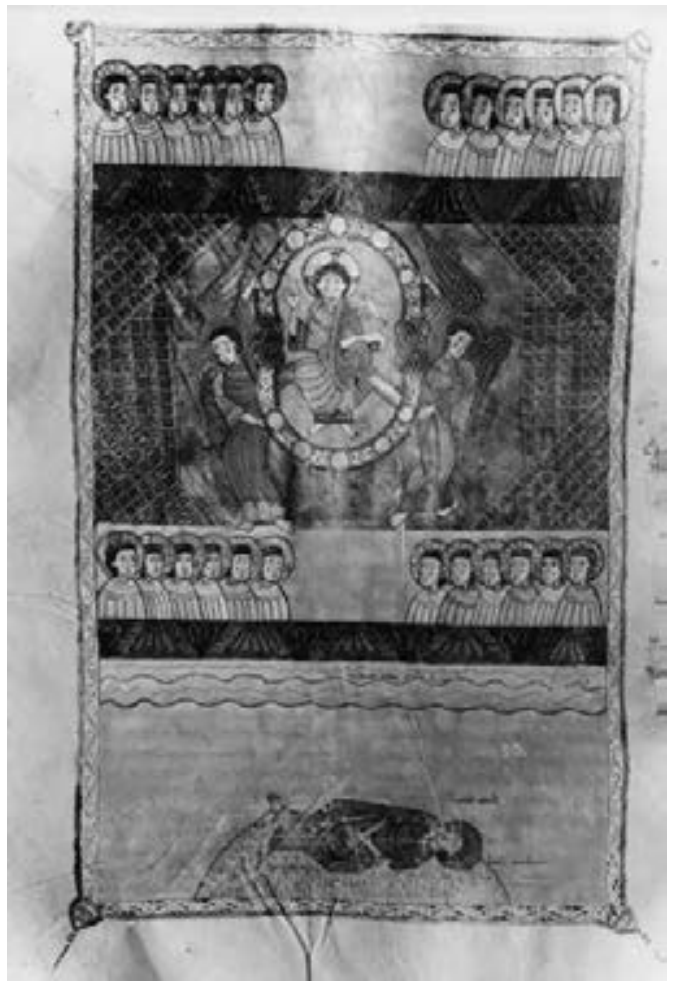

Photo: John Williams

because of the circumstances of survival. One of the copies with the first recension of the text, made in the Gascon monastery of Saint-Sever (No.13), displays a set of illustrations matching the most advanced phase of the iconography. Although it shares this text, the oldest Branch I copy, Vitrina 14-1 (No. 3), is severely mutilated. The second oldest copy, San Millán (No. 9), is only partially illustrated. Later copies, like that of Burgo de Osma (No. 14), tend to be less faithful to the archetype.

The Beatus illustrations were essentially visual reprises of the written storiae, as is evident in Geneva's version of the Vision of God Enthroned (see Fig. 118). The fourth chapter of the Apocalypse had inspired the classic image of Christ in Majesty for Western medieval art, combining both the enthroned Elders and the animal symbols of the Evangelists. However, Beatus divided this chapter so that the storia included the Twenty-four Elders, but the symbols of the Evangelists were relegated to the following storia. The Geneva miniature is quite literal and its design is unusually disciplined in its regular alignment with the text. The number of Elders, twenty-four, corresponds to the number in the storia, where they are said to be wearing crowns of gold. Beneath the heavenly court a narrow zone with undulating green lines represents the transparent sea, a "sea of glass like to crystal." In the lowest register John receives the vision from the angel, with a literal take on the "voice like a trumpet."

We are fortunate to have this same illustration in one of the Commentaries that is textually closest to Geneva, the Escorial Beatus (Fig. 93; No. 10). Style aside, the two versions essentially coincide in translating the text rather literally. The Spanish artist varied the headgear to account for the explanatio's identification of the Elders as apostles as well as patriarchs. This same basic composition appears on folio $70^{\mathrm{v}}$ of a more distant member of this branch of texts, the Osma Beatus from the great monastery of Sahagún (Fig. 94; No. 14). Looking at these illustrations, we can say with confidence that, like the text, Geneva's pictorial content belongs to the earlier of the two main branches of the family tree.

In the case of the Last Judgment from the Geneva Commentary (see Fig. 165), this illustration aids us in establishing the original composition for one of the major themes of medieval Christian art. Outside Iberia, the European version was slow to be formulated and was essentially based on the scene composed for Byzantine art, whereas the version in the Beatus Commentaries was older and different. In the Geneva Beatus, the inscriptions on the Last Judgment scene show a clear 
Figure 95 Last Judgment, Osma Beatus, fol. 157. Burgo de Osma, Cabildo de la Catedral

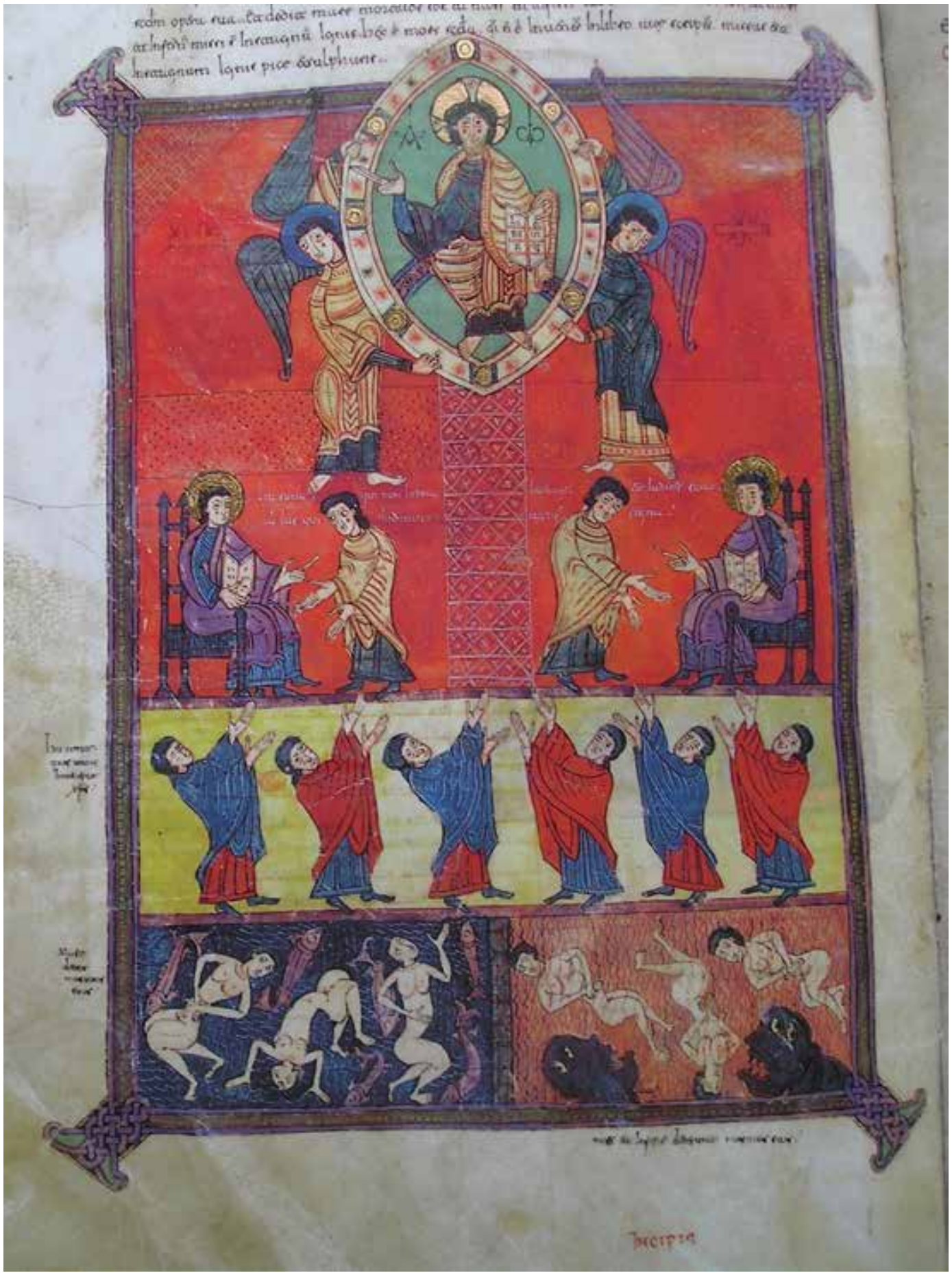

Photo: John Williams 
Figure 96 The Opening of the Sixth Seal: The Earthquake (Apoc. VI, 12-17). Osma Beatus, fol. 89. Burgo de Osma, Cabildo de la Catedral

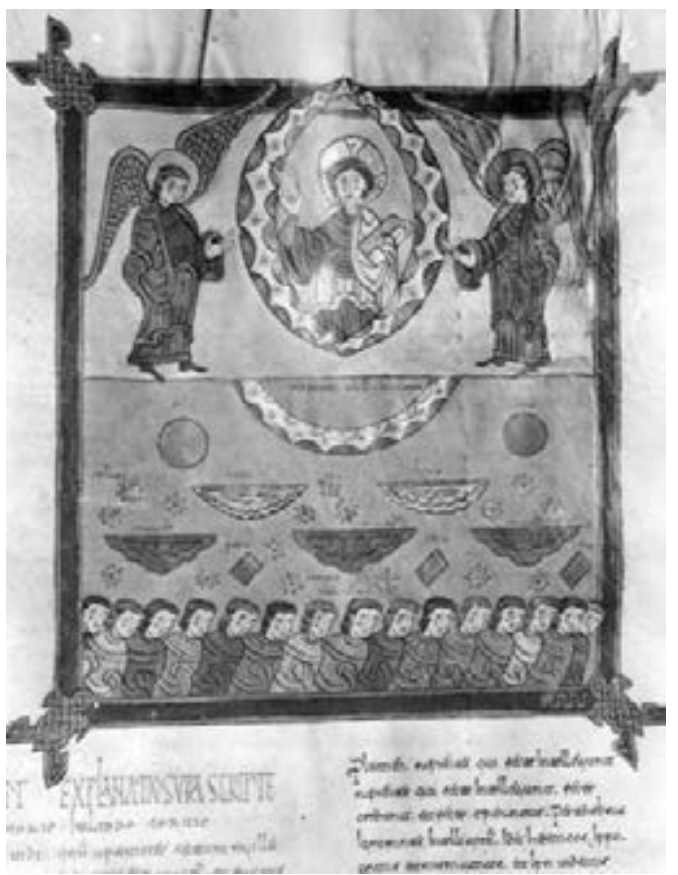

Photo: John Williams

dependence on the illustration in the Spanish copy that served as its model, as the description of judgment is taken not from the storia or the explanatio flanking this picture, but from that of the First Trumpet Angel (fol. 199), a passage borrowed by Beatus from Gregory the Great's Moralia in Iob. These legends are standard in all branches of the Beatus family tree.

While the inscriptions show a clear dependence on a Beatus archetype, the Geneva composition does not resemble that in the Branch I Commentary of Burgo de Osma (Fig. 95; No. 14). It is possible that this Geneva image is closer to the archetype than is the one in the Osma copy. However, for most of the Geneva scenes, the traditional formulas utilized for the illustrations in Spain were

\author{
Figure 97 The Opening of the Sixth Seal: The \\ Earthquake (Apoc. VI, 12-17). Morgan \\ Beatus, fol. 112. New York, The Morgan \\ Library \& Museum, MS M.644
}

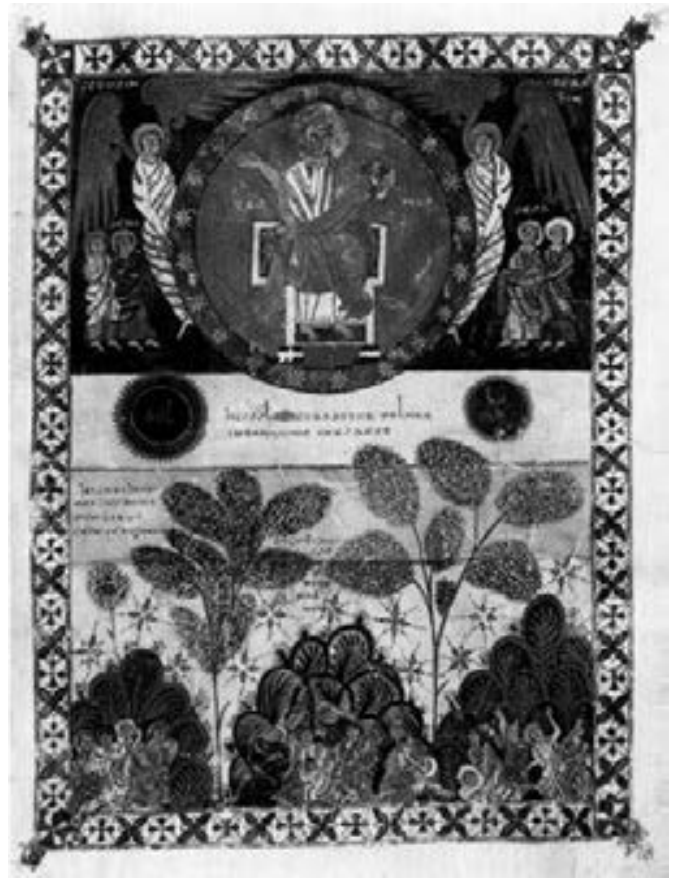

Photo: Joseph Zehavi

ignored. Let us take Geneva's image of the Opening of the Sixth Seal (Apoc. VI, 12-17; see Fig. 121). It is typical of the tradition in that there is no attempt to include allegorical meanings pictorially. Most surprising, however, is the decision to render "dens and rocks of the mountains" as an arcaded, man-made structure. This formula is absolutely unique within the Beatus tradition; in the Osma Beatus (Fig. 96) the scene took a more or less literal approach. A century earlier at Tábara, Maius had liberated himself from the restrictions imposed by the original pictorial format, and so he was able to do justice to the storia in the Morgan copy (Fig. 97; No. 2). And a century later, the southern Italian artist of the Berlin Commentary, copying a Beatus from Sahagún, 
Figure 98 The Opening of the Sixth Seal: The Earthquake (Apoc. VI, 12-17). Berlin Beatus, fol. 50. Berlin, Staatsbibliothek Preussischer Kulturbesitz, MS Theol. lat. Fol. 561

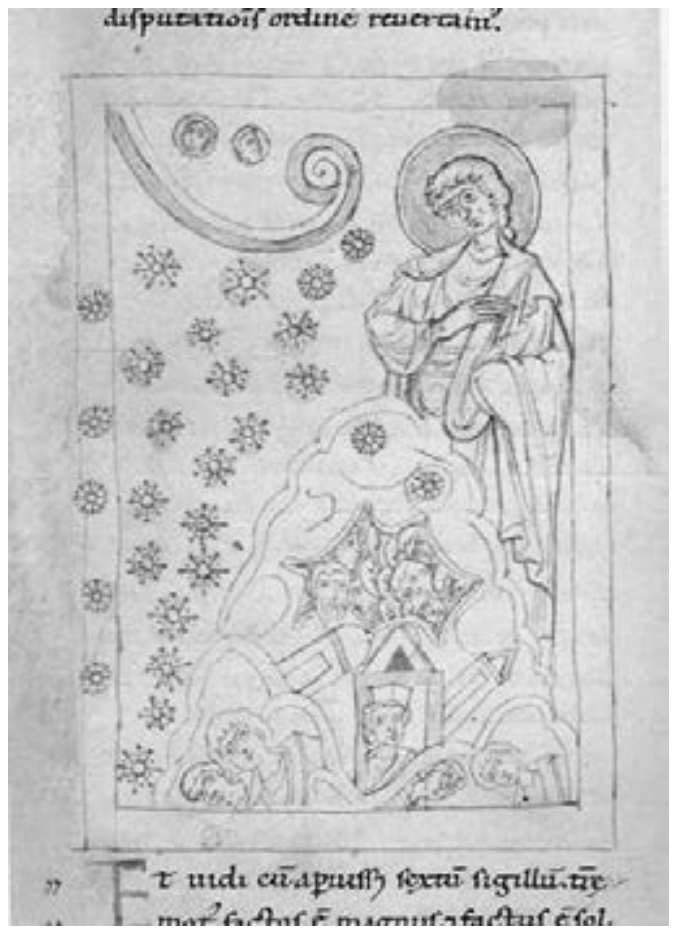

Photo: John Williams

responded to the same storia with a far more disciplined and accurate illustration (Fig. 98; No. 19).

With this Geneva illustration of The Opening of the Sixth Seal, we are faced with the enigma addressed earlier: why is there such a seemingly capricious alignment of text and picture? Clearly the word stare has been written so that it overlaps the blue arch, confirming the priority of the picture. This allows us to sequence the procedure followed by the illustrator here and on many other pages, beginning with the drawing of the various visual elements chosen to be present, then continuing with the writing of the text.

\section{The Scriptorium}

In the eleventh century, southern Italy had produced magnificent illuminated codices, such as the Exultet rolls. ${ }^{91}$ The infelicitous application of color and the lack of disciplined order in the relationship between text and picture, however, endow the Geneva Commentary with an improvisational character that might suggest it was produced by an eccentric scribe/painter and/or a scriptorium of limited experience with illuminated manuscripts. While elements of this conclusion may be true, it would be a mistake to conclude that only a minor scriptorium could have been responsible: the underdrawings are sophisticated, even if the application of paint is often not. The exceptionally lavish use of gold throughout also calls for caution in this regard.

Few medieval Italian scriptoria were more important and experienced than Monte Cassino in the production of illustrated manuscripts. The De rerum naturis of Hrabanus Maurus (Cod. Casin. 132), which was produced at Monte Cassino under Abbot Teobaldo in the second quarter of the eleventh century, represents the scriptorium at its finest artistic level..$^{2}$ Moreover, this manuscript offers analogies to the Geneva Beatus. Both include an extraordinarily lengthy sequence of illustrations with compositions and techniques that resemble each other's. That the Dererum naturis displays similar adjustment of text to picture rather than vice versa is apparent on many pages (Fig. 99). ${ }^{93}$ Although not to the same extent, perhaps, the application of paint to drawing is comparably rough. ${ }^{94}$ To be sure, the design of

\footnotetext{
91 Cavallo 1994.

92 Orofino 2000, 50-86, Tav. X-LXV.

93 Orofino 2000, Tav. XV, XXIII, XXVIII, XXXI, XXXIV, XLII, XLIII, XLIV.

94 Orofino 2000, Tav. XXXIV, XXXV, XXXIX
} 


\section{Figure 99 De rerum naturis by Hrabanus Maurus, Cod. Casin. 132, fol. 73, Archivio dell'Abbazia di} Montecassino

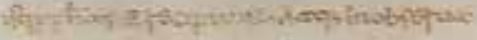

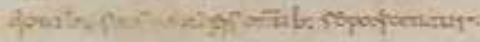

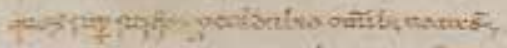

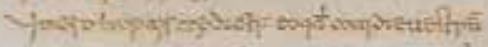

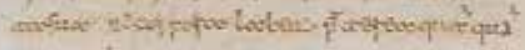

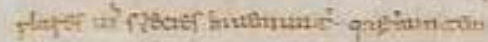

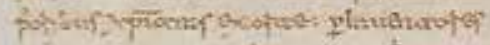

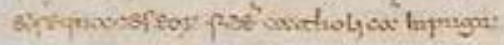

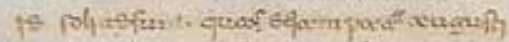

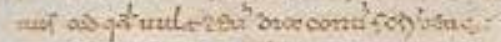

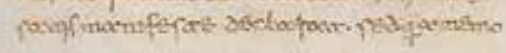

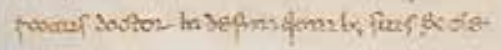

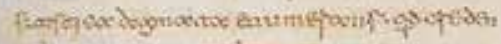

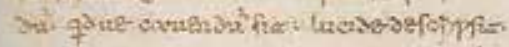
omplofistanfoy axcortivgo: pag coscho lyes lute tatwoe op

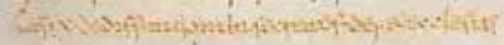

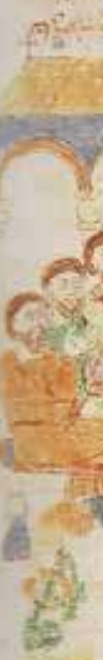
Aft Agmatert?

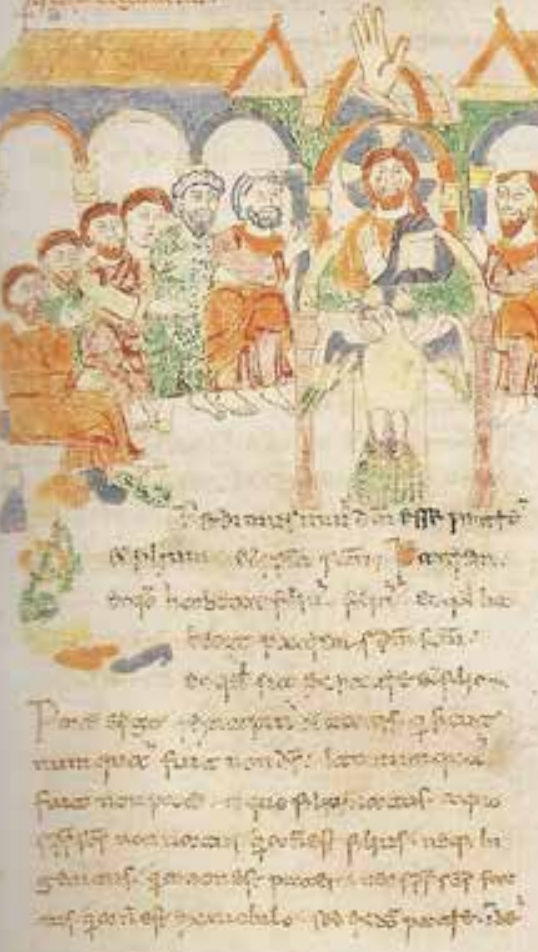

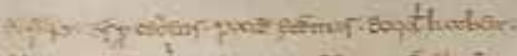

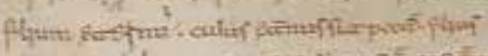

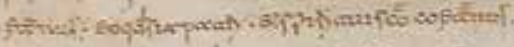

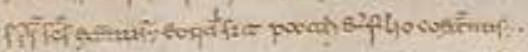

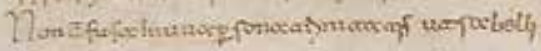

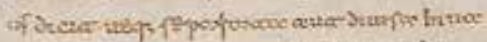

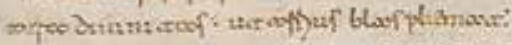

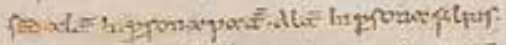

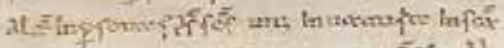

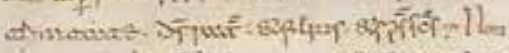

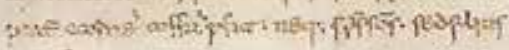

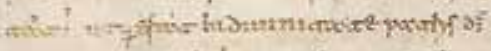

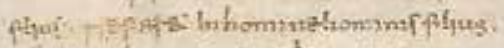

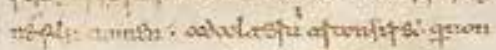

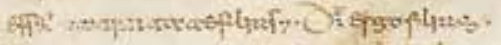

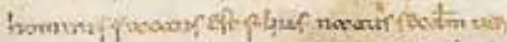

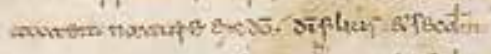

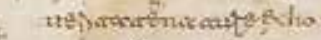

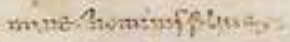
ue ust arof fothens nim

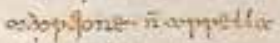

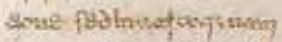

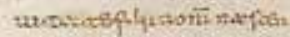

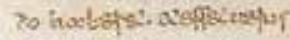

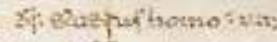

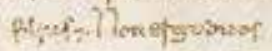

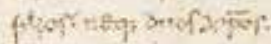

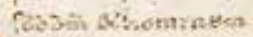

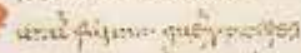
Gitures byani zumatis.

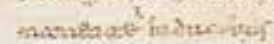

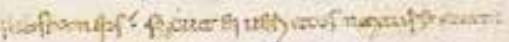

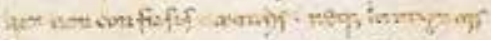

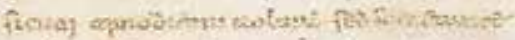

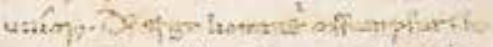

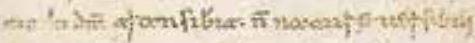

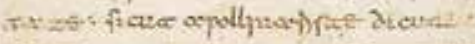

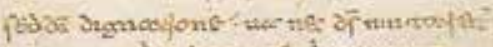

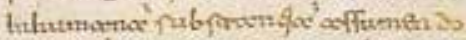

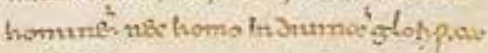

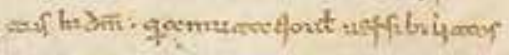


figures differs from those in the Geneva Beatus. Geneva's formulaic faces with spotted cheeks and a strongly marked depression between nose and upper lip make no appearance in the Hrabanus Maurus. ${ }^{95}$ They do appear, however, in other Cassinese manuscripts.$^{96}$ These parallels do not point to an origin at Monte Cassino for the Geneva Apocalypse, but they do reduce somewhat its initial impression of extreme eccentricity.

As for the professional experience of the individual responsible for the drawings, figures in the Geneva Commentary are convincingly articulated and well-proportioned, with drapery patterns consistent with established conventions of the time, that is, the middle of the eleventh century. One must assume that this was not the first time the draftsman undertook an artistic project. Color, however, was applied in a surprisingly undisciplined way, not only failing to follow closely the lines of the drawing, but even capricious on occasion, as seen, for example, in the application of colors to the sensitively drawn head of the Angel of the Seventh Trumpet on folio $207^{\mathrm{v}}$ (see Fig. 136). Within this context, even the extravagant use of gold - unparalleled in other copies of the Beatus Commentary - merely compounds the impression of a provincial product, despite the indication of a well-endowed scriptorium or a patron of high rank.

The illustrations of another Italian Beatus, the Berlin Commentary (No.19), display a set of untinted drawings produced in some southern Italian location a few decades after the Geneva copy (see Figs. 67-68). ${ }^{97}$ Was Geneva originally conceived for uncolored drawings, with paint and gold only added in a second campaign? I

95 See also the angels in Cas. 132 (Orofino 2000, Tav. $\mathrm{X})$ and on Geneva fol. $162^{\mathrm{v}}$.

96 Orofino 1996, Tav. LXXVII.

97 Klein, 2011d. think not: there is no convincing support for such a conclusion, and the possibility of a later renewed interest involving the addition of color is hard to justify. Still, in terms of its technique, the pictorial part of the Geneva Beatus comes across as "unprofessional" in comparison to the highly sophisticated series of Exultet rolls produced contemporaneously in southern Italy. However, nothing in the Geneva Commentary sinks to the low technical level of the illustrations of Monte Cassino $442^{\mathrm{I}-\mathrm{III}}$, which, like our manuscript, makes use of both Beneventan and Caroline script, and is dated to the eleventh century (Fig. 100)..$^{98}$

A conclusion, however, that the Geneva copy was the typical result of a professional scriptorium would be remiss. Its geographical origin is a question matched in importance by the motivation for its creation. Unfortunately, neither can yet be answered categorically. As we saw previously, Beatus's original Commentary must have been motivated by the approach of the year 800 and the end of ordinary time according to traditional calculation. It is unlikely - and certainly undocumented - that such an expectation produced the Geneva Beatus in the eleventh century, where its writing fits best. As for the contributions of the images to the establishment of Geneva's date, the lack of Byzantinizing formulas in the figural drapery and the absence of initials with elaborate interlace, which would become common at the end of the eleventh century, indicate a chronology no later than the middle of that century. While the initials in Monte Cassino 5 (Fig. 101), ${ }^{99}$ dated 1011-22 - a manuscript that, like Geneva, combines Beneventan and Caroline script - are

98 Orofino 2000, 107-10, Tav. LXXVII, LXXXVIII.

99 Orofino 1996, 26-30, Tav. VIII-XIIC. It combines Beneventan and Caroline script of a type that has been assigned to the northeastern part of southern Italy, near Capitanata; see also Tristano 1979, 100-02. 
Figure 100 Cod. Casin. 442 ${ }^{1-11}$, fol. 12, Archivio dell'Abbazia di Montecassino

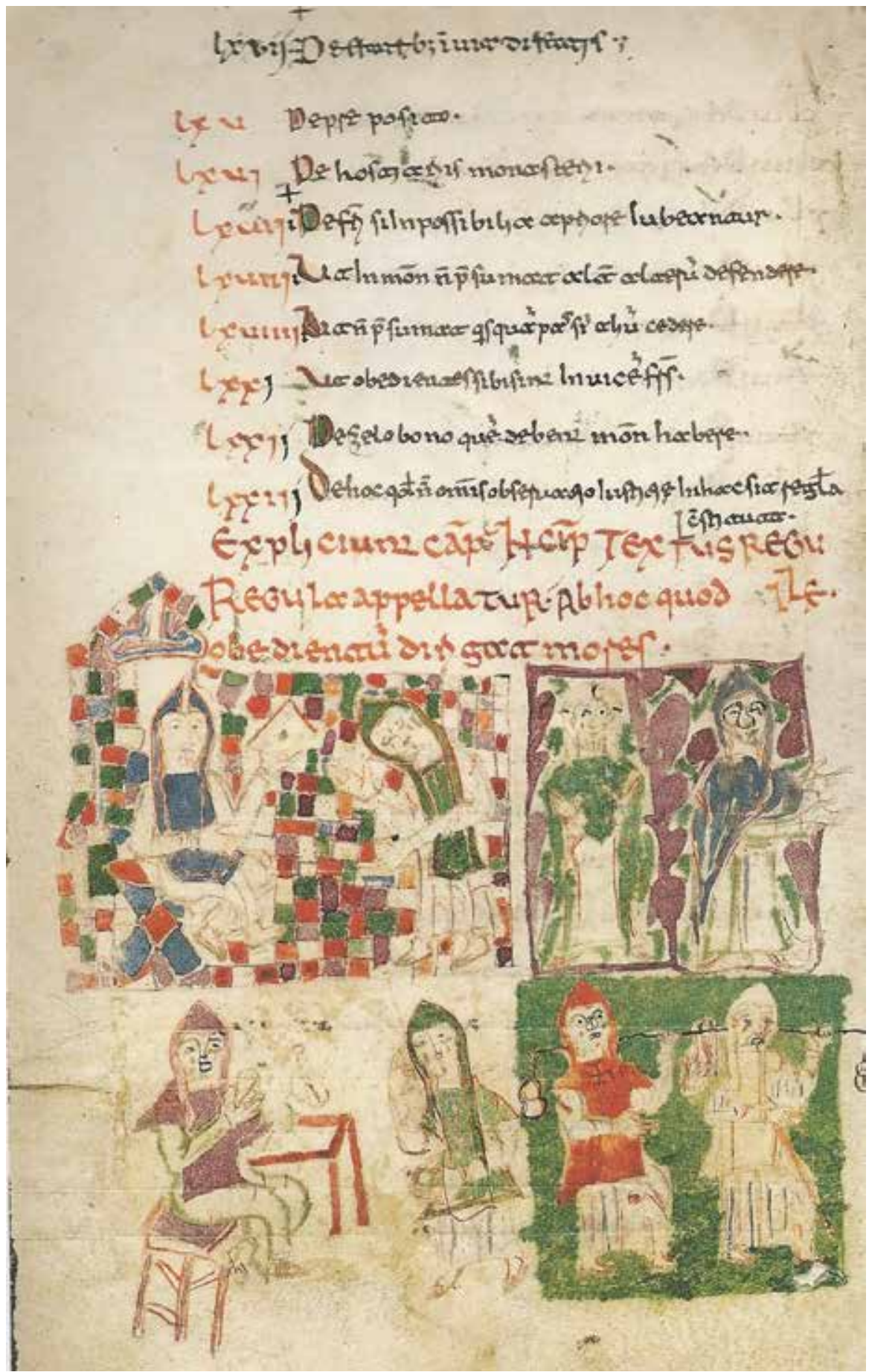


Figure 101 Cod. Casin. 5, fol. 349, Archivio dell'Abbazia di Montecassino

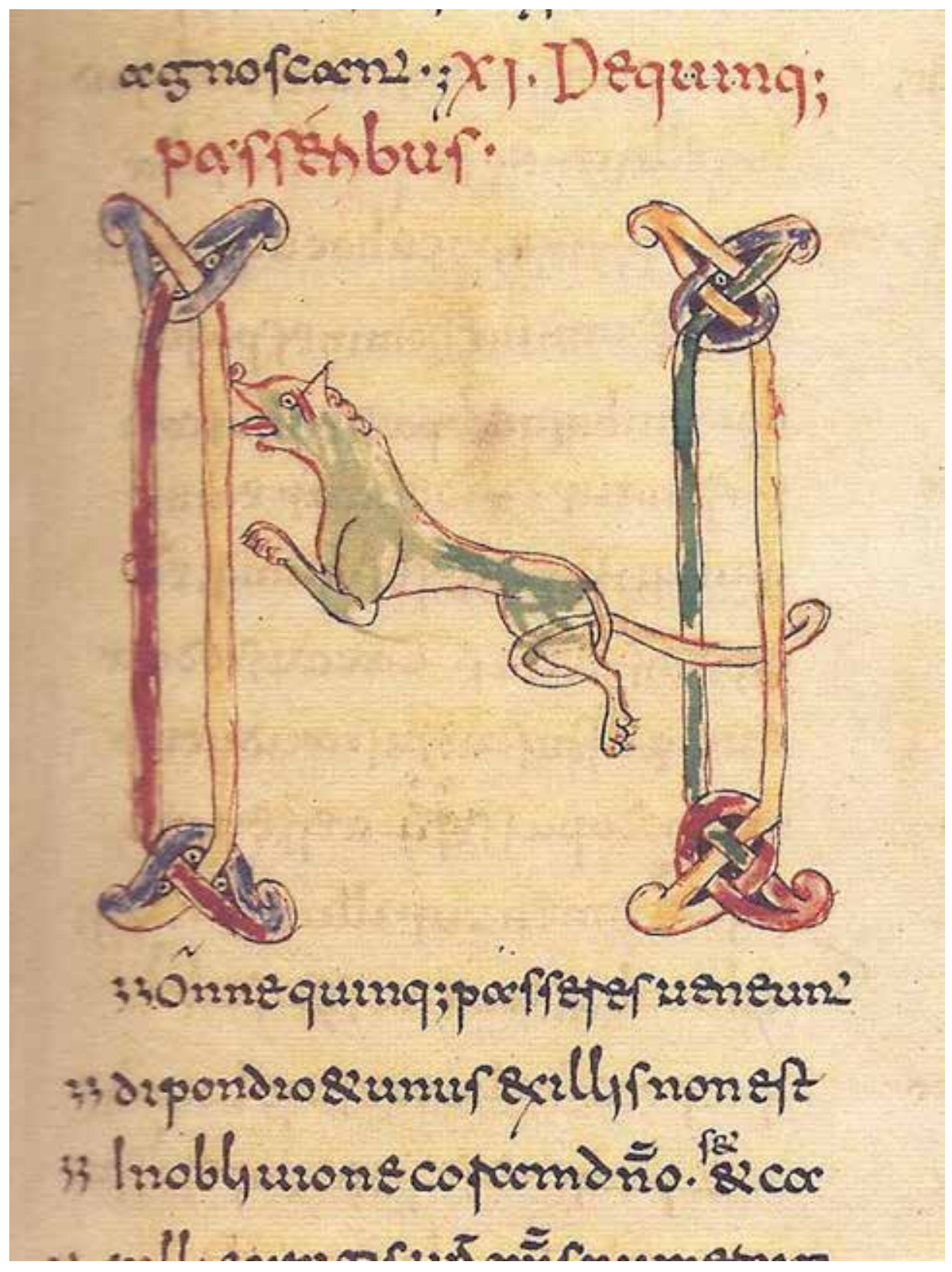


not based on the same formula, in simplicity and technique they are analogous to the single initial in the Geneva Beatus (see Fig. 116).

\section{The Illustrator's Contributions}

In the following section of this volume, in which each illustration in the Geneva copy is reproduced and analyzed, the word "unique" appears an extraordinary number of times for a discussion of a Beatus Commentary. I use this term advisedly, as these images appear nowhere else in the Beatus tradition. In these illustrations, we can see the original contributions of the Geneva draftsman, who took ancient formulas - such as a dove to represent the soul - and gave them his or her own strikingly different interpretation: on folio $185^{\mathrm{v}}$, the doves emerge directly from the bleeding necks of decapitated martyrs (see Fig. 120). At times these drawings omit details seen commonly in other Beatus copies or add original figures; both characteristics can be found in the scene of the Angel of the Abyss and the Locusts on folio 202 (see Fig. 129), where the representation of locusts normally includes the victims stung by these creatures (Apoc. IX, 7-12). The Geneva Commentary, however, not only leaves the victims out of this illustration, but also uniquely includes a bestial, satanic figure to represent the angel. It is unlikely that this figure appeared in the Commentary used as a model by our unknown miniaturist. 


\section{Geneva Illustrations with Apocalyptic Storiae and Analysis of the Images}

In this section, I address in greater detail issues of workshop practices, models and copies, parallels and originality, and the place of the Geneva manuscript within the Beatus tradition. The Apocalyptic storiae from the Vetus Latina and my analyses of the images are followed by illustrations of each of the painted folios from the Geneva Beatus.

\section{Inscriptions Accompanying the Miniatures}

The descriptions of the inscriptions follow the convention established by Williams, The Illustrated Beatus (1994-2003), with "/" indicating a text or line break, and "//" indicating a different section of the drawing. Italics are used when a caption is in red. All inscriptions, except where otherwise noted, are written in a Beneventan script in a small and fine hand; they were added after the illustrations were drawn, for the texts are often arranged around the figures and activities in the illustrations. Not all drawings have inscriptions.

This Beatus Commentary comprises folios $149-245^{\mathrm{V}}$ of the manuscript, which has been bound together with Priscian's Institutiones grammaticae (fols. 1-148 ${ }^{\mathrm{v}}$ ).

\section{The Woman on the Beast (fol. 149)}

Apoc. Prol. Book II.8. See Fig. 108, p. 208.

The woman seated on the beast is seduction, and the works of iniquity and worldly pleasures, and fornication, and impurity, and greed, and jealousy, and calumny, and envy, and vainglory, and pride, and gluttony [...]
Inscriptions:

de muliere super uestiam.

[The abbreviation stroke for " $\mathrm{m}$ " in uestiam and the punctuation immediately following were added in black ink.]

The 'Woman' will be described and illustrated later in the Commentary when she appears in Chapter XVII, 1-3 of the Apocalypse as the Great Whore Seated on the Waters and the Woman Seated on the Scarlet Beast (see Figs. 153-154). Among other iniquitous works, "they who inhabit the earth have been made drunk with the wine of her immorality." Although here she holds an object that by its size and shape may not readily suggest a cup or chalice, the picture of the Great Whore Seated on the Waters confirms that it is. This is true also of the similarly shaped vessels in the illustration of Vitrina 14-1 (No. 3, fol. $137^{\mathrm{v}}$ ), as well as that of the Woman Seated on the Beast of the Escorial Beatus (see Fig. 105, No.10, fol. 24v), although not proportionately so large.

Letters to the Churches of Asia (fols. 152, $154 \mathrm{~V}, 157 \mathrm{~V}, 16 \mathrm{o}, 162 \mathrm{~V}, 165 \mathrm{~V}, 169$ ) Apoc. II, 1-7; II, 8-11; II, 12-17; II, 18-19; III, 1-6; III, 7-13; III, 14-22. See Figs. 109-115, pp. 209-215.

Inscriptions:

fol. $154^{v}$ ubi scribit // angelum ecclesie zmirne

fol. $165^{\mathrm{v}}$ ubi dat scriptum angela [?] fila/ delfie ecclesie

John was commanded to deliver his prophecy to the angels of the Seven Churches, that is, the Christian communities of the Roman province of Asia: Ephesus, Smyrna, Pergamum, 
Thyatira, Sardis, Philadelphia, and Laodicea. Located in what is today western Turkey, these sites were Early Christian communities near the island of Patmos, where John received the Apocalypse. In the other Beatus copies, the episode is similarly simple: John passes a book to an angel standing before him. In many cases an arch represents the Church. To indicate the transcendent nature of revelation, the book of Revelation, elongated to identify it as a scroll, is here gilded.

The depictions of the actions for the Churches of Ephesus (Fig. 109), Smyrna (Fig. 110), and Thyatira (Fig. 112) especially make it evident that the illustrations were in place before the text was written, a reversal of the procedure indicated in many Beatus Commentaries, but not uncommon in contemporary Italian manuscripts, where initials were routinely drawn or painted before the text was added. The order - picture followed by written text - suggests that the writer and illustrator may have been one and the same, or at the very least worked side by side. However, the degree of differences that can be seen, for example, in a comparison of technical finesse in the angels of Philadelphia (Fig. 114) and Laodicea (Fig. 115), suggests that more than one colorist intervened in the production of this book.

Initial P (fol. 171v). See Fig. 116, p. 216.

This is the only surviving figural initial. Judging by other Beatus copies, it is probable that the missing introduction to this Commentary would have been decorated with an even more ambitious initial. In fact, the initial on folio $171^{\mathrm{v}}$ serves as an incipit for the beginning of Book III. A single shaft supports the bows of two Ps, the lower one formed by a naked man, which introduce in successive paragraphs the word "Post." Initials combining a floriated shaft with human or animal figures were widespread through the eleventh century, but would largely be supplanted by geometric forms in the twelfth.

\section{Vision of God Enthroned with the Elders}

(fol. 172)

Apoc. IV, 1-6. See Fig. 117, p. 217.

After this I looked, and behold, a door standing open in heaven, and the former voice, which I had heard as of a trumpet speaking with me, said, "Come up hither, and I will show you things that must come to pass hereafter." 2. Immediately I was in the spirit; and behold, there was a throne set in heaven, and upon the throne One was sitting. 3. And he who sat was in appearance like to a jasper-stone and a sardius, and there was a rainbow round about the throne, in appearance like to an emerald. 4. And round about the throne are twenty-four seats; and upon the seats twenty-four elders sitting, clothed in white garments, and on their heads crowns of gold. 5. And from the throne proceed flashes of lightning, rumblings and peals of thunder; and there are seven lamps burning before the throne, which are the seven spirits of God. 6. And before the throne there is, as it were, a sea of glass like to crystal.

Inscriptions:

seniores//

thronum//

se/nio/res//

ubi iohanes duc/tus fuit ad thro/num/dei

Chapter 4 of the Apocalypse inspired the classic image of Christ in Majesty for Western medieval art, combining both the animal symbols of the Evangelists and the Twenty-four Elders. This scene would be magisterially represented, for example, in the great tympanum of the church of Moissac in the early twelfth century (Fig. 102). Although Emile Mâle proposed that 
Figure 102 Christ in Majesty tympanum, St.-Pierre de Moissac

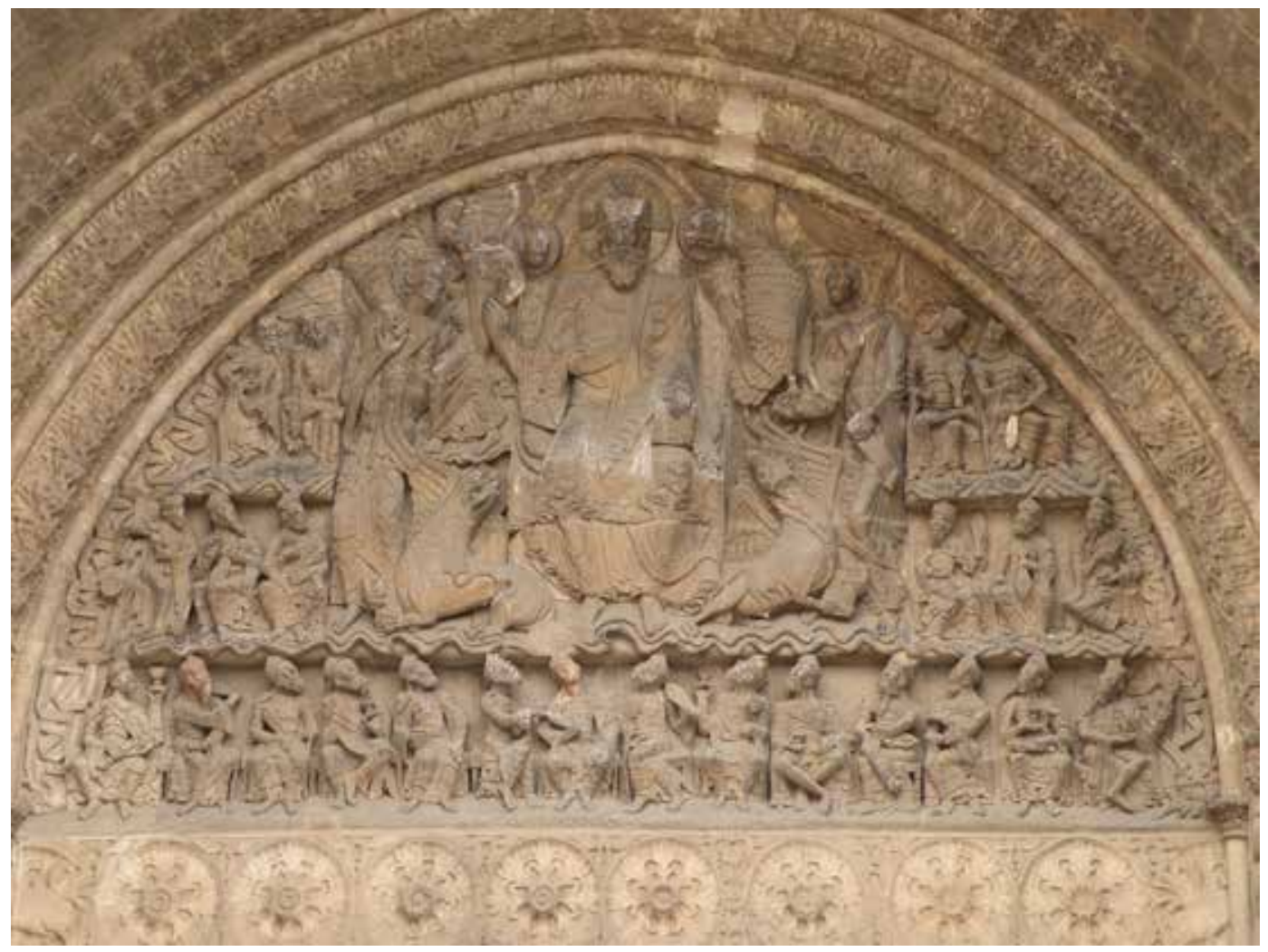

Photo: Therese Martin

this tympanum was inspired by a Beatus illustration, Beatus had divided Chapter 4 so that this storia included the Twenty-four Elders, while the Evangelist symbols followed in the next storia.

This Geneva illustration is among the most literal of the series and its design among the most disciplined in its regular alignment with the text. In the explanatio the Twenty-four Elders are said to be wearing crowns of gold, but the miniaturist chose to use pointed hats, reflecting the Commentary's association of the Elders with the "choir of patriarchs" and the apostles. In the Escorial Beatus (see Fig. 93; No. 10) several types of headdress are employed to reflect the various identities of the Elders.

The strip of undulating green lines underneath the heavenly court represents the transparent sea resembling glass. In the lowest register John receives the vision from the angel. The composition is essentially that which appears in the Branch I illustration in the Burgo de Osma Beatus (see Fig. 94, No. 14, fol. $70^{v}$ ) and the version in the Escorial Beatus, but in those John is prone and alone as he receives the revelation. With a greater respect for the storia, which has the vision revealed by a voice like a trumpet, here John is accompanied by a trumpet-bearing angel. 
Vision of God Enthroned with the Four

Living Creatures (fol. 174)

Apoc. IV, 6-V, 14. See Fig. 118, p. 218.

And I saw in the midst of the throne and round the throne four living creatures, full of eyes before and behind. 7. And the first living creature is like a lion and the second like a calf, and the third has the face, as it were, of a man, and the fourth is like an eagle flying. 8. And the four living creatures have each of them six wings; round about and within they are full of eyes. And they do not rest day and night, saying, "Holy, holy, holy, the Lord God Almighty, who was, and who is, and who is coming." 9. And when those living creatures give glory and honor and benediction to him who sits on the throne, who lives forever and ever, 10. the twenty-four elders will fall down before him who sits upon the throne, and will worship him who lives forever and ever, and will cast their crowns before the throne, saying, 11. "Worthy are you, O Lord our God, to receive glory and honor and power; foryou have created all things, and because of your will they existed, and were created." $V$, I. And I saw upon the right hand of him who sits upon the throne a book written within and without, sealed with seven seals. 2. And I saw a strong angel proclaiming with a loud voice, "Who is worthy to open the book, and to break the seals thereof?" 3 . And no one in heaven, or on earth, or under the earth, was able to open the book or to look thereon. 4. And I wept much, because no one was found worthy to open the book or to look thereon. 5 . And one of the elders said to me, "Do not weep; behold, the lion of the tribe ofJudah, the root of David, has overcome to open the book and its seven seals." 6. And I saw, and behold, in the midst of the throne and of the four living creatures, and in the midst of the elders, a Lamb standing, as if slain, having seven horns and seven eyes, which are the seven spirits of God sent forth into all the earth. 7 . And he came and took the book out of the right hand of him who sat upon the throne. 8. And when he had opened the book, the four living creatures and the twentyfour elders fell down before the Lamb, having each a harp and golden bowls full of incense, which are the prayers of the saints. 9. And they sang a new canticle, saying, "Worthy are you to take the book and to open its seals; for you were slain, and have redeemed us for God with your blood, out of every tribe and tongue and people and nation, 10. and have made them for our God a kingdom and priests, and they shall reign over the earth." 11. And I beheld, and I heard a voice of many angels round about the throne, and the living creatures and the elders, and the number of them was thousands of thousands, 12. saying with a loud voice, "Worthy is the Lamb who was slain to receive power and dignity and wisdom and strength and honor and glory and blessing." 13. And every creature that is in heaven and on the earth and under the earth, and such as are on the sea, and all that are in them, I heard them all saying, "To him who sits upon the throne, and to the Lamb, blessing and honor and glory and dominion, forever and ever." 14 . And the four living creatures said, "Amen," and the elders fell down and worshipped.

\section{Inscriptions:}

[erasure [in red?] or offset impression?]

Two images of almighty power are celebrated in this storia, the One, or Christ in Majesty, who was honored in the previous storia, and the Lamb, who is encircled by the Four Living Creatures: the lion, the calf or ox, the man, and the eagle. In the explanatio the Living Creatures are identified with the four Evangelists. In time the specific identifications made by St. Jerome (d. 420) - the calf as Luke, the lion as Mark, the man as Matthew, and the eagle as John - would become orthodox. Since this section of the explanatio was taken from Isidore 
Figure 103 Christ in Majesty. Osma Beatus, fol. 73v. Burgo de Osma, Cabildo de la Catedral

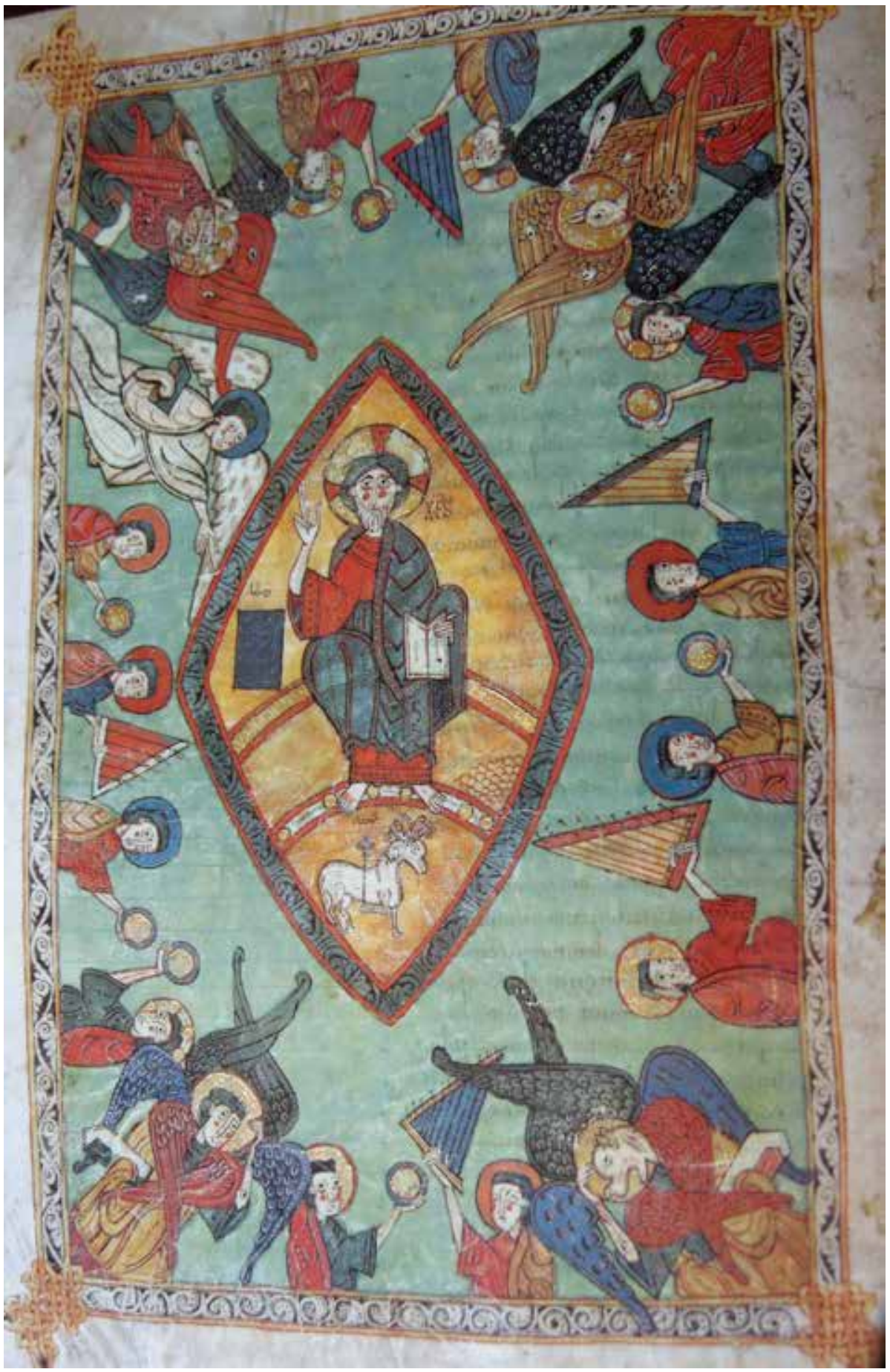

Photo: John Williams. 
and Apringius, Hispanic writers who lived after Jerome, the "orthodox" identifications are to be expected.

The manuscripts of Branch II agree in honoring the enthroned Lamb rather than the One as the center of circular compositions. Some Branch I manuscripts do as well, namely the San Millán Beatus (see Fig. 48; No. 9) and the Beatus from Lorvão (No. 22, fol. 90). This is not the case in the Geneva Commentary. The image of Christ in Majesty holding a book depends on the description of the Enthroned from the previous storia, in which the Four Living Creatures with wings covered with eyes are described (see Fig. 118). There is, however, a Branch I manuscript that shares this idiosyncrasy, the 1086 Beatus of Burgo de Osma (Fig. 103; No. 14). As was normal for the later copies, the Osma illustration is no longer restricted to a space within the column of text, but occupies a full page. As in the Geneva copy, Christ sits within a mandorla with the beasts on either side. The Twenty-four Elders, who are not present in the Geneva Beatus, are reduced to twelve in the Osma Commentary. The Living Creatures, who occupy the four corners of the rectangular field, have wings covered with eyes and beast heads on human bodies. Neither the storia nor the explanatio prescribe this formula, but it was a favored one in the Iberian Peninsula, and it entered the Beatus tradition in the tenth century with the iconographic revision accompanying the Branch II Commentaries. The beasts in the Geneva Beatus have their animal bodies, which was surely the case in the original Commentary.

One must allow the possibility that the enthroned Christ of the Osma Beatus represents a substitution inspired by the prominence of Christ in Majesty as a rising theme in medieval art. There is a suggestion of this updating in the illustration of the Seven Angels with Trumpets in the Osma Beatus, where the enthroned Christ is especially large and may have caused a scene originally designed for a single page to expand to two (fols. 102-102 ${ }^{\mathrm{v}}$ ). This preference for the popular Maiestas image occurred also in the Osma Beatus in the illustration of the Sixth Trumpet: The Angels of the Euphrates (Apoc. IX, 13-16; fol. 109), and the same kind of substitution seems to have taken place in the Geneva Beatus.

\section{The Opening of the First Four Seals: The}

Four Horsemen (fol. 183 ${ }^{\mathrm{v}}$ )

Apoc. VI, 1-8. See Fig. 119, p. 219.

And I saw that the Lamb had opened one of the seven seals, and I heard one of the four living creatures, as it were the voice of thunder, saying: "Come, and see." 2. And I saw: and behold a white horse, and he that sat on him had a bow, and there was a crown given him, and he went forth conquering that he might conquer. 3. And when he had opened the second seal, I heard the second living creature, saying: "Come, and see." 4. And there went out another horse that was red: and to him that sat thereon, it was given that he should take peace from the earth, and that they should kill one another, and a great sword was given to him. 5. And when he had opened the third seal, I heard the third living creature saying: "Come, and see." And behold a black horse, and he that sat on him had a pair of scales in his hand. 6. And I heard as it were a voice in the midst of the four living creatures, saying: "Two pounds of wheat for a penny, and thrice two pounds of barley for a penny, and see you hurt not the wine and the oil." 7 . And when he had opened the fourth seal, I heard the voice of the fourth living creature, saying: "Come, and see." 8. And behold a pale horse, and he that sat upon him, his name was death, and hell followed him. And power was given to him over the four parts of the earth, to kill with sword, with famine, and with death, and with the beasts of the earth. 
Inscriptions:

Added by a later hand in early round gothic, perhaps by a corrector of the text proper; each inscription appears next to the appropriate figure in the manner of a label, and the text is not continuous.

$\begin{array}{ll}\text { pridicator [for predicator?]// } & \text { diabolus// } \\ \text { equs albus// } & \text { equs ruffus// } \\ \text { infernus [to left]// } & \text { diabolus// } \\ \text { mors [to right]// } & \text { equs niger } \\ \text { equs pallidus } & \end{array}$

On this folio it is patently clear that the illustration preceded the writing. Also evident is the fact that the illuminator began with the rider on the white horse, for the more generous space allotted to him means that there was less room for the figures on the right side. The four horses, organized in clockwise order, are not only rendered in the colors assigned them in the text but labeled boldly as to color as well. Typical of this manuscript, the paint appears to have been applied somewhat hastily over the careful drawing. Although the storia gives the rider of the red horse a large sword, here he is instead represented as threatening the rider of the white horse with a spear. The red horse's rider is also provided with the name Devil (diabolus), not mentioned in the storia, but applied to him later in the explanatio. The figure opposite and below, Death (mors), rides a pale green horse; he is followed by Hell (infernus). Appropriately, Hell is covered in flames, and great tongues of fire issue from his mouth.

In the post-medieval readings of the Apocalypse, all four horsemen were agents of devastation. Vicente Blasco Ibáñez invoked this section of the Apocalypse in the modern era when he wrote The Four Horsemen of the Apocalypse, his widely read 1916 novel of the tragedy of World War I. However, in Beatus's explanatio, following in this instance St.
Jerome's edition of the Commentary on the Apocalypse by Victorinus, the first rider is an allegorical figure representing the preachers of the faith. His white horse and the arrow symbolize the words of his message, and the crown he wears is a gift of the Holy Spirit. Although the composition does not make it clear, the white horse's rider is a champion of the word of God against the other riders, and in some Commentaries he is shown battling the second horseman. The other riders, indeed, represent scourges of mankind, but, read allegorically, on the spiritual plane. According to the explanatio the second rider, on a red horse, represents future wars of church against church; the third rider stands for hunger for the word of God; and the fourth rider symbolizes the revelation of the false prophets, who kill spiritually.

The Opening of the Fifth Seal: The Souls of the Martyrs under the Altar (fol. 185 $5^{\mathrm{v}}$ )

Apoc. VI, 9-11. See Fig. 120, p. 220.

And when he opened the fifth seal, I saw under the altar the souls of those who had been slain for the word of God, and for the witness that they bore. 10. And they cried with a loud voice, saying, "How long, O Lord dost thou refrain from judging and from avenging our blood on those who dwell on the earth?" 11. And there was given to each of them a white robe; and they were told to rest a little while longer, until the number of their fellow servants and their brethren who are to be slain, even as they had been, should be complete.

Inscriptions:

sustinete/ [altar in between] modicum/ tempus//

animas interfectorum//

isti dicunt iudica/ domine et defende sanguinem/ nostrum. 
This is the subject of the oldest Beatus illustration surviving, the late ninth-century fragment of the Commentary in the library of the monastery of Santo Domingo de Silos (see Fig. 34; No.1). Because of its resemblance compositionally to the same subject in the Commentary from Lorvão (see Fig. 74; No. 22), the Silos fragment would seem to belong to Branch I. However, there is an unusual lack of uniformity in the composition of the illustrations of this narrative, and some uncertainty over content involving the presence or absence of Christ. $\mathrm{He}$ is least ambiguously present in a Branch I Commentary, the tenth-century Vitrina 14-1 (No. 3, fol. $75^{\mathrm{v}}$ ), where he sits enthroned holding a book to the left of the altar. The hand of God that reaches from heaven to the left side of the altar of the Geneva Beatus is unambiguous. In the Silos fragment and the Lorvão Commentary the scene is divided into an upper and a lower zone, and includes two altars, probably because of the reference to two in the explanatio. Our Geneva illustration does not have two levels, instead following the storia rather literally.

The Geneva manuscript uses gold in an unexpectedly generous way for a Beatus Commentary. In this image, the gold of the altar may be linked to the explanatio, where the first part of the text, based on St. Jerome's version of the Commentary by Victorinus, speaks of two altars of gold, one internal and one external. This would explain the presence, in the illustration, of an altar inscribed within an outer one. Their shape, a table on a single support, reflects the actual shape of Iberian altars before the ninth century. ${ }^{100}$ This illustration resembles in still other respects the version in Vitrina 14-1 (No. 3), for the martyrs' full bodies, not just their heads, are depicted. However, Geneva makes use of an ancient formula, in which the souls of the martyrs are present in the guise of

100 Sastre 2013 doves. Uniquely, however, the doves are here shown emerging directly from the decapitated bodies whose bleeding heads have fallen to the ground.

\section{The Opening of the Sixth Seal: The}

Earthquake (fol. 187)

Apoc. VI, 12-17. See Fig. 121, p. 221.

And I saw, when he had opened the sixth seal, and behold there was a great earthquake, and the sun became black as sackcloth of hair: and the whole moon became as blood: 13. And the stars of heaven fell upon the earth, as the fig tree loses its fat fruit when it is shaken by a great wind: 14. And heaven drew back like a rolled-up book, and everymountain and the islands were moved out of their places. 15. And the kings of the earth, and the princes, and tribunes, and the rich, and the strong, and every bondman, and every freeman hid themselves in the dens and in the rocks of the mountains: 16. And they say to the mountains and the rocks, "Fall upon us, and hide us from the face of him who sits upon the throne, and from the wrath of the Lamb: 17. For the great day of theirwrath is come, and who shall be able to stand?"

\section{Inscriptions:}

ubi sol et luna obscura/ti sunt//

ubi stelle de cello cadunt in terra.//

ubi reges et/ magistratus/ et tribune ab/ sconderunt se/ in speluncis.

According to the explanatio, the sun and the moon represent the Church, within which are both the wise and the ignorant; the latter are heretics, schismatics, and hypocrites. The stars that fall are the faithful - some true, some false; they will find themselves distressed by the coming of the Antichrist, who will be accompanied by an earthquake. As for the mountains, they signify refuge, for they are the apostles, 
and it is to them that the kings and the powerful - that is, the saints who refuse to submit their necks to the swords of the impious - flee for protection.

Beyond the fact that the sun is darkened and the moon is red, the picture scarcely reflects the content of the storia. Moreover, it differs markedly from the two surviving Branch I versions, namely that of the Beatus of Burgo de Osma (see Fig. 96; No. 14) and that in the Lorvão Commentary (No. 22, fol. 115). A Christ in Majesty flanked by angels occupies the upper half of the scene in the Osma Beatus, while in the lower half the sun and moon, mountains, islands, and rocks hover over a line of fifteen bust-length figures labeled men, neither nimbed nor crowned. Were it detached from the text, the illustration in the Lorvão Beatus would be difficult to identify. As with Osma, there are two registers, but the upper one has a single king riding a horse and holding a bow that has loosed an arrow, piercing the heart of a figure outside the frame of the picture; below, a frontally posed figure raises his arms wide in prayer. He is flanked by trees that separate him from two figures who face him; they point both to the central man and to the king above. Neither the storia nor the explanatio justifies such a composition. ${ }^{101}$

While the illustrations of the Lorvão Beatus tend to be idiosyncratic, with the exception of a few obvious revisions that modernized it, the Osma Beatus in general provides a reliable guide to the compositions of Branch I. The Branch II division as displayed, for example, in the Morgan Beatus (see Fig. 97; No. 2) is essentially the same as that in Osma. Are we

101 Neuss 1931, I: 159, thought the horseman symbolized the "wrath of him who sits on the throne." By contrast, Nordström 1976, 10-12, saw him as the Antichrist shooting an arrow at a martyr. to conclude that in both cases the archetypal composition was followed? Or was Martinus, the Osma illuminator at Sahagún, influenced by some copy from the Branch II reformation of the pictorial content? The Osma Beatus does not seem to exhibit such an influence elsewhere, so this illustration must reflect the archetype. The lack of significant parallels to the archetype in the interpretation of the Opening of the Sixth Seal must mean either that there was no illustration of this scene in the model used for the Geneva Beatus, or, more likely, the illustrator of the Geneva Beatus chose for some reason to reinvent the scene. In the storia the kings and the other "saints" hide themselves in the caves and in the rocks of the mountains. Although the arcades that the kings approach are usually the formula employed for architecture, the label between these columns, "where kings and magistrates and tribunes hide themselves in caves," identifies these arches as caves.

This page exemplifies the unusually improvisational and original character of some Geneva illustrations, which shift away from the pattern offered by the manuscript that served as its model.

\section{The Four Angels of the Winds (fol. 189)}

Apoc. VII, 1-3. See Fig. 122, p. 222.

After these things, I saw four angels standing on the four corners of the earth, holding the four winds of the earth, that they should not blow upon the earth, nor upon the sea, nor on any tree. 2. And Isaw another angel ascending from the rising of the sun, having the sign of the living God; and he cried with a loud voice to the four angels, to whom it was given to hurt the earth and the sea, 3. Saying: "Hurt not the earth, nor the sea, nor the trees, tillwe sign the servants of our God on their foreheads." 
Inscriptions:

signum dei uiui//

isti sunt angeli qui tenent// quattuor uentos terre.

In a general way this illustration resembles those of the other Branch I versions: angels supporting trumpet-blowing busts of the "winds" stand at the corners of a rectangle representing the world. As in the Geneva picture, the miniature in the Osma Beatus (No. 14, fol. 91) includes the angel ascending from the rising sun in the upper margin, holding a cross, the symbol of the living God. Above the cross is the sun. However, the center of each composition suggests that its original configuration was not well understood, for they differ radically. In Osma a circle displaying a cross has four floral forms at its cardinal points. The Lorvão Beatus (see Fig. 73; No. 22) omits the angel from the east. It also has a circle at the center, but within it are four busts of nimbed figures at the cardinal points. In the Geneva Beatus the central circle is filled with a single face. The inscription, "Here are angels who have the four winds of the earth," suggests that the face is a personification of the earth, just as on folios $201^{\mathrm{v}}$ and $208^{\mathrm{v}}$, the sun and the moon, respectively, are each given a face.

\section{The Sealing of the Elect (fol. 190)}

Apoc. VII, 4-12. See Fig. 123, p. 223.

And I heard the number of them that were sealed, an hundred forty-four thousand were sealed, of every tribe of the children of Israel. 5. Of the tribe of Judah, were twelve thousand sealed: Of the tribe of Ruben, twelve thousand sealed: Of the tribe of Gad, twelve thousand sealed: 6. Of the tribe of Aser, twelve thousand sealed: Of the tribe of Nephthali, twelve thousand sealed: Of the tribe of Manasses, twelve thousand sealed: 7. Of the tribe of Simeon, twelve thousand sealed: Of the tribe of Levi, twelve thousand sealed: Of the tribe of Issachar, twelve thousand sealed: 8. Of the tribe of Zabulon, twelve thousand sealed: Of the tribe of Joseph, twelve thousand sealed: Of the tribe of Benjamin, twelve thousand sealed. 9. After this I saw a great multitude, which no man could number, of all nations, and tribes, and peoples, and tongues, standing before the throne, and in sight of the Lamb, clothed with white robes, and palms in their hands: 10. And they cried with a loud voice, saying: "Salvation to our God, who sits upon the throne, and to the Lamb." 11. And all the angels stood round about the throne, and the ancients, and the four living creatures; and they fell on their faces before the throne and adored God, 12. Saying: "Amen. Benediction, and glory, and wisdom, and thanksgiving, honor, and power, and strength to our God for ever and ever. Amen."

\section{Inscriptions:}

[arranged in four rows of three figures each]

ex tribuiuda/ ex tribu ruben/

ex tribu aser/

ex tribu symeon/

ex tribu ioseph/ ex tribu naptalim/ ex tribu isachar/ ex tribu beniamin/ ex tribu gaad/ ex tribu manasse/ ex tribu zobulo/ ex tribu dan/ 
The Lamb stands within a gilt triangle in the center of the composition. Above, the 144,000 sealed are represented in four groups of three symbolizing the twelve tribes of Israel, each identified by a label. Below the Lamb is a throng of men making up "all nations and tribes and peoples and tongues." They hold palms as they celebrate the Lamb, although contrary to the storia, they are not dressed in white robes, but in ordinary knee-length garments of various colors.

It was within the explanatio of this part of the Commentary that Beatus stated that the end of the sixth age since creation was approaching. The seventh age was expected to usher in the rule of Christ. No reflection of this expectation is found in the Geneva illustration. Indeed, the enthroned God and the four creatures symbolizing the Evangelists - imagery that one would expect in a scene of the Parousia, or Second Coming, and included in the storia - are here omitted, so that the image loses its eschatological implications.

This was true as well in the illustration in the Commentary in Burgo de Osma (No. 14, fol. $92^{\mathrm{v}}$ ). Although there the Lamb is raised to the level of the ranks of the sealed, the components are identical.

\section{The Seven Angels with Trumpets (fol. 198 $8^{\mathrm{v}}$ )}

Apoc. VIII, 2-5. See Fig. 124, p. 224.

And I saw seven angels standing in the presence of God; and there were given to them seven trumpets. 3. And another angel came, and stood before the altar, having a golden censer; and there was given to him much incense, that he should offer it with the prayers of all the saints upon the golden altar, which is before the throne of God. 4. And the smoke of the incense of the prayers of the saints ascended up before God from the hand of the angel. 5. And the angel took the censer, and filled it with the fire of the altar, and cast it on the earth, and there were thunders and voices and lightnings, and a great earthquake.
This illustration is a rather literal pictorial version of Verses 2-4 of the storia. However, the calamitous result that attends the emptying of the censer by the angel is not alluded to. In the Branch II pictorial reform this latter part of the narrative produced a striking landscape. Once again, of the Branch I copies, only the Lorvão (No. 22) and Osma (No. 14) manuscripts have retained their illustrations of this episode. Both spread the scene across two pages, and both include a panel in which arrows represent, one assumes, the flashes of lightning. Beatus himself would return to the Commentary of this passage for his conception of the Last Judgment (see Fig. 165).

\section{The First Trumpet: Hail, Fire, and Blood}

(fol. 199)

Apoc. VIII, 6-7. See Fig. 125, p. 225.

And the seven angels who had the seven trumpets prepared to sound them [that is, the seven churches readied themselves to preach]. 7. And the first angel sounded the trumpet, and there followed hail and fire, mingled with blood [The ire of God was ignited, which involved the death of many], and it was cast on the earth, and the third part of the earth was burnt up, and the third part of the trees was burnt up, and all green grass was burnt up.

Uniquely, this storia was never separated and labeled as such by Beatus; rather, it appears at the end of the previous explanatio. Although the Branch II Commentaries offer dramatic scenes of fire, hail, and burning trees, the primitive stage of the iconography presented only the trumpeting angel seen here and in the same form in the Escorial Beatus (No.10, fol. 92), the Corsini Commentary (No. 17, fol. 116), and other Branch I copies. 


\section{The Second Trumpet: The Mountain Cast} into the Sea (fol. 20o)

Apoc. VIII, 8-9. See Fig. 126, p. 226.

And the second angel sounded the trumpet: and as it were a great mountain, burning with fire, was cast into the sea, and the third part of the sea became blood: 9. And the third part of those creatures died, which had life in the sea, and the third part of the ships was destroyed.

Inscriptions:

mons ignis [?]//

ubi tertia/ pars maris/ sanguis efficitur

In the left column of folio 200, the burning mountain is included as a red pyramidal shape perched above a sea that is divided into three parts, the central one of which has fish among red waves, indicating blood. The remaining two parts are sea green in color. This interpretation finds a parallel in the same illustration in Vitrina 14-1 (No. 3, fol. 96), where a brown sea is populated with fish. Here the human victims that are included in the Escorial Beatus (No. 10, fol. $93^{\mathrm{v}}$ ) and the Osma Commentary (No. 14, fol. $104^{v}$ ), presumably casualties of the ships that perished, are omitted.

\section{The Third Trumpet: The Burning Star}

(fol. 200)

Apoc. VIII, 10-11. See Fig. 126, p. 226.

And the third angel sounded the trumpet, and a great star fell from heaven, burning as it were a torch, and it fell on the third part of the rivers, and upon the fountains of waters: 11. And the name of the star is called Wormwood. And the third part of the waters became wormwood; and manymen died of the waters, because they were made bitter.

In the right column of folio 200 , the arc of heaven releases a red, eight-pointed star that enters a green sea. As in the illustrations of Vitrina 14-1 (No. 3, fol. $96^{\mathrm{v}}$ ) and the Osma Beatus (No. 14, fol. 105), there are no human victims of the poisonous absinthe. Although the composition of the Escorial Commentary (No. 10, fol. 94) resembles the Osma illustration, in the Escorial version the bodies of the dead are included.

The Fourth Trumpet: The Darkening of the Sun, the Moon, and the Stars (fol. 200 ${ }^{v}$ )

Apoc. VIII, 12-13. See Fig. 127, p. 227.

And the fourth angel sounded the trumpet, and the third part of the sun was smitten, and the third part of the moon, and the third part of the stars, so that the third part of them was darkened, and the day for a third part of it might not shine, and the night likewise. 13. And I beheld, and heard the voice of an eagle flying through the midst of heaven, saying with a loud voice: "Woe, woe, woe" to the inhabitants of the earth because of the rest of the trumpet voices of the three angels who were about to sound the trumpet.

Inscriptions:

perhaps "luna" written on corresponding image of moon?

The painter translated the text rather literally by darkening the discs of the red sun and pale moon by a third, along with three points of each nine-pointed star.

\section{The Fifth Trumpet: The Star that Falls} from Heaven and the Plague of the Locusts (fol. 201 ${ }^{v}$ )

Apoc. IX, 1-6. See Fig. 128, p. 228.

And the fifth angel sounded the trumpet, and I saw a star fall from heaven upon the earth, and there was given to him the key of the bottomless pit. 2. And he opened the bottomless pit: and the smoke of the pit arose, as the smoke of 
a great furnace; and the sun and the air were darkened with the smoke of the pit. 3. And from the smoke of the pit there came out locusts upon the earth. And power was given to them, as the scorpions of the earth have power: 4 . And it was commanded them that they should not hurt the grass of the earth, nor any green thing, nor any tree: but only the men who have not the sign of
God on their foreheads. 5. And it was given unto them that they should not kill them; but that they should torment them fivemonths: and their torment was as the torment of a scorpion when he strikes a man. 6. And in those days men shall seek death, and will not find it: and they shall desire to die, and death shall fly from them.

Inscriptions:

[toward the left:] ubi stella/ de celo cecidit// ubi locuste producunt [toward the right:] fumus [or furnus?] putei [?]// puteus [?]
Although four Branch I Commentaries preserve this illustration, there is little agreement among the versions due to an apparent confusion about the nature of locusts. The Latin word locusta can designate a winged insect or a marine animal, a kind of lobster or crab. Here the artist must have assumed a creature of the latter type, but more like a lamprey or large, vicious eel. While in Vitrina 14-1 (No. 3, fol. 98 ${ }^{\mathrm{v}}$ ) these creatures make no appearance, the other three Branch I copies include locusts that are neither eels nor winged insects. The locusts of the Osma Beatus (No. 14, fol. 106) resemble dogs, but with tails that end in barbs. The locusts of the Escorial copy (No. 10, fol. 95 ${ }^{v}$ ), on the other hand, are vaguely bird-like, especially their pairs of claws. Moreover, they are accompanied, uniquely, by nimbed males, who hold their tails. With the major reform of the pictorial tradition in the middle of the tenth century, Maius elected in the Morgan Beatus (No. 2, fol. 140 ${ }^{v}$ ) to identify them as scorpions, the analogous creatures cited in the storia (Verse 3). Only in the version in the Lorvão Beatus of 1189 (No. 22, fol. $140^{v}$ ) do the locustae resemble winged insects.

Between these creatures and the abyss is the key of the well of the abyss. Unique, too, in the Geneva illustration is the red disc occupied somewhat indistinctly by the bust of a male (?) figure. It is the sun toward which the smoke rises. As with the earth on folio 189, it is personified.

\section{The Angel of the Abyss and the Locusts}

(fol. 202)

Apoc. IX, 7-12. See Fig. 129, p. 229.

\begin{abstract}
And in appearance the locusts were like horses prepared for battle; and on their heads were crowns like gold, and their faces were as the faces of men. 8. And they had hair like the hair of women; and their teeth were like the teeth of lions: 9. And they had breastplates like breastplates of iron; and the noise of their wings was as the noise of chariots and many horses running to battle. 10. And they had tails like those of scorpions, and there were stings in their tails; and they had power to hurt mankind for five months. 11. And they had over them a king, the angel of the bottomless pit; whose name in Hebrew is Abaddon, and in the Greek Apollyon; in Latin Destroyer. 12. The first woe is past; behold, two woes are yet to come hereafter.
\end{abstract}

The Geneva Commentary's illustration is unique in that it omits victims stung by the locusts, a detail included in copies at the Escorial (No. 10, fol. $96^{\mathrm{v}}$ ) and Burgo de Osma 
(No. 14, fol. 108). Also unique is the inclusion of the angel of the abyss. He is presented as the bestial, satanic figure invoked in the explanatio. In his hand he holds, as if it were a scepter, a flaming miniature abyss, a detail inspired by the storia: "and they had over them a king," the angel of the abyss. It is unlikely that this figure was in the Commentary used as a model by our miniaturist.

\section{The Sixth Trumpet: The Angels of the}

Euphrates (fol. 202 ${ }^{\mathrm{v}}$ )

Apoc. IX, 13-16. See Fig. 130, p. 230.

And the sixth angel sounded the trumpet: and I heard a voice from the four horns of the golden altar, which is before the eyes of God, 14. saying to the sixth angel who had the trumpet, "Loose the four angels who are bound in the great river Euphrates." 15. And the four angels were loosed who had been kept ready for the hour, and a day, and a month, and ayear that theymight kill the third part of mankind. 16. And the number of the army of horsemen was a thousand times ten thousand twice over. And I heard the number of them.

\section{Inscriptions:}

ubi quattuor/ angeli[s?] tenentur trans/ flumen eufra/ten.// angelos liga/tos.

The regularity of the columns of text and the inversion of the angel's wing suggest that this illustration, unlike the majority, was inserted after the writing. The space left was too small to include the golden altar.

\section{The Horses of Death and Their Riders}

(fol. 203 ${ }^{v}$ )

Apoc. IX, 17-21. See Fig. 131, p. 231.

And this is how I saw the horses in the vision: they who sat on them had breastplates as offire and hyacinth and sulphur, and the heads of the horses were like the heads of lions: and from their mouths proceeded fire, and smoke, and sulphur. 18. And by these three plagues the third part of mankind was killed, by the fire and by the smoke and by the sulphur which issued out of their mouths. 19. For the power of the horses is in their mouths, and in their tails. For their tails are like serpents and have heads, and with them they do harm. 20. And the rest of mankind, they who are not killed by these plagues, did not repent of the works of their hands so as not to worship the demons and the idols of gold and of silver and of brass and of stone and of wood, which can neither see, nor hear, nor walk. 21. And they did not repent of their murders or of their sorceries or of their immorality or of their thefts.

This illustration, like the previous one, omits essential details, in this case the fire, smoke, and sulphur that issue from the mouths of the horses, and their number has been reduced in a scene that evidently was inserted after the page had been filled with writing. The tails of the horses are indeed like serpents, but for some reason they are gilt, like the helmet of the rider. The rider does not wear a breastplate of the color of fire, but rather a blue shirt that is covered with circles, suggesting chain mail, as in the riders of the Osma Beatus (No. 14, fol. 110).

\section{The Strong Angel: St. John Eats the Book}

(fol. 204)

Apoc. X, 1 - XI, 2. See Fig. 132, p. 232.

And I saw another mighty angel come down from heaven, clothed in a cloud, and a rainbow was over his head, and his face was like the sun, and his feet like pillars of fire. 2. And he had in his hand an open book; and he set his right foot upon the sea, and his left upon the earth. 3. And he cried with a loud voice as when a lion 
roars. And when he had cried, seven thunders spoke out their voices. 4. And when the seven thunders had uttered their voices, I was about to write; and I heard a voice from heaven saying to me: "Seal up the things which the seven thunders spoke and do not write them." 5. And the angel whom I saw standing on the sea and on the earth, lifted up his hand to heaven, 6. and swore by him who lives forever and ever, who created heaven and the things that are therein, and the earth and the things that are therein, and the sea and the things that are therein, that there shall be delay no longer, 7. but that in the days of the voice of the seventh angel, when he begins to sound the trumpet, the mystery of God will be accomplished, as he declared by his servants, the prophets. 8. And I heard a voice from heaven again speaking to me, and saying: "Go, and take the book that is open, from the hand of the angel who stands upon the sea, and upon the earth." 9. And I went to the angel, telling him to give me the book. And he said to me: "Take the book, and eat it up: and it shall make your stomach bitter, but in your mouth it will be sweet as honey." 10. And I took the book from the hand of the angel, and ate it up, and it was in my mouth sweet as honey, but when I had eaten it, my stomach was bitter. 11. And he said to me: "You must prophesy again to many nations, and peoples, and tongues, and kings." $X I, 1$. And there was given me a reed like a rod, and I was told: "Arise, and measure the temple of God, and the altar and those that worship within. 2. But the court outside the temple, reject it and do not measure it, for it has been given to the nations, and the holy city they will trample under foot for forty-two months."

Inscriptions:

per uibentem [for uiuentem] in secula quia/ tempus amplius non erit.

[Text from Apoc. X, 6 written on plaque held by angel, with script washed in ochre.]
One is immediately struck by the unorthodox dress of the large figure standing to the right of John. Not only does his size indicate his identity as the strong angel, but this role is confirmed by the rainbow over his head, the book in his right hand, and the green and brown areas representing the sea and the earth on which he stands. In his left hand he holds a framed text that is inspired by, but paraphrases, the storia: "[he swore] by Him who lives forever, because time is short."

John carries a rod with which to measure the temple, but that act is not included. Although in other Commentaries it is represented and features a temple with worshippers (Escorial, No. 10, fol. 100; Osma, No. 14, fol. 111), no space has been reserved for this important detail. Here one is again led to believe that, contrary to many illustrations in Geneva, this picture was composed after the writing had filled the page.

\section{The Two Witnesses (fol. $205^{\mathrm{v}}$ )}

Apoc. XI, 3-6. See Fig. 133, p. 233.

And I will grant to my two witnesses to prophesy for a thousand two hundred and sixty days, clothed in sackcloth. 4. These are the two olive trees and the two lampstands that stand before the Lord of the earth. 5. And if anyone desires to harm them, fire will come out of theirmouths and will devour their enemies. And if anyone desires to injure them, he must in this manner be killed. 6. These have power to shut heaven, so that it will notrain during the days of their prophesying; and they have power over the waters to turn them into blood, and to smite the earth with every plague as often as they desire. 7. This is my testimony, and he vanquished them and killed them, 8. and their dead bodies will lie in the streets of the great city.

Inscriptions:

helia// enoc 
Although neither Witness is identified in the storia, in the explanatio for this section, following Jerome's edition of the Commentary on the Apocalypse by Victorinus, one is recognized as Elijah, the prophet of I Kings, and the second as the prophet Jeremiah. However, the Preface of the Beatus Commentary, relying on Tyconius, provides the name Greek name Elias paired with Enoch, an identification that proved more popular in the Commentary and in medieval discussions of the Apocalypse elsewhere. In fact, the names Elias and Enoch are attached to the Witnesses in this illustration.

The beards and hooded robes, exceptional although not unique in Beatus illustration, enhance their identities as Old Testament prophets. Although the storia speak of them allegorically as two olive trees and two candelabra, this composition does not include either of these attributes (candelabra would be added in the Branch II Commentaries). Although two palms appear between the Witnesses in the Osma Beatus (No. 14, fol. 113), they are not part of the illustration in the Branch I Commentaries of Saint-Sever (No. 13, fol. 153) or Vitrina 14-1 (No. 3, fol. 104); in the picture in the late twelfth/early thirteenth-century Navarre Commentary in Paris (No. 23, fol. 97 v), the prophets pluck fruit from a bifurcated tree. Unfortunately, the Escorial Beatus has lost this illustration and so it cannot contribute to the question of the original composition. The absence of the palms in the Geneva Beatus, however, suggests they were not in the archetype.

Although the storia ends with the death of the witnesses, that event is not discussed in the explanatio, but is taken up and illustrated in the following section.

\section{The Two Witnesses Killed by the Antichrist}

(fol. $206^{v}$ )

Apoc. XI, 7-10. See Fig. 134, p. 234.

He shall vanquish them, and kill them. 8. And their bodies shall lie in the streets of the great city, which is called spiritually Sodom and Egypt, where their Lord also was crucified. 9 . And they of the tribes, and peoples, and tongues, and nations, shall see their bodies for three days and a half: and they shall not suffer their dead bodies to be laid in sepulchres. 10. And they that dwell upon the earth shall rejoice over them, and make merry: andshall send gifts one to another, because these two prophets tormented them that dwelt upon the earth.

Inscriptions:

antichristus// ubi occiditur/ elia et [?] enoch [?]

The Vulgate associates the beast from the abyss with the death of the Witnesses, but the Beatus text, based on the African Vetus Latina, does not name an agent. Nevertheless, the explanatio assigns their death to the Antichrist and that label appears beside the enthroned figure here. Although the Antichrist is crowned in the Osma Beatus (No. 14, fol. 114), the Geneva copy is the only one in which he is so regally installed. In both Branch I and Branch II Commentaries the swordsman about to sever the head of a Witness is labeled the Antichrist, but in the Geneva Beatus, the inscription beside the figure who removes their heads reads "where Elias and Enoch are killed."

The final degradation of the Witnesses - their bodies left lying in the streets of the city allegorically identified as Sodom and Egypt according to the storia - is minimally alluded to by the structure of the throne of the Antichrist. 
The Two Witnesses Ascend into Heaven and an Earthquake Is Produced (fol. 207)

Apoc. XI, 11-14. See Fig. 135, p. 235.

And after three days and a half, the spirit of life from God entered into them. And they stood upon their feet, and great fear fell upon those who saw them. 12. And they heard a great voice from heaven saying to them, "Come up hither." And they went up to heaven in acloud, and their enemies saw them. 13. And at that hour there was a great earthquake, and the tenth part of the city fell; and there were slain in the earthquake seven thousand men, and the rest were frightened and gave glory to God and to heaven. 14. The second woe is past; and behold, the third woe will come quickly.

Inscriptions:

helia// enocha//

isti remanserunt in terre motu//

isti sunt qui ceciderunt in terre/ motu cum suis [?] ciui/tatis [or -tatibus? text damaged]

Elias and Enoch stand within a cloud beneath the arc of heaven. Beneath them, framed by the battlements of the city, can be seen a multitude of the enemies who witnessed their ascension. As a result of the earthquake half of the city has been neatly sliced off and its victims buried.

\section{The Angel of the Seventh Trumpet (fol. $207^{v}$ )} Apoc. XI, 15-18. See Fig. 136, p. 236.

And the seventh angel sounded the trumpet: and there were great voices in heaven, saying, "The kingdom of this world is become our Lord's and his Christ's, and he shall reign for ever and ever." [FINIT]. 16. And the twenty-four elders who sit upon their thrones before God fell on their faces and worshipped God saying, 17. "We give you thanks, O Lord God almighty, who is, who was, because you have taken your great power and have begun your reign. 18. And the nations were angered, butyour wrath came and the time for the dead to bejudged, and for giving the reward to your servants - the prophets and the saints, and those who fear your name, the small and the great - and for destroying those who corrupted the earth."

Although the storia invokes the adoration of The twenty-four Elders, who in Chapter IV of the Apocalypse help constitute the court of the Almighty, only the angel of the seventh trumpet is represented in this copy, as in all others illustrated Beatus Commentaries.

Clearly this figure was painted before most of the text of the second column was written, with the commencement of each line of text carefully adapted to the angel's bent leg.

\section{The Temple of the Ark and the Beast of the}

Abyss (fol. 208)

Apoc. XI, 19 + Bk. VI. See Fig. 137, p. 237.

And the temple of God was opened, in heaven: and the ark of his testament was seen in his temple, and there were lightnings, and voices, and an earthquake, and great hail. [And I saw, it says, the beast ascending from the abyss].

\section{Inscriptions:}

ubi templum apertum/ [on other side of drawing] est.

et arca testimen/ti appa/ruit.//

arca [no inscription for bestia in second column]

This Apocalyptic text appears not as a storia, but as the conclusion of the introduction to Book VI. It is unusual, too, in reaching back to incorporate an earlier verse (XI, 7). In the pictorial reform of Branch II the Beast was made part of the Temple, but in the Escorial Beatus (No. 10, fols. 103 ${ }^{\mathrm{v}}-104$ ) 
and the Burgo de Osma copy (No. 14, fols. 116 $6^{\mathrm{v}}$ 117), the Beast is separated from the Temple and appears within the text of the explanatio, as here.

On the other hand, in those same two Commentaries, the Temple was not rendered as a building holding an ark, but as an abstract design featuring a rectangular frame with a quadrilobe inscribed within. In the Geneva Beatus, however, there is a structure resembling the kind of ciborium found in a church, an interpretation enunciated in the opening of the explanatio. It is labeled the open temple, with the Ark appearing as a gilt rectangle sheltered below. In the adjacent column the Beast rises diagonally with what appears to be an evocation of the smoke that issues forth from the abyss on folio $201^{v}$ in the illustration of the Fifth Trumpet (Apoc. IX, 1-6; see Fig. 128).

\section{The Woman Clothed in the Sun (fol. $208^{\mathrm{v}}$ )}

Apoc. XII, 1-18. See Fig. 138, p. 238

And a great sign appeared in heaven: a woman clothed in the sun, and the moon was under her feet, and upon her head a crown of twelve stars. 2. And being with child she cried out in her labor and was in the anguish of delivery. 3. And another sign was seen in heaven, and behold, a great red dragon having seven heads and ten horns, and upon his heads seven crowns. 4. And his tail was dragging along the third part of the stars of heaven, and it dashed them to the earth; and the dragon stood before the woman who was about to deliver, that when she delivered he might devour her son. 5. And she brought forth a male child, who is to rule all nations with a rod of iron; and her child was caught up to God and to his throne. 6. And the woman fled into the wilderness, where she has a place prepared by God, that there she may be nourished for a thousand two hundred and sixty days. 7. And there was a battle in heaven. Michael and his angels battled with the dragon, and the dragon fought, and his angels. 8. And they did not prevail, neither was their place found any more in heaven. 9. And that great dragon was cast down, the ancient serpent, he who is called the devil and Satan, who leads astray the whole world; and he was cast down to the earth and with him his angels were cast down. 10. And I heard a loud voice in heaven saying, "Now has come the salvation, and the power and the kingdom of our God, and the authority of his Christ; for the accuser of our brothers has been cast down, he who accused them before our God day and night. 11. And they overcame him through the blood of the Lamb and through the word of their witness, for they did not love their lives even in face of death. 12. Therefore rejoice $O$ heavens, and you who dwell therein. Woe to the earth and to the sea, because the devil has gone down to you in great wrath, knowing that he has but a short time." 13. And when the dragon saw that he was cast down to the earth, he pursued the woman who had delivered the male child. 14. And there was given to the woman the two wings of the great eagle that she might fly into the wilderness unto her place, where she is nourished for a time and times and a halftime, away from the serpent 15. And the serpent cast out of his mouth after the woman water like a river that he might cause her to be carried away by the river. 16. And the earth helped the woman, and the earth opened her mouth and swallowed the river that the dragon had cast out of his mouth. 17. And the dragon was angered at the woman, and went away to wage war against the rest of her offspring, who keep the commandments of God, and hold fast the testimony ofJesus. 18. And he stood upon the sand of the sea.

Inscriptions:

sol//

mulier amicta sole//

draco uomuit post mulierem//

luna//

ubi mulier fugit ad [smudge]/-dem 
Figure 104 The Woman Clothed in the Sun (Apoc. XII, 1-18). Escorial Beatus, fols. 104"-105. Escorial, Biblioteca del Monasterio, \&.II.5


Photos: John Williams 
Nowhere else is the challenge to fit an illustration into a single column of space so extreme as in this case, the longest storia of the Beatus Commentary. The illustrator managed, nevertheless, to include the Woman, twelve stars, the sun and the moon with delicately drawn faces, and the seven-headed red dragon whose tail encloses five stars and whose mouth spews forth a green river. On the lowest level the Woman, who has given birth, holds her son, "he who is to rule all nations with a rod of iron." She gazes upward, but the enthroned God was not included for want of space.

Not even Vitrina 14-1 (No. 3, fol. 109v) attempted to restrict this scene to one column. Due to the fortuitous distribution of the text, in both it and the Escorial Beatus (Fig. 104; No. 10) the double columns of space dedicated to the illustration were on facing pages.

There was no possibility that the tumultuous battle between the Archangel Michael and his angels, and the dragon and his angels - a mismatched contest that ended with the downfall of Satan and his followers - could be included. As a result, the Geneva illustration is essentially half of that in the Branch I versions of both the Escorial Beatus and the Burgo de Osma Commentary $\left(\right.$ No. 14, fol. $\left.117^{v}\right)$. In the case of the Geneva Beatus, however, there was no attempt to include the events of the latter part of the storia, for the text continues on the verso unbroken.

As the storia tells us, the woman is heavily pregnant; however, the Geneva Beatus is unique in making this obvious in the illustration (see Figs. 68 and 78).

\section{The Beast from the Sea (fol. 211)}

Apoc. XIII, 1-10. See Fig. 139, p. 239.

And I saw a beast coming up out of the sea, having seven heads and ten horns, and upon his horns ten diadems, and upon his heads names of blasphemy. 2. And the beast I saw was like a leopard, and his feet were like the feet of a bear, and his mouth like the mouth of a lion. And the dragon gave him his own strength, and great authority.3. And I saw one of its heads was as if it were killed, but the mortal wound was healed. And all the earth followed the beast in wonder. 4. And they worshipped the dragon because he gave authority to the beast: and theyworshipped the beast, saying, "Who is like to the beast? and who shall be able to fight with him?" 5 . And there was given to him a mouth to speak great things and blasphemies; and there was given to him authority to work for forty-two months. 6 . And he opened his mouth to blaspheme against God, to blaspheme his name, and his tabernacle, and them that dwell in heaven. 7. And he was allowed to wage war against the saints, and to overcome them. And authority was given to him over every tribe, and people, and tongue, and nation. 8. And all the inhabitants of the earth will adore him, whose names are not written in the book of life of the Lamb who has been slain from the beginning of the world. 9. If any man has an ear, let him hear. 10. He who is for captivity, into captivity he goes; he who kills by the sword, by the sword must he be killed. Here is the patience and the faith of the saints.

Inscriptions:

ubi draco/ dedit potesta [remainder trimmed]/ uestie [for bestie].

John was inspired here by the vision in the Book of Daniel, Chapter VII, where the four beasts that arise from the sea include a leopard and a beast with ten horns. Although the dragon is represented, there is no attempt to show those who worshipped him, a standard component in the other Commentaries. With the application of spots of color, the Geneva Commentary, uniquely once more, attempts to convey the fact that the beast is a leopard, in accordance with the storia. 
The Beast from the Earth (fol. 213)

Apoc. XIII, 11-17. See Fig. 140, p. 240.

And I saw another beast coming up out of the earth, and he had two horns, like those of a lamb, but he spoke like a dragon. 12. And he exercised all the authority of the former beast in his sight; and he caused the earth and its inhabitants to worship the first beast, whose deadly wound was healed. 13. And he did great signs, so that he made fire to come down from heaven upon the earth in the sight of men. 14. And he seduced them that dwell on the earth by the signs which were given him to do in the sight of the beast, saying to them that dwell on the earth that they should make the image of the beast which had the wound of the sword, and yet lived. 15. And it was permitted to give life to the image of the beast, that the image of the beast should both speak and should cause that whoever will not adore the image of the beast should be killed. 16. And he shall make all, both little and great, rich and poor, freemen and bondmen, to have a mark on their right hand or on their foreheads. 17. And will bring it about that no one might buy or sell, except him that has the mark, or the name of the beast, or the number of his name.

In the explanatio the beast from the earth represents the heretical and false priests and bishops in the Church, who disguise themselves in order to deceive. Thus the horns that would make them appear to be the Lamb stand in for the two testaments. As is the rule with the Beatus illustrations, there is no attempt to hint at these symbolic meanings in the illustration.

\section{To Know the Number and Name of the} Beast, Table I (fol. 217). See Fig. 141, p. 241.

Here is wisdom. He who has understanding, let him calculate the number of the beast, for it is the number of a man (Apoc. XIII, 18), that is, of
Christ, whose name the beast took as his own. Each of the individual letters contributes the quantity that pertains to this number and name, and the whole is interpreted thus: 666 (Commentary, Bk. VI).

This verse never was distinguished as a storia. It appears, however, in the explanatio for the Beast from the Earth, at which point the text is interrupted in order to insert two tables that calculate the number of the Beast. Beatus provided a "Key to the List and the Value of the Letters." This part of the Commentary drew on Jerome's edition of the Commentary on the Apocalypse by Victorinus of Pettau, and the Tables may have come from the same source, although they survive only in the Beatus Commentaries.

The eight names given to the Antichrist were Antechristum, Gensericus, Teitan, Damnatus, Diclux, Evantas, Antemus, and Acxyme. Numerical values were assigned to the letters of the alphabet, Greek and Latin, and the two Tables tally, each in its own way, the total value of the letters of each name. Thus in Antichrist Table I (fol. 217) the section at the upper left provides in its three columns, "For $\mathrm{A}=1$, for $\mathrm{N}$ $=40$, for $\mathrm{T}=100$, for $\mathrm{I}=5$, for $\mathrm{X}=4$, for $\mathrm{H}=8$, for $R=80$, for $I=8$, for $S=60$, for $T=100$, for $U=$ 200 , for $\mathrm{M}=30$." The total is then given as 666 .

In the Geneva Beatus only the first of the two Antichrist tables that formed from the beginning a standard component of the Beatus Commentary was included. Although it is announced in red letters on folio $217^{\mathrm{v}}$ (THE INSTRUCTOR OF THIS REGISTER AND THE MEANING OF ITS LETTERS), the second table, which normally followed the text at the top of the next page, was not attempted.

In general structure Table I in the Geneva Beatus resembles those of the Branch I copies, rather than Branch II. A comparison of the six Branch I Commentaries with Table I shows 
that Geneva differs most markedly from the schema found in the Commentary in Burgo de Osma (No. 14, fol. 127) and its two relatives, the Lorvão Beatus (No. 22, fol. 167) and the copy in the Corsini library in Rome (No. 17 , fol. 141). ${ }^{102}$ Closest in design are the Tables in Vitrina 14-1 (see Fig. 86; No. 3) of the first half of the tenth century, and in the $c .1000$ Escorial Beatus (see Fig. 87 ; No. 10). Both of these Commentaries have been linked to San Millán de la Cogolla, the latter firmly, the former more tenuously. ${ }^{103}$ Unfortunately, another Branch I copy from San Millán that is now in the Real Academia de la Historia (No. 9) does not preserve Table I, but its Table II was shown by Klein to be closely related to Vitrina 14-1, and we must assume that this would have been true of Table I as well. It is possible, therefore, that the model for the Geneva Beatus originated in San Millán, but this conclusion is subject to the possibility of a more or less faithful copying of the original Table in early Branch I copies wherever they were produced.

\section{The Lamb on Mount Sion and the Chaste}

(fol. 218)

Apoc. XIV, 1-5. See Fig. 142, p. 242.

And I saw and behold the Lamb stood upon Mount Sion, and with him a hundred and fortyfour thousand, having his name and the name of his father written on their foreheads. 2. And I heard a voice from heaven like the voice of many waters and like the voice of great thunder; and the voice that I heard was as the voice of harpers playing on their harps. 3. And they sang as it were a new song before the throne and before the four living creatures, and the elders; and no one could learn the song but those hundred forty-four thousand, who were ransomed from

102 Klein 1976, I: 323.

103 Williams 1994b, 34-37; Klein 2011a, 55-56. the earth. 4. These are they who were not defiled with women; for they are virgins. These follow the Lamb wherever he goes. These were ransomed from among men, the first-fruits to God and to the Lamb, 5. And in their mouth there was found no lie; they are immaculate.

Beneath Mount Sion and the Lamb who stands on it is a group of fifteen bust-length figures. They represent the 144,000 who for their chastity have been rescued by the Lamb and by the Father. Although other copies of the primitive family include the harp-playing musicians mentioned in Verse 2 as analogous to the voices singing the Lamb's praise, there is no attempt to do so here.

\section{The Angel with the Everlasting Gospel}

(fol. 219)

Apoc. XIV, 6-13. See Fig. 143, p. 243

And I saw another angel flying through the midst of heaven, having the eternal gospel to preach to those who dwell upon the earth, and to everynation, and tribe, and tongue, and people, 7. saying with a loud voice, "Fear God and give him honor, because the hour of his judgment is come; and worship him who made heaven and earth, the sea, and the fountains of waters." 8 . And another angel followed, saying, "She has fallen, Babylon the great, who of the wine of the wrath of her fornication has given all the nations to drink." 9. And the third angel followed them, saying with a loud voice, "If anyone worships the beast and his image, and receives a mark on hisforehead, or on his hand, 10. he also shall drink of the wine of the wrath of God, which is mingled unmixed with the wine in the cup of his wrath; and he shall be tormented with fire and brimstone in the sight of the holy angels, and in the sight of the Lamb. 11. And the smoke of their torments shall ascend forever and ever; and they rest neither day nor night, they who 
have adored the beast and his image, and anyone who receives the mark of his name." 12. Here is the patience of the saints, who keep the commandments of God, and the faith of Jesus. 13. And I heard a voice from heaven, saying to me, "Write: Blessed are the dead, who die in the Lord henceforth. Yes, says the Spirit, let them rest from their labors for their works follow them."

Inscription:

Timete dominum quia ue/nit hora iudicii eius.

[Text from Apoc. XIV, 7 written on plaque held by angel, with script washed in ochre.]

In other members of the Branch I family the illustrations for this storia include all three angelic messengers as well as, if only minimally, a part of the fallen city of Babylon, with its victims as dismembered bodies. The illustrator of the Geneva Commentary reduced the scene to a single impressive figure, the first angelic messenger, who holds up the Everlasting Gospel as an open scroll, displaying the message, "Fear the Lord and give him glory because the day of judgment has arrived."

\section{The Harvest of the Wrath of God (fol. 22o)}

Apoc. XIV, 14-20. See Fig. 144, p. 244.

And I saw, and behold, a white cloud; and upon the cloud one sitting like to the Son of Man, having on his head a crown of gold, and in his hand a sharp sickle. 15. And another angel came out from the temple crying with a loud voice to him that sat upon the cloud, "Thrust in your sickle, and reap, because the hour is come to reap, for the harvest of the earth is ripe." 16 . And he who sat on the cloud threw his sickle onto the earth, and the earth was reaped. 17. And another angel came out of the temple which is in heaven, he also having a sharp sickle. 18. And another angel came forth from the altar, who had authority over the fire, and he cried with a loud voice to him that had the sharp sickle, saying, "Put forth your sharp sickle, and gather the clusters of the vineyard of the earth, for its grapes are ripe." 19. And the angel cast his sharp sickle onto the earth, and gathered the vintage of the earth, and cast it into the great wine press of the wrath of God: 20. And the press was trodden outside the city, and blood came out of the wine press, up to the horses' bridles, for a thousand and six hundred stadia.

Inscriptions:

[at bottom of first column:] nubem

[beginning at top of second column and running down almost the full length of the column:] templum// iste uindemiat// ciuitatem idest ecclesiam// sanguis usque ad frenum equorum// iste [followed by smudged text, some in red]// iste metet

The illustration of this elaborate allegory of the Last Judgment was seriously challenged by a format that inserted images into single columns of text. Despite the limited space, the scene is unusually inclusive. The "Son of Man" on a cloud is shown as Christ in the Church. He appears wearing a crown of gold and holding a sharp sickle at the foot of the first column of text. The angel orders him to reap the harvest of the earth from the temple. The result of the command is represented just above and to the right, where an ordinarily dressed man harvests the stalks of the fruit of the earth.

The narrative shifts then to the top of the second column of text, where the temple that is in heaven shelters an altar and another angel, who, without the authority of the storia, holds a sickle and orders the harvesting of the grapes (iste vindemiat). Contrary to the storia, the harvest is carried out by a secular figure rather than an angel. Below is an arcade of four arches representing "the city, that is, the church." 
In contrast to the rather fully realized machines that appear in the Escorial Beatus (No. 10, fol. 120), Vitrina 14-1 (see Fig. 38; No. 3), and the Beatus of Burgo de Osma (No. 14, fol. 131 $1^{\mathrm{v}}$ ), here the wine press "outside the city" is only sketchily suggested. However, the illustration of the Geneva Commentary does justice in a literal way to the blood that came forth "out of the wine press up to the horses' bridles" by including a bright red panel that indeed rises to the jaw of the horse. Unique to the Geneva Beatus is the bearded figure who faces the horse. An inscription to the right is illegible, but he may be satanic, for the explanatio states that the horses, who represent "the princes and rulers of the world," are ridden by the devil, "putting into action the more rapidly the evil of his works."

\section{The Seven Angels with the Seven Plagues}

(fol. 221 ${ }^{v}$ )

Apoc. XV, 1-4. See Fig. 145, p. 245.

And I saw another sign in heaven, great and wonderful: seven angels having the seven last plagues. For in them is filled up the wrath of God. 2. And I saw as it were a sea of glass mingled with fire, and them that had overcome the beast, and his image, and the number of his name, standing on the sea of glass, having the harps of God: 3. And singing the canticle of Moses, the servant of God, and the canticle of the Lamb, saying: "Great and wonderful are thy works, O Lord God Almighty; just and true are thy ways, $O$ King of Ages. 4. Who shall not fear thee, O Lord, and magnify thy name? For thou only art holy: for all nations shall come, and shall adore in thy sight, because thy judgments are manifest."

Inscriptions:

[above illustration of waves:] mare uitreum// [beneath illustration in lower margin:] Isti sunt angeli tenentes plagas nobissimas [for nouissimas].
Seven, the "perfect" number, resonates through the Commentary: Revelation was addressed to the seven Churches of Asia, and the opening of the seven seals of the Lamb visited the earth with deadly scourges. Now the unregenerate world is to suffer seven further scourges before the day of reckoning. Like the seven Trumpet Angels, the Plague Angels are, in allegorical terms, the seven Churches of Asia, in essence the One Church. The plagues are spiritual in nature, the seven vices of the human condition. There is no reference in the storia as to how the angels carry the plagues. In the Escorial Beatus (No. 10, fol. 122 ${ }^{v}$ ) they hold plates, while in the Osma Commentary (No. 14, fol. 133) they carry jars. In the next storia, Apocalypse XV, 5-8, the seven angels receive phialas aureas, golden bowls or saucers, and the cups held in the Geneva Beatus are indeed golden.

This illustration includes just half of the scene as described in the storia. In the other copies, "those who had overcome the beast" appear in a row holding harps (Osma) or lutes (Escorial), or in the case of Vitrina 14-1, stringed instruments played with bows (see Fig. 37; No. 3). The figures resemble the angels with plagues and are seven in number; they stand upon the sea of glass. In the Geneva Beatus the sea of glass appears above the seven Plague Angels, rather than beneath them as the storia prescribes. For lack of space only the first angel at the left is winged.

The Angels with the Plagues Exit the Temple (fol. 222)

Apoc. XV, 5-8. See Fig. 146, p. 246.

And after these things I looked; and behold, the temple of the tabernacle of the testimony in heaven was opened: 6 . And the seven angels came out of the temple, having the seven plagues, clothed with clean and white linen, 
and girt about the breasts with golden girdles. 7. And one of the four living creatures gave to the seven angels seven golden phials full of the wrath of God, who lives for ever and ever. 8. And the temple was filled with smoke from the majesty of God, and from his power; and no man was able to enter into the temple, till the seven plagues of the seven angels were fulfilled.

With the presence of the four living creatures we are returned to the celestial court of Chapters VII and XIV. Only the eagle is present; this symbol in Christian iconographic tradition represents St. John, the reputed author of the Apocalypse. Of the three surviving Branch I illustrations, only the Escorial Beatus includes the eagle (No. 10, fol. 123 v).

It is noteworthy that gold is applied liberally throughout Geneva and in this case in particular to both the golden phials and the structure, perhaps as a way of identifying the latter as the temple of the tabernacle; however, the illustrator ignored the stipulation in the storia that the angels wore golden girdles.

Omitted: The Plague Angels Are Ordered to Empty their Bowls (fol. 223)

Apoc. XVI, 1. See Fig. 147, p. 247.

And I heard a great voice out of the temple, saying to the seven angels: "Go, and pour out the seven phials of the wrath of God upon the earth."

The storia is followed immediately by the $e x$ planatio at the top of the first column on folio 223 without the insertion of an illustration. In all other Beatus copies the storia is followed by a picture of seven standing angels with their bowls. In Geneva, the illustrations of the action of the first three angels appear next to Verses 2, 3, and 4 as they are presented within the explanatio.
The First Angel Empties His Bowl on the

Earth (fol. 223 ${ }^{\mathrm{v}}$ )

Apoc. XVI, 2. See Fig. 148, p. 248.

And the first went, and poured out his phial upon the earth, and there fell a sore and grievous wound upon men, who had the mark of the beast; and upon them that adored the image thereof.

This text was a challenge for all Beatus illustrators. The earth of the illustration in the Geneva Beatus is enigmatically designed, but may in coloring represent an attempt to distinguish between land (green) and water (blue).

The Second Angel Empties His Bowl in the

Sea (fol. 224)

Apoc. XVI, 3. See Fig. 149, p. 249.

And the second angel poured out his phial upon the sea, and there came forth blood as it were of a dead man; and every living soul died in the sea.

The Third Angel Empties His Bowl in the Rivers (fol. 224) Apoc. XVI, 4-7. See Fig. 149, p. 249.

And the third poured out his phial upon the rivers and the fountains of waters; and they became blood. 5. And I heard the angel of the waters saying, "You are just, OLord, who is, and who was, O Holy One, because you have judged these things: 6. For they have shed the blood of saints and prophets, and have given them blood to drink; they deserve it." 7 . And I heard the altar saying, "Yes, O Lord God Almighty, true and just are your judgments." 
Inscriptions:

[unidentified symbol or word next to image in lower portion of first column]

There is little to distinguish the second from the third angel. Neither bodies of water were colored so as to indicate their conversion to blood. The third angel was clearly in place before the writing proceeded, as the text had to be fitted around the painting of the waters below and of the tip of the angel's wing in the second column.

\section{The Fourth Angel Empties His Bowl in the}

Sun (fol. 225)

Apoc. XVI, 8-9. See Fig. 150, p. 250.

And the fourth angel poured out his phial upon the sun, and it was given unto him to afflict men with heat and fire: 9. And men were scorched with great heat, and they blasphemed the name of God, who has power over these plagues, and they did not repent and give him glory.

Nearly identical in underdrawing to the second and third Plague Angels on folio 224 yet distinct in the manner of painting, a comparison of these angels indicates the likelihood that the Geneva Beatus was drawn by a single individual but colored by two. The colorist of this illustration is distinguished by the tendency to apply multiple sketchy lines of paint rather than filling in blocks of color.

\section{The Fifth Angel Empties His Bowl on the}

Throne of the Beast (fol. 225 ${ }^{\mathrm{v}}$ )

Apoc. XVI, 10-11. See Fig. 151, p. 251.

And the fifth angel poured out his phial upon the throne of the beast; and his kingdom became dark, and they gnawed their tongues for pain: 11. And they blasphemed the God of heaven because of their pains and wounds, and they did not repent of their works.

We last saw the seven-headed beast on folio 211 as he arose from the sea. There he was spotted as if to identify a leopard (see Fig. 139). Here, on the upper left side of the page, in response to the storia, where "his kingdom remained dark," he is tinted black.

\section{The Sixth Angel Empties His Bowl on the}

Euphrates (fol. 225 v)

Apoc. XVI, 12. See Fig. 151, p. 251.

And the sixth angel poured out his phial upon that great river Euphrates; and dried up the water thereof, that a waymight be prepared for the kings from the rising sun.

This illustration, at the lower left, differs little from the other Plague Angels to this point, although each varies slightly in gestures, position of wings, and shapes of cloaks.

\section{The Unclean Spirits like Frogs (fol. 225 )}

Apoc. XVI, 13-16. See Fig. 151, p. 251.

And I saw issuing from the mouth of the dragon, and from the mouth of the beast, and from the mouth of the false prophet, three unclean spirits like frogs. 14. For they are spirits of demons working signs, and they go forth unto the kings of the whole earth to gather them together for the battle on the great day of God Almighty. 15. "Behold, I come as a thief! Blessed is he who watches and keeps his garments, lest he walk naked and they see his shame." 16. And he gathered them together in a place that is called in Hebrew Armageddon.

The prophet, the beast, and the serpent/dragon appear one above the other in the right column, each with a frog issuing from his mouth. There 
is a curious detail without evident explanation: the side of the beast, an equine figure with the exception of his feet, has been pierced by a sword. Although the storia and the explanatio refer to the great battle on the day of judgment, there is no mention of an attack on any of the three creatures.

The Seventh Angel Empties His Bowl in the Air (fol. 227)

Apoc. XVI, 17-21. See Fig. 152, p. $25^{2}$.

And the seventh angel poured out his phial upon the air, and there came forth a great voice from the temple and from the throne, saying: "It is done." 18. And there was lightning, rumblings and peals of thunder, and there was a great earthquake, such a one as never had been since men were upon the earth, so great an earthquake it was. 19. And the great city was divided into three parts; and the cities of the nations fell. And Babylon the great was remembered before God, to give her the cup of the wine of his fierce wrath. 20. And every island fled away, and the mountains were not found. 21. And great hail, like a talent, came down from heaven upon men; and men blasphemed God because of the plague of the hail, for itwas very great.

\section{Inscriptions:}

[unidentified symbol or word next to image - perhaps related to the symbol or word on fol. 224?]

The location of the explanatio next to the legs of the angel rather than aligned with the left margin, as the storia written above, clearly indicates that the illustration on this folio preceded the execution of the explanatio. The illustrator chose to represent Babylon with a checkerboard pattern of masonry, a convention often used in medieval illustrations. The division into three parts follows the storia, but not in a way suggesting the effect of an earthquake, nor is the further natural violence hinted at. In contrast, the Commentary of Burgo de Osma (No. 14, fol. 140 ${ }^{v}$ ) depicts the destruction in terms of fallen columns, inverted arcades, and the heads, hands, and feet of victims. The Escorial Beatus (No. 10, fol. 132), however, does not include any sign of destruction. Rather, it adheres to the storia's claim that the city was divided into three parts, in a way completely unrelated to that employed in the Geneva Commentary, by framing the word civitas in three of the four corners of the frame of the composition. The content was expanded in the Escorial Beatus by suggesting through varying patterns of marks the presence of lightning, thunder, and the plague of hail, details not included in the Geneva copy. The Lorvão Beatus (No. 22, fol. $184^{v}$ ), a relative of the Osma Commentary, also fails to include a destroyed city, and the simpler version of the Geneva Beatus probably reflects the original illustration more faithfully than Osma's does.

\section{The Great Whore Seated upon the Waters}

(fol. 227 ${ }^{v}$ )

Apoc. XVII, 1-3. See Fig. 153, p. 253.

And there came one of the seven angels who had the seven phials, and spoke with me, saying: "Come, I will show you the condemnation of the great whore who sits upon many waters, 2. with whom the kings of the earth have committed fornication, and they who inhabit the earth have been made drunk with the wine of her immorality." 3 . And he tookme away in spirit into a desert.

The Whore was first introduced in the Prologue to Book II (see Fig. 108), where she rode the Beast. In that brief exegetical passage she 
Figure 105 The Great Whore and the Kings of the Earth (Apoc. XVII, 1-3). Escorial Beatus, fol. 133. Escorial, Biblioteca del Monasterio, \&.II.5

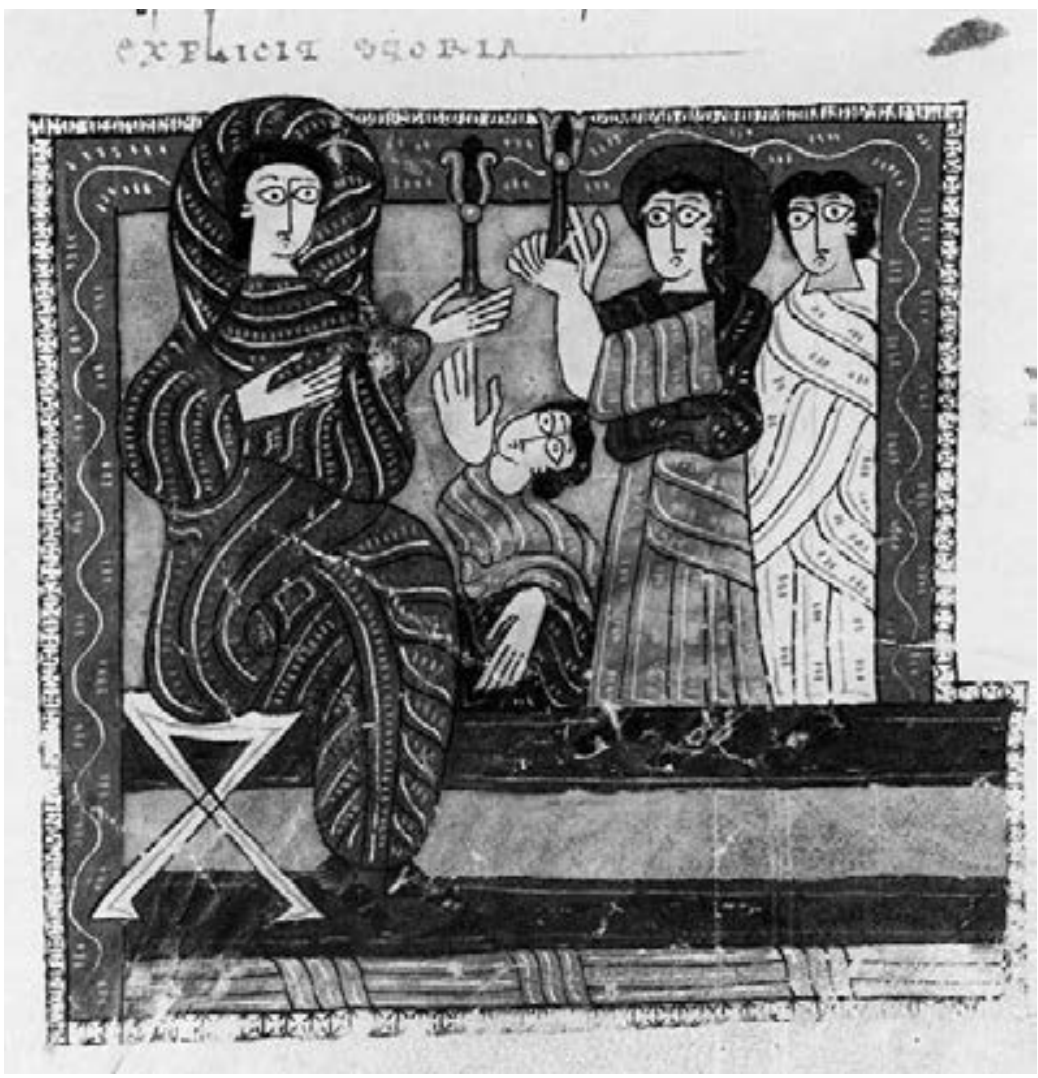

Photo: John Williams

stands for the injustices suffered by the people of the world, a community whose vast extent is symbolized here by the waters. The representations of the scene found in the two earliest Branch I Commentaries, Vitrina 14-1 (see Fig. 11; No. 3) and the Escorial Beatus (Fig. 105; No. 10), differ from each other and from the Geneva version. Despite the close relationship between the text of the Escorial Beatus and that of Geneva, the Escorial illustration is radically different. In the Escorial image, it is the Whore, rather than a king, who sits on the throne. She faces three of the inhabitants of the earth who were made drunk with the wine of her fornication.
The Geneva Beatus reverses the position of the figures: the Whore is seated to the right directly upon the waters and she offers the cup to the crowned and bearded figure seated on an elaborate throne at the left. In Vitrina 14-1, the Whore is seated at the left and enthroned over two flowing streams. She holds a pitcher and a cup, and offers the latter to a youthful male figure seated to the right. Since his head supports what may have been intended as a crown and he is enthroned, it may be that he is one of the kings. If so, this is essentially the composition and content of the scene in the Osma Beatus (No. 14, fol. 141 ${ }^{v}$ ), except for the absence of the angels. The illustration in the 
Figure 106 The Great Whore and the Kings of the Earth (Apoc. XVII, 1-3). Navarre Beatus, fol. 128. Paris, Bibliothèque nationale de France, Nouv. acq. lat. 1366

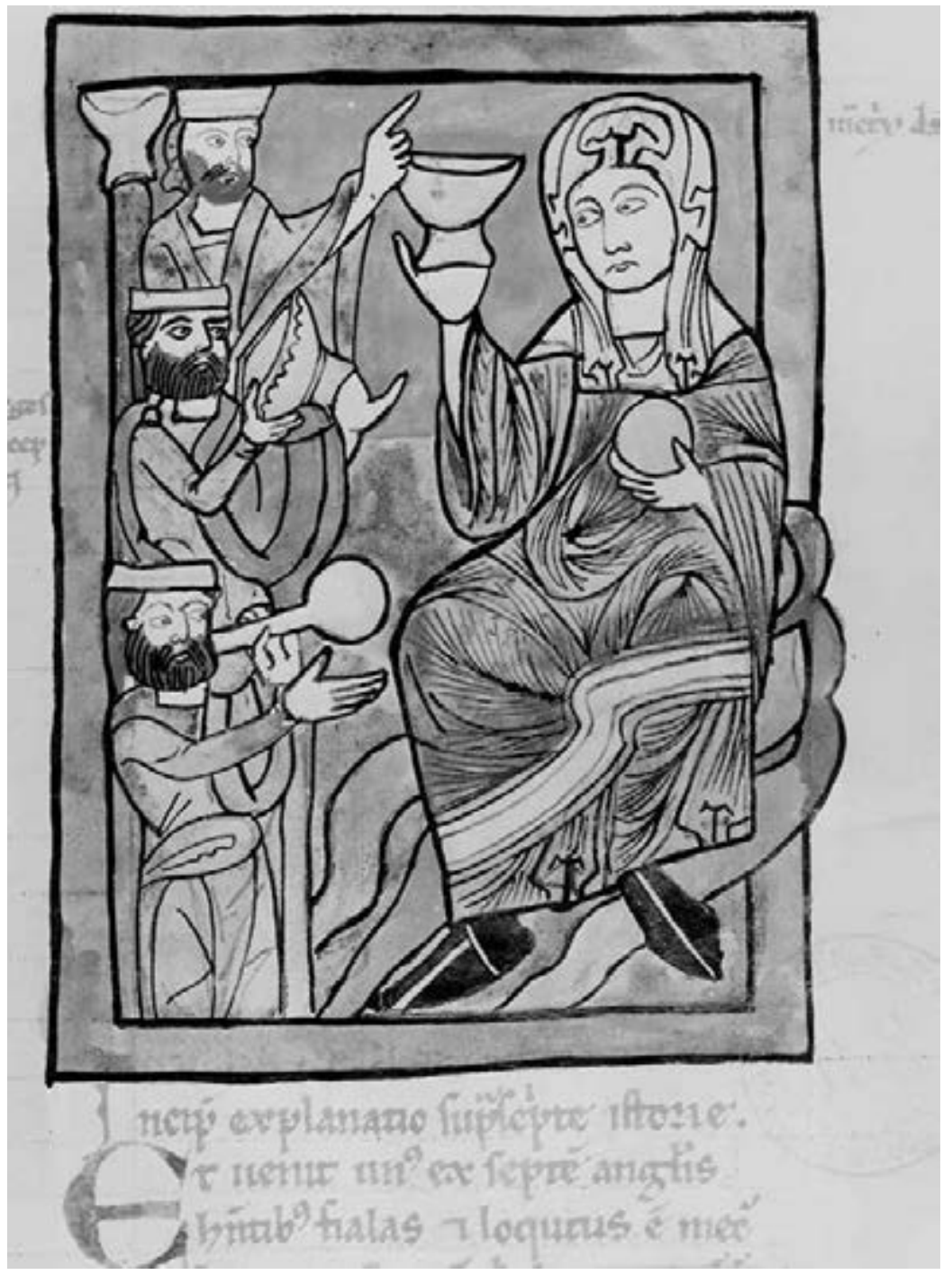

Photo: John Williams

Branch I Navarre copy in Paris (Fig. 106; No. 23), though it presents three kings instead of one, offers the closest parallel to that of Geneva: the Whore is seated to the right on cloud-like waters, and she offers a cup to bearded kings who face her.
The Woman Seated on the Scarlet Beast (fol. 228)

Apoc. XVII, 3-13. See Fig. 154, p. 254.

And I saw a woman seated upon a scarletcolored beast, full of names of blasphemy, having seven heads and ten horns. 4. And the woman was clothed in purple and scarlet, and 
covered with gold, and precious stones and pearls, having a golden cup in her hand, full of the abomination and filthiness of her immorality. 5. And on her forehead a name was written: A mystery; Babylon the great, the mother of the fornications, and the abominations of the earth. 6. And I saw the woman drunk with the blood of the saints and with the blood of the martyrs of Jesus. And when I saw her I wondered with great wonder. 7. And the angel said to me, "Wherefore do you wonder? I will tell you the mystery of the woman, and of the beast that carries her which has the seven heads and the ten horns. 8. The beast that you saw was, and is not, and is about to come up from the abyss, and will go to destruction. And the inhabitants of the earthwhose names have not been written in the book of life from the foundation of the world - will wonder when they see the beast which was and is not. 9. And here is the meaning for him who has wisdom. The seven heads are seven mountains upon which the woman sits; and they are seven kings; 10. five of them have fallen, one is, and the other has not yet come; and when he comes, he must remain a short time. 11. And the beast that was, and is not, is moreover himselfeighth, and is of the seven, and is on his way to destruction. 12. And the ten horns thatyou saw are ten kings, who have not received a kingdom asyet, but they will receive authority as kings for an hour with the beast. 13. These have one purpose, and their power and authority they give to the beast."

Although there is no attempt to dress the Woman in purple and scarlet, the painter did adorn her with a large circular polylobed brooch and grand earrings, along with bejewelled borders on her ample sleeves, so that externally, as the Commentary says, "she is shown with all kinds of allurements and false claims to truth in order to appear outwardly as Christianity." The only scarlet for both Woman and Beast is the deep red outlining each figure.

\section{The Victory of the Lamb (fol. 231)}

Apoc. XVII, 14-18. See Fig. 155, p. 255.

These ten kings will fight with the Lamb, and the Lamb will overcome them, for he is Lord of lords, and King of kings, and they that are with him are called, and chosen, and faithful. 15. And he said to me: "The waters which you saw, where the whore sits, are peoples, and nations, and tongues. 16. And the ten horns which you saw, and the beast, these will hate the whore, and will make her desolate and naked, and will eat her flesh, and will burn her with fire. 17. For God has put into their hearts to carry out his purpose, to give their kingdom to the beast, until the words of God be fulfilled. 18. And the woman whom you saw, is the great city, which has kingship over the kings of the earth."

\section{Inscriptions:}

Agnus uincet [neck of animal] pseudo prophetas/ .et draconem. et diabo [neck of animal] lum et bestia [sic]

Although the Lamb is at war with the Kings, in this illustration the Lamb stands victorious above the Beast, the Pseudo-prophet, and the Dragon, as the inscription specifies: "the lamb conquers the pseudo-prophet and the dragon and the devil and the beast." These enemies are not actually specified in the storia, but the explanatio mentions that the dragon, actually the devil, is an enemy, and cites false priests and hypocrites among the evil ones. The legend is not, therefore, a summary of the storia, as is usually the case. It provides, however, confirmation that the iconography is orthodox, for this legend matches that found in most copies of both Branch I and Branch II. Moreover the illustration in the Escorial Beatus displays a similar organization (see Fig. 9o; No. 10). While the legend confirms indirectly the orthodoxy of Geneva's iconography, it less certainly indicates 
that the model for the Geneva copy belonged to the part of the family tree related to the Escorial Beatus.

\section{The Burning of Babylon (fol. 232)}

Apoc. XVIII, 1-20. See Fig. 156, p. 256.

And after this I saw another angel coming down from heaven, having great authority, and the earth was lighted up by his glory. 2. And he cried out with a mighty voice, saying, "She has fallen, she has fallen, Babylon the great; and has become a habitation of demons, a stronghold of every unclean spirit, a stronghold of every unclean and hateful bird; 3 . Because all the nations have drunk of the wrath of her immorality, and the kings of the earth have committed fornication with her, and by the power of her wantonness the merchants of the earth have grown rich." 4 . And I heard another voice from heaven saying, "Go out from her, my people, that you may not share in her sins, and that you may not receive of her plagues. 5. For her sins have reached even to heaven, and the Lord has remembered her iniquities. 6. Render to her as she also has rendered, and give her double according to her works; in the cup that she has mixed, mix for her double. 7. As much as she glorified herself and gave herself to wantonness, so much torment and mourning give to her. Because in her heart she says, II sit a queen, I am no widow, and I shall not see mourning.' 8 . Therefore in one day her plagues shall come, death and mourning and famine; and she shall be burnt up in fire; for strong is God who will judge her. 9. And the kings of the earth who with her committed fornication and lived wantonly will weep and mourn over her when they see the smoke of her burning, 10. standing afar off for fear of her torments, saying, 'Woe, woe, the great city, Babylon, the strong city, for in one hour has your judgment come!' 11. And the merchants of the earth will weep and mourn over her; for no one will buy their merchandise anymore, 12. merchandise of gold and silver, and precious stones and pearls and fine linen and purple, and silk and scarlet, and all thyine wood, and all vessels of ivory, and allvessels of precious stones, and of brass, and of iron, and of marble, 13. and cinnamon and amomum and spices and ointment and frankincense, and wine and oil, and fine flour and wheat, and beasts of burden and sheep and horses, and chariots and slaves, and souls of men. 14. And the fruit which was the desire of your souldeparted from you; and all the fat and splendid things perished from you, and men will find them nevermore. 15. The merchants of these things, who grew rich by her, will stand afar off for fear of her torments, weeping and mourning, 16. and saying, 'Woe, woe, the great city which was clothed in fine linen and purple and scarlet, and gilded in gold, and precious stone and pearls; 17. For in one hour riches so great were laid waste!' And every shipmaster, and everyone who sails to a place, and mariners, and all who work upon the sea, stood afar off, 18. and cried out as they saw the place of her burning, saying, 'What city is like to this great city?' 19. And they cast dust on their heads, and cried out weeping and mourning, saying, 'Woe, woe, the great city, wherein all who had their ships at sea were made rich out of her wealth; for in one hour she has been laid waste!' 20. Make merry over her, O heaven, and you the saints and the apostles and the prophets, for God has judged your cause upon her."

Here the painter enjoyed an unusually generous and ordered space across both columns of text that might have served a picture accompanying this unusually long storia filled with stunning detail. Babylon, "the city of the devil," has fallen to God's judgment, with fire the instrument of destruction. The resulting collapse of the city is suggested by arcades that are 
destabilizing, and the fire is indicated through a pattern of sinuous red strokes. However, the decorative regularity of their disposition and the sense of stability created by the symmetry of the arches effectively undermines the chaos invoked by the storia. There is no sign of the merchants, kings, or mariners who witness the city's downfall. These victims appear in other copies, ordinarily within the city or standing outside it. Their presence on a facing page in Vitrina 14-1 (No. 3, fol. $143^{\mathrm{v}}$ ) suggests that such figures did appear in the illustration that served as the model for the scene in the Geneva Beatus.

\section{The Angel Casts the Millstone into the Sea}

\section{(fol. 233')}

Apoc. XVIII, 21-24. See Fig. 157, p. 257.

And a mighty angel took up a stone, as it were a great millstone, and cast it into the sea, saying: "With such violence as this shall Babylon, that great city, be thrown down, and will be found no more. 22. And the sound of harpers and musicians and flute players and trumpet will not be heard in you any more; and no craftsman or any craft will be found inyou any more; and the sound of the millstone will not be heard in you any more. 23. And lamp light will not shine in you any more, and the voice of bridegroom and of bride will not be heard in you any more; because your merchants were the great men of the earth, for by your sorcery all the nations have been led astray. 24. And in her was found the blood of prophets and of saints, and of all who have been slain upon the earth."

Despite the complexity of the storia, this image limits itself to a representation of just the first line, showing only the angel who begins to place the millstone into the sea. Sparse brush strokes of blue, green, and red waves flow over the stone, which has not been painted with the same sense of three-dimensionality as the figure who holds it. In contrast, both the Escorial (No. 10, fol. 141 ${ }^{\mathrm{v}}$ ) and Osma (No. 14, fol. 149) compositions indicate through the angels' postures the great weight of the stones that each is about to drop into seas teeming with fish.

As with many other Geneva illustrations, here we can again see that the image was drawn before the text was filled in around the angel's legs and feet.

\section{The Multitude in Heaven Praise God}

(fols. 234-234 ${ }^{v}$ )

Apoc. XIX, 1-10. See Fig. 158, p. $25^{8}$.

After these things I heard as it were the voice of a great crowd in heaven, saying, "Alleluia. Salvation, and glory, and power belong to our God. 2. For true and just are his judgments, who has judged the great whore who corrupted the earth with her fornication, and has avenged the blood of his servants, at her hands." 3. Andagain they have said, "Alleluia! And her smoke goes up for ever and ever!" 4. And the twenty-four elders and the four living creatures fell down and worshipped Godwho sits on the throne, saying: "Amen; Alleluia!" 5 . And a voice came forth from the throne, saying: "Praise our God, allyou his servants; and you who fear him, small and great!" 6 . And I heard as it were the voice of a great crowd, like the voice of many waters, and the voice of mighty thunders, saying, "Alleluia: for the Lord our God Almighty now reigns. 7. Let us be glad and rejoice, and give glory to him; for the marriage of the Lamb has come, and his spouse has prepared herself. 8. And it is granted to her to clothe herself in fine linen, glittering and bright, for the fine linen is the just deeds of the saints." 9. And he said to me, "Write: Blessed are they that are called to the marriage supper of the Lamb." And he said to me, "These are true words of God." 10. And Ifell down before his feet 
to worship him. And he said to me, "You must not do that. I amyourfellow servant, and ofyour brothers who give the testimony of Jesus. Worship God! For the testimony of Jesus is the spirit of prophecy."

Inscriptions:

fol. 234, [ochre wash on plaque, but no inscription]

fol. $234^{v}$ [inscription on ochre-washed plaque:] ubi iohannes angelum adorare uoluit

Since the final words of the storia, $D[e u] m$ adora, are written over the cross behind the head of Christ on folio 234, it is evident that the picture was already in place at the time of writing. Thus, it was the illustrator who determined that a relatively small amount of space should be allotted to this scene. Although the heavenly court described in the narrative included the four symbolic beasts and the twenty-four elders, only angels appear in the illustration, and the singing multitude is not alluded to pictorially. The figure of John receiving the command to write, a part of the scene in the Escorial Beatus (No. 10, fol. $142^{v}$ ) and that of Osma (No. 14, fol. $149^{v}$ ), appears in the space atop the first column of text on the following page, indicating again the priority of picture before text.

\section{The Rider Faithful and True (fol. 235)}

Apoc. XIX, 11-16. See Fig. 159, p. 259.

And I saw heaven opened, and behold a white horse; and he who sat upon it is called faithful and true, and with justice he judges and wages war. 12. And his eyes are as a flame offire, and on his head are many diadems, and he has a name written which no man knows except himself. 13. And he is clothed in a garment sprinkled with blood; and his name is called the Word of God. 14. And the armies of heaven, clothed in fine linen, white and pure, were following him on white horses. 15. And from his mouth goes out a sharp sword with which to smite the nations. And he will rule them with a rod of iron, and he treads the winepress of the fierce wrath of GodAlmighty. 16. And he has on his garment, and on his thigh a name written, King of Kings, and Lord of Lords.

Inspired by the opening words of the storia, the painter began by using a compass to draw the arc of heaven, ranging the figures that made up the army of heaven dressed in fine linen against the arc. On a larger scale than the rest appears a powerful image of the Rider, whose exalted rank as the Lord is suggested by an elaborate nimbus behind his crowned head. Certain details in the storia, such as the sword issuing from his mouth and the scepter of iron, were ignored in favor of a gold sword brandished over the Rider's head.

\section{The Angel Standing in the Sun (fol. 235 ${ }^{\mathrm{v}}$ )}

Apoc. XIX, 17-18. See Fig. 16o, p. 260.

\begin{abstract}
And I saw an angel standing in the sun, and he cried with a loud voice, saying to all the birds that fly through the midst of heaven, "Come, gather yourselves together to the great supper of God, 18. that you may eat the flesh of kings, and the flesh of tribunes, and the flesh of mighty men, and the flesh of horses, and of those that sit upon them, and the flesh of all men, free and bond, small and great."
\end{abstract}

Inscriptions:

The twelve months arranged within a circular drawing with Roman numerals not perfectly aligned with the months.

A comparison with the illustrations in the Escorial copy (No. 10, fol. 149) and the Osma Beatus (No.14, fol.152) indicates an almost exact alignment on the part of the Geneva Commentary with what must have been the archetypal composition. However, while retaining the original 
design, in which an angel stands behind the sun and addresses birds around its circumference, the Geneva Beatus has substituted a solar calendar for the usual fiery disc of the sun. ${ }^{104}$ It illustrates the relationship between the months of the Roman solar year, with the sun's entry into each of the signs of the Zodiac. Twelve overlapping circles divide the surface. The spaces created by the overlapping arcs of the circles have been inscribed with the names of the months, and numerals for the days. This temporal scheme of overlapping circles was not invented by the illuminator, but rather inherited from the Carolingian past, as may be seen in the ninth-century diagram in Paris, Bibliothèque nationale de France, MS lat. 5543 (fol. 141) that accompanies the De temporum ratione of the Venerable Bede in his chapter on "The Signs of the Twelve Months." ${ }^{105}$ A copy of this text, or one that involved cosmic schemes, must have been in the library of the unknown monastery that produced the Geneva Beatus.

In the words of the Commentary, the sun symbolizes the faith of the Catholic church and the angel standing in the sun is likened to the Archangel Michael, standing ready for battle when the last persecution of the Antichrist occurs at the end of time.

\section{The Defeat of the Beast (fol. 236)}

Apoc. XIX, 19-21. See Fig. 161, p. 261.

And I saw the beast, and the kings of the earth and their armies gathered together to wage war against him who sat upon the horse, and against his army. 20. And the beastwas taken, and with him the false prophet, who wrought signs before him, wherewith he deceived those who received

104 I am very much indebted to Faith Wallis for enlightenment as to the character and history of this type of solar calendar.

105 Migne 1862, cols. 373-74. the mark of the beast, and who worshipped his image. These two were cast alive into the pool of fire that burns with brimstone. 21. And the rest were slain by the sword of him that sits upon the horse, the sword that goes forth out of his mouth; and all the birds were filled with their flesh.

In the Escorial Beatus (No. 10, fol. 150) the Beast is seized at the top of the illustration, while below a swordsman grasps the hair of a figure that appears to have been killed. He is presumably the False Prophet. The seven behind him who have suffered the same fate would be the army of the kings of the earth. The inscription, "the beast is captured and the pseudo-prophet is captured" (bestia capta est pseudopropheta captus est) is, therefore, an apt one. Although there is no inscription here, the Geneva picture repeats the content of the Escorial illustration, including the omission of "him that sits upon the horse," but not the details or composition. A crowned warrior in chain mail cleaves with his sword the head of a man who is presumably the False Prophet, while one of the king's army thrusts a spear into the breast of the Beast, and another spears a follower of the False Prophet.

\section{The Devil Chained in the Abyss (fol. $236^{\mathrm{v}}$ )}

Apoc. XX, 1-3. See Fig. 162, p. 262.

And I saw an angel coming down from heaven, having the key of the abyss and a great chain in his hand. 2. And he laid hold of the dragon, the ancient serpent, who is the devil and Satan, and bound him for a thousand years. 3. And he cast him into the abyss and closed and sealed it over him, that he should no more deceive the nations, until the thousandyears should be finished. And after that he must be loosed for a little time.
Inscriptions:
clabes [for claues]
abissi/l
serpens/
diabolus 
With one exception, Geneva's illustration duplicates the compositions in the Escorial Beatus (see Fig. 89; No. 10) and that of Burgo de Osma (see Fig. 88; No. 14). In those two manuscripts it is the Devil rather than the Beast that is imprisoned. In showing the shackled head of the Beast emerging from the abyss, the illustrator of the Geneva Commentary followed the storia more literally, for it is the Beast who symbolizes the enchained Devil. The identity of the two is confirmed by the inscription beside the head: serpens/diabolus. The keys to the abyss, dangling from the angel's left hand, would be hard to recognize as such were they not labeled.

\section{The Millennial Judges and the Souls of the} Martyrs (fol. 237 ${ }^{\mathrm{v}}$, illustration omitted) Apoc. XX, 4-6

And I saw thrones and those who sat upon them and judgment was given to them. And I saw the souls of those who were beheaded for the witness of Jesus and for the word of God, and who had not worshipped the beast or his image, nor received his mark on theirforeheads, or upon their hands; and they lived and reigned with Christ a thousand years. 5. [the rest of the dead did not come to life till the thousandyears was finished.] 6. Blessed and holy is he who has part in the first resurrection. Over these the second death has no power; but they will be priests of God and of Christ; and will reign with him a thousandyears.

On folio $237^{\mathrm{v}}$ the text passes from the storia of Apocalypse XX, 4-6, to the explanatio without inserting its illustration.

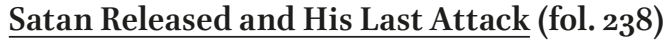
Apoc. XX, 7-9. See Fig. 163, p. 263.

And when the thousand years are finished, Satan will be loosed from his prison, and will go forth, and deceive the nations which are in the four quarters of the earth, Gog and Magog, [and will gather them together for the battle,] the number of whom is as the sand of the sea. 8. And they went up over the breadth of the earth and encompassed the camp of the saints, and the beloved city. 9. And fire came down out of heaven and devoured them.

Inscriptions:

[bottom of first column:] ubi angelus sol/uit satanas// ubi ignis/ cecedit/ super anti/christus [top of second column:] castra sanctorum

[in outer margin:] ubi absconduntur a facie anti/christus

This illustration presents perhaps the most radical departure from tradition. It begins at the bottom of the first column of text. Although not mentioned in the storia, an angel holds chains that break and allow the release of Sa$\tan$. At the top of the second column "the camp of the saints," identified by the legend castra sanctorum, shelters a group of the sanctified within a walled structure. They are threatened by Gog and Magog, names that appear in the Old Testament book of Ezekiel (Chapters XXXVIII, XXXIX) as the enemies of the Jews and here symbolize the vast multitude of the impious from the four corners of the earth, although neither of the two symbolic figures is depicted. While this multitude was destroyed by fire in Verse 9, it is only in the next storia, where the fire is repeated, that the punishment is illustrated.

Within an oval frame to the right of the camp of the righteous appears a multitude labeled as those who hide from the Antichrist. There is no reference in the storia to those who hide, but in the explanatio Beatus cites the Gospel of Matthew XXIV, 16: "they that are in Judea, let them flee to the mountains," so they may escape the destruction visited by the Antichrist. The illustration of the scene in the Escorial Beatus (see 
Fig. 51; No. 10) places figures in the mountains, but no inscription labels them. Even so, this picture differs fundamentally from that in the Geneva Beatus in its interpretation of the storia. On the one hand the Escorial Commentary does not include the figure of Satan being loosed, while on the other the Geneva draftsman chose to eliminate the two giant figures of Gog and Magog, who in the Escorial Beatus hold the "camp of the saints" in their hands. Escorial's interpretation must have been the archetypal formula, for it reappears in the Lorvão Beatus (No. 22, fol. 203 ${ }^{v}$ ). Gog and Magog also appear in the Osma Beatus (No. 14, fol. $155^{v}$ ), but there the camp is depicted as an arcaded city.

The Devil, the Beast, and the False Prophet in the Lake of Fire (fol. 239 ${ }^{v}$ )

Apoc. XX, 9-10. See Fig. 164, p. 264.

And fire from God came down out of heaven and devoured them. And the devil who deceived them was cast into the pool of fire and brimstone, where are also the beast 10. and the false prophet; and they will be tormented day and night for ever and ever.

\section{Inscriptions:}

[in outer margin to left of drawing:] infernus [to right of drawing:] diabolus

In this unusual reflection of the short storia, dagger-like flames descend from the arc of heaven and punish the impious people who had threatened the righteous in the previous storia. These include the most unexpected appearance of a centrally placed female figure. Also depicted are the Devil (identified by a legend), the Beast, and presumably the False Prophet at the left, here with a clerical tonsure. The representations in this scene of a naked woman and a tonsured man are unique within the Beatus tradition.
This picture is lacking in the Escorial Beatus, while the version in Osma (No. 14, fol. 157) features only an angel pushing a naked male figure, mounted on the beast, into the lake of fire; it is thus fundamentally different from the scene in the Geneva Beatus. The Branch II versions are in more general agreement with Geneva, so we must imagine that this reflects aspects of the archetype.

\section{The Last Judgment (fol. 240)}

Apoc. XX, 11-15. See Fig. 165, p. 265.

And I saw a great white throne, and the one who sat upon it, from his face the earth and heaven fled away, and there was no place found for them. 12. And I saw the dead, great and small, standing before the throne, and the books were opened; and another book was opened, which is the book of life; and the dead were judged by those things written in the books, according to their works. 13. And the sea gave up the dead that were in it, and death and hell gave up their dead that were in them; and they were judged every one according to their works. 14. And hell and death were cast into the pool of fire. This is the second death. 15. And whosoever was not found written in the book of life, he was cast into the pool of fire.

Inscriptions:

[three parallel bands of text, with ochre wash]

[1] Hii sunt qui non iudicabuntur. et iudices sunt. cum his qui iudicabuntur. utrique [?] regnant.//

[2] Hii sunt quos uibos [for uiuos] inuenerit. christus//

[3] Isti sunt mortui de inferno. qui non erant iudicati.

The Last Judgment became one of the central themes of medieval art, culminating in the 
grand portals of Gothic cathedrals. The version that developed outside Iberia was essentially based on the scene from Byzantine art, while the version in the Beatus Commentaries was older and different. Through the inscriptions of this illustration in the Geneva Beatus we can recognize the Italian designer's dependence on the Spanish Commentary that served as Geneva's model. The first line of the inscription, those "who are not to be judged and are judges and those who are judged yet reign" would apply to the figures flanking Christ. In the next register below are those "who are alive and encounter Christ," as the legend tells us. Those in the bottom register are characterized by the third line of inscription as the "dead in Hell who were not judged." ${ }^{{ }^{106}}$ This description of judgment is taken not from the storia or the explanatio flanking this picture, but from the First Trumpet Angel (fol. 199), a passage borrowed by Beatus from Gregory the Great's Moralia in Iob. These legends are standard in all branches of the Beatus family tree.

While the inscriptions show a clear dependence on a Beatus archetype, the composition does not resemble that in the Osma Beatus (see Fig. 95; No. 14) or its relative, the Corsini Beatus (No. 17, fol. 170), where seated figures judge and the damned fall into a fiery pit and deep waters. The picture in the Navarre Beatus (No. 23, fol. 146) also includes the punishment of the damned, as well as the "open scrolls" of the storia. ${ }^{107}$ However, in the other surviving Branch I version, the Lorvão Beatus now in Lisbon (No. 22, fol. 207), the punished are omitted in favor of two registers of bust-length figures similar to the Geneva Beatus. Although the Lorvão copy exhibits many parallels with the Osma Commentary, it is not based on it, offering instead another witness to the Branch

106 Klein 2011b, 287. 107 Klein 2011b, 287.
I tradition. It is possible that the Geneva picture is closer to the archetype than that in the Osma Beatus.

\section{The Heavenly Jerusalem (fol. 241)}

Apoc. XXI, 1-27. See Fig. 166, p. 266.

And I saw a new heaven and a new earth. For the first heaven and the first earth passed away, and the sea is no more. 2. And I saw the holy city, the New Jerusalem, coming down out of heaven from God, made ready as a bride adorned for her husband. 3. And I heard a loud voice from the throne saying, "Behold the dwelling of God with men, and he will dwell with them. And they will be his people, and God himself will be with them as their God. 4. And God will wipe away every tear from their eyes. And death shall be no more; neither shall there be mourning, nor crying, nor pain anymore, for the former things have passed away." 5 . And he who was sitting on the throne said, "Behold, I make all things new!" And he said, "Write, for these words are trustworthy and true." 6. And he said to me, "It is done! I am the Alpha and the Omega, the beginning and the end. To him who thirsts I will give the fountain of the water of life freely. 7. He who overcomes shall possess these things, and I will be his God, and he shall be my son. 8. But as for the cowardly and unbelieving, and abominable and murderers, and fornicators and sorcerers, and idolaters and all liars, their portion shall be in the pool that burns with fire and brimstone, which is the second death." 9. And there came one of the seven angels who had the bowls full of the seven last plagues; and he spoke to me, saying, "Come, I will show thee the bride, the spouse of the Lamb." 10. And he took me up in spirit to a mountain, great and high, and showed me the holy city Jerusalem, coming down out of heaven from God, 11. having the glory of God. Its light was like to a precious stone, as it were a jasper stone, clear as crystal. 12. And it had a 
wall great and high with twelve gates, and at the gates twelve angels, and names written on them, which are the names of the twelve tribes of the children ofIsrael. 13. On the east are three gates, and on the north three gates, and on the south three gates, and on the west three gates. 14. And the wall of the city has twelve foundation stones, and on them twelve names of the twelve apostles of the Lamb. 15. And he who spoke with me had a measure, a golden reed, to measure the city and the gates thereof and the wall. 16. And the city stands foursquare, and its length is as great as its breadth [...] 18. And the material of its wall was jasper; but the city itself was pure gold, like pure glass. 19. And the foundations of the wall of the city were adorned with every precious stone. The first foundation, jasper; the second, sapphire; the third, agate; the fourth, emerald; 20. the fifth, sardonyx; the sixth, sardius; the seventh, chrysolite; the eighth, beryl; the ninth, topaz; the tenth, chrysoprase; the eleventh, jacinth; the twelfth, amethyst. 21. And the twelve gates were twelve pearls; that is, each gate was a single pearl. And the street of the city was pure gold, as it were transparent glass. 22. And I saw no temple therein. For the Lord God almighty and the Lamb are the temple thereof. 23. And the city has no need of the sun or the moon to shine upon it. For the glory of God lights it up, and the Lamb is the lamp thereof. 24. And the nations shall walk by the light thereof; and the kings of the earth shall bring their glory and honor to it. 25. And its gates shall not be shut by day; for there shall be no night there. 26. And they shall bring the glory and the honor of nations into it. 27. And there shall not enter into it anything defiled, nor he who practises abomination and falsehood, but those only who are written in the book of life of the Lamb.

Inscriptions:

[The names of gems, except the first, appear outside the frame, and the names of apostles within, beginning at the upper left corner and moving clockwise around the square:] iaspis/ petrus/ saffirus/ andreas/ calcedonus// iacobus/ smaragdus/ simon/ sardonium [?]/ bartholomeus/ sardinum/ iacobus// griso/ ioannes/berillus/ philippus/ topation/ thomas// grisofus/ [no inscription for Jude Thaddeus]/ iacinthus [?]/ matheus/ [no inscription for amethyst]/ mathia/

Although John was the target of revelation, here he is not honored with the gilt nimbus that adorns his fellow apostles, including his own bust, which appears just below the figure of John within the city. He does not, for some reason, face the angel of revelation, and his hands are posed in a way that suggests reaction rather than submission. As for the angel, he does not hold the rod that he uses in the storia to measure the city. This omission aside, the composition resembles closely the Heavenly Jerusalem in the Branch I Commentary carried out in the twelfth century at the Portuguese monastery of Lorvão (Fig. 107; No. 22). Unfortunately, the Osma copy has no Heavenly Jerusalem.

With very few exceptions, medieval depictions of city walls and buildings, like those of the Roman world that preceded them, showed them in elevation, the view of ordinary experience. Here, however, the perspective may reflect a bird's-eye view consistent with the storia, where the city is seen from "a mountain, great and high." Although the city described in the storia is square, a perfect figure, the rectangular shape of the page clearly determined the form of its representation. Liberal in its application of gold throughout the manuscript, this feature, uncommon in all other known illustrated Beatus manuscripts, is especially apparent here. The scene in the Geneva copy is unique among all surviving Commentaries for the degree to which it emphasizes the city as being composed of "pure gold," and it is also 
Figure 107 The Heavenly Jerusalem. Lorvão Beatus, fol. 209v. Lisbon, Arquivo Nacional da Torre do Tombo

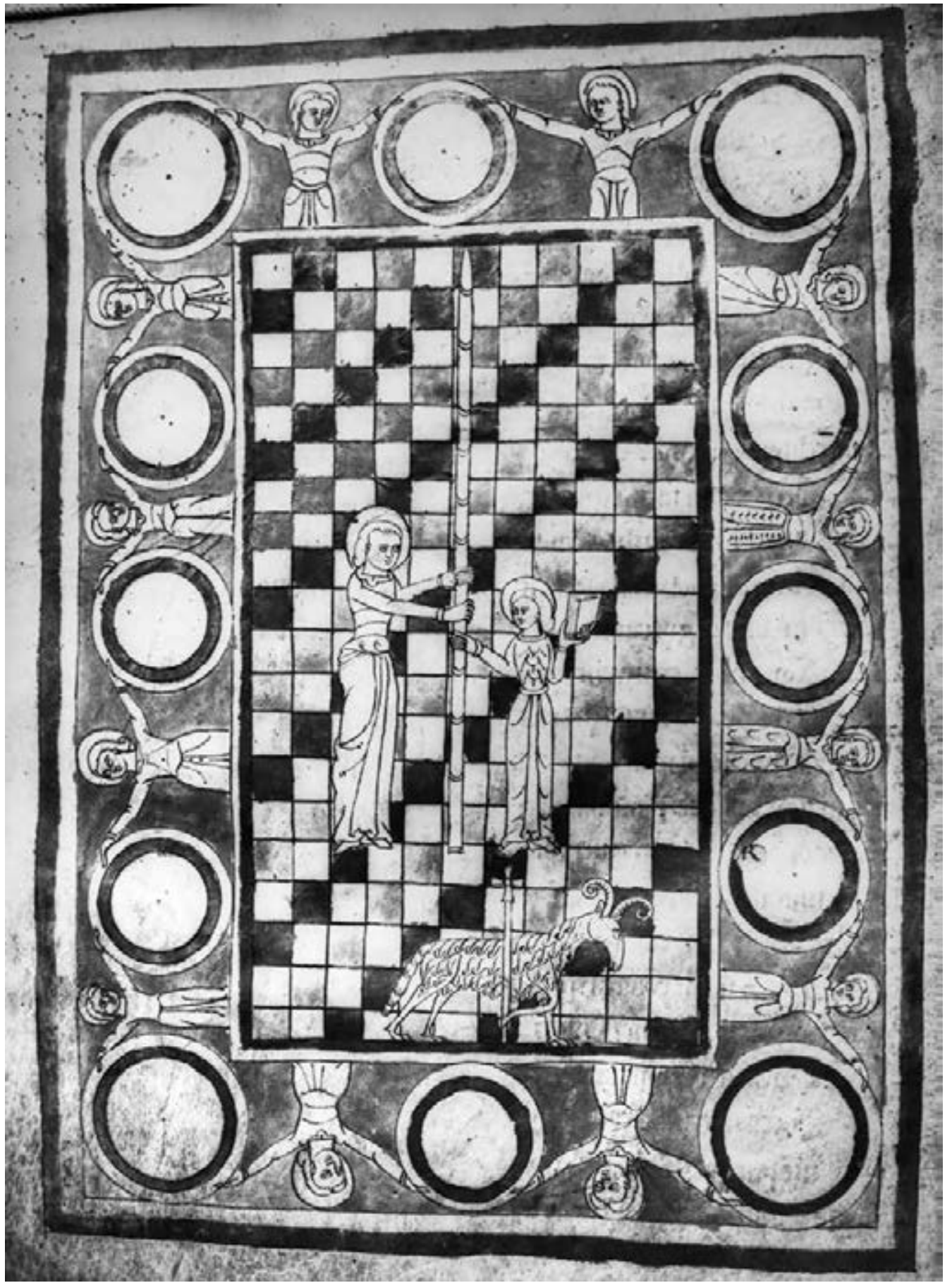

Photo: John Williams 
unique within Geneva itself for being a nearly full-page illustration.

The precious stones appear as discs alternating with the heads of the twelve apostles; their labels appear in the margins outside the city's frame, except the first - jasper - which is tucked into the upper left corner, and they follow the order of their appearance in the storia. In various instances the artist made an effort to evoke the actual color of a given stone. Thus on the right side the emerald is green, the sardonyx is layered, and the sardius (carnelian) is red.

Normally a depiction of the River of Life would have immediately followed, for the narrative describing it (Apoc. XXII, 1-5) was attached to the storia of the Heavenly Jerusalem. Since there is no loss of text, Geneva's illustrator/scribe must have decided to omit the picture, which is preserved in one other Branch I copy, the Lorvão Beatus (No. 22, fol. 210). Instead, the next illustration, St. John at the Feet of the Angel of the Apocalypse, reprises the principle elements of the scene, namely the Vision of God Enthroned and the Tree of Life.

\section{St. John at the Feet of the Angel of the}

Apocalypse (fol. 244 ${ }^{v}$ )

Apoc. XXII, 6-21. See Fig. 167, p. 267.

And he said to me, "These words are trustworthy and true; and the Lord, the God of the spirits of the prophets, sent his angel to show to his servants what must shortly come to pass. 7 . And behold, I come quickly. Blessed is he who keeps the words of the prophecy of this book." 8. And I, John, who have heard and seen these things, after I had heard and seen, Ifell down to worship at the feet of the angel, who showed me these things. 9. And he said to me, "You must not do that, I am a fellow servant of yours, of your brethren the prophets, and of those who keep the words of this book. Worship God!" 10. And he said to me, "Do not seal up the words of the prophecy of this book; for the time is at hand. 11. He who does wrong, let him do wrong still; and he who is filthy, let him be filthy still; [and he who is just, let him be just still; and he who is holy, let him be holy still.] 12. Behold, I come quickly! And my reward is with me, to render to each one according to his works. 13. I am the Alpha and the Omega, the first and the last, the beginning and the end." 14. Blessed are they who wash their robes that they may have a right to the tree of life, and may enter in by the gates into the city. 15. Outside are the dogs and the sorcerers, and the fornicators, and the murderers, and the idolaters, and everyone who loves and practises falsehood. 16. "I, Jesus, have sent my angel to testify to you these things concerning the churches. I am the root and the offspring of David, the bright morning star." 17. And the spirit and the bride say, "Come!" And let him who hears say, "Come!" And let him who thirsts come; and he who wishes, let him receive the water of life freely. 18. I testify to everyone who hears the words of the prophecy of this book. If anyone shalladd to them, God will add unto him the plagues that are written in this book. 19. And if any one shall take away from the words of the book of this prophecy, God will take away his portion from the tree of life, and from the holy city, and from the things that are written in this book. 20. He who testifies to these things, says, "It is true, I come quickly!" Come, LordJesus! 21. The grace of our Lord Jesus Christ be with all. Amen.

Inscriptions:

[to left:] ubi iohannes angelum adorat; aut et dixit angelus [text rubbed at end]

[only some of the names of churches are legible within architectural arches:] filadelfin/ ephesum/ tiatjra/ laudacia [lower portion of drawing badly rubbed]

This, the final vision granted to John, fittingly offers a brief recapitulation of the Apocalypse. 
Appropriately, the illustration resembles the depiction of the Vision of God and the Commission to Write (Apoc. I, 10-20), a scene not included in the Geneva Beatus. In fact, the storia offers little for the illustrator to draw on. Thus, despite not being mentioned in the storia, the seven Churches of Asia are presented as arches duly labeled with the names of the churches, as they are in other copies that incorporate the Vision of God and the Commission to Write. In the Osma Beatus (No. 14, fol. 159 v) and the Commentary from Lorvão (No. 22, fols. $\left.217-217^{v}\right)$, the labeled arches also appear, so they were not invented by Geneva's illustrator. On the other hand, the prominence given to the Tree of Life, not present in other copies, makes the scene a conflation of the previous storia, the River of Life Flowing from the Throne of God (fol. 240 ${ }^{v}$ ), for wavy vertical lines indeed depict water flowing down from the throne. As noted in the discussion of the Heavenly Jerusalem in the previous image, the illustration of the River of Life was omitted from the Geneva Beatus, but it must have been present in the manuscript serving as a model. 
Figure 108 The Woman on the Beast (Apoc. Prol. Book II.8), Geneva Beatus, fol. 149. Bibliothèque de Genève, MS lat. 357. For storia and image analysis, see page 167.

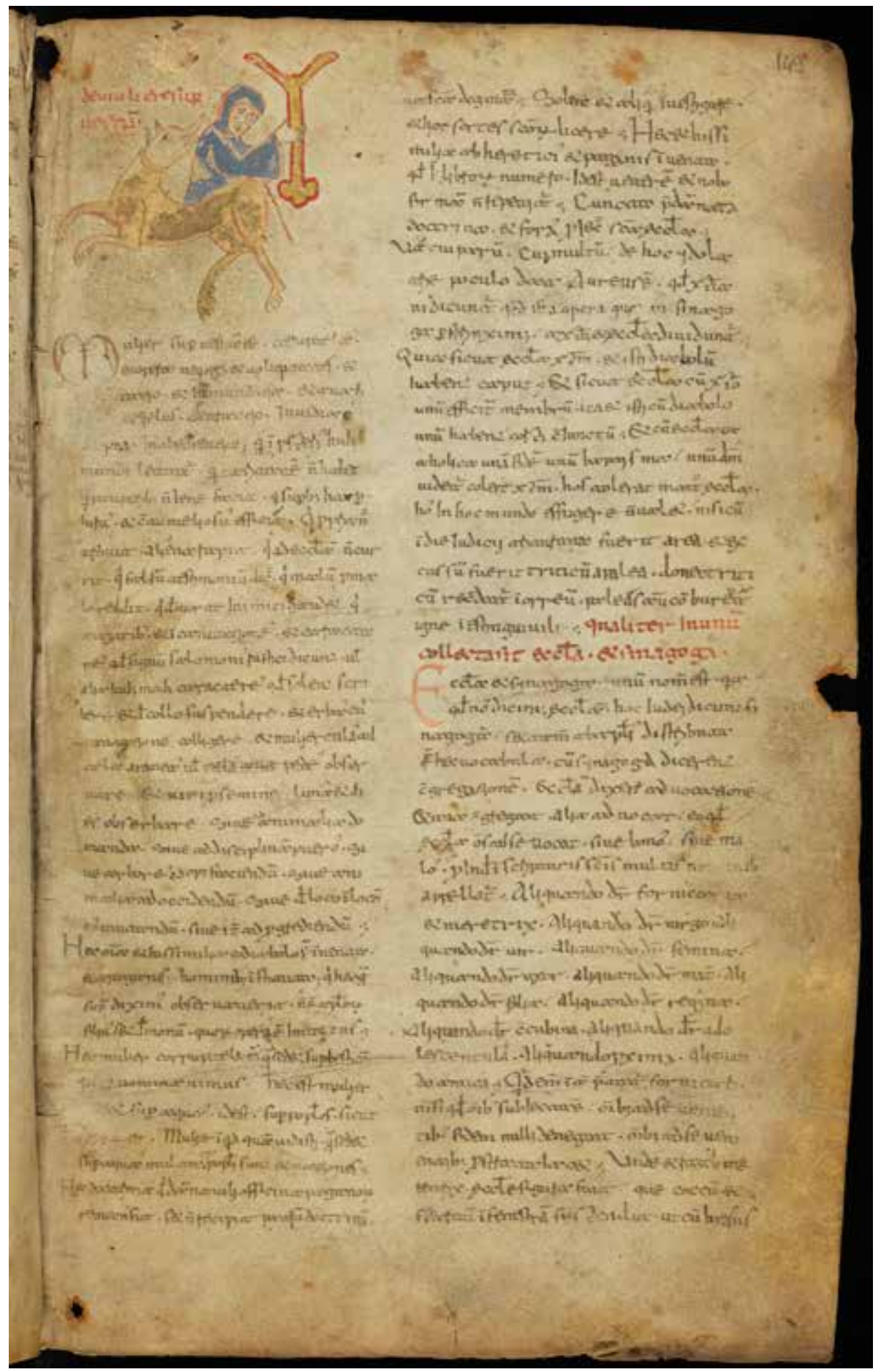


Figure 109 Letter to the Church of Ephesus (Apoc. II, 1-7). Geneva Beatus, fol. 152. Bibliothèque de Genève, MS lat. 357. For storia and image analysis, see page 167.

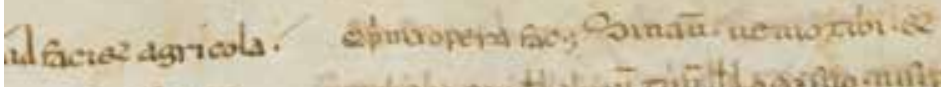
cocapartễ mes -ídurena rufa elie Imaganibus llo oreprane the for cam̃n aurueloxef - Lambå̃ Tearriz.

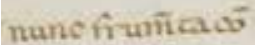
ruenerümulatu. ppopulat:.Faieren? ragtüpomides; mitu. Inmiculion a.latis enzidioundä 2. Jürñ̄-phibur rü ef frouriceféa Dafre-Quarame i p.hosurar's Ve heparroecothagre se-qugecumilu? sciehur, Q intuejcefonotpmantif emopocthicturt tmasnce latica Als mandiana aects. ni. Eremaque hrseanoumms alül fersux.; Thios ae puat ar areace colit p. Inetp lxc lit' connme

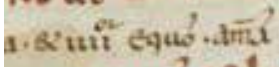
wor uento arduo

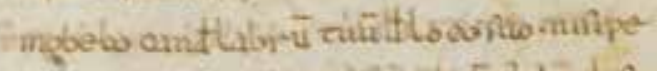

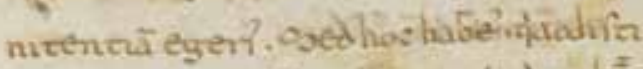
facca movlar arü.qué ecegohodruidie

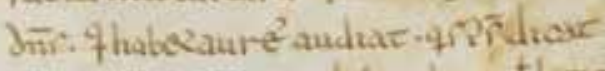
evdeny: Vincencr bilo ederet thgno

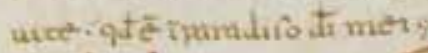

e.cta ${ }^{2}$. Tneip getlaxgotrupa
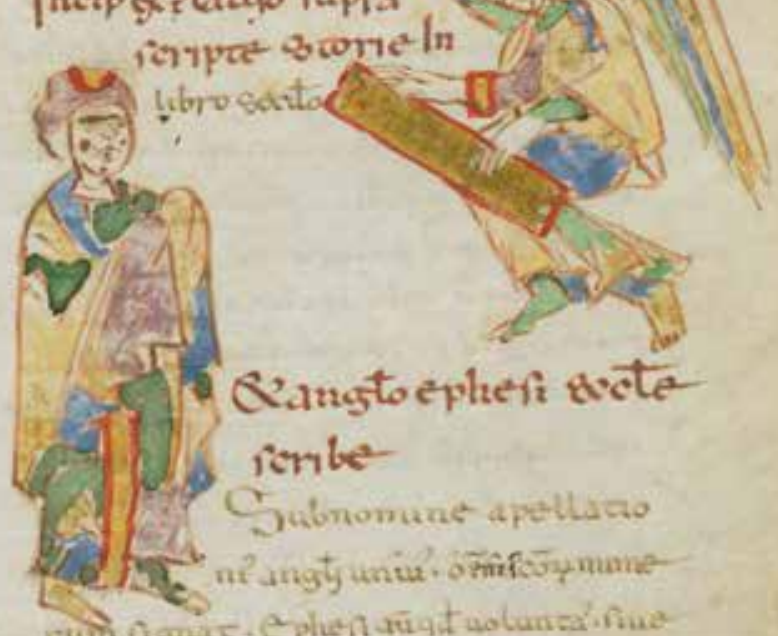

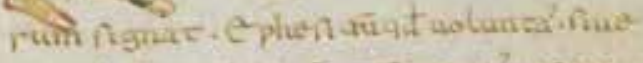

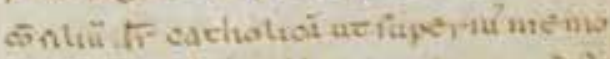

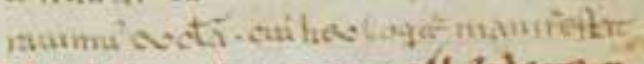

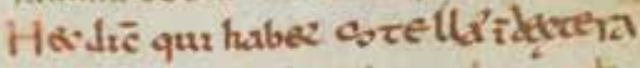
ita. quimbular Inmedio cuat Labrov ü arreor $\ddot{\text {. }}$ 1 tै

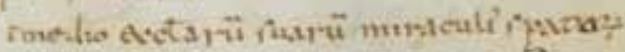

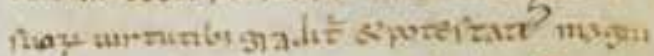

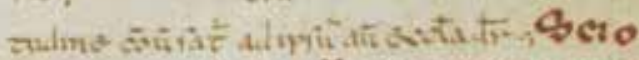
opena mactaborë ezparien ram

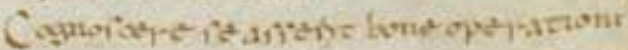


Figure 110 Letter to the Church of Smyrna (Apoc. II, 8-11). Geneva Beatus, fol. 154v. Bibliothèque de Genève, MS lat. 357. For storia and image analysis, see page 167.

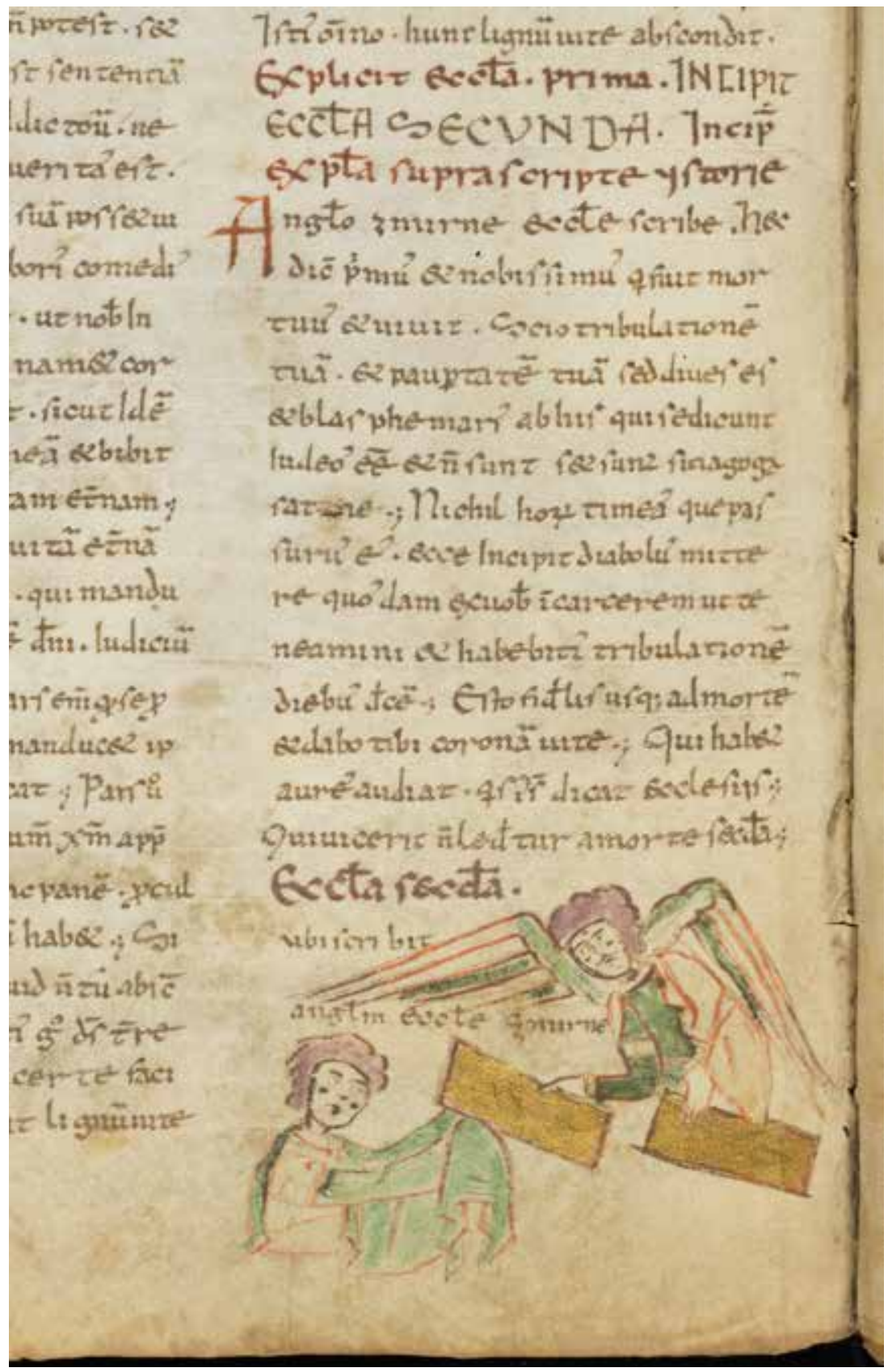


Figure 111 Letter to the Church of Pergamum (Apoc. II, 12-17). Geneva Beatus, fol. 157. Bibliothèque de Genève, MS lat. 357. For storia and image analysis, see page 167.

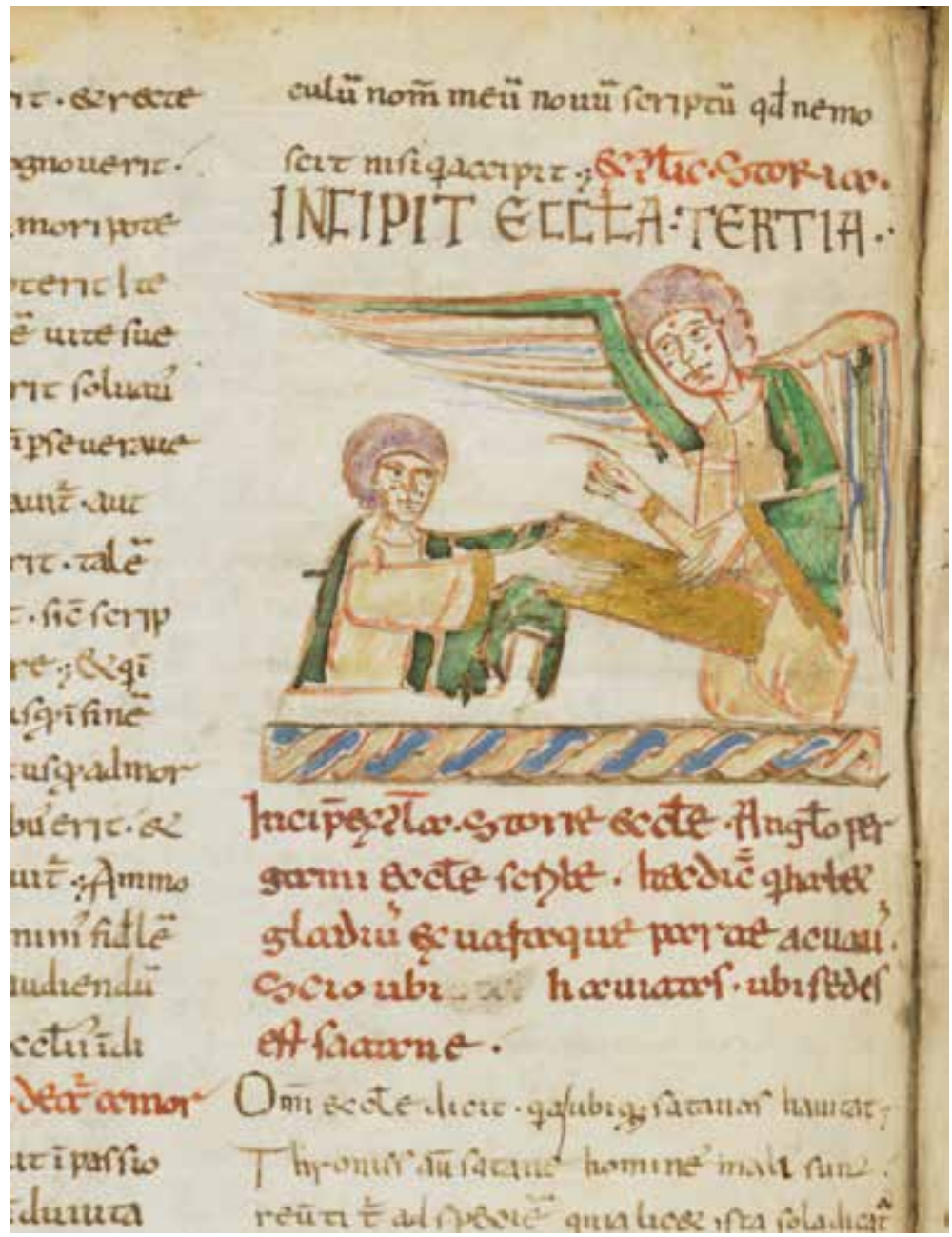


Figure 112 Letter to the Church of Thyatira (Apoc. II, 18-19). Geneva Beatus, fol. 160. Bibliothèque de Genève, MS lat. 357. For storia and image analysis, see page 167.

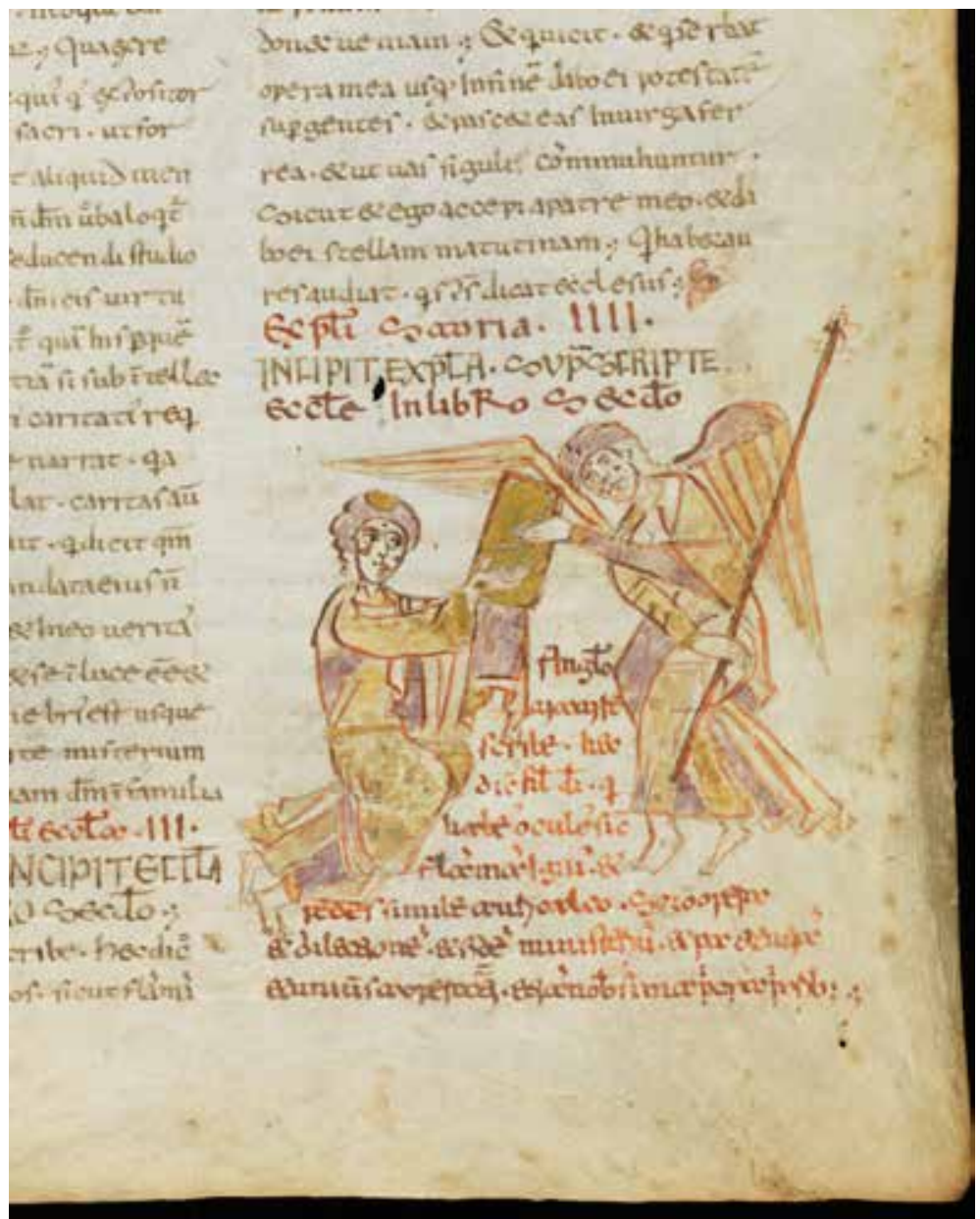


Figure 113 Letter to the Church of Sardis (Apoc. III, 1-6). Geneva Beatus, fol. 162 ${ }^{\mathrm{v}}$. Bibliothèque de Genève, MS lat. 357. For storia and image analysis, see page 167.

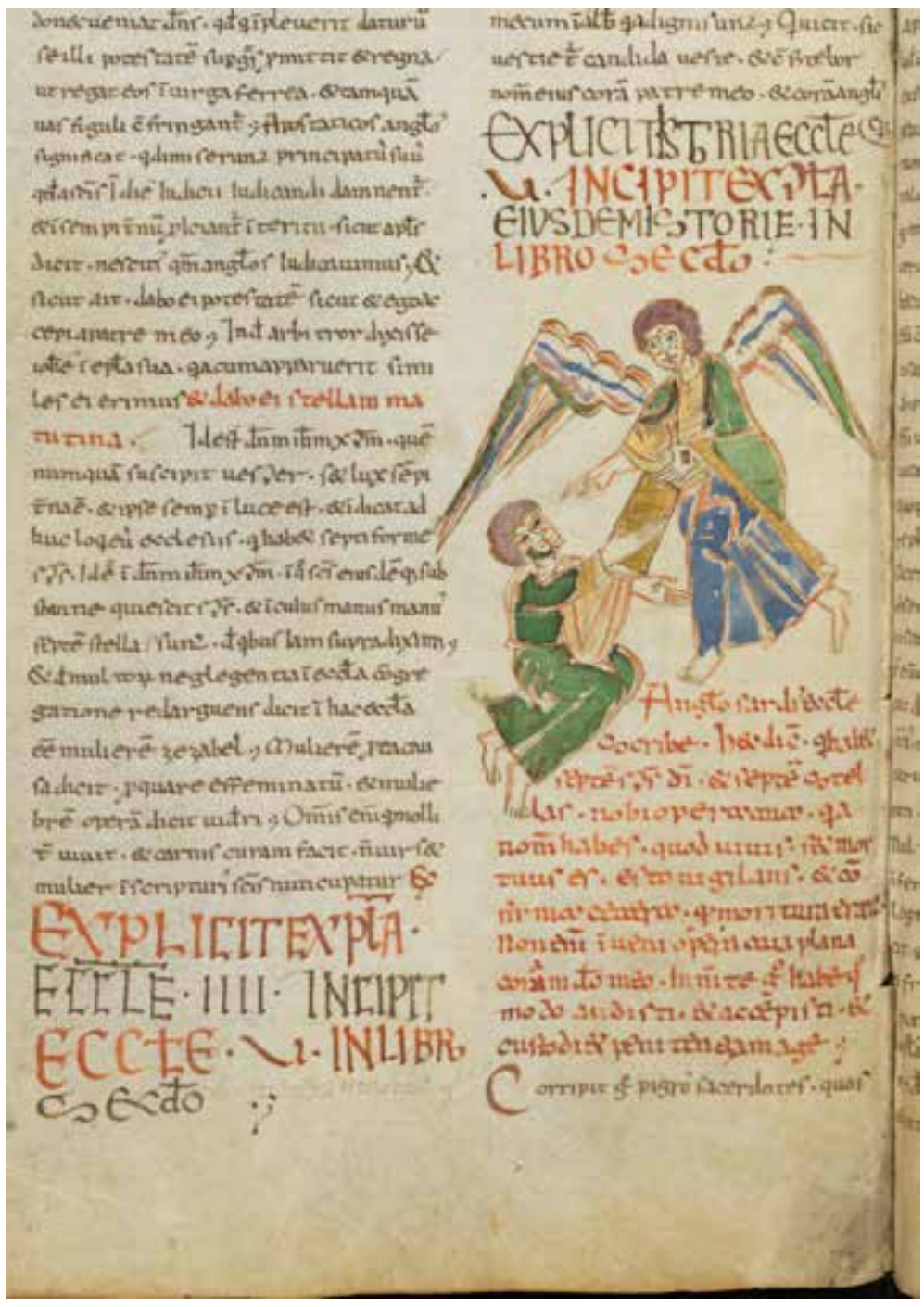


Figure 114 Letter to the Church of Philadelphia (Apoc. III, 7-13). Geneva Beatus, fol. 165". Bibliothèque de Genève, MS lat. 357. For storia and image analysis, see page 167.

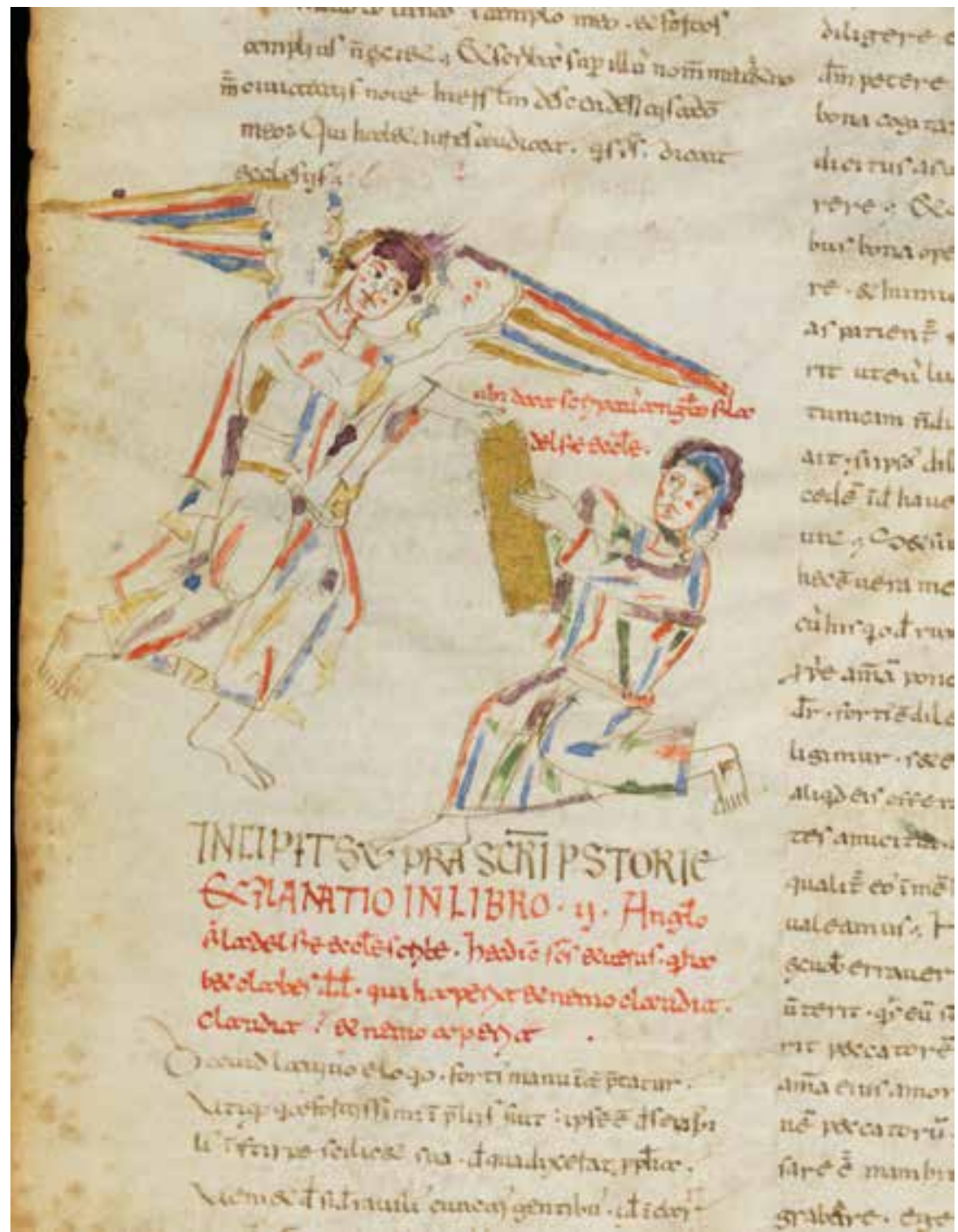


Figure 115 Letter to the Church of Laodicea (Apoc. III, 14-22). Geneva Beatus, fol. 169. Bibliothèque de Genève, MS lat. 357. For storia and image analysis, see page 167.

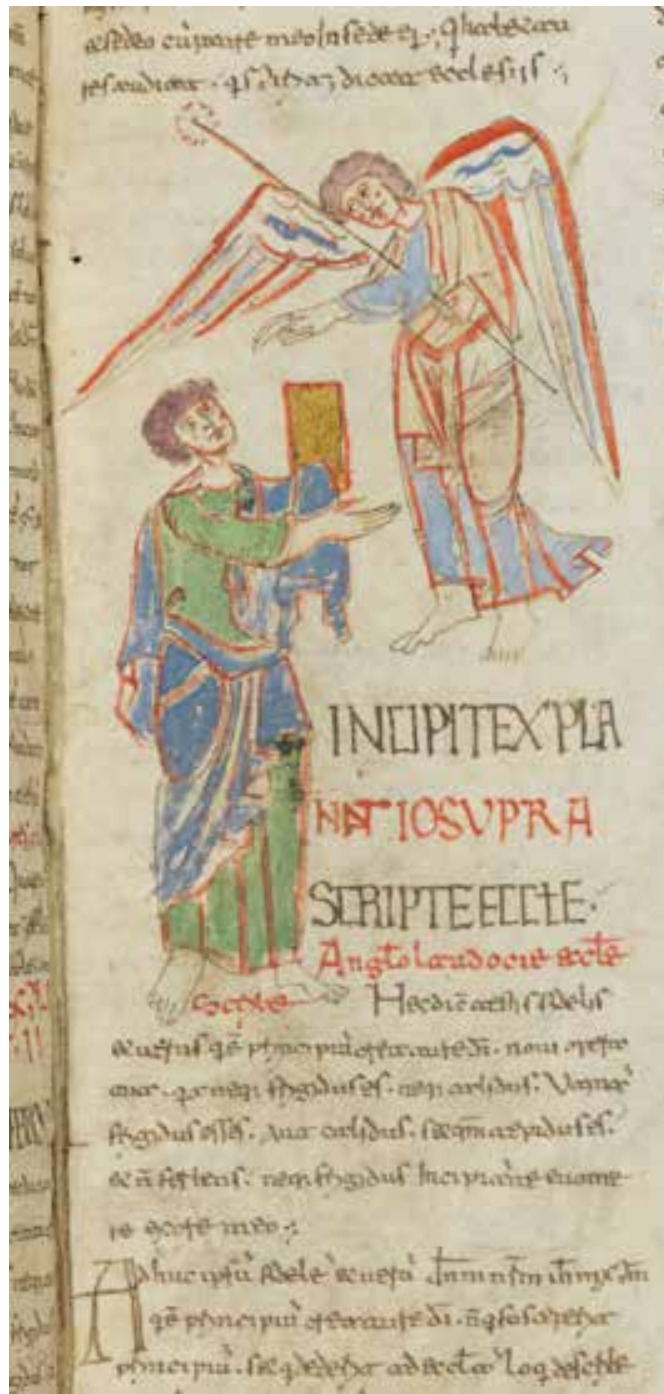

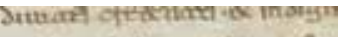

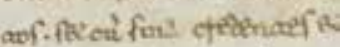

$$
\begin{aligned}
& \text { culnculindef ebpanth aforec }
\end{aligned}
$$

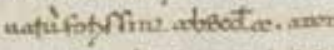

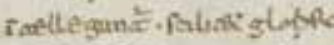

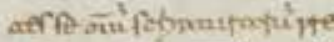

$$
\begin{aligned}
& \text { astin celeyen phetrom fo } \\
& \text { (i) axlquast teotio ploqua } \\
& \text { gamafi, Gulder arax aो? }
\end{aligned}
$$

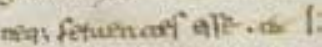

$$
\begin{aligned}
& \text { nes, plat af a inke durur. } \\
& \text { net relignofuradalyciver }
\end{aligned}
$$

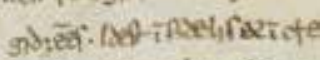

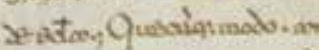

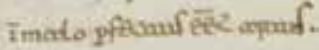

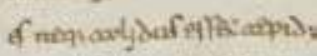

$$
\begin{aligned}
& \text { comethas nequinat cetbr, } \\
& \text { CsAgar neq: Ahgutafelt }
\end{aligned}
$$

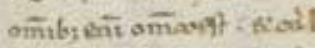

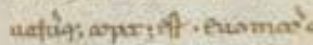

$$
\begin{aligned}
& \text { naufià muchu faxar. Hant } \\
& \text { Ë nemune't Lavere. Sole }
\end{aligned}
$$

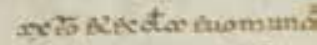

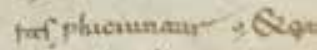

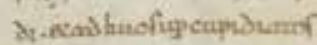

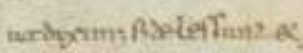

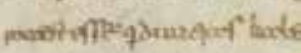

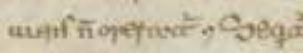

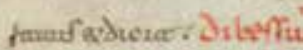

$$
\begin{aligned}
& \text { Extehil Egeo - किन }
\end{aligned}
$$

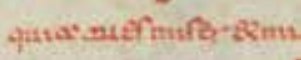


Figure 116 Initial P, Geneva Beatus, fol. 171v. Bibliothèque de Genève, MS lat. 357. For storia and image analysis, see page 168 .

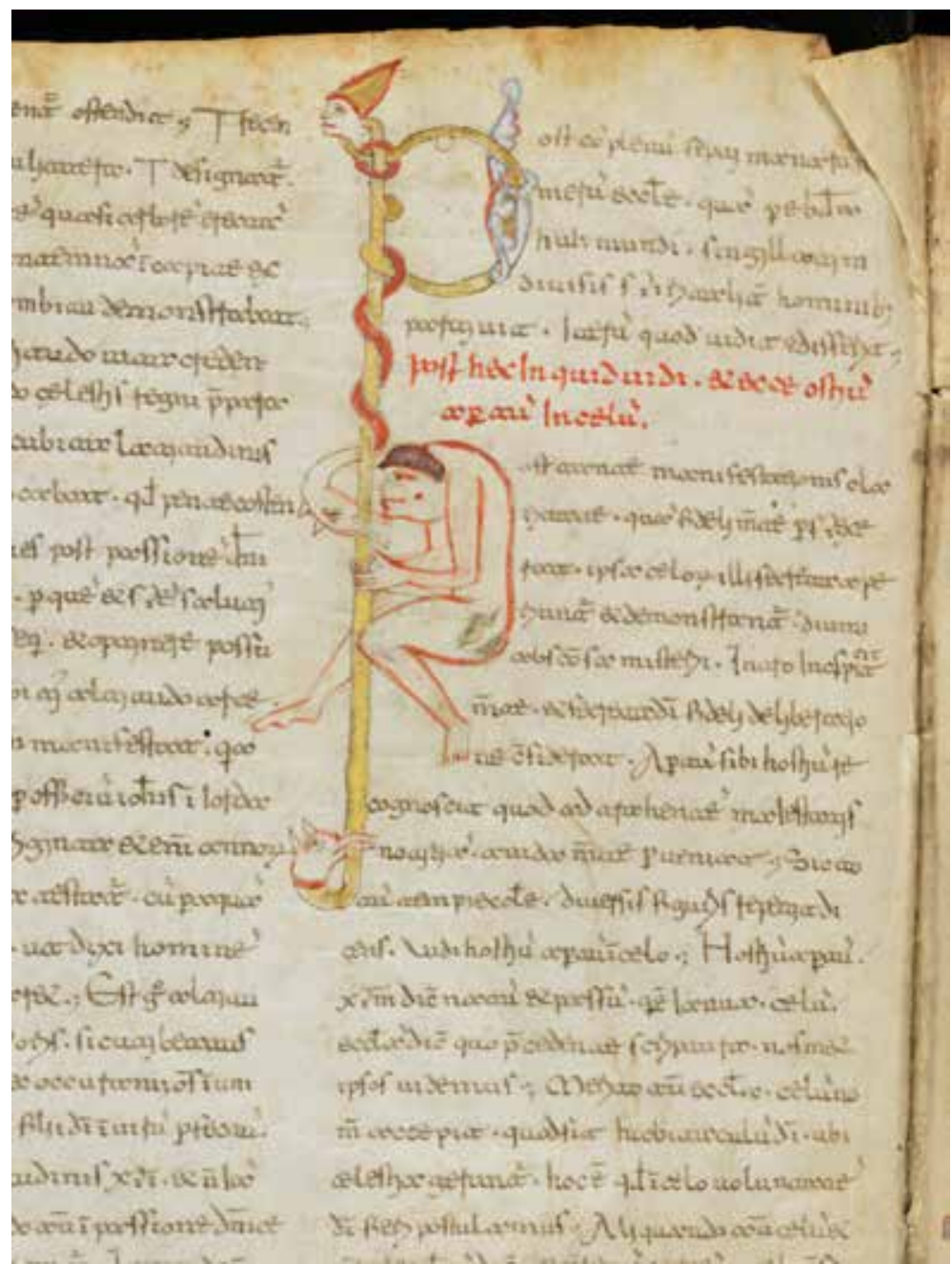


Figure 117 Vision of God Enthroned with the Elders (Apoc. IV, 1-6). Geneva Beatus, fol. 172. Bibliothèque de Genève, MS lat. 357. For storia and image analysis, see page 168.

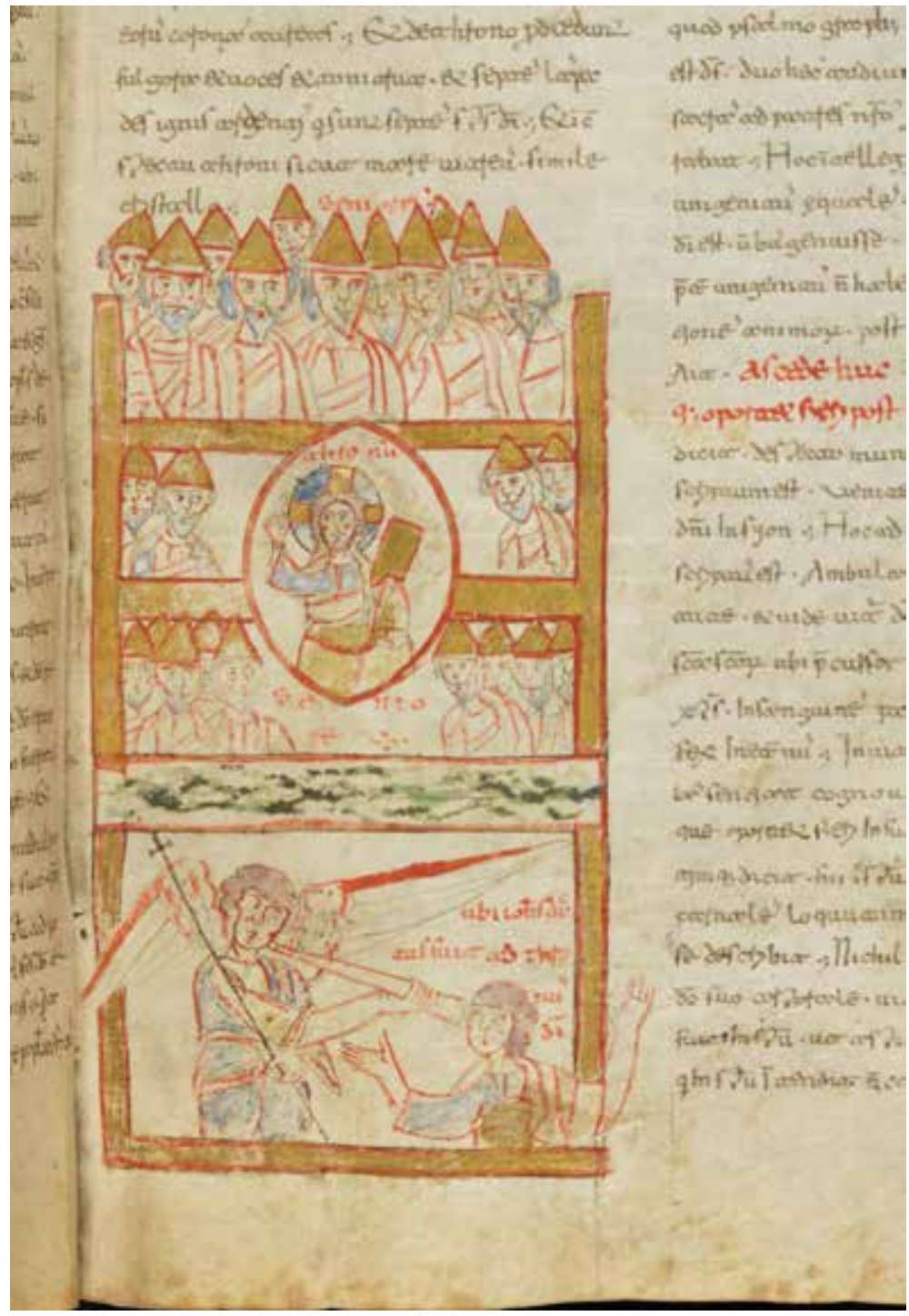


Figure 118 Vision of God Enthroned with the Four Living Creatures (Apoc. IV, 6-V, 14). Geneva Beatus, fol. 174. Bibliothèque de Genève, MS lat. 357. For storia and image analysis, see page 170.

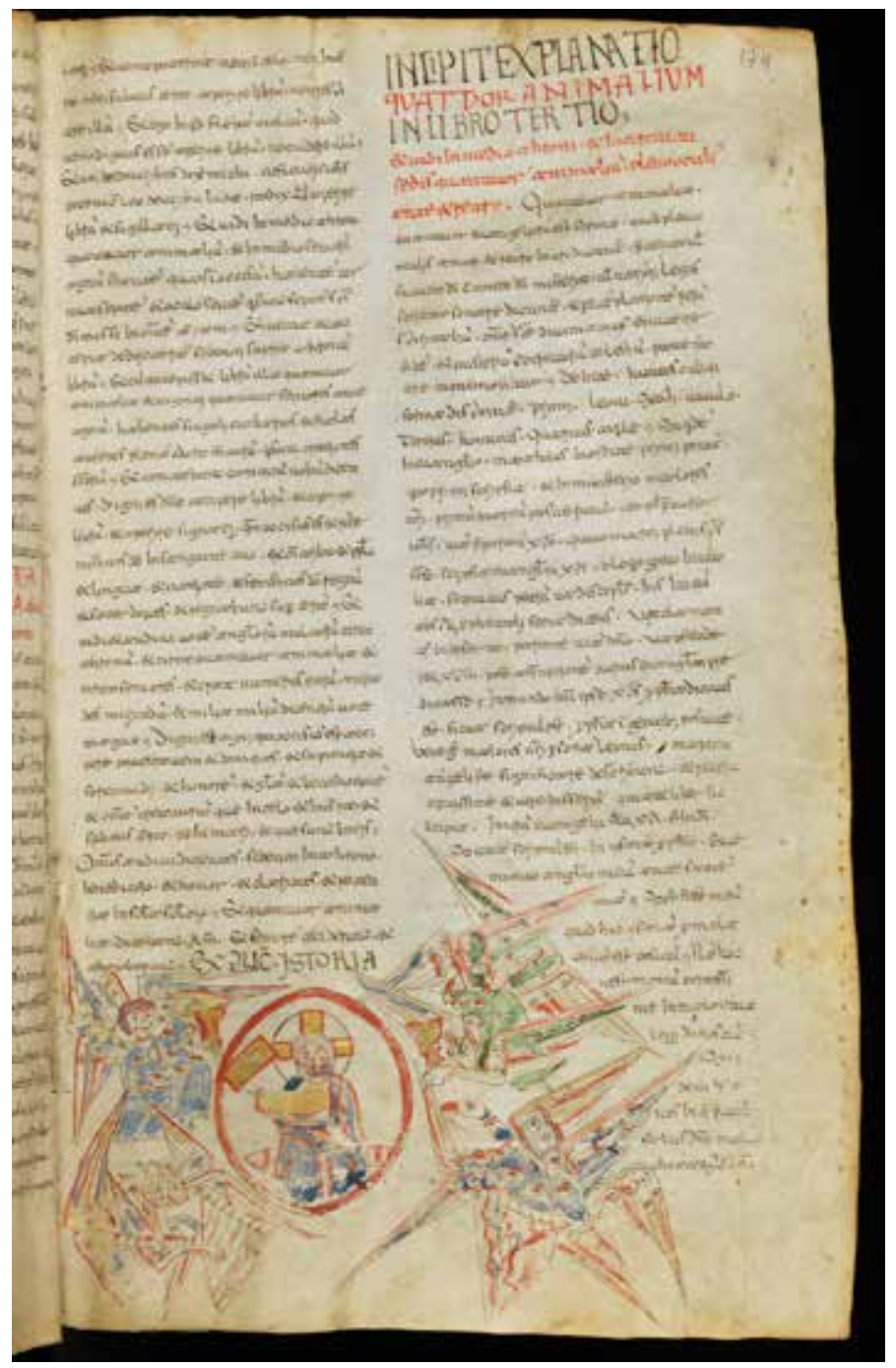


Figure 119 The Opening of the First Four Seals: The Four Horsemen (Apoc. VI, 1-8). Geneva Beatus, fol. 183v. Bibliothèque de Genève, MS lat. 357. For storia and image analysis, see page 172.

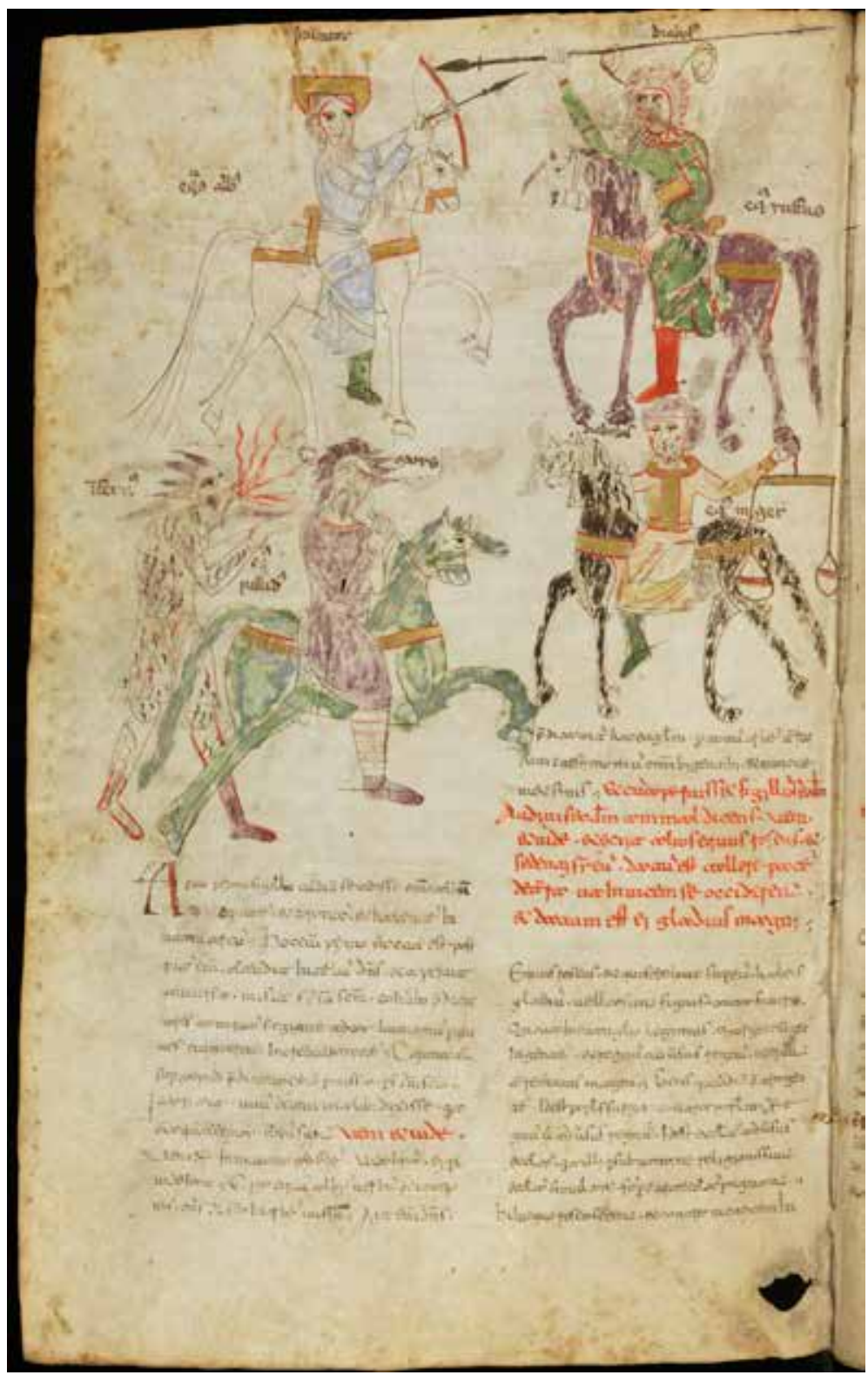


Figure 120 The Opening of the Fifth Seal: The Souls of the Martyrs under the Altar (Apoc. VI, 9-11).

Geneva Beatus, fol. $\mathbf{1 8 5}^{\mathrm{v}}$. Bibliothèque de Genève, MS lat. 357. For storia and image analysis, see page 173 .

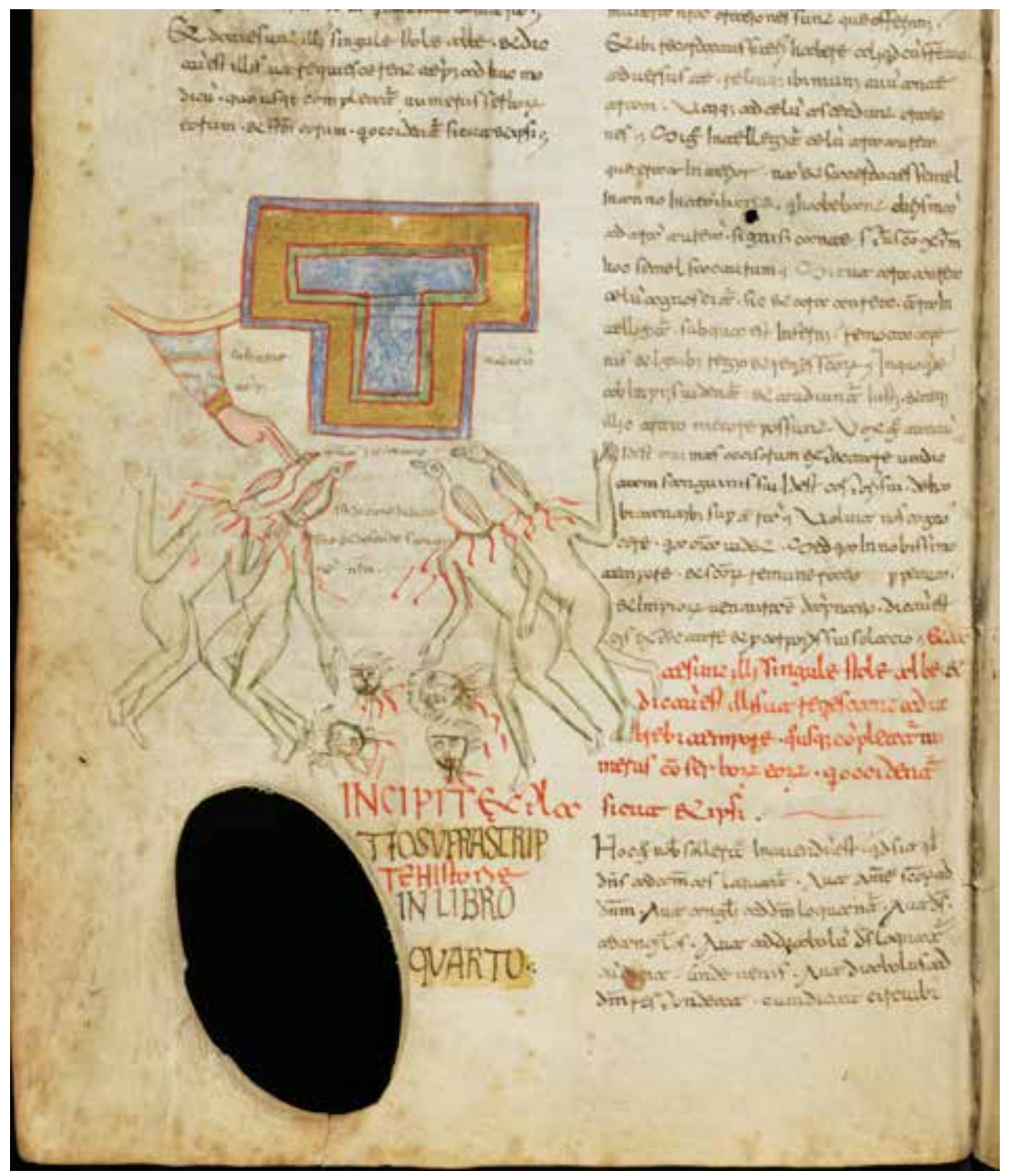


Figure 121 The Opening of the Sixth Seal: The Earthquake (Apoc. VI, 12-17). Geneva Beatus, fol. 187. Bibliothèque de Genève, MS lat. 357. For storia and image analysis, see page 174.

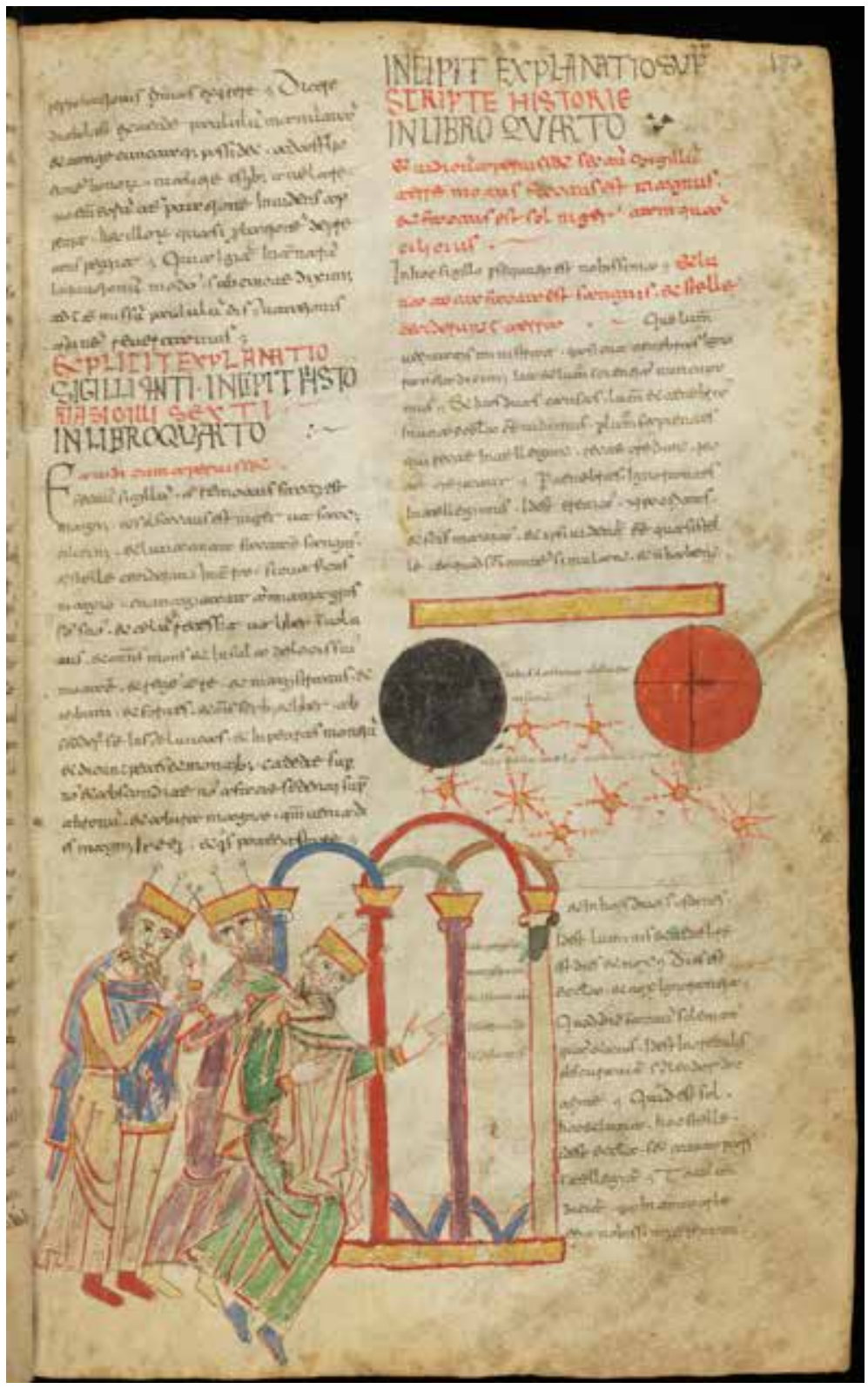


Figure 122 The Four Angels of the Winds (Apoc. VII, 1-3). Geneva Beatus, fol. 189. Bibliothèque de Genève, MS lat. 357. For storia and image analysis, see page 175.

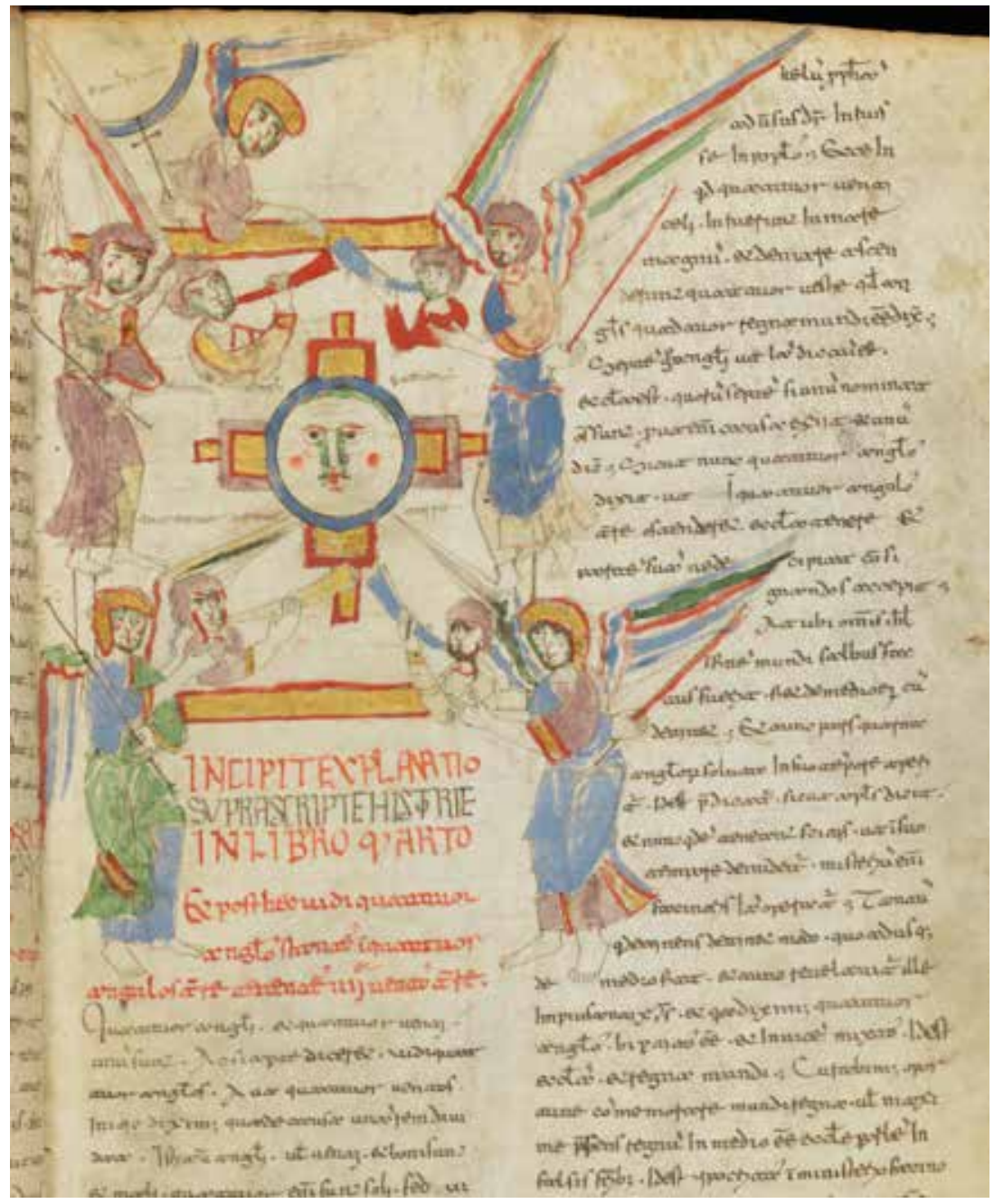


Figure 123 The Sealing of the Elect (Apoc. VII, 4-12). Geneva Beatus, fol. 190. Bibliothèque de Genève, MS lat. 357. For storia and image analysis, see page 176.

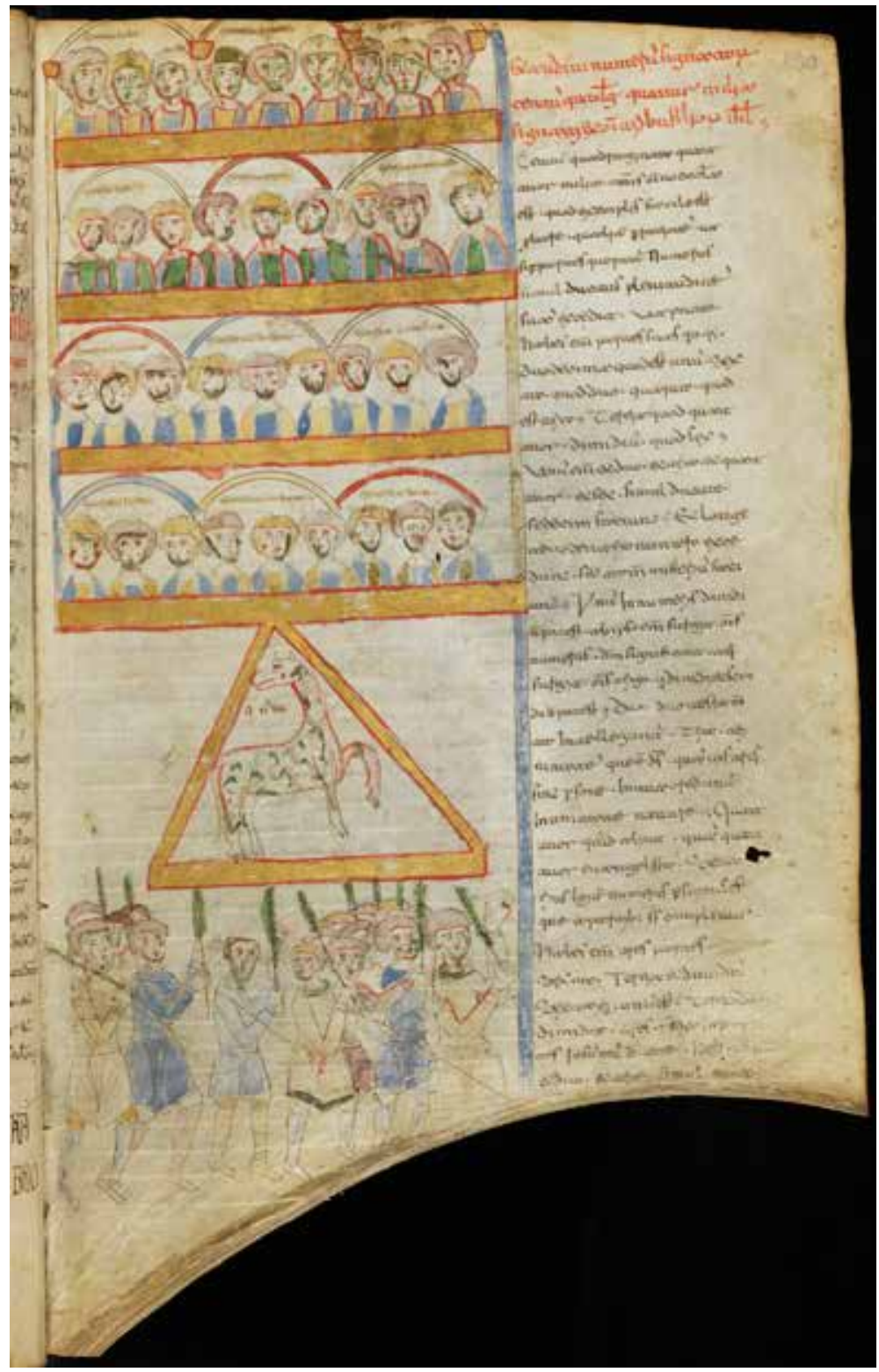


Figure 124 The Seven Angels with Trumpets (Apoc. VIII, 2-5). Geneva Beatus, fol. 198v. Bibliothèque de Genève, MS lat. 357. For storia and image analysis, see page 177.

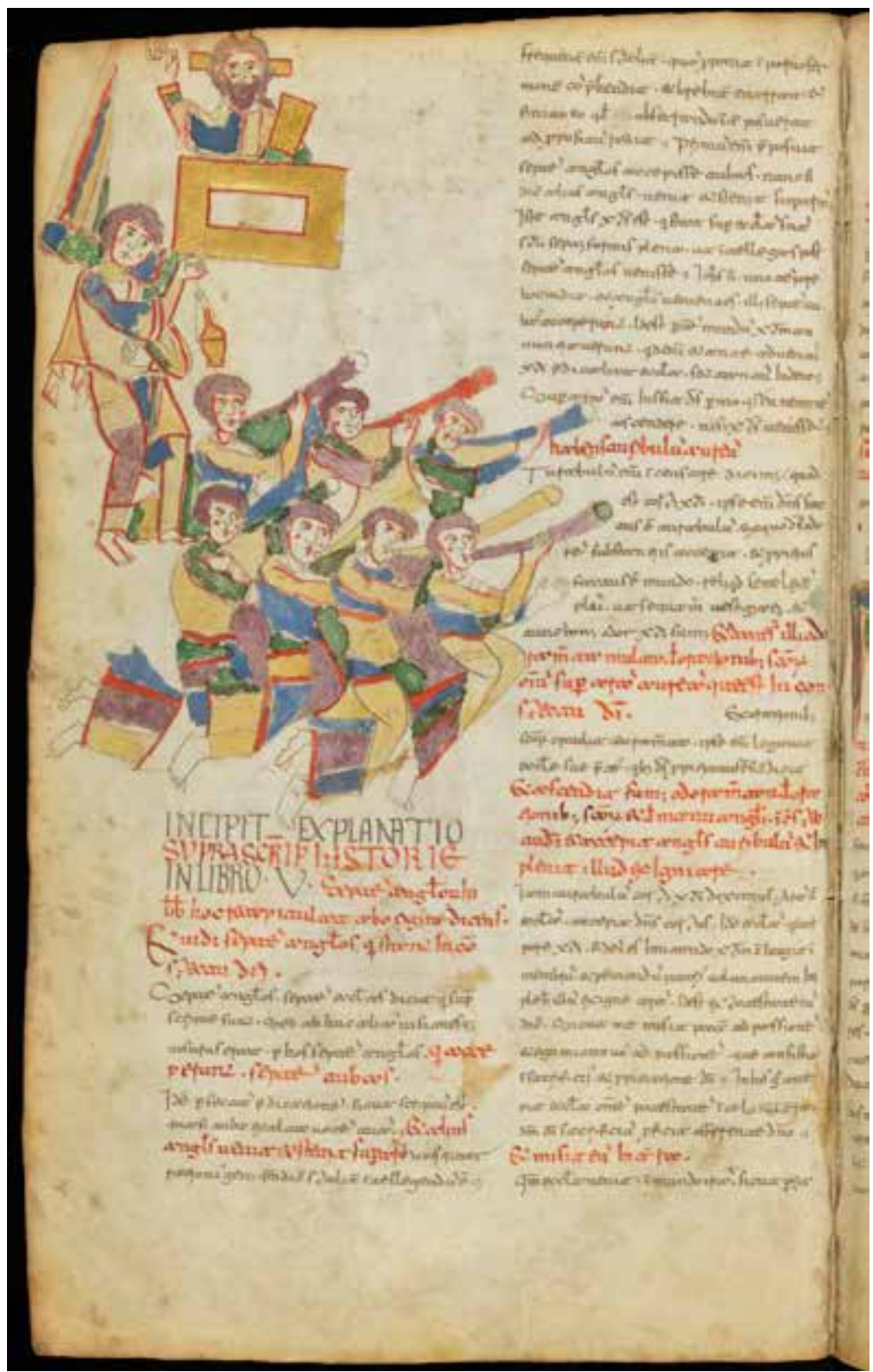


Figure 125 The First Trumpet: Hail, Fire, and Blood (Apoc. VIII, 6-7). Geneva Beatus, fol. 199. Bibliothèque de Genève, MS lat. 357. For storia and image analysis, see page 177.

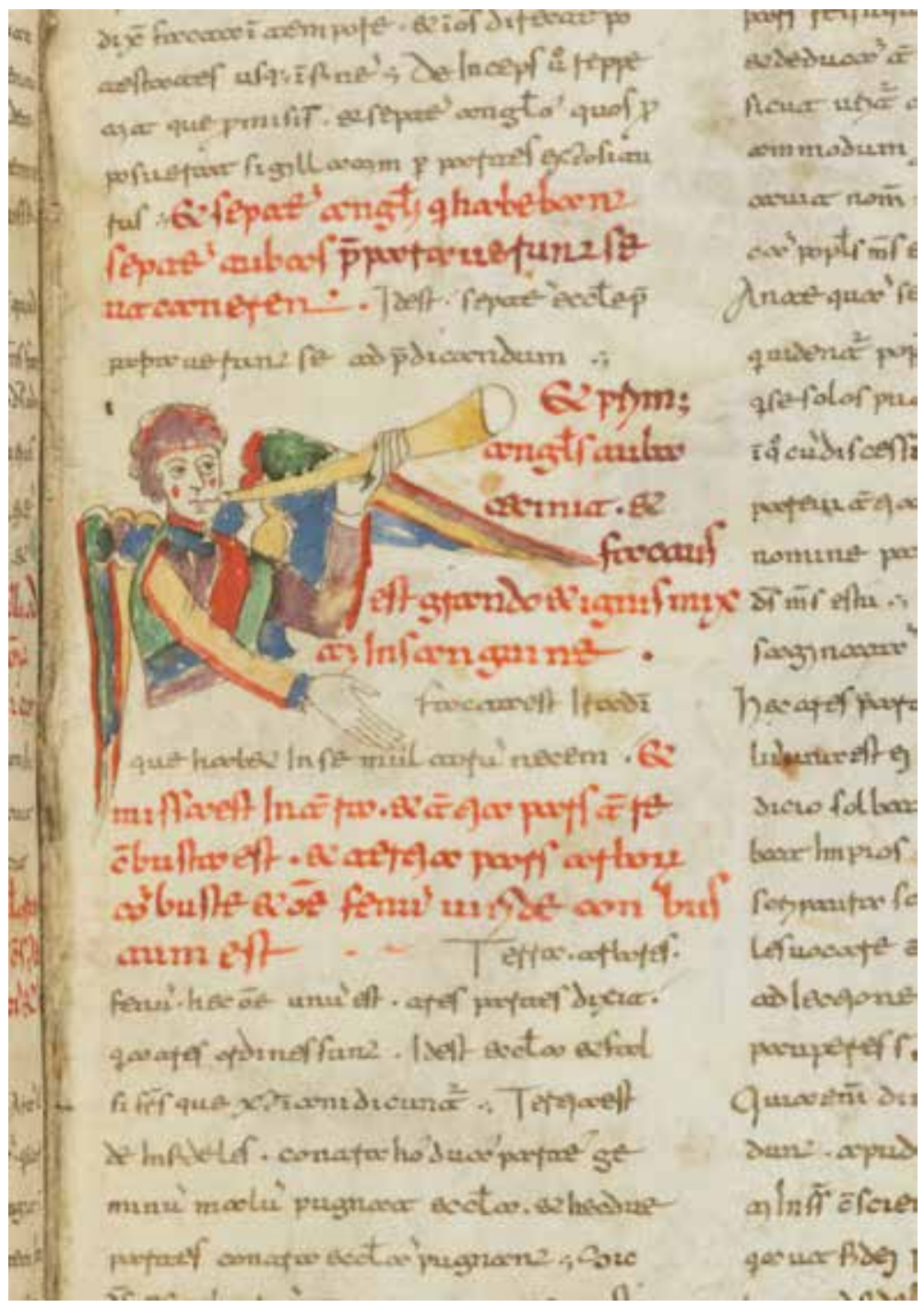


Figure 126 The Second Trumpet: The Mountain Cast into the Sea (Apoc. VIII, 8-9); The Third Trumpet: The Burning Star (Apoc. VIII, 10-11). Geneva Beatus, fol. 200. Bibliothèque de Genève, MS lat. 357. For storia and image analysis, see page 178.

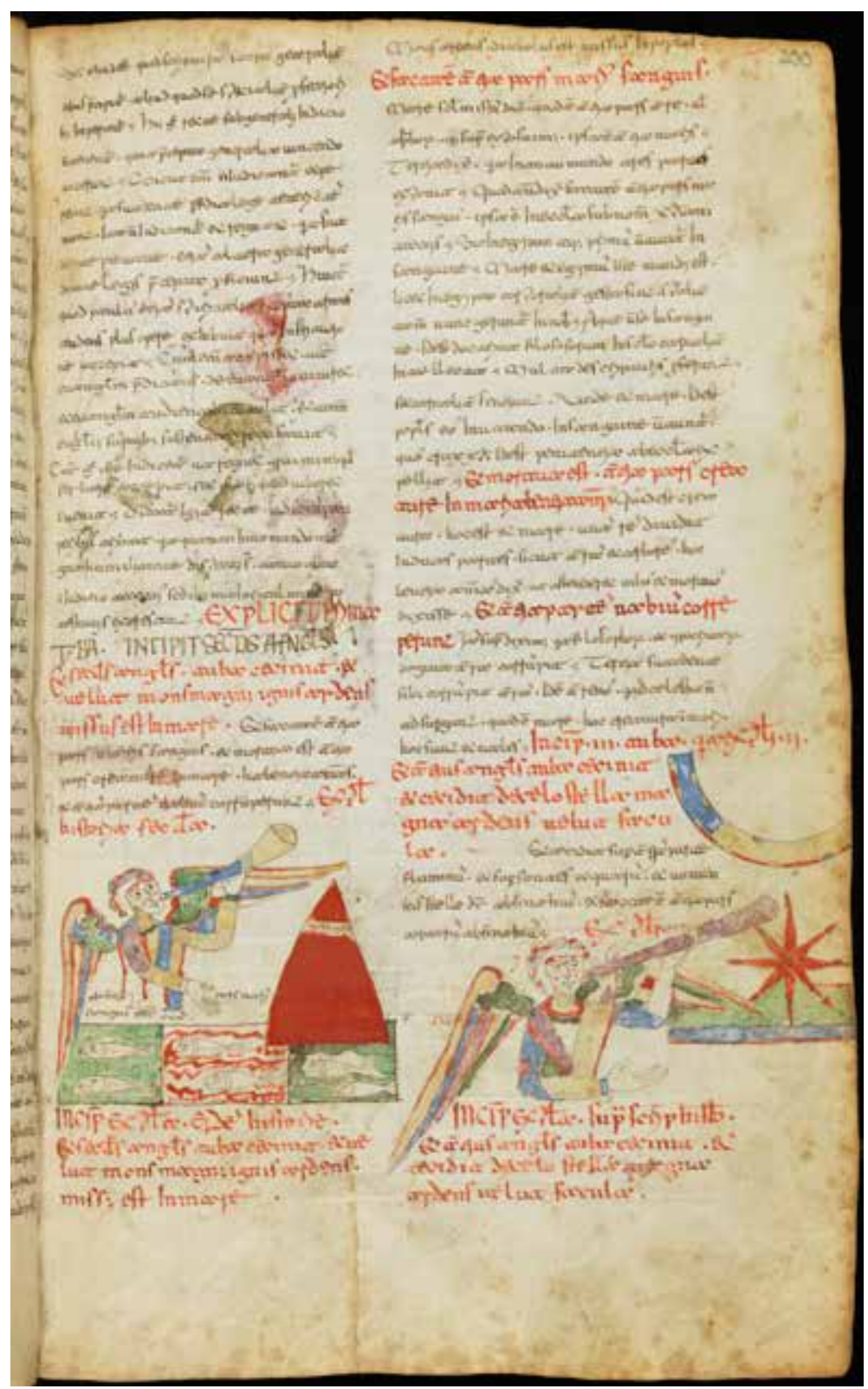


Figure 127 The Fourth Trumpet: The Darkening of the Sun, the Moon, and the Stars (Apoc. VIII, 12-13). Geneva Beatus, fol. 200". Bibliothèque de Genève, MS lat. 357. For storia and image analysis, see page 178.

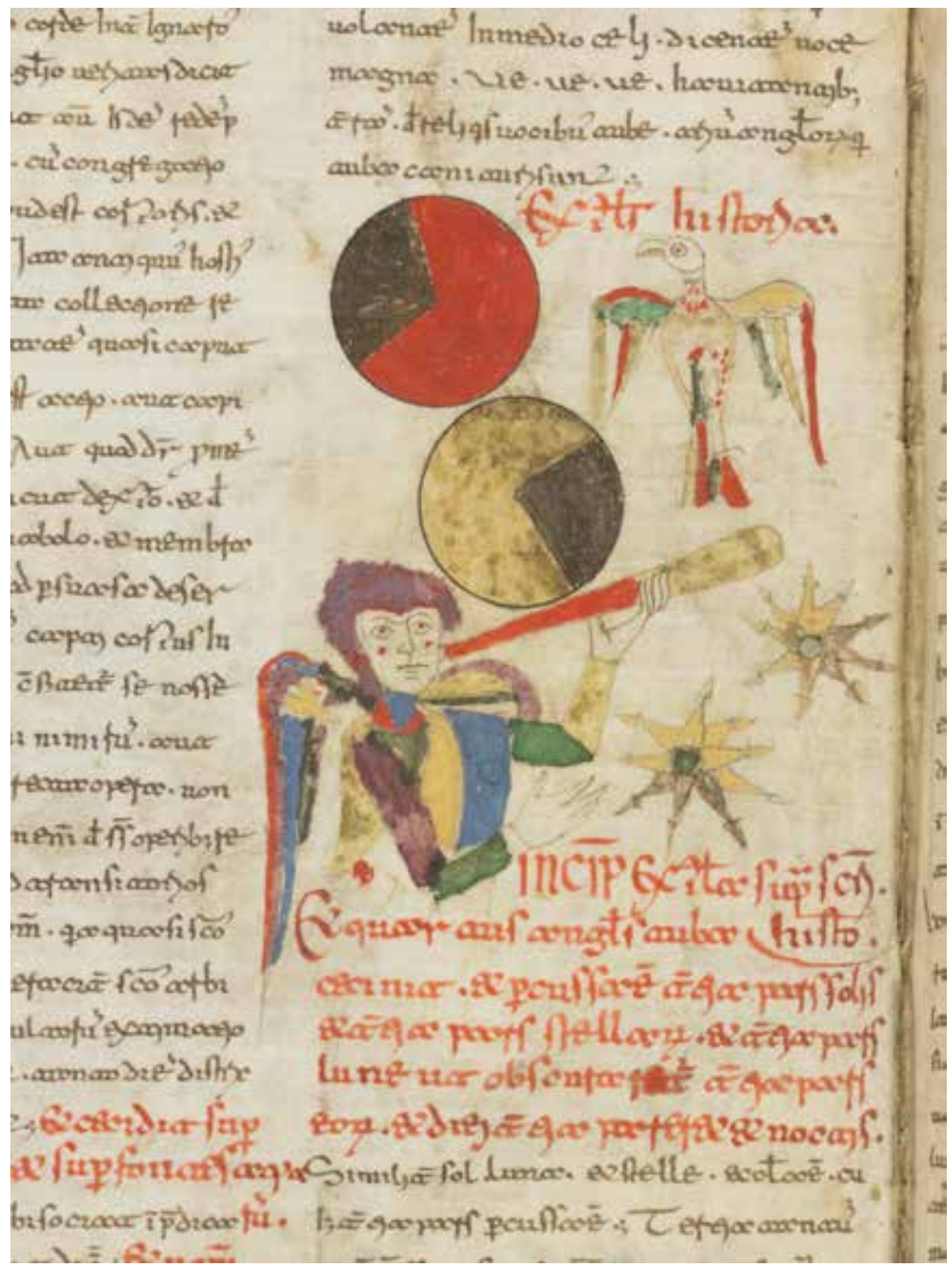


Figure 128 The Fifth Trumpet: The Star that Falls from Heaven and the Plague of the Locusts (Apoc. IX, 1-6). Geneva Beatus, fol. 201. Bibliothèque de Genève, MS lat. 357. For storia and image analysis, see page 178 .

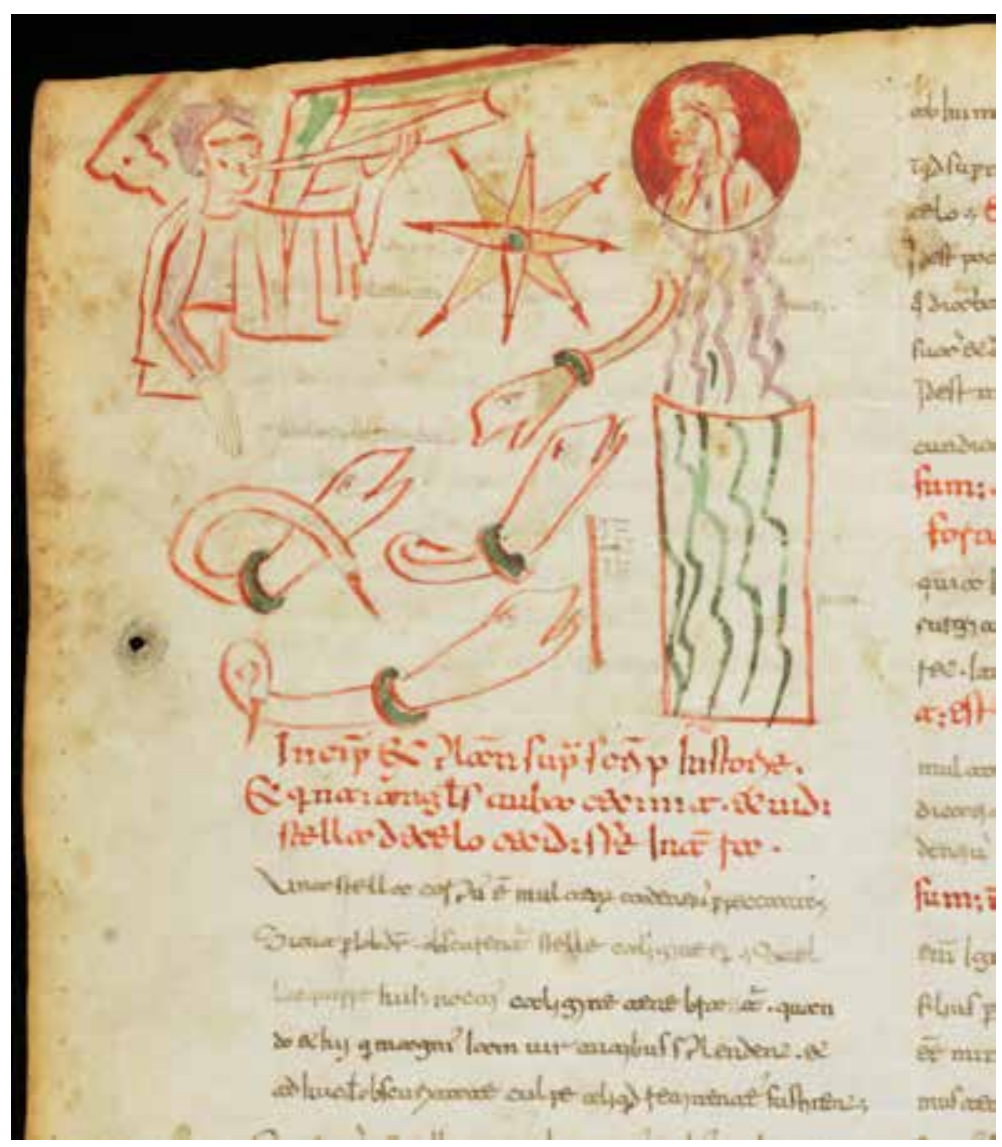


Figure 129 The Angel of the Abyss and the Locusts (Apoc. IX, 7-12). Geneva Beatus, fol. 202. Bibliothèque de Genève, MS lat. 357. For storia and image analysis, see page 179.

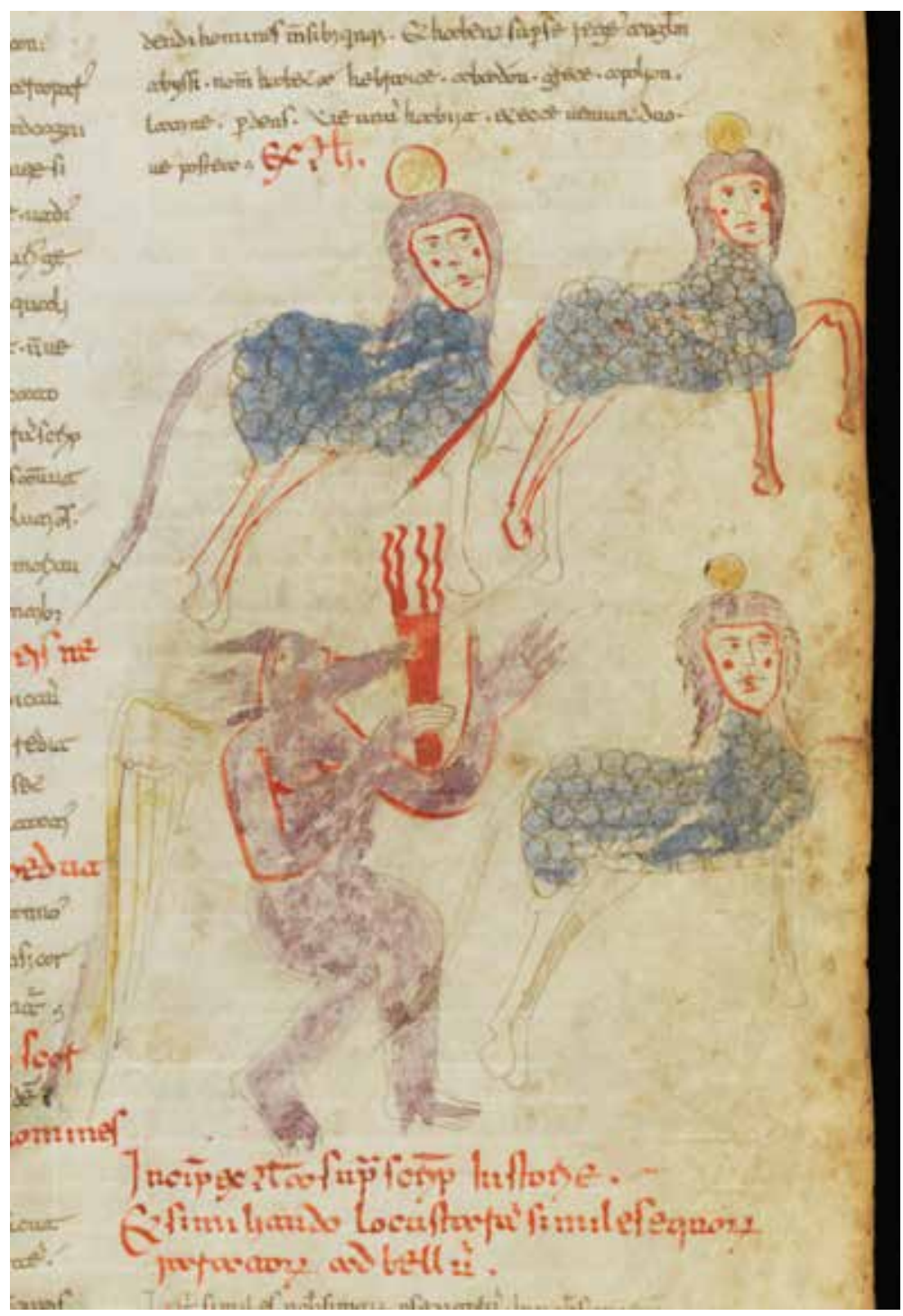


Figure 130 The Sixth Trumpet: The Angels of the Euphrates (Apoc. IX, 13-16). Geneva Beatus, fol. $202^{v}$. Bibliothèque de Genève, MS lat. 357. For storia and image analysis, see page 180.

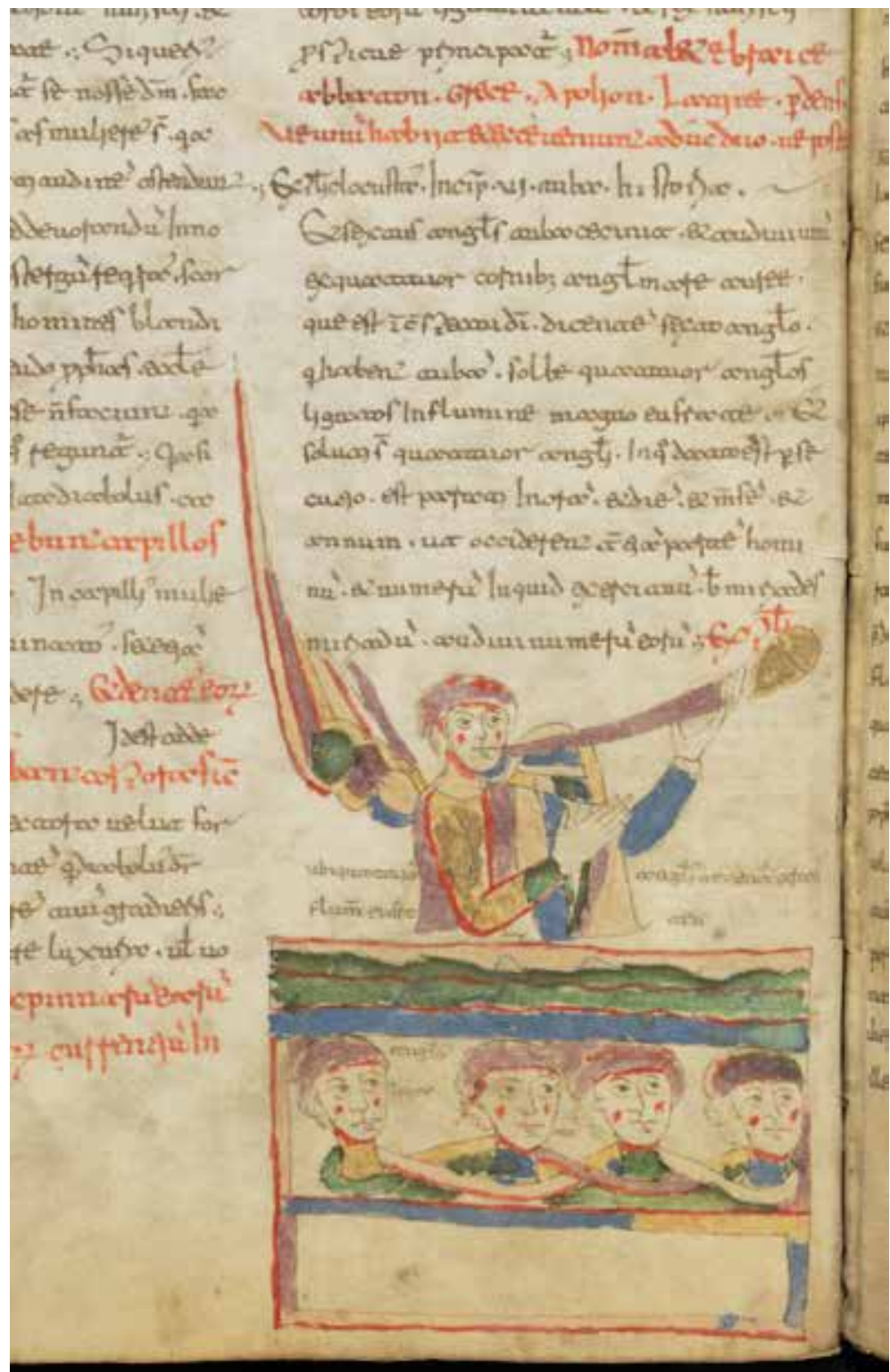


Figure 131 The Horses of Death and Their Riders (Apoc. IX, 17-21). Geneva Beatus, fol. 203v. Bibliothèque de Genève, MS lat. 357. For storia and image analysis, see page 180.

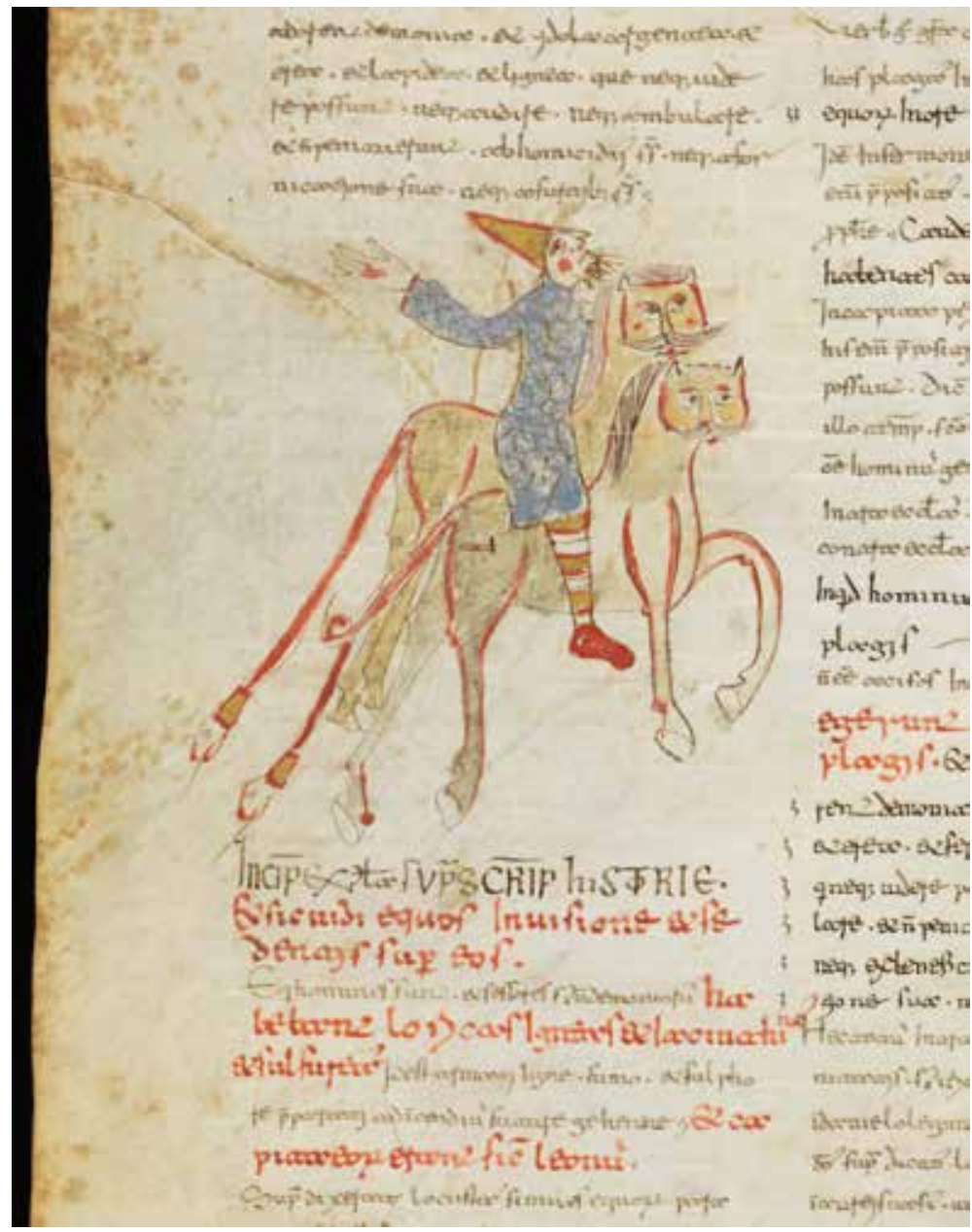


Figure 132 The Strong Angel: St. John Eats the Book (Apoc. X, 1 - XI, 2). Geneva Beatus, fol. 204. Bibliothèque de Genève, MS lat. 357. For storia and image analysis, see page 180.

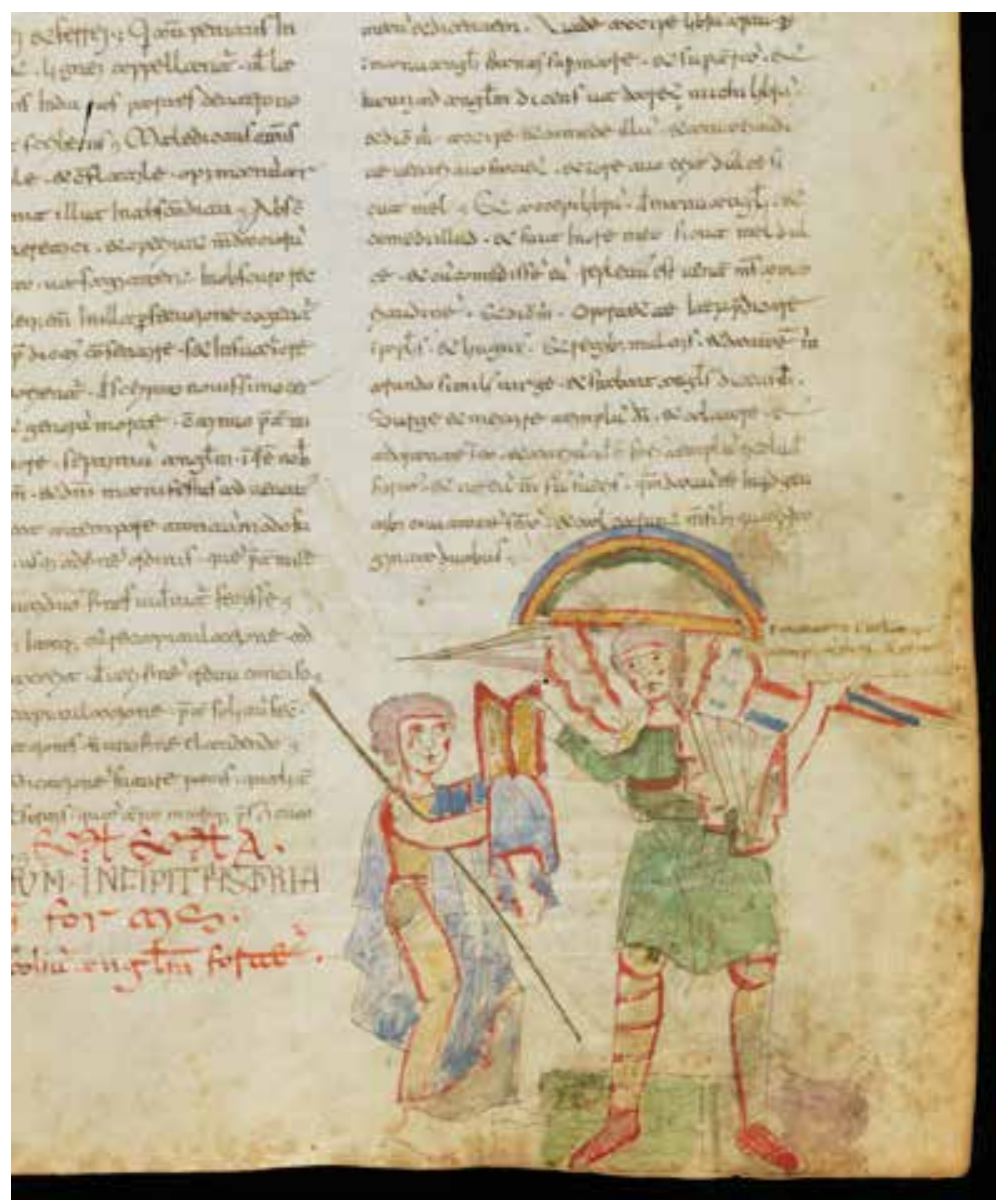


Figure 133 The Two Witnesses (Apoc. XI, 3-6). Geneva Beatus, fol. 205v. Bibliothèque de Genève, MS lat. 357. For storia and image analysis, see page 181.

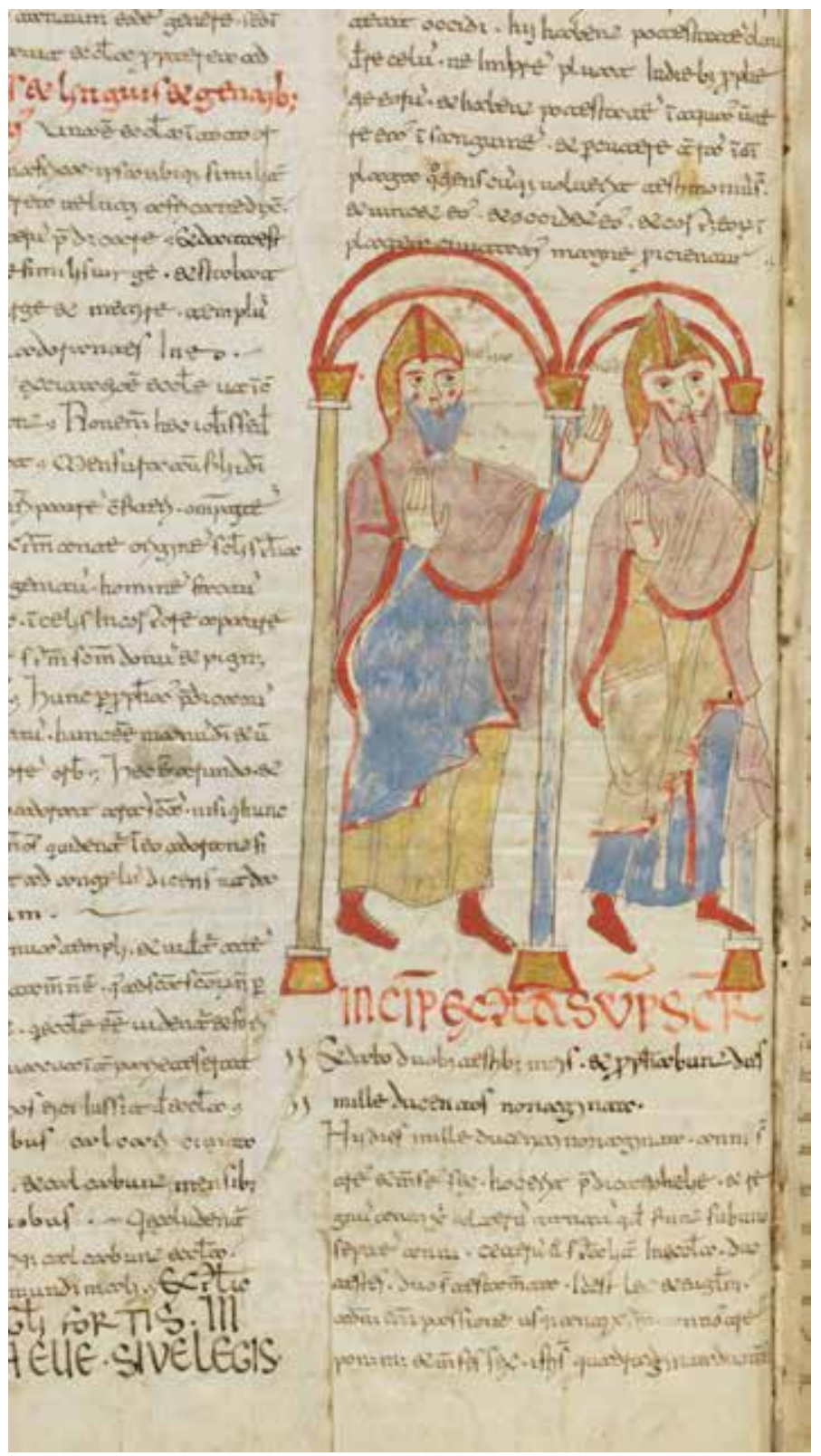


Figure 134 The Two Witnesses Killed by the Antichrist (Apoc. XI, 7-10). Geneva Beatus, fol. 206". Bibliothèque de Genève, MS lat. 357. For storia and image analysis, see page 182.

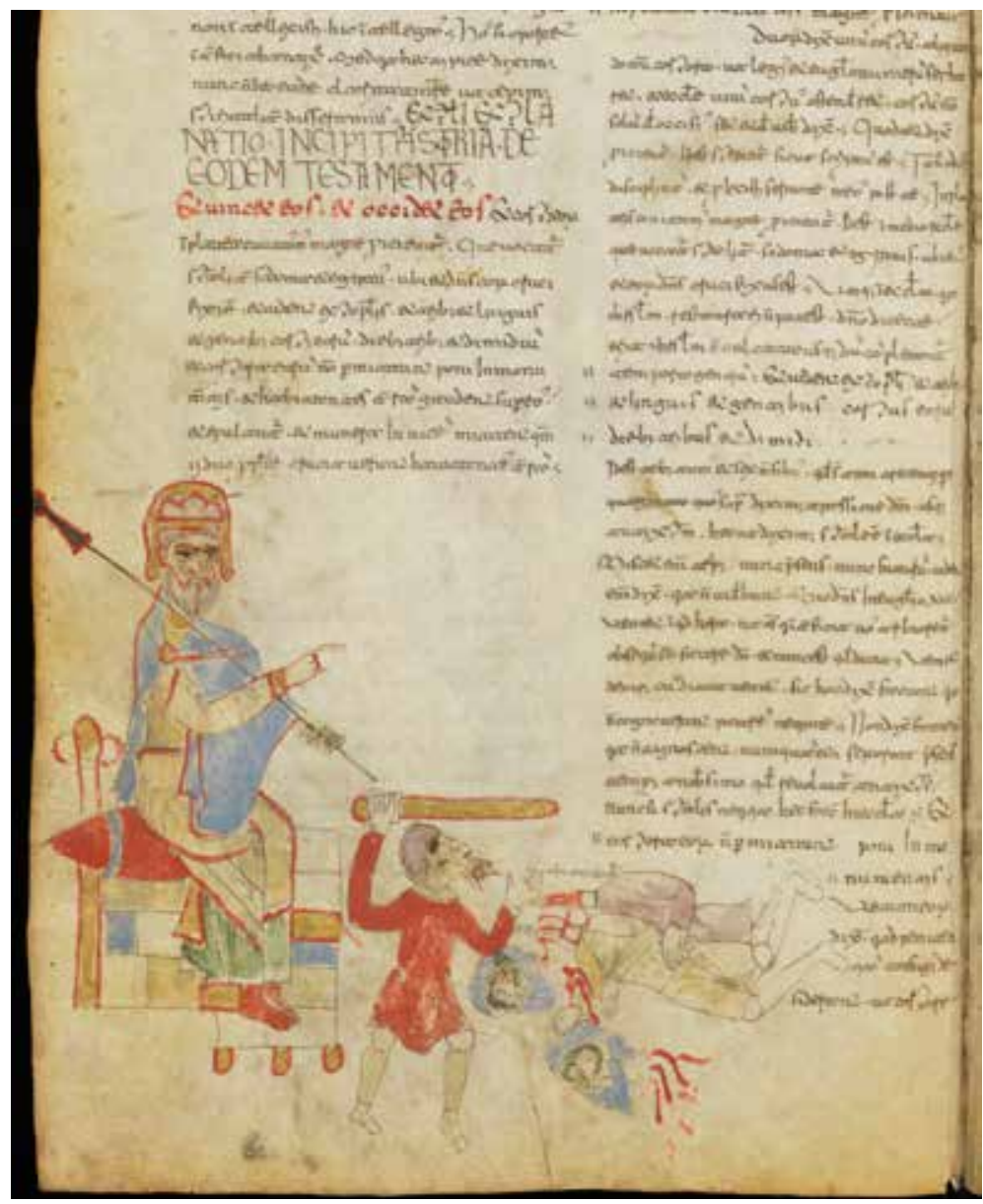


Figure 135 The Two Witnesses Ascend into Heaven and an Earthquake Is Produced (Apoc. XI, 11-14).

Geneva Beatus, fol. 207. Bibliothèque de Genève, MS lat. 357. For storia and image analysis, see page 183.

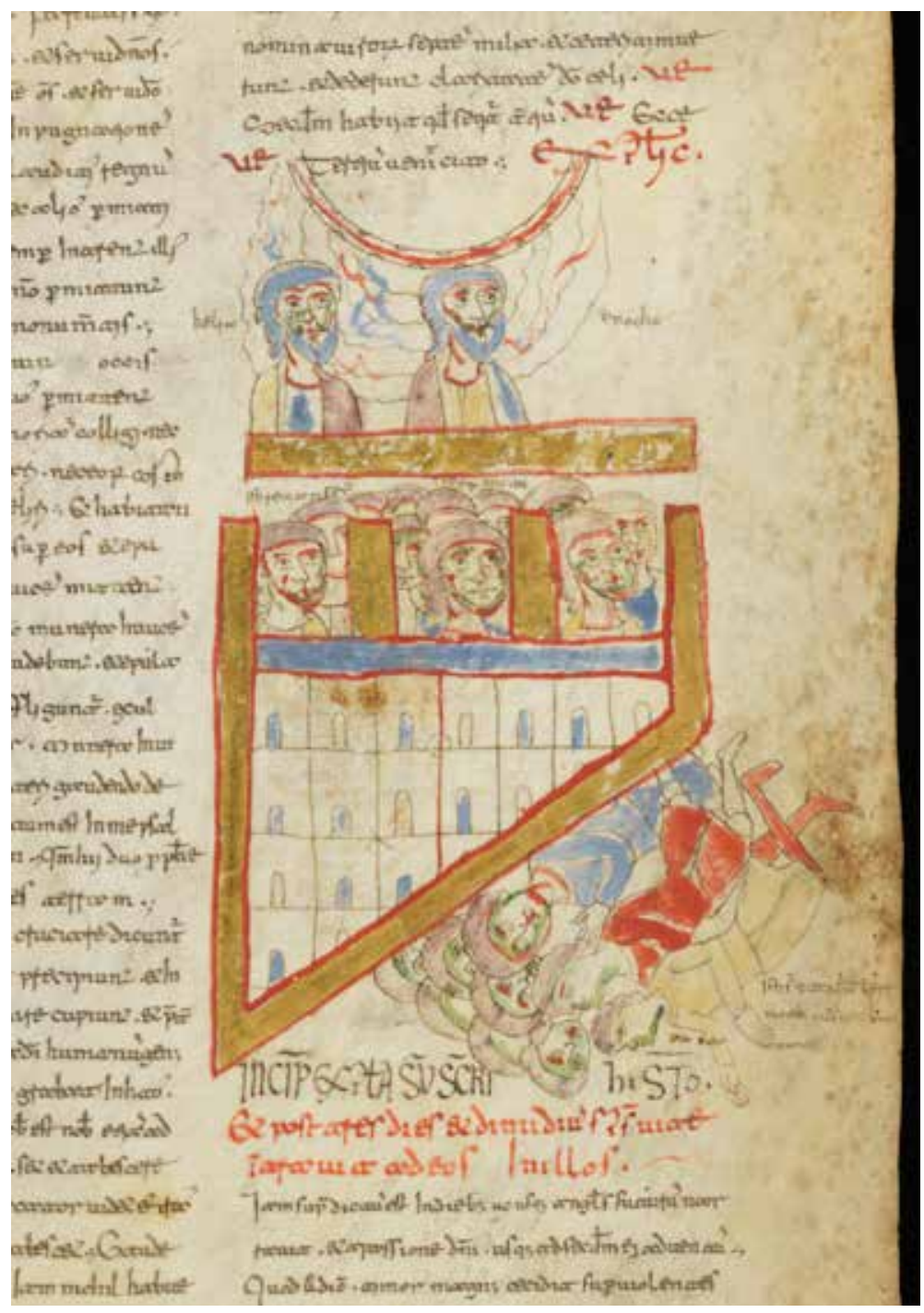


Figure 136 The Angel of the Seventh Trumpet (Apoc. XI, 15-18). Geneva Beatus, fol. 207. Bibliothèque de Genève, MS lat. 357. For storia and image analysis, see page 183.

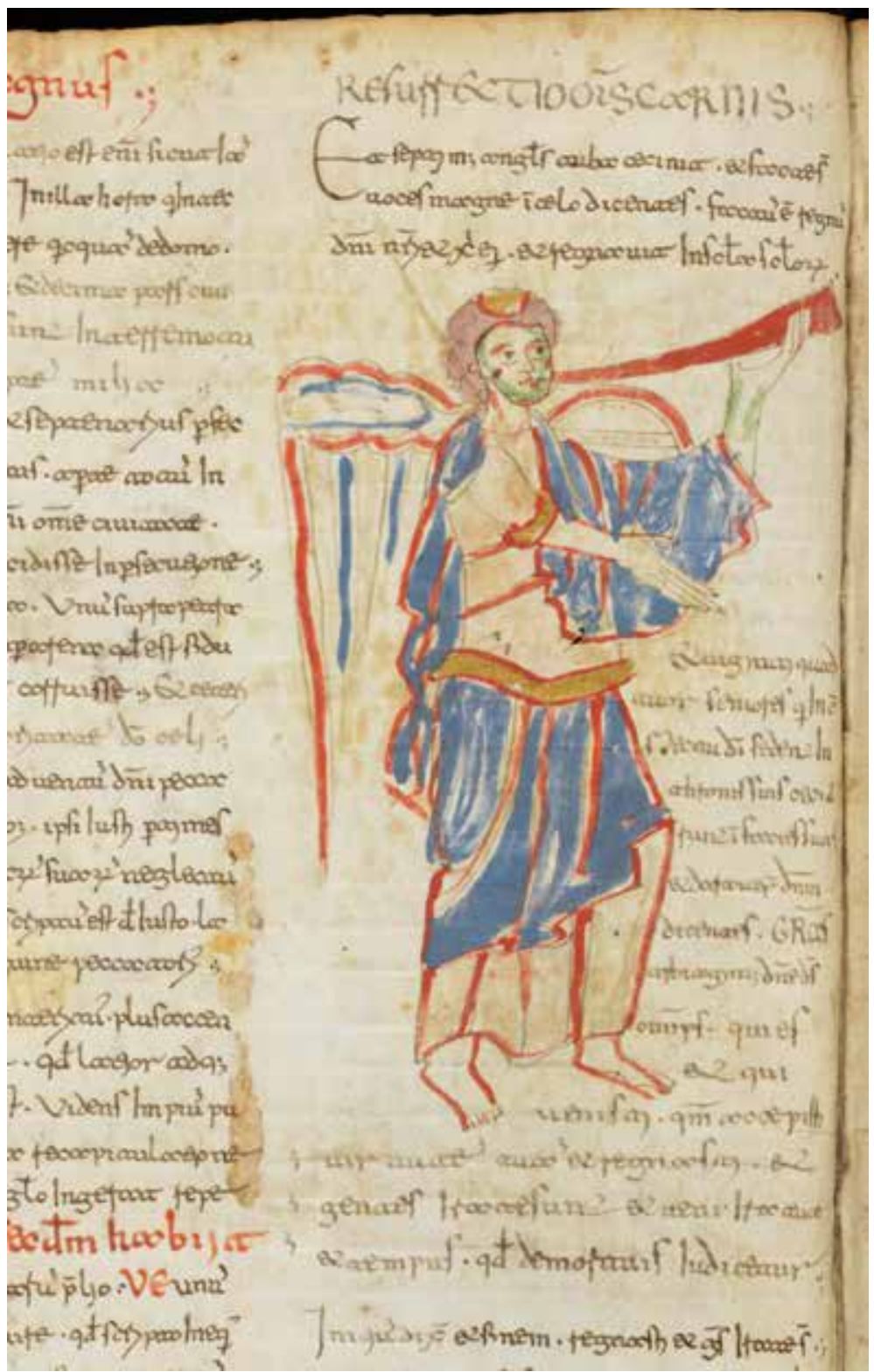


Figure 137 The Temple of the Ark and the Beast of the Abyss (Apoc. XI, 19 + Bk. VI). Geneva Beatus, fol. 208. Bibliothèque de Genève, MS lat. 357. For storia and image analysis, see page 183.

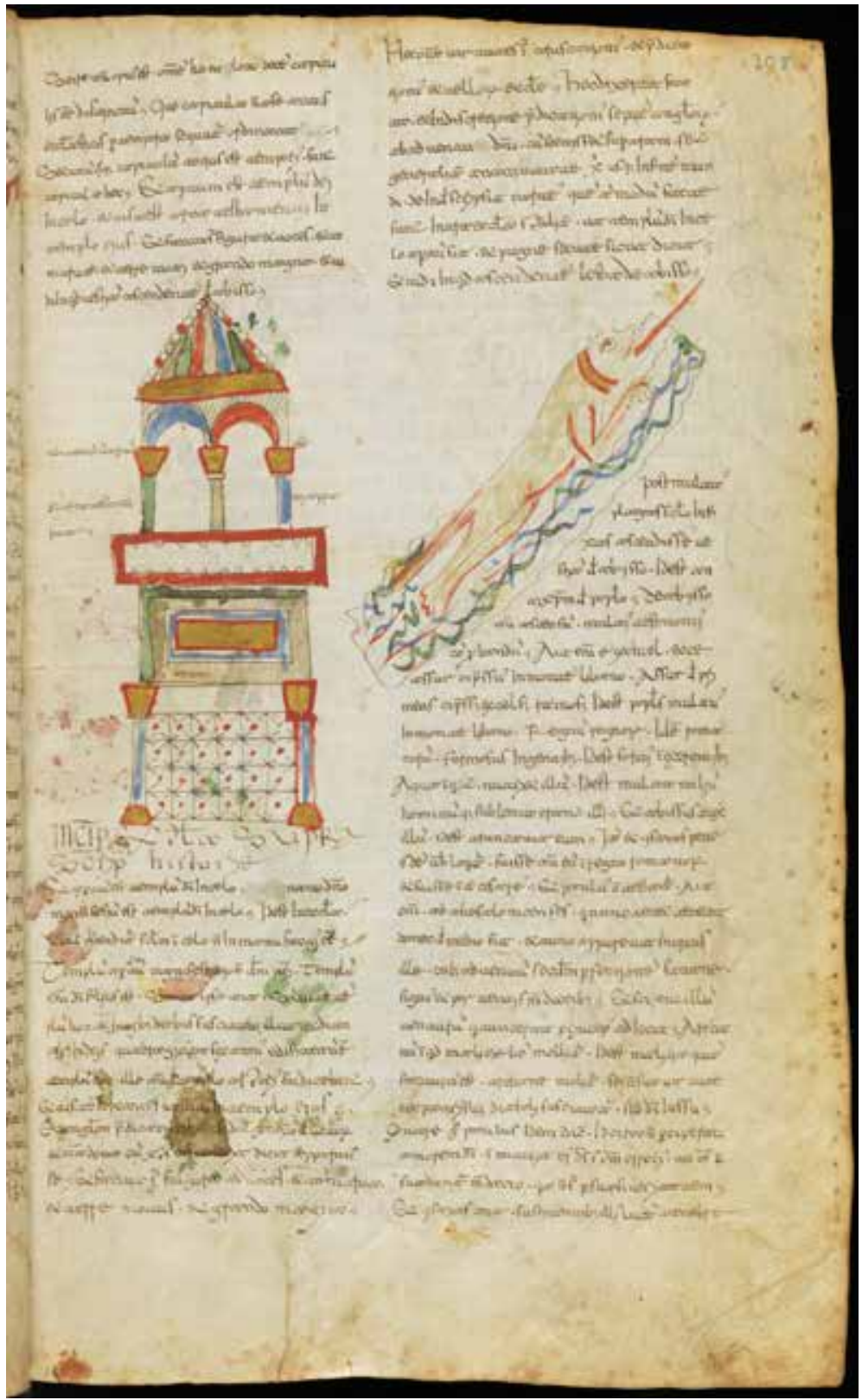


Figure 138 The Woman Clothed in the Sun (Apoc. XII, 1-18). Geneva Beatus, fol. 208vi . Bibliothèque de Genève, MS lat. 357. For storia and image analysis, see page 184.

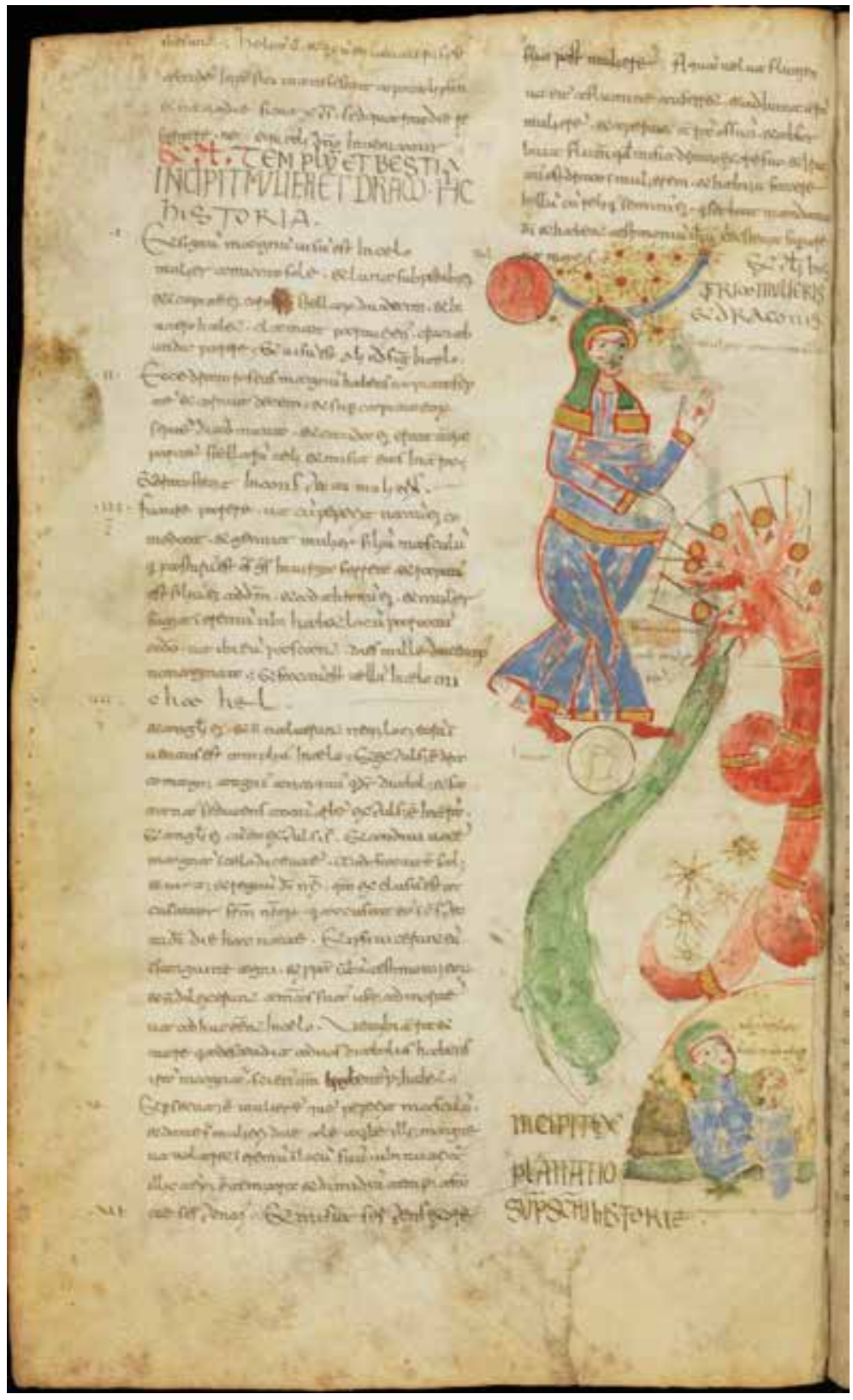


Figure 139 The Beast from the Sea (Apoc. XIII, 1-10). Geneva Beatus, fol. 211. Bibliothèque de Genève, MS lat. 357. For storia and image analysis, see page 186.

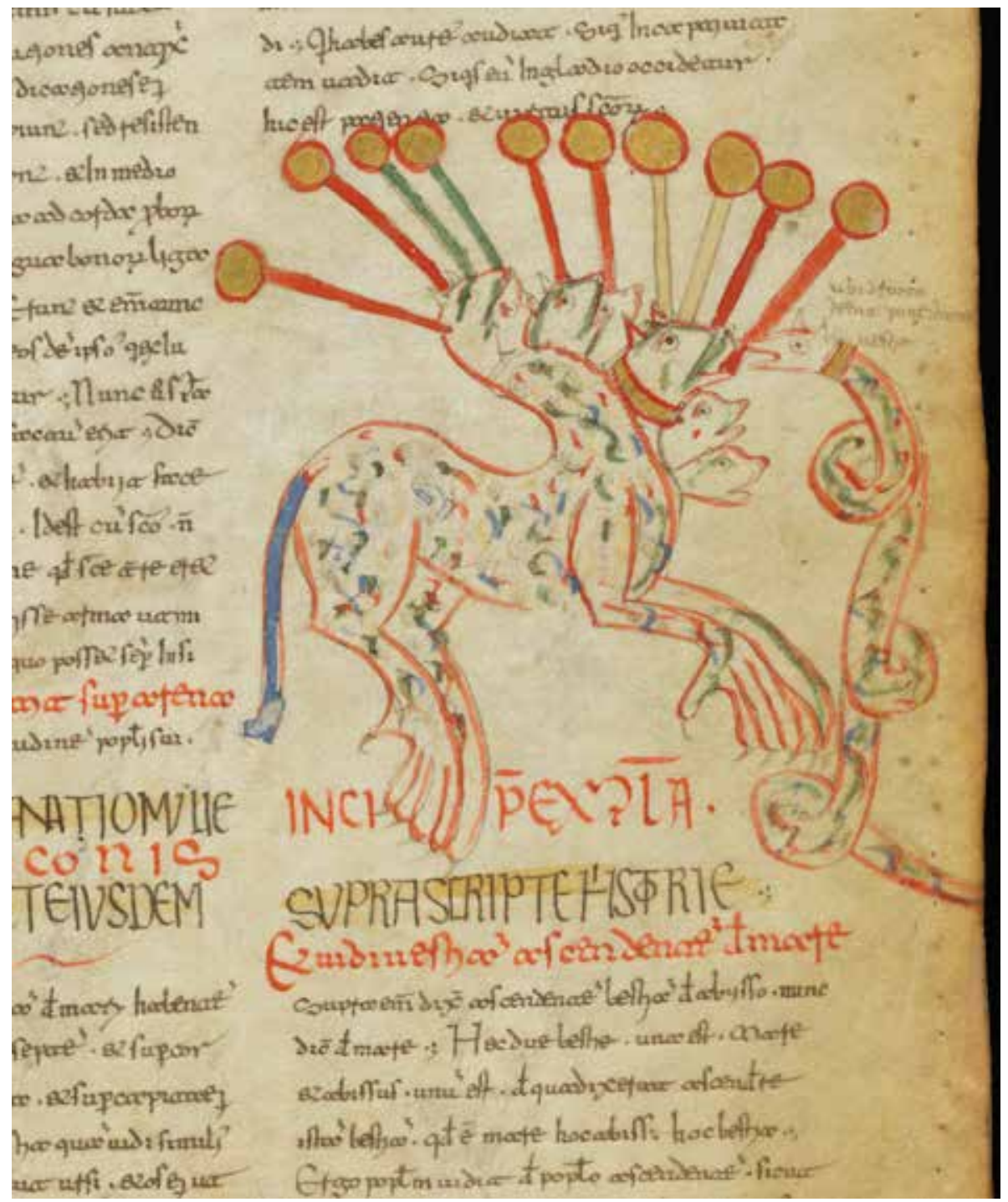


Figure 140 The Beast from the Earth (Apoc. XIII, 11-17). Geneva Beatus, fol. 213. Bibliothèque de Genève, MS lat. 357. For storia and image analysis, see page 187.




Figure 141 To Know the Number and Name of the Beast (Apoc. XIII, 18; Bk. VI). Table I, Geneva Beatus, fol. 217. Bibliothèque de Genève, MS lat. 357. For storia and image analysis, see page 187.

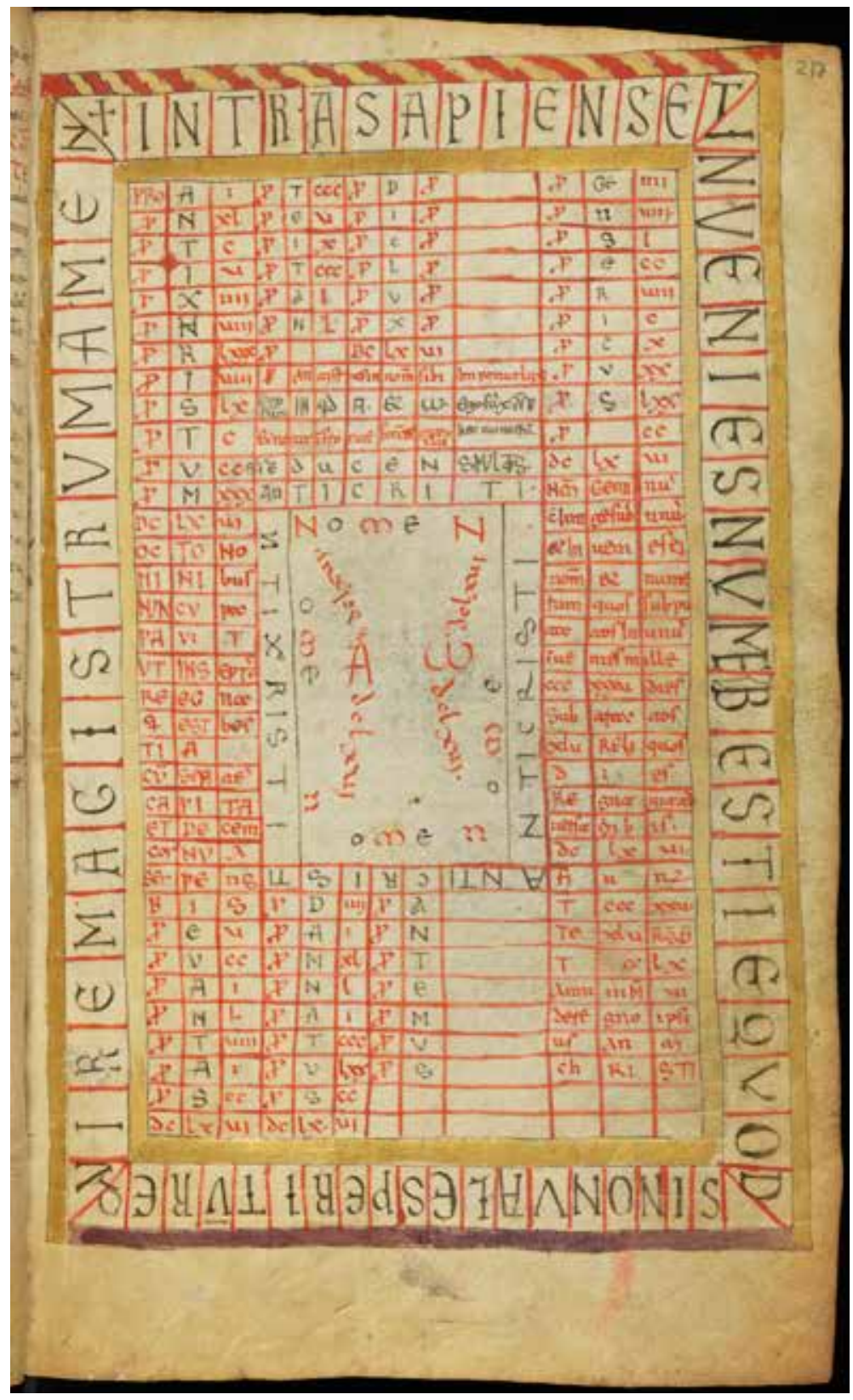


Figure 142 The Lamb on Mount Sion and the Chaste (Apoc. XIV, 1-5). Geneva Beatus, fol. 218.

Bibliothèque de Genève, MS lat. 357. For storia and image analysis, see page 188.

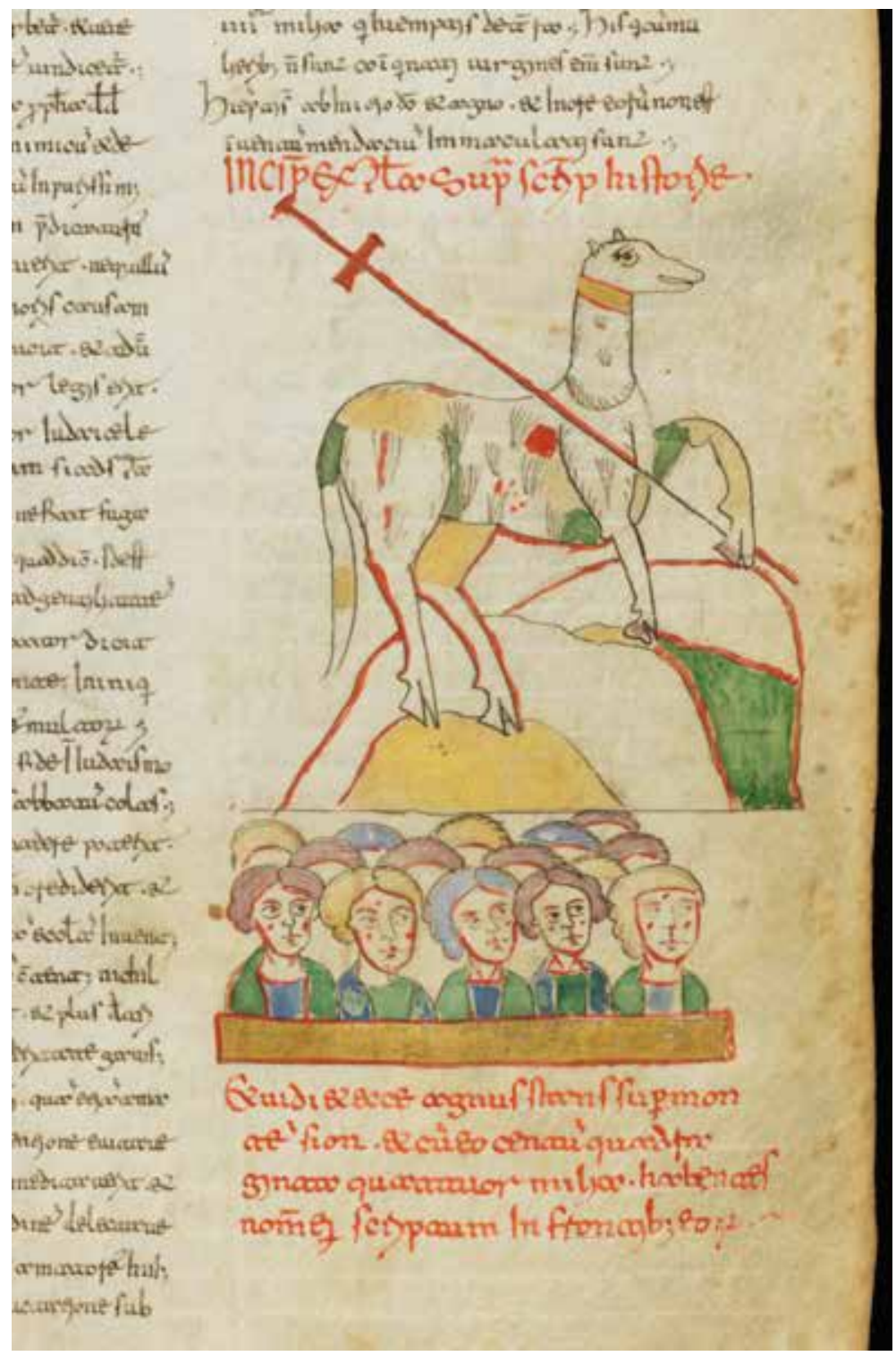


Figure 143 The Angel with the Everlasting Gospel (Apoc. XIV, 6-13). Geneva Beatus, fol. 219. Bibliothèque de Genève, MS lat. 357. For storia and image analysis, see page 188.

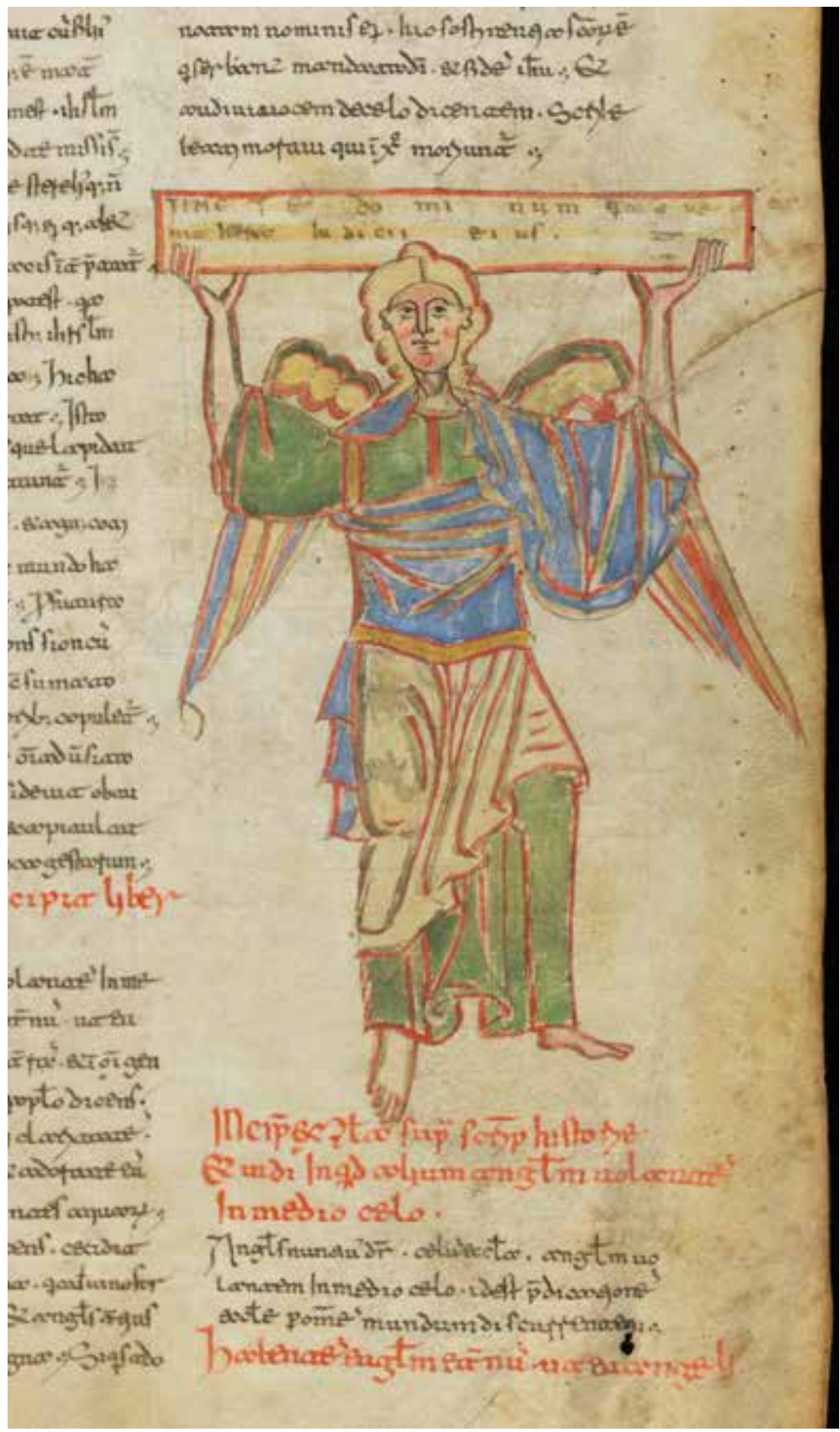


Figure 144 The Harvest of the Wrath of God (Apoc. XIV, 14-20). Geneva Beatus, fol. 220. Bibliothèque de Genève, MS lat. 357. For storia and image analysis, see page 189.

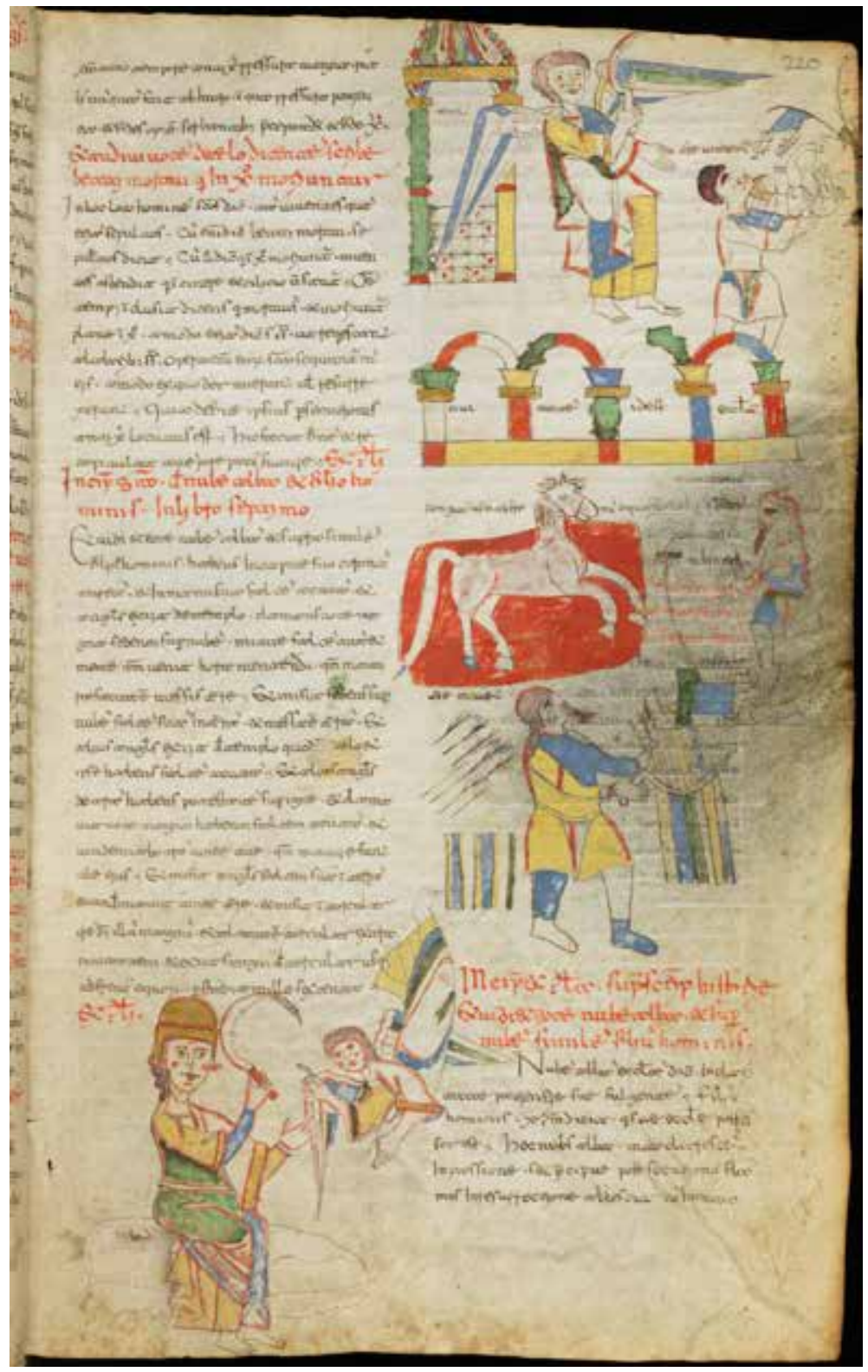


Figure 145 The Seven Angels with the Seven Plagues (Apoc. XV, 1-4). Geneva Beatus, fol. 221v. Bibliothèque de Genève, MS lat. 357. For storia and image analysis, see page 190.

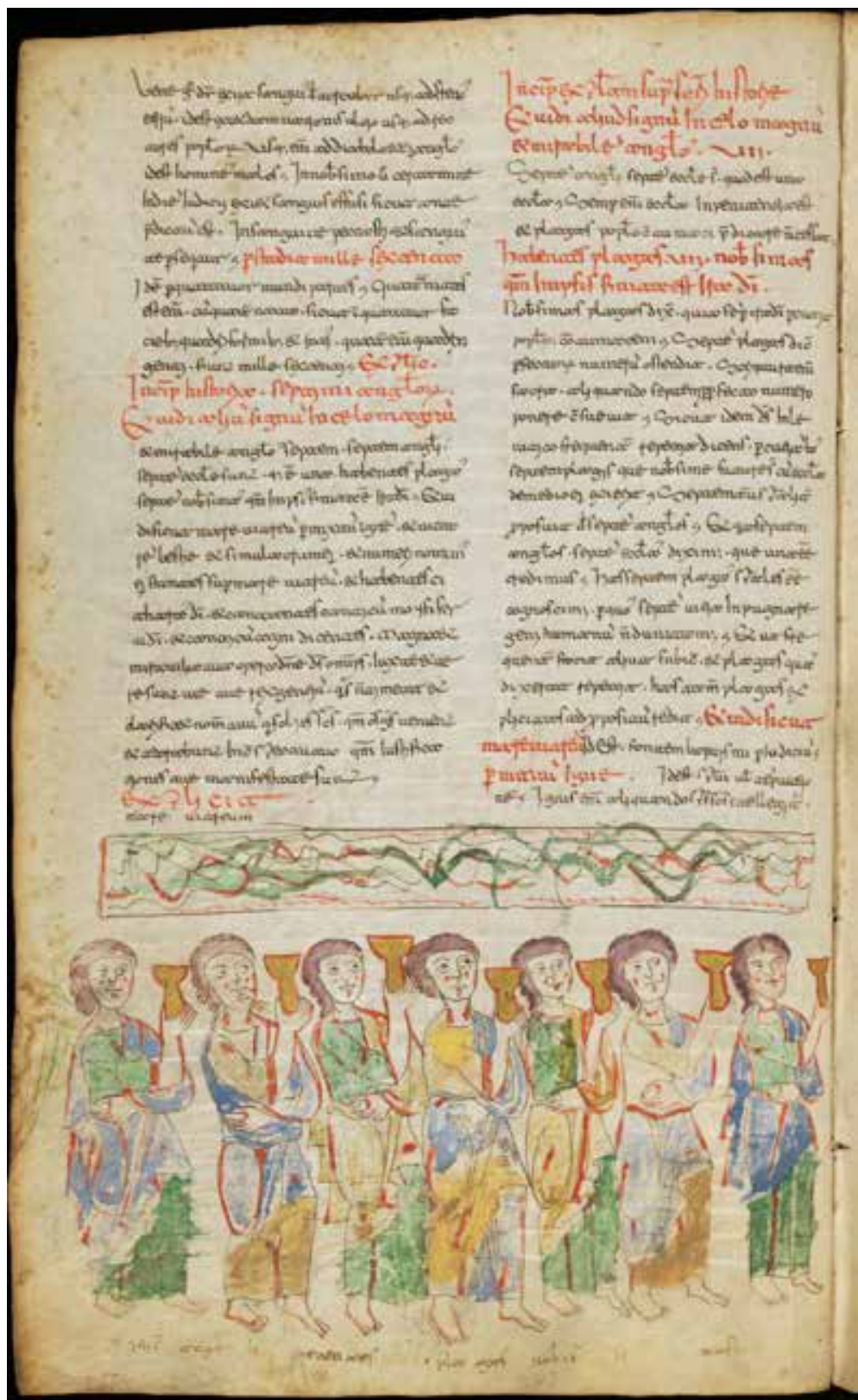


Figure 146 The Angels with the Plagues Exit the Temple (Apoc. XV, 5-8). Geneva Beatus, fol. 222. Bibliothèque de Genève, MS lat. 357. For storia and image analysis, see page 190.

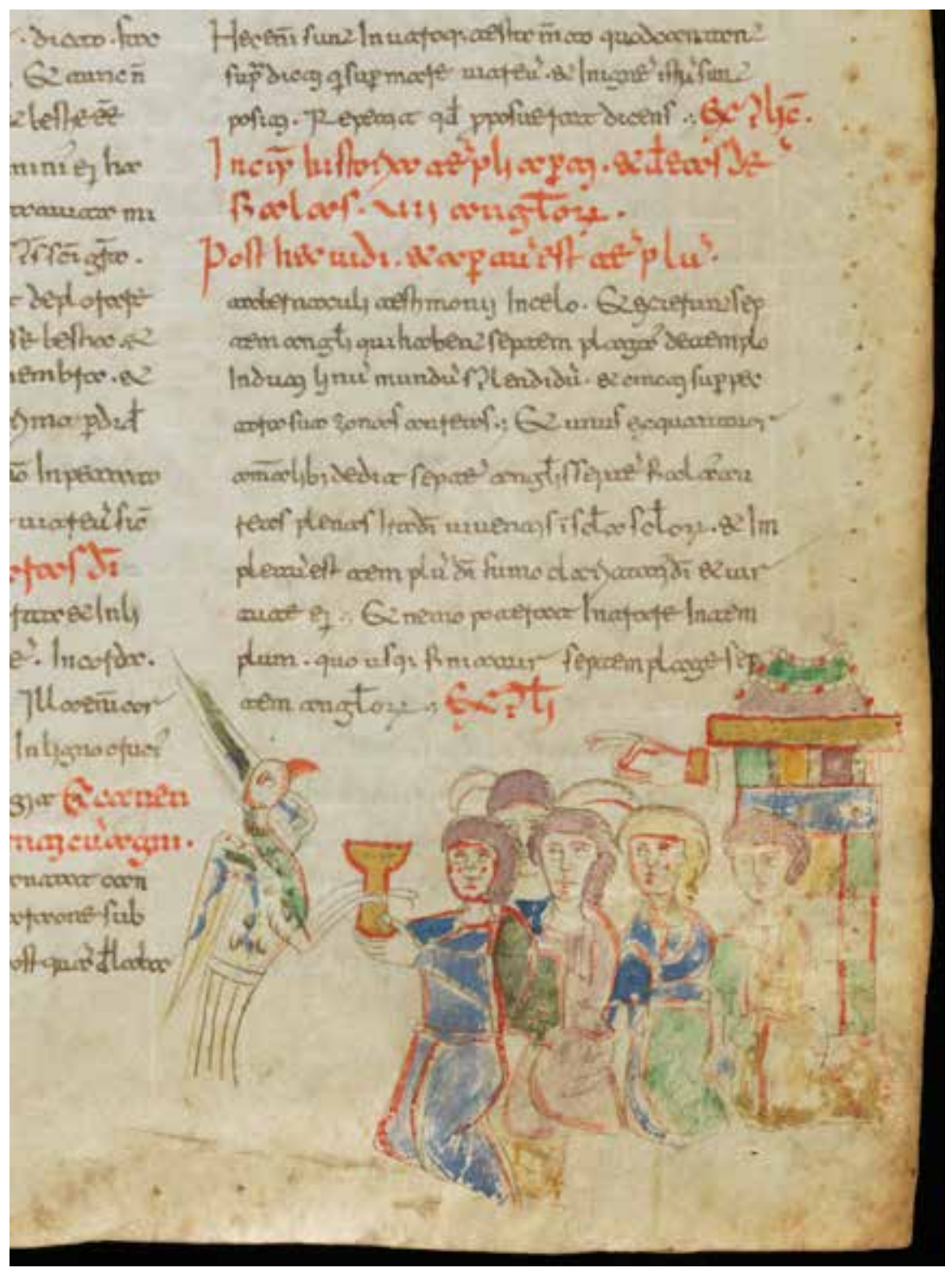


Figure 147 The Plague Angels Are Ordered to Empty Their Bowls (Apoc. XVI, 1). Geneva Beatus, fol. 223. Bibliothèque de Genève, MS lat. 357. For storia and image analysis, see page 191.

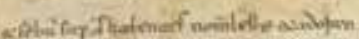

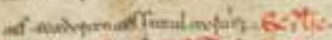

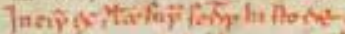

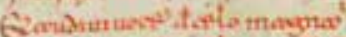

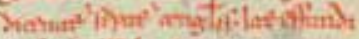
\pm Eatar'si hiffix.

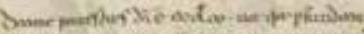

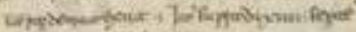

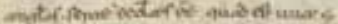

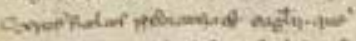

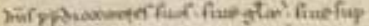

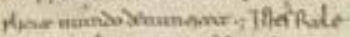

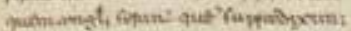

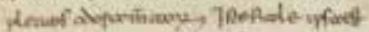

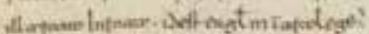

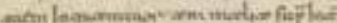

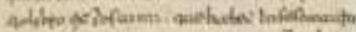

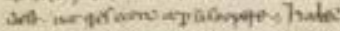

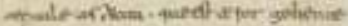

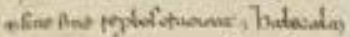

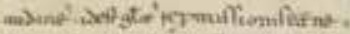

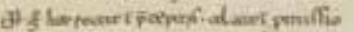

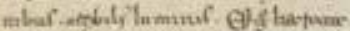

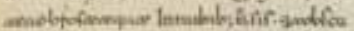

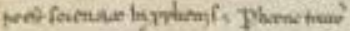

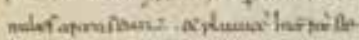

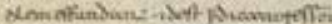

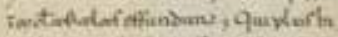

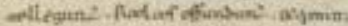

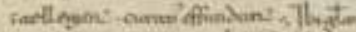

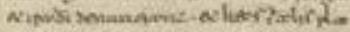

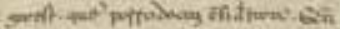

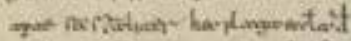

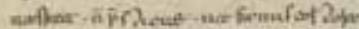

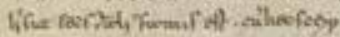

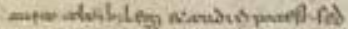

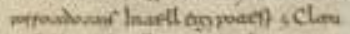

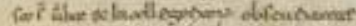

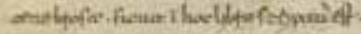

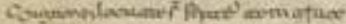

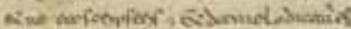

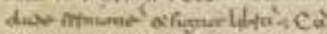

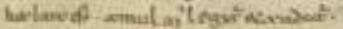

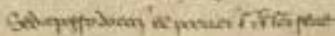

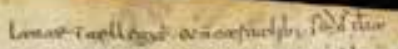

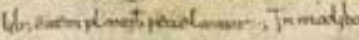

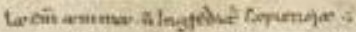

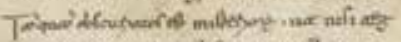

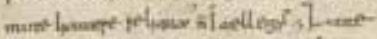

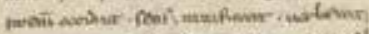

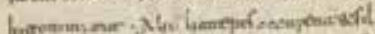

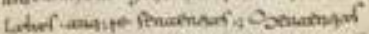

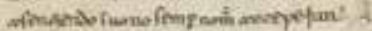

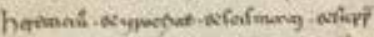

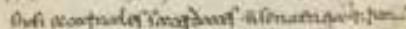

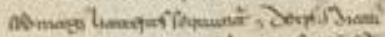

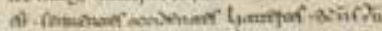

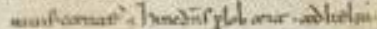

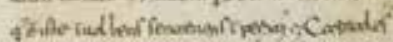

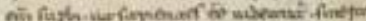

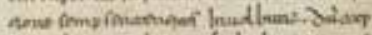

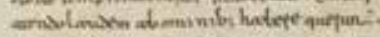

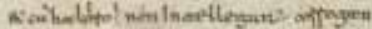

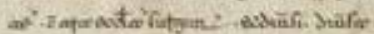

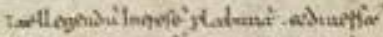

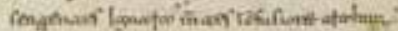

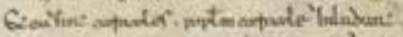

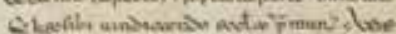

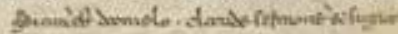

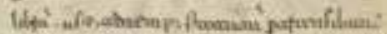

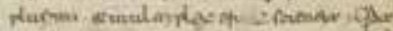

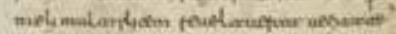

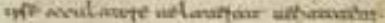

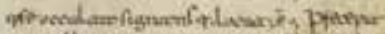

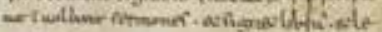

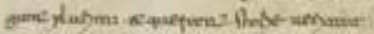

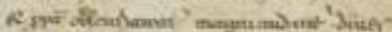

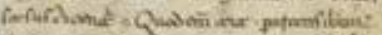

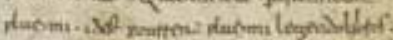

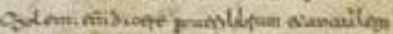

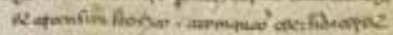

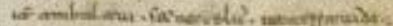

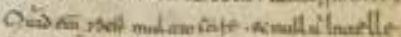

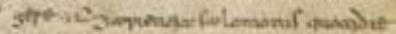

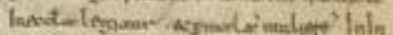

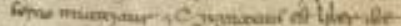

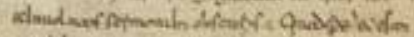

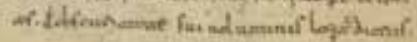


Figure 148 The First Angel Empties His Bowl on the Earth (Apoc. XVI, 2). Geneva Beatus, fol. 223v. Bibliothèque de Genève, MS lat. 357. For storia and image analysis, see page 191.

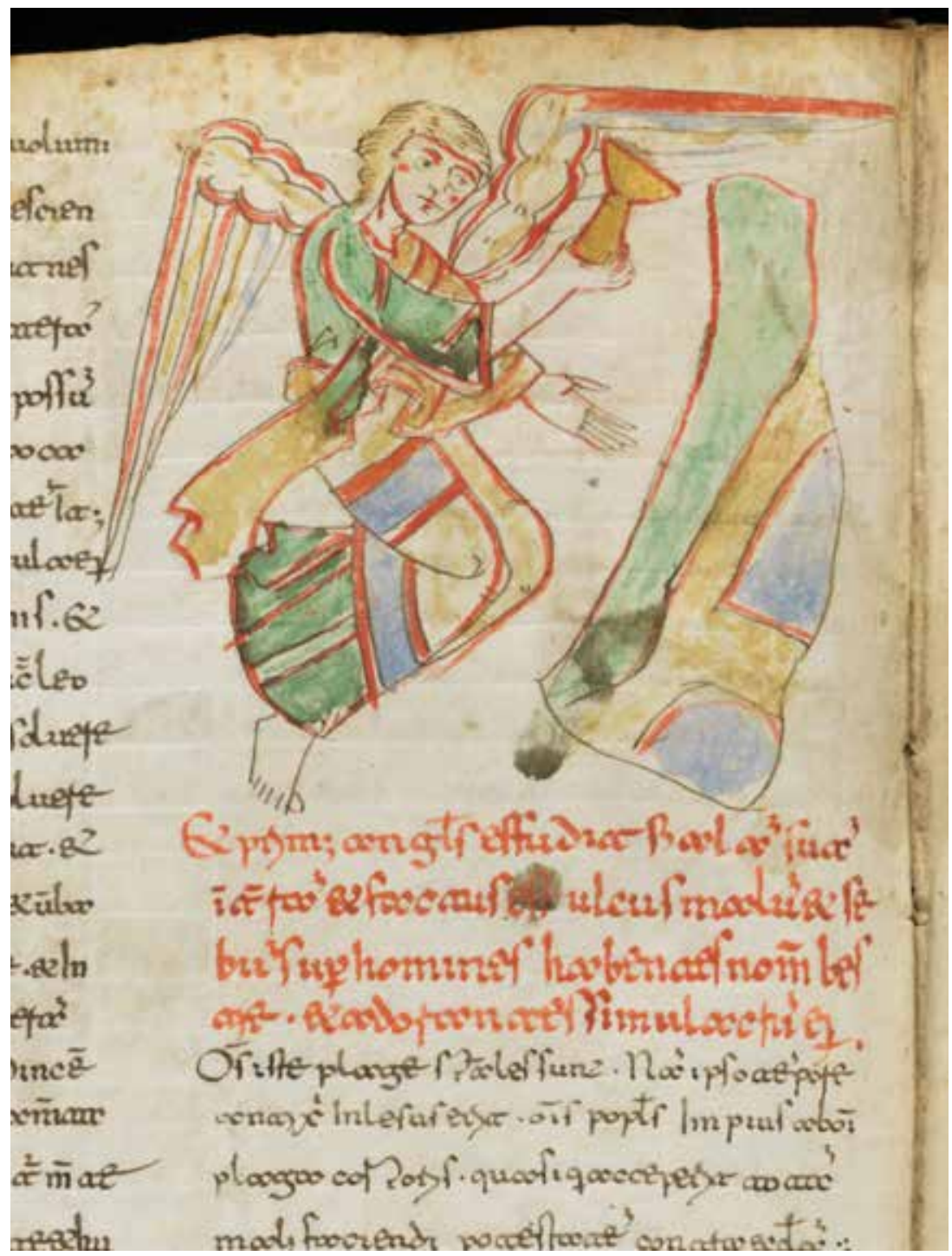


Figure 149 The Second Angel Empties His Bowl in the Sea (Apoc. XVI, 3); The Third Angel Empties His Bowl in the Rivers (Apoc. XVI, 4-7). Geneva Beatus, fol. 224. Bibliothèque de Genève, MS lat. 357. For storia and image analysis, see page 191.

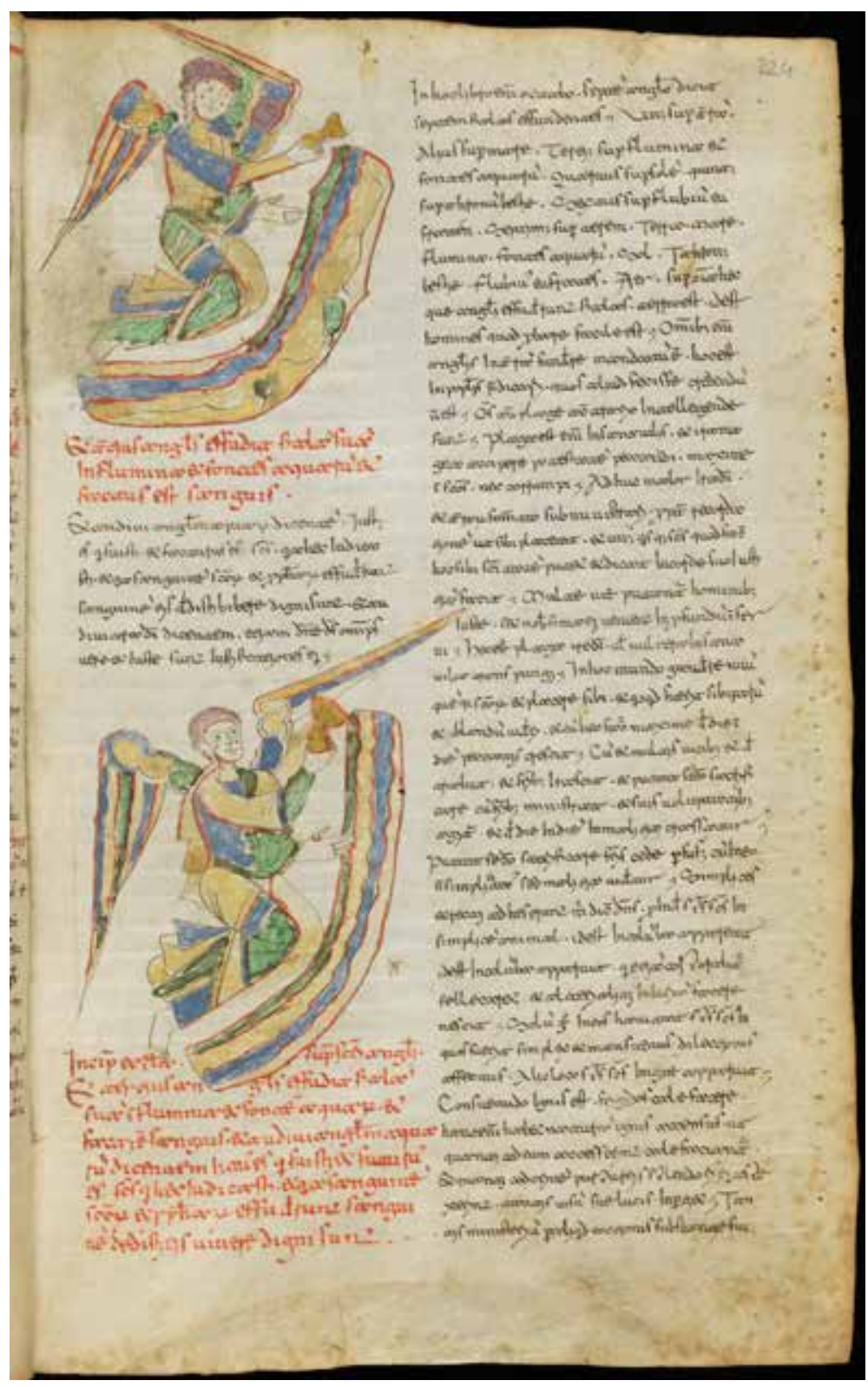


Figure 150 The Fourth Angel Empties His Bowl in the Sun (Apoc. XVI, 8-9). Geneva Beatus, fol. 225. Bibliothèque de Genève, MS lat. 357. For storia and image analysis, see page 192.

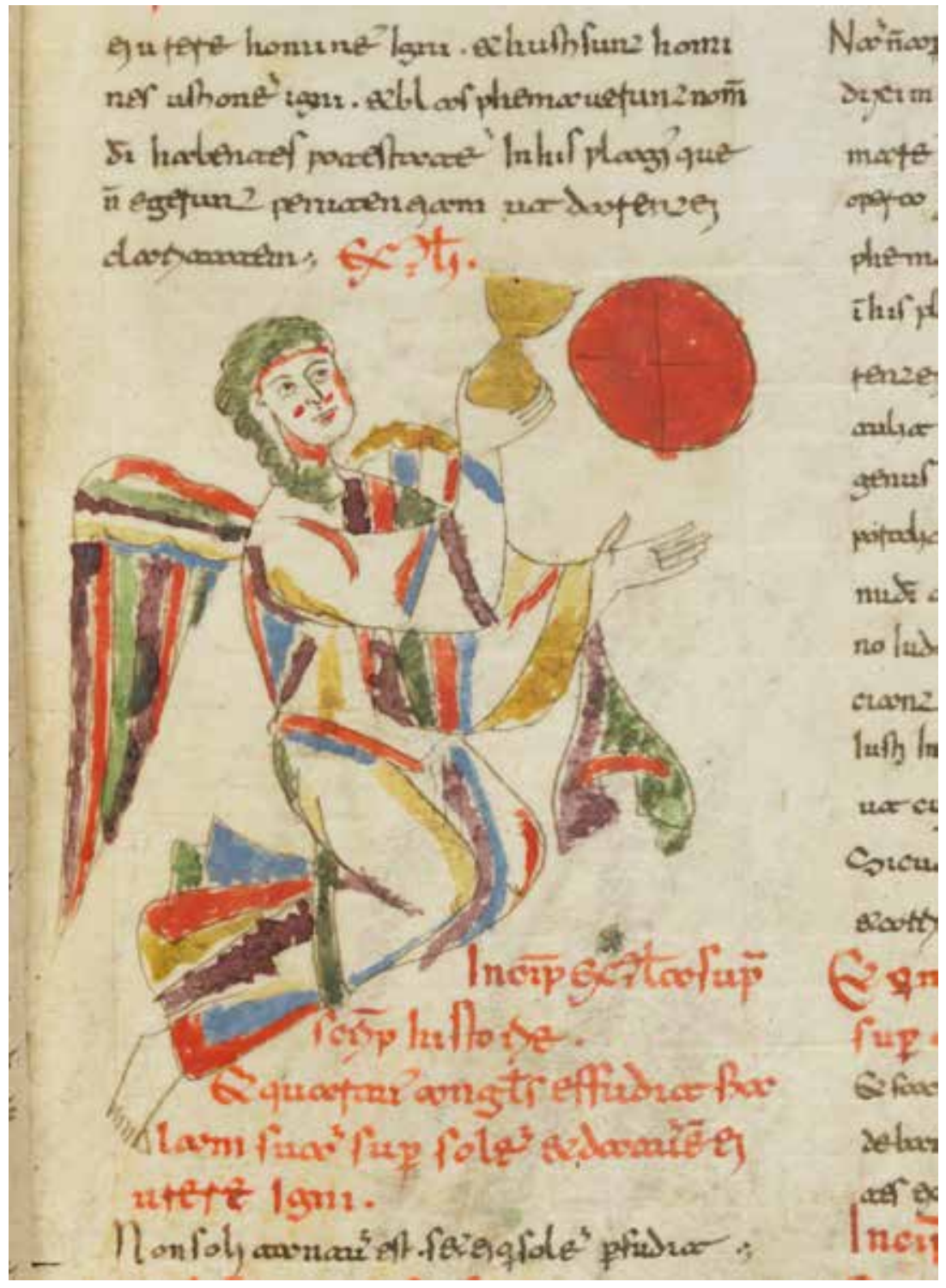


Figure 151 The Fifth Angel Empties His Bowl on the Throne of the Beast (Apoc. XVI, 10-11); The Sixth Angel Empties His Bowl on the Euphrates (Apoc. XVI, 12); The Unclean Spirits Like Frogs (Apoc. XVI, 13-16). Geneva Beatus, fol. 225․ Bibliothèque de Genève, MS lat. 357. For storia and image analysis, see page 192.

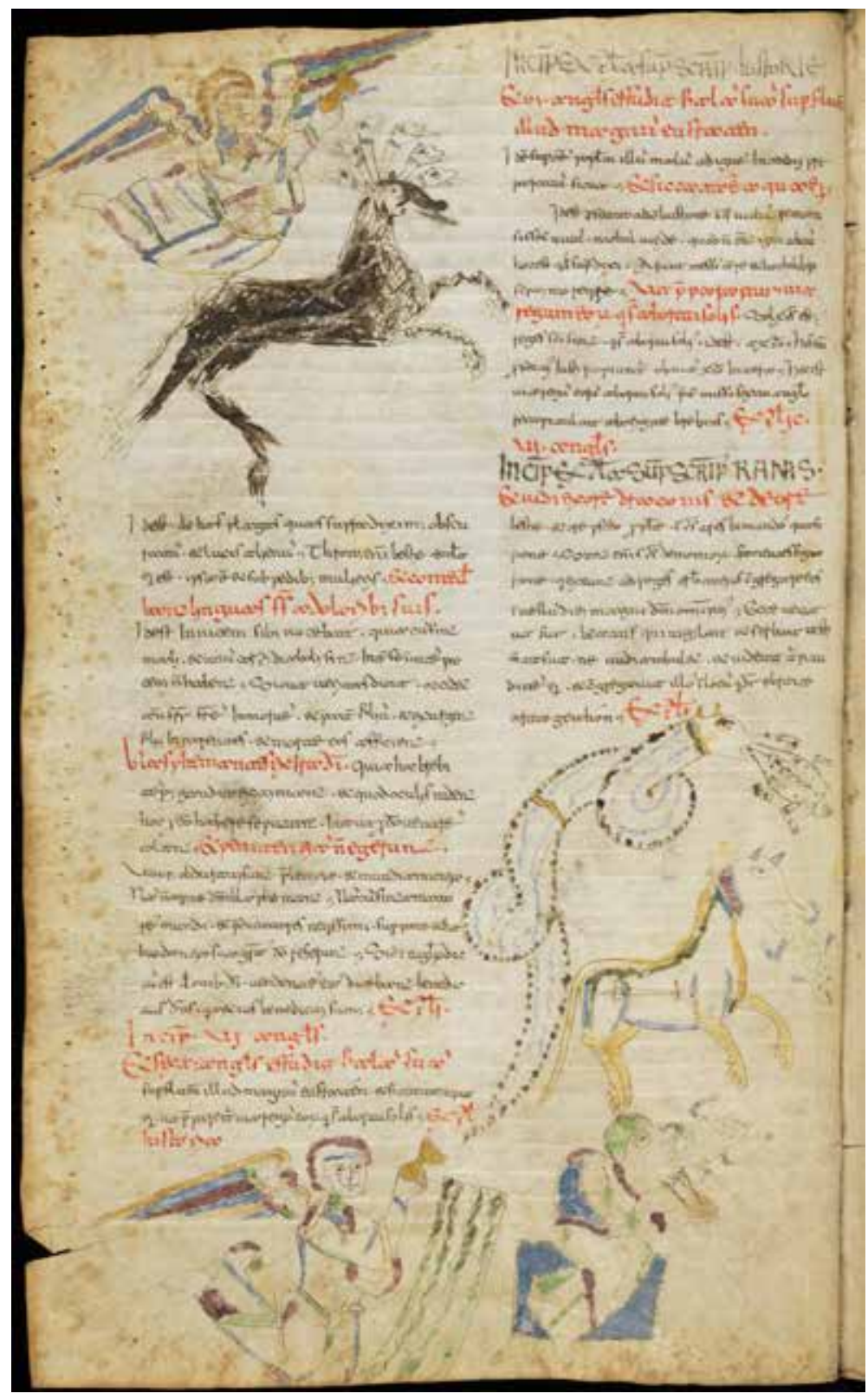


Figure 152 The Seventh Angel Empties His Bowl in the Air (Apoc. XVI, 17-21). Geneva Beatus, fol. 227. Bibliothèque de Genève, MS lat. 357. For storia and image analysis, see page 193.

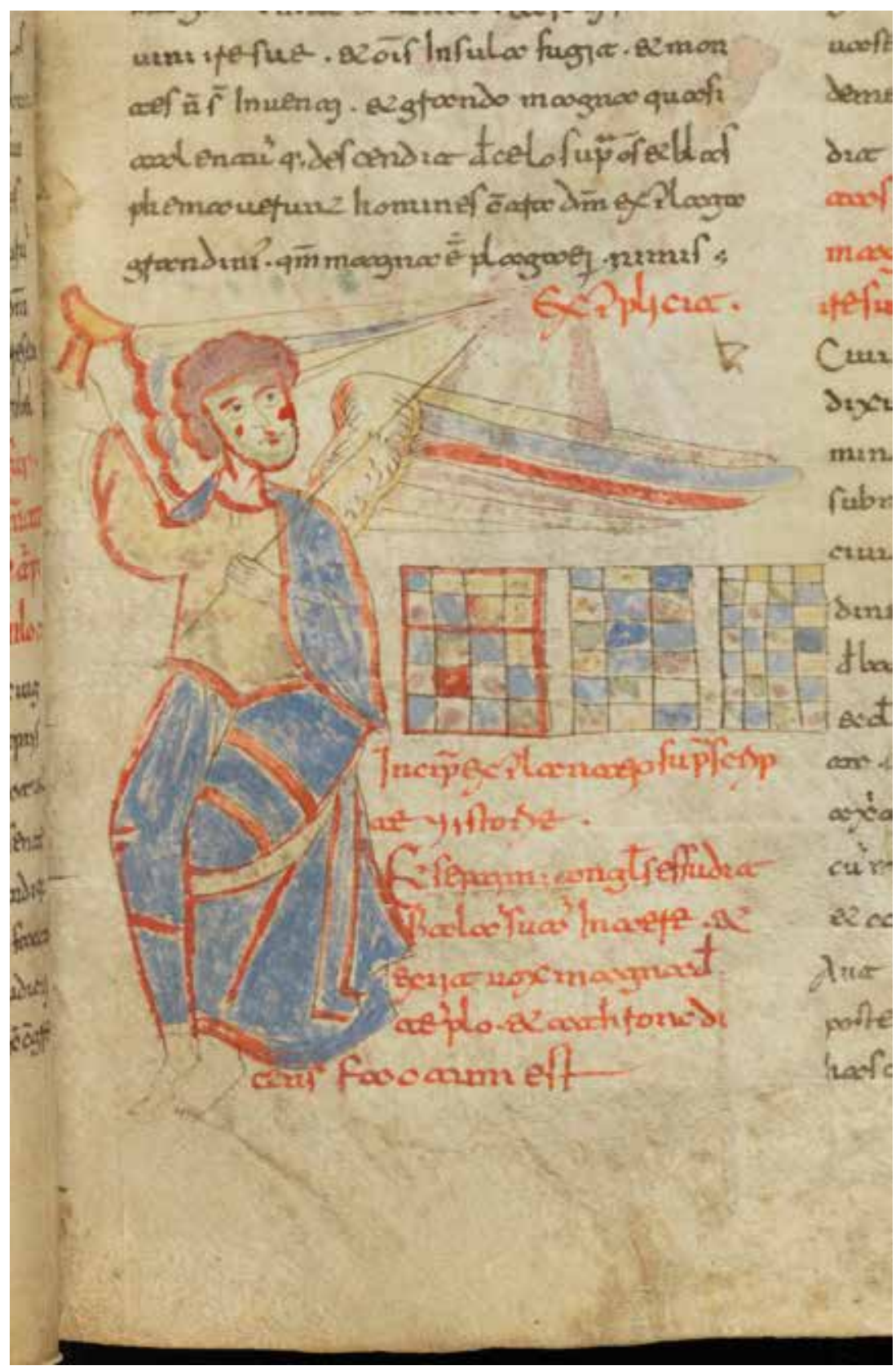


Figure 153 The Great Whore Seated upon the Waters (Apoc. XVII, 1-3). Geneva Beatus, fol. 227 . Bibliothèque de Genève, MS lat. 357. For storia and image analysis, see page 193.

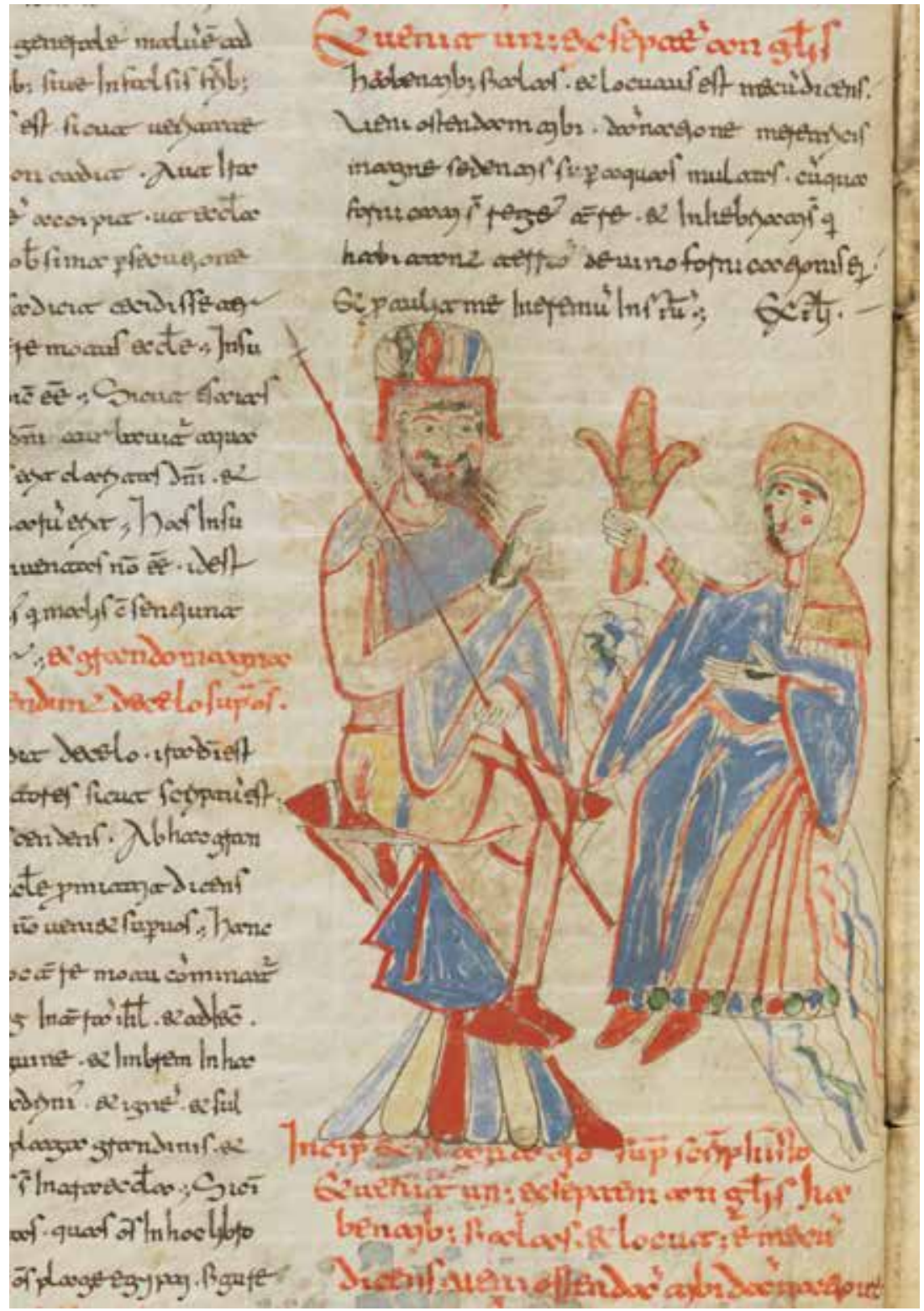


Figure 154 The Woman Seated on the Scarlet Beast (Apoc. XVII, 3-13). Geneva Beatus, fol. 228.

Bibliothèque de Genève, MS lat. 357. For storia and image analysis, see page 195.

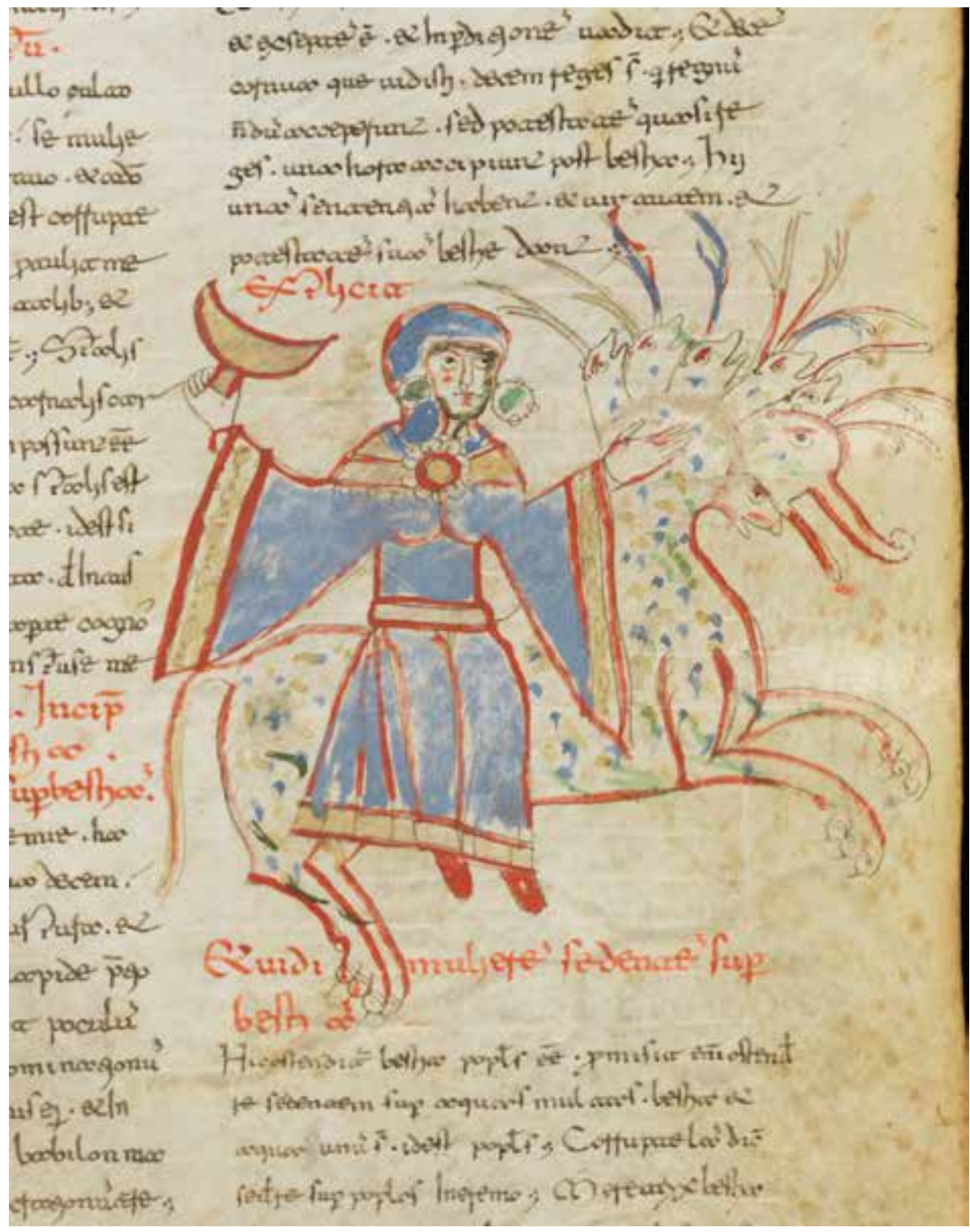


Figure 155 The Victory of the Lamb (Apoc. XVII, 14-18). Geneva Beatus, fol. 231. Bibliothèque de Genève, MS lat. 357. For storia and image analysis, see page 196.

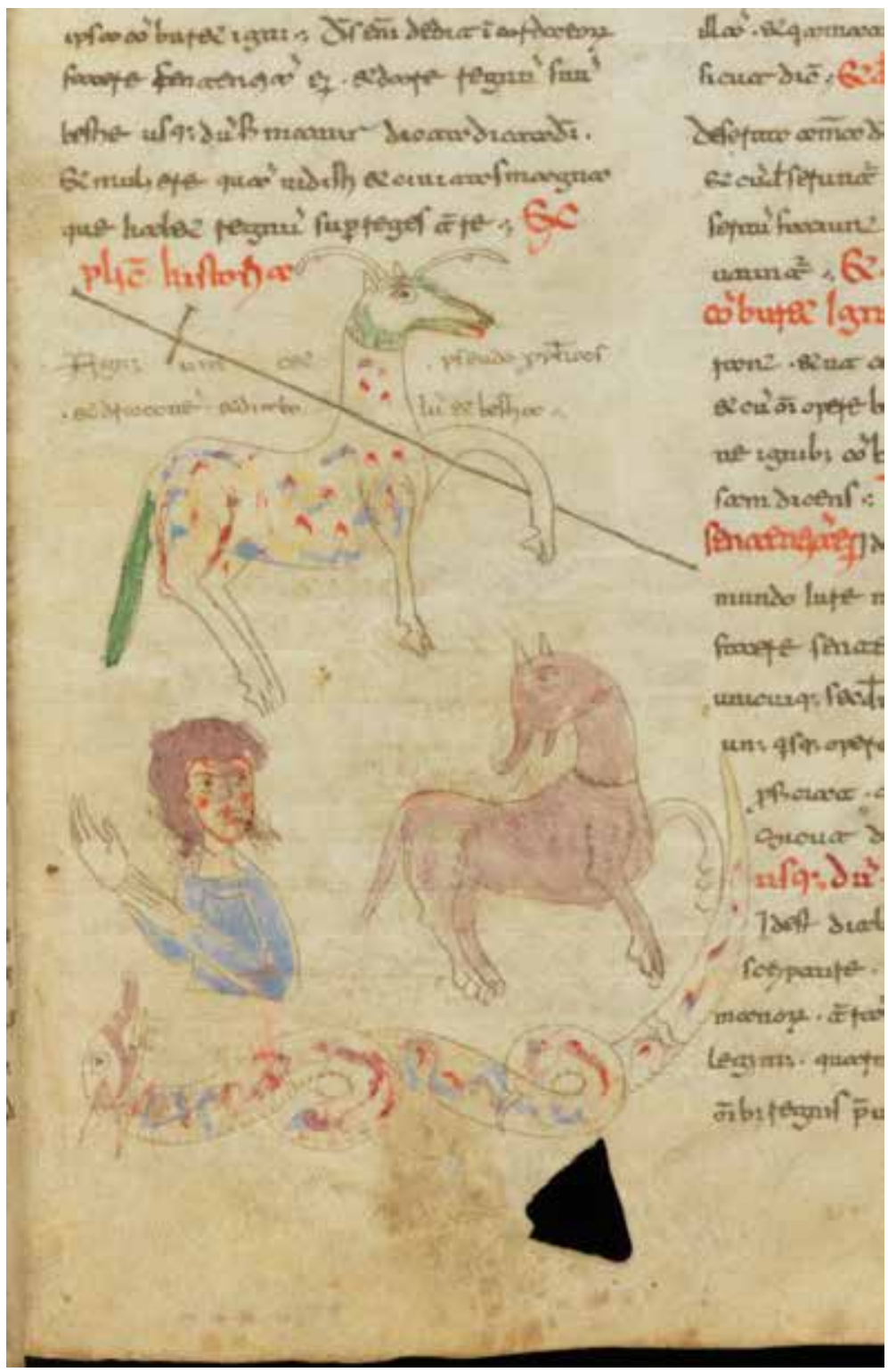


Figure 156 The Burning of Babylon (Apoc. XVIII, 1-20). Geneva Beatus, fol. 232. Bibliothèque de Genève, MS lat. 357. For storia and image analysis, see page 197.

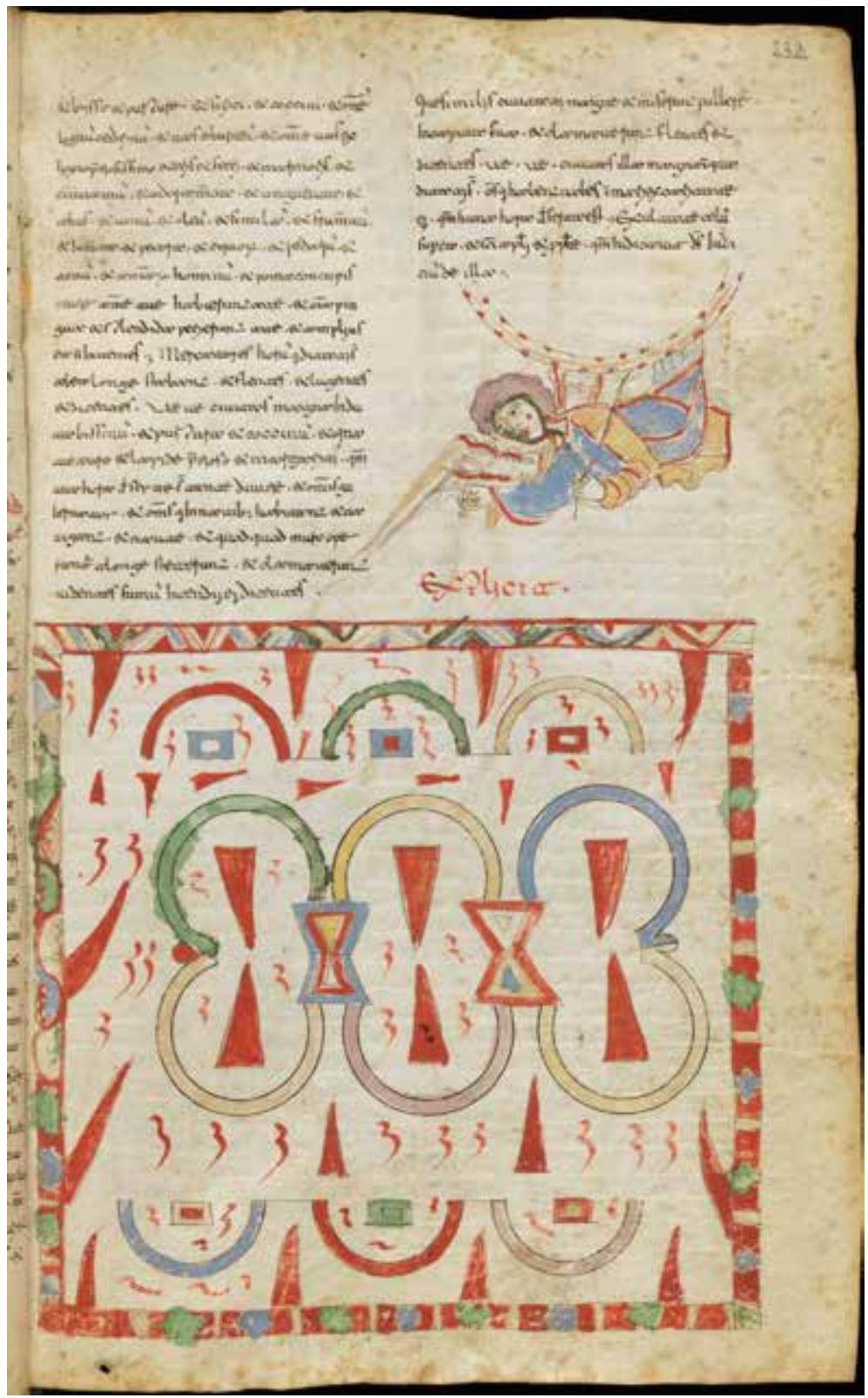


Figure 157 The Angel Casts the Millstone into the Sea (Apoc. XVIII, 21-24). Geneva Beatus, fol. 233v". Bibliothèque de Genève, MS lat. 357. For storia and image analysis, see page 198.

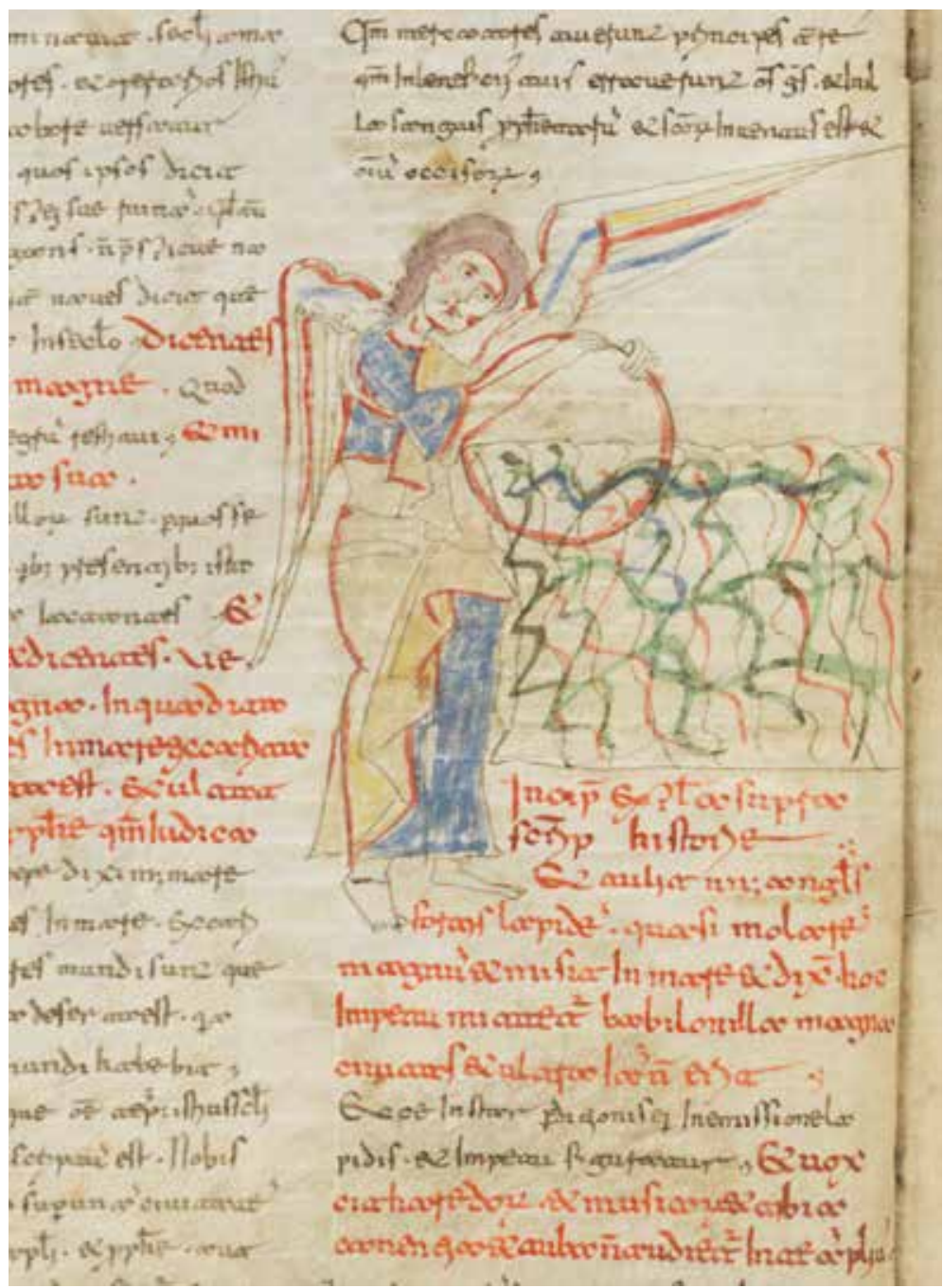


Figure 158 The Multitude in Heaven Praise God (Apoc. XIX, 1-10). Geneva Beatus, fols. 234-234".

Bibliothèque de Genève, MS lat. 357. For storia and image analysis, see page 198.

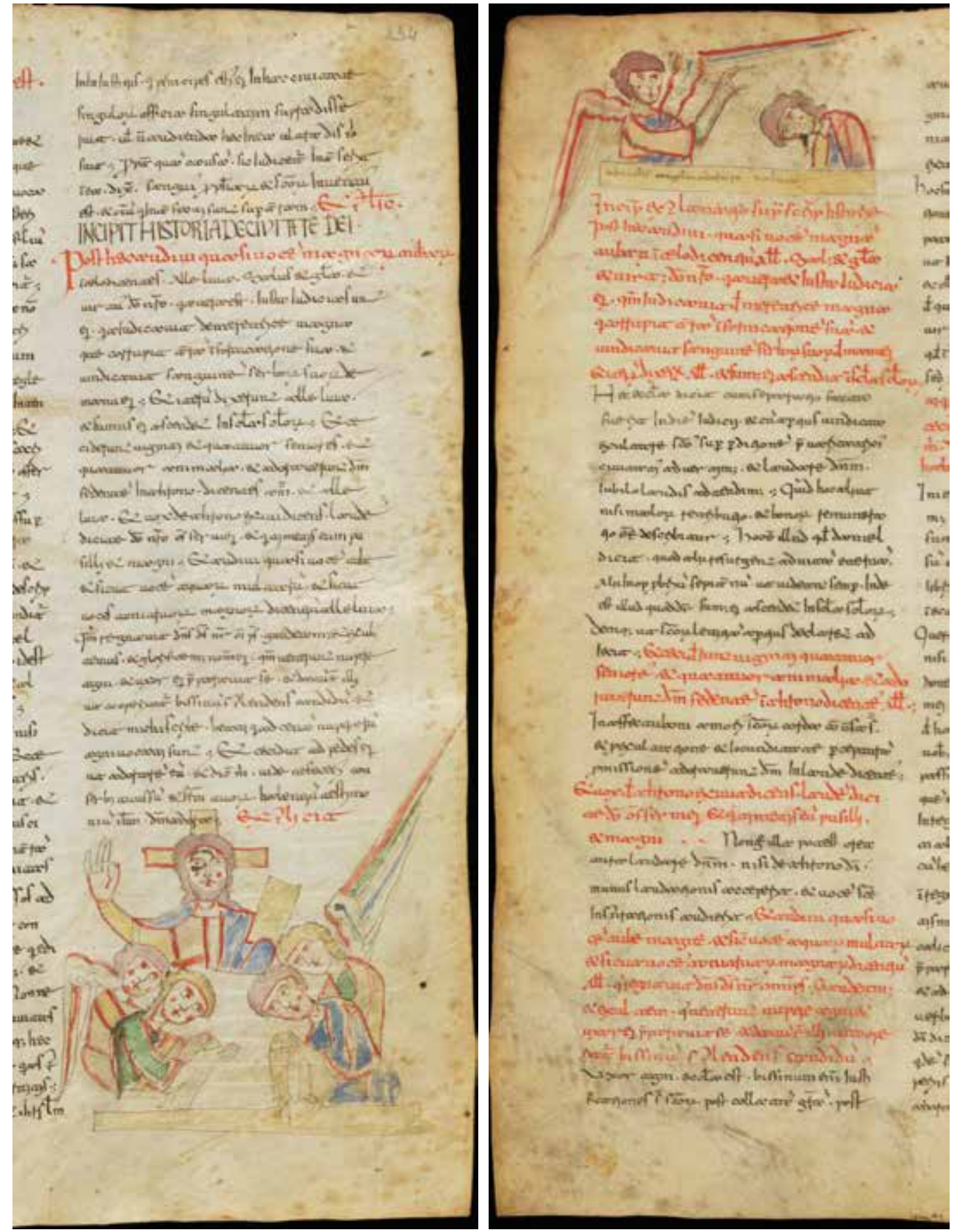


Figure 159 The Rider Faithful and True (Apoc. XIX, 11-16). Geneva Beatus, fol. 235. Bibliothèque de Genève, MS lat. 357. For storia and image analysis, see page 199.

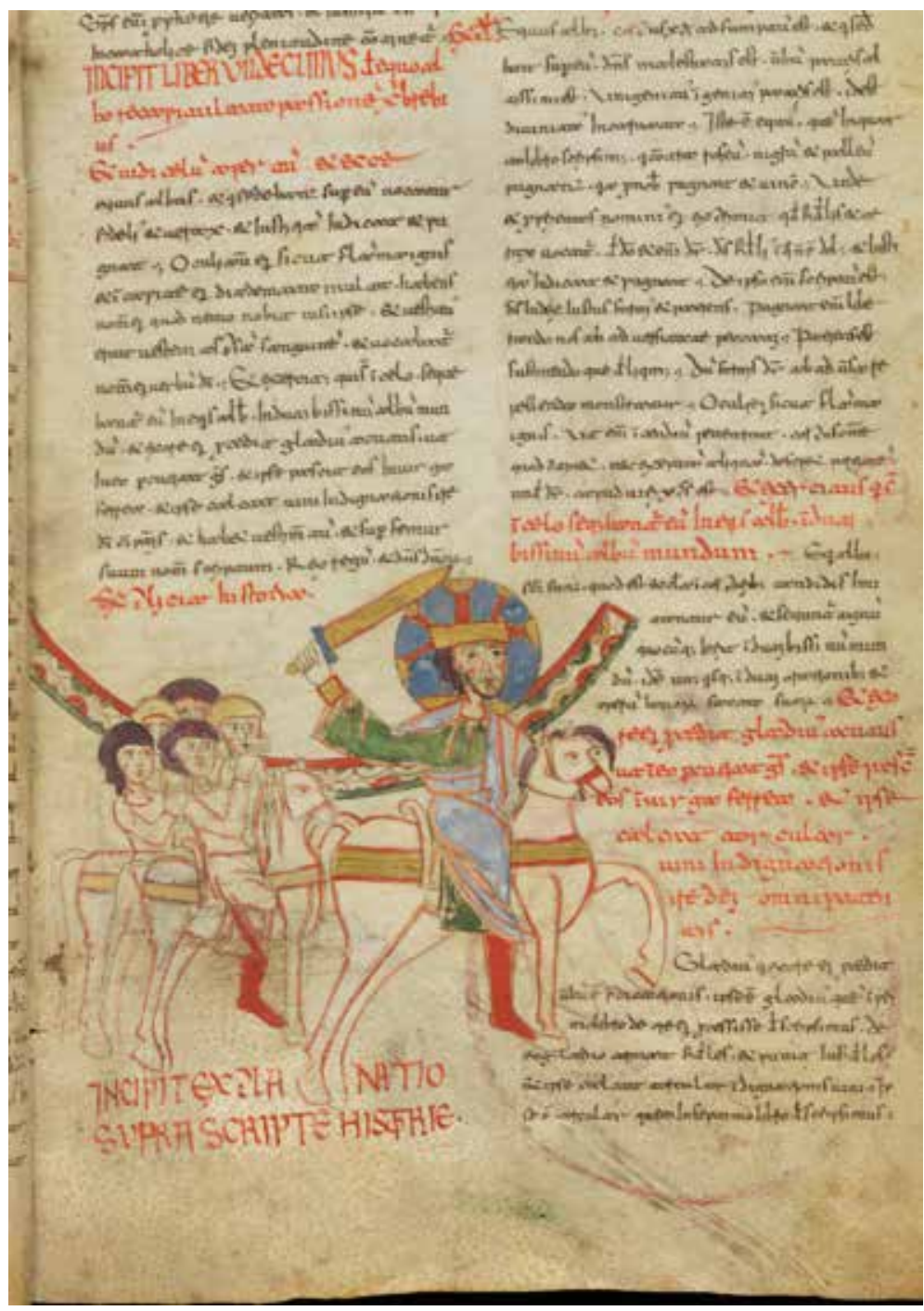


Figure 160 The Angel Standing in the Sun (Apoc. XIX, 17-18). Geneva Beatus, fol. 235". Bibliothèque de Genève, MS lat. 357. For storia and image analysis, see page 199.

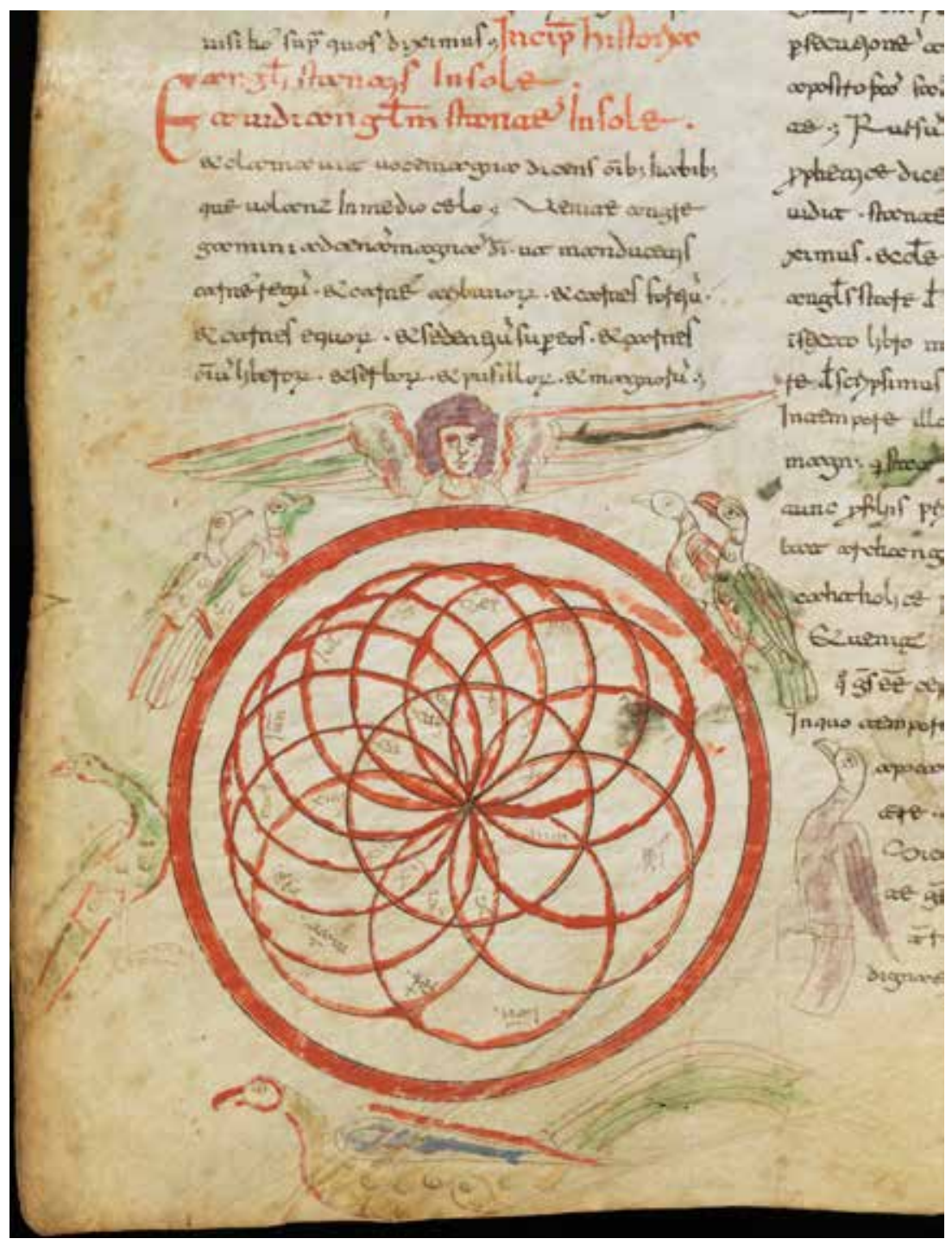


Figure 161 The Defeat of the Beast (Apoc. XIX, 19-21). Geneva Beatus, fol. 236. Bibliothèque de Genève, MS lat. 357. For storia and image analysis, see page 200.

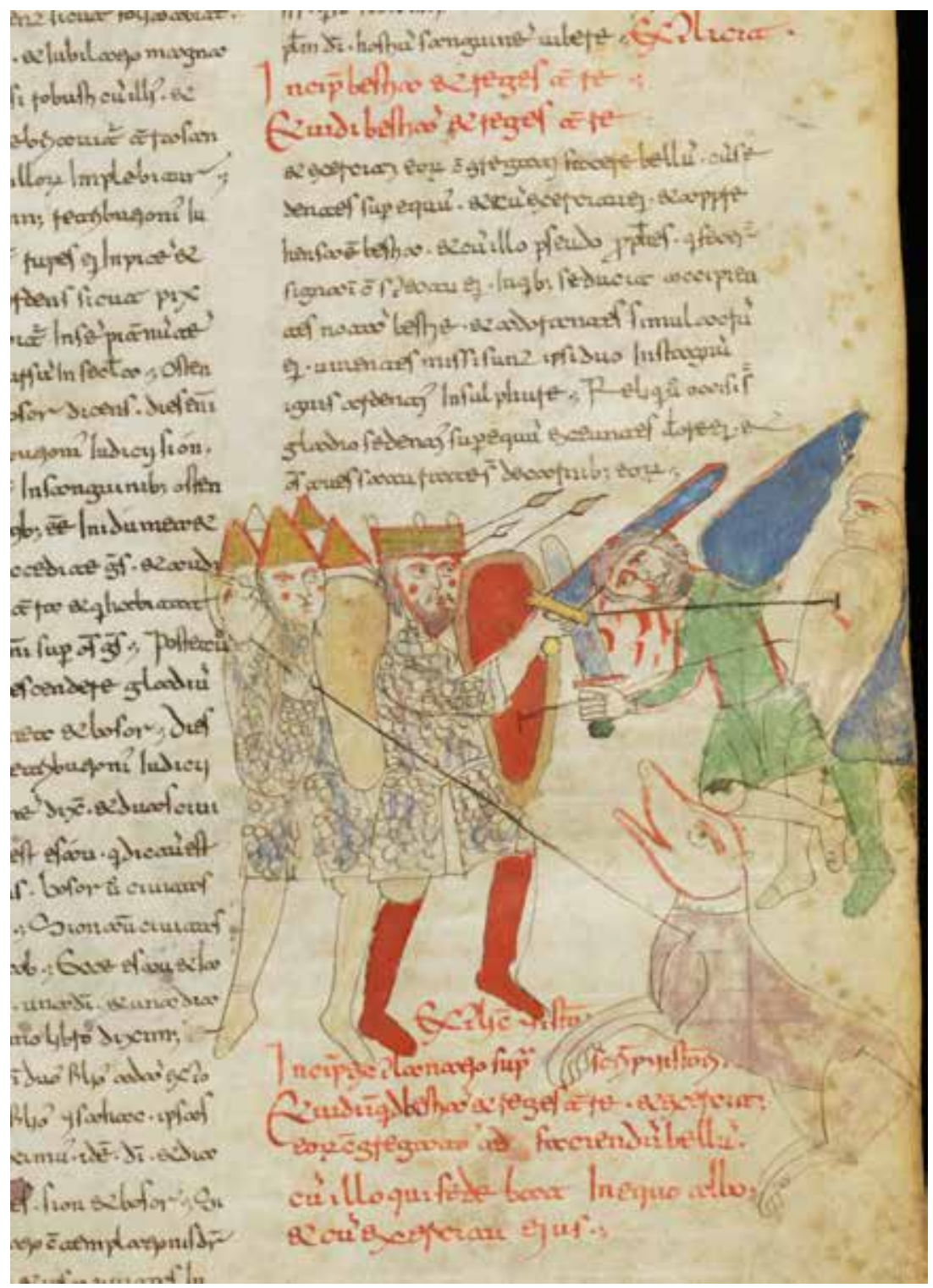


Figure 162 The Devil Chained in the Abyss (Apoc. XX, 1-3). Geneva Beatus, fol. 236*. Bibliothèque de Genève, MS lat. 357. For storia and image analysis, see page 200.

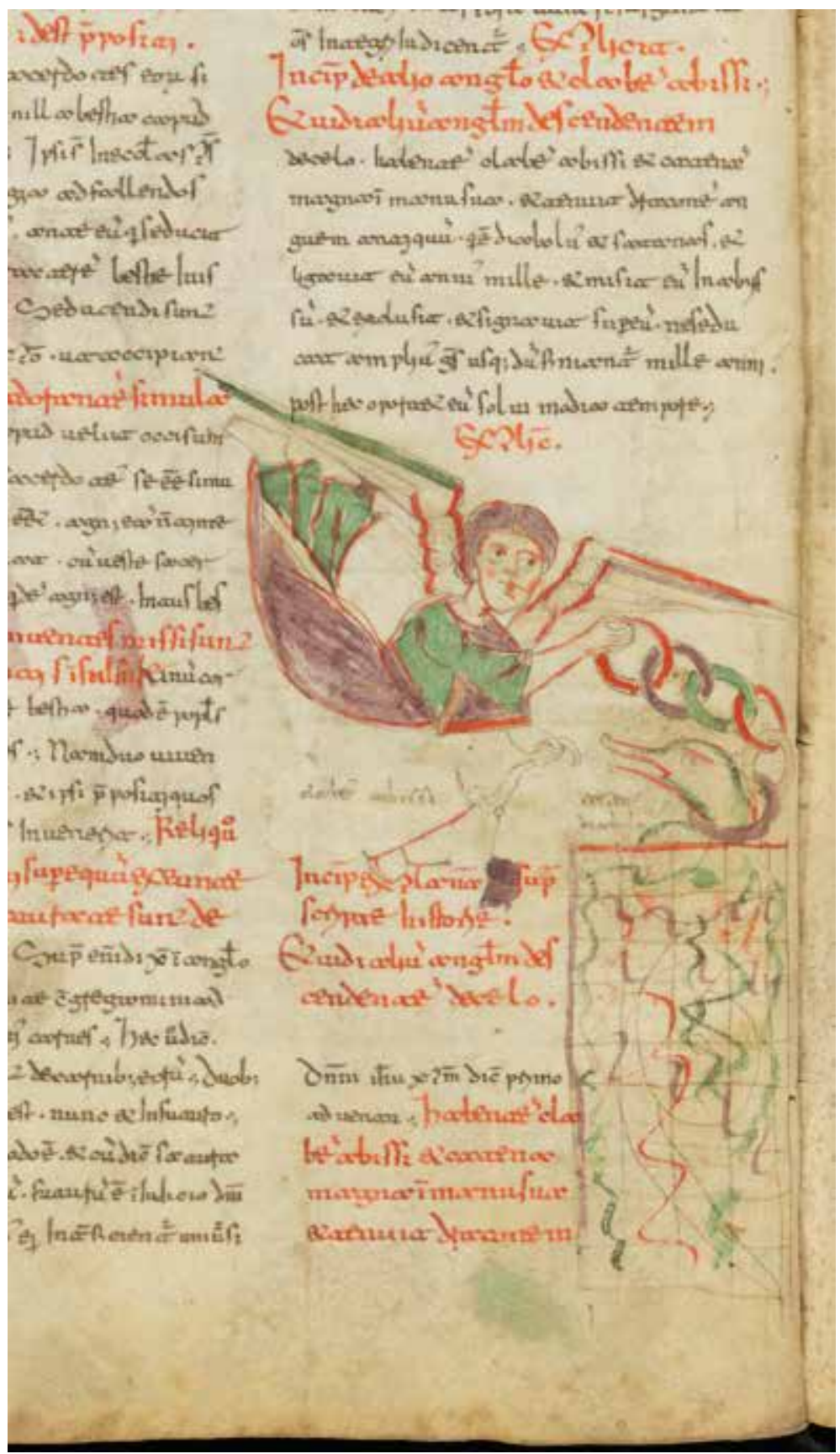


Figure 163 Satan Released and His Last Attack (Apoc. XX, 7-9). Geneva Beatus, fol. 238. Bibliothèque de Genève, MS lat. 357. For storia and image analysis, see page 201.

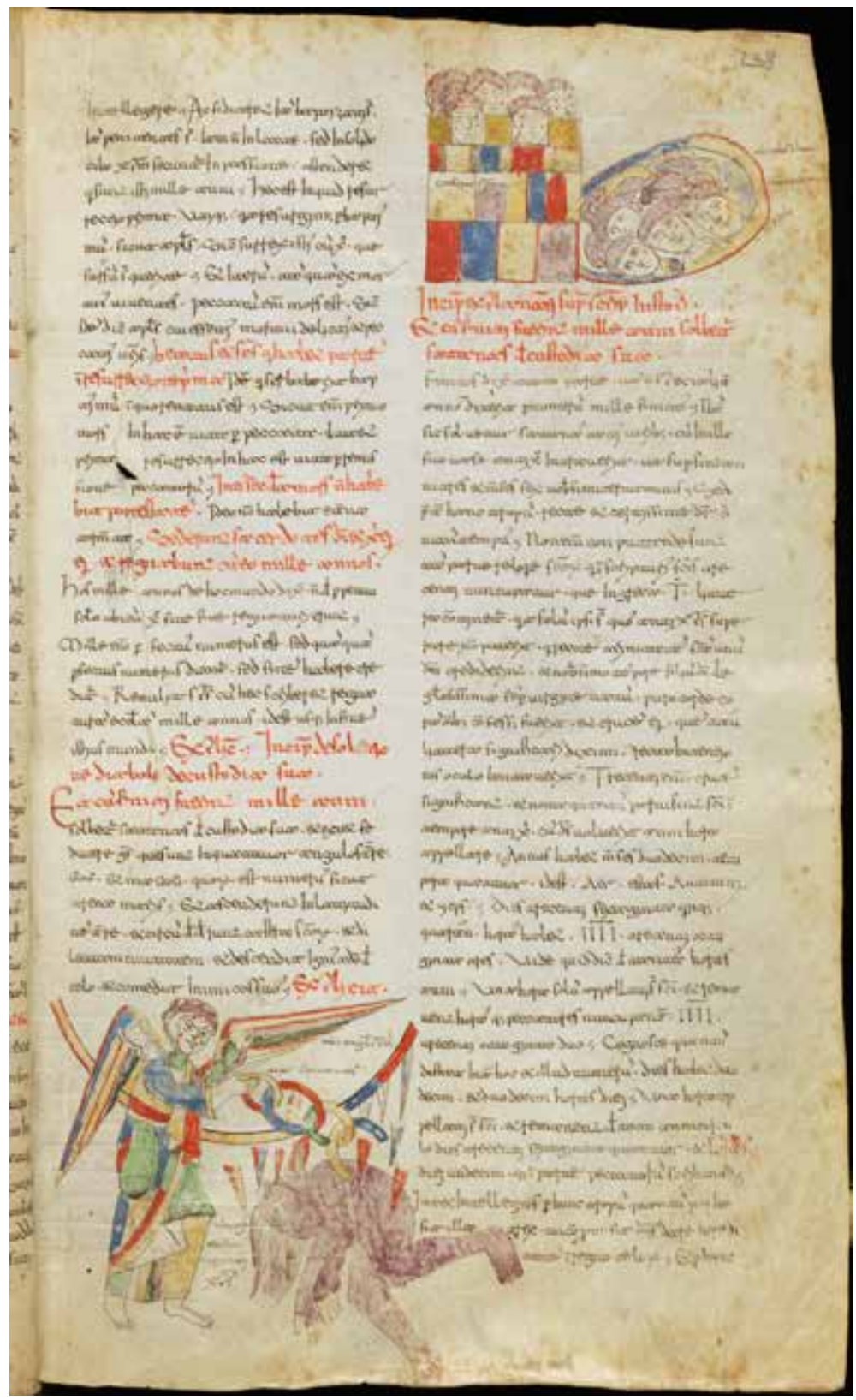


Figure 164 The Devil, the Beast, and the False Prophet in the Lake of Fire (Apoc. XX, 9-10). Geneva Beatus, fol. 239v. Bibliothèque de Genève, MS lat. 357. For storia and image analysis, see page 202.

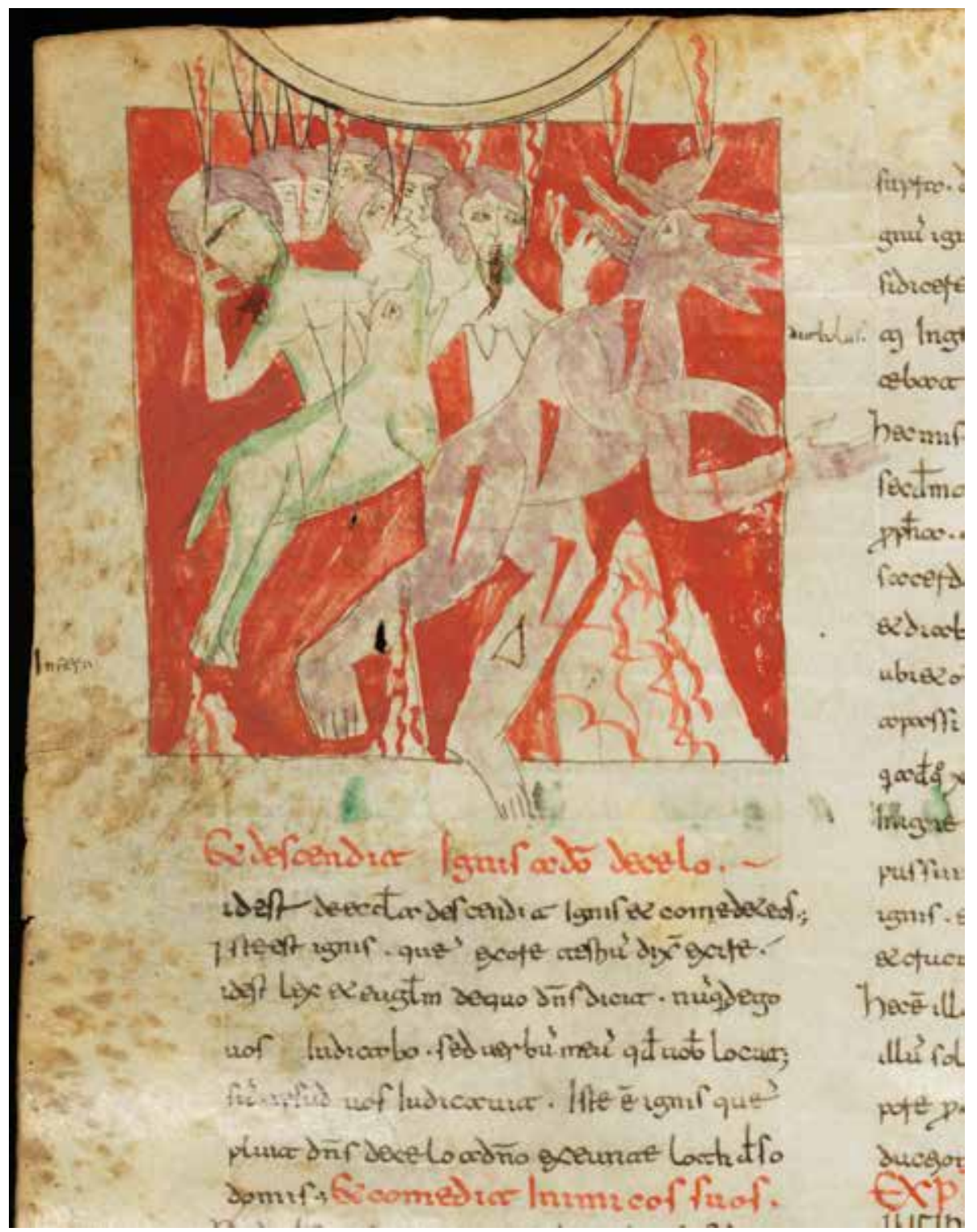


Figure 165 The Last Judgment (Apoc. XX, 11-15). Geneva Beatus, fol. 240. Bibliothèque de Genève, MS lat. 357. For storia and image analysis, see page 202.

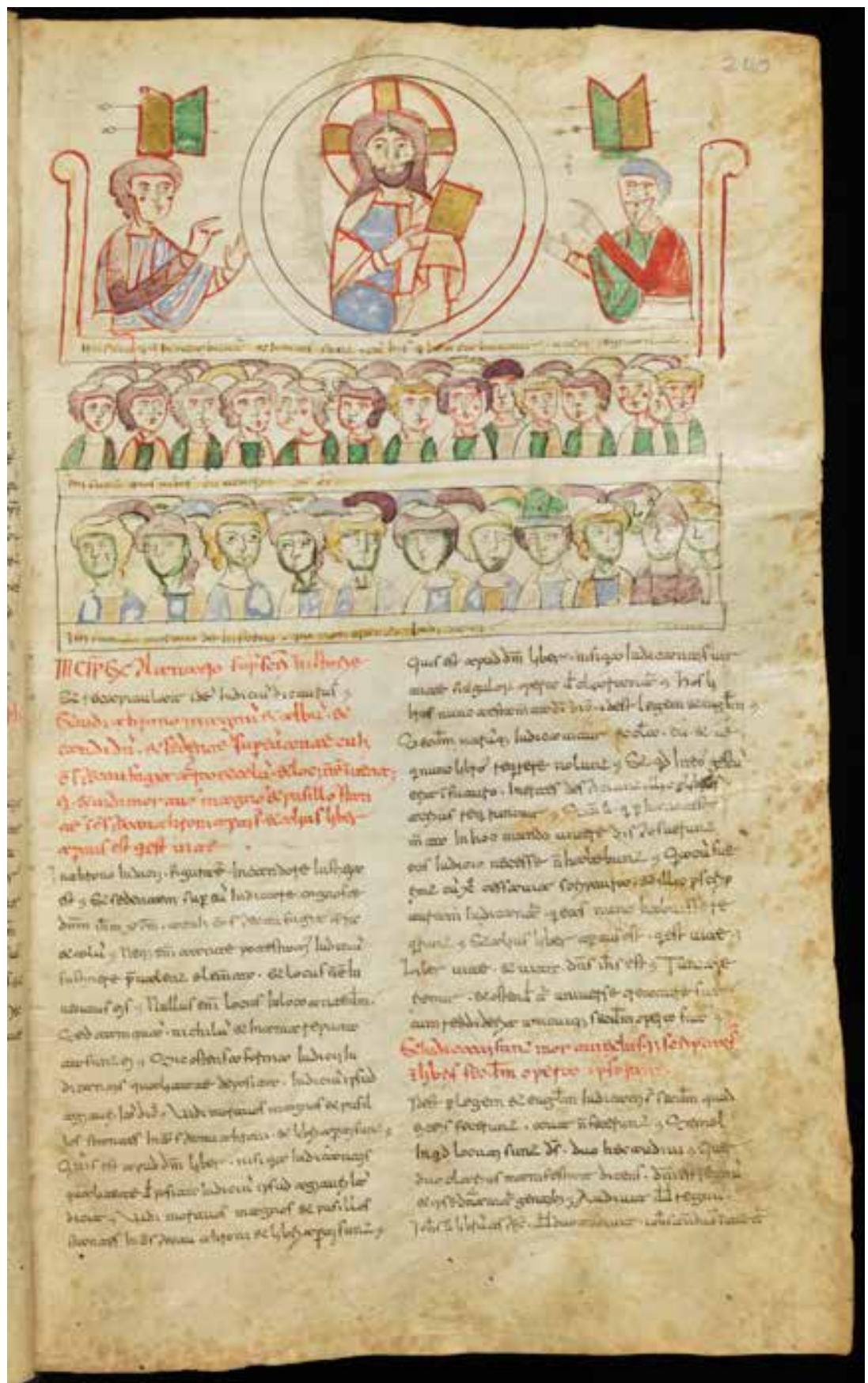


Figure 166 The Heavenly Jerusalem (Apoc. XXI, 1-27). Geneva Beatus, fol. 241. Bibliothèque de Genève, MS lat. 357. For storia and image analysis, see page 203.

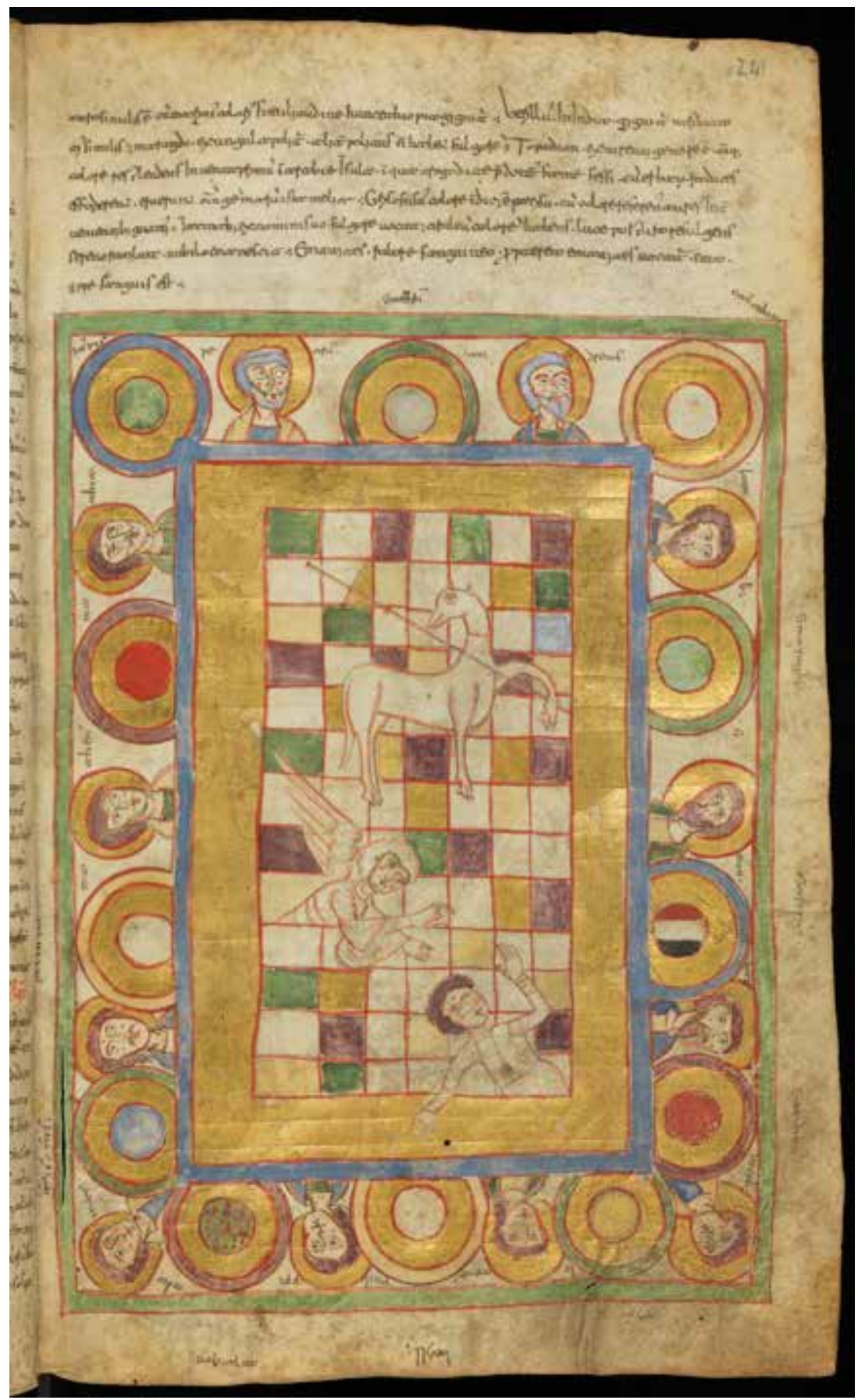


Figure 167 St. John at the Feet of the Angel of the Apocalypse (Apoc. XXII, 6-21). Geneva Beatus, fol. 244v. Bibliothèque de Genève, MS lat. 357. For storia and image analysis, see page 206.

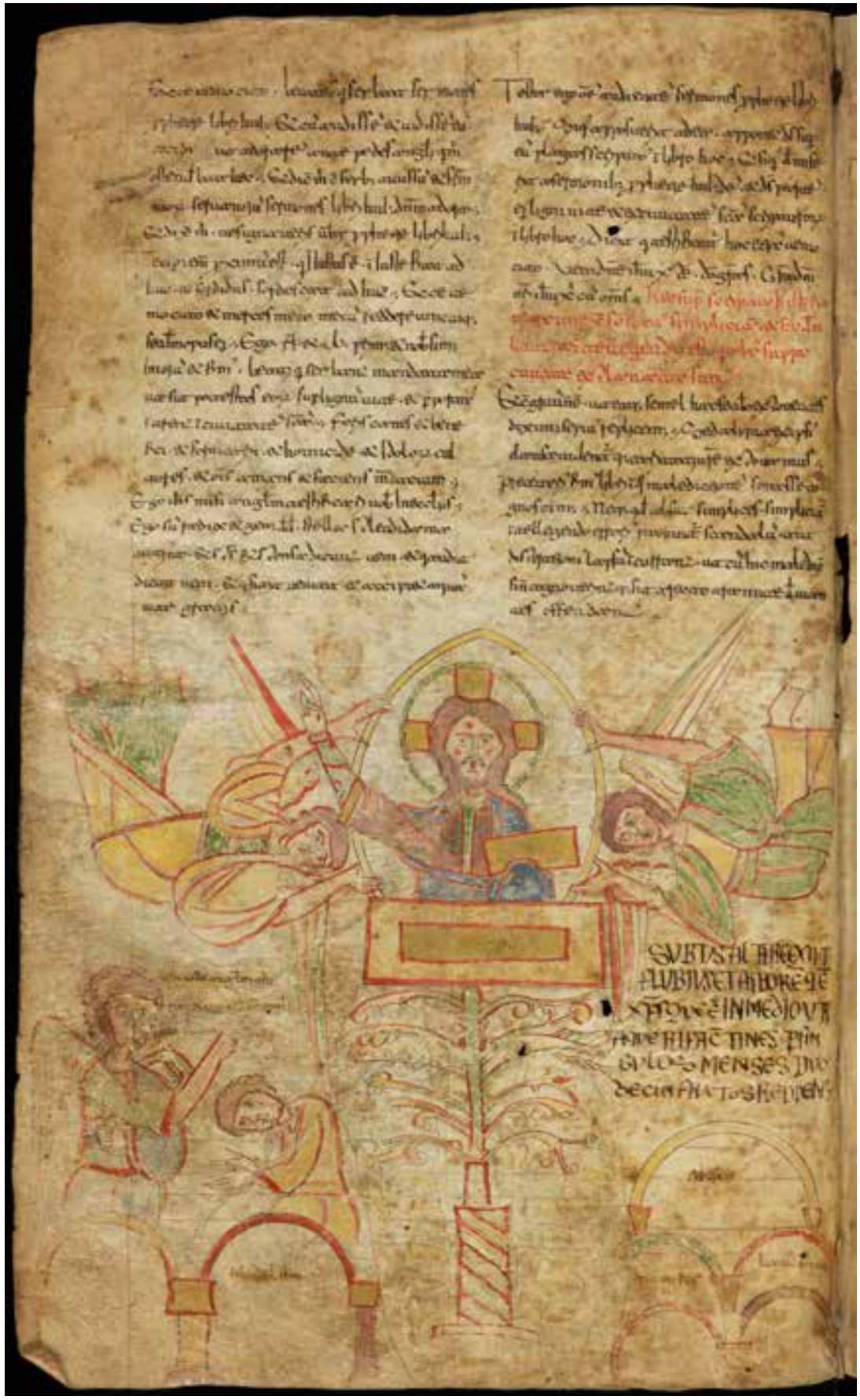





\section{Appendix}

\section{Geneva Beatus Codicological Construction}

The following brief descriptive commentaries schematically represent the current construction of the Geneva Beatus manuscript.

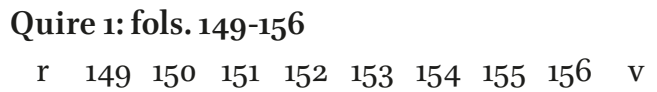
though folio $149^{\mathrm{r}}$ is worn and somewhat damaged, with rust spots appearing along the outer edge (presumably from the fore-edge clasp) and in upper and lower inner corners near the gutter (from bosses or other metal hardware). Similar rust stains occur in the first five leaves of the gathering.

Illuminations appear on folios $149^{\mathrm{r}}$ (The Woman on the Beast), $15^{2}$ (Letter to the Church of Ephesus), and $154^{\mathrm{v}}$ (Letter to the Church of Smyrna).

There is neither a quire mark nor catchwords present.

Quire 2: fols. 157-164

$\begin{array}{llllllllll}\text { r } & 157 & 158 & 159 & 160 & 161 & 162 & 163 & 164 & \mathrm{~V}\end{array}$ The gathering of eight leaves is complete.

Illuminations appear on folios $157^{\mathrm{V}}$ (Letter to the Church of Pergamum), $160^{\mathrm{r}}$ (Letter to the Church of Thyatira), and $162^{\mathrm{v}}$ (Letter to the Church of Sardis).

A quire mark occurs in the lower margin of folio $164^{\mathrm{v}}$, just to the right of the left vertical bounding line for the inner column (.ij. representing “Quaternion II”).

Quire 3: fols. 165-172

$\begin{array}{llllllllll}\text { r } & 165 & 166 & 167 & 168 & 169 & 170 & 171 & 172 & \mathrm{~V}\end{array}$

The gathering of eight leaves is complete.

Illuminations appear on folios $165^{\mathrm{v}}$ (Letter to the Church of Philadelphia), $169^{\mathrm{r}}$ (Letter to the Church of Laodicea), and $172^{\mathrm{r}}$ (Vision of God Enthroned with the Elders). Two decorative and interlinked initial "P"s appear on folio $171^{\mathrm{v}}$, with the upper one containing the head of a grotesque [?], and the lower one containing the figures of two serpent-like creatures and the body of a naked man.

A quire mark occurs in the center of the lower edge of the lower margin of folio $172^{\mathrm{v}}$, between the inner vertical rulings for the two text columns (iii representing "Quaternion III").

Quire 4: fols. 173-178

$\begin{array}{llllllll}\text { r } & 173 & 174 & 175 & 176 & 177 & 178 & \text { v }\end{array}$

The gathering of six leaves is complete with no text missing.

An illumination, slightly cropped along the lower edge, extends into the lower margin on folio $174^{\mathrm{r}}$ (Vision of God Enthroned with Four Living Creatures). There is also a loss of some words due to severe trimming along the upper edges of the gathering.

The quire is signed with a Roman numeral (iiij) along the lower edge of folio $178^{\mathrm{v}}$, and is centered between the vertical bounding lines of the two columns.

Quire 5: fols. 179-186

$\begin{array}{llllllllll}\mathrm{r} & 179 & 180 & 181 & 182 & 183 & 184 & 185 & 186 & \mathrm{~V}\end{array}$

The gathering of eight leaves is complete.

Illuminations appear on folios $183^{\mathrm{v}}$ (The Opening of the First Four Seals: The Four Horsemen) and $185^{\mathrm{v}}$ (The Opening of the Fifth Seal: The Souls of the Martyrs under the Altar).

Anomalies in page format include the double row of prickings for the horizontal rulings on folios 179 and 180 in the outer margins, and 
prickings for vertical bounding lines that occur in the lower margin fairly close to the written space.

The quire is signed with a Roman numeral $(\mathrm{u}=\mathrm{v})$ along the lower edge of folio $178^{\mathrm{v}}$, and is centered between vertical bounding lines of the two columns.

Quire 6: fols. 187-194

$\begin{array}{llllllllll}\mathrm{r} & 187 & 188 & 189 & 190 & 191 & 192 & 193 & 194 & \mathrm{~V}\end{array}$

The gathering of eight leaves is complete.

Illuminations appear on folios $187^{\mathrm{r}}$ (The Opening of the Sixth Seal: The Earthquake), $189^{\mathrm{r}}$ (The Four Angels of the Winds), and $190^{\mathrm{r}}$ (The Sealing of the Elect).

Prickings for vertical bounding lines occur along the lower edges of the leaves; two horizontal upper rulings and single lower rulings, both full across to the outer edge, appear only on folios 187 and 188.

A quire mark appears in the lower margin of folio $194^{v}$, just to the right of the left vertical bounding line for the inner column (ui. representing "Quaternion VI").

Quire 7: fols. 195-202

$\begin{array}{llllllllll}\text { r } & 195 & 196 & 197 & 198 & 199 & 200 & 201 & 202 & \text { v }\end{array}$

The gathering of eight leaves is complete, but has the following complexities: the second column of folio $196^{\mathrm{r}}$ is written in Caroline script; folio $198^{\mathrm{r}}$ has space left over at the bottom of the second column. Explicits within the text begin to show much influence of Beneventan scribal practices, and then also the incipits. There is loss of text due to cropping of the upper edge of folio 202 .

Illuminations appear on folios $198^{\mathrm{v}}$ (The Seven Angels with Trumpets), $199^{\mathrm{r}}$ (The First Trumpet: Hail, Fire, and Blood), 200 ${ }^{\mathrm{r}}$ (The Second Trumpet: The Mountain Cast into the Sea; The Third Trumpet: The Burning Star), 200 ${ }^{v}$ (The Fourth Trumpet: The Darkening of the Sun, the Moon, and the Stars), 201 ${ }^{\mathrm{v}}$ (The Fifth
Trumpet: The Star that Falls from Heaven and the Plague of the Locusts), $202^{\mathrm{r}}$ (The Angel of the Abyss and the Locusts), and $202^{\mathrm{v}}$ (The Sixth Trumpet: The Angels of the Euphrates).

The gathering is signed by neither quire mark nor catchwords.

\section{Quire 8: fols. 203-210}

r $203204205206207208209210 \quad$ V

The gathering of eight leaves is complete.

The display script exhibits much Beneventan influence in the ligatures, especially that of the letter $\mathrm{P}$ following $\mathrm{X}$, and I following $\mathrm{L}$. There is awkward spacing of text on folio $210^{\mathrm{r}-\mathrm{v}}$.

Illuminations appear on folios $203^{\mathrm{v}}$ (The Horses of Death and Their Riders), 204 ${ }^{\mathrm{r}}$ (The Strong Angel: St. John Eats the Book), $205^{\mathrm{v}}$ (The Two Witnesses), 206 (The Two Witnesses Killed by the Antichrist), $207^{\mathrm{r}}$ (The Two Witnesses Ascend into Heaven and an Earthquake Is Produced), $207^{\mathrm{v}}$ (The Angel of the Seventh Trumpet), $208^{\mathrm{r}}$ (The Temple of the Ark and the Beast of the Abyss), and $208^{\mathrm{v}}$ (The Woman Clothed in the Sun).

The gathering is signed by neither quire mark nor catchwords.

Quire 9: fols. 211-218

$\begin{array}{llllllllll}\text { r } & 211 & 212 & 213 & 214 & 215 & 216 & 217 & 218 & \text { v }\end{array}$

The gathering of eight leaves is complete, though there is some loss of text on folios 211-213 due to the cropping of the top of the leaves.

Horizontal text rulings appear to run straight through the gutter.

Illuminations appear on folios $211^{\mathrm{r}}$ (The Beast from the Sea), $213^{\mathrm{r}}$ (The Beast from the Earth), $217^{\mathrm{r}}$ (Table I: To Know the Number and the Name of the Beast), and $218^{\mathrm{r}}$ (The Lamb on Mount Sion and the Chaste). The second column on folio $216^{\mathrm{v}}$ ends short in order to accommodate the full-page Antichrist table on the subsequent recto (fol. $217^{\mathrm{r}}$ ). 
The gathering is signed by neither quire mark nor catchwords.

Quire 10: fols. 219-226

$\begin{array}{llllllllll}\text { r } & 219 & 220 & 221 & 222 & 223 & 224 & 225 & 226 & \text { V }\end{array}$

The gathering of eight leaves is complete.

Horizontal text rulings appear to run straight through the gutter.

Illuminations appear on folios $219^{\mathrm{r}}$ (The Angel with the Everlasting Gospel), $220^{\mathrm{r}}$ (The Harvest of the Wrath of God), 221 ${ }^{\mathrm{v}}$ (The Seven Angels with the Seven Plagues), 222 ${ }^{\mathrm{r}}$ (The Angels with the Plagues Exit the Temple), $223^{v}$ (The First Angel Empties His Bowl on the Earth), 224 ${ }^{\mathrm{r}}$ (The Second Angel Empties His Bowl in the Sea; The Third Angel Empties His Bowl in the Rivers), $225^{\mathrm{r}}$ (The Fourth Angel Empties His Bowl on the Sun), and $225^{\mathrm{v}}$ (The Fifth Angel Empties His Bowl on the Throne of the Beast; The Sixth Angel Empties His Bowl on the Euphrates; The Unclean Spirits like Frogs). These final three images on folio $225^{\mathrm{v}}$ may be unfinished since they display little in the way of the customary red outlining.

The quire is signed with the Roman numeral x. centered along the lower edge of folio $226^{\mathrm{v}}$.

Quire 11: fols. 227-234

$\begin{array}{llllllllll}\text { r } & 227 & 228 & 229 & 230 & 231 & 232 & 233 & 234 & \text { v }\end{array}$

The gathering of eight leaves is complete.

On folio $229^{\mathrm{r}}$ is a Caroline script for eleven and a half lines in the middle of column one; this appears to be the same scribe as the one responsible for the second column of folio $196^{\mathrm{r}}$ in Quire 7 , who does not seem to be from southern Italy.

Horizontal text rulings appear to run straight through the gutter, as in Quire 10.

Illuminations appear on folios $227^{\mathrm{r}}$ (The Seventh Angel Empties His Bowl in the Air),
$227^{\mathrm{V}}$ (The Great Whore that Sat upon the Waters), $228^{\mathrm{r}}$ (The Woman Seated on the Scarlet Beast), $23^{\mathrm{r}}{ }^{\mathrm{r}}$ (The Victory of the Lamb), $232^{\mathrm{r}}$ (The Burning of Babylon), 233 (The Angel Casts the Millstone into the Sea), and $234^{r-v}$ (The Multitude in Heaven Praise God). It is unusual that there is a placard along the lower edge of the image on folio $234^{\mathrm{r}}$, but no text is written on it.

The cropped remains of the quire signature (xi) appears along the lower edge of folio $234^{\mathrm{v}}$, to the right of the inner bounding line of the second column.

Quire 12: fols. 235-242

$\begin{array}{llllllllll}\text { r } & 235 & 236 & 237 & 238 & 239 & 240 & 241 & 242 & \mathrm{v}\end{array}$

The gathering of eight leaves is complete.

Illuminations appear on folios $235^{\mathrm{r}}$ (The Rider Faithful and True), $235^{\mathrm{v}}$ (The Angel Standing in the Sun), $236^{r}$ (The Defeat of the Beast), $26^{\mathrm{v}}$ (The Devil Chained in the Abyss), $238^{\mathrm{r}}$ (Satan Released and His Last Attack), 239 ${ }^{\mathrm{v}}$ (The Devil, the Beast, and the False Prophet in the Lake of Fire), $240^{\mathrm{r}}$ (The Last Judgment), and $241^{\mathrm{r}}$ (The Heavenly Jerusalem).

A faint residue of red ink in the lower margin of folio $242^{\mathrm{v}}$ may be the illegible remains of a quire mark.

Quire 13: fols. 243-245

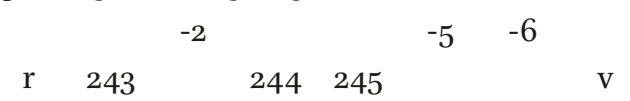

The gathering appears to have been a ternion that is now missing its second, fifth, and sixth leaves; there is sewing through the middle of bifolium 244-245. There is text missing after folio 245 .

An illumination appears on folio $244^{\mathrm{v}}$ (St. John at the Feet of the Angel of the Apocalypse). 



\section{Bibliography}

This is essentially an update to the complete bibliography that can be found in John Williams, The Illustrated Beatus: A Corpus of the Illustrations of the Commentary on the Apocalypse, 5 vols. (London, 1994-2003). In addition, it includes all works cited in the present book. Although the author continued to maintain a current bibliography of all publications on the subject of the Beatus Commentaries until 2014, and the editor has sought out further works for incorporation here, there are likely to be additional publications that did not come to our attention in time for inclusion within this volume.

www.e-codices.unifr.ch/en/bge/lato357/149r/o/ Sequence-137

www.stgallplan.org/en/index_plan.html

\section{Alonso Cardona 1993}

Esther Alonso Cardona, "Aproximación al Beato del Museo Arqueológico Nacional de Madrid”, Boletín del Museo Arqueológico Nacional, 11 (1993), 63-78.

Alonso Cardona 1995

Esther Alonso Cardona, "Estructuración del Beato del Museo Arqueológico Nacional”, Boletín del Museo Arqueológico Nacional, 13 (1995), 85-102.

Andrés 1978

Gregorio de Andrés, "Nuevas aportaciones documentales sobre los códices 'Beatos', Revista de archivos, bibliotecas y museos, 81 (1978), 519-52.

Apocalipsis 2006 Apocalipsis: El ciclo histórico de Beato de Liébana, exh. cat. (Santander, 2006).

Ara Gil 2002

Clementina Julia Ara Gil, "El Beato de Valladolid: Contribución al estudio de sus miniaturas", in $E l$ Beato de la Universidad de Valladolid: original conservado en la Biblioteca de Santa Cruz de la Universidad de Valladolid, ed. by Manuel Ruiz Asencio and Irene Ruiz Albi (Madrid, 2002), pp. 93-195.
Arbeiter - Noack-Haley 1999

Achim Arbeiter and Sabine Noack-Haley, Christliche Denkmäler des frühen Mittelalters: vom 8. bis ins 11. Jahrhundert (Mainz, 1999).

Art of Medieval Spain 1993

The Art of Medieval Spain, A.D. 500-1200 (New York, 1993).

Bernis 1998

Carmen Bernis, "Estudio arqueológico de las miniaturas", in Beato de Liébana, Códice del Monasterio Cisterciense de San Andrés de Arroyo (Barcelona, 1998), pp. 111-28.

Bishko 1968

Charles Julian Bishko, "Fernando I y los orígenes de la alianza castellano-leonesa con Cluny", Cuadernos de historia de España, 47-48 (1968), 31-135.

Bord - Skubiszewski 2000

Lucien-Jean Bord and Piotr Skubiszewski, L'Image de Babylone aux serpents dans les Beatus: Contribution à l'étude des influences du Proche-Orient antique dans l'art du haut Moyen Age (Paris, 2000).

Boylan 2005

Ann Boylan, "The Silos Beatus and the Silos Scriptorium", in Church, State, Vellum, and Stone: Essays on Medieval Spain in Honor ofJohn Williams, ed. by Therese Martin and Julie A. Harris (Leiden, 2005), pp. 173-205.

Brincken 1973

Anna-Dorothee von den Brincken, "Europa en la cartografía medieval (perspectiva histórica)", Mayurqa, 10 (1973), 59-75.

Bronisch 2009

Alexander Pierre Bronisch, "Ideología y realidad en la fuente principal para la historia del Reino de Asturias: el relato de Covadonga", in Cristianos y musulmanes en la península ibérica: la guerra, la frontera y la convivencia, ed. by Juan Ignacio Ruiz de la Peña (León, 2009), pp. 69-110.

Brown 2012

Virginia Brown, Beneventan Discoveries: Collected Manuscript Catalogues, 1978-2008, ed. by Roger E. Reynolds (Toronto, 2012). 
Burón Castro 2000

Taurino Burón Castro, "Fragmentos de Beato", in León y su historia. Miscelánea histórica, VI (León, 2000), pp. 125-39.

Cabanes Pecourt 2005

María de los Desamparados Cabanes Pecourt, "El beato de Fanlo: análisis paleográfico y codicológico", in El beato del abad Banzo del monasterio de San Andrés de Fanlo, un Apocalipsis aragonés recuperado, coord. by Fernando Buenaventura Galtier Martí (Zaragoza, 2005), pp. 103-53.

Cabanot - Pon 2009

Jean Cabanot and Georges Pon, "Les origines. La légende et la fondation", in Abbaye de Saint-Sever: Nouvelles approches documentaires (988-1359), ed. by Benoît Cursente and Jean Cabanot (Dax, 2009), pp. 31-54.

Cabanot - Pon 2013

Jean Cabanot and Georges Pon, "La mappemonde de Saint-Sever", Bulletin de la Societé de Borda, 138e année (2013), no. 509, 3-18; no. 510, 131-58.

Cabrero-Ravel 2009

Laurence Cabrero-Ravel, "Le Beatus de Saint-Sever: un état des questions", in Abbaye de Saint-Sever: Nouvelles approches documentaires (988-1359), ed. by Benoît Cursente and Jean Cabanot (Dax, 2009), pp. 311-38.

Cagigós Soro 2001

Antonio Cagigós Soro, El Beato de la Seu d'Urgelly todas sus miniaturas. Un libro del primer milenio con mensajes para hoy (La Seu d'Urgell, 2001).

Campo - González Echegaray - Freeman 2004 Alberto del Campo Hernández, Joaquín González Echegaray, and Les G. Freeman, "Comentario de San Jerónimo sobre el Libro del profeta Daniel: texto latino. Versiones española e inglesa", in Estudio del manuscrito del Beato de Las Huelgas, Ms. 429 (Valencia, 2004).

Carnicer Arribas 2002

Soledad Carnicer Arribas, "Bibliografía sobre el Beato de Valladolid", in El Beato de la Universidad de Valladolid: original conservado en la Biblioteca de Santa Cruz de la Universidad de Valladolid (Madrid, 2002), pp. 261-78.

Carruthers 1990

Mary Carruthers, The Book of Memory: A Study of Memory in Medieval Culture (Cambridge, 1990).
Carruthers 1998

Mary Carruthers, The Craft of Thought: Meditation, Rhetoric, and the Making of Images, 400-1200 (Cambridge, 1998).

Castiñeiras 2011 Manuel Castiñeiras, El Tapís de la Creació / El Tapiz de la Creación (Girona, 2011).

Cavallo 1994 Guglielmo Cavallo, dir., Exultet. Rotoli liturgici del medioevo meridionale (Rome, 1994).

Cherubini - Valdés Gallego - García Leal 2010 Paolo Cherubini, José Antonio Valdés Gallego, and Alfonso García Leal, La Biblia de Danila (Codex Biblicus Cavensis, Ms. 1 de la Abadía de la Santísima Trinidad de Cava dei Tirreni) (Oviedo, 2010).

Christe 2015

Yves Christe, "Beatus: un bilan des études sur son commentaire de l'Apocalypse depuis 1976", Bulletin Monumental, 173/4 (2015), 357-367.

Coffey 2010 Heather M. Coffey, "Contesting the Eschaton in Medieval Iberia: The Polemical Intersection of Beatus of Liébana's Commentary on the Apocalypse and the Prophet's Mi'rājnāma", in The Prophet's Ascension: Cross-Cultural Encounters with the Islamic Micrāj Tales, ed. by Christiane Gruber and Frederick Colby (Bloomington IN, 2010), pp. 97-137.

Cursente 2009

Benoît Cursente, "Introduction", in Abbaye de SaintSever: Nouvelles approches documentaires (988-1359), ed. by Benoît Cursente and Jean Cabanot (Dax, 2009), pp. 9-29.

Deswarte 2010

Thomas Deswarte, "Géographie sacrée ou géographie du sacré? Les mappamondes du Commentaire de Beatus aux $\mathrm{X}^{\grave{e}}$ et $\mathrm{XI}^{\mathrm{I}}$ siècles", in De l'espace aux territoires: La territorialité des processus sociaux et culturels au Moyen Âge, ed. by Stéphane Boissellier (Turnhout, 2010), pp. 113-31.

Díaz y Díaz 1979

Manuel C. Díaz y Díaz, Libros y librerías en la Rioja altomedieval (Logroño, 1979).

Díaz y Díaz 1992 Manuel C. Díaz y Díaz, "El escriptorio de Silos", Revista de musicología, 15 (1992), 389-401.

Díaz y Díaz 1999

Manuel C. Díaz y Díaz, "El escriptorio de Valeránica”, in Codex biblicus legionensis: veinte estudios, ed. by César Álvarez Álvarez and Antonio Viñayo González (León, 1999), pp. 143-6o. 
Díaz y Díaz 2005

Manuel C. Díaz y Díaz, "El Beato de la Academia: Aspectos textuales y codicológicos", in Manuel C. Díaz y Díaz and John Williams, Beato de San Millán: Códice 33, original conservado en la Biblioteca de la Real Academia de la Historia (Madrid, 2005), pp. 7-81.

Diego Barrado 2005

Lourdes Diego Barrado and Fernando Buenaventura Galtier Martí, "El beato de Fanlo: análisis artístico", in El beato del abad Banzo del monasterio de San Andrés de Fanlo, un Apocalipsis aragonés recuperado, coord. by Fernando Buenaventura Galtier Martí (Zaragoza, 2005), pp. 155-85.

Dubuis - Jeger 2009

Paule Hochuli Dubuis and Isabelle Jeger, "Un Beatus découvert à Genève", Bibliografia dei manoscritti in scrittura beneventana, 17 (2009), 11-29.

Edson 1993

Evelyn Edson, "The Oldest World Maps: Classical Sources of Three Eighth-Century Mappaemundi", The Ancient World, 24 (1993), 169-84.

Edson 1997

Evelyn Edson, Mapping Time and Space: How Medieval Mapmakers Viewed Their World (London, 1997).

Edson 2005

Evelyn Edson, "Mapping the Middle Ages: The Imaginary and the Real Universe of the Mappaemundi", in Monsters, Marvels and Miracles: Imaginary Journeys and Landscapes in the Middle Ages, ed. by Leif Søndergaard and Rasmus Thorning Hansen (Odense, Denmark, 2005), pp. 11-25.

Emmerson 2016

Richard K. Emmerson, "Medieval Illustrated Apocalypse Manuscripts”, in A Companion to the Premodern Apocalypse, ed. by Michael A. Ryan (Leiden, 2016), pp. 19-66.

Faulhaber 1983

Charles B. Faulhaber, Medieval Manuscripts in the Library of the Hispanic Society of America, I (New York, 1983).

Fernández Flórez 1995

José Antonio Fernández Flórez, intro. and trans., Beato de Liébana [facsimile edition of Escorial \&.II.5] (Colección Scriptorium 6) (Madrid, 1995).

Fernández Flórez 2002 José Antonio Fernández Flórez, "Apocalipsis y Beatos. A propósito del Beato de Valladolid", in El Beato de la Universidad de Valladolid:original conservado en la Biblioteca de Santa Cruz de la Universidad de Valladolid (Madrid, 2002), pp. 7-38.

Fernández González - Miguélez Cavero 2008

Etelvina Fernández González and Alicia Miguélez Cavero, "Mikroarchitekturen in Darstellungen der Sieben Gemeinden von Asien in den ikonografischen Zyklen der Apokalypse im spanischen Mittelalter", in Mikroarchitektur im Mittelalter: Ein gattungsübergreifendes Phänomen zwischen Realität und Imagination, ed. by Christine Kratzke and Uwe Albrecht (Leipzig, 2008), pp. 455-76.

Ferrer Dalgá 1993

María Rosa Ferrer Dalgá, "Una miniaturista en tierras de repoblación”, in Seminario: repoblación y reconquista. Actas del III curso de cultura medieval, coord. by José Luis Hernando Garrido and Miguel Ángel García Guinea (Aguilar de Campoo, 1993), pp. 267-72.

Ferrero Gutiérrez 2011

José Ferrero Gutiérrez, Valdetábara, su entorno geográfico, socialy político: apuntes históricos (Zamora, 2011).

Fingernagel 1999

Andreas Fingernagel, Die illuminierten lateinischen Handschriften süd-, west- und nordeuropäischer Provenienz der Staatsbibliothek zu Berlin, Preussischer Kulturbesitz (Wiesbaden, 1999).

Franco Mata 1993

Ángela Franco Mata, "Los Beatos", in Kunst im Zeitalter der Kaiserin Theophanu: Akten des Internationalen Colloquiums veranstaltet vom Schnütgen Museum, Köln, 13.-15. Juni 1991, ed. by Anton von Euw and Peter Schreiner (Cologne, 1993), pp. 201-55.

Franco Mata 2001a

Ángela Franco Mata, "El Beato de San Pedro de Cardeña. Introducción”, in Beato de Liébana, Códice del Monasterio de San Pedro de Cardeña, coord. by Ángela Franco Mata (Barcelona, 2001), pp. 15-25.

Franco Mata 2001b

Ángela Franco Mata, "Las ilustraciones del Beato de San Pedro de Cardeña”, in Beato de Liébana, Códice del Monasterio de San Pedro de Cardeña, coord. by Ángela Franco Mata (Barcelona, 2001), pp. 117-273.

Franco Mata 2003

Ángela Franco, "Las ilustraciones del Beato del Monasterio de Santo Domingo de Silos. Consideraciones sobre cronología, autores y estilo", in Beato de Liébana. Códice del Monasterio de Santo Domingo de Silos (Barcelona, 2003), pp. 73-235. 


\section{Franco Mata 2005}

Ángela Franco, "Observations on the Illustrations of the Silos Beatus Manuscript", in Church, State, Vellum, and Stone: Essays on Medieval Spain in Honor ofJohn Williams, ed. by Therese Martin and Julie A. Harris (Leiden, 2005), pp. 207-33.

Franco Mata 2010

Ángela Franco, "La diáspora de los apóstoles y relaciones de los Beatos con el Islam", in Seis estudios sobre Beatos medievales, coord. by Maurilio Pérez (León, 2010), pp. 131-202.

Fried 1989

Johannes Fried, "Endzeiterwartung um die Jahrtausendwende”, Deutsches Archiv für Erforschung des Mittelalters, 45 (1989), 381-473.

\section{Galtier Martí 2005a}

Fernando Buenaventura Galtier Martí, "El monasterio de San Andrés de Fanlo, el abad Banzo y el rey Ramiro I", in El beato del abad Banzo del monasterio de San Andrés de Fanlo, un Apocalipsis aragonés recuperado, coord. by Fernando Buenaventura Galtier Martí (Zaragoza, 2005), pp. 241-65.

Galtier Martí 2005b

Fernando Buenaventura Galtier Martí, "Aragón en la época del beato de Fanlo", in El beato del abad Banzo del monasterio de San Andrés de Fanlo, un Apocalipsis aragonés recuperado, coord. by Fernando Buenaventura Galtier Martí (Zaragoza, 2005), pp. 189-239.

Galtier Martí 2005c

Fernando Buenaventura Galtier Martí, "Beati in Apocalypsin, Codex Fanlensis. Introducción y síntesis del libro", in El beato del abad Banzo del monasterio de San Andrés de Fanlo, un Apocalipsis aragonés recuperado, coord. by Fernando Buenaventura Galtier Martí (Zaragoza, 2005), pp. 13-38.

Galván Freile 1996

Fernando Galván Freile, "Notas sobre la iluminación del fragmento de Beato procedente de Astorga", Astórica, 13 (1996), 211-18.

Galván Freile 2000

Fernando Galván Freile, Fragmentos de manuscritos iluminados en el Archivo Histórico Provincial de León (c. 1200) (León, 2000).

García-Aráez Ferrer 1992

Hermenegildo García-Aráez Ferrer, La miniatura en los Códices de Beato de Liébana: su tradición pictórica (Madrid, 1992).
García Leal 2007

Alfonso García Leal, Beato de Fernando I y doña Sancha: Madrid, Biblioteca Nacional de España, Ms. Vtr. 14-2: libro de estudios (Valencia, 2007).

García Leal 2014

Alfonso García Leal, "Beato de Liébana, Comentario al Apocalipsis: texto e ilustración en los códices visigóticos relativos al vino", in Auctor et Auctoritas in Latinis Medii Aevi Litteris / Author and Authorship in Medieval Latin Literature: Proceedings of the 6th Congress of the International Medieval Latin Committee (Benevento-Naples, November 9-13, 2010), ed. by Edoardo D'Angelo and Jan Ziolkowski (Florence, 2014), pp. 397-410.

García Lobo 2005

Vicente García Lobo, "El Beato de Tábara”, in Beato de Tábara: original conservado en el Archivo Histórico Nacional. Estudios (Madrid, 2005), pp. 5-143.

García Lobo - Cavero 2014

Vicente García Lobo and Gregoria Cavero Domínguez, eds., San Miguel de Escalada (913-2013) (León, 2014).

García Molinos 2004 Elena García Molinos, "Florencio de Valeránica, calígrafo y notario del siglo X", in El reino de León en la edad media, XI (León, 2004), pp. 243-431.

Gómez-Moreno 1919 Manuel Gómez-Moreno, Iglesias mozárabes: arte español de los siglos IX a XI (Madrid, 1919).

González Echegaray 2006 Joaquín González Echegaray, "Beato de Liébana y su mundo", in Beato de Fernando Iy Sancha (Barcelona, 2006), pp. 15-29.

González Echegaray 2011 Joaquín González Echegaray, "Beatus of Liébana in His Historical Context", in Beatus "Emilianense" from the Spanish National Library in Madrid, Tenth Century, Original Held in the Biblioteca Nacional de España, "Vitr. 14-1", Studies (Burgos, 2011), pp. 15-32.

González Echegaray - Campo - Freeman 1995 Joaquín González Echegaray, Alberto del Campo, and Leslie G. Freeman, Obras completas de Beato de Liébana (Toledo, 1995).

Grabar - Nordenfalk 1957 André Grabar and Carl Nordenfalk, Early Medieval Painting from the Fourth to the Eleventh Century (Lausanne, 1957).

Gryson 1999

Roger Gryson, review of John Williams, The Illustrated Beatus: A Corpus of the Illustrations of the 
Commentary on the Apocalypse, Revue d'histoire ecclésiastique, 94 (1999), 538-43.

Gryson 2004

Roger Gryson, review of John Williams, The Illustrated Beatus: A Corpus of the Illustrations of the Commentary on the Apocalypse, Revue d'histoire ecclésiastique, 99 (2004), 826-28.

Gryson 2011

Roger Gryson, intro. and trans., Tyconius, Commentaire de l'A pocalypse (Turnhout, 2011).

Gryson 2012

Roger Gryson, ed., Beati Liebanensis Tractatus de Apocalipsin (Turnhout, 2012).

Gryson 2015

Roger Gryson, Beato de Liébana, Códice de Ginebra. Original conservado en la Biblioteca Pública del Estado de Ginebra (Burgos, 2015).

Guilmain 1960

Jacques Guilmain, "Interlace Decoration and the Influence of the North on Mozarabic Illumination", Art Bulletin, 42 (1960), 211-18.

\section{Harris 2014}

Julie A. Harris, “Meyer Schapiro's 'Road Not Taken': San Millán de la Cogolla and Resistance to the Roman Rite", Hispanic Research Journal, 15 (2014), 381-97.

Henriet 2011

Patrick Henriet, "La imagen en la imagen. Estatuas, imperios terrestres e idolatría en las miniaturas del Comentario del Apocalipsis de Beato de Liébana y del Libro de Daniel de San Jerónimo (siglos X-XIII)", Codex Aquilarensis, 27 (2011), 19-38.

Henriet 2016

Patrick Henriet, "Traces d'un discours antiislamique dans les enluminures du Commentaire de L'Apocalypse de Beatus de Liébana?", in Orígenesy desarrollo de la Guerra Santa en la Península Ibérica. Palabras e imágenes para una legitimación (siglos $X-X I V)$, ed. by Carlos de Ayala Martínez, Patrick Henriet and J. Santiago Palacios Ontalva, Collection de la Casa de Velázquez, vol. 154 (Madrid, 2016), pp. 261-77.

Herrero de la Fuente 1988

Marta Herrero de la Fuente, Colección diplomática del monasterio de Sahagún, II (1000-1073) (León, 1988).

Herrero Jiménez 2001

Mauricio Herrero Jiménez, Beato de Turín (Madrid, 2001).
Herrero Jiménez 2002

Mauricio Herrero Jiménez, "Aproximación histórica al Monasterio de Valcavado", in El Beato de la Universidad de Valladolid: original conservado en la Biblioteca de Santa Cruz de la Universidad de Valladolid, ed. by José Antonio Fernández Flórez (Madrid, 2002), pp. 39-62.

Horn - Born 1979

Walter Horn and Ernest Born, The Plan of St. Gall: A Study of the Architecture and Economy of, and Life in, a Paradigmatic Carolingian Monastery, 3 vols. (Berkeley, 1979).

Iluminura 1999

A iluminura em Portugal: Identidade e influências, exh. cat. (Lisbon, 1999).

Klein 1976

Peter K. Klein, Der ältere Beatus-Kodex Vitr. 14-1 der Biblioteca Nacional zu Madrid, 2 vols. (Hildesheim, 1976).

Klein 1987

Peter K. Klein, "La fonction et la 'popularité' des Beatus, ou Umberto Eco et les risques d'un dilettantisme historique", in Études roussillonnaises offertes à Pierre Ponsich: mélanges d'archéologie, d'histoire et d'histoire de l'art du Roussillon et de la Cerdagne, ed. by Marie Grau and Olivier Poisson (Perpignan, 1987), pp. 313-27.

Klein 1990

Peter K. Klein, In Apocalypsin Commentarius: Manchester, the John Rylands University Library, Latin MS 8, color microfiche edition (Munich, 1990).

Klein 1998

Peter K. Klein, Beatus de Liébana, Codex Urgellensis (Madrid, 1998).

Klein 2001

Peter K. Klein, Beatus de Liébana, Codex Urgellensis. Kommentarband zur Faksimile-Ausgabe = Comentario a la edición facsímil (Madrid, 2001).

Klein 2002

Peter K. Klein, Beato de Liébana: la ilustración de los manuscritos de Beato y el códice de Manchester (Valencia, 2002).

Klein 2004a

Peter K. Klein, Beato de Liébana: la ilustración de los manuscritos de Beato y el Apocalipsis de Lorvão (Valencia, 2004). 
Klein 2004b

Peter K. Klein, "Las ilustraciones del Códice del Beato de Las Huelgas", in Estudio del manuscrito del Beato de Las Huelgas, M. 429 (Valencia, 2004), pp. 11-96 [with English text, pp. 99-176].

Klein 2005

Peter K. Klein, "Eschatological Expectations and the Revised Beatus", in Church, State, Vellum, and Stone: Essays on Medieval Spain in Honor ofJohn Williams, ed. by Therese Martin and Julie A. Harris (Leiden, 2005), pp. 147-71.

Klein 2006

Peter K. Klein, "Eine Bildmetapher des Sieges Christi über den Satan: Michael und der Drache im BeatusKodex aus Las Huelgas", Ikonotheka, 19 (2006), 81-92. Klein 2010

Peter K. Klein, El Beato de Berlín: Berlín, Staatsbibliothek, Preussischer Kulturbesitz, Ms. Theol. lat.fol. 567 (Madrid, 2010).

Klein 2011a

Peter Klein, “The Beatus 'Aemilianense' Ms. Vitr. 14-1 of the Biblioteca Nacional in Madrid", in Beatus "Emilianense" from the Spanish National Library in Madrid, Tenth Century, Original Held in the Biblioteca Nacional de España, "Vitr. 14-1", Studies, ed. by Juan José García Gil and Pablo Molinero Hernando (Burgos, 2011), pp. 33-202 [with Spanish translation].

Klein $2011 b$

Peter K. Klein, "Medieval Apocalypse Cycles and Eschatological Expectations: The So-called 'Terrors' of the Year 100o", in L'Apocalisse nel Medioevo, ed. by Rossana E. Guglielmetti (Florence, 2011), pp. 267-301.

Klein 2012

Peter K. Klein, "Commentary”, in The Saint-Sever Beatus and Its Influence on Picasso's Guernica (Valencia, 2012), pp. 101-335.

Klein 2013

Peter K. Klein, "Remarques sur le manuscrit bénéventin de Beatus récemment découvert à Genève", Cahiers de civilisation médiévale, 56 (2013), 3-38.

Klein 2014a

Peter K. Klein, "The Role of Prototypes and Models in the Transmission of Medieval Picture Cycles: The Case of the Beatus Manuscripts", in The Use of Models in Medieval Book Painting, ed. by Monika E. Müller (Newcastle-upon-Tyne, 2014), pp. 1-27.

Klein 2014b

Peter K. Klein, "Apokalypse-Darstellung und Exegese bis zum hohen Mittelalter", in Tot sacramenta quot verba. Zur Kommentierung der Apokalypse des
Johannes von den Anfängen bis ins 12. Jahrhundert, ed. by Konrad Huber et al. (Münster, 2014), pp. 311331, 397-417.

Klein 2016a

Peter K. Klein, El Beato de Burgo de Osma, s. XI (Valencia, 2016).

Klein 2016b

Peter K. Klein, "Im Spannungsfeld von Endzeitängsten, Konflikten mit dem Islam und liturgischer Praxis: die Erneuerung der Beatus-Illustration im 10. Jahrhundert", in Im Schnittpunkt der Kulturen. Architektur und ihre Ausstattung aufder iberischen Halbinsel im 6.-10./11. Jahrhundert = Cruce de Culturas. Arquitectura y su decoración en la Península Ibérica del siglo VI alX/XI, ed. by Ines Käflein, Jochen Staebel, and Matthias Untermann (Frankfurt am Main, 2016), pp. 11-48.

Klein 2016c

Peter K. Klein, "Le Beatus de Saint-Sever: Contexte historique et iconographique", Cahiers de Fanjeaux, $5^{1}(2016), 13-36$.

Klein 2016d

Peter K. Klein, Review of Roger Gryson, éd. - Beatus Liebanensis. Tractatus de Apocalipsin : Pars altera. I / Pars prior. II. Turnhout, Brepols, 2012, $613+$ CXLVIII-373 p., ill. (Corpus Christianorum Series Latina, 107 B et 107 C), Cahiers de civilisation médiévale, 59 (2016), 95-97.

Klinka 2009

Emmanuelle Klinka, "El Mappa Mundi del Beato de Osma: un testimonio de las tensiones de su tiempo", in Alfonso VIy su legado: Actas del Congreso internacional (Sahagún, 29 de octubre al 1 de noviembre de 20o9); IX Centenario de Alfonso VI (nog-20og), coord. by Carlos Estepa Díez, Etelvina Fernández González, and Javier Rivera Blanco (León, 2012), pp. 153-6o.

Kume 2005

Junko Kume, "Aspectos de la influencia iconográfica carolingia en la miniatura hispánica de los siglos X y XI", in El arte foráneo en España: presencia e influencia, coord. by Miguel Cabañas Bravo (Madrid, 2005), pp. 207-14.

Lacarra 1972

José María Lacarra, Historia política del reino de Navarra: desde sus orígenes hasta su incorporación a Castilla, I (Pamplona, 1972). 
Lowe 1972

E.A. Lowe, "The Codex Cavensis: New Light on Its Later History", in Paleographical Papers, 1907-1965 (Oxford, 1972), I, pp. 335-41.

Mentré 1994

Mireille Mentré, El estilo mozárabe: la pintura cristiana hispánica en torno al año mil (Madrid, 1994).

Mentré 1996

Mireille Mentré, Illuminated Manuscripts of Medieval Spain (New York, 1996).

Migne 1862

J.-P. Migne, Patrologiae Latina, XC (Paris, 1862).

Miguélez Cavero et al. 2016

Alicia Miguélez Cavero, Maria João Melo, Maria Adelaide Miranda, Rita Castro, and Conceição Casanova, "Beatus Manuscripts under the Microscope: The Alcobaça Beatus and the Iberian Cistercian Tradition Revisited", Journal of Medieval Iberian Studies 8, no. 2, (2016), 217-51.

Miller 1895

Konrad Miller, Mappaemundi: Die ältesten Weltkarten, I, Die Weltkarte des Beatus (776 n. Chr.) (Stuttgart, 1895).

Miranda, C. 1998a

Carlos Miranda, "Estudio iconográfico", in Beato de Liébana, Códice del Monasterio Cisterciense de San Andrés de Arroyo (Barcelona, 1998), pp. 133-338.

Miranda, C. 1998b

Carlos Miranda, "La retórica de la imagen: la mnemótica en el Beato de San Andrés de Arroyo", in Beato de Liébana, Códice del Monasterio Cisterciense de San Andrés de Arroyo (Barcelona, 1998), pp. 339-49.

Miranda, C. 2004

Carlos Miranda García-Tejedor, "Estudio estilístico e iconográfico del Beato de Girona”, in Beato de Liébana, Códice de Girona (Barcelona, 2004), pp. 23-309. Miranda, M.A. 1999

Maria Adelaide Miranda, "A iluminura românica em Portugal”, in A iluminura em Portugal: Identidade e influências, ed. by Maria Adelaide Miranda and Isabel Vilares Cepeda (Lisbon, 1999).

Miranda, M.A. 2001

Maria Adelaide Miranda, "Imagens do sagrado na iluminura e ourivesaria românicas em Portugal", in El arte románico en Galicia y Portugal = A arte românica em Portugale Galiza, exh. cat., ed. by Xose Carlos Valle Pérez and Jorge Rodrigues (A CoruñaLisbon, 2001).
Monneret de Villard $195^{\circ}$

Ugo Monneret de Villard, Le pitture musulmane al soffitto della Cappella Palatina in Palermo (Rome, 1950).

Monreal Jimeno 1988 Luis Alberto Monreal Jimeno, "San Millán de Suso. Aportaciones sobre las primeras etapas del cenobio emilianense", Príncipe de Viana, 49 (1988), 71-95.

Moralejo 1992

Serafín Moralejo Álvarez, "El mundo y el tiempo en el mapa del Beato de Osma”, in Apocalypsis Beati Liebanensis Burgi Oxomensis, II, El Beato de Osma: Estudios (Valencia, 1992), pp. 151-79.

Morte García 2005

Carmen Morte García, "Lastanosa, el conde de Guimerá y Uztarroz: el entorno del manuscrito", in El beato del abad Banzo del monasterio de San Andrés de Fanlo, un Apocalipsis aragonés recuperado, coord. by Fernando Buenaventura Galtier Martí (Zaragoza, 2005), pp. 39-81.

Mussot-Goulard 1982

Renée Mussot-Goulard, Les princes de Gascogne (Marsolan, 1982).

Neuss 1931

Wilhelm Neuss, Die Apokalypse des Hl. Johannes in der altspanischen und altchristlichen BibelIllustration, 2 vols. (Münster, 1931).

Nordström 1976

Carl-Otto Nordström, "Text and Myth in Some Beatus Miniatures, Part I", Cahiers archéologiques, 25 (1976), 10-12.

Ocón 1998

Dulce Ocón, "Aproximación estilística", in Beato de Liébana, Códice del Monasterio Cisterciense de San Andrés de Arroyo (Barcelona, 1998), pp. 75-107.

Olarte 1999 Juan Bautista Olarte, "El escritorio de San Millán de la Cogolla”, in El Beato de San Millán de la Cogolla, ed. by Soledad de Silva y Verástegui and Juan B. Olarte (Madrid, 1999), pp. 113-6o.

Orofino 1996

Giulia Orofino, ed., I codici decorati dell'Archivio di Montecassino, II.1, I codici preteobaldiani e teobaldiani (Rome, 1996).

Orofino 2000

Giulia Orofino, ed., I codici decorati dell'Archivio di Montecassino, II.2, I codici preteobaldiani e teobaldiani (Rome, 2000). 
Peixeiro 1995

Horácio Augusto Peixeiro, "Algumas reflexões sobre a iluminura em Portugal", Revista da Biblioteca Nacional, 10 (1995), 169-94.

Pérez 2010

Maurilio Pérez, "Tres colofones de Beatos: su texto, traducción y comentario", in Seis estudios sobre Beatos medievales, coord. by Maurilio Pérez (León, 2010), pp. 221-31.

Pérez de Urbel 1945

Justo Pérez de Urbel, Los monjes españoles en la Edad Media, 2 vols. (Madrid, 1945).

Pérez de Urbel 1977

Justo Pérez de Urbel, "El escriba Eximeno y los comienzos del escritorio de San Millán de la Cogolla", Boletín de la Institución Fernán González, 56 (1977), 75-95.

Prado-Vilar 2013

Francisco Prado-Vilar, “Silentium: El silencio cósmico como imagen en la Edad Media y la modernidad", Revista de poética medieval, 27 (2013), 21-43.

\section{Raizman 2004}

David Raizman, "El último Beato (M.429) de la Biblioteca Morgan: Descripción, función, estilo y proveniencia", in Beato del Monasterio de Las Huelgas: Ms. M.429, II, Estudio del manuscrito del Beato de Las Huelgas: M.429 (Valencia, 2004), pp. 179-206 [with English text pp. 209-36].

Raizman 2005

David Raizman, "Prayer, Patronage, and Piety at Las Huelgas: New Observations on the Later Morgan Beatus (M. 429)", in Church, State, Vellum, and Stone: Essays on Medieval Spain in Honor ofJohn Williams, ed. by Therese Martin and Julie A. Harris (Leiden, 2005), pp. 235-73.

Ramos Blassi 2011

Ricardo Ramos Blassi, "Le Beatus de San Miguel de Escalada”, Cahiers de civilisation médiévale, 54 (2011), 287-323.

Regueras Grande - García-Aráez Ferrer 2001 Fernando Regueras Grande and Hermenegildo García-Aráez Ferrer, Scriptorium: Tábara visigoda y mozárabe (Salamanca, 2001).

Reynolds 2009

Roger E. Reynolds, Studies on Medieval Liturgical and Legal Manuscripts from Spain and Southern Italy (Farnham, 2009).
Reynolds 2012

Roger E. Reynolds, “Apocalypses New: The Recently Discovered Beneventan Illustrated Beatus in Geneva in Its South Italian Context", Peregrinations, 3, no. 4 (2012), 1-44.

Rodríguez Viejo 2014 Jesús Rodríguez Viejo, "El Beatus Beneventanus de Ginebra, Románico, 19 (2014), 8-15.

Romero Pose 2008

Eugenio Romero Pose, Estudios sobre el Donatismo, Ticonio y Beato de Liébana (Madrid, 2008).

Rossi 2015

Marco Rossi, "Distruzione e trasfigurazione della natura nei cicli altomedioevali dell'Apocalisse: variantiiconografiche e stilistiche", in Medioevo natura e figura. Atti del Convegno internazionale di studi Parma, 20-25 settembre 2011, ed. Arturo Carlo Quintavalle (Geneva-Milan, 2015), pp. 163-78.

Roura i Güibas 2004

Gabriel Roura i Güibas, "Notas para el estudio del Beato de Girona”, in Beato de Liébana. Códice de Girona (Barcelona, 2004), pp. 13-17.

Ruiz Asencio 1993 José Manuel Ruiz Asencio, coord., Beato de Valcavado. Estudios (Valladolid, 1993).

Ruiz Asencio 2002 José Manuel Ruiz Asencio, "El códice del Beato de la Universidad de Valladolid", in El Beato de la Universidad de Valladolid: original conservado en la Biblioteca de Santa Cruz de la Universidad de Valladolid, ed. by José Antonio Fernández Flórez (Madrid, 2002), pp. 63-91.

Ruiz García 2001

Elisa Ruiz García, "El Ms 2 del Museo Arqueológico Nacional: estudio codicológico y paleográfico", in Beato de Liébana, Códice del Monasterio de San Pedro de Cardeña, coord. by Ángela Franco Mata (Barcelona, 2001), pp. 43-114.

Ruiz García 2007

Elisa Ruiz García, "Estudio codicológico, paleográfico y textual del Beato de Navarra", in Beato de Navarra: Ms. Nouv. Acq. Lat. 1366 de la Bibliothèque nationale de France, ed. by Elisa Ruiz García and Soledad de Silva y Verástegui (Madrid, 2007), pp. 11-82.

Ruiz García 2011

Elisa Ruiz García, "Beato de Liébana, Commentarius in Apocalypsin. Códice de Fernando I y Dña. Sancha”, in Biblioteca Nacional de España: 300 años haciendo 
historia, exh. cat., ed. by José Manuel Lucía Megías (Madrid, 2011), pp. 52-57.

Ruiz Larrea 1998

Elena Ruiz Larrea, "Beato de San Andrés de Arroyo: cuestiones cronológicas”, Goya: Revista de Arte, 263 (1998), 66-74.

Sáenz-López 2006

Sandra Sáenz-López Pérez, "La Reconquista cartográfica: el Islam peninsular en la cartografía medieval hispana", Treballs de la Societat Catalana de Geografia, 61-62 (2006), 279-301.

Sáenz-López 2008

Sandra Sáenz-López Pérez, "Sobre el origen astorgano del Beato Navarro: una rueda de molino para la imagen de Astorga de su mappamundi", in Actas del $6^{\circ}$ Congreso Internacional de Molinología, ed. by J. M. Garrido Aranda, M. F. Moreno Pérez, and J. Roldán Cañas (Córdoba, 2008), pp. 175-86.

Sáenz-López 2011

Sandra Sáenz-López Pérez, "Peregrinatio in stabilitate: la transformación de un mapa de los Beatos en herramienta de peregrinación espiritual", Anales de historia del arte, special issue: Alfonso VIy el arte de suépoca (2011), 317-34.

Sáenz-López 2014a

Sandra Sáenz-López Pérez, The Beatus Maps: The Revelation of the World in the Middle Ages (Burgos, 2014).

Sáenz-López 2014b

Sandra Sáenz-López Pérez, "The Image of France in the Beatus Map of Saint-Sever", in Space in the Medieval West: Places, Territories and Imagined Geographies, ed. by Meredith Cohen and Fanny Madeline (Farnham, 2014), pp. 159-74.

Sánchez Mariana 1994

Manuel Sánchez Mariana, "Introducción histórica”, in El Beato de Liébana, códice de Fernando Iy doña Sancha (Barcelona, 1994), pp. 9-55.

Sánchez Mariana 2001

Manuel Sánchez Mariana, "El Beato de San Pedro de Cardeña: Historia del códice”, in Beato de Liébana, Códice del Monasterio de San Pedro de Cardeña, coord. by Ángela Franco Mata (Barcelona, 2001), pp. 29-39.

Sánchez Mariana 2006

Manuel Sánchez Mariana, "La tradición de los Beatos y el Beato de Fernando Iy Sancha", in Beato de Fernando Iy Sancha (Barcelona, 2006), pp. 33-58.
Sastre 2013

Isaac Sastre de Diego, Los altares de las iglesias hispanas tardoantiguas y altomedievales: Estudio arqueológico (Oxford, 2013).

Schapiro 1939

Meyer Schapiro, "From Mozarabic to Romanesque in Silos", Art Bulletin, 21 (1939), 313-74.

Schlunk 1945

Helmut Schlunk, "Observaciones en torno al problema de la miniatura visigoda", Archivo español de arte, 18 (1945), 241-65.

Senra 2011

José Luis Senra, “En torno a un espacio de evocación: las Res Gesta Domini Adefonsi y la iglesia monástica de Sahagún", in La construcción medieval de la memoria regia, ed. by Pascual Martínez Sopena and Ana Rodríguez (Valencia, 2011), pp. 243-91.

Shadis 2009

Miriam Shadis, Berenguela of Castile (1180-1246) and Political Women in the High Middle Ages (New York, 2009).

Shailor 1992

Barbara A. Shailor, "The Beatus of Burgo de Osma: A Paleographical and Codicological Study", in Apocalypsis Beati Liebanensis Burgi Oxomensis, II, El Beato de Osma: Estudios (Valencia, 1992), pp. 29-52.

Shailor 2000

Barbara Shailor, "Maius and the Scriptorium of Tábara", in Estudio del manuscrito del Apocalipsis de San Juan: Beato de Liébana de San Miguel de Escalada (Valencia, 2000), pp. 635-39.

Shailor 2015

Barbara Shailor, Beato de Liébana, Códice de Ginebra. Original conservado en la Biblioteca Pública del Estado de Ginebra (Burgos, 2015).

Shailor 2016

Barbara Shailor, Beato de la Biblioteca Corsiniana (Burgos, 2016).

Shepherd 1978

Dorothy G. Shepherd, "A Treasure from a ThirteenthCentury Spanish Tomb", The Bulletin of the Cleveland Museum of Art, 65 (1978), 111-34.

Silva y Verástegui 1984 Soledad de Silva y Verástegui, Iconografía del siglo X en el reino de Pamplona-Nájera (Pamplona, 1984).

Silva y Verástegui 1999

Soledad de Silva y Verástegui, "El Beato Emilianense de la Academia de la Historia”, in El Beato de 
San Millán de la Cogolla, ed. by Soledad de Silva y Verástegui and Juan B. Olarte (Madrid, 1999), pp. 11-112.

Silva y Verástegui 2003

Soledad de Silva y Verástegui, "La miniatura en los códices de Silos”, in Silos: Un milenio. Actas del Congreso Internacional sobre la Abadía de Santo Domingo de Silos, IV, Arte, dir. by Alberto C. Ibáñez Pérez (Burgos, 2003), pp. 211-54.

Silva y Verástegui 2004

Soledad de Silva y Verástegui, "Una nueva interpretación de las imágenes que ilustran el Apocalipsis 12, 1-18, en los Beatos", in Patrimonio artístico de Galiciay otros estudios. Homenaje al Prof. Dr. Serafín Moralejo Álvarez, coord. by Ángela Franco Mata, III (Santiago de Compostela, 2004), pp. 275-81.

Silva y Verástegui 2007

Soledad de Silva y Verástegui, "El Beato de Navarra. Estado de la cuestión y estudio iconográfico", in Beato de Navarra: Ms. Nouv. Acq. Lat. 1366 de la Bibliothèque nationale de France, ed. by Elisa Ruiz García and Soledad de Silva y Verástegui (Madrid, 2007), pp. 87-162.

Suárez González 2003

Ana Suárez González, Fragmentos de libros, bibliotecas de fragmentos (en torno al Beato del A.H.P. de Zamora) (Zamora, 2003).

Suárez González 2007

Ana Isabel Suárez González, "El libro en los claustros cistercienses (una aproximación c. 1140-1240)", in El monacato en los reinos de León y Castilla (siglos VII-XIII), Ponencias del Congreso de Estudios Medievales (Ávila, 2007), pp. 263-325.

Suárez González 2009

Ana Súarez González, "Los otros Beatos", in Fragmentos de Beatos (Madrid, 2009), pp. 5-99.

Suárez González 2010a

Ana Suárez González, "Beatos: la historia interminable", in Seis estudios sobre Beatos medievales, coord. by Maurilio Pérez (León, 2010), pp. 71-129.

Suárez González 2010b

Ana Suárez González, "On the Origin of Transition Romanesque Bibles: Reality and Fiction", presentation given at the international conference "Patronage and the Sacred Book in the Medieval Mediterranean" (October 2010, Brandeis University).
Tristano 1979

Caterina Tristano, "Scrittura beneventana et scrittura carolina in manoscritti dell'Italia meridionale", Scrittura e Civiltà, 3 (1979), 89-150.

Vivancos 1996

Miguel C. Vivancos Gómez, Glosas y notas marginales de los manuscritos visigóticos del monasterio de Santo Domingo de Silos (Silos, 1996), pp. 109-12.

Vivancos 1998

Miguel C. Vivancos, "El Beato de San Andrés de Arroyo", in Beato de Liébana, Códice del Monasterio Cisterciense de San Andrés de Arroyo (Barcelona, 1998), pp. 13-70.

Vivancos 2003

Miguel C. Vivancos, “Consideraciones históricas y codicológicas en torno al Beato de Silos", in Beato de Liébana, Códice del Monasterio de Santo Domingo de Silos (Barcelona, 2003), pp. 13-69.

Vivancos 2010

Miguel C. Vivancos, "Beato y Santiago: los orígenes del culto y patronazgo hispano del apóstol Santiago", in Seis estudios sobre Beatos medievales, coord. by Maurilio Pérez (León, 2010), pp. 203-20.

Voelkle 2000

William M. Voelkle, "Provenance of the Manuscript", in Estudio del manuscrito del Apocalipsis de San Juan: Beato de Liébana de San Miguel de Escalada (Valencia, 2000), pp. 9-11.

\section{Walker 1998}

Rose Walker, Views of Transition: Liturgy and Illumination in Medieval Spain (London, 1998).

Wallis 1999

Faith Wallis, trans., Bede: The Reckoning of Time (Liverpool, 1999).

Werckmeister 1993

O.K. Werckmeister, "Art of the Frontier: Mozarabic Monasticism", in The Art of Medieval Spain, A.D. 500-1200 (New York, 1993), pp. 121-32.

Werckmeister 1997

O.K. Werckmeister, "The Islamic Rider in the Beatus of Girona", Gesta, 36 (1997), 101-o6.

Werckmeister 2007

O.K. Werckmeister, "Santo Domingo de Silos, 1 de julio de 1109. El Beato musical", in El legado de Al-Andalus. El arte andalusí en los reinos de León y Castilla durante la Edad Media, ed. by Manuel Valdés Fernández (Valladolid, 2007), pp. 89-113. 
Werckmeister 2012a

Otto Karl Werckmeister, "The Beatus Commentary and the Abbey Church of Saint-Sever", in Le plaisir de l'art du Moyen Âge: Commande, production et réception de l'oeuvre d'art. Mélanges en hommage à Xavier Barral $i$ Altet, ed. by Rosa Alcoy et al. (Paris, 2012), pp. 903-09.

Werckmeister 2012b

Otto Karl Werckmeister, "Introduction", in The SaintSever Beatus and Its Influence on Picasso's Guernica (Valencia, 2012), pp. 13-99.

Williams 1965

John W. Williams, "A Castilian Tradition of Bible Illustration: The Romanesque Bible from San Millán", Journal of the Warburg and Courtauld Institutes, 28 (1965), 66-85.

Williams 1970

John Williams, "A Contribution to the History of the Castilian Monastery of Valeranica and the Scribe Florentius", Madrider Mitteilungen, 11 (1970), 231-48. Williams 1977

John Williams, Early Spanish Manuscript Illumination (New York, 1977).

Williams 1987 John Williams, "Tours and the Early Medieval Art of Spain", in Florilegium in Honorem Carl Nordenfalk Octogenarii Contextum, ed. by Per Bjurström, NilsGöran Hökby, and Florentine Mütherich (Stockholm, 1987), pp. 197-208.

Williams 1992

John Williams, Apocalypsis Beati Liebanensis Burgi Oxomensis, II, El Beato de Osma, Estudios (Valencia, 1992), pp. 9-28, 109-50.

Williams $1994 \mathrm{a}$

John Williams, The Illustrated Beatus: A Corpus of the Illustrations of the Commentary on the Apocalypse, I, Introduction (London, 1994).

Williams 1994b John Williams, The Illustrated Beatus: A Corpus of the Illustrations of the Commentary on the Apocalypse, II, The Ninth and Tenth Centuries (London, 1994).

Williams 1997a John Williams, "Isidore, Orosius and the Beatus Map”, Imago Mundi, 49 (1997), 7-32.

Williams 1997b

John Williams, "Arte mozarabica”, in Enciclopedia dell'arte medievale, VIII (Rome, 1997), pp. 598-6o2.
Williams 1998

John Williams, The Illustrated Beatus: A Corpus of the Illustrations of the Commentary on the Apocalypse, III, The Tenth and Eleventh Centuries (London, 1998).

Williams 1999a John Williams, "The Bible in Spain", in Imaging the Early Medieval Bible, ed. by John Williams (University Park, PA, 1999), pp. 179-218.

Williams 1999b John Williams, "Orígenes de las miniaturas de la Biblia de San Isidoro”, in Codex biblicus legionensis: veinte estudios (León, 1999), pp. 143-6o.

Williams 2000a

John Williams, "Introduction", in Estudio del manuscrito del Apocalipsis de San Juan: Beato de Liébana de San Miguel de Escalada (Valencia, 2000), pp. 599-605.

Williams 200ob John Williams, "Commentaries on the Illumination", in Estudio del manuscrito del Apocalipsis de San Juan: Beato de Liébana de San Miguel de Escalada (Valencia, 200o), pp. 6o6-24.

Williams 2002

John Williams, The Illustrated Beatus: A Corpus of the Illustrations of the Commentary on the Apocalypse, IV, The Eleventh and Twelfth Centuries (London, 2002).

Williams 2003a

John Williams, The Illustrated Beatus: A Corpus of the Illustrations of the Commentary on the Apocalypse, $\mathrm{V}$, The Twelfth and Thirteenth Centuries (London, 2003).

Williams 2003b John Williams, "Meyer Schapiro in Silos: Pursuing an Iconography of Style”, Art Bulletin, 85 (2003), 442-68.

Williams 2003c

John Williams, "Meyer Schapiro y el Beato de Silos", in Silos: Un milenio. Actas del Congreso Internacional sobre la Abadía de Santo Domingo de Silos, IV, Arte, dir. by Alberto C. Ibáñez Pérez (Burgos, 2003), pp. 531-42.

Williams 2004

John Williams, "Los Beatos and the reconquista", in Patrimonio artístico de Galicia y otros estudios. Homenaje al Prof. Dr. Serafín Moralejo Álvarez, coord. by Ángela Franco Mata (Santiago de Compostela, 2004), III, pp. 297-302.

Williams 2005a John Williams, "El Beato de Tábara", in Beato de Tábara: original conservado en el Archivo Histórico Nacional. Estudios (Madrid, 2005), pp. 147-71. 
Williams 2005b

John Williams, "El Beato de San Millán y el arte de los Beatos”, in El Beato de San Millán: Códice 33, original conservado en la Biblioteca de la Real Academia de la Historia (Madrid, 2005), pp. 85-134.

Williams 2006a

John Williams, "Beato de Liébana y la tradición del Beato", in Apocalipsis: El ciclo histórico de Beato de Liébana, exh. cat., ed. by Raquel Peña Suárez and Pedro Ángel Fernández Vega (Santander, 2006), pp. 107-16.

Williams 2006b

John Williams, "Prólogo", in Beato de Fernando Iy Sancha (Barcelona, 2006), pp. 11-12.

Williams 2009

John Williams, "Los Beatos de Santo Domingo de Silos, San Pedro de León, Fragmento de León y Fragmento de Rioseco", in Fragmentos de Beatos (Madrid, 2009), pp. 101-17.

Williams 2010

John Williams, "Maius y la revolución pictórica del Beato", in Seis estudios sobre Beatos medievales, coord. by Maurilio Pérez (León, 2010), pp. 17-34.

Williams 2011a

John Williams, El scriptorium de Tábara, cuna del renacimiento de los Beatos (Valladolid, 2011).

Williams 2011b

John Williams, "Fernando I and Alfonso VI as Patrons of the Arts", Anales de historia del arte, special issue: Alfonso VIy el arte de su época (2011), 413-35.

Williams 2012a

John Williams, "Alfonso VI and Illuminated Manuscripts", in Alfonso VI y su legado: Actas del congreso internacional (Sahagún, 29 de octubre al 1 de noviembre de 20o9); IX Centenario de Alfonso VI (1109-2009), coord. by Carlos Estepa Díez, Etelvina Fernández González, and Javier Rivera Blanco (León, 2012), pp. 303-10.

Williams 2012b

John Williams, "San Salvador de Oña: Biblias y Beatos”, in Oña: Un milenio. Actas del Congreso
Internacional sobre el Monasterio de Oña (1011-2011), coord. by Rafael Sánchez Domingo (Burgos, 2012), pp. 350-61.

Williams 2014

John Williams, review of Sandra Sáenz-López Pérez, The Beatus Maps: The Revelation of the World in the Middle Ages, Speculum, 89 (2014), 823-24.

Williams 2015

John Williams, Beato de Liébana, Códice de Ginebra. Original conservado en la Biblioteca Pública del Estado de Ginebra (Burgos, 2015).

Williams 2016

John Williams, Beato de la Biblioteca Corsiniana (Burgos, 2016).

Yarza 1985

Joaquín Yarza Luaces, “La peregrinación a Santiago y la pintura y miniatura románicas", Compostellanum 30 (1985), 369-93.

Yarza 1994 Joaquín Yarza Luaces, "La ilustración del Beato de Fernando y Sancha”, in El Beato de Liébana, códice de Fernando I y doña Sancha (Barcelona, 1994), pp. 57-235.

Yarza 1998a Joaquín Yarza Luaces, Beato de Liébana:manuscritos iluminados (Barcelona, 1998).

Yarza 1998b Joaquín Yarza Luaces, "Manuscritos iluminados en el Cister", in Monjes y monasterios. El Cister en el medievo de Castilla y León, coord. by Isidro G. Bango Torviso (Valladolid, 1998), pp. 399-409.

Yarza 2006 Joaquín Yarza Luaces, "Las miniaturas", in Beato de Fernando Iy Sancha (Barcelona, 2006), pp. 92-305.

Yarza 2009

Joaquín Yarza Luaces, "Ilustración y ornamento en la Biblia románica de Burgos", in Biblia románica de Burgos, siglo XII: original conservado en la Biblioteca Pública del Estado de Burgos (Burgos, 2009), pp. 163-225. 


\section{Index of People}

Abd al-Rahman I, emir of Córdoba (r. 756-88) 22

Adosinda, wife of Silo of Asturias 21

Alfonso II, king of Asturias (r. 791-842) 21

Alfonso III, king of Asturias (r. 866-910) 22, 26, 57, 67

Alfonso VI, king of León and Castile (r. 1065-1109) 57, $90,107,135$

Alfonso VII, king of León and Castile (r. 1126-57) 64

Alfonso VIII, king of Castile (r. 1158-1214) 64, 138, 141

Al-Mansur (Almanzor), vizier of Córdoba (d. 1002) 30, $41,61,81$

Apringius, bishop of Beja (active 531-548) 172

Augustine, saint and bishop of Hippo (d. 430) 81

Banzo (see Pantio)

Beatrice of Swabia, wife of Fernando III 135, 138, 141

Beatus of Liébana, abbot and author of the Commentary on the Apocalypse 21-27, 78

Bede the Venerable (d. 735) 200

Belasco, abbot of Valeránica 63

Berenguela, queen of León and Castile (1180-1246) 135,138

Bernard de La Sauvetat, archbishop of Toledo (d. 1125) 57,107

Blanca (Blanche), daughter of Alfonso VIII (d. 1252) 141

Charles III, king of Navarre (d. 1425) 132

Domingo, abbot of Santo Domingo de Silos (d. 1073) 112

Dominico, scribe at Sahagún 47

Dominicus, scribe at Silos 112

Egeas, scribe at Lorvão 58,129

Eleanor of Aquitaine (d. 1204) 64

Emeterius, priest and scribe at Tábara 30, 47, 52, 57, $66,78,81,82$

Emilian (San Millán), saint 58, 63

En, scribe and illuminator at Tábara 47, 52, 82-85

Eximinus, scribe at San Millán 61

Fernán González, count of Castile (d. 970) 64

Fernando I, king of León and Castile (r. 1037-65) 61, 64, 90, 96, 105, 108, 135

Fernando II, king of León (r. 1157-88) 64

Fernando III, king of Castile and León (d. 1252) 135, 138

Florentius of Valeránica, scribe and illuminator 24, $29,34,37,41,42,57,60,63,64,98,112$

Fortunius, abbot of Santo Domingo de Silos 112

Fredenando Flaginiz, nobleman 53

Froilanus, saint and bishop of León (d. 905) 29, 30

Fructuosus, scribe at San Millán 61

García, king of Pamplona 64

Garsia (see Stephanus Garsia)
Gregory, bishop of Elvira (d. c. 392) 122, 143-144

Gregory the Great, pope (d. 6o4) 26, 160

Gregory Muntaner, Abbott of Saint-Sever-sur-l'Adour (1028-72) 102

Guillaume-Sanche, count/duke of Gascony (d. 996) 63,104

Henry II, king of England (r. 1154-89) 64

Hrabanus Maurus (d. 856) 161-163

Isidore, archbishop of Seville (d. 636) 23, 24, 108, 170, 172

James (Santiago), apostle 21-22

Jerome, saint (d. 420) 34, 52, 78, 90, 146, 170, 173, 174, 182 Josephus, historian (d. c. 100) 50

Leodegundia, nun and scribe 47

Leonor, wife of Alfonso VIII (d. 1214) 64, 141

Louis VIII, king of France (r. 1223-26) 141

Maius (Magius), scribe and illuminator 29-31, 34, 41, $47,61,63,66,69,78,81-82,93,160,179$

Martinus, illuminator at Sahagún 58, 105, 108, 175

Mauregatus, king of Asturias (d. 789) 21

Mauritius Bordinho (antipope Gregory VIII) 157 n89

Mencía, executrix of Alfonso VIII of Castile 138

Monnius, scribe at Tábara 78

Munnius, scribe at Silos 29 n20, 112

Nunnus, abbot of Santo Domingo de Silos 112

Obecus, scribe and illuminator at Valcavado 29, 75, 78

Pantio (Banzo), abbot of Fanlo 96, 102

Petrus, illuminator at Silos 112

Petrus, scribe at Sahagún 58, 105, 112, 115

Philip II, king of Spain (r. 1556-98) 75

Placidus, illuminator at Saint-Sever-sur-l'Adour 102

Ramiro I, King of Aragon (r. 1035-63) 102

Sancha García, abbess of Las Huelgas (1207-30) 138

Sancha, queen of León-Castile, wife of Fernando I (d. 1067) $61,64,90,96,105,108,138$

Sanche-Guillaume, duke of Gascony (r. 1010-32) 64

Santius (Sancius), scribe at Fanlo 99-102

Sempronius, abbot of Valcavado 75

Senior, scribe at Tábara 78,82

Silo, king of Asturias (r. 774-83) 21

Sisnando, abbot of Liébana and bishop of Santiago 22

Smaragdus, author (d. c. 840) 29

Stephanus Garsia, illuminator at Saint-Sever-sur-

l'Adour 27, 102, 105

Tyconius, author (active 370-90) 24

Urraca, wife of Guillaume-Sanche of Gascony 63-64, 104

Victorinus of Pettau, author (d. c. 303) 146, 174, 182 


\section{Index of Places}

\section{(specific location, modern-day country)}

al-Andalus, Spain 22, 42, 64, 72, 75, 78, 81, 113

Alcobaça, Portugal monastery of 132

Aragon, Spain 27, 59, 64, 72, 87, 90, 96, 99, 102, 109, 132,151

Astorga, Spain 118, 132 cathedral of 34

Avignon, France monastery of Saint-Rufe 30

Beneventum, Italy

Berzé-la-Ville, France 90

Burgo de Osma, Spain cathedral of $58,90,15^{1}$

Burgos, Spain 64-65, 122, 135 monastery of Santa María la Real de las Huelgas $65,122,135,138,141$

Cardeña, Spain monastery of San Pedro 65, 122, 127

Cantabria, Spain 22

Cirueña, Spain monastery of San Andrés 59, 69

Cluny, France 115

Córdoba, Spain 22, 30, 53, 81-82 Great Mosque of Córdoba 21, 51-52, 81

El Escorial, Spain monastery of San Lorenzo 93

Egypt 50, 182

Estella, Spain San Miguel 122, 126

Fanlo, Spain monastery of 59, 96, 102

Gascony, France monastery of Saint-Sever-sur-l'Adour 63

Girona, Spain 109, 112, 122 cathedral of $45,47,82$

Las Navas de Tolosa, Spain 64

León, Spain 27, 30, 58, 61, 64, 69, 73, 75, 81, 87, 90, 96, $107,118,127,132,135,144$ cathedral of 42 church of Santa Marina la Real 143 monastery of San Isidoro 64, 143 parish of San Pedro 143

Liébana, Spain 22, 28, 58 monastery of 22

Lisbon, Portugal 58, 132, 203
Lorvão, Portugal 58, 129, 132

monastery of 58,204

Madinat al-Zahra, Spain 81

Madrid, Spain 81

Mazote, Spain monastery of San Cebrián 52

Medina de Rioseco, Spain 141

Moissac, France

monastery of Saint-Pierre 113, 168-169

Monte Cassino, Italy 147, 161-163

Moreruela, Spain monastery of San Miguel 30, 69

Navarre, Spain 58, 63, 64, 66, 67, 87, 132, 133, 134, 135, $182,195,203$

Navasa, Spain church of 64

Oviedo, Spain Cámara Santa 127 cathedral of 34

Palermo, Italy Capella Palatina 53

Pamplona, Spain 63-64 cathedral of 132

Poblet, Spain 109

Quintanilla de las Viñas, Spain 27

Ripoll, Spain monastery of Santa María 112

Roda de Isábena, Spain cathedral of 132

Sahagún, Spain 28, 57, 58, 6o, 63, 9o, 115, 148, 151, 156, 175 monastery of 47, 57, 75, 107, 109, 115, $15^{8}$

San Andrés de Arroyo, Spain 65

San Juan de la Peña, Spain 90

San Miguel de Escalada, Spain 30, 69

San Millán de la Cogolla, Spain 28, 57-59, 64, 67, 9o, $93,148,156,188$ monastery of 102, 145, 149, 151

San Pedro de la Nave, Spain 24

San Pedro de las Dueñas, Spain monastery of 57,144

Santiago de Compostela 21-22, 61, 108-109, 122 cathedral of 21

Seu d'Urgell, Spain 87 
Silos, Spain monastery of Santo Domingo 26, 37

St. Gall, Switzerland 29

Tábara, Spain 29-30, 41-42, 47, 50, 52, 57-58, 6o, 63, 65 , $66,69,72,81-82,85,90,93,135,160$ church of Santa María 28, 81 monastery of San Salvador 28, 30, 78, 81, 85 Toledo, Spain 53, 57, 65, 107 monastery of San Clemente 135
Toulouse, France monastery of Saint-Sernin 113 Tours, France 41-42, 47, 57, 66, 82 Saint-Martin 42, 72

Valcavado, Spain monastery of 75,78

Valeránica, Spain monastery of $24,34,41-42,57,60-61,63,69,73,75$, 98

Valladolid, Spain 141 


\section{Index of Subjects}

\section{List OF Illustrated Beatus ManUSCRIPTS}

1. The Silos fragment

Silos, Biblioteca del Monasterio de Santo Domingo, frag. 4

Figure: 34

Pages: $25,26-27,59-60,67-69,174$

\section{The Morgan Beatus}

New York, The Morgan Library \& Museum, MS M.644 Figure: 35

Pages: $23,25,34-35,38,41-42,45,52,64,69-72,81,87$, $108,125,160,175,179$

3. The Vitrina 14-1 Beatus

Madrid, Biblioteca Nacional de España, MS Vitrina 14-1

Figures: $11,37,38,86$

Pages: 25, 59-61, 63-64, 73, 75, 104, 144, 150-151, 158, 167, $174,178-179,182,186,188,190,194,198$

4. The Valcavado Beatus

Valladolid, Biblioteca de la Universidad, MS 433

Figures: 39, 40

Pages: $25,75^{-78}, 85,87,99$

5. The Tábara Beatus

Madrid, Archivo Histórico Nacional, Cod. ${ }_{1097}$ B

Figures: 10, 41, 42

Pages: 25, 28, 29, 31, 41, 47, 52-53, 65-66, 78, 81-82, 122, 135,138

\section{The Girona Beatus}

Museu de la Catedral de Girona, Num. Inv. 7(11)

Figures: 24, 25, 26, 29, 30,43, 44

Pages: 25, 41, 42, 45, 50, 52, 53, 78, 82, 87, 109, 112-113, 122,126

\section{The Vitrina 14-2 fragment}

Madrid, Biblioteca Nacional de España, MS Vitrina 14-2, fols. 1-5

Figures: 45, 52, 53

Pages: 85,86

\section{The Urgell Beatus}

Museu Diocesà de la Seu d'Urgell, Num. Inv. 501 Figures: 46,47

Pages: 25,87

\section{The San Millán Beatus}

Madrid, Real Academia de la Historia, Cod. 33

Figures: 48, 49, 92

Pages: $25,59-61,67,90-93,150-151,155,158,172$

10. The Escorial Beatus

Escorial, Biblioteca del Monasterio, \&.II.5

Figures: 50, 51, 90, 91, 93, 104, 105

Pages: 25, 59-6o, 90, 93, 96, 102, 132, 145, 149-151, $153-154,156,158,167,169,177-179,182-183,186,188$, 190-191, 193-194, 196, 199-202

11. The Facundus Beatus

Madrid, Biblioteca Nacional de España, Vitrina 14-2 Figures: 52, 53

Pages: 25, 58, 64, 85, 96, 98-99, 112, 126, 138

\section{The Fanlo Beatus}

New York, The Morgan Library \& Museum, MS M.1079, fols. 6-12

Figures: 54,55

Pages: 59-6o, 96, 99, 102, 151

13. The Saint-Sever Beatus

Paris, Bibliothèque nationale de France, MS lat. 8878 Figures: 56, 57

Pages: $25,26-27,61,63-64,75,102,104-105,108,158,182$

\section{The Osma Beatus}

Burgo de Osma, Cabildo de la Catedral

Figures: 58, 59, 88, 94, 95, 96, 103

Pages: 25, 58, 61, 63, 105, 107-108, 115, 118, 126, 129, 146, $151,156,158,160,169,172,175-176,178-184,186,188$, 190-191, 193-194, 198-199, 201-204, 207

15. The Turin Beatus

Turin, Biblioteca Nazionale Universitaria, Sgn. I.II.I

Figures: 60,61

Pages: 25, 109, 112 
16. The Silos Beatus

London, British Library, MS Add. 11695

Figures: 17, 63

Pages: 25, 37, 29, 64, 98, 112-113, 115

17. The Corsini Beatus

Rome, Biblioteca dell'Accademia Nazionale dei Lincei e Corsiniana, Segn. 4o.E.6

Figures: 64,65

Pages: 25, 63, 115, 119, 177, 203

\section{The León Fragment}

León, Archivo Histórico Provincial, Perg., Astorga 1

Figure: 66

Pages: 118, 144

19. The Berlin Beatus

Berlin, Staatsbibliothek Preussischer Kulturbesitz, MS theol. lat. fol. 561

Figures: $67,68,98$

Pages: $25,58,63,115,119,146,156,160,163$

20. The Rylands Beatus

Manchester, John Rylands University Library, MS lat. 8

Figures: 69, 70

Pages: $25,65,81,122,125-126,135,138$

\section{The Cardeña Beatus}

Madrid, Museo Arqueológico Nacional, MS 2

Figures: 71,72

Pages: $25,65,122,125-127,138$

\section{The Lorvão Beatus}

Lisbon, Arquivo Nacional da Torre do Tombo

Figures: 73, 74, 106

Pages: $25,66-67,108,118,129,132,146,148,172,174-177$, 179, 188, 193, 202-204, 206-207
23. The Navarre Beatus

Paris, Bibliothèque nationale de France, Nouv. acq. lat. 1366

Figures: $75,76,106$

Pages: 25, 132, 182, 195, 203

24. The Las Huelgas Beatus

New York, The Morgan Library \& Museum, MS M.429

Figures: 77,78

Pages: $25,65-66,78,81,96,122,132,135,138,141$

25. The Arroyo Beatus

Paris, Bibliothèque nationale de France, Nouv. acq. lat. 2290

Figures: 79, 80

Pages: 25, 65-66, 108, 138, 141

26. The Rioseco Fragment

Ciudad de México, Archivo General de la Nación, Illustración 4852

Figure: 81

Pages: 141-142

27. The San Pedro de León Fragment

León, Archivo Parroquial de Santa Marina la Real de León, sig. ASM (SP), Libro de Difuntos, 4

Figure: 82

Pages: 143-144

28. The Milan Fragment

Milan, Archivio di Stato, Rubriche notarili 3823

Figure: 83

Pages: $25,63,67,115,144$

29. The Geneva Beatus

Geneva, Bibliothèque de Genève, MS lat. 357

Figures: $84,85,108-167$

Pages: $25,60,63,67,102,115,119,144-151,155^{-15} 6,158$, $161,163,166-167,172,174-176,182,184,186-188$, 190-194, 198, 200, 202, 207 
Abbess 47,138

Abbot 22, 47, 57, 63, 69, 75, 78, 96, 102, 107, 112, 161

Adam and Eve 23, 34, 60, 93, 94

Allegory 52, 53, 189

Alpha (Greek letter) 58, 96, 97, 99, 203, 206

Alphabet 102, 150, 187

Altar 68, 69, 112, 131, 135, 173-174, 177, 180, 181, 191, 220, 269

Angels; see also Cherubim 27, 34, 52, 6o, 69, 72, 73, 92, $108,110,111,118,122,130,138,141,143,144,147,151$, 155, 16o, 163, 166-170, 172, 175-181, 183-184, 189-191, 197-198, 200-201, 203-206, 222, 224, 229, 230, 232, $236,243,245-252,257,260,267,270-271$

Antichrist 41, 81, 88, 102, 115, 116, 126, 133, 134, 146, 149-151, 174, 175, 182, 187, 190, 200-201, 234, 270 Antiquities of the Jews $5^{\circ}$

Architecture 52, 72, 82, 146, 175, 206

Benedictines 64-65

Bible; see also Gospels 22, 87

Book of Daniel 34, 52, 78, 90, 125, 186

Book of Ezekiel 201

Book of Genesis 23, 46, 6o, 127

Book of Kings (I) 182

Book of Revelation 22, 23, 52, 6o, 67, 69, 102, 108, $118,126,132,141,151,160,166,167-207$

Hispalense 42-43

Moutier-Grandval 46

of Burgos 127, 129

of La Cava dei Tirreni 42, 157

of 920, Cathedral of León 42, 44

of 96o, San Isidoro de León 34, 35, 37, 40, 6o-61, 85 of 1162, San Isidoro de León 64-65

of San Millán 63

of Tours 41,47

Valeránican 24, 34, 41 , 61, 73

Vetus Latina 166-206

Birds; see also Doves, Eagles, Simurgh 129, 199, 200

Bishops 22, 26, 57, 65, 107, 122, 157, 187

Book of Councils, El Escorial 60

Byzantine art and culture 90, 119, 126, 138, 158, 203

Carolingian art and culture 42, 82, 105, 155, 200

Cherubim; see also Angels 34, 37

Christianization of Spain 21-23

Cistercians 58, 64, 65, 66, 122, 129, 132, 135, 138, 143

Colophons 30, 37, 41, 65, 69, 81, 129

Coptic art $5^{2}$

Creation Embroidery, Girona Cathedral 109, 112

Cross 47, 6o, 82, 96, 101-102, 150, 176, 199

De apostolis 23

De natura rerum 24

De ortu et obitu patrum 23

Doves 53, 69, 141, 166, 174
Duplex (double) monasteries 47

Eagles 50, 82, 170, 178, 184, 191

Etymologiae 23

Evangelists; see also Bible, Gospel of 34, 43, 44, 6o, 108, $158,168,170,177$

explanatio 22, 66, 108, 119, 125, 133, 143, 158, 160, 169, 170, 172-177, 180, 182, 184, 187, 190, 191, 193, 196, 201, 203

Exultet Rolls 161

Frontispiece 37, 41, 45-47, 58, 6o, 82, 87, 96, 99, 101, 113, $115,125-126,129$

Gazelles 50, 82

Gifts 30

Gold (gilding) 41, 69, 72, 96, 144, 147, 158, 161, 163, 168, 169, 170, 174, 177, 179, 180, 189, 190, 191, 196, 197, 199, 204

Gospels 22, 34, 72, 96, 188, 189, 243, 271 of Matthew 53, 122, 201

Greek 150, 179, 182, 187

Hell 83, 113-115, 129, 141, 146, 172, 173, 202, 203

Hispanic rite $26 \mathrm{n} 14$

Idolatry 26

incipit 145, 168, 270

Iconography

Adoration of the Lamb 34, 38, 53

Adoration of the Magi 34, 38, 49, 50, 127

Angels Restraining the Winds 52, 130

Christ in Majesty 34, 36, 39, 40, 45, 47, 82, 84, 115, $127,158,168-172,175$

Christ in the Clouds 117, 133

Devil Chained in the Abyss 151-153, 200, 262, 271

Feast of Baltassar 52, 78, 80, 87, 104

Flight into Egypt 49, 50

Gog and Magog 95, 201-202

Horses of the Apocalypse and Their Riders 180, 231, 270

Jacob Wrestling with the Angel 60

Last Judgment 77, 113, 133, 140, 141, 158, 159, 177, 189, $202,265,271$

Omega (Greek letter) 30, 32, 47, 48, 81, 82, 203, 206

Opening of the Six Seals 67, 104, 131, 145-147, 16o, $161,172-175,184,190,219,220,221,269,270$

Symbols of the Evangelists 43, 44, 6o, 158, 168

Vision of God Enthroned with the Elders 157, 158, 168, 170, 206, 217, 218, 269

Whore of Babylon 33, 108, 167, 193-196, 198, 253, 271

Woman Clothed in the Sun 119, 121, 135, 137, 184, $185,238,270$

Infantazgo 30

Initials $34,41,42,45,69,72,75,82,87,93,96,105,115$, $122,129,141,156,163,166,168,216,269$ 
Inscriptions $5^{0}, 69,81,115,125,146,151,158,160$, 167-207

Islamic art and culture $42,52-53,72,75,81-82,85,93$, 109, 155

Ivories 53, 56, 197

Kingdom of Heaven 125

Kings 21, 22, 33, 57, 58, 64, 78, 96, 98, 106, 108, 125, $132,135,139,141,146,154,174,175,177,179,180,190$, 192-201, 204

Latin $24,150,167,179,187$

Lions $35,53,82,170,179,180,186$

Liturgy 26 n14, 57, 107

Locusts 166, 178, 179, 228, 229, 270

Map of the World 23, 6o, 93, 104, 107-109, 129, 132, 133

Marginal glosses 26, 66, 81, 109, 112, 132, 206

Millennial anxiety 41-42

Monks 22, 26, 28-30, 41, 47, 52, 57, 58, 61, 63, 69, 75, 78, $104,105,107,132$

Moralia in Iob 34, 36, 160, 203

Mozarabic art and culture 34, 42, 52, 53, 58, 6o, 63, 64, $72,73,75,82,87,90,93,98,99,107,108,112,113$

Muslim conquest of the Iberian Peninsula 22-24

Nuns 21, 29, 41, 47, 65, 85, 122, 129, 132

O Dei Verbum 21

Omega (Greek letter) 30, 32, 47, 48, 81, 82, 203, 206

Orientalization 52

Paradise 23, 53, 125

Pilgrimage 22, 61, 63, 122
Prayer books 61, 62, 99, 105

Priests 30, 47, 57, 170, 187, 196, 201

Queens 61, 64, 90, 96, 105, 108, 125, 135, 138, 197

Roman rite 26 n14, 59, 107

Romanesque style 27, 42, 58, 61, 64, 72, 90, 93, 96, 99, $105,107-109,112,115,132,138$

Sassanian art $5^{2}$

Scribes 24, 27, 28, 29, 34, 37, 41, 42, 47, 57, 58, 6o, 61, $63-65,66,67,81,85,87,96,102,109,112,129,135$, $146,156,161,206,271$

Scripts

Arabic 75, 81

Beneventan 17, 119, 144, 145, 157, 163-164, 167, 270

Caroline 115, 118, 119, 145, 163-164, 270, 271

Kufic/pseudo-Kufic 75, 81

Visigothic 90, 115

Scriptoria 27-31, 42, 47, 57-6o, 63, 65, 66, 69, 75, 79, 81, $82,87,93,105,107,109,112,118,122,127,135,136,138$, $147-148,149,151,156,161-166$

Serpents 52, 53, 55, 87, 125, 180, 184, 192, 200, 269

Silver 34, 37, 72, 96, 180, 197

Simurgh 50, 82

Storiae 22-24, 26, 52, 108, 119, 132, 133, 145, 146, 158, $160-161,167,169-175,177,179-183,186,187,190-193$, 195, 197-199, 201-204, 206-207

Visigothic art and culture 24, 52, 63, 90, 115

Wars of the Jews $5^{\circ}$

Windows 28, 29, 93 
